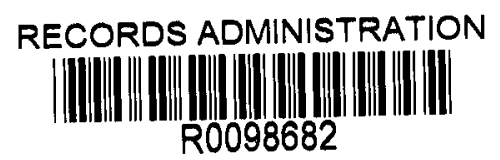

\title{
Bases, Assumptions, and Results of the Flowsheet Calculations for the Short List Salt Disposition Alternatives
}

\author{
Prepared By: Scot Beck \\ Joe T. Carter \\ Richard A. Dimenna \\ Oscar E. Duarte \\ Herbert H. Elder \\ John R. Fowler \\ Michael V. Gregory \\ Thong Hang \\ Roy A. Jacobs \\ Pran K. Paul \\ Reid A. Peterson \\ Ken Rueter \\ Paul L. Rutland \\ David M. Schaffer \\ Martin A. Shadday \\ Frank G. Smith III \\ Glenn A. Taylor \\ Anatia L. Whittenburg \\ Mark H. Wilson
}




\section{APPROVALS}

\section{Flowsheet Alternative Leads}
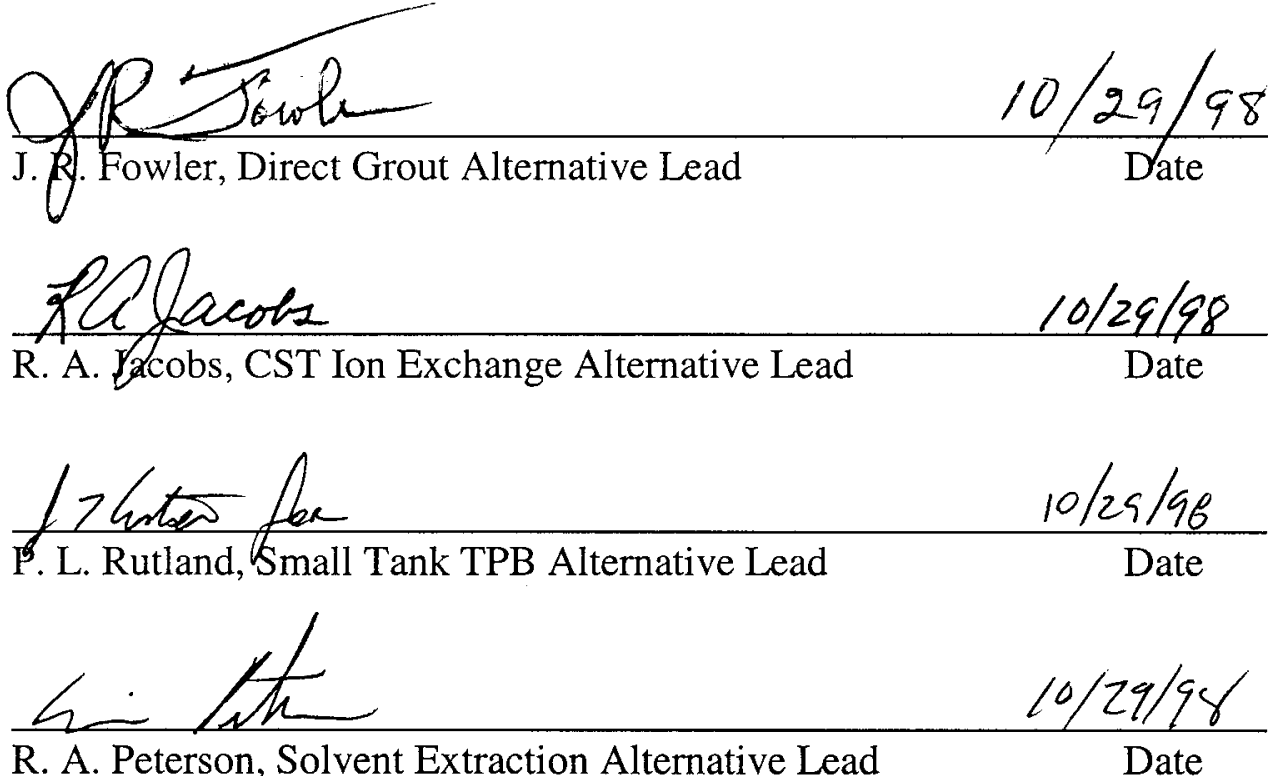

R. A. Peterson, Solvent Extraction Alternative Lead Date

\section{Approvals}
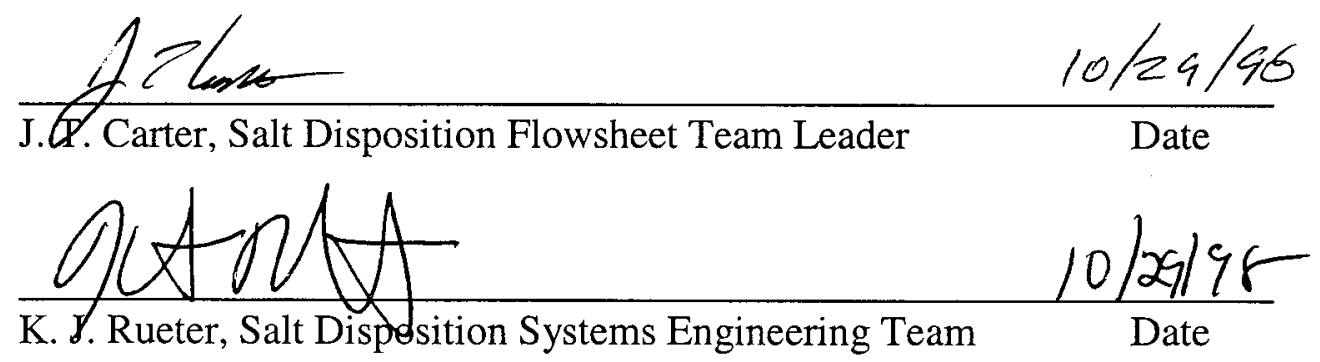


\section{REVISION SUMMARY}

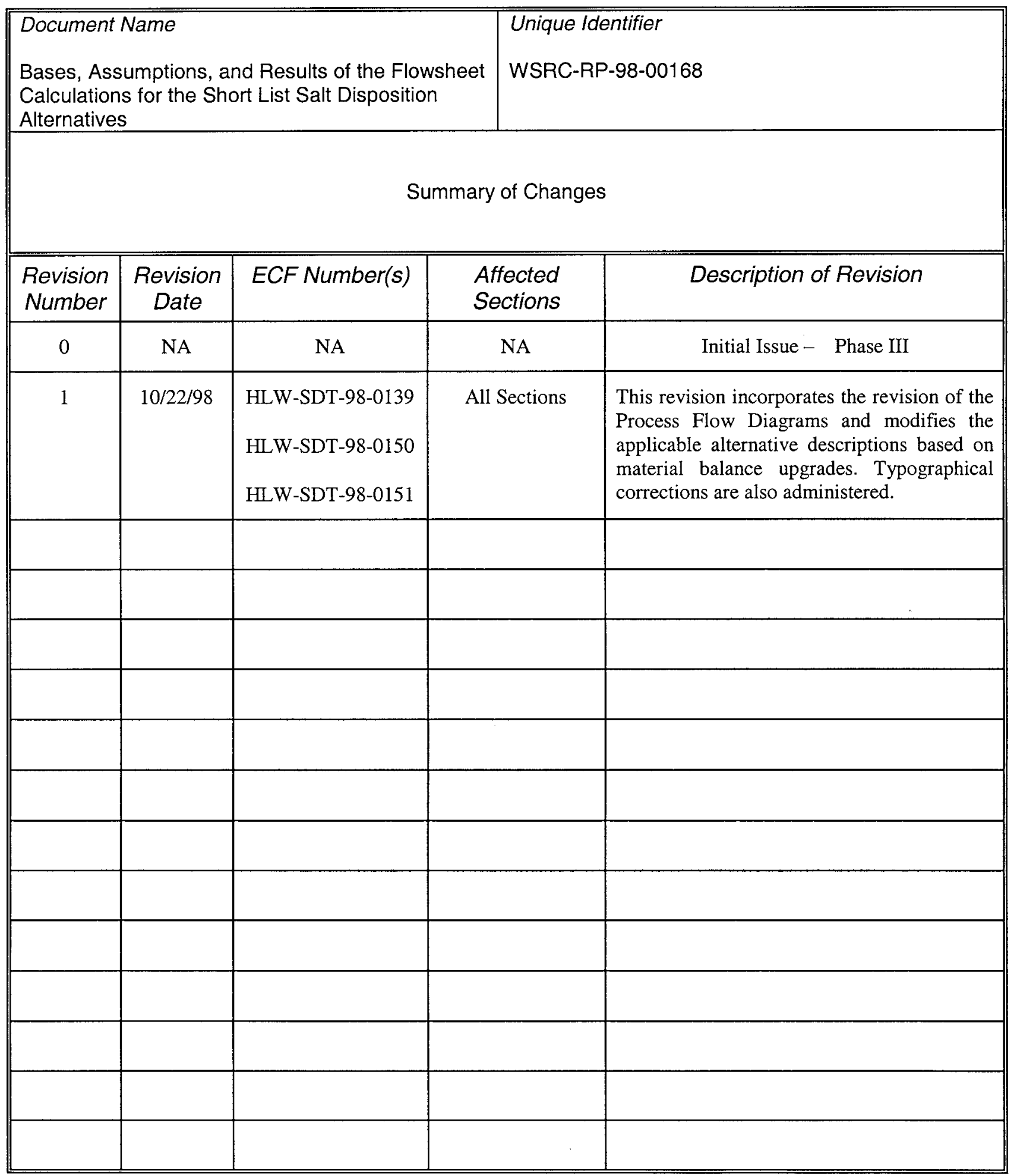




\section{TABLE OF CONTENTS}

Section

Title

Page

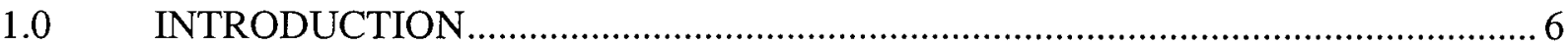

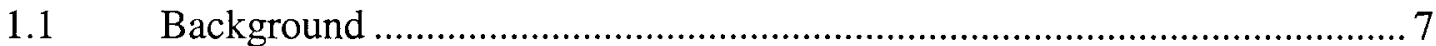

$1.2 \quad$ High Level Waste System Mission ........................................................ 9

1.3 High Level Waste System Overview …………....................................... 9

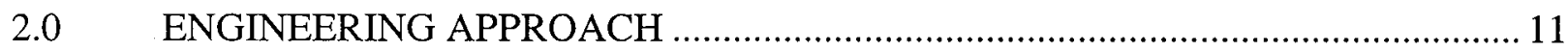

2.1 Workscope Planning, Management, Application, and Control..................... 12

2.2 Models For Interfacing Facilities ............................................................. 21

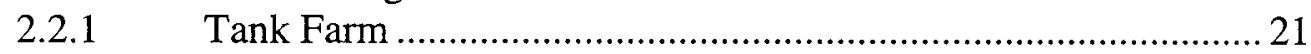

2.2.1.1 Alternative Salt Feed Blending ...............................2 21

2.2.1.2 Tank Farm Strategy .............................................. 22

2.2.1.3 Flowsheet Salt Blending...................................... 22

2.2.2 Defense Waste Processing Facility …………............................ 23

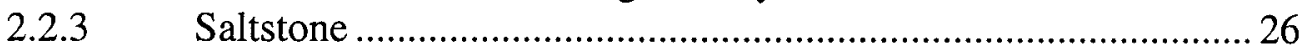

2.2.4 Sinks To Represent Unit Operations Not Modeled...................... 26

2.3 Limitations on Production for Phase III Material Balances ......................... 26

2.3.1.1 Chemical Processing Cell...................................... 27

2.3.1.2 Salt Processing Cell ...............................................22

2.3.1.3 Salt Removal Limitations ...................................... 28

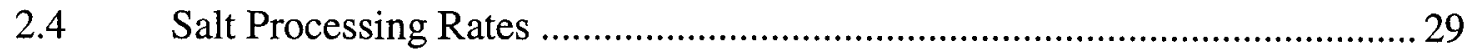

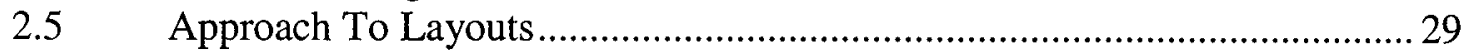

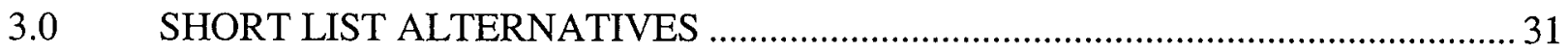

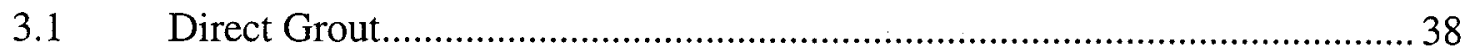

3.1.1 Alternative Description ............................................................. 38

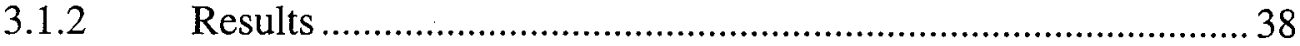

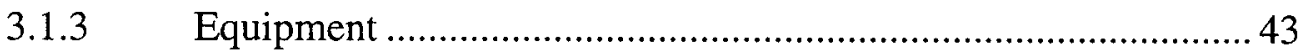

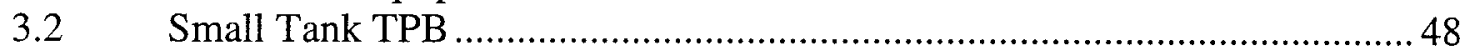

3.2.1 Alternative Description ............................................................... 48

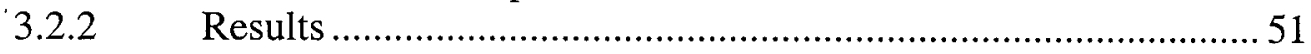

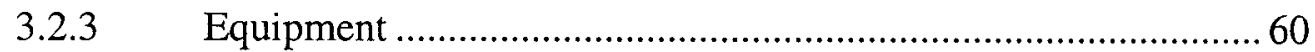

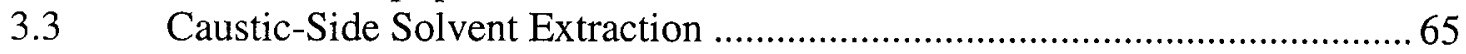

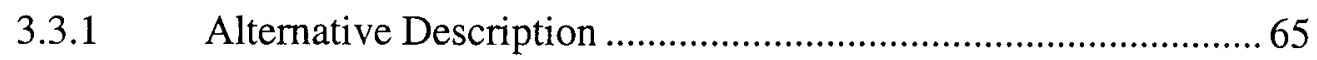

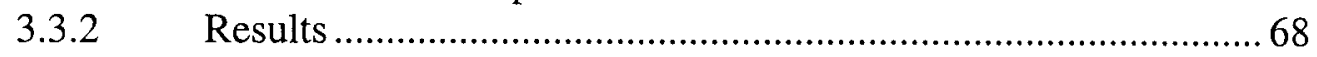

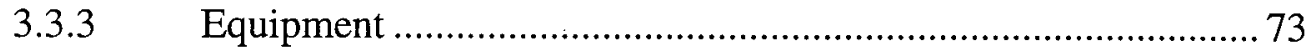

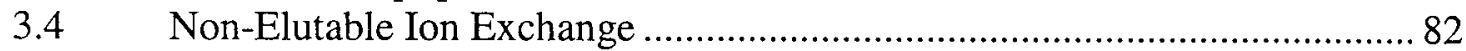

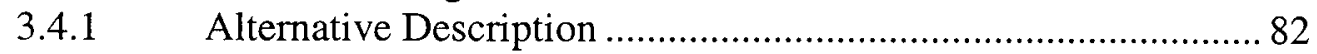

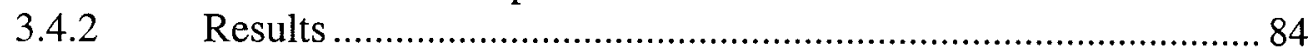

3.4.2.1 Introduction ........................................................ 84

3.4.2.2 Resin Loading Properties ....................................... 84

3.4.2.3 Equipment Sizing .................................................. 86 


\section{TABLE OF CONTENTS}

Section Title Page

3.4.2.4 Expected Performance. 77

3.4.2.5 Phase III Bases Changes and Their Effect on IX

Column Performance. .81

3.4.2.6

Material Balance Results.

3.4 .2 .7

CST Disposition Issues 84

3.4.2.8

Conclusions

\section{4 .3}

Equipment

4.0 ALTERNATIVE VARIATIONS. 98

5.0 SUMMARY OF ALTERNATIVE RESULTS 99

6.0 REFERENCES 102

\section{APPENDICES}

APPENDIX A BASES APPENDIX B APPENDIX C DETAILED JUMPER TABLES APPENDIX D APPENDIX E APPENDIX F APPENDIX G APPENDIX $\mathrm{H}$ APPENDIX I APPENDIX J APPENDIX K VERIFICATION OF ProdMod AND TFARM MODELS INITIAL TANK INVENTORY COMPARISON OF SOLVENT EXTRACTION MODELS ENGINEERING INTEGRATED COMMITMENT MATRIX YEARLY FEED STREAM COMPOSITION SPEEDUP TIME-SERIES PLOTS PROCESS FLOW DIAGRAMS .EQUIPMENT LAYOUT AND SITE DRAWINGS VARIATIONS 


\section{$1.0 \quad$ INTRODUCTION}

The High Level Waste (HLW) Salt Disposition Systems Engineering Team (henceforth referred to as Team) was formed on March 13, 1998, under the sponsorship of the Westinghouse Savannah River Company (WSRC) High Level Waste Vice President and General Manager. The Team is chartered to identify options, evaluate alternatives and recommend a selected alternative(s) for processing HLW salt to a permitted waste form. This requirement arises because the existing In-Tank Precipitation (ITP) process, as currently configured, cannot simultaneously meet the HLW production and Authorization Basis safety requirements.

During Phase I the Team used multiple approaches to identify alternative processes to meet the production and safety requirements for salt disposition. The resulting list of approximately 130 alternatives was evaluated against a set of minimum screening criteria. The outcome of the exercise was an "initial list" of eighteen alternatives selected for further evaluation, which were grouped in categories including: Crystallization, Electrochemical Separation, Ion Exchange, Precipitation, Solvent Extraction and Vitrification.

During Phase II, the Team focused on the application of screening criteria for performance of a preliminary technical and programmatic risk assessment of the eighteen alternatives to establish a short list for detailed evaluation. As part of this assessment, the Team requested the HLW Flowsheet Team to provide preliminary material balances, cycle times, and HLW system wide impacts for the eighteen alternatives. The results of this effort is documented in the WSRC-RP-98-00166 (Reference 1).

The engineering scope in Phase III was to evaluate the Short List alternatives in a greater level of detail to support life cycle and schedule assessment efforts. The HLW Flowsheet Team completed material balances in addition to any required energy balances. Some uncertainties and assumptions involved in Phase II were replaced with data obtained through additional research, literature reviews, calculations, and experiments on the selected alternatives. The physical components of the Phase III models, such as tanks and ion exchange columns, were defined to a greater level of detail. Equipment sizing was developed and used to develop pre-conceptual facility layouts and process flow configurations. The layouts were used by others to develop project and life cycle cost estimates and project schedules for the facilities.

This document provides the technical bases, assumptions and results of this engineering effort. 


\subsection{BACKGROUND}

The High-Level Waste System is a set of seven different interconnected processes (Figure 11) operated by the High Level Waste and Solid Waste Divisions. These processes function as one large treatment plant that receives, stores, and treats high-level wastes at SRS and converts these wastes into forms suitable for final disposal. The three major permitted disposal forms are borosilicate glass, planned for disposal at a Federal Repository; saltstone grout, disposed in vaults on the SRS site; and treated water effluent, released to the environment. Final disposition of mercury metal, which is recovered and purified as part of vitrification, has not been fully defined.

These processes currently include:

1) High-Level Waste Storage and Evaporation ( $\mathrm{F}$ and $\mathrm{H}$ Area Tank Farms)

2) Salt Processing (In-Tank Precipitation and Late Wash Facilities)

3) Sludge Processing (Extended Sludge Processing Facility)

4) Vitrification (Defense Waste Processing Facility)

5) Wastewater Treatment (Effluent Treatment Facility)

6) Solidification (Saltstone Facility)

7) Organic Destruction (Consolidated Incineration Facility)

F and H Tank Farm, Extended Sludge Processing, Defense Waste Processing Facility, Effluent Treatment Facility, Saltstone Facility and the Consolidated Incineration Facility are all operational. In Tank Precipitation Facility operations are limited to safe storage and transfer of materials. The Late Wash Facility has been tested and is in a dry lay-up status. The In-Tank Precipitation Facility (ITP) initiated radioactive operation in Tank $48 \mathrm{H}$ in September of 1995. During pump operation in December of 1995, benzene evolved from Tank $48 \mathrm{H}$ at higher rates than expected, though the operational safety limit was never approached. The benzene was generated as a byproduct of the process from the catalytic decomposition of sodium tetraphenylborate (NaTPB).

In August 1996, the Defense Nuclear Facility Safety Board (DNFSB) issued Recommendation 96-1. The DNFSB recommended that operating and testing in the ITP Facility not proceed without an improved understanding of the mechanisms of benzene generation, retention, and release. In response to Recommendation 96-1, the chemical, physical, and mechanical properties for the large tank ITP process were studied to understand and explain benzene generation, retention, and release. This research was done from August 1996 through March 1998.

These studies indicated that production goals and safety requirements for processing of HLW could not be met in the ITP Facility, as configured. This resulted in a WSRC recommendation to the Department of Energy in January 1998 to conduct a systems evaluation of salt disposition options and to recommend the preferred alternative. The salt 
will remain in storage until an alternative salt pre-treatment process is identified and implemented. Alternative processes will be evaluated throughout 1998.

\section{Figure 1-1: HLW System Major Interfaces}

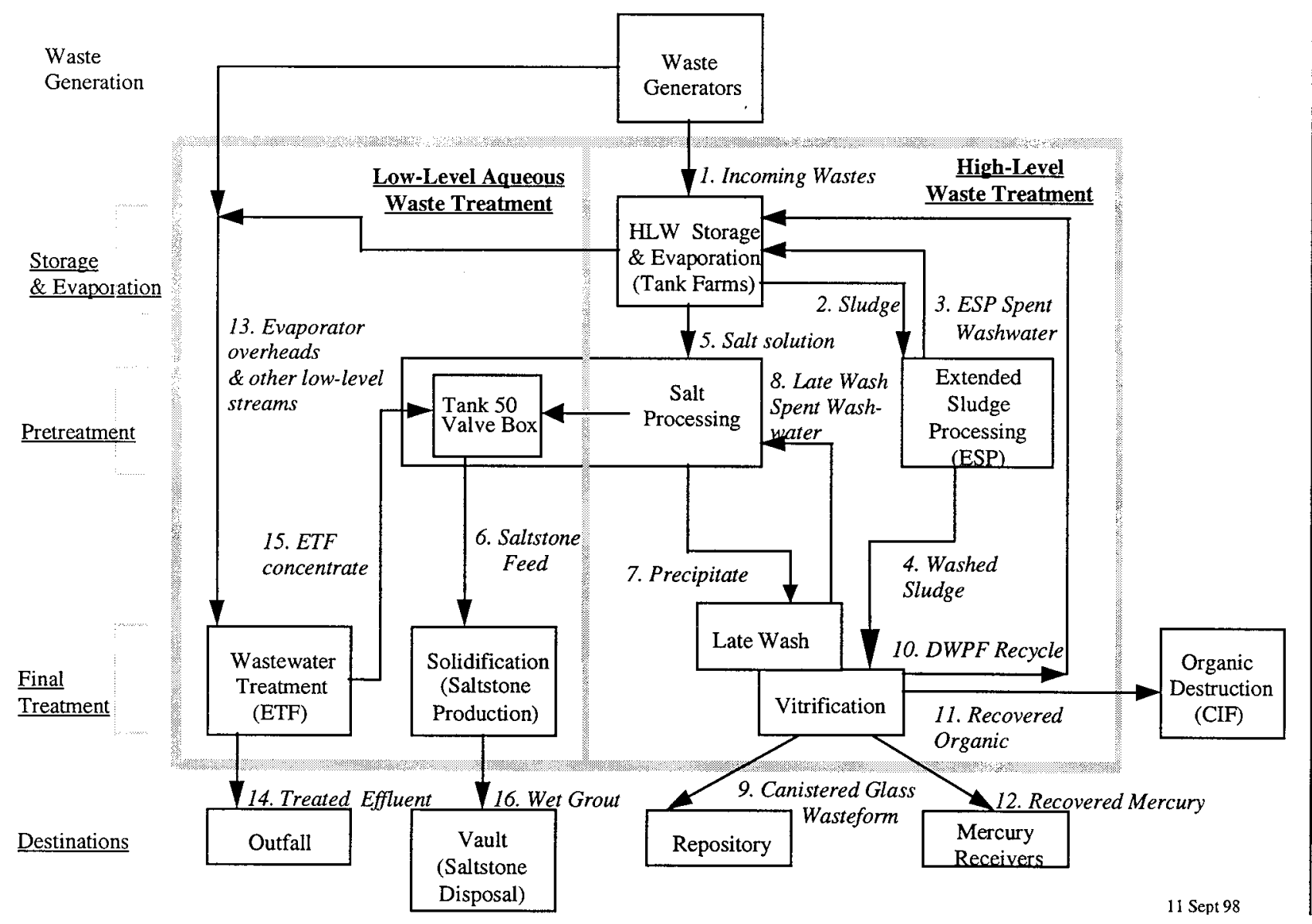

In March 1998, a team was selected to perform a structured systems engineering analysis of options for salt disposition. Guidance for the Team is documented in the charter (Reference 2). Evaluation of salt disposition is broad based in technical scope and is not limited to any single process. Precipitation methods, ion exchange processes, other chemical or mechanical separation techniques, direct vitrification options, or combinations of these options are being considered.

Although the process selected will be specifically for HLW salt disposition, the team must address the system impact for all HLW facilities. Additionally, the selected alternative must interface safely and efficiently with the remainder of processing facilities outside of HLW. 
Timely selection of an alternative is key to support tank farm space and water inventory management and the Federal Facility Agreement (FFA) for tank closure. The FFA for SRS addresses the DOE committed schedule for removing the wastes from the tanks.

\subsection{HIGH LEVEL WASTE SYSTEM MISSION}

The mission of the HLW System is to receive and store SRS high-level wastes in a safe and environmentally sound manner and to convert these wastes into forms suitable for final disposal. The planned forms are: 1) borosilicate glass to be sent to a Federal repository, 2) saltstone to be disposed of on site, and 3) treated wastewater to be released to the environment. The storage tanks and facilities used to process the high-level waste also must be left in a state such that they can be closed and decommissioned in a cost-effective manner and in accordance with applicable regulations and regulatory agreements.

The FFA requires removal of the waste from the high-level waste tanks to resolve several safety and regulatory concerns. Some tanks have leaked observable quantities of waste from primary to secondary containment. Other tanks have known penetrations above the liquid level, although no waste has been observed to leak through these penetrations. The "old style" tanks do not meet EPA secondary containment standards for storage of hazardous waste (effective January 12, 1987).

All high-level wastes in storage at SRS are Land Disposal Restricted (LDR) wastes, which are prohibited from permanent storage or direct disposal. Since the planned processing of these wastes will require considerable time and therefore continued storage of the waste, DOE has entered into a compliance agreement with the EPA and SCDHEC. This compliance agreement is implemented through the Site Treatment Plan (STP) which requires processing of all the high-level waste at SRS according to a schedule negotiated between the parties.

The problem confronting the HLW overall mission is that the currently configured in-tank precipitation process cannot simultaneously meet the HLW flowsheet production goals and the safety requirements. The WSRC recommended that alternative concepts and technologies be evaluated. The HLW Salt Disposition Systems Engineering Team was formed and chartered to perform this task. The Mission Need defined for the Team is:

"The SRS HLW salt needs to be immobilized for final disposition in support of environmental protection, safety, and current and planned missions".

\subsection{HIGH LEVEL WASTE SYSTEM OVERVIEW}

Figure 1-1 schematically illustrates the normal flow of wastes through the HLW System. The various processes within the system and external processes are shown in rectangles. The numbered streams identified in italics are the interface streams between the various processes. The discussion below represents the HLW system configuration as of January 1998. 
Incoming high-level wastes are received into HLW Storage and Evaporation (F and $\mathrm{H}$ Tank Farms) (Stream 1). The function of HLW Storage and Evaporation is to safely concentrate and store these wastes until downstream processes are available for further processing. The decontaminated liquid from the evaporators are sent to Effluent Treatment Facility (ETF) (Stream 13).

The insoluble sludges that settle to the bottom of waste receipt tanks in HLW Storage and Evaporation are slurried using hydraulic slurrying techniques and sent to Extended Sludge Processing (ESP) (Stream 2). In ESP, sludges high in aluminum are processed to remove some of the insoluble aluminum compounds. All sludges, including those that have been processed to remove aluminum, are washed with water to reduce their soluble salt content. The spent washwater from this process is returned to the HLW Storage and Evaporation (Stream 3). Washed sludge is sent to Vitrification (DWPF) for feed pretreatment and vitrification (Stream 4).

Saltcake is dissolved using hydraulic slurrying techniques similar to sludge slurrying. As currently designed, the salt solutions from this operation and other salt solutions from HLW Storage and Evaporation were intended for feed to Salt Processing (ITP) (Stream 5). In ITP, the salt solution is processed to remove radionuclides, which are concentrated into an organic precipitate. The decontaminated filtrate is then be sent to Tank 50. A concentrated organic precipitate, containing most of the radionuclides, is produced by the process. This precipitate is washed with water to remove soluble salts. However, some soluble corrosion inhibitors which interfere with DWPF processing must be left in the precipitate after washing, because the precipitate is stored in carbon steel tanks, which are susceptible to corrosive attack by uninhibited precipitate wastes.

The precipitate is transferred to Late Wash for further washing in stainless steel tanks to reduce the level of soluble corrosion inhibitors to acceptable levels for the DWPF process (Stream 7). The washwater from this process is returned to ITP to be reused in the ITP process (Stream 8).

The washed precipitate from Late Wash is then sent to the DWPF Vitrification Building (221-S). In the Vitrification Building, the precipitate is catalytically decomposed and separated into two streams: a mildly contaminated organic stream and an aqueous stream containing virtually all of the radionuclides. The mildly contaminated organics are stored at DWPF and eventually transferred to Organic Destruction (CIF) (Stream 11). The aqueous stream is combined with the washed sludge from ESP, which has undergone further processing within the DWPF, and the resulting mixture vitrified.

The washed sludge from ESP (Stream 4) is chemically adjusted in the DWPF to prepare the sludge for feed to the glass melter. As part of this process, mercury is stripped out, purified and sent to mercury receivers (Stream 12). The aqueous product from organic decomposition is added to the chemically adjusted sludge. The mixture is then combined with glass frit and sent to the glass melter. The glass melter drives off the water and melts the wastes into a 
borosilicate glass matrix, which is poured into a canister. The canistered glass waste form is sent on to site interim storage, and will eventually be disposed of in a Federal repository for disposal (Stream 9).

The water vapor driven from the melter is condensed and combined with other aqueous streams generated throughout the DWPF Vitrification Building. This aqueous waste is recycled to HLW Storage and Evaporation for processing (Stream 10).

Overheads from the HLW Storage and Evaporation evaporators are combined with overheads from evaporators in the F and $\mathrm{H}$ Area Separations processes and other low-level streams from various waste generators. This mixture of low-level wastes is sent to the ETF (Stream 13).

In the ETF, these low-level wastes are decontaminated by a series of cleaning processes. The decontaminated water effluent is sent to the $\mathrm{H}$ Area outfall and eventually flows to local creeks and the Savannah River (Stream 14). The contaminants removed from the water are concentrated and sent to Tank 50 (Stream 15).

In Tank 50 the concentrate from the ETF is combined with the decontaminated filtrate from the ITP and sent to Saltstone (Stream 6). In the Saltstone Facility the liquid waste is combined with cement formers and pumped as a wet grout to a landfill vault (Stream 16). In the vault, the cement formers hydrate and cure, forming a solid saltstone monolith. The Saltstone Facility vaults will eventually be closed as a landfill.

\subsection{ENGINEERING APPROACH}

The flowsheets for Phase III were initially developed from the basis established by the Phase II modeling efforts. The Phase III model results were used to produce equipment lists, equipment sizing, and building layout requirements. These equipment lists, sizing and building layout information were used to estimate the construction, startup, and operations costs for each shortlist alternative. Revised material balances produced for the Phase III program will be used to verify that the equipment sizing, layouts, and cost for each of the options is accurately reflected.

The mass balances and any required energy balances for determining expected flowsheet performance have incorporated additional data obtained from Phase III research efforts to reduce uncertainties and assumptions defined in the Phase II, as that data became available. The physical components of the Phase III models, such as tanks and ion exchange columns, are defined to a greater level of detail. Actual dimensions based on existing equipment characteristics and thermodynamic values were considered in the development of the models.

The additional experimental data was developed at the Savannah River Technology Center (SRTC), Oak Ridge National Laboratory (ORNL), Argonne National Laboratory (ANL), and other facilities as defined in the Phase III scope of work. 
The models, developed in Phase III, describe the alternative processes mathematically by way of differential equations used to represent system components and performance. The models were developed from consistent bases, assumptions, and constraints with as many common unit operations as possible. Engineering calculations and the SPEEDUP ${ }^{\mathrm{TM}}$ equation solver were used to execute the models and generate the performance results and material balances for the alternatives.

\subsection{Workscope Planning, Management, Application, and Control}

For the selection phase of the Salt Disposition effort, a scope of work matrix was developed and distributed by the Salt Disposition Systems Engineering Team. The matrix was used to identify specific work activities for the Engineering, Research and Development, and Safety Management support organizations. This matrix laid the foundation for evaluating the various areas of engineering, research and development, and safety management as they apply to the alternative layout, cost estimates, schedule, impacts, and application of uncertainty for each alternative.

Through the use of a "Road Mapping" approach (Figures 2.1-1 through 2.1-5), a logical and consistent plan of action was applied to the scope of work activities for each alternative and a Engineering Integrated Commitment matrix was developed for managing outstanding items, work activities, deliverables, and plans. The completed version of the workscope is shown in Reference 3.

Examples of the scope of work matrix and the engineering integrated commitment matrix (ICM) are shown in Figures 2.1-6 \& Figure 2.1-7, respectively. The scope of work matrix identifies the outstanding items; type (assumption or constraint); considerations made by the Team during the evaluation; and a recommended path forward including resources, timing, scope, deliverables, and the responsible organization.

The ICM is a modified version of the scope of work matrix used by the Salt Disposition Systems Engineering Team and the Flowsheet Team. The ICM serves as a tool to identify and track commitment deliverables; test plans; task sheet approvals; completed research and development reports; and the specific sections of this document (WSRC-RP-98-00168) that address the items specified on the scope of work matrix and shown on the road maps. The final ICM is contained in Appendix F.

For example, Item 3 of Figure 2.1-6 defines the work activity for identifying the adsorption kinetics (column sizing velocity) and effects of varying column lengths on the cesium loading onto the CST resin. The Flowsheet Team was concerned that a long breakthrough curve at low velocities may produce poor mass transfer.

The path forward approach taken by the Flowsheet Team was to develop a column sizing model and resulting calculation to address this issue (Reference 4). As explained in Section A.16 of Appendix A, the mass transfer and column sizing effects were evaluated by 
comparing results to the results from models produced at Texas A\&M and Purdue University (References 5 and 6 respectively). As steps were taken to close this issue, the appropriate areas of the ICM were completed to track the progression.

As shown in Figure 2.1-3, a logic path exists on the Road Map to use the CST Equilibrium Curve and Kinetics data and information to determine column sizing. The size of the columns ultimately determine the CST Ion Exchange Alternative Process Layout (Area "A" on Figure 2.1-3). The Equipment layout drawings, a product of this process, which contain the CST ion exchange columns are shown in Appendix H (X-PG-H-0003, sheets 1 and 2). The Road Map thereby shows the Team how the items in the scope of work matrix are manifested in the Phase III pre-conceptual project. 


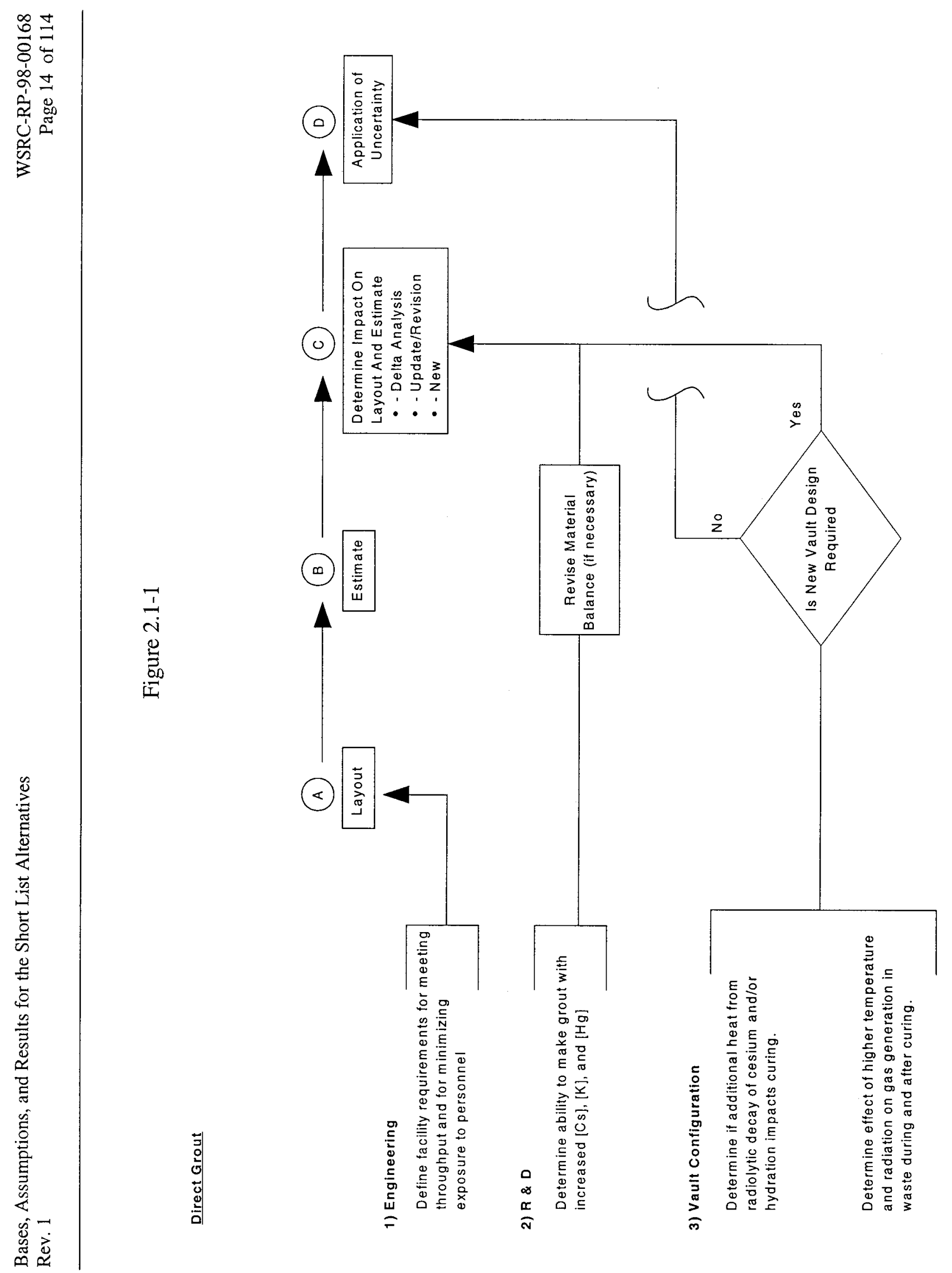


$\infty$
0
0
0
0
0
0
0
0
0
0
0
0
$\vdots$
3

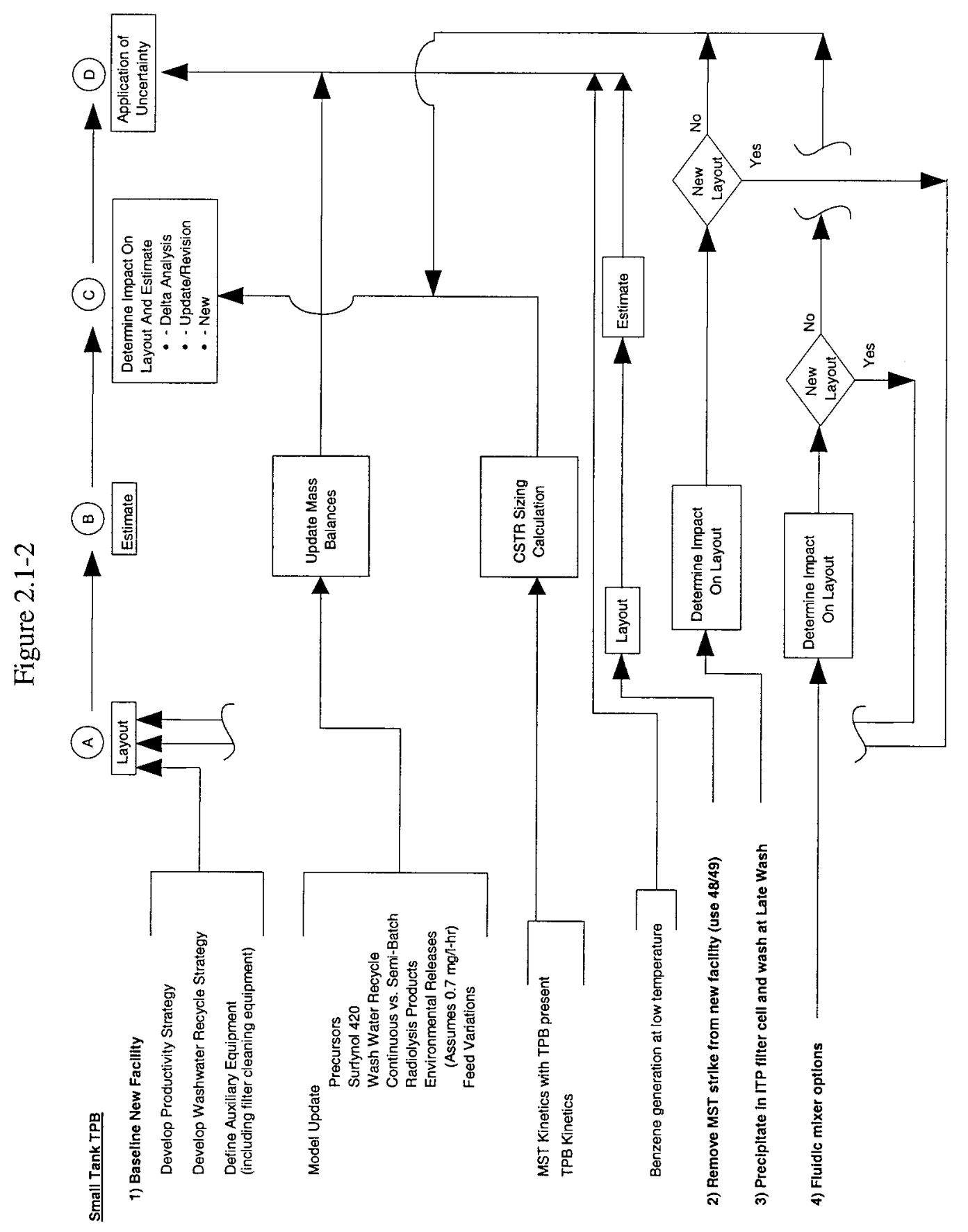




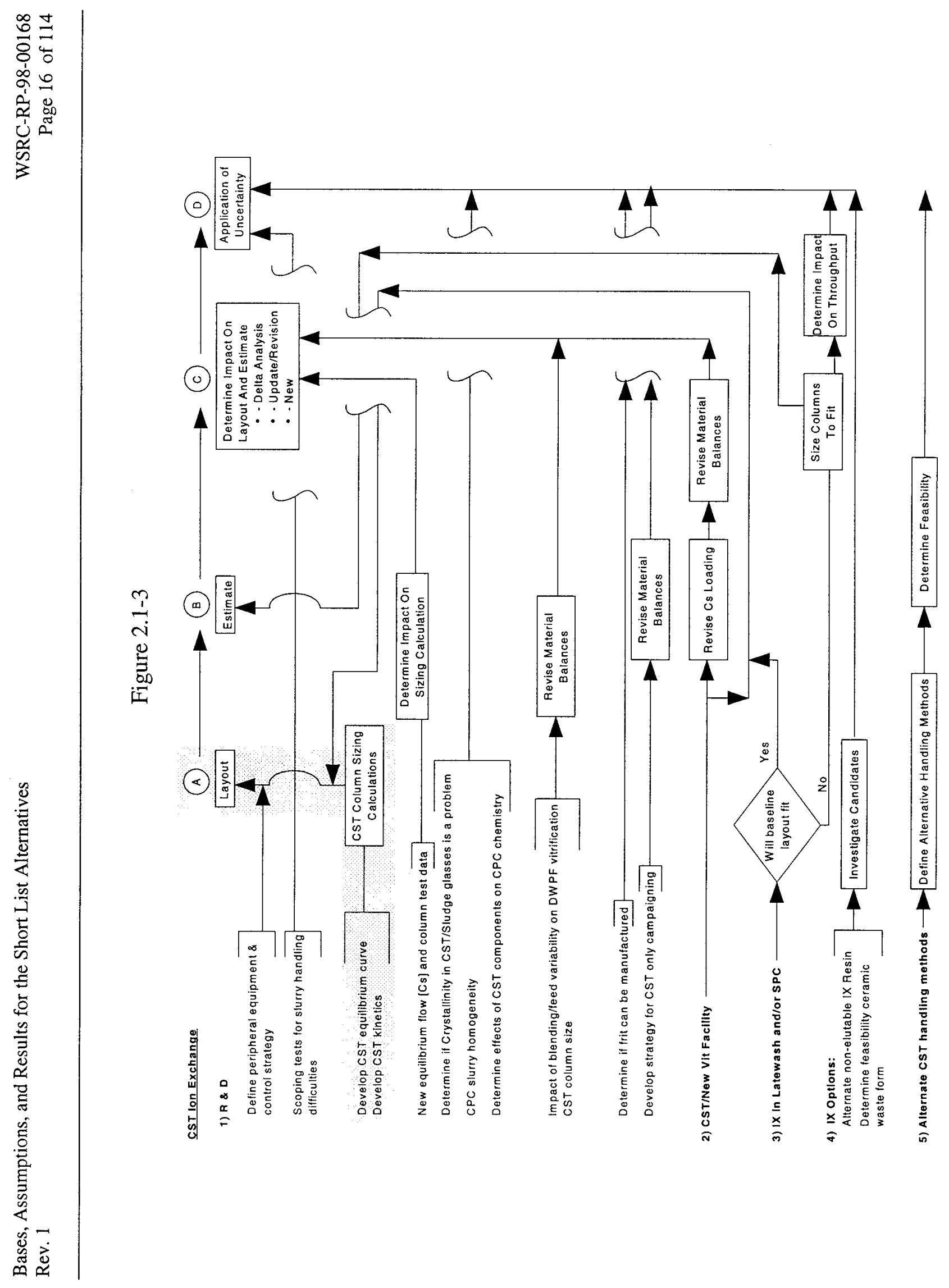




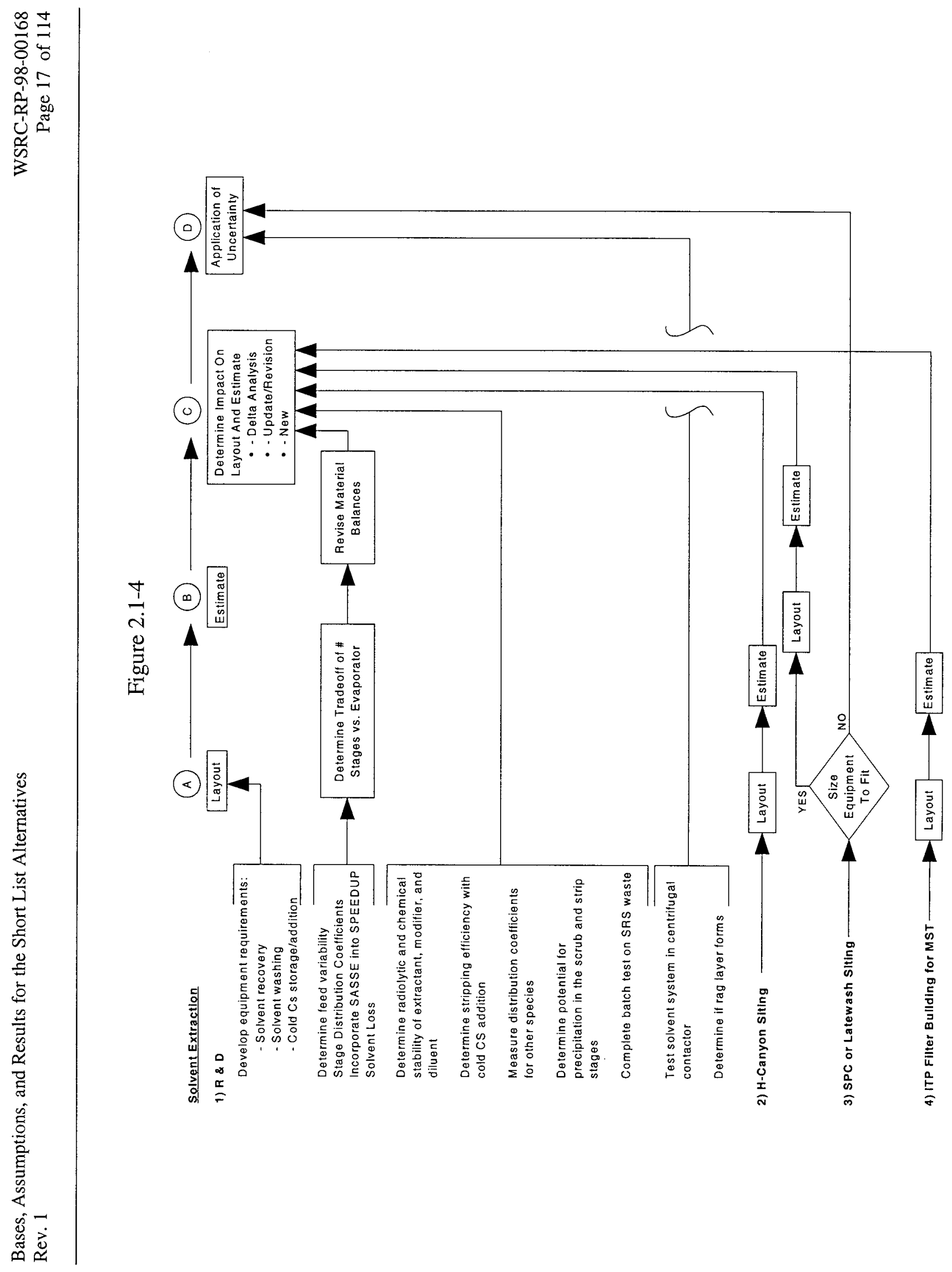




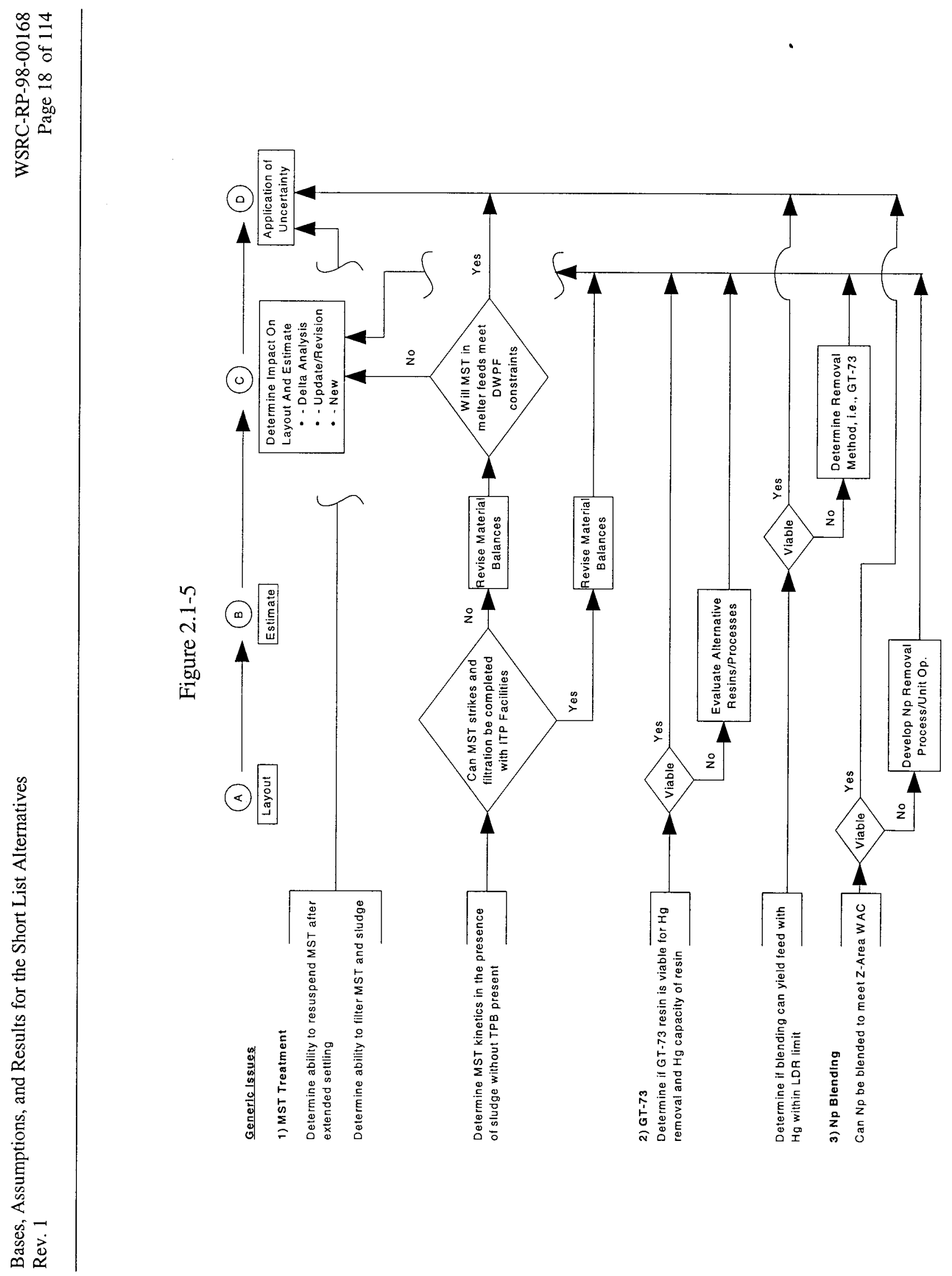




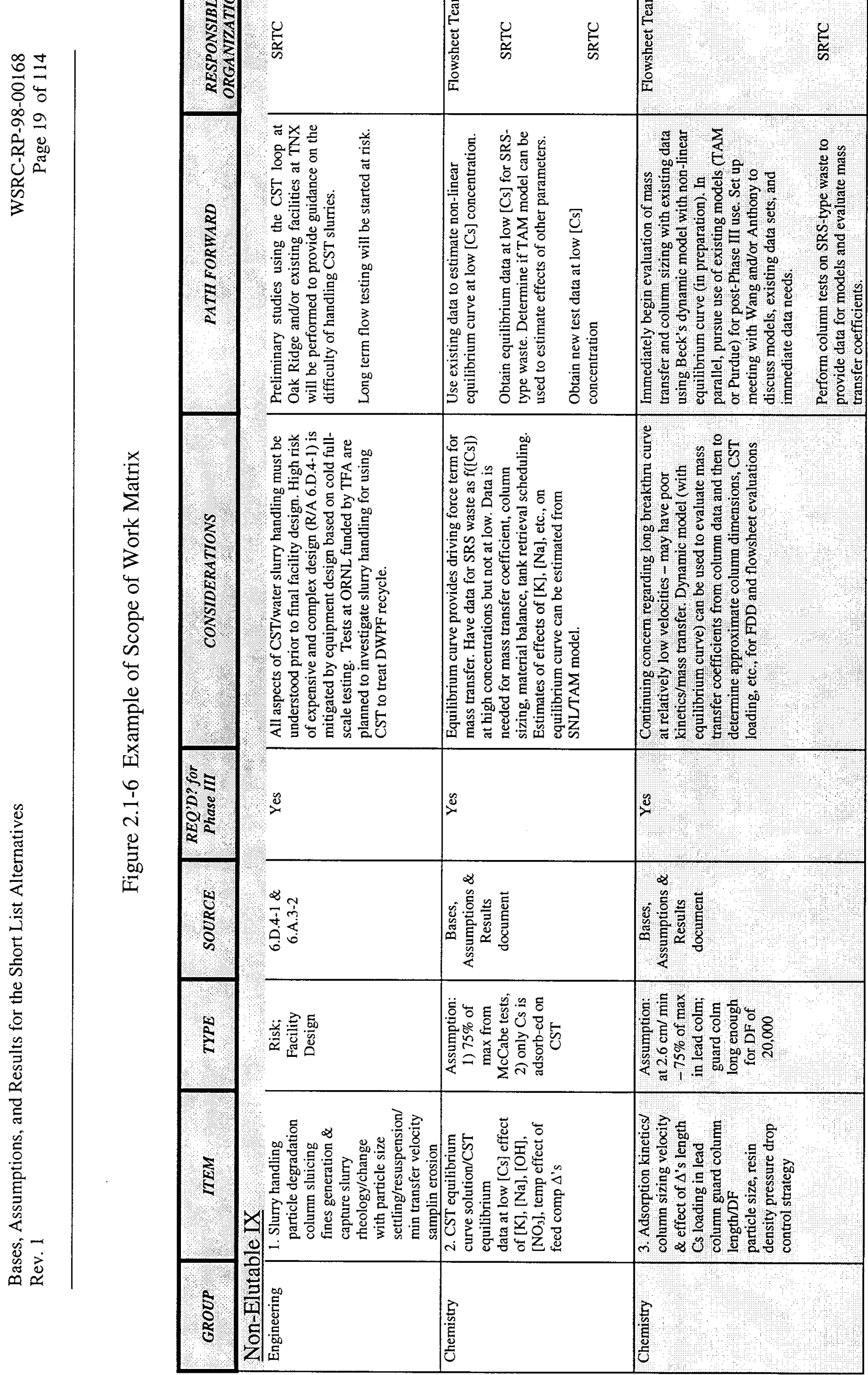




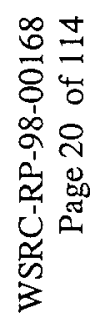

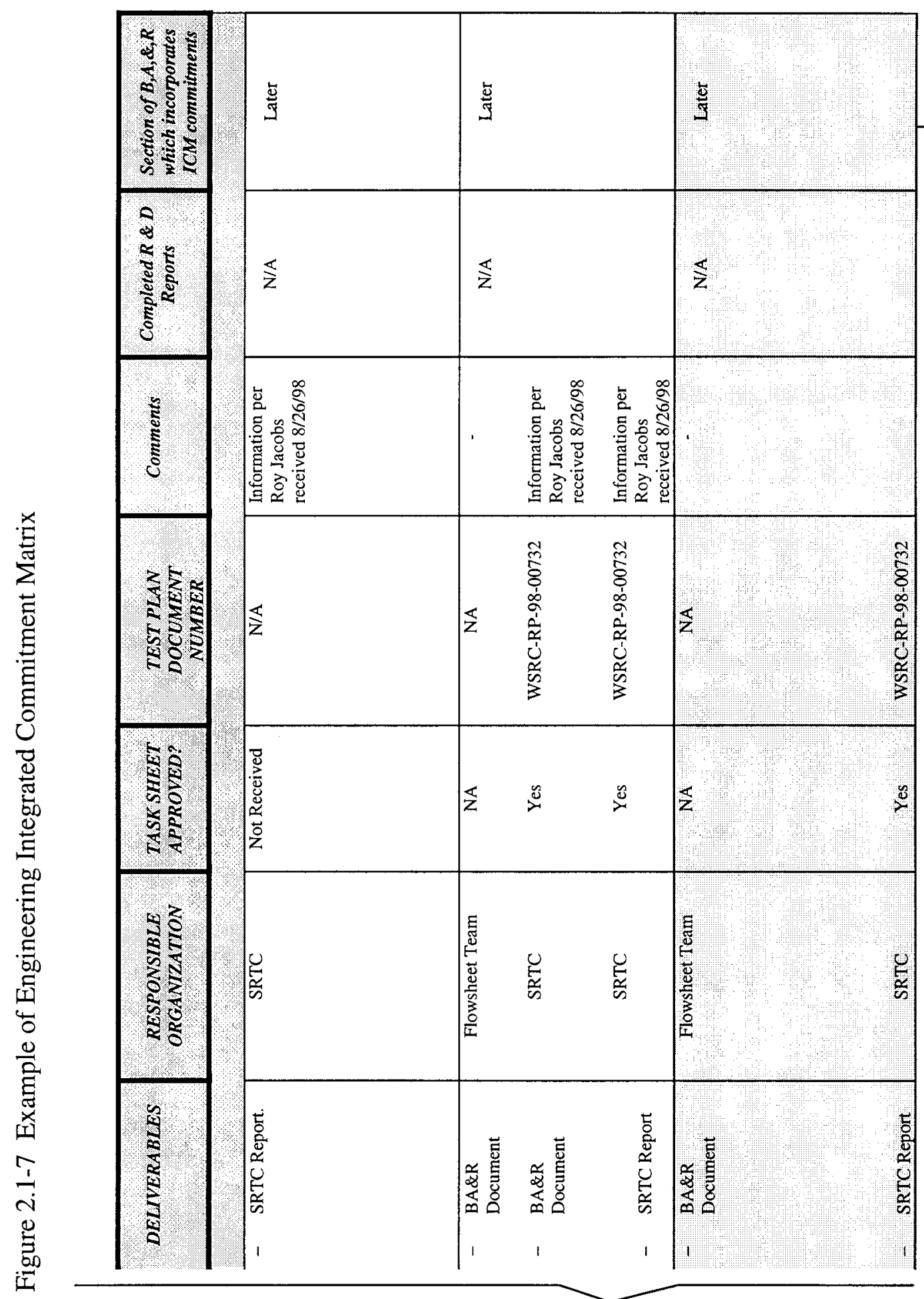

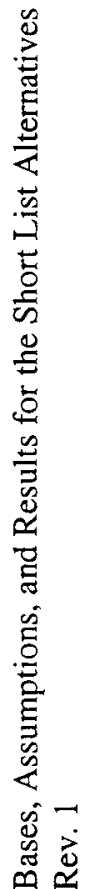

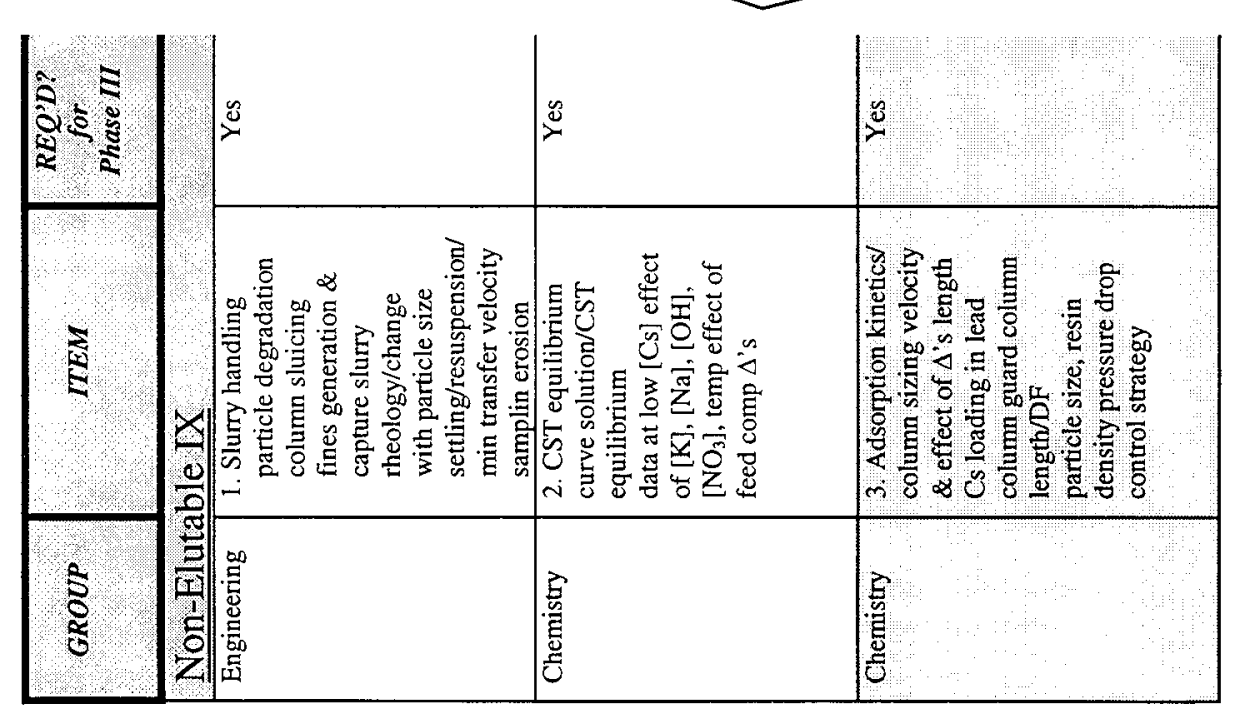

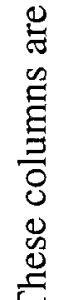

.

ఫ్ర

$\stackrel{\circ}{\circ}$

䒕

E

8

$\circ$

导

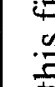

ב

今

品

త్ర

급

3

동

2

i

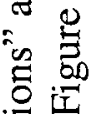

讧

電.

矛

$\checkmark 0$

音

豆

$\because$ 串

온 


\subsection{MODELS FOR INTERFACING FACILITIES}

\subsubsection{TANK FARM}

The H/F Tank Farms are assumed to provide up to 6,000,000 gal/yr (Reference 8) of 6.44 molar sodium feed for the alternatives on an average basis. The feed composition will vary over time based on the sequence of the feed tanks. The ProdMod model was used to generate the feed sequence. ProdMod is the model used to determine tank transfers in the development of the High Level Waste System Plans. Various scenarios were run for each of the alternatives based upon when their assumed start-up would occur. The feed stream composition to an alternative was then determined based on a yearly combination of the feed tanks produced by ProdMod.

\subsubsection{Alternative Salt Feed Blending}

For the Phase II flowsheets, 20 year average salt and sludge compositions were used. These compositions provided a consistent basis to assess the salt disposition alternative processes. For Phase III, an expected range of compositions was desired in order to perform sensitivity analysis where needed. This was accomplished by developing a tank farm feed strategy for each alternative, evaluating the composition of the feed stream based on the tank farm strategy, and then selecting compositions which would be representative of the extremes the alternative would expect. This approach ensured the feed aspects of the respective alternative was bounded. Following is a brief discussion of the salt feed strategy development and the assessment of the feed streams. Note that it is assumed that the sludge feed schedule, a feed to DWPF only, is the same for all alternatives, and is unchanged from HLW System Plan (Reference 8). The Phase III material balances were composed using the average sludge compositions. This is acceptable because:

- The Direct Grout flowsheet interacts with DWPF only through a small stream of residual sludge and monosodium titanate. The expected variation is reflected in the MST usage in other alternatives. The Solvent Extraction flowsheet interacts in the same way, plus a stream of dilute nitric acid and cesium nitrate is sent. DWPF operation is very little different from current sludge only operation and so choice of sludge to model has no real impact on the results. This is also the reason that the DWPF model results for both flowsheets are nearly identical.

- The Ion Exchange ("CST") produces a slurry of loaded resin which can be vitrified. CST/sludge/frit glasses are acceptable over a wide range of CST and sludge loadings (Reference 7). Loaded CST contains frit and sludge elements, which are already oxidized. This gives CST a blending range which is large and insensitive to sludge composition. 
- The Precipitate Process product is treated in DWPF to produce a "precipitate hydrolysis aqueous" (PHA). The main glass forming elements in PHA either replace frit in the glass formulation (e.g. boron) or provide additional alkali. Alkali content of the glass is adjusted by sludge washing or frit composition. The operating strategy of the high level waste system can be set to accommodate variation in sludge composition. In any event, the vitrification of PHA/frit/sludge blends have been modeled in detail (Reference 8) and there is no need to repeat this verification for this study.

\subsubsection{Tank Farm Strategy}

The Tank Farm Strategy is the manner in which it is envisioned to empty the tanks in the tank farms. This analysis is performed by the ProdMod model, which has been extensively used for the development of the HLW System Plans (Reference 8). ProdMod contains sufficient detail so that a few important parameters can be tracked to determine the efficacy of a plan. ProdMod was run for the assumed life of an alternative, which is the time for all the salt in the tank farms to be processed. ProdMod does this by taking one year time steps, that is, the contents of the tanks are the yearly average of the tanks' content. ProdMod performs all the transfers expected within the HLW system along with evaporating waste.

Four ProdMod runs were made for Phase III, one for each alternative. These separate runs were made because of different projected start-up times and processing rates for each alternative. The different start-up times made for slightly different strategies for the tank farms, and these differences are reflected in the early feed compositions. Once these strategies were developed, they were fed to a blending routine (TFARM) which created the feed vector for the flowsheet modeling.

\subsubsection{Flowsheet Salt Blending}

Once the feed schedule to the alternatives was determined, it was necessary to develop the feed composition vectors. The feed vector consists of 51 compounds, but all were not necessarily calculated due to their being in very small concentrations that have no effect on the models. The concentrations of each compound were calculated based on the schedule provided by ProdMod. The schedule supplied both a transfer schedule and the amount transferred for all tanks in the tank farms. For each year of an alternative there is a unique feed stream composition. (See Appendix G) These feed streams compositions were then assessed to determine the periods of interest, and then these were run with the flowsheet model.

The initial tank composition and tank inventory (See Appendix D) was based upon the information contained in HLCATS, the chemical composition database of the tank farms. This database contains many more compounds than called for in the feed vector, so a reduced data set was created that reflected the desired compounds. The reduced data set 
maintained an overall mass balance, but partitioned ions between different compounds as required by the feed vector. The reduced data set can be seen in Appendix G.

\subsubsection{DEFENSE WASTE PROCESSING FACILITY}

The Defense Waste Processing Facility (DWPF) model was developed to evaluate the effect of the various alternatives on the quality and quantity of glass produced.

The model is split into two sections, the Salt Processing Cell (SPC), and the Chemical Processing Cell (CPC)/Melter operations. By modeling in this manner, the SPC model can be deleted as necessary, when alternative processes are evaluated.

Only the small tank ITP process uses the DWPF salt cell to hydrolyze the tetraphenylborate salt complexes generated by the ITP process. As can be seen in Fig. 2.2-1, the salt cell process has been simplified for the purposes of this model calculation. We have neglected the organic evaporator entirely since it should not be limiting to the overall processing times.

The SPC model (Figure 2.2-1) includes the Precipitate Reactor (PR), Organic Recovery, and the Precipitate Reactor Bottoms Tank (PRBT). The model determines the amounts of copper nitrate and formic acid required. Cycle times and volume limits are based on DWPF cold chemical run experience. (See Section 2.3.1.1) The salt cell can process two batches of precipitate over the same cycle time as the SRAT in the chemical cell.

All four options send material to the SRAT in the DWPF chemical cell. For the Direct Grout option, only an MST stream from alpha decontamination operations is sent to the SRAT. For Solvent Extraction, the MST stream and a $0.05 \mathrm{M} \mathrm{NaOH}$ stream containing the extracted cesium is also sent to the glass plant. For the ion exchange option, the MST stream and the spent IX resin are processed through the SRAT.

The CPC/melter model (Figure 2.2-2) includes the Sludge Receipt and Adjustment Tank (SRAT), Slurry Mix Evaporator (SME), Melter Feed Tank (MFT), Melter, and Recycle Collection Tank (RCT).

Nitric and formic acid demands are determined, along with glass compositions, properties and quantities. Recycle water is chemically adjusted for Tank Farm corrosion control. The RCT flow is integrated to monitor the volume and composition for comparison to the Tank Farm control.

The PCCS model was used to determine the optimal (minimum frit) glass blend for the Direct Grout and Solvent Extraction case studies. For Small Tank ITP, the amounts of sludge, salt and frit processes through DWPF were set to a predetermined ratios to ensure that the inventories of sludge and salt would be worked off at same rate. 
Cycle times are based on DWPF radioactive operating experience and equipment limitations such as evaporation rates. (See Section 2.3.1.2)

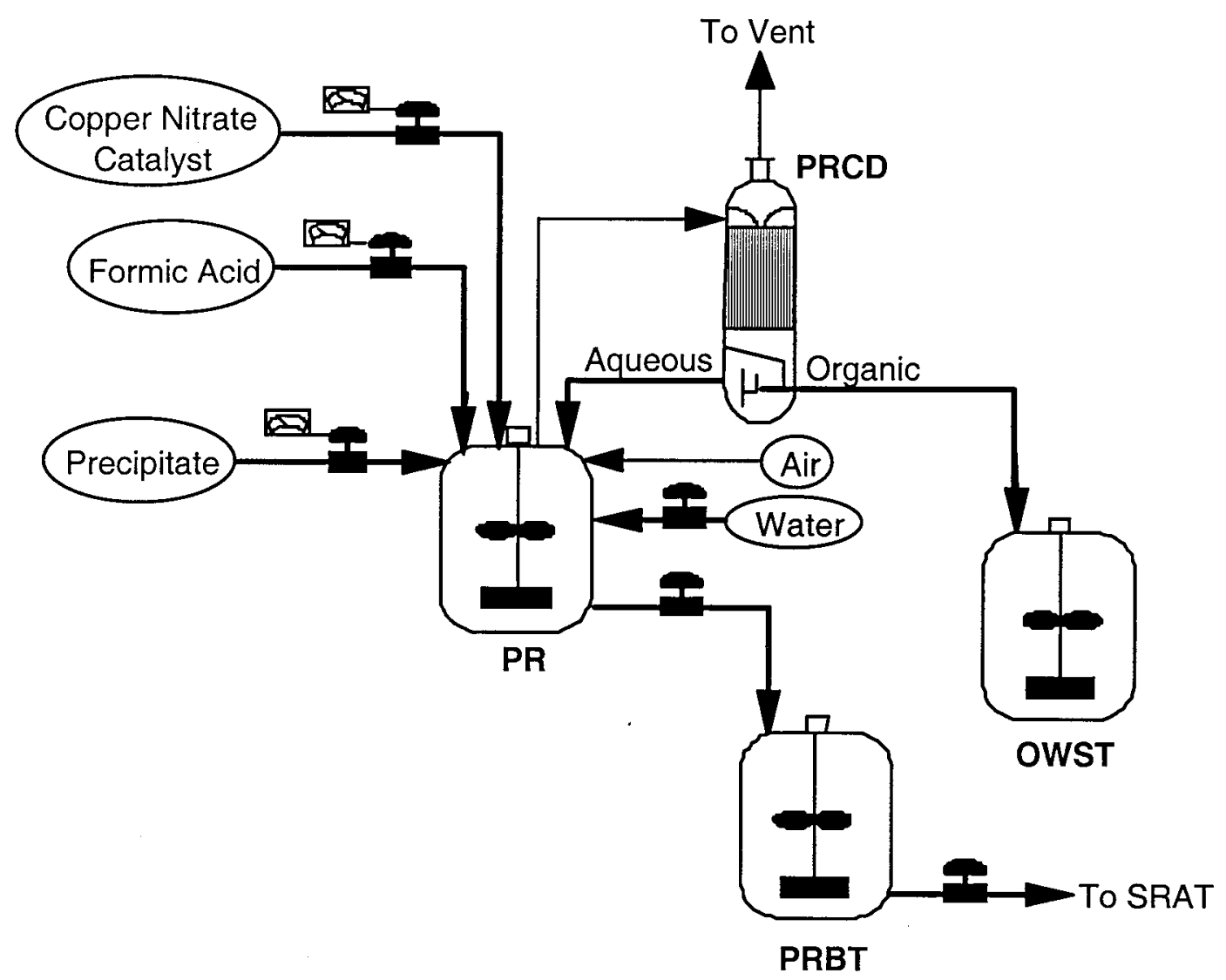

Figure 2.2-1. Schematic representation of DWPF Salt Cell model. 


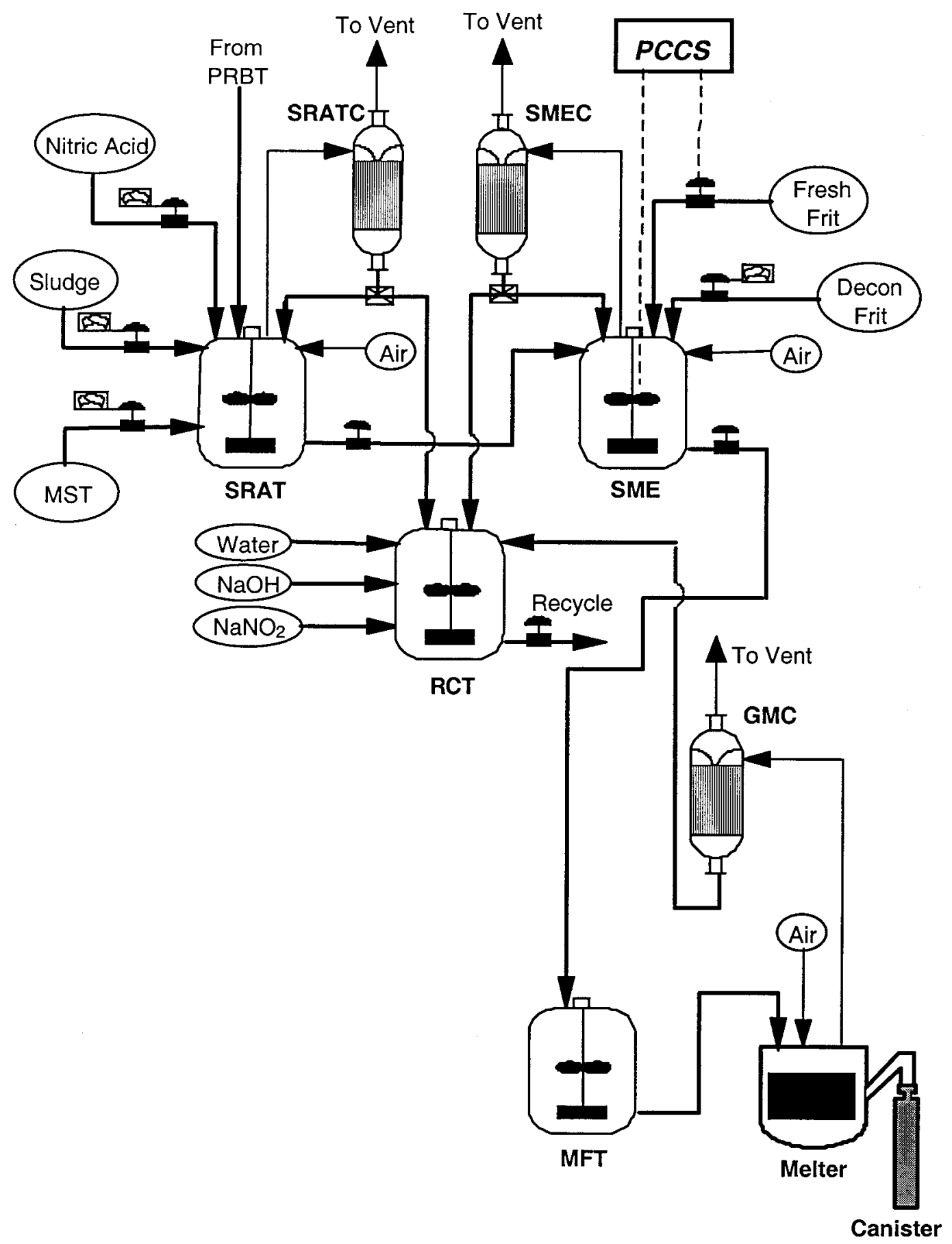

Figure 2.2-2. Schematic representation of DWPF Chemical and Melt Cell model. 


\subsubsection{SALTSTONE}

The Saltstone unit operation accepts decontaminated solutions from various processes in the alternative flowsheets. The Saltstone unit is treated as a sink; that is, the flows into it are integrated to monitor the volume and composition of material in the facility, but there is no other modeling done.

For the Direct Disposal Alternative, a time-dependent, 1-dimensional heat transfer calculation was performed. This calculation includes the effects of both heat of hydration and gamma/beta energy deposition. This model was used to determine the rate at which saltstone could be poured without exceeding its temperature criterion. (Reference 13) All saltstone material balances were determined according to Section A.10 of Appendix A.

\subsubsection{SINKS TO REPRESENT UNIT OPERATIONS NOT MODELED}

To keep the models as simple as possible, and to improve their performance, most of the recycle streams that would appear in the coupled HLW system flowsheet are treated as sinks. Off-gases are also treated as sinks. Any stream which has no effect on the evaluation of the alternative flowsheets is treated as a sink. All flows to sinks are integrated so that the total amount of material and composition in those streams can be assessed.

\subsection{Limitations on Production for Phase III Material Balances}

The limitations as described below were applied to the Phase III material balances for applicable short list alternatives.

\subsubsection{DWPF Canister Production}

Three of the salt disposition options send cesium, in some form, to the DWPF for vitrification. Estimating the life cycle cost for the entire HLW system will require that DWPF's production capability be estimated.

DWPF production rate is limited by the sustainable melt rate. Although slurry feed melters "similar" to the DWPF at different scales have shown a melt flux of 8 pounds per foot ${ }^{2}$-hour (228 pph, DWPF basis), DWPF has not sustained this rate. The apparent sustainable melt rate (FY 98 data) is about $195 \mathrm{pph}$. This is equivalent to 425 canisters per year, 4000 pounds net each at $100 \%$ attainment or 320 canisters at $75 \%$ attainment. Including an allowance for lengthy outages to changeout a melter, the long term average canister rate is $320(2 / 2.5)=256$ canisters per year.

A production rate of 320 (4000 pounds net) canisters per year is the maximum capability assumed for the operating life cycle cost estimates for the four proposed Salt Disposition flowsheets. 


\subsubsection{Chemical Processing Cell}

Over the past two years of radioactive operations, the Chemical Processing Cell (CPC) batch size has been increased to partially offset the longer than design basis cycle time (86 hours). This has increased the average canister production to $6.25 \mathrm{cans} / \mathrm{SME}$ batch. If the CPC is assumed to not limit the overall DWPF production rate then $320 / 6.25=50$ cycles per year are required (320/6.25), corresponding to $131 \mathrm{hrs}$ per batch $\left(8760^{*} 0.75 / 50\right)$ or 5.5 days. The CPC cycle time consists of the following steps:

SME: Transfer SRAT product to SME Heat and Concentrate Material (CDC frit) Add process frit and Concentrate Formic Acid Addition Analyze SME product SME Total

SRAT Sludge transfer to the SRAT

Sample and Analyze

Heat SRAT and Add Acids

Reflux to remove $\mathrm{Hg}$

Feed solution containing $\mathrm{Cs}$

Cool, Sample and Analyze

SRAT Total
2 hrs
40 hrs
30 hrs
4 hrs
$\underline{48 \mathrm{hrs}}$
$125 \mathrm{hrs}$

$$
\begin{array}{r}
14 \mathrm{hrs} \\
32 \mathrm{hrs} \\
6 \mathrm{hrs} \\
17 \mathrm{hrs} \\
20 \mathrm{hrs} \\
36 \mathrm{hrs} \\
\hline 125 \mathrm{hrs}
\end{array}
$$

\subsubsection{Salt Processing Cell}

If the SPC is assumed to not limit the overall production rate and salt workoff is maximized such that two salt cell batches are required for each CPC batch then 100 SPC batches per year are required. The maximum SPC cycle time is $65 \mathrm{hrs}$. This results in an expected vs. design basis cycle time ratio of $1.41(65 / 46)$ and is considered reasonable when compared to the CPC actual vs. design basis ratio of $1.45(125 / 86)$. The SPC cycle time is therefore:

SPC: Make-up and analyze PR heel $12 \mathrm{hrs}$

Heat PR and Feed Precipitate 4000 gallons @ 30 gpm 5 hrs

Hold at 90 degree $\mathrm{C}$

$5 \mathrm{hrs}$

Reflux

$10 \mathrm{hrs}$

Sample and Analyze PR

$20 \mathrm{hrs}$

Post purge Sample

$12 \mathrm{hrs}$

Transfer to PRBT

2 hrs

Total SPC

$66 \mathrm{hrs}$

Based on the maximum batch size of 4000 gallons, the annual $10 \mathrm{wt} \%$ precipitate usage is 400,000 gallons or on a continuous basis $1.0 \mathrm{gpm} @ 75 \%$ attainment. This equates to a salt (6.44M Na) workoff rate of $16.5 \mathrm{gpm} @ 75 \%$ attainment or $6,500,000$ gallons of $6.44 \mathrm{M} \mathrm{Na}$ Salt solution on an annualized basis. 
The salt cell rate can only be improved by increasing the TPB solids content. An increase from 10 to $12 \mathrm{wt} \%$ would allow the salt workoff rate to increase by $20 \%$ or to $7,800,000$ gallons of $6.44 \mathrm{M}$ salt solution. This proposal has not been demonstrated.

Note that the SPC process may have other rate limitations (such as the time required for in-leakage testing) which may require additional development.

\subsubsection{Salt Removal Limitations}

The salt removal limitation has been provided as a long-term average of $6,000,000$ gallons per year. Two cases are derived from this limitation.

For options which do not couple with the DWPF, the salt workoff rate is $6,000,000$ gallons per year. This equates to $11.4 \mathrm{gpm} @ 100$ attainment, or $15.2 \mathrm{gpm} @ 75 \%$ attainment corresponding to 154,000 gallons per week. Since Saltstone operates on a 8 hour per day / 5 day per week basis ( $6 \mathrm{hrs} /$ day actual grout production), the design basis Saltstone rate is $85 \mathrm{gpm}$ of $6.44 \mathrm{M}$ salt solution $(154,000 \mathrm{gallons} / 30 \mathrm{hr} / 60 \mathrm{~min} / \mathrm{hr}$ ) or 92 gpm of $6.0 \mathrm{M}$ salt solution. The $100 \mathrm{gpm}$ mixer design is recommended.

For options which couple with DWPF, 6,000,000 gallons made available every year equates to $6,000,000 * 2.5 / 2=7,500,000$ gallons made available in any given year. The salt processing facilities have 60 days of product storage included in the phase 3 flowsheets. This allows the options to operate 2.17 years out of every 2.5 years or workoff $6,900,000$ gallons of $6.44 \mathrm{M}$ salt solution on an annualized basis.

Salt workoff rates are therefore $13.1 \mathrm{gpm} @ 100 \%$ attainment or $17.5 \mathrm{gpm} @ 75 \%$ attainment.

\subsection{Impact on CST}

Recent sizing calculations and discussions with the subject matter experts resulted in the development of an improved CST loading strategy which will use three columns in series (with a fourth column for resin change out). The first column is loaded until $>90 \%$ breakthru, which results in the highest loading of Cs on the CST and results in the lowest CST usage (also lowest material cost). The resin is expected to be loaded to $90 \%$ of capacity vs. the $75 \%$ used for Phase II. The second column is sized to contain the mass transfer zone at $5.0 \mathrm{~cm} / \mathrm{min}$ and results in a single train column size of $5 \mathrm{ft}$ diameter $\mathrm{x} 16$ $\mathrm{ft}$ long. A third column serves as an on-line guard column since at $100 \%$ breakthru on the first column the second column may not always achieve the $40 \mathrm{nCi} / \mathrm{gm}$ effluent concentration.

The $5 \mathrm{~cm} / \mathrm{min}$ velocity will allow $24 \mathrm{gpm}$ of $5.6 \mathrm{M}$ salt solution to be processed or 20.8 gpm of $6.44 \mathrm{M}$ salt solution. This ensures the highest salt workoff removal rate of 19.0 gpm is covered and an operating margin is provided. 
The rate of CST produced at $24 \mathrm{gpm}$ can be processed in 320 canisters per year of DWPF CST and Sludge.

\subsection{Impact on Solvent Extraction}

The pilot scale demonstration (Reference 22) used a scaled flowrate of $23.5 \mathrm{gpm}$ of $6.44 \mathrm{M}$ salt solution and required an organic flowrate of $6.5 \mathrm{gpm}$ (scaled) for a total flowrate of $30 \mathrm{gpm}$. The $25 \mathrm{~cm}$ contactor has a nominal capacity of $40 \mathrm{gpm}$. The test indicated that the operating window with this solvent system will accommodate $30 \mathrm{gpm}$. Based on these results, the proposed salt flowrate of $17.5 \mathrm{gpm}$ can be obtained with 25 $\mathrm{cm}$ contactors.

\subsection{Salt Processing Rates}

The phase three material balances were completed at the following flowrates:

\begin{tabular}{|c|c|c|c|c|c|c|}
\hline Option & $\begin{array}{c}\text { Salt Workoff, } \\
\text { gpm @ } 6.44 \text { M } \\
{[\mathrm{Na}+] / 75 \% \text {, }} \\
\text { Attainment }\end{array}$ & $\begin{array}{c}\text { One Year's } \\
\text { Operating } \\
\text { Production, } \\
\text { gallons }\end{array}$ & $\begin{array}{c}\text { Long } \\
\text { Term } \\
\text { A verage } \\
\text { (gal/yr) }\end{array}$ & $\begin{array}{c}{[\mathrm{Na}+], \mathrm{M}} \\
\text { within } \\
\text { Facility }\end{array}$ & $\begin{array}{c}\text { Flowrate, } \\
\text { within } \\
\text { Facility } \\
\text { gpm }\end{array}$ & $\begin{array}{l}\text { Throughput } \\
\text { Limitation }\end{array}$ \\
\hline Grout & 15.2 & $6,000,000^{2}$ & $6,000,000$ & $\leq 6.0$ & 100.0 & $\begin{array}{l}\text { Salt Removal } \\
\text { Rate }\end{array}$ \\
\hline $\begin{array}{l}\text { Small } \\
\text { Tank ITP }\end{array}$ & 16.5 & $6,500,000$ & $5,642,000$ & $\begin{array}{l}6.44 \\
(4.7)\end{array}$ & $\begin{array}{c}16.5 \\
(22.6)\end{array}$ & $\begin{array}{l}\text { DWPF } \\
\text { Processing Rate }\end{array}$ \\
\hline $\begin{array}{l}\text { CST Ion } \\
\text { Exchange }\end{array}$ & 17.5 & $6,900,000$ & $6,000,000$ & 5.6 & 20.1 & $\begin{array}{l}\text { Spent Resin } \\
\text { Storage during } \\
\text { DWPF Melter } \\
\text { Outages }\end{array}$ \\
\hline Extraction & 17.5 & $6,900,000$ & $6,000,000$ & 6.44 & 17.5 & $\begin{array}{l}\text { Strip Solution } \\
\text { Storage During } \\
\text { DWPF Melter } \\
\text { Outages }\end{array}$ \\
\hline
\end{tabular}

\section{$2.5 \quad$ Approach To Layouts}

\section{Process Building}

The process building is of reinforced concrete construction and contains heavily shielded processing cells and maintenance areas partially below grade. The building is patterned after the SRS DWPF process building. Adjacent operating areas are at grade.

\footnotetext{
${ }^{1}$ The flowrate is not $19.0 \mathrm{gpm}$ based on a storage period of only two months.

${ }^{2}$ Since Direct Grout can operate while DWPF is in an outage for melter change-out, the facility can keep up with the salt removal rate of 6,000,000 gallons per year, even when DWPF is not vitrifying waste, until the Sludge Solids Receipt Tank and tanks between the new grout facility and DWPF are filled (total capacity of MST/Sludge slurry of about 40,000 gallons containing about 5 to $6 \mathrm{wt} \%$ insoluble solids).
} 
The shielded process cells are lined with stainless steel, and contain storage and processing tanks and components with agitators, transfer and sample pumps, and sumps with leak detection and leakage collection capability. The process cells are protected by concrete cell covers and are accessible with the use of a remotely operated overhead bridge crane. In-cell tanks and components are of a remotable design for ease of maintenance, replacement and later decommissioning. Interconnections between process tanks are accomplished through the use of remotable jumpers. An overhead bridge crane is provided to facilitate jumper changes and removal of equipment for maintenance. Process cell widths are set by the diameter of the largest vessel.

Shielded maintenance areas are provided for remoted equipment laydown, remoted equipment decontamination, and bridge crane maintenance. The building configuration permits crane access to all shielded process, maintenance and sampling areas.

The building footprint for three of the four alternatives is driven by the need for large 100,000 gallon salt storage and alpha sorption tanks to ensure a daily processing rate of 25,000 gallons per day. These tanks also decouple the continuous flow processes from the tank farm batch flows and ensure the capability to process the expected $6,000,000$ gallon/yr transfer capacity from the tank farm. Sizing of other process tanks were based on the type of process, a nominal $20 \mathrm{gpm}$ salt solution flow rate and the capacity necessary to support the daily process flow.

The operating area extends around the perimeter of the process cells and contains chemical feed pumps and tanks, laboratories for testing samples, electrical, mechanical equipment and HVAC areas, shielded filter backpulse chamber area, truck unloading area and maintenance and decon areas.

\section{Service Building}

A standard commercial office building which contains the control rooms (Process, Crane, and Supervising), maintenance shops (Mechanical, Manipulator Repair, Electrical and Instrumentation), direct supervision offices, and other change rooms.

\section{Office Building}

A standard commercial office building (approximately 100 people) is assumed for each option. See Appendix J.

\section{$\underline{\text { Site Plans }}$}

The site plans for the alternatives are provided in Appendix $K$. The direct grout alternative is sited in Z-Area where the permitted disposal site currently exists.

Small tank, solvent extraction, and CST are located near the current Latewash Facility. This location is optimum for reuse of existing interarea transfer lines. 


\subsection{SHORTLIST ALTERNATIVES}

\subsubsection{Common Issues}

\subsubsection{Mercury Removal}

As noted in phase II documentation, mercury removal is unnecessary if tanks containing higher concentrations of $\mathrm{Hg}$ can be successfully blended with waste containing little or no mercury. Based on the projected waste removal schedule, the small volumes of free supernate that exceed $260 \mathrm{mg} / \mathrm{L}$ mercury can be blended in a way that eliminates GT-73 ion exchange treatment to reduce the mercury concentration in feeds to the saltstone process. All of the salt compositions projected for each fiscal year are well within the limit of $260 \mathrm{mg} / \mathrm{L}$, with mercury concentrations no greater than about $50 \mathrm{mg} / \mathrm{L}$ for all four blend schemes. Accordingly, mercury removal using GT-73 ion exchange can be eliminated from the Direct Grout, the CST Ion Exchange and the Solvent Extraction alternatives. Mercury removal by precipitation in the Small Tank ITP process is an integral part of that process, and is unaffected by eliminating GT-73 ion exchange from mercury removal.

\subsubsection{Tank Farm Blending: MST Sorption Requirements for Alpha and Strontium}

After obtaining data on MST sorption kinetics, preliminary evaluation of tank sizing for batch MST sorption (Direct Grout, Solvent Extraction, and Non-Elutable Ion Exchange) and for continuous MST sorption (Small Tank TPB Precipitation) was performed.

To gain a perspective on the alpha and strontium sorption requirements, the average concentrations for the Tank Farm were evaluated. Using 72.5E6 gallons at 6.44 $\mathrm{M} \mathrm{Na}$, $\mathrm{Sg}=1.28$ at $6.0 \mathrm{M} \mathrm{Na}$, and using the quantities in Table 3.0-1 obtained from Appendix $\mathrm{D}$,

Table 3.0-1 Tank Farm Quantities

\begin{tabular}{|l|l|l|}
\hline \multicolumn{1}{|c|}{ Component } & Total $\mathrm{Ci}$ & Total gms \\
\hline $\mathrm{Pu} / \mathrm{Am}$ & $7.69 \mathrm{E} 4$ & $5.79 \mathrm{E} 4$ \\
\hline $\mathrm{U}$ & 9.07 & $1.74 \mathrm{E} 7$ \\
\hline $\mathrm{Np}$ & 3.22 & $4.57 \mathrm{E} 3$ \\
\hline $\mathrm{Sr}$ & $6.75 \mathrm{E} 4$ & $4.77 \mathrm{E} 2$ \\
\hline
\end{tabular}

the average values in Table 3.0-2 were computed. Table 2 also shows worst case (bounding) values as noted, the Saltstone Waste Acceptance Criteria, and the required $\mathrm{K}_{\mathrm{d}}$ for the bounding values assuming $0.2 \mathrm{~g} / \mathrm{L}$ of MST. 
Table 3.0-2 Tank Farm Concentrations @ 6.0 $\mathrm{M} \mathrm{Na}^{+}$

\begin{tabular}{|c|c|c|c|c|c|c|}
\hline & \multicolumn{2}{|c|}{ Concentration } & \multicolumn{2}{|c|}{ Activity } & \multirow{2}{*}{$\begin{array}{c}\text { Saltstone } \\
\text { WAC } \\
(n C i / g)\end{array}$} & \multirow{2}{*}{$\begin{array}{c}\text { Required } K_{d} \\
w / 0.2 \mathrm{~g} / \mathrm{L} \\
M S T\end{array}$} \\
\hline Component & $\begin{array}{c}\text { Average } \\
(m g / L)\end{array}$ & $\begin{array}{c}\text { Bounding } \\
(m g / L)\end{array}$ & $\begin{array}{c}\text { Average } \\
(n \mathrm{Ci} / \mathrm{g})\end{array}$ & $\begin{array}{c}\text { Bounding } \\
(n \mathrm{Ci} / \mathrm{g})\end{array}$ & & \\
\hline $\mathrm{Pu} / \mathrm{Am}$ & 0.20 & $1.0^{1}$ & 205 & $1000^{1}$ & $18(\operatorname{total} \alpha)$ & $2.73 \mathrm{E} 5$ \\
\hline $\mathrm{U}$ & 59.1 & $1030^{2}$ & 0.024 & $0.62^{2}$ & $18($ total $\alpha)$ & not req'd \\
\hline $\mathrm{Np}$ & 0.016 & $1.8^{3}$ & 0.009 & $1.0^{3}$ & 0.03 & $3.67 \mathrm{E} 4$ \\
\hline $\mathrm{Sr}$ & 0.0016 & $0.0095^{4}$ & 178 & $1050^{4}$ & 40 & $1.26 \mathrm{E} 5$ \\
\hline & $\begin{array}{l}{ }^{1} \text { Based } \\
2 \text { Based } \\
{ }^{3} \text { Based } \\
{ }^{4} \text { Based }\end{array}$ & $\begin{array}{l}\mathrm{p}-237 \text { in } \mathrm{T} \\
\mathrm{r}-90 \text { in Tan }\end{array}$ & $\begin{array}{l}: 1.8 \mathrm{Ci} \text { in } \\
280 \mathrm{Ci} \text { in }\end{array}$ & $\begin{array}{l}\text { A gallons } \\
\text { M gallons }\end{array}$ & $\begin{array}{l}\mathrm{s} \\
\left.\mathrm{Na}^{+}\right) \\
\left..0 \mathrm{M} \mathrm{Na}^{+}\right) \\
\left.6.0 \mathrm{M} \mathrm{Na}^{+}\right)\end{array}$ & \\
\hline
\end{tabular}

Note: One tank provides a much higher "bounding" value for $\mathrm{Sr}$ than Tank 19. It is Tank 11 which contains approximately $30,000 \mathrm{nCi} / \mathrm{g}$. The required $\mathrm{K}_{\mathrm{d}}$ would be $3.75 \times 10^{6}$ for $0.2 \mathrm{~g} / \mathrm{L}$ MST. This required $\mathrm{K}_{d}$ is not achievable based on the data in Reference 9. The contents of this tank need to be blended over several salt batches.

Conclusions drawn from Table 3.0-2 include:

- While the concentration of $U$ can be high, its contribution to total $\alpha$ is negligible.

- Based on data in Reference 9, it appears the required $K_{d}$ for the bounding $N p$ is so high that removal by MST is not likely to be successful. Tanks 33 and 34, which contain essentially all the $\mathrm{Np}$ in the Tank Farm, need to be blended over several salt batches.

- The predicted TRU "spikes" contribute the most burden to meeting the total $\alpha$ removal requirements. (Approximately 65\% of TRU is predicted to arrive in just two out of 12.5 years for the CST blends; these spike are reflected in the bounding $\mathrm{Pu} / \mathrm{Am}$ concentration.)

Table 3.0-3 shows the experimental matrix used in the MST kinetics studies compared with the average and maximum Tank Farm values.

Table 3.0-3 Experimental vs. Actual

\begin{tabular}{l|c|c|c|}
\cline { 3 - 4 } \multicolumn{2}{c|}{} & \multicolumn{2}{c|}{ Tank Farm } \\
\hline \multicolumn{1}{c|}{ Parameter } & Experimental & Avg & Max \\
\hline $\mathrm{Na}+-\mathrm{M}$ & $4.5,6.0,7.5$ & -- & -- \\
\hline $\mathrm{MST}-\mathrm{g} / \mathrm{L}$ & $0.2,1.1,2.0$ & -- & -- \\
\hline $\mathrm{Pu}-\mathrm{mg} / \mathrm{L}$ & $\sim 0.1, \sim 1.0^{1}$ & 0.20 & 1.0 \\
\hline $\mathrm{U}-\mathrm{mg} / \mathrm{L}$ & $\sim 1.0, \sim 10^{1}$ & 59.1 & 1030 \\
\hline $\mathrm{Np}-\mathrm{mg} / \mathrm{L}$ & $\sim 4.0, \sim 40^{1}$ & 0.016 & 1.8 \\
\hline $\mathrm{Sr}-\mathrm{mg} / \mathrm{L}$ & $\sim 0.1, \sim 1.0^{1}$ & 0.0016 & 0.0095 \\
\hline
\end{tabular}


A quick estimate of $\mathrm{TiO}_{2}$ in the glass from MST (which is $80 \% \mathrm{TiO}_{2}$ ) can be used to put the MST concentrations in perspective. Assuming $15 \mathrm{gal} / \mathrm{min}$ salt solution at $75 \%$ utility and $900 \mathrm{k}$ lbs of glass per year $(225 \mathrm{cans} / \mathrm{yr})$, the $\mathrm{TiO}_{2}$ concentration for $1.1 \mathrm{~g} / \mathrm{L} \mathrm{MST}$ of salt solution is $\sim 6.0 \mathrm{wt} \%$ in the glass - which is $6 \mathrm{X}$ higher than the current glass limit. Experimental work should be performed at MST $\leq 0.2 \mathrm{~g} / \mathrm{L}$.

Table 3.0-3 also indicates most of the radionuclide concentrations are not in the correct ranges. The $\mathrm{U}$ should be much higher while the $\mathrm{Np}$ and the $\mathrm{Sr}$ should be much lower. While the uranium contribution to total $\alpha$ is negligible, its very high concentration could compete for MST capacity.

\section{Conclusions:}

- The experimental matrix for MST kinetics studies needs to be redefined to better reflect the predicted salt solution blends.

- Future studies need to be at lower MST concentrations consistent with DWPF glass limits.

- While the uranium contribution to total $\alpha$ is negligible, its very high concentration could compete for MST capacity.

- Tank 11 needs to be carefully blended to avoid excessive Sr.

- Tanks 33 and 34 need to be carefully blended to average out the Np concentration.

- If possible, the predicted spikes in TRU should be avoided by blending.

\subsubsection{Batch Removal of Alpha and Strontium}

Three of the four options use MST to sorb alpha (from $\mathrm{Pu}, \mathrm{U}$, and $\mathrm{Np}$ ) and $\beta / \gamma$ (from $\mathrm{Sr}$ ) in batches of approximately $100 \mathrm{k}$ gallons at about $6 \mathrm{M} \mathrm{Na}^{+}$. The batch cycle allows 24 hours for the sorption to progress sufficiently for sample analysis and confirmation. The 24-hour hold period is evaluated using the kinetic information supplied in the recent MST kinetics studies (Reference 9). Some of the data in the following discussion is not contained in Reference 9 but is taken from data files supplied by the authors.

The total $\alpha$ requirement for Saltstone is $<18 \mathrm{nCi} / \mathrm{g}$. As discussed in the previous section, essentially all the alpha removal burden comes from $\mathrm{Pu}$. (While $\mathrm{Np}-237$ is also an alpha emitter, it has its own limit of $0.03 \mathrm{nCi} / \mathrm{g}$.) The bounding $\mathrm{Pu}$ removal requirement is 1000 $\mathrm{nCi} / \mathrm{g}$ down to 18 ; a DF of $\sim 56$ requiring a $\mathrm{K}_{\mathrm{d}}$ of $2.73 \times 10^{5}$.

It is difficult to evaluate the time for $\mathrm{Pu}$ removal directly from Reference 9 or from the data tables because the experimental matrix does not match the projected salt blends. The closest match of experimental data is the low activity solution with $0.2 \mathrm{~g} / \mathrm{L}$ MST. This data was collected at 7.5 and $4.5 \mathrm{M} \mathrm{Na}^{+}$while the operating sodium concentration will be approximately $6 \mathrm{M}$. The data in Table VI (Reference 9) clearly show a strong dependence on sodium molarity - likely due to ionic strength and viscosity (i.e., 
diffusivity). Figure 3.0-1 shows this data on a log plot including, for comparison, $6.0 \mathrm{M}$ with $1.1 \mathrm{~g} / \mathrm{L}$ MST and the required DF. If the required DF is plotted so that it falls between $4.5 \mathrm{M}$ and $7.5 \mathrm{M}$, it is parallel to the $6.0 \mathrm{M}$ and indicates a hold time of about 34 hours for an MST concentration of $1.1 \mathrm{~g} / \mathrm{L}$.

This approach is not rigorous and is intended only to provide an understanding for whether or not the required DF at bounding conditions can be achieved. It would appear that it may not - although treatment in a larger vessel with more holdup time would certainly provide sufficient decontamination.

Figure 3.0-1

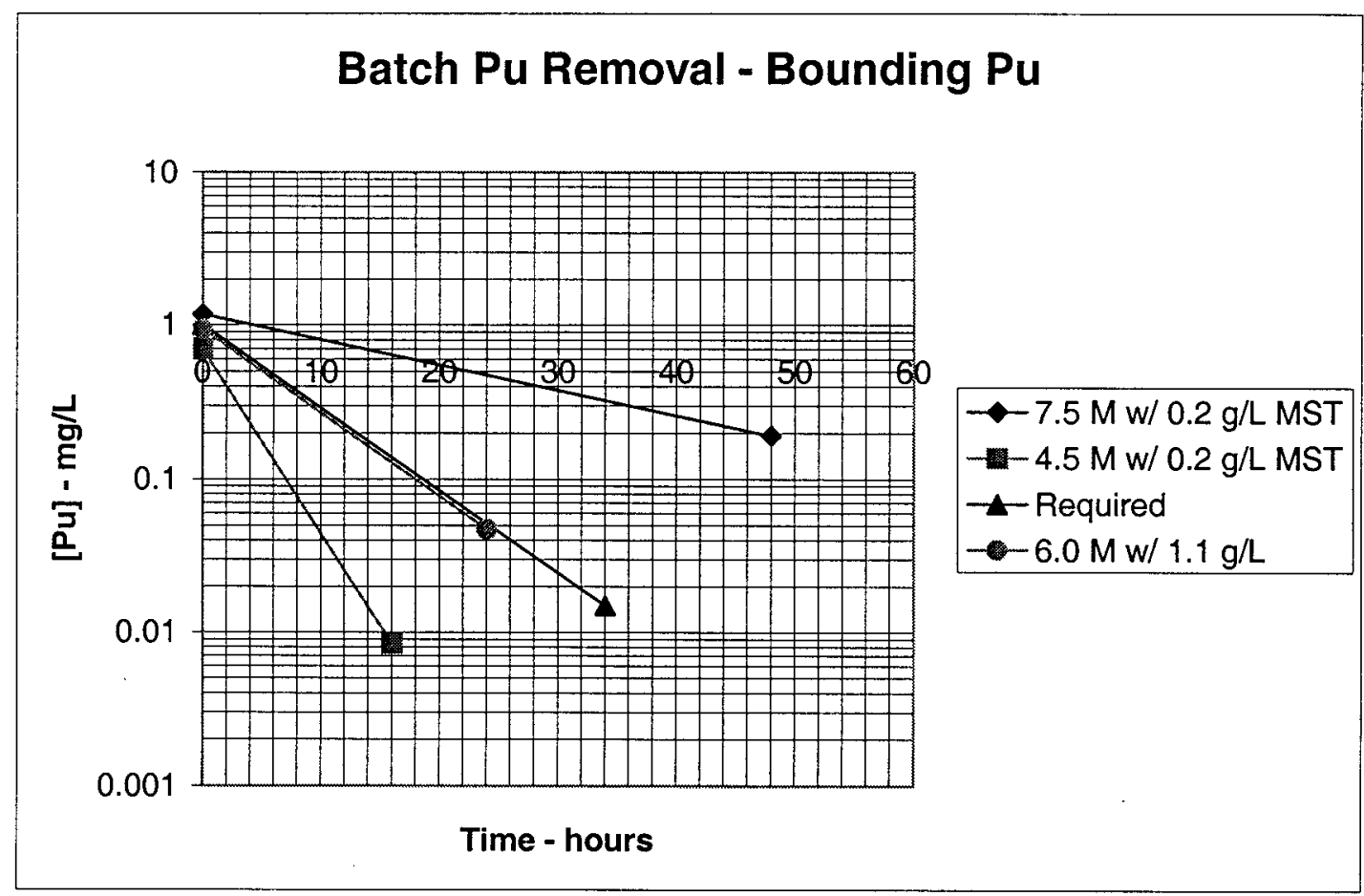

A similar treatment of $\mathrm{Sr}$ removal is shown in Figure 3.0-2. The data used is based on the 24-hour samples. In this case, the bounding $\mathrm{Sr}$ concentration and required removal are well below the experimental data. However, the slope for the required removal is almost exactly the same as for the $4.5 \mathrm{M}$ at $0.2 \mathrm{~g} / \mathrm{L}$ and the $6.0 \mathrm{M}$ at $1.1 \mathrm{~g} / \mathrm{L}$. It would appear that a 24-hour hold time may be sufficient for the bounding $\mathrm{Sr}$ removal. 
Figure 3.0-2

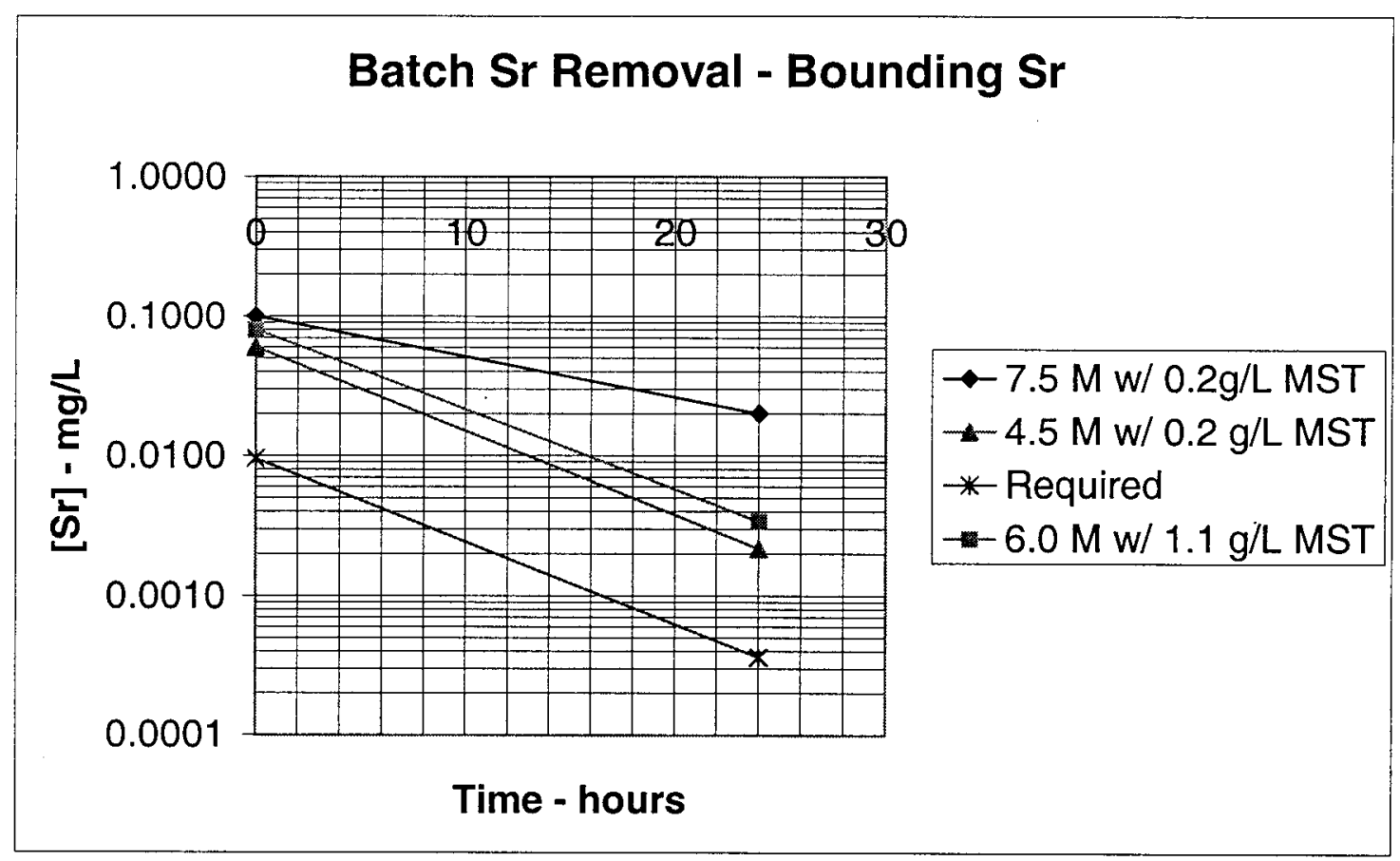

\section{Conclusions:}

- More experimental work is required to provide the required removal data for batch reactor design.

- The 24-hour hold period for removal of bounding $\alpha$ may not be long enough. The required time may be about $50 \%$ longer than that.

The 24-hour hold period appears to be just sufficient for removal of bounding Sr.

\subsubsection{Filtration of MST/Sludge}

Recent filter performance tests show that cross-flow filtration can be used to remove insoluble sludge and MST solids from the salt stream without TPB present. Pilot scale data were obtained using the Filter Research Engineering Demonstration unit (FRED) located at the University of South Carolina in Columbia (Reference 10). The FRED unit contains seven filter tubes each of which are 10 feet long. The FRED unit has a filter surface area of $11.2 \mathrm{ft}^{2}$. The FRED results were independently checked using similar conditions for the Parallel Rheological Experimental Filter (PREF) located at the SRS (Reference 11). The PREF contains a single Mott filter tube that is 4 feet long and has a filter surface area of $1.05 \mathrm{ft}^{2}$. The tubes in both units have a specified porosity of 0.50 microns. 
Filtrate flux remained above $0.05 \mathrm{gpm} / \mathrm{ft}^{2}$ for 24 hours in a filtration time test using the FRED unit. This flux was maintained using $0.62 \mathrm{~g} / \mathrm{L}$ and $9.3 \mathrm{~g} / \mathrm{L}$ solids concentrations (Reference 10).

At least four process variables control the filtrate flux through the surface of the filter tubes. If the concentration of insoluble solids in the feed to the alpha sorption process is low, then filtration can continue through several batches of salt solution. However, only gravity settling will be used to minimize the insoluble solids concentration in the salt feeds. Thus, low solids content is not readily controlled, and other variables must be used. Tests have been completed using a range of MST/sludge solids concentrations (suspended fines, $0.62 \mathrm{~g} / \mathrm{L}, 1.24 \mathrm{~g} / \mathrm{L}, 9.3 \mathrm{~g} / \mathrm{L}$ ). The suspended fines simulate conditions when filtration begins, while the other concentrations represent the effect of concentrating the slurry by filtration. (Reference 10 )

The thickness of the filter cake that builds up on the tube surface(s) can be minimized by periodically back-flushing (back-pulsing) through the filters to dislodge solids collected on the surface of the filters. Back-pulsing relies on a rapid reversal of the transmembrane differential pressure $(\Delta \mathrm{P})$ to remove filter cake from the filter surface. The backpulsing design has been implemented, installed and operated in the existing ITP facilities. Higher axial flow velocity through the tubes sweeps insoluble solids through the unit, rather than building up a thicker filter cake on the tubes. High velocity also assists in purging solids dislodged during backpulsing. An axial velocity ranging from 4 to $14 \mathrm{ft} / \mathrm{sec}$ was used in tests at USC and SRTC. Changing the $\triangle \mathrm{P}$ across the filter unit can also be altered to enhance or retard the filtrate flux.

Examples of data obtained at a $\Delta \mathrm{P}$ of $30 \mathrm{psi}$ in initial tests are shown in Table 3.0-4. These results enable a preliminary estimate of the surface area requirements, and axial velocity for filtration. This $\Delta \mathrm{P}$ was selected as the basis for this calculation because flux over a range of $\Delta \mathrm{P}$ peaked at $30 \mathrm{psi}$ under conditions used in these tests. Based on the observed minimum and maximum flux over a broad range of conditions, a median flux of $0.07 \mathrm{gpm} / \mathrm{ft}^{2}$ is projected for this operation. To yield filtrate production rate of $50 \mathrm{gpm}$, a minimum of $715 \mathrm{ft}^{2}$ of filter surface area is specified. The axial velocity should be maintained in the range of 9 to $12 \mathrm{ft} / \mathrm{sec}$.

Based on $715 \mathrm{ft}^{2}$ of filter surface and the tube dimensions in the existing filter unit now installed in ITP (10 ft long, 0.723 inside diameter), each filter unit for the alpha sorption process using MST will contain around 380 tubes. To maintain the axial velocity used in the experimental units, a total volumetric flow of about 5000 gallons per minute is required.

These results apply to the direct grout disposal, CST ion exchange, and solvent extraction alternatives. 
Table 3.0-4 Filter Flux Dependence on Flow Velocity

\begin{tabular}{|c|c|c|c|c|c|c|}
\hline & \multicolumn{3}{|c|}{ PREF } & \multicolumn{3}{|c|}{ FRED } \\
\hline $\begin{array}{r}\text { Transmembrane } \\
\text { Pressure }=\end{array}$ & \multicolumn{3}{|c|}{$(\Delta P)=30$} & \multicolumn{3}{|c|}{$(\Delta P)=30$} \\
\hline Solids Loading $=$ & \multicolumn{3}{|c|}{$9.3 \mathrm{~g} / \mathrm{L}$} & \multicolumn{3}{|c|}{$9.3 \mathrm{~g} / \mathrm{L}$} \\
\hline & \multicolumn{3}{|c|}{ Flux, gpm $/ \mathrm{ft}^{2}$} & \multicolumn{3}{|c|}{ Flux, gpm/ft" } \\
\hline Axial Flow Velocity & minimum & median & maximum & minimum & median & maximum \\
\hline 4 & 0.045 & 0.048 & 0.050 & 0.035 & 0.035 & 0.035 \\
\hline 6 & 0.045 & 0.058 & 0.070 & 0.039 & 0.045 & 0.050 \\
\hline 9 & 0.050 & 0.080 & 0.11 & 0.041 & 0.052 & 0.062 \\
\hline 12 & 0.070 & 0.105 & 0.14 & 0.055 & 0.068 & 0.080 \\
\hline 14 & 0.085 & 0.102 & -- & 0.068 & 0.074 & -- \\
\hline
\end{tabular}

\begin{tabular}{|c|c|c|c|c|c|c|}
\hline & \multicolumn{3}{|c|}{ PREF } & \multicolumn{3}{|c|}{ FRED } \\
\hline $\begin{array}{l}\text { Transmembrane } \\
\text { Pressure }\end{array}$ & \multicolumn{3}{|c|}{$(\Delta \mathrm{P})=30$} & \multicolumn{3}{|c|}{$\left({ }_{\Delta} \mathrm{P}\right)=30$} \\
\hline Solids Loading $=$ & \multicolumn{3}{|c|}{$0.62 \mathrm{~g} / \mathrm{L}$} & \multicolumn{3}{|c|}{$0.62 \mathrm{~g} / \mathrm{L}$} \\
\hline & \multicolumn{3}{|c|}{ Flux, gpm/ft ${ }^{2}$} & \multicolumn{3}{|c|}{ Flux, gpm/ft ${ }^{2}$} \\
\hline Axial Flow Velocity & minimum & median & maximum & minimum & median & maximum \\
\hline 4 & 0.070 & 0.048 & 0.115 & 0.035 & 0.035 & 0.035 \\
\hline 6 & 0.075 & 0.058 & 0.135 & 0.039 & 0.045 & 0.050 \\
\hline 9 & 0.080 & 0.080 & 0.15 & 0.041 & 0.052 & 0.062 \\
\hline 12 & 0.10 & 0.105 & 0.17 & 0.055 & 0.068 & 0.080 \\
\hline 14 & 0.12 & 0.102 & -- & 0.068 & 0.074 & \\
\hline
\end{tabular}

\begin{tabular}{|c|c|c|c|c|c|c|}
\hline & \multicolumn{3}{|c|}{ PREF } & \multicolumn{3}{|c|}{ FRED } \\
\hline $\begin{array}{r}\text { Transmembrane } \\
\text { Pressure }=\end{array}$ & \multicolumn{3}{|c|}{$(\Delta P)=30$} & \multicolumn{3}{|c|}{$\left({ }_{\Delta} \mathrm{P}\right)=30$} \\
\hline Solids Loadina $=$ & \multicolumn{3}{|c|}{ Suspended Fines } & \multirow{2}{*}{\multicolumn{3}{|c|}{ Suspended Fines }} \\
\hline \multirow{3}{*}{$\begin{array}{c}\text { Axial Flow Velocity } \\
4\end{array}$} & \multicolumn{3}{|c|}{ Flux, gpm/ft ${ }^{2}$} & \multicolumn{2}{|c|}{ Flux, gpm/ft ${ }^{2}$} & \\
\hline & minimum & median & maximum & minimum & median & maximum \\
\hline & 0.45 & 0.45 & 0.45 & 2.1 & 2.1 & -- \\
\hline 6 & 0.50 & 0.54 & 0.59 & 1.8 & 1.9 & 2.1 \\
\hline 9 & 0.65 & 0.80 & 0.95 & 1.4 & 1.7 & 2.0 \\
\hline 12 & 1.0 & 1.0 & -- & 1.8 & 1.8 & 1.8 \\
\hline 14 & -- & -- & -- & 1.8 & 1.8 & .. \\
\hline
\end{tabular}




\subsection{DIRECT GROUT}

\subsubsection{Alternative Description}

In this proposed process, ${ }^{137} \mathrm{Cs}$ is not separated from the salt waste or concentrated supernate. All soluble waste is sent to a new shielded grout production facility. The saltstone waste form generated from dissolved saltcake solution must meet NRC Class C LLW disposal requirements for near-surface disposal. The vaults presently used in the Saltstone Facility meet current regulations for NRC Class $\mathrm{C}$ disposal, although the current permit restricts the average Ci content in a disposal unit (cell) to be within NRC Class A limits for disposed saltstone. Treatment of salt solution is required to remove entrained sludge so that soluble alpha activity is no greater than $100 \mathrm{nCi} / \mathrm{g}$. If the mercury concentration in the solution is greater than $260 \mathrm{mg} / \mathrm{L}$, it must also be treated to remove mercury before converting the solution to saltstone. At the projected concentration of ${ }^{137} \mathrm{Cs}$, grout production must be done within a new shielded cell facility, using grout production equipment modified to enable remote operation and maintenance.

In the proposed Direct Grout alternative, the concentrated supernate and salt cake solution are combined and transferred to a tank within the new shielded facility. The solution is first treated to remove soluble alpha contaminants by sorbing them on monosodium titanate (MST). The resulting slurry is then filtered to remove the MST and any entrained sludge solids that accompany the salt solution (see Section A.14). The filtrate from the MST treatment would then be processed to produce saltstone grout for disposal.

The grout composition is based on formulations that are the same as the current Saltstone Facility (see Section A.10). The clarified salt solution must be diluted either to the greater of $6.0 \mathrm{M}$ sodium concentration or diluting the ${ }^{137} \mathrm{Cs}$ concentration such that the final solid waste product does not exceed $4600 \mathrm{Ci}{ }^{137} \mathrm{Cs}$ per cubic meter. Dry materials are added at the rates provided in Appendix A.

\subsubsection{Results}

Figure 3.0-3 shows a schematic representation of the Direct Grout material balance model. The model feeds salt solution batches into the Alpha Sorption Tank (AST). MST slurry (11 wt\% MST in water) is added to the tank in $10 \%$ excess over the stoichiometric amount required to complex uranium, strontium and plutonium salts in the solution. Each AST batch is held for 24 hours to simulate the adsorption process. Following the hold time, the AST batch is continuously passed through a filtration step. For this model, filter is assumed to be $100 \%$ efficient in removing solids from the incoming salt solution. The solids fraction includes metal oxides, MST and MST complexes of ${ }^{90} \mathrm{Sr}$ and TRU contaminants. Output from the filter is separated into filtrate and solids slurry streams. Water is added to the solids stream at the specified flush ratio. The filtrate is collected in the Salt Solution Holding Tank (SSHT) and from there fed continuously to the grout 
plant. The solids fraction is collected in the Sludge Slurry Receipt Tank (SSRT). The volume of material collected in the SSRT is added as an input stream to the DWPF model.

In the grout plant model, cement, fly ash and slag are blended to the current specification for salt solution and then added in the ratio currently used for premix in the saltstone production facility. The blended premix is then added to the salt solution based on the water content of the salt solution feed to the mixer. A water-to-premix ratio of 0.57 was used to determine the amount of premix to add. The model checks that the salt solution meets the processing constraints of no more than $4600 \mathrm{Ci}{ }^{137} \mathrm{Cs}$ per cubic meter and 6.0 $\mathrm{M}$ sodium. If the solution fed to the mixer exceeds either of these values, dilution water is added such that the constraints will be met.

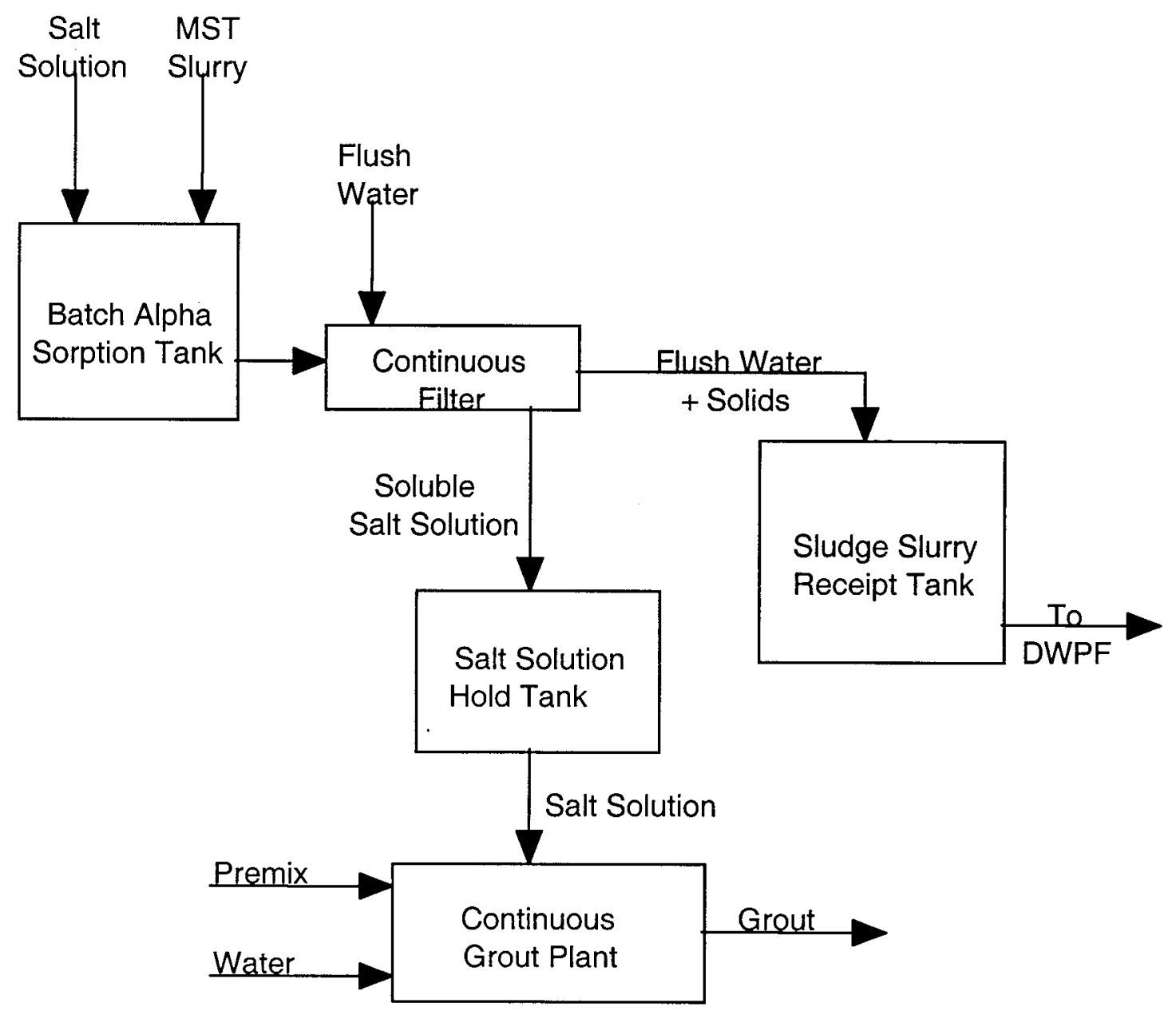

Figure 3.0-3. Schematic representation of Direct Grout model. 


\section{Selection of the FY2010 Blend}

Using the Tank Farm waste inventory database, the compositions of soluble waste in each tank were converted into vectors suitable for input to various Speedup computer models (Appendix D). This set of Tank composition vectors were combined with the blending outputs from ProdMod to develop projected soluble waste compositions for the various alternatives. The TFARM waste blending module was developed to track the mass of up to 34 waste components through the projected removal and blending operations. The TFARM module generates an output vector of waste composition that serves as the input vector for process models.

Thirteen separate waste compositions representing the volume of waste to be processed in a given fiscal year were prepared for possible input to the process model for the Direct Disposal as Grout Alternative. These compositions were reviewed to select one composition to serve as the basis for the subsequent material balance calculations completed by the process model. For this alternative, three contaminants are of concern, specifically ${ }^{137} \mathrm{Cs}$, transuranics and mercury.

The FY2010 composition was selected based on the highest mercury concentration $(\sim 50$ $\mathrm{mg} / \mathrm{L})$, the second highest $\mathrm{Cs}$ concentration $(\sim 1.7 \mathrm{Ci} / \mathrm{gal})$, and an unusually high alpha concentration $(\sim 600 \mathrm{nCi} / \mathrm{g})$. This alpha concentration is 4 to 5 times higher than the overall average for the tank farm. The high alpha content translates directly into increased demand for MST, which is the only significant contributor to the waste vitrification process from the Direct Disposal of Grout alternative. Accordingly, this composition is ideal to test the process capacity, since additional titanate usage requires higher production rates through the MST alpha sorption operation. The increased usage of titanate should also generate more saltstone, since a higher volume of titanate will require additional wash water to minimize the alkali content in the stream sent to the DWPF for conversion to glass. Thus the material balance for this composition represents a bounding composition for this alternative.

\section{Thermal Modeling of Saltstone Curing}

A heat transfer model of the saltstone pouring and curing process was developed to predict temperature transients in saltstone to guide the frequency of pouring into a vault cell during periods of high production of saltstone (Reference 12). This model was modified to determine the impact of higher concentrations of ${ }^{137} \mathrm{Cs}$ on the temperature transients during curing (Reference 13). Results show that hydration heat remains the major contributor to the peak temperature in a large monolith of saltstone. The peak temperature is reached in about 3 months after a cell is filled. Decay heat is only a minor contributor to the peak temperature reached within the waste. The principal effect observed because of higher ${ }^{137} \mathrm{Cs}$ in the waste is a reduced rate of cooling after closure of the landfill is completed. 
Previously, the model showed the temperature limit of $95^{\circ} \mathrm{C}$ would not be exceeded during extended daily production if daily grout pours alternated between at least 3 disposal cells. A similar approach for the Direct Disposal of Grout will also eliminate the need for special cooling in the vaults. Based on model results, this approach predicts a peak grout temperature of less than $90^{\circ} \mathrm{C}$ if at least 4 cells are used in the pouring rotation. With 6 cells in the rotation, the peak temperature does not exceed $70^{\circ} \mathrm{C}$. Accordingly, the design of the grout transfer lines to the vault include a provision to alternate daily pours among a set of 6 disposal cells. All other alternatives will require a similar (unshielded) modification to enable alternating grout pours between at least 4 cells. By alternating between cells, a cooling system in the disposal vaults to remove the heat from the hydration of dry materials is not needed, if the grout temperature is less than $40^{\circ} \mathrm{C}$ at the time of pouring.

\section{$\underline{\text { Vault Design }}$}

Based on the results of the thermal modeling, the vault design for this alternative was assumed to be the same as the existing Saltstone vault (which meets Class C requirements) with the additional attributes noted below:

- A 500-scfm ventilation system with HEPA filters is required to control contamination during vault filling;

- The roof concrete thickness is increased to 18 inches for shielding;

- Two thermocouple assemblies were assumed for each cell;

- A valve box and associated piping are provided to meet the six cell pouring rotation as required by the energy balance;

- A six cell $\left(100^{\prime} \times 100^{\prime} \times 25^{\prime}\right)$ vault design is assumed to meet the pouring rotation requirement.

\section{$\underline{\text { Saltstone Properties and Long-Term Environmental Performance }}$}

Tests using simulants at higher sodium molarity (up to $6.4 \mathrm{M}$ sodium), confirmed the existing formulations of dry materials yield an acceptable solid grout product. Evidence of surface drying and cracking was observed when samples were cured at higher temperature $\left(90^{\circ} \mathrm{C}\right)$, but this may have been an artifact of the method used to cure these particular samples. All samples cured at lower temperature were maintained in an atmosphere of $100 \%$ relative humidity (approximates vault conditions), while these higher temperature samples were not. Additional testing may be required, if regulatory agencies (e.g., NRC or SCDHEC) perceive cracking to be a loss of structural stability for the waste form. Structural stability for either the waste form or it's container is a requirement for the disposal of NRC Class C waste. All samples met ANSI standards for leaching, and compressive strength was in excess of 1000 psi (Reference 14). 
Gas generation from radiolysis of the grout was also evaluated. The rate of generation is too low to pose a significant explosion hazard within a vault cell during active disposal operations. The grout actually contains interconnected pore structure that provides a route for any gas to be released as it is generated. The disposal permit from SCDHEC requires void space within a disposal unit to be minimized prior to final closure. As part of vault closure, any voids remaining within a vault cell will be filled with nonradioactive grout (Reference 14).

The potential effects on the results of the Saltstone Performance Assessment (PA) due to increased radionuclide concentrations in the Saltstone feed from the this alternative were considered. The groundwater pathway analysis performed as part of the PA should now consider ${ }^{135} \mathrm{Cs}$ because of its much higher concentration in the feed. This change in composition will not impact the results obtained for the composite analysis for the General Separations Area, which includes both Z-Area and E-Area landfill disposal sites for low-level solid waste. A more rigorous intruder analysis is also needed to provide reasonable assurance that long-term performance requirements for saltstone disposal from this alternative are met (Reference 15).

\section{Alpha Removal Results}

The blend selected for the material balance contains about $600 \mathrm{nCi} / \mathrm{g}$ soluble alpha activity. This high concentration is about a factor of 5 to 8 times higher than the overall average alpha concentration expected from waste removal. Thus the balance reflects a bounding case for MST usage. The annual MST usage for this blend, included in the summary tables, reflects the usage for this unusually high concentration of alpha. Average annual usage over the project life will be at least a factor of 5 lower than the quantity shown.

The high MST usage for this salt blend exceeds the titanium limit for waste glass produced in the DWPF, even though the total solids generated from this blend are well within the capacity of DWPF glass production. This potential production impact on vitrification is not unique to this alternative, since MST treatment is common to all of the alternatives. Possible changes to avoid this potential process limitation include: (1) modifying waste removal schedules to smooth out the alpha concentration, similar to the blending done to eliminate mercury removal; (2) modify frit or waste glass formulations to accommodate higher titanium loading; or (3) reduce the rate of salt removal and saltstone production to match the maximum titanium loading in waste glass when "high alpha" salt solution is being processed.

\section{Affect of More Frequent Filter Cleaning and Washing}

This balance assumes filter cleaning will be done after two batch cycles and washing of MST/sludge solids will be done after 4 cycles of processing salt solution through the MST process. If cleaning and washing are required after every batch cycle, the volume of grout produced would increase by about $5 \%$. Note that this increase would apply to any 
alternative using a separate MST sorption and filtration process, not just the direct disposal as grout alternative.

\subsubsection{Equipment}

\subsubsection{Building Layout}

For the Direct Grout process salt waste or supernate is feed to a large 100,000 gallon Alpha Sorption tank where MST solution is added to the waste and the contents agitated. The MST separates the alpha emitting radionuclides from the waste in the form of a precipitate. The solution is then circulated through cross-flow filters with clarified salt solution still containing Cesium passing through the filters, and the remaining salt solution with concentrated amounts of precipitate returning to the tank. Filtration continues until the desired concentration of sludge solids in the Alpha Sorption tank. Periodically the cross-flow filters are backpulsed to remove trapped particles and cleaned using a weak oxalic acid solution. Spent wash solution is then periodically returned to the Alpha Sorption Tank and processed with the next batch of waste.

The concentrated sludge is then pumped to the Sludge Solids Receipt Tank where it is washed with process water to remove residual salts. The contents of the Sludge Solids Receipt Tank is filtered again to concentrate the sludge and remove any remaining salt.

The concentrated sludge solution is then pumped to the DWPF for vitrification.

The clarified salt solution passing through filters is directed either to the Mercury Removal Feed Tank for processing through mercury removal columns containing GT-73 type resin if required, or directly to the 100,000 Salt Solution Storage Tank where it is accumulated until the next grout preparation cycle.

When preparing grout the clarified salt solution is pumped a mixer where it is combined with flyash, cement and slag to form grout and pumped to a 500 gallon Saltstone Hold Tank. The Saltstone Hold Tank serves as a feed tank for the Grout Feed Pumps which pump the grout to the Saltstone Vaults. After each grout preparation the grout transfer lines, the mixer, Saltstone Hold Tank and Grout Feed Pumps are flushed to remove any remaining grout.

Building layout based on shielding and function area sizes of the Direct Grout alternative compared to equivalent DWPF facility layouts are provided below in Table 3.1-1. Major process equipment consists of chemical storage and feed tanks, a large alpha sorption tank, transfer pumps, agitators, 1 set of crossflow filters, wash and concentration tanks, filter cleaning tanks, resin hold tanks, mercury removal ion exchange columns, product hold tanks, grout feed storage silos, grout mixers and transfer pumps and grout transfer equipment and line flush tank. 
Table 3.1-1 DIRECT GROUT

\begin{tabular}{|c|c|c|c|}
\hline & DWPF & GROUT & $\begin{array}{l}\text { GROUT } \\
\% \text { DWPF }\end{array}$ \\
\hline \multicolumn{4}{|l|}{ AREA (SQ.FT) } \\
\hline SHIELDED & 16,278 & 7,664 & $47 \%$ \\
\hline UNLOADING WELL & 2,175 & 1,550 & $71 \%$ \\
\hline \multicolumn{4}{|l|}{ LOW SHIELD } \\
\hline OPERATING CORRIDOR & 59,029 & 17,085 & $29 \%$ \\
\hline CRANE OPERATING & 18,457 & 13,894 & $75 \%$ \\
\hline TOTAL & 95,939 & 40,193 & $42 \%$ \\
\hline \multicolumn{4}{|l|}{ VOLUME(CU.FT) } \\
\hline SHIELDED & 640,344 & 343,980 & $54 \%$ \\
\hline UNLOADING WELL & 86,348 & 69,750 & $81 \%$ \\
\hline \multicolumn{4}{|l|}{ LOW SHIELD } \\
\hline OPERATING CORRIDOR & $1,081,583$ & 509,970 & $47 \&$ \\
\hline CRANE OPERATING & 700,261 & 402,926 & $58 \%$ \\
\hline TOTAL & $2,508,536$ & $1,326,626$ & $53 \%$ \\
\hline
\end{tabular}




\subsubsection{Tanks}

Table 3.1-2 Tanks for Direct Grout Alternative

\begin{tabular}{|c|c|c|}
\hline Tank & Tank Size & Sizing Assumption \\
\hline $\begin{array}{l}\text { MST Storage Tank } \\
\text { (non-rad) }\end{array}$ & 400 gallons & $\begin{array}{l}\text { Sized for approximately four } \\
\text { weeks of storage }\end{array}$ \\
\hline $\begin{array}{l}\text { Process Water Tank } \\
\text { (non-rad) }\end{array}$ & 5000 gallons & $\begin{array}{l}\text { Sized to support chemical } \\
\text { addition tanks and filter } \\
\text { backpulse }\end{array}$ \\
\hline $\begin{array}{l}\text { Oxalic Acid Feed Tank } \\
\text { (non-rad) }\end{array}$ & 200 gallons & $\begin{array}{l}\text { Sized to hold the solution to } \\
\text { clean one cross-flow filter }\end{array}$ \\
\hline $\begin{array}{l}\text { Caustic Feed Tank } \\
\text { (non-rad) }\end{array}$ & 500 gallons & $\begin{array}{l}\text { Sized to hold the solution to } \\
\text { neutralize oxalic acid for one } \\
\text { cross-flow filter cleaning }\end{array}$ \\
\hline $\begin{array}{l}\text { Caustic Storage Tank } \\
\text { (non-rad) }\end{array}$ & 5000 gallons & $\begin{array}{l}\text { Receives one tanker load of } \\
\text { caustic for cleaning of cross- } \\
\text { flow filters. }\end{array}$ \\
\hline Alpha Sorption Tank & 100,000 gallons & $\begin{array}{l}\text { Sized to hold one batch of salt } \\
\text { solution }\end{array}$ \\
\hline Sludge Solids Receipt Tank & 10,000 gallons & $\begin{array}{l}\text { Sized to receive multiple filter } \\
\text { cleaning cycles as well as sludge } \\
\text { solids prior to washing and } \\
\text { pumping to DWPF }\end{array}$ \\
\hline $\begin{array}{l}\text { Cleaning Solution Dump } \\
\text { Tank }\end{array}$ & 1000 gallons & $\begin{array}{l}\text { Sized to circulate material to } \\
\text { clean the cross-flow filters }\end{array}$ \\
\hline Salt Solution Hold Tank & 100,000 gallons & $\begin{array}{l}\text { Sized to hold material for one } \\
\text { day of processing, assuming two } \\
\text { shift operation in the "Saltstone- } \\
\text { like" facility }\end{array}$ \\
\hline Flush Water Receipt Tank & 10,000 gallons & $\begin{array}{l}\text { Sized to collect neutralized } \\
\text { decon liquid due to preparation } \\
\text { for contact maintenance as well } \\
\text { as flush liquid during shutdown }\end{array}$ \\
\hline
\end{tabular}




\begin{tabular}{|l|l|l|}
\hline \multicolumn{1}{|c|}{ Tank } & \multicolumn{1}{|c|}{ Tank Size } & \multicolumn{1}{c|}{ Sizing Assumption } \\
\hline Saltstone Hold Tank & 500 gallons & $\begin{array}{l}\text { Provides grout feed to prevent } \\
\text { cavitation of the transfer pumps } \\
\text { and is comparable to the } \\
\text { Saltstone Hold Tank in the } \\
\text { current Saltstone Facility. }\end{array}$ \\
\hline
\end{tabular}

\subsubsection{Transfer Lines}

Fresh Waste will be pumped to Tank 50. ETF Bottoms material will be pumped from the new 50,000 gallon ETF Bottoms Tank to Tank 50 via the existing interarea transfer line. The salt solution will either be sampled and 'qualified' prior to being pumped to Tank 50 or will be sampled while in Tank 50 prior to transfer to the new Grout Facility.

The salt solution will be pumped to a new Low Point Drain Tank Facility (LPDT) via the existing interarea transfer line. A new LPDT Facility is needed to provide adequate shielding for the higher activity in the waste as compared to current feed. This new LPDT Facility is assumed to be similar to the Low Point Pump Pit (LPPP) in the Defense Waste Processing Facility (DWPF). Two tanks will be needed in the new Facility: one tank for transferring salt solution to the new Grout Facility and the second tank for transferring washed slurry of Monosodium Titanate (MST) and sludge solids from the new Grout Facility to the LPPP and subsequently DWPF. The tank handling MST and sludge slurries in the new LPDT facility and in the DWPF salt cell will be sized to hold the contents of the SSRT located in the new grout facility $(10,000$ gallons working capacity each).

From the new LPDT facility, the salt solution is pumped via the existing interarea transfer line to the new Grout Facility, which will be located in the current Z-Area.

The salt solution in the new Grout Facility will be treated using Monosodium Titanate (MST) to remove uranium, plutonium, and strontium from the salt solution. The salt solution is then filtered to remove sludge and MST solids. After washing to remove soluble salts, these solids will be pumped from the SSRT to the new LPDT sludge tank via a new interarea transfer line.

From the LPDT sludge tank, the sludge and MST solids will be pumped to the current Low Point Pump Pit Precipitate Tank (LPPPPT). A new section of interarea transfer line will be needed from the LPDT sludge tank to the 'abandoned' precipitate line from the Late Wash Facility to the LPPPPT.

From the LPPPPT, the MST solids and sludge solids will be pumped to a new tank in the Salt Processing Cell (SPC) in DWPF. The MST and sludge solids will then be pumped from this new tank in the SPC to the Sludge Receipt and Adjustment Tank. See Figure 3.1-1. 


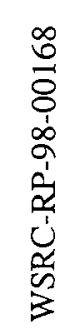

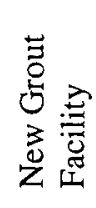
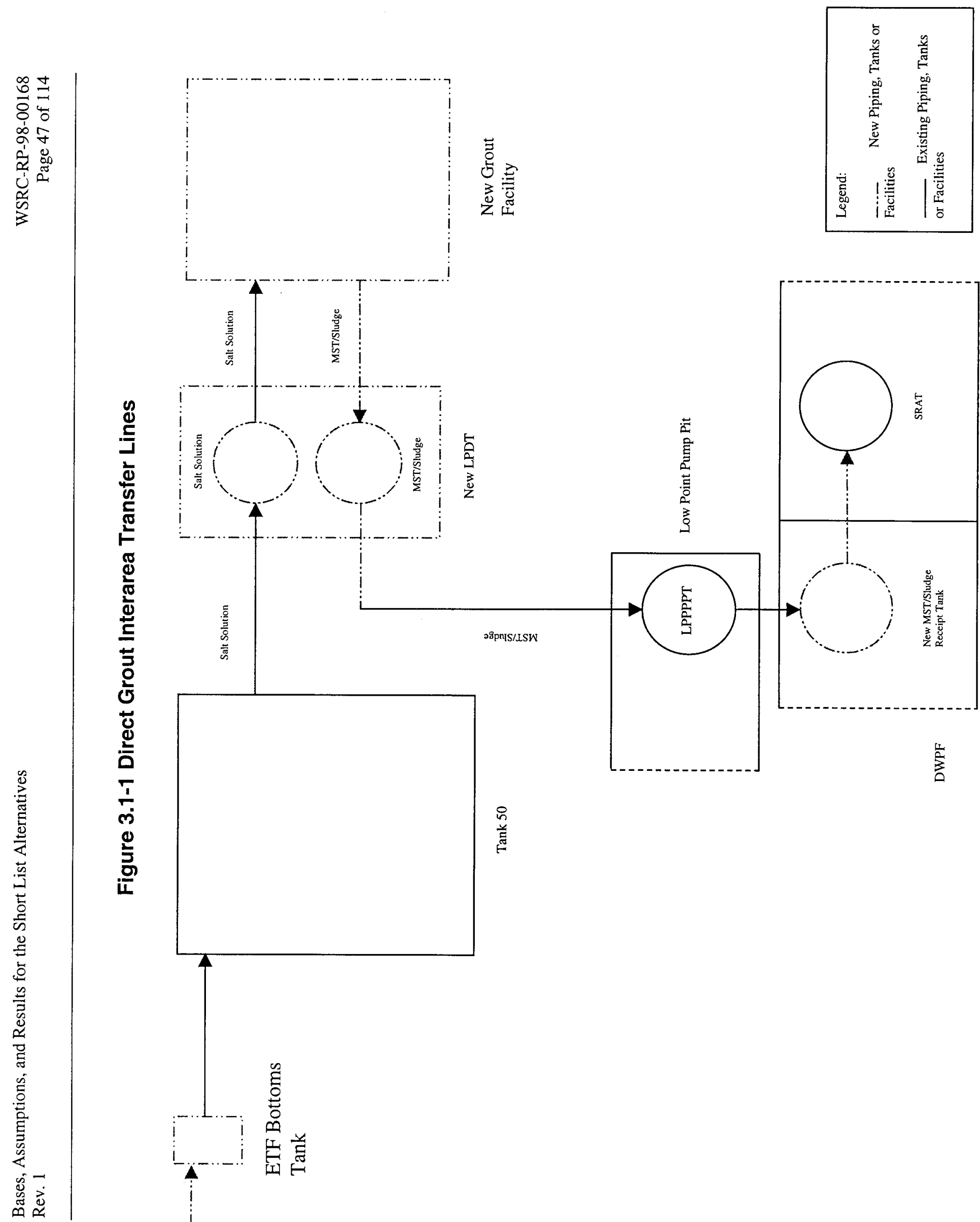

告

号

㟔 


\subsubsection{Jumpers}

Table 3.1-4 summarizes the number of jumpers and associated jumper applications for the Direct Grout alternative. See Appendix B1 for a detailed tabulation of jumper usage.

Table 3.1-4 Summary of Jumper Usage for Direct Grout Alternative

\begin{tabular}{|l|c|}
\hline \multicolumn{1}{|c|}{ Jumper Application } & Number of Jumpers \\
\hline Process Jumpers & 130 \\
\hline Process Jumpers with MOVs & 14 \\
\hline 3-way Process Jumpers & 1 \\
\hline 3-way Process Jumpers w/2 MOVs & 9 \\
\hline Electrical Jumpers & 44 \\
\hline Instrumentation Jumpers & 27 \\
\hline TOTAL & 225 \\
\hline
\end{tabular}

\subsection{SMALL TANK TPB}

\subsubsection{Alternative Description}

In the tetraphenylborate (TPB) precipitation process, soluble radioactive metal ionscesium, strontium, uranium, and plutonium are precipitated with sodium tetraphenylborate or adsorbed on monosodium titanate to form insoluble solids. The resulting precipitate, which contains most of the radionuclides, is filtered to concentrate the solids. The precipitate is sent to the DWPF for vitrification in glass. The decontaminated salt solution, or filtrate, containing primarily sodium salts of hydroxide, nitrate, and nitrite, is transferred to Saltstone for disposal.

\section{$\underline{\text { Precipitation }}$}

Salt solution is pumped from the F/H Tank Farms and is decontaminated in a series of two continuous stirred tank reactions (CSTR) shown in Figure 3.2-1. In the first CSTR, salt solution is mixed with process water and recycled wash water, sodium tetraphenylborate (NaTPB or $\mathrm{NaB}\left(\mathrm{C}_{6} \mathrm{H}_{5}\right)_{4}$ ), and monosodium titanate (MST or $\mathrm{NaTi}_{2} \mathrm{O}_{5} \mathrm{H}$ ). The purpose of the process water or recycled wash water is to reduce the total sodium content to 4.7 molar to optimize the precipitation reaction. The most abundant radionuclide present in salt solution is ${ }^{137} \mathrm{Cs}$. Sodium tetraphenylborate is added to precipitate the cesium as a tetraphenylborate salt. The non-radioactive potassium, cesium, and ammonium ions are also precipitated in this process. The 
potassium ion concentration is nominally 100 times that of the total cesium concentration, although this ratio can vary widely. An excess of NaTPB is added to suppress the solubility of cesium. The basis for modeling the precipitation process is provided in Section A.4.

Monosodium titanate is added to adsorb the soluble strontium, plutonium, and uranium ions if these radionuclides are present in quantities exceeding the limit in Saltstone. The basis for modeling alpha decontamination by MST is provided in Section A.3.

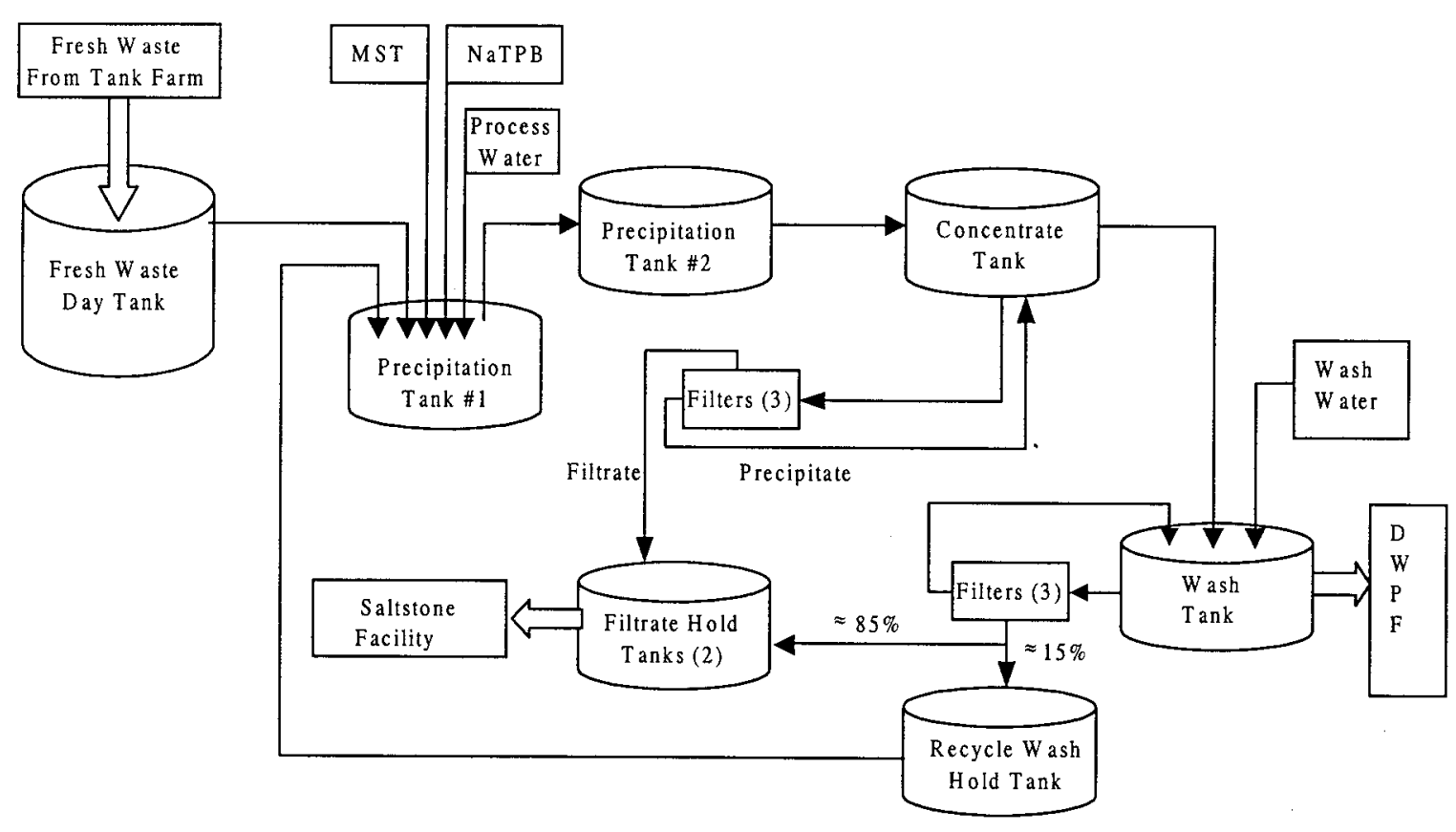

Figure 3.2-1 Small Tank TPB

\section{Concentration}

The slurry contains about $1 \mathrm{wt} \%$ of insoluble MST and precipitated tetraphenylborate solids after precipitation. The slurry is transferred from the second CSTR to the Concentrate Tank where it is concentrated continuously by cross-flow filtration to approximately $10 \mathrm{wt} \%$. Filtrate is transferred to the Decontaminated Salt Solution Storage Tank prior to being transferred to Saltstone. When 4000 gallons of $10 \mathrm{wt} \%$ precipitate slurry is accumulated in the Concentration Tank, it is transferred to the Wash Tank. 


\section{Precipitate Washing}

The slurry is then washed to remove soluble sodium salts by adding process water and removing spent wash water by filtration. The spent wash water is transferred to either the Recycle Tank for use in subsequent batches as dilution water or to the Decontaminated Salt Solution Storage Tank prior to transfer to Saltstone. The washing endpoint is set at $0.01 \mathrm{M} \mathrm{NO}_{2}^{-}$. All of the vessels used in this part of the process are stainless steel to eliminate corrosion concerns.

\section{Benzene Generation}

After precipitation, NaTPB, KTPB and CsTPB undergo radiolytic degradation (See Section A.6) and, under certain conditions, catalytic degradation (See Section A.7). MTPB decomposes to aromatic organics (benzene, biphenyls, and triphenyls) and salts of sodium and boron. The exact mechanism for the catalytic degradation is not completely understood. The catalytic decomposition of TPB results in the formation of triphenylborane, diphenylborinic acid, phenylboric acid, and benzene. The degradation intermediates also decompose catalytically to form benzene. Testing has demonstrated that catalysis with copper ions and sludge solids (Pd has been identified as a primary catalyst in the sludge solids) can significantly increase the rate of decomposition of tetraphenylborate slurries. The kinetics for these decomposition mechanisms are described in Sections A.6 and A.7.

The benzene generation will be set at $10 \mathrm{mg} / \mathrm{L}-\mathrm{hr}$ when excess TPB is present and 1 $\mathrm{mg} / \mathrm{L}$-hr when only solid TPB is present. These have been set at this value to match the current test results by SRTC for decomposition at $25^{\circ} \mathrm{C}$ (Reference 16).

\section{Benzene Removal Process}

Benzene removal must be controlled because of flammability concerns. To avoid the formation of a free benzene layer (uncontrolled benzene release), accumulation above the saturation limit is avoided by continuous agitation.

The Small Tank TPB Precipitation operating conditions are outlined in Table 3.2-1. Cycle times are summarized in Table 3.2-2.

Table 3.2-1 ITP Operating Parameters

\begin{tabular}{|l|c|}
\hline Parameter & Operating Specification \\
\hline Excess TPB & $33 \%$ \\
\hline $\mathrm{Na}^{+}$Concentration after precipitation & $4.7 \mathrm{M}$ \\
\hline $\mathrm{Cs}^{137}$ Concentration after precipitation & $<35 \mathrm{nCi} / \mathrm{g}$ \\
\hline Alpha Concentration after Titanate addition & $<18 \mathrm{nCi} / \mathrm{g}($ Ref. 1$)$ \\
\hline Maximum Temperature & $25^{\circ} \mathrm{C}$ \\
\hline
\end{tabular}




\begin{tabular}{|l|c|}
\hline Parameter & Operating Specification \\
\hline Maximum filtrate rate & $\begin{array}{c}\text { Determined by the model to allow future } \\
\text { filter sizing }\end{array}$ \\
\hline Wash Rate & $\begin{array}{c}\text { Determined by the model to allow future } \\
\text { filter sizing }\end{array}$ \\
\hline Washing Endpoint & $0.01 \mathrm{M} \mathrm{NO}^{2}$ \\
\hline
\end{tabular}

Table 3.2-2 ITP Cycle Times During Washing

\begin{tabular}{|l|c|}
\hline Process Step & Duration \\
\hline Precipitation & Continuous \\
\hline Concentration & Continuous \\
\hline Washing & Approximately 28 hours at $15 \mathrm{gpm}$ \\
\hline
\end{tabular}

\subsubsection{Results}

\section{$\underline{\text { Small Tank Model }}$}

The SPEEDUP ${ }^{\mathrm{TM}}$ representation of the Small Tank TPB Precipitation alternative is a comprehensive dynamic model of the overall process. It is composed of variants of preexisting models originally developed for the High Level Waste Integrated Flowsheet Model (HLWIFM). Thus precipitation kinetics, filtration, solubility, evaporation, decomposition, absorption, and dissolution are treated in full dynamic detail as part of the mass balance for 34 distinct chemical species. The basic building block of the models is the original HLWIFM Tank 48 model, with modifications to suit the new small tank design. The main extension to the original Tank 48 model is the addition of the dynamic equations to calculate benzene generation due to soluble NaTPB decomposition in the presence of copper or palladium catalyst. A brief summary of the models follows:

Accum_Tank: An artificial construct used to interface the continuous precipitation and concentration unit operations with the batch-wise precipitate washing step. Based on Tank 48 model with filtration logic removed. Accumulates concentrated product until the predefined batch volume is available; then passes batches forward to be washed.

Collect_Tank: Used to integrate the grout volume leaving Saltstone Complex.

Conc_Tank: Represents the concentration operation that follows the precipitation steps. Based on Tank 48 model running in a continuous operation mode. Holds up slurry from precipitation operation until solids weight percent criterion is met through filtration; then starts transferring concentrated product continuously to Accum_Tank. 
Filtrate_Tank: Combines filtrate from Conc_Tank with spent wash water from Spent_Wash_Tank and passes result onwards to Saltstone_Complex.

Precip_Tank: Represents the precipitation operation. Accumulates slurry from either the Salt_Feed_Tank or the downstream Precip_Tank for the duration of the defined hold-up interval, then passes precipitated slurry on to either the next Precip_Tank or the Conc_Tank. Current representation has two Precip_Tanks in series, with STPB and MST additions into the first tank only. Based on Tank 48 model running in a continuous operation mode with filtration logic removed.

Recycler: Controls dilution water source, either provided by Spent_Wash_Tank or by a fixed source.

Saltstone_Complex: Represents the Saltstone and grout processes, based on the same model in HLWIFM.

Salt_Feed_Tank: Used to provide the salt solution feed that drives the entire process. Takes the input composition and adds sufficient dilution water to meet the Na molarity specification.

Spent_Wash_Tank: Used to accumulate spent wash from Wash_Tank and send it on either for use as dilution in Salt_Feed_Tank or for mixing into Filtrate_Tank.

Wash_Tank: Represents the batched precipitate washing process. Fed by Accum_Tank with the batch steps under control of the External Data Interface. Washed precipitate is sent onward to the DPWF process which is outside the current model. Based on Tank 48 model.

\section{Assumptions}

Two significant conditions were assumed for the Small Tank model: benzene is released as it is generated; and slurry temperatures are fixed at $25^{\circ} \mathrm{C}$. Modeling details are given within the listings for the above models which are essentially self-documenting. All input specifications are found within the OPERATION section of the SPEEDUPTM problem file.

\section{$\underline{\text { Small Tank Sensitivity Analysis }}$}

The Small Tank Tetraphenylborate Precipitation process was modeled for years 2006 and 2017. These years were selected based on the $\mathrm{Cs}^{137}$ to $\mathrm{K}$ ratio. Year 2017 had the highest $\mathrm{Cs}^{137}$ content for any of the compositions generated by ProdMod. It also had a lower than average $\mathrm{K}^{+}$concentration resulting in the highest curie loading in the $10 \mathrm{wt} \%$ precipitate. The results of the model for these two extremes showed very little difference in the material balances; therefore, only year 2017 is reflected in the discussion that follows. 


\section{$\underline{\text { Scope Matrix Results }}$}

The cesium concentration for year 2017 is $44 \mathrm{Ci} /$ gal for the slurry transferred to the salt cell. This value is within the baseline for the DWPF salt cell process. Organic formation and subsequent recycle to the Tank Farm are within the specifications outlined in the DWPF baseline (Scope Matrix Items 1 and 10). The amount of Surfynol 420 that was incorporated into the flowsheet was selected to match the amount that would have been added to the Late Wash flowsheet for the same amount of precipitate; therefore, there is no impact on downstream processes. (Scope Matrix Item 15) Other Scope Matrix results are covered elsewhere or on the drawings in Appendices I, J, and $\mathrm{K}$.

\section{Laboratory Results}

SRTC conducted experimental work in three areas: low temperature tetraphenylborate (TPB) decomposition, MST kinetics, and TPB precipitation kinetics. The experimental work at low temperature indicates that TPB will decompose at $25^{\circ} \mathrm{C}$ (Reference 16). The decomposition is directly proportional to the TPB concentration. The subsequent benzene generation rates range as high as $6-7 \mathrm{mg} / \mathrm{L}-\mathrm{hr}$ at conditions consistent with the process. The rate for benzene selected for the Precipitation, Concentrate, and Wash tanks was set at $10 \mathrm{mg} / \mathrm{L}-\mathrm{hr}$. Since the benzene generation rate is directly proportional to the TPB concentration, the washed precipitate benzene generation rate is set conservatively at an assumed rate of $1.0 \mathrm{mg} / \mathrm{L}-\mathrm{hr}$. The resulting benzene release to the environment is 19.1 tons/yr compared to the current ITP permit limit of 23 tons/yr. This benzene generation rate does not take credit for any delay time before catalyst activation.

The CSTR was sized by assuming a 24 hour holdup in the precipitation tank. Two 15,000 gallon vessels were selected to meet the 24 hour processing requirement and process flow diagrams and building layouts were developed (Appendices I and J). The initial work conducted by SRTC on TPB precipitation kinetics indicated that an additional tank might be necessary to increase holdup time in the CSTRs to 72 hours (Reference 17). Building layouts were developed for a three-tier CSTR process. These are also included in Appendix $\mathrm{H}$ along with the proposed two CSTR arrangement. Subsequent experiments indicate that with good mixing two CSTRs should be adequate for ${ }^{137} \mathrm{Cs}$ decontamination. The ASST adsorption kinetie tests indieate that 24 hour holdup $/ 7 \mathrm{c} / 29 / \mathrm{s}_{0}$ (two-CSTRs) should be sufficient to achieve alpha-decontamination (Reference-18).

\section{CSTR Sizing for TRU Removal and TPB Strike}

The separation of TRU and Cs from contaminated salt solution is to be performed by reaction with monosodium titanate (MST) and tetraphenylborate (TPB) respectively. TRU removal by MST is universal to all salt disposition options. Cs removal by TPB is limited to Small Tank Precipitation. The reactions are to be carried out in continuous stirred tank reactors (CSTR's). Based on the kinetics of the reactions, the CSTR's must be sized to provide the residence time necessary to achieve the desired percent conversion or decontamination factor. This section of the document provides a summary 
of the batch kinetic data provided by SRTC and the required tank sizes determined for this batch data. Tanks in series are considered to minimize the total tank volume.

\section{$\underline{\text { Sizing Methodology }}$}

The sizing of a continuous stirred tank reactor begins with a material balance for species $A$ in the reactor (Reference 19). This material balance results in an expression relating the required residence time $(\tau)$ to the initial reactant's concentration $\left(C_{A 0}\right)$, the percent conversion $\left(\mathrm{X}_{\mathrm{A}}\right)$ which is a representation of $\mathrm{ED}\left(\mathrm{DF}=\mathrm{C}_{\mathrm{A} 0} / \mathrm{C}_{\mathrm{A}}\right)$, and the rate of destruction of $A\left(-r_{A}\right)$. The tank volume $(V)$ is determined by multiplying the residence time by the volumetric flow rate through the tank $\left(v_{0}\right)$.

$$
\tau=\frac{V}{v_{0}}=\frac{C_{A 0} X_{A}}{-r_{A}} \text { with } X_{A}=1-\frac{C_{A}}{C_{A 0}}
$$

The above equation shows that if one plots the $C_{A 0} /\left(-r_{A}\right)$ versus $X_{A}$, the area containing the curve represents the residence time. If one chooses to design multiple tanks, the $\mathrm{X}_{\mathrm{A}}$ range can be divided into various segments with each segment representing the required residence time of an individual tank $\left(\tau_{\mathfrak{i}}\right)$.

$$
\tau_{i}=\frac{V_{i}}{v_{0}}=\frac{C_{A 0}\left(X_{A(i)}-X_{A(i-1)}\right)}{-r_{A(i)}}
$$

This method of CSTR sizing is independent of reaction rate order. The only information required is a measure of reaction rate as a function of percent conversion. This information is provided through batch experimentation.

\section{MST Kinetics}

MST kinetics have been reported (Reference 20) as a function of temperature $\left(25^{\circ} \mathrm{C}\right.$ ), sodium concentration (4.5-7.5M), MST concentration (0.2-2.0 g/L), plutonium concentration (0.1-1.0 mg/L), and degree of mixing (Reference 9). In this report, the percent conversion of TRU elements is traced in time. Based on tank farm inventory and expected TRU concentrations (see section Tank Farm Blending: MST Sorption Requirements for Alpha and Strontium), plutonium is bounded by $1 \mathrm{mg} / \mathrm{L}$ and requires a $\mathrm{DF}=56, \mathrm{X}_{\mathrm{A}}=1-(1 / \mathrm{DF})=0.982$. Based on the titanium limit in glass, the MST addition is closer to $0.2 \mathrm{~g} / \mathrm{L}$. Therefore, the sizing of the MST continuous stirred tank reactors is based on the high plutonium, $25{ }^{\circ} \mathrm{C}, 4.5 \mathrm{M} \mathrm{Na}, 0.2 \mathrm{~g} / \mathrm{L}$ MST experimental data. Table 3.2-3 contains the $\mathrm{K}_{\mathrm{d}}$ versus time information necessary for CSTR sizing.

The determination of reaction rate as a function of percent conversion is susceptible to experimental noise. Therefore, a smooth curve is drawn through the data points. The rate, change in concentration/change in time, is based on the smooth curve and not the 
experimental data. The choice of curve fitting is arbitrary as long as the curve provides an adequate representation of the entire data set. A non-linear interpolation routine was used with the MST kinetics.

Table 3.2-3 contains the plutonium versus time information necessary for CSTR sizing. This table contains an anomaly at 4 and 8 hours that has not been resolved at the time of this report. The plutonium concentration can not decrease and then increase between 4 and 8 hours. Therefore, one of these data points is incorrect. In order to provide a bounding design, two scenarios are generated based on the inclusion/exclusion of the 4 and 8-hour data points.

Figure 3.2-2 provides the plutonium concentration versus time for the two scenarios mentioned above. Including the 4-hour data point (excluding the 8-hour) yields a very rapid response. Performing the sizing methodology mentioned above indicates that two 10,000 gallon tanks operating at $17.5 \mathrm{GPM}$ would achieve the DF. These tanks are labeled Tank \#1 and Tank \#2 in the lower graph. Including the 8-hour data point (excluding the 4-hour point) yields a sluggish response. Performing the sizing calculation reveals that approximately three 30,000 tanks operating at $17.5 \mathrm{GPM}$ would achieve the DF. These tanks are labeled Tank A, Tank B, and Tank C in the lower graph.

Based on the uncertainty in the experimental data, the tanks required to achieve a $\mathrm{DF}_{\mathrm{Pu}}=56$ can vary between two 10,000 gallon tanks and three 30,000 gallon tanks. Fable 3.2-3 provides additionat information on the rentum with MST. This-data set contained $4.5 \mathrm{M}$ sodium and $0.2 \mathrm{e}-3 \mathrm{~g} / \mathrm{mt}$ MST. The last column provides the distribution coefficient as a function of time. Dat provides an inconsistency at 4 and 8 hours.-One of these data peints must be incorrect. The CSTR-sizing-analysis will pursue each of the data points being correct and excluding the other-to-arrive-at two design. scenarios.

Table 3.2-3

\begin{tabular}{|c|c|}
\hline Elapsed Time $(\mathrm{h})$ & $\mathrm{Kd}(\mathrm{mL} / \mathrm{g})$ \\
\hline 0 & \\
\hline 1.98 & $4.33 \mathrm{E}+03$ \\
\hline 4.17 & $4.10 \mathrm{E}+05$ \\
\hline 8.10 & $1.59 \mathrm{E}+04$ \\
\hline 24.10 & $4.10 \mathrm{E}+05$ \\
\hline 48.13 & $4.10 \mathrm{E}+05$ \\
\hline 168.33 & $4.10 \mathrm{E}+05$ \\
\hline 239.40 & $\mathrm{NA}$ \\
\hline
\end{tabular}




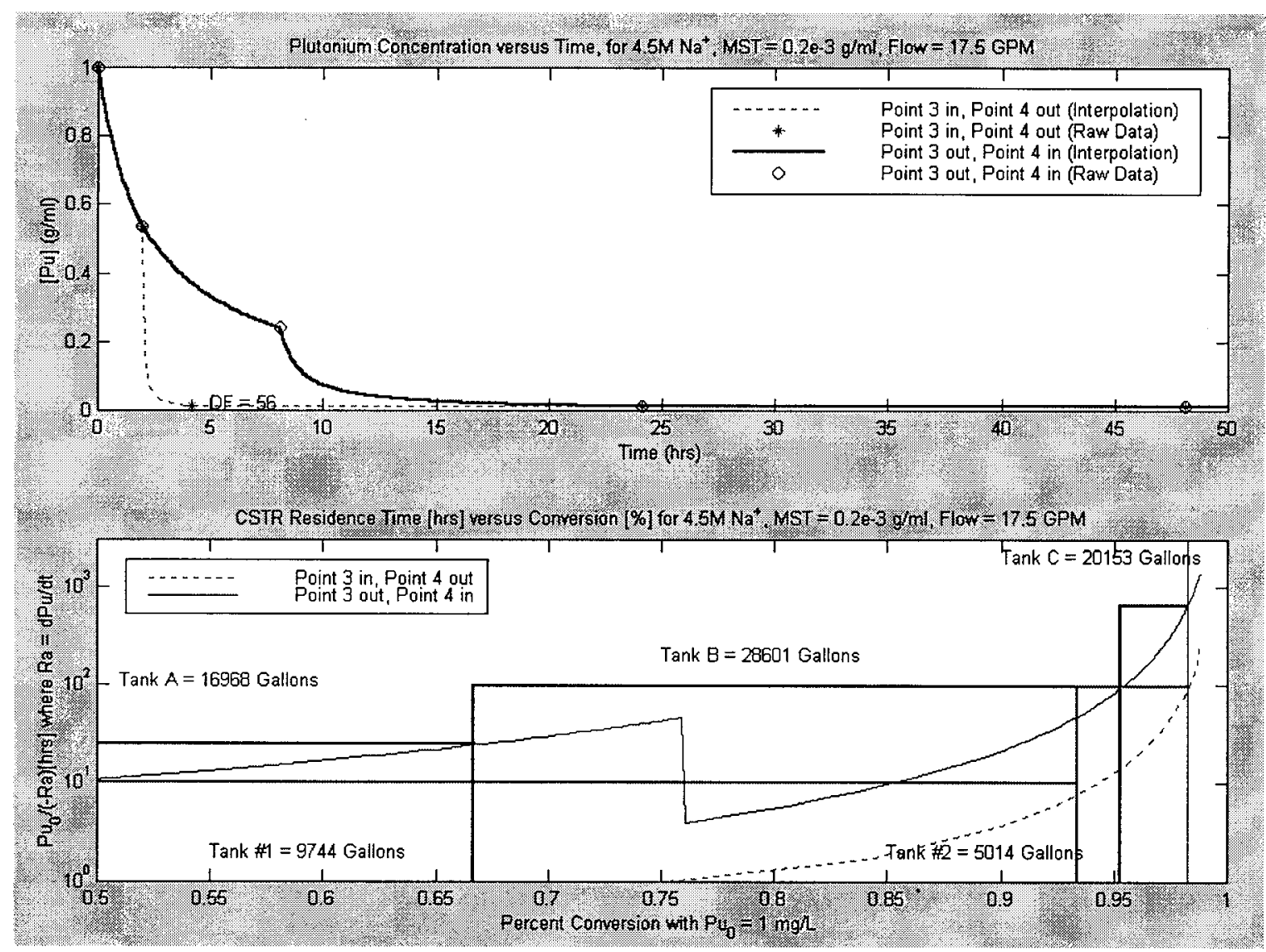

Figure 3.2-2 This figure plots the information necessary to size the CSTR's. The top graph is a plot of plutonium concentration versus time. The solid line represents the inclusion of the 8 hour data point, exclusion of the 4 hour point. The solid line provides a sluggish response. The dotted line represents the inclusion of the 4 hour data point, exclusion of the 8 hour point. This response is very rapid. The lower figure plots the percent conversion as a function of inverse rate. Partitioning the lower curves into tanks shows that if the rapid response is used, the desired DF could be obtained with two approximately 10,000 gallon tanks. If the sluggish response is used, approximately three 30,000 gallon tanks are required.

\section{TPB Kinetics}

The precipitation of cesium by tetraphenylborate (TPB) has been characterized as a function of sodium concentration (4-6M), percent excess TPB (33-100\%), and degree of stirring (Reference 17). The fastest reaction rates occur with low sodium concentration, high excess TPB, and pronounced stirring ( $300 \mathrm{rpm}$ versus $70 \mathrm{rpm}$ ). At a fixed sodium concentration (5M), the removal rate of cesium benefits from both increased TPB excess and agitation. Figure 3.2-3 (top graph) reveals how favorable the rates kinetics are for excess TPB $(100 \%) /$ good mixing $(300 \mathrm{rpm})$ and how unfavorable the rate kinetics are for low excess TPB $(33 \%) /$ poor mixing $(70 \mathrm{rpm})$. The individual benefit of \% excess TPB versus increased agitation rate is undetermined based on the plateaus in the cesium versus time graph. The experiments appear to suffer from insufficient mixing in general, and inadequate mixing negates the benefit of excess TPB by limiting the amount of TPB 
making it into solution. Only the high excess TPB/high agitation experiment appears to proceed smoothly with no unusual or unexpected periods with little or no reaction. In order to provide an adequate CSTR design, the Salt Disposition Flowsheet Team chose to size the CSTRs based on each experimental data set in Figure 3.2-3 and to follow these scenarios with a discussion of how the CSTR size is completely determined by the degree of mixing.

As in the MST sizing analysis, the rate of cesium removal must be known as a function of percent conversion. A linear interpolation routine was used to smooth the experimental data. The lower graph in Figure 3.2-3 displays the required residence time as a function of percent conversion. As a rule, the required residence time increases with increased DF or percent conversion. Determining the size and number of CSTR's is performed by placing rectangles in the Figure 3.2-3 (lower graph) that include the data points and the desired percent conversion. Three CSTR's in series were used in the following analysis. Table 3.2-4 provides the tank sizes required to achieve the DF as a function of the kinetic batch data. 


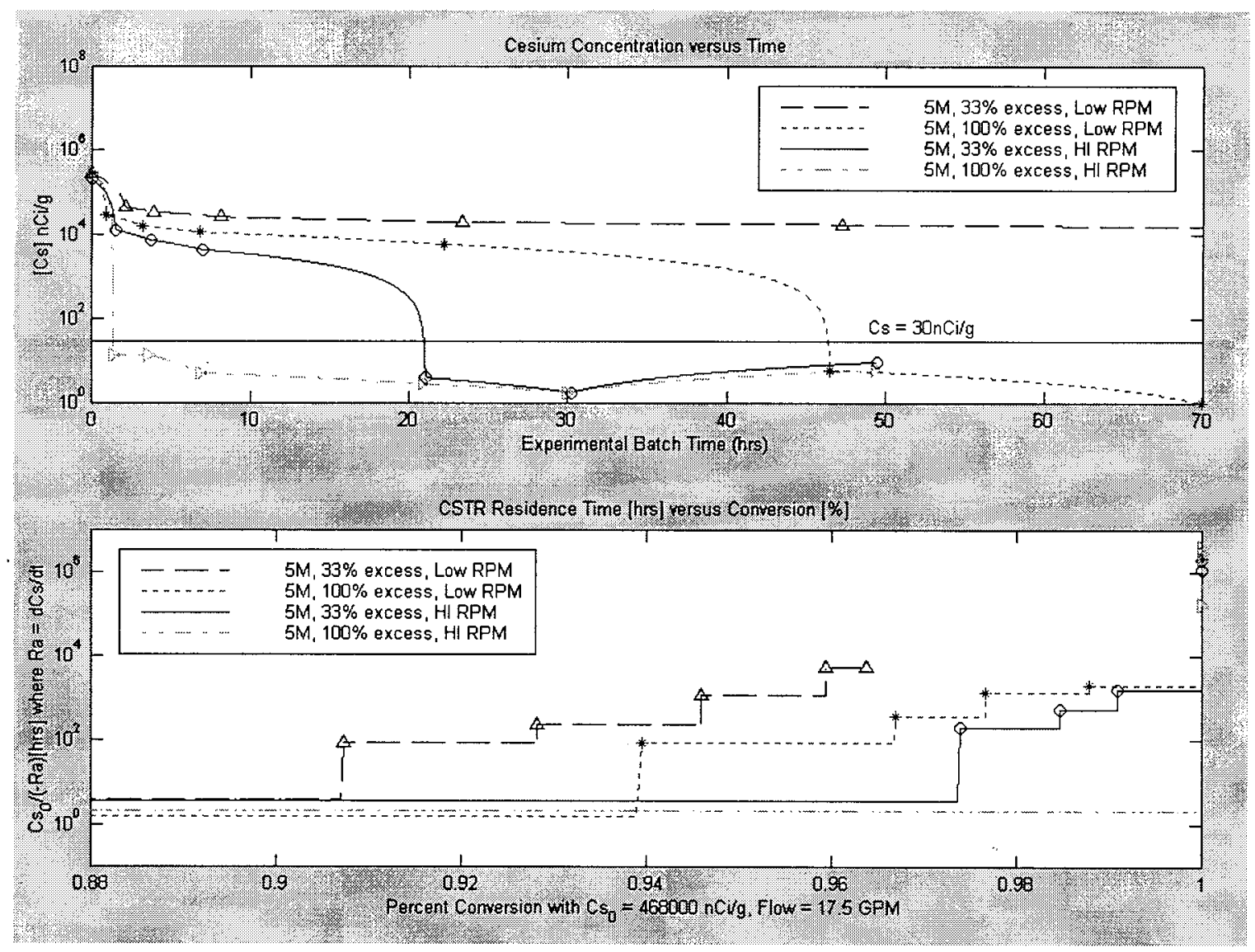

Figure 3.2-3. The rate of cesium precipitation by TPB is shown for four $5 \mathrm{M}$ sodium batch runs with varying degrees of percent excess TPB and agitation. The upper graph reveals the apparent inability to react the excess TPB due to lack of adequate mixing. Several runs contain a timeframe where the reaction rate slows down and then speeds up. Only the high excess TPB/high agitation run reveals the lack of "plateau". The lower graph indicates that various residence times required for various ranges in percent conversion. These residence times are converted into tank volumes in Table 3.2-4.

CSTR sizes depend on the ability to dissolve TPB into solution. As shown in Table 3.24, at low percent excess TPB and low agitation rates, the CSTR's must be very large to provide the residence time for the percent conversion. At high percent excess TPB and high agitation rates, the CSTR's are very small. This large discrepancy in CSTR sizes suggests the need for full understanding of how to dissolve TPB into solution. The salt work-off rate is 17.5 GPM. If one assumes that either temperature and/or proper agitation will solve the dissolution issue, two 15,000 gallon tanks would easily suffice. 
Table 3.2-4

\begin{tabular}{|c|c|c|c|c|}
\hline Tank \# & $\begin{array}{c}5 \mathrm{M}, 33 \% \text { excess } \\
\text { TPB, } 70 \text { rpm }\end{array}$ & $\begin{array}{c}5 \mathrm{M}, 100 \% \text { excess } \\
\text { TPB }, 70 \mathrm{rpm}\end{array}$ & $\begin{array}{c}5 \mathrm{M}, 33 \% \text { excess } \\
\text { TPB, } 300 \mathrm{rpm}\end{array}$ & $\begin{array}{c}5 \mathrm{M}, 100 \% \text { excess } \\
\mathrm{TPB}, 300 \mathrm{rpm}\end{array}$ \\
\hline 1 & 3900 gallons & 1600 gallons & 3900 gallons & 2000 gallons \\
\hline 2 & 59000 gallons & 17900 gallons & 9000 gallons & 100 gallons \\
\hline 3 & 294600 gallons & 50400 gallons & 16200 gallons & 100 gallons \\
\hline
\end{tabular}

\section{Conclusions}

Preliminary sizing CSTR's for TRU removal and Cs decontamination has been performed. The plutonium rate kinetics were used to size for the MST adsorption, and cesium kinetics were used to size for the precipitation of cesium and potassium. If TRU removal and Cs decontamination are to occur within the same tanks, the TRU removal drives the tank sizes to be three 30,000 gallon tanks based upon the uncertainty of the data. If the TRU removal occurs separately from Cs decontamination, the Small Tank Precipitation reaction could occur easily in two 15,000 gallon tanks. Provided the dissolution of TPB is guaranteed in the final tank design, the tanks sizes could be much smaller.

The uncertainties in both the MST and TPB experimental data have introduced a level of conservatism in the CSTR tank sizes. This level of conservatism can be considerably reduced after duplication/improvement of the experiment.

Model Results

The results of the material balance modeling efforts for the process are shown in Table $3.2-5$.

Table 3.2-5 Modeling Effort Results

\begin{tabular}{|l|c|c|c|c|c|c|c|c|}
\hline $\begin{array}{l}\text { Small Tank ITP } \\
\text { Year 2017 }\end{array}$ & $\begin{array}{c}\text { Salt } \\
\text { Polution } \\
\text { Processed } \\
\text { kgal/yr }\end{array}$ & $\begin{array}{c}\text { Sludge } \\
\text { Processed } \\
\text { klb/yr }\end{array}$ & $\begin{array}{c}\text { NaTPB } \\
\text { klb/yr }\end{array}$ & $\begin{array}{c}\text { ST } \\
\text { klb/yr }\end{array}$ & $\begin{array}{c}\text { Tank } \\
\text { Farm } \\
\text { Recycle } \\
\mathbf{k g a l} / \mathbf{y r}\end{array}$ & $\begin{array}{c}\text { Grout } \\
\text { Produced } \\
\mathbf{k g a l} / \mathbf{y r}\end{array}$ & $\begin{array}{c}\text { Glass } \\
\text { Produced } \\
\mathbf{k l b} / \mathbf{y r}\end{array}$ & $\begin{array}{c}\text { Canisters } \\
\text { Made } \\
\text { No. }\end{array}$ \\
\hline $\mathbf{1 0 0 \% \text { Attainment }}$ & $8672 @ 5.02 \mathrm{M}$ & 2167 & 423.1 & 9.9 & 1572 & 21129 & 936 & 241.7 \\
\hline $\mathbf{7 5 \% \text { Attainment }}$ & 6504 & 1625 & 317.3 & 7.43 & 1179 & 15847 & 812 & 181.3 \\
\hline $\begin{array}{l}\text { Long Term } \\
\text { Average }\end{array}$ & 5646 & 1411 & 275.4 & 6.44 & 1023 & 13755 & 705 & 157.3 \\
\hline
\end{tabular}

The long term average incorporates both a $75 \%$ attainment and melter outages into the flowsheet results. The number of canisters made for year 2017 is low because the low balancing of the remaining sludge in the Tank Farm is low and the ratio of salt, sludge, and frit must be balanced. The amount of $10 \mathrm{wt} \%$ TPB slurry made in this year is less 
than the amount which can be processed by DWPF (460,000 gallons vs. 540,000 gallons at $100 \%$ attainment) due to the lower potassium content of the salt waste stream compared to the average. Other years may have higher or lower slurry production, depending on the potassium concentration in the feed.

\subsubsection{Equipment}

\subsubsection{Building Layout}

Building layout based on shielding and functional area sizes of the Small Tank ITP alternative compared to equivalent DWPF facility layouts are provided below in Table 3.2-6. Major process equipment consists of chemical storage and feed tanks, continuously stirred reactors (CSTR), transfer pumps, agitators, 2 sets of crossflow filters, wash and concentration tanks, filter cleaning tanks and product hold tanks.

TABLE 3.2-6 SMALL TANK ITP

\begin{tabular}{|c|c|c|c|}
\hline & DWPF & $\begin{array}{c}\text { SMALL } \\
\text { TANK }\end{array}$ & $\begin{array}{c}\text { SMALL } \\
\text { TANK } \\
\text { \%DWPF }\end{array}$ \\
\hline AREA (SQ.FT) & & & \\
\hline SHIELDED & 16,278 & 10,321 & $63 \%$ \\
\hline UNLOADING WELL & 2,175 & 2,100 & $97 \%$ \\
\hline LOW SHIELD & & 2,100 & \\
\hline OPERATING CORRIDOR & 59,029 & 30,767 & $52 \%$ \\
\hline CRANE OPERATING & 18,457 & 17,466 & $95 \%$ \\
\hline TOTAL & 95,939 & 62,754 & $65 \%$ \\
\hline VOLUME(CU.FT) & & & \\
\hline SHIELDED & 640,344 & 455,908 & $71 \%$ \\
\hline UNLOADING WELL & 86,348 & 100,800 & $117 \%$ \\
\hline LOW SHIELD & & 100,800 & \\
\hline OPERATING CORRIDOR & $1,081,583$ & 738,408 & $68 \%$ \\
\hline CRANE OPERATING & 700,261 & 659,281 & $94 \%$ \\
\hline & & & \\
\hline TOTAL & $2,508,536$ & $2,055,197$ & $82 \%$ \\
\hline
\end{tabular}




\subsubsection{Tanks}

Table 3.2-7 Tanks for Small Tank TPB Alternative

\begin{tabular}{|c|c|c|}
\hline Tank & Tank Size & Sizing Assumption \\
\hline $\begin{array}{l}\text { Precipitation } \\
\text { Tank }\end{array}$ & $\begin{array}{c}2 \text { tanks each } \\
15,000 \text { gallons }\end{array}$ & $\begin{array}{l}\text { Sized for a } 24 \text { hour hold up to allow the } \\
\text { monosodium titanate (MST) contact time with the } \\
\text { salt solution prior to concentration }\end{array}$ \\
\hline $\begin{array}{l}\text { MST Storage } \\
\text { Tank }\end{array}$ & 400 gallons & Sized for approximately four weeks of storage \\
\hline $\begin{array}{l}\text { Process Water } \\
\text { Tank }\end{array}$ & 80,000 gallons & $\begin{array}{l}\text { Provides storage capacity for approximately one } \\
\text { week for supplying dilution water to the } \\
\text { Precipitation Tank and wash water for the Wash } \\
\text { Water Tank. }\end{array}$ \\
\hline $\begin{array}{l}\text { NaTPB Storage } \\
\text { Tank }\end{array}$ & 20,000 gallons & Sized for approximately four weeks of storage \\
\hline Concentrate Tank & 10,000 gallons & $\begin{array}{l}\text { As precipitate is concentrated, the required storage } \\
\text { capacity in the Concentrate Tank will decrease as } \\
\text { compared to the Precipitation Tank. Precipitate } \\
\text { will be produced at a rate of approximately } 1150 \\
\text { gallons/day. DWPF will consume approximately } \\
4000 \text { gallons every } 65 \text { hours. Storage capacity for } \\
\text { two batches is assumed. }\end{array}$ \\
\hline $\begin{array}{l}\text { Filtrate Hold } \\
\text { Tanks }\end{array}$ & $\begin{array}{c}2 \text { tanks each } \\
100,000 \text { gallons }\end{array}$ & $\begin{array}{l}\text { Approximately } 24,000 \text { gallons of filtrate per day } \\
\text { will be produced. } 100,000 \text { gallons is equivalent to } \\
\text { approximately four days of storage. (Note: } \\
\text { Saltstone Facility can process approximately } \\
60,000 \text { gallons of salt solution per day assuming } \\
\text { two shift operation.) The Filtrate Hold Tanks also } \\
\text { allows hold-up of material for analysis to ensure } \\
\text { that the Saltstone Waste Acceptance Criteria is } \\
\text { met (assumes that analysis for Benzene, TPB, Hg, } \\
\text { Sr, Pu, U, and others as necessary.) Two tanks are } \\
\text { identified to allow the sampling of one tank while } \\
\text { the second tank is being filled. }\end{array}$ \\
\hline
\end{tabular}




\begin{tabular}{|l|c|l|}
\hline \multicolumn{1}{|c|}{ Tank } & Tank Size & \multicolumn{1}{c|}{ Sizing Assumption } \\
\hline Wash Tank & 10,000 gallons & $\begin{array}{l}\text { As the precipitate is concentrated, the required } \\
\text { storage capacity in the Wash Tank will decrease as } \\
\text { compared to the Precipitation Tank. Precipitate } \\
\text { will be produced at a rate of approximately 1150 } \\
\text { gallons/day. DWPF will consume approximately } \\
\text { 4000 gallons every 65 days. Storage capacity for } \\
\text { two batches is assumed. 4000 gallons of } \\
\text { concentrated precipitate can be washed in 28 hours } \\
\text { at a wash rate of 15 gpm. }\end{array}$ \\
\hline $\begin{array}{l}\text { Recycle Wash } \\
\text { Hold Tank }\end{array}$ & $\begin{array}{l}\text { The Recycle Wash Hold Tank was added to } \\
\text { reduce the amount of process water used as } \\
\text { dilution water in the Precipitation Tank. Initial } \\
\text { wash water will be transferred to the Filtrate Hold } \\
\text { Tanks. As Cs levels increase in the wash water, } \\
\text { the water is diverted to the recycle wash hold tank. } \\
\text { The tank is sized to hold 50\% of the wash water } \\
\text { from a single batch. }\end{array}$ \\
\hline $\begin{array}{l}\text { Precipitate Surge } \\
\text { Tank }\end{array}$ & 75,000 gallons & $\begin{array}{l}\text { This tank will provide approximately 60 days of } \\
\text { storage capacity for the precipitate. This storage } \\
\text { capability is needed to effectively de-couple thel } \\
\text { Small Tank ITP Facility from DWPF. The Low } \\
\text { Point Pump Pit Precipitate Tank will be bypassed } \\
\text { to avoid modification of this facility. }\end{array}$ \\
\hline $\begin{array}{l}\text { Cleaning Solution } \\
\text { Dump Tanks }\end{array}$ & $\begin{array}{l}\text { The Cleaning Solution Dump Tanks will receive } \\
\text { chemicals sequentially for cleaning of the } \\
\text { concentrate tank filters and wash tank filters. }\end{array}$ \\
\hline
\end{tabular}

\subsubsection{Transfer Lines}

Fresh Waste will be pumped to Tank 48 . The salt solution will either be sampled and 'qualified' prior to being pumped to Tank 48 or will be sampled while in Tank 48 prior to transfer to the new Small Tank ITP Facility.

The salt solution will then be pumped to the new Small Tank ITP Facility via the existing interarea transfer line, which will be modified. The new Small Tank ITP Facility will be located near the current Late Wash Facility. A section of new interarea transfer line will be needed to connect the current interarea transfer line to the new Facility. This tie-in will be near the Low Point Drain Tank. 
The precipitate will be pumped to the Low Point Pump Pit Precipitate Tank (LPPPPT) via a modified interarea transfer line. A new section of interarea transfer line will connect the new Small Tank ITP Facility to the 'abandoned' precipitate line from the Late Wash Facility.

The precipitate will then be pumped from the LPPPPT to the Precipitate Reaction Feed Tank in the Salt Process Cell in the Defense Waste Processing Facility.

The decontaminated salt solution will be pumped via a new interarea transfer line to a valve box near the current Low Point Drain Tank (LPDT). The valve box will allow the Saltstone Facility to receive material from ETF or the new Small Tank ITP Facility.

The ETF Bottoms will be transferred to a new 50,000-gallon ETF Bottoms Tank via a new interarea transfer line. The new interarea transfer line is needed because the current line will be used to transfer high activity salt solution to the new Small Tank ITP Facility. The new ETF Bottoms Tank will hold approximately 4-5 months of ETF Evaporator Bottoms based on current production rates. The ETF Bottoms can then be campaigned when a new salt solution batch is being sampled.

The new valve box will then be used to transfer either the decontaminated salt solution or the ETF Bottoms to the Saltstone Facility via the current interarea transfer line at the Low Point Drain Tank. See Figure 3.2-4. 


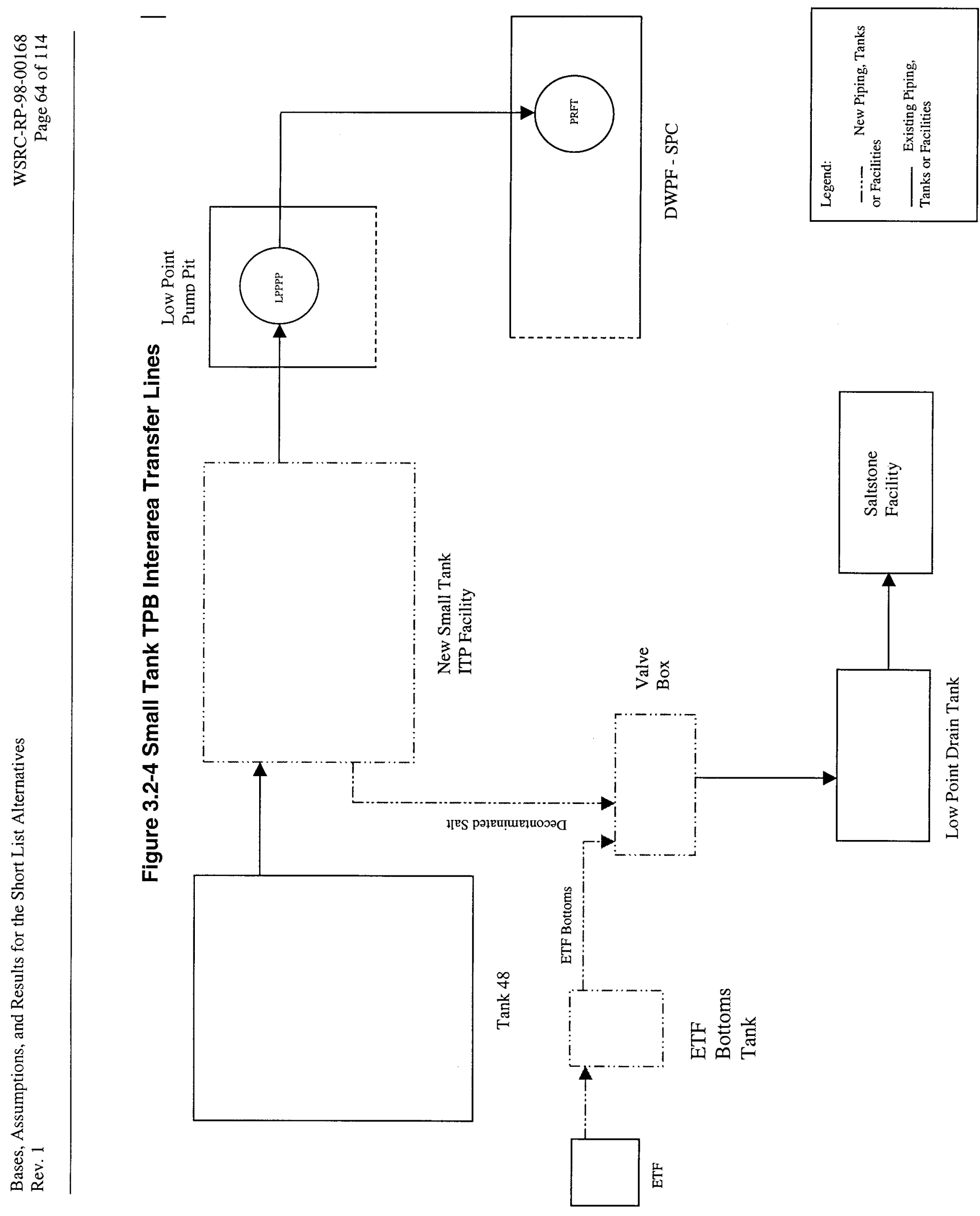




\subsubsection{Jumpers}

Table 3.2-8 Summary of Jumper Usage for Small Tank TPB Alternative

\begin{tabular}{|l|c|}
\hline \multicolumn{1}{|c|}{ Jumper Application } & Number of Jumpers \\
\hline Process Jumpers & 86 \\
\hline Process Jumpers with MOVs & 20 \\
\hline 3-way Process Jumpers & 3 \\
\hline 3-way Process Jumpers w/2 MOVs & 1 \\
\hline Electrical Jumpers & 43 \\
\hline Instrumentation Jumpers & 35 \\
\hline TOTAL & 188 \\
\hline
\end{tabular}

\subsection{CAUSTIC-SIDE SOLVENT EXTRACTION}

\subsubsection{Alternative Description}

The basic principle of solvent extraction is to use a sparingly soluble diluent material that carries an extractant that will complex with the cesium ions in the caustic solution. The decontaminated aqueous stream (raffinate) is then sent to saltstone for disposal. The cesium contained in the organic phase (solvent) can then be stripped into an aqueous phase ready for transfer to DWPF. The solvent is then recycled.

The alkaline salt waste is clarified by adding monosodium titanate to sorb the actinides. The slurry is then filtered to remove the MST and sludge solids.

The solvent consisting of $0.01 \mathrm{M} \mathrm{BoBCalixC6}$ extractant, $0.2 \mathrm{M} \mathrm{Cs}-3$ modifier, and the balance Isopar $\mathrm{L} \otimes$ diluent is contacted with the alkaline waste stream in a series of countercurrent centrifugal contactors (the extraction stages). The resulting clean aqueous raffinate is transferred to Saltstone for disposal. Following cesium extraction, the solvent is scrubbed with dilute acid to remove other soluble salts from the solvent stream (the scrub stages). The solvent is then contacted with a very dilute $(.0005 \mathrm{M})$ acid stream containing a small quantity of non-radioactive cesium (.0001M) to transfer the cesium to the acid stream (the strip stages). The strip effluent is transferred to the DWPF.

In the extraction stages, cesium and nitrate are extracted into the solvent phase. The cesium is stabilized in the solvent phase by the calixarene molecule while the nitrate ion is stabilized by the modifier molecules. Due to the small size of the opening in the calixarene molecules, cesium is removed in dramatic presence to other cations, in 
particular sodium and potassium. This selectivity is more than two orders of magnitude versus potassium and more than four order of magnitude versus sodium. This high selectivity is required to achieve the desired separation of the cesium ions from the bulk sodium ions.

In the proposed process, the cesium concentration in the organic phase is 4.3 times that in the aqueous feed solution. For a typical high level waste feed solution containing 0.27 $\mathrm{mM}$ cesium, the concentration in the organic stream leaving the extraction stages is approximately $1 \mathrm{mM}$. Note that this is significantly below the $10 \mathrm{mM}$ concentration of calixarene in the solvent. Thus, a large excess of available calixarene sites are available for extraction. However, due to the high concentrations of sodium and potassium in the feed stream, a measurable quantity of both sodium and potassium are extracted, and thus do take up a portion of the sites.

To provide an essentially pure cesium nitrate raffinate stream, the potassium and sodium are scrubbed out of the organic phase using two scrubbing stages between the extraction and strip stages. In addition to removing sodium and potassium from the organic phase, the scrub stages also work to remove aluminum, iron and mercury from the organic phase. The scrub stages also work to neutralize any caustic carryover into the scrub stages. The neutralization of these species is essential to control precipitation and to allow stable operation of the stripping stages. Since the strip stages employ a weak acidic solution, introduction of caustic into the strip stages would likely result in significant $\mathrm{pH}$ shifts and thereby diminish process operability.

In the strip stages, the nitrate ion concentration in the aqueous phase is more than 3 orders of magnitude lower than in the extraction stages. This decrease in the nitrate ion concentration shifts the equilibrium to favor transport of nitrate into the organic phase. However, due to disassociation of cesium and nitrate in the organic phase, the concentration of extracted cations in the organic phase must be maintained at approximately 10-5 M. This objective is achieved by adding cold cesium to the strip feed. Through the use of the cold cesium addition, low distribution coefficients are maintained in the stripping stages.

Over long periods of time, degradation of either the modifier or the calixarene may occur. The most likely degradation is that of the modifier to form a phenolic compound that is highly soluble in the organic phase. Gradual degradation of the solvent will result in some loss of performance. The proposed flowsheet contains two additional unit operations intended to maintain solvent performance.

The two proposed unit operations involve first an acidic wash of the solvent followed by a caustic wash of the solvent. These two wash stages are intended to take out any either acidic or caustic impurities that may develop in the solvent system over time. In particular, the caustic wash is known to remove many of the modifier degradation products. In addition, the proposed flowsheet has also assumed that to maintain system performance the solvent will be replaced on an annual basis. 
After extraction, the aqueous phase will contain either soluble or entrained organics. The proposed process contains two additional contactor stages designed to remove soluble organics and in particular to remove calixarene and modifier from the exiting raffinate stream. A small amount of Iso-par $\mathrm{L} \otimes$ is introduced into the stages and used to extract any of the modifier or calixarene from the aqueous phase. The organic phase from these two stages is then mixed with the recycled organic phase and returned to the extraction stages. The aqueous phase from this stage is then sent to a stilling tank where any remaining entrained organics (mostly the Iso-par $\mathrm{L} \otimes$ ) is allowed to float and is decanted. From the stilling tank, the raffinate is transferred to on of two hold tanks to allow decay of the short half life beta in the raffinate stream. These two tanks are sized to allow sufficient hold time for sufficient beta decay to facilitate determination if the target decontamination has been met to allow transfer of the raffinate material to the saltstone facility. The scrub solutions from the organic clean up process are also transferred to saltstone.

A similar solvent recovery process has been designed for the strip effluent. The proposed process contains two additional contactor stages designed to remove soluble organics from the exiting strip effluent. Again, a small amount of Iso-par $L$ « is introduced into the stages and used to extract any of the modifier or calixarene from the aqeous phase. This organic stream can then be returned to the strip stages. The aqeous phase leaves the clean-up stage and is transferred to a stilling tank where the Iso-par $\mathrm{L} \circledast$ is allowed to float and is decanted.

Since Iso-par $L \circledR$ was added in the two solvent recovery processes, removal of this additional diluent is required. The proposed process employs a kerosene still after the caustic wash to boil of the kerosene at low temperatures. Since the Iso-par $\mathrm{L} \otimes$ was added to the bulk solvent stream, the still must be used to evaporate some of this diluent. The overheads from this still are then condensed and sent to CIF. The cleaned and reconcentrated solvent stream is then sent back to service in the solvent hold tank.

Note that the feed stream is feed to the process from a 100,000 gallon tank. The use of a relatively large tank provide approximately 4 days of feed storage and some decoupling of the solvent extraction process from the up stream alpha removal process. Also note that the aqueous strip effluent leaves the stilling tank and is sent to a large storage tank (45 days capacity). The use of a large tank provides for some decoupling of the solvent extraction process and the DWPF. Also note, however, that DWPF can operate completely decoupled from the solvent extraction process (i.e., DWPF can run with or without feed from the solvent extraction process). However, the solvent extraction process can only operate as long as DWPF is operating or storage volume remains in the tanks between the solvent extraction process and DWPF. Cold chemical feed tanks have generally been designed to provide a days worth of feed to the process. These feed tanks are feed from larger feed makeup tanks that will provide a buffer in operations to allow for limited (less than a week) outages of process water and other input chemicals. 
Strip effluent storage is provided to accommodate the differences in cycle times for the SRAT in DWPF and to allow for disengagement of any organic carry-over from the extraction process. Strip effluent will be provided at a rate of $1.5 \mathrm{gpm}$, thereby eliminating the need for an evaporator. The strip effluent transferred to DWPF is assumed to contain the diluent at the saturation limit $(20 \mathrm{mg} / \mathrm{L})$. The strip effluent is evaporated in the DWPF SRAT where the nitric acid content is used to offset the nominal nitric acid requirement. The effluent would contain $<.01 \mathrm{M} \mathrm{Na},<0.001 \mathrm{M}$ of other metals.

The bases for the solvent extraction process is provided in Section A.18.

\subsubsection{Results}

\subsubsection{Model Results}

\section{$\underline{\text { Solvent Extraction Material Balance Model }}$}

Figure 3.3-1 shows a schematic diagram of the Solvent Extraction Material Balance. The alpha decontamination and grout production parts of this models are identical to those discussed in the Direct Grout model. The solvent extraction process adds a continuous counter-current solvent extraction process to remove cesium from the salt solution in the SSHT prior to grouting. The solvent extraction model consists of three parts:

A 16-stage extraction unit where cesium is removed from the salt solution into the solvent. The aqueous effluent from the extraction stage is sent to the grout plant.

A 2-stage scrubber where $0.05 \mathrm{M}$ nitric acid is added the aqueous phase.

A 16-stage stripper where $0.0005 \mathrm{M}$ nitric acid and $0.0001 \mathrm{M}$ cesium nitrate is used to strip the cesium from the organic phase back into the aqueous phase. The aqueous phase from the stripper is accumulated and added as an input stream to the DWPF model.

The organic solvent used in the extraction unit is continuously recycled from the output of the stripping stages to the input of the extraction stages. A series of trial calculations showed that a flow rate of $5.7 \mathrm{gpm}$ solvent maximized the amount of cesium removed from the salt solution. The scrub flow was set to $20 \%$ of the solvent flow and the strip flow was fixed at $1.5 \mathrm{gpm}$. Cesium was assumed to be the only component extracted from the salt solution.

This model was compared to results obtained from prior work (Reference 21), with the results of the comparison being shown in Appendix E.

The speedup model was modified to provide material balances for the proposed solvent extraction process. These modifications included increasing the salt flowrate, decreasing the strip flow rate and adding the caustic wash solution. The results of this model are summarized in Table 3.3-1. 


\section{Table 3.3-1 Summary of Solvent Extraction SPEEDUP Model}

\begin{tabular}{|c|c|}
\hline Parameter (@ 100\% attainment) & Model Result \\
\hline Salt Processed (kgal/year) & 9,247 \\
\hline Grout Made (kgal/year) & 16,291 \\
\hline Strip Solution to DWPF (kgal/year) & 789 \\
\hline Canisters (per year) & 426 \\
\hline Solvent Used (kgal/year) & 1 \\
\hline
\end{tabular}

The raffinate sent to Saltstone from this process contains less than $40 \mathrm{nCi} / \mathrm{g}$ of ${ }^{137} \mathrm{Cs}$ and contains only trace $(<20 \mathrm{ppm})$ concentrations of organics. This feed stream to Saltstone is approximately $5.7 \mathrm{M}$ sodium. The strip effluent sent to DWPF from this process contains approximately $20 \mathrm{Ci} /$ gallon of $\mathrm{Cs}^{137}$ and contains only trace $(<20 \mathrm{ppm})$ concentrations of organics. This feed stream to DWPF consists primarily of dilute nitric acid and cesium nitrate. Integration of this stream into the DWPF facility is relatively seamless. 


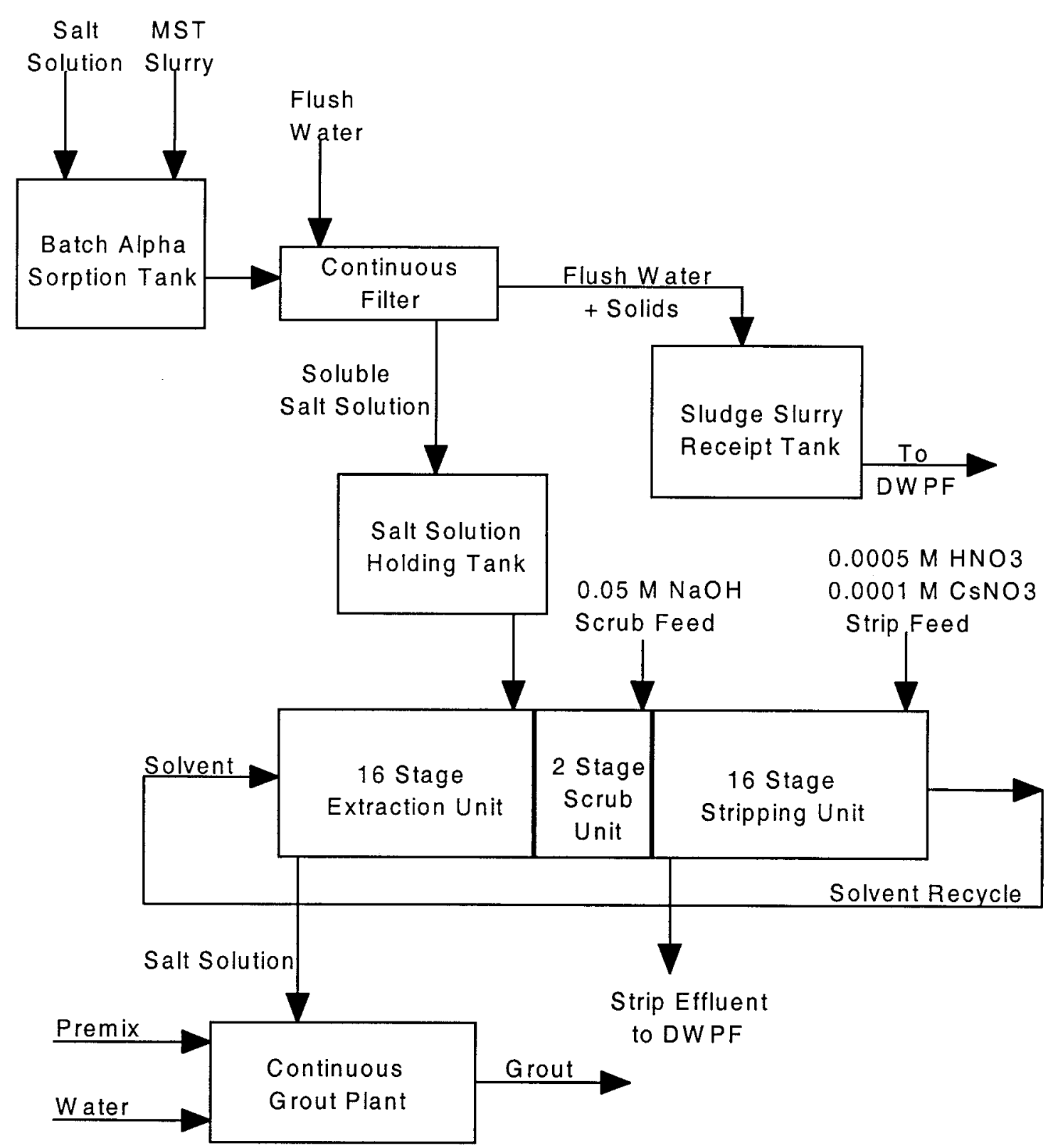

Figure 3.3-1. Schematic representation of Solvent Extraction Model.

\subsubsection{Experimental Results}

An extensive experimental program was completed in support of phase III evaluation. The results of these investigations have been evaluated to determine the potential impacts on the proposed process. The following is a summary of those impacts. 


\section{High Level Waste Performance}

SRTC personnel completed a test to determine the extraction, scrubbing and stripping performance of the solvent system with a sample of SRS High Level Waste (Reference 22). This test employed two extraction, one scrub and three strip contacts. Personnel determined distribution coefficients for each of these contacts. The distribution coefficient for extraction exceeds 11 , versus the design basis value of 8 . In addition, the stripping distribution coefficients proved less than 0.1 , again an improvement over the design basis value of 0.2 . The additional margin between the measured values and those employed in the design basis indicate that the proposed process likely contains a significant amount of over design. Modification of the proposed process based on these values could result in the elimination of as many as 16 contactor stages from the proposed process.

\section{Temperature Control}

The cesium equilibrium between solvent and aqueous phase is strongly dependent upon the temperature of the system. Under extraction and stripping conditions typical of expected plant operations, the equilibrium distribution coefficients will change by at least a factor of 2 for every $10^{\circ} \mathrm{C}$. Selection of the organic flow rate is highly dependent upon these distribution coefficients. Therefore, to facilitate smooth operation of the proposed solvent extraction facility, limited temperature control is required. Based on the proposed organic flowrate, this requirement is manifested as operational temperature limits of $\geq 30$ ${ }^{\circ} \mathrm{C}$ for the strip stages (to obtain $\mathrm{D}_{\mathrm{CS}} \geq 8.0$ ) and $\leq 25^{\circ} \mathrm{C}$ in the extraction stages (to obtain $\mathrm{D}_{\mathrm{CS}} \leq 0.2$ ).

In addition, more stringent temperature controls, such as setting the strip temperature to > $37^{\circ} \mathrm{C}$ could greatly decrease the number of stages required for operation. At a stripping temperature of $>37^{\circ} \mathrm{C}$ (to obtain $\mathrm{D}_{\mathrm{CS}} \leq 0.06$ ), the number of required processing stages could be reduced to 20 (Reference 23). Such a reduction in the number of required stages would eliminate 2 six-packs of contactor stages and their associated jumpers.

\section{$\underline{\text { Amine Addition }}$}

Similarly, the addition of $1 \times 10^{-4} \mathrm{M}$ trioctyl amine (TOA) to the solvent has been shown to decrease the stripping distribution coefficient by 10 fold (Reference 24). If TOA is used, the temperature controls indicated above could be relaxed. Furthermore, addition of TOA to the solvent would reduce the required number of processing stages to 20 .

\section{$\underline{\text { Solvent Recovery }}$}

Testing has shown that calixarene and the modifier are sparingly soluble in aqueous solutions (Reference 24). The partition coefficients for modifier are on the order of 50,000 while those for calixarene are greater than 1 million. Based on these values, less than $15 \%$ of the low cost modifier and less than $1 \%$ of the calixarene would be lost from 
the system in a year. Thus, a simple decantation of the raffinate and the effluent should prove sufficient means for solvent recovery and limit the organic carryover to downstream processes. Use of decantation would eliminate the need for four solvent recovery stages, a kerosene still, and a kerosene condensate tank.

\section{$\underline{\text { Solvent Stability and Cleanup }}$}

Chemical stability testing under caustic conditions at $53^{\circ} \mathrm{C}$ (the extraction stages) indicated that the modifier decomposed at a rate of $2 \%$ per day (Reference 24 ). The primary products of decomposition were $\mathrm{p}$-(t-octyl)phenol and fluorinated alcohol. Under these conditions, no detectable decomposition of the calixarene was observed (Reference 24). Since the extraction stages will have a temperature limit of approximately $25^{\circ} \mathrm{C}$, significantly lower decomposition of the modifier is expected in the extraction stages. Additional tests under acidic conditions produced much lower modifier decomposition rates, indicating that decomposition of the modifier will be low in the strip stages.

Based on an average concentration of $3.5 \times 10^{-5} \mathrm{M}{ }^{137} \mathrm{Cs}$ in the organic phases, the solvent is expected to receive about $8 \mathrm{Mrad}$ of dose. Note that this dose rate does not credit residence time outside of the contactor stages (i.e., residence time in the solvent hold tank). A solvent sample was analyzed following exposure to $25 \mathrm{Mrad}$ of dose. No noticeable degradation of calixarene was detectable and less than $5 \%$ degradation of the modifier was observed (Reference 25).

This data suggests that less than $10 \%$ of the calixarene is likely to require replacement each year. This low rate of calixarene replacement would reduce the estimated annual cost of solvent (based on $100 \%$ replacement per year).

Testing at ORNL showed that a $0.5 \mathrm{M}$ caustic scrub will be moderately effective in controlling the concentration of degradation products in the solvent system (Reference 24). Under these conditions, the partition coefficient for $\mathrm{p}$-(t-octyl)phenol (the primary degradation product from the modifier) is approximately 30 . The use of a $1 \mathrm{gpm}$ caustic scrub would limit the concentration of the p-(t-octyl)phenol to less than $10 \%$ of the modifier concentration at a decomposition rate of $2 \%$ per day for the modifier. At lower decomposition rates, lower flowrates can be used to maintain low p-(t-octyl)phenol concentrations in the solvent. The resultant scrub solution would contain less than 40 $\mathrm{nCi} / \mathrm{g}$ Cs. The caustic scrub solutions will be disposed at Saltstone.

\section{Temperature Dependence of CST Equilibrium/Loading}

The equilibrium between the $\mathrm{Cs}$ in salt solution and the Cs on the CST ion exchange material is a function of temperature. As the temperature increases, the proportion of Cs exchanged from solution onto the CST decreases. In other words, for a given feed composition the capacity of the CST decreases with increasing temperature. Figure 3.3-2 
shows the temperature dependence as predicted by the TAMU equilibrium model (Reference 26).

Figure 3.3-2

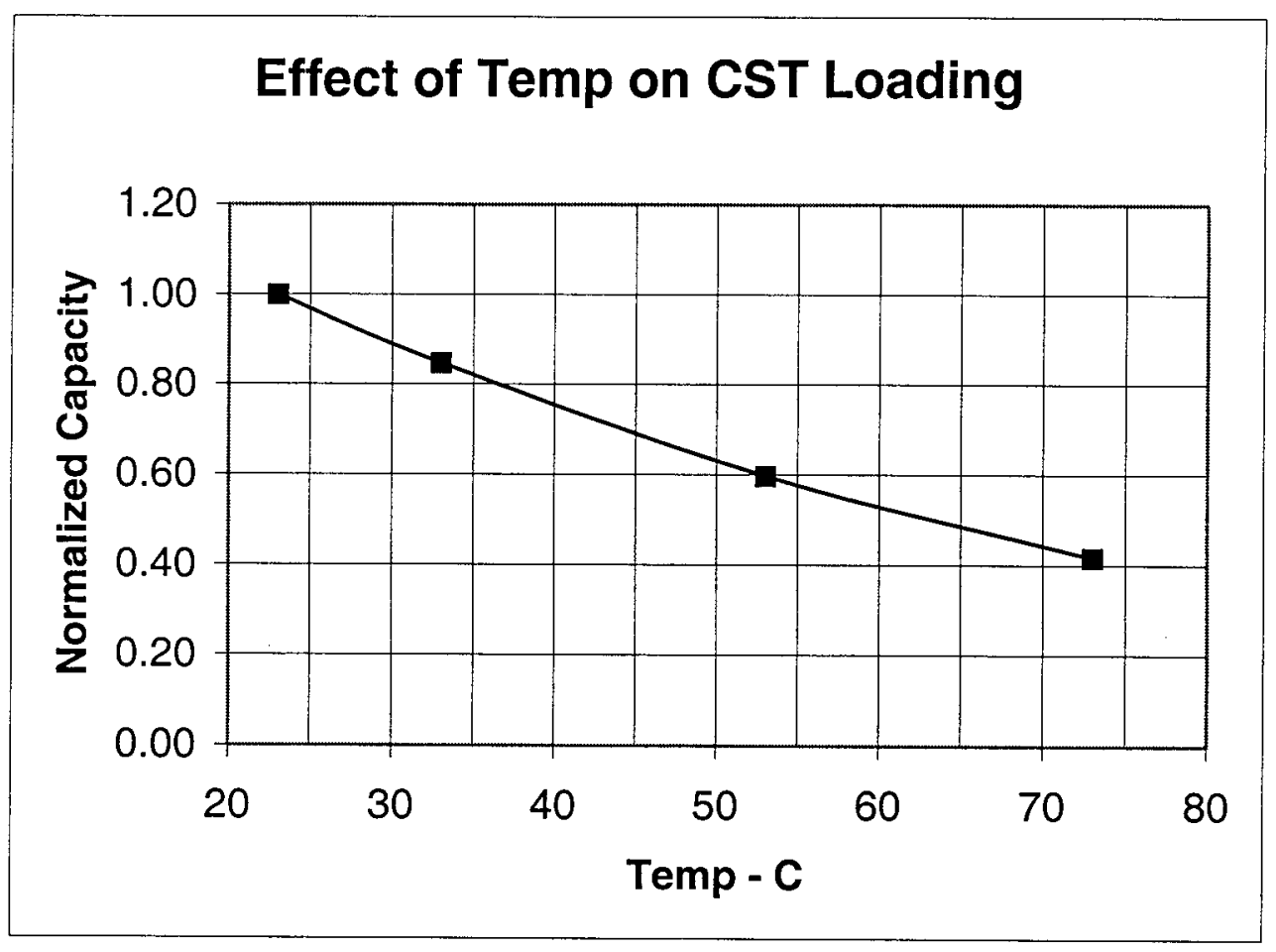

The equilibrium capacity (in $\mathrm{mg} \mathrm{Cs} / \mathrm{g} \mathrm{CST}$ ) is normalized to the capacity at $23{ }^{\circ} \mathrm{C}$. It shows that for a $10{ }^{\circ} \mathrm{C}$ increase (from 23 to $33^{\circ} \mathrm{C}$ ), the capacity decreases by $\sim 15 \%$. For an increase from 23 to $53{ }^{\circ} \mathrm{C}$, the capacity decreases by $40 \%$.

The temperature dependence has some implications for CST usage and the resulting concentration in the DWPF glass. However, the primary concern would be desorption from the CST if the operating temperature increased by more than a few degrees after Cs had been exchanged onto the material. It is likely that heat exchangers/chillers will have to be provided to maintain temperature control.

\subsubsection{Equipment}

\subsubsection{Building Layout}

Building layout based on shielding and functional area sizes of the Caustic Side Solvent Extraction alternative compared to equivalent DWPF facility layouts are provided below in Table 3.3-2 and 3.3-3. Major process equipment consists of chemical storage and feed tanks, a large alpha sorption tank, transfer pumps, agitators, 1 set of crossflow filters, filter cleaning tanks, resin hold tanks, mercury removal ion exchange columns, product 
hold tanks, multi-stage extraction contactors, multi-stage effluent strip contactors, organic removal contactors, solvent cleanup tanks

Table 3.3-2 Building Layout Based On Solvent Extraction

\begin{tabular}{|c|c|c|c|}
\hline & DWPF & SOLVENT & $\begin{array}{c}\text { SOLVENT } \\
\% \text { DWPF }\end{array}$ \\
\hline AREA (SQ.FT) & & & \\
\hline SHIELDED & 16,278 & 10,323 & $63 \%$ \\
\hline UNLOADING WELL & 2,175 & 2,320 & $107 \%$ \\
\hline LOW SHIELD & & 4,297 & \\
\hline OPERATING CORRIDOR & 59,029 & 31,387 & $53 \%$ \\
\hline CRANE OPERATING & 18,457 & 20,302 & $110 \%$ \\
\hline & & & \\
\hline TOTAL & 95,939 & 68,629 & $72 \%$ \\
\hline VOLUME(CU.FT) & & & \\
\hline SHIELDED & 640,344 & 464,535 & $73 \%$ \\
\hline UNLOADING WELL & 86,348 & 104,400 & $121 \%$ \\
\hline LOW SHIELD & & 193,365 & \\
\hline OPERATING CORRIDOR & $1,081,583$ & 776,156 & $72 \%$ \\
\hline CRANE OPERATING & 700,261 & 579,382 & $83 \%$ \\
\hline & & & \\
\hline TOTAL & $2,508,536$ & $2,117,838$ & $84 \%$ \\
\hline
\end{tabular}

\subsubsection{Tanks}

Table 3.3-3 Tanks for Caustic Side Solvent Extraction Alternative

\begin{tabular}{|l|c|l|}
\hline \multicolumn{1}{|c|}{ Tank } & Tank Size & \multicolumn{1}{c|}{ Sizing Assumption } \\
\hline Scrub Feed Tank & 2500 gallons & $\begin{array}{l}\text { Sized to provide storage for one day of } \\
\text { processing material. }\end{array}$ \\
\hline Strip Feed Tank & 4000 gallons & $\begin{array}{l}\text { Sized to provide storage for one day of } \\
\text { processing material. }\end{array}$ \\
\hline $\begin{array}{l}\text { Solvent Makeup } \\
\text { Tank }\end{array}$ & 1000 gallons & $\begin{array}{l}\text { Sized to hold the estimated volume of the } 36 \\
\text { centrifugal contactors, Solvent Hold Tank, } \\
\text { and associated piping. The tank volume will } \\
\text { allow make-up of the full solvent system if } \\
\text { complete changeout of solvent is needed. }\end{array}$ \\
\hline
\end{tabular}




\begin{tabular}{|l|c|l|}
\hline \multicolumn{1}{|c|}{ Tank } & Tank Size & \multicolumn{1}{c|}{ Sizing Assumption } \\
\hline Solvent Hold Tank & 1000 gallons & $\begin{array}{l}\text { Sized to hold the estimated volume of the 36 } \\
\text { centrifugal contactors and associated piping } \\
\text { and provide on-line make-up for the solvent } \\
\text { recirculation system. }\end{array}$ \\
\hline $\begin{array}{l}\text { Nitric Acid Feed } \\
\text { Tank }\end{array}$ & 1000 gallons & $\begin{array}{l}\text { Sized to provide make-up for the strip feed } \\
\text { and scrub feed systems. }\end{array}$ \\
\hline Process Water Tank & 25,000 gallons & $\begin{array}{l}\text { Sized to provide make-up for the chemical } \\
\text { addition tanks, GT-73 resin make-up, and } \\
\text { cooling system. }\end{array}$ \\
\hline $\begin{array}{l}\text { DWPF Salt Feed } \\
\text { Tank }\end{array}$ & 100,000 gallons & $\begin{array}{l}\text { This tank will hold a 45-day supply of salt } \\
\text { for processing in DWPF. The Solvent } \\
\text { Extraction Facility will be effectively de- } \\
\text { coupled from DWPF. }\end{array}$ \\
\hline $\begin{array}{l}\text { Clean Solvent Hold } \\
\text { Tank }\end{array}$ & 1000 gallons & $\begin{array}{l}\text { Sized to hold the estimated volume of } \\
\text { solvent in the 36 centrifugal contactors, } \\
\text { Solvent Hold Tank, and associated piping } \\
\text { during the solvent cleaning process. }\end{array}$ \\
\hline $\begin{array}{l}\text { Solvent Wash } \\
\text { Solution Make-up } \\
\text { Tank }\end{array}$ & 1000 gallons & $\begin{array}{l}\text { Sized to hold the wash solution for cleaning } \\
\text { the solvent. }\end{array}$ \\
\hline $\begin{array}{l}\text { Solvent Wash } \\
\text { Solution Receipt } \\
\text { Tank }\end{array}$ & 1000 gallons & $\begin{array}{l}\text { Sized to hold the used wash solution } \\
\text { following the cleaning of the solvent. }\end{array}$ \\
\hline $\begin{array}{l}\text { Strip Effluent } \\
\text { Stilling Tank }\end{array}$ & 500 gallons & $\begin{array}{l}\text { Sized to hold-up the strip solution to allow } \\
\text { decanting the organic from the aqueous in } \\
\text { the strip stream. }\end{array}$ \\
\hline $\begin{array}{l}\text { DWPF Hold Tank } \\
\text { Stilling Tank }\end{array}$ & $\begin{array}{l}\text { Sized to provide a six-day make-up to the } \\
\text { evaporator. }\end{array}$ \\
\hline Ba-137 Decay Tank & $\begin{array}{l}\text { Sized to hold up the raffinate solution to } \\
\text { allow decanting the organic from the } \\
\text { aqueous raffinate stream. }\end{array}$ \\
\hline
\end{tabular}




\begin{tabular}{|c|c|c|}
\hline Tank & Tank Size & Sizing Assumption \\
\hline $\begin{array}{l}\text { Kerosene Make-up } \\
\text { Tank }\end{array}$ & 2000 gallons & $\begin{array}{l}\text { Sized for one week of storage for make-up } \\
\text { to the Raffinate Organic Removal Stages and } \\
\text { the Strip Organic Removal Stages }\end{array}$ \\
\hline $\begin{array}{l}\text { Mercury Removal } \\
\text { Feed Tank }\end{array}$ & 2500 gallons & $\begin{array}{l}\text { Sized to receive one Ba-137 Decay Tank } \\
\text { batch. The Mercury Removal System will be } \\
\text { used if the mercury concentration in the } \\
\text { clarified salt solution exceeds the Saltstone } \\
\text { Waste Acceptance Criteria. }\end{array}$ \\
\hline MST Storage Tank & 400 gallons & $\begin{array}{l}\text { Sized for approximately four weeks of } \\
\text { storage. }\end{array}$ \\
\hline $\begin{array}{l}\text { Alpha Sorption } \\
\text { Tank }\end{array}$ & 100,000 gallons & Sized to hold one batch of salt solution. \\
\hline $\begin{array}{l}\text { Clarified Salt } \\
\text { Solution Tank }\end{array}$ & 100,000 gallons & $\begin{array}{l}\text { Sized to hold one batch of clarified salt } \\
\text { solution. }\end{array}$ \\
\hline $\begin{array}{l}\text { Sludge Solids } \\
\text { Receipt Tank }\end{array}$ & 10,000 gallons & $\begin{array}{l}\text { Sized to receive multiple filter cleaning } \\
\text { cycles and sludge solids prior to pumping to } \\
\text { DWPF. }\end{array}$ \\
\hline Process Water Tank & 5000 gallons & $\begin{array}{l}\text { Sized to support chemical addition tanks and } \\
\text { filter backpulse. }\end{array}$ \\
\hline $\begin{array}{l}\text { Oxalic Acid Feed } \\
\text { Tank }\end{array}$ & 200 gallons & $\begin{array}{l}\text { Sized to hold the solution to clean one cross- } \\
\text { flow filter. }\end{array}$ \\
\hline $\begin{array}{l}\text { Filter Cleaning } \\
\text { Caustic Tank }\end{array}$ & 500 gallons & $\begin{array}{l}\text { Sized hold the solution to clean one cross- } \\
\text { flow filter. }\end{array}$ \\
\hline
\end{tabular}




\begin{tabular}{|c|c|c|}
\hline Tank & Tank Size & Sizing Assumption \\
\hline DSS Hold Tanks & $\begin{array}{l}2 \text { tanks each } \\
100,000 \text { gallons }\end{array}$ & $\begin{array}{l}\text { The tanks are sized to allow five days of } \\
\text { hold-up of the material to verify mercury } \\
\text { removal, if applicable, meets the Saltstone } \\
\text { Waste Acceptance Criteria. The tanks also } \\
\text { allow hold-up of material during the time } \\
\text { that the Saltstone Facility is de-staffed and } \\
\text { somewhat de-couple the Saltstone Facility } \\
\text { from the Solvent Extraction Facility. Two } \\
\text { tanks will allow filling of one tank while } \\
\text { waiting for sample results of the second. } \\
\text { NOTE: These tanks allow for five days of } \\
\text { product storage from the Solvent Extraction } \\
\text { Facility. This five days of product is less } \\
\text { than four days of operation of the Saltstone } \\
\text { Facility. }\end{array}$ \\
\hline $\begin{array}{l}\text { Chemical Additive } \\
\text { Tank }\end{array}$ & 100 gallons & $\begin{array}{l}\text { Sized to support the make-up of small } \\
\text { volumes of additives such as the } \mathrm{CsNO}_{3} \text {. }\end{array}$ \\
\hline Isopar Hold Tank & 5000 gallons & $\begin{array}{l}\text { Sized to provide storage of the Isopar prior to } \\
\text { use in the Solvent Make-up Tank and } \\
\text { Kerosene Make-up Tank. }\end{array}$ \\
\hline $\begin{array}{l}\text { Strip Effluent Hold } \\
\text { Tank }\end{array}$ & 10,000 gallons & $\begin{array}{l}\text { Sized to support the volume of strip solution } \\
\text { needed for two SRAT batches. }\end{array}$ \\
\hline $\begin{array}{l}\text { Mercury Removal } \\
\text { Caustic Tank }\end{array}$ & 200 gallons & $\begin{array}{l}\text { Sized to support the make-up of one GT- } 73 \\
\text { resin column for mercury removal. }\end{array}$ \\
\hline $\begin{array}{l}\text { Slurry Make-up } \\
\text { Tank }\end{array}$ & 3000 gallons & $\begin{array}{l}\text { Sized to make-up one GT- } 73 \text { resin column } \\
\text { for mercury removal. }\end{array}$ \\
\hline $\begin{array}{l}\text { Sodium Nitrate } \\
\text { Tank }\end{array}$ & 200 gallons & Sized to treat one GT- 73 resin column. \\
\hline Spent Resin Tank & 3000 gallons & Sized to treat one GT-73 resin column. \\
\hline $\begin{array}{l}\text { Resin Loading and } \\
\text { Wash Overflow } \\
\text { Tank }\end{array}$ & 3000 gallons & $\begin{array}{l}\text { Sized to treat one column volume of GT- } 73 \\
\text { resin. }\end{array}$ \\
\hline $\begin{array}{l}\text { Cleaning Solution } \\
\text { Dump Tank }\end{array}$ & 1000 gallons & \\
\hline $\begin{array}{l}\text { BOBCalix Feed } \\
\text { Tank }\end{array}$ & 50 gallons & $\begin{array}{l}\text { Sized to provide the make-up necessary for } \\
\text { the Solvent Make-up Tank and any addition } \\
\text { to the Solvent Hold Tank during operation. }\end{array}$ \\
\hline
\end{tabular}




\begin{tabular}{|c|c|c|}
\hline Tank & Tank Size & Sizing Assumption \\
\hline Modifier Feed Tank & 500 gallons & $\begin{array}{l}\text { Sized to provide the make-up necessary for } \\
\text { the Solvent Make-up Tank and any addition } \\
\text { to the Solvent Hold Tank during operation. }\end{array}$ \\
\hline $\begin{array}{l}\text { Nitric Acid Charge } \\
\text { Tank }\end{array}$ & 1 gallon & $\begin{array}{l}\text { Sized to provide the } 50 \% \text { Nitric Acid } \\
\text { necessary to reach the } 0.0001 \mathrm{M} \mathrm{HNO}_{3} \text { for } \\
\text { the Strip Feed Tank. }\end{array}$ \\
\hline $\begin{array}{l}\text { Scrub Make-up } \\
\text { Tank }\end{array}$ & 15,000 gallons & $\begin{array}{l}\text { Sized to make-up one week of scrub feed. } \\
\text { This will allow chemical mixing and } \\
\text { sampling prior to pumping to the Scrub Feed } \\
\text { Tank. }\end{array}$ \\
\hline $\begin{array}{l}\text { Strip Make-up } \\
\text { Tank }\end{array}$ & 25,000 gallons & $\begin{array}{l}\text { Sized to make-up one week of strip feed. } \\
\text { This will allow chemical mixing and } \\
\text { sampling prior to pumping to the Strip Feed } \\
\text { Tank. }\end{array}$ \\
\hline $\begin{array}{l}\text { Salt Solution Feed } \\
\text { Tank }\end{array}$ & 100,000 gallons & $\begin{array}{l}\text { Sized to hold enough clarified salt solution } \\
\text { for five days of processing in the Solvent } \\
\text { Extraction Facility. This tank will also } \\
\text { provide as a recirculation receipt tank during } \\
\text { start-up of the solvent extraction process. }\end{array}$ \\
\hline Caustic Feed Tank & 1000 gallons & $\begin{array}{l}\text { Sized to receive the } 50 \% \text { caustic solution and } \\
\text { store for use in the Re-alkaline Stages of the } \\
\text { solvent extraction process as well as the GT- } \\
73 \text { resin treatment process. }\end{array}$ \\
\hline $\begin{array}{l}\text { Caustic Make-up } \\
\text { Tank }\end{array}$ & 1000 gallons & $\begin{array}{l}\text { Sized to make-up the caustic to the molarity } \\
\text { needed in the Re-alkaline Stages of the } \\
\text { solvent extraction process. }\end{array}$ \\
\hline $\begin{array}{l}\text { Kerosene Vacuum } \\
\text { Still }\end{array}$ & & $\begin{array}{l}\text { Used to remove the excess kerosene in the } \\
\text { solvent extraction process. The excess } \\
\text { kerosene will be transferred to the } \\
\text { Consolidated Incineration Facility. (with } \\
\text { Kerosene Condensate Tank) }\end{array}$ \\
\hline Re-Alkaline Stages & Two Stages & $\begin{array}{l}\text { These two stages will be used to increase the } \\
\mathrm{pH} \text { in the solvent after scrubbing. }\end{array}$ \\
\hline $\begin{array}{l}\text { Strip Organic } \\
\text { Removal Stages }\end{array}$ & Two stages & $\begin{array}{l}\text { These two stages are used to remove organic } \\
\text { from the aqueous strip stream. }\end{array}$ \\
\hline $\begin{array}{l}\text { Raffinate Organic } \\
\text { Removal Stages }\end{array}$ & Two stages & $\begin{array}{l}\text { These two stages are used to remove organic } \\
\text { from the aqueous raffinate stream. }\end{array}$ \\
\hline
\end{tabular}




\subsubsection{Transfer Lines}

Fresh Waste will be pumped to Tank 50. The salt solution will either be sampled and 'qualified' prior to being pumped to Tank 50 or will be sampled while in Tank 50 prior to transfer to the new Solvent Extraction Facility.

The salt solution will then be pumped to the new Solvent Extraction Facility via the existing interarea transfer line, which will be modified. The new Solvent Extraction Facility will be located near the current Late Wash Facility. A section of new interarea transfer line will be needed to connect the current interarea transfer line to the new Facility. This tie-in will be near the Late Wash Facility.

The salt solution in the new Solvent Extraction Facility will be treated using Monosodium Titanate (MST) to remove uranium, plutonium, and strontium from the salt solution. The salt solution is filtered to remove the sludge solids and the MST solids. These solids will be pumped to a new Pump Pit sludge tank via a new interarea transfer line. This new Pump Pit will be in the vicinity of the current Low Point Pump Pit (LPPP) in the Defense Waste Processing Facility (DWPF).

A new interarea transfer line will be required between the new Pump Pit and the DWPF Salt Processing Cell (SPC). The MST solids and the sludge solids will be pumped via this new interarea transfer line to a new tank located in the SPC. The MST solids and sludge solids will then be pumped to the Sludge Receipt and Adjustment Tank (SRAT).

The Cesium Strip Solution will be transferred from the new Solvent Extraction Facility to the Low Point Pump Pit Precipitate Tank (LPPPPT) via a new interarea transfer line. This new interarea transfer line can tie into the 'abandoned' precipitate line from the Late Wash Facility.

The Cesium Strip Solution will then be transferred from the LPPPPT to a new Strip Effluent Hold Tank located in the SPC. This transfer will occur via the existing interarea transfer line.

The Raffinate from the new Solvent Extraction Facility will be transferred to a new valve box which will allow the Saltstone Facility to receive material from ETF or the new Solvent Extraction Facility.

The ETF Bottoms will be transferred to a new 50,000-gallon ETF Bottoms Tank via a new interarea transfer line. The new interarea transfer line is needed because the current line will be used to transfer high activity salt solution to the new Solvent Extraction Facility. The new ETF Bottoms Tank will hold approximately 4-5 months of ETF Evaporator Bottoms based on current production rates. The ETF Bottoms can then be campaigned when a new salt solution batch is being sampled. 
The new valve box will then be used to transfer either the Raffinate or the ETF Bottoms to the Saltstone Facility via the current interarea transfer line at the Low Point Drain Tank. See Figure 3.3-3. 

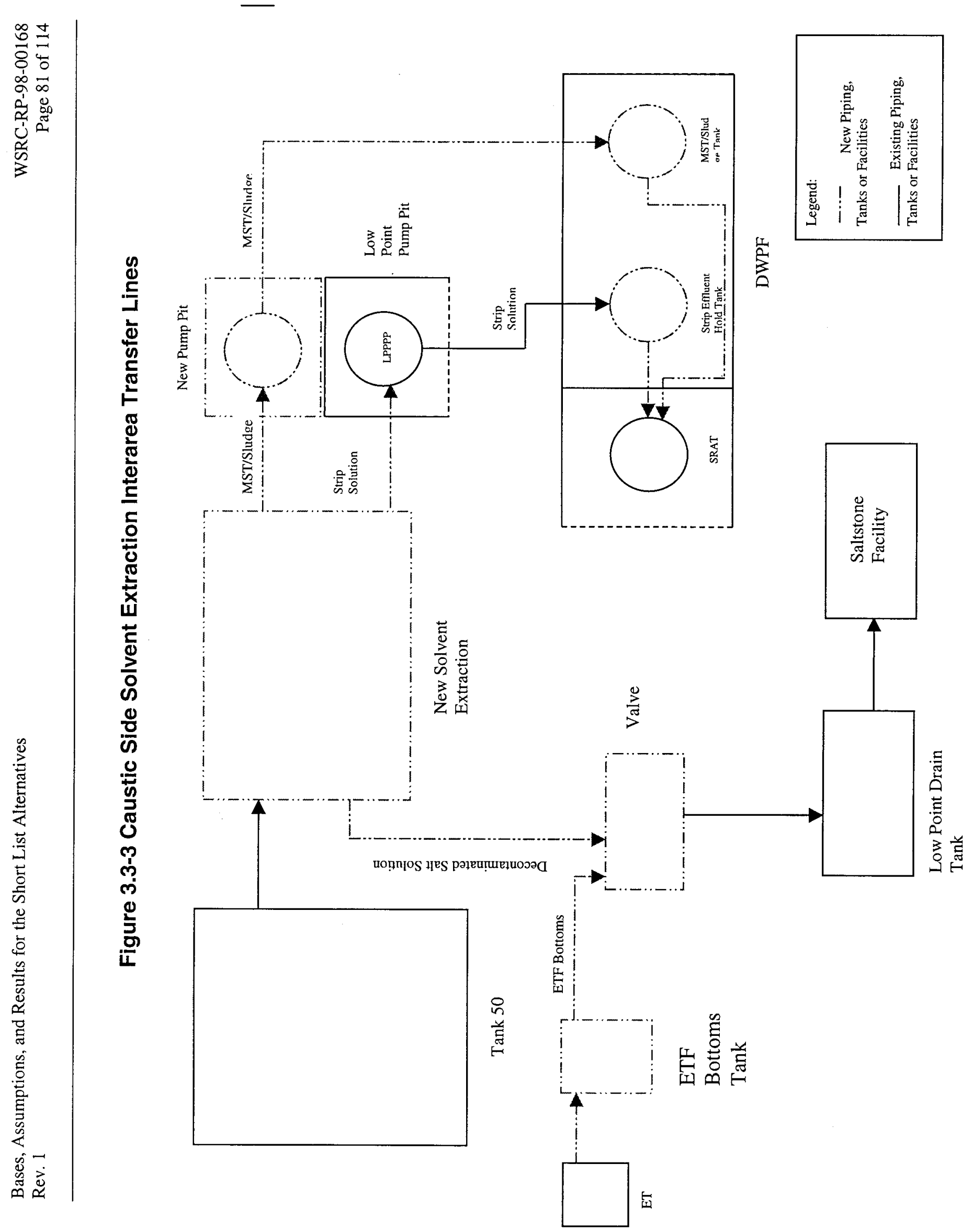


\subsubsection{Jumpers}

Table 3.3-4 Summary of Jumper Usage for Solvent Extraction Alternative

\begin{tabular}{|l|c|}
\hline \multicolumn{1}{|c|}{ Jumper Application } & Number of Jumpers \\
\hline Process Jumpers & 144 \\
\hline Process Jumpers with MOVs & 13 \\
\hline 3-way Process Jumpers & 5 \\
\hline 3-way Process Jumpers w/2 MOVs & 1 \\
\hline Electrical Jumpers & 95 \\
\hline Instrumentation Jumpers & 37 \\
\hline TOTAL & 253 \\
\hline
\end{tabular}

\subsection{NON-ELUTABLE ION EXCHANGE}

The proposed process would employ crystalline silicotitanate (CST) resin to remove Cs from the salt solution. $\mathrm{Sr}, \mathrm{Pr}$, and $\mathrm{U}$ are removed beforehand by monosodium titanate (MST) addition. Since the Cs cannot be eluted from the CST, the loaded resin would be transferred to the DWPF to be combined with sludge and frit to produce borosilicate glass. The decontaminated salt solution would go to the Saltstone Facility to be made into a Class A grout after treatment to remove $\mathrm{Hg}$.

The process would include these steps: MST addition to remove $\mathrm{Sr}, \mathrm{Pu}$, and $\mathrm{U}$ to meet Saltstone TRU limits. Filtration to remove sludge and MST solids from the salt solution to prevent plugging of the ion exchange (IX) columns. After washing to remove soluble salts, the solids would flow to the DWPF. The clarified salt solution flows through a series of CST beds (columns) to remove the Cs. Cs-loaded CST is slurried from the bed and transferred to the DWPF. The decontaminated salt solution would be transferred to Hg removal (GT-73) and then to the Saltstone Facility to produce a Class A waste.

\subsubsection{Alternative Description}

The salt solution contains insoluble sludge and soluble species that must be removed to meet Saltstone requirements. In addition, the sludge must be removed to prevent plugging the IX column bed. The first step is to add MST (an insoluble solid) that sorbs the soluble $\mathrm{Sr}, \mathrm{Pu}$, and $\mathrm{U}$. Both the MST and sludge are then removed by cross-flow filtration and concentrated to about $5 \mathrm{wt} \%$ solids. These solids are transferred to the DWPF for incorporation in the glass but must be washed first to avoid excessive alkali to DWPF.

The clarified salt solution flows to the Recycle Blend Tank in the CST IX portion of the process (Figure 3.4-1). 
Figure 3.4-1

\section{CST Ion Exchange}

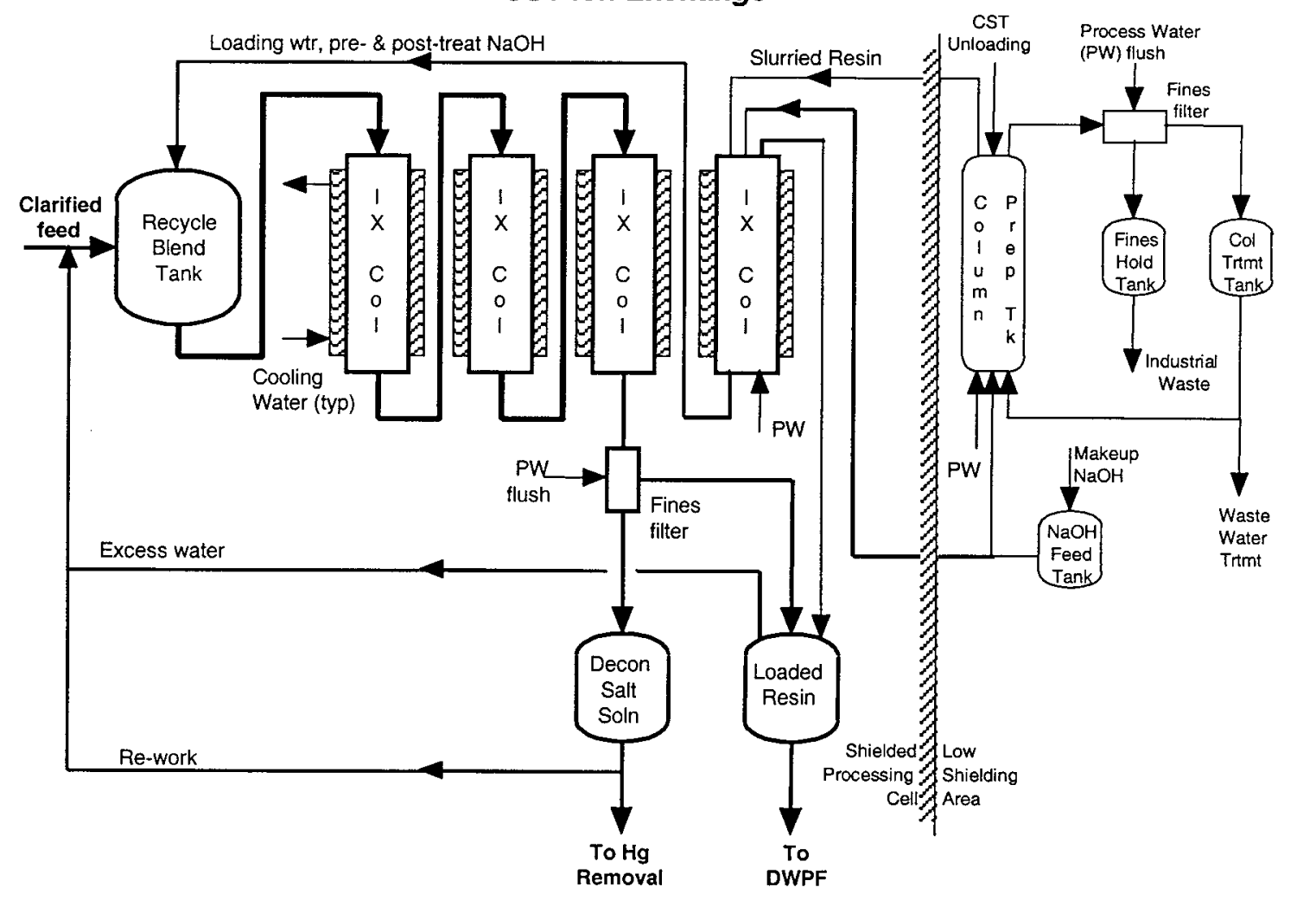

In the Recycle Blend Tank, clarified salt solution is combined with the water used to load and unload CST and with the pre- and post-treatment $\mathrm{NaOH}$ before feeding to the IX train. The train consists of three columns in series where the Cs is exchanged onto the CST. The effluent from the last bed is passed through a fines filter to prevent Cs-loaded fines from contaminating the salt solution. The filtered salt solution flows to the Decontaminated Salt Solution Tank and the activity is measured to ensure it meets the saltstone limit for ${ }^{137} \mathrm{Cs}$. It then flows to the $\mathrm{Hg}$ removal ion exchange column, if necessary, where $\mathrm{Hg}$ is adsorbed onto GT-73 resin. The decontaminated salt solution then flows to Saltstone.

A fourth column is provided to allow continued operation while Cs-loaded CST is being removed and fresh CST is being added to the column. When the first column in the train is close to saturation (expected to be $>90 \%$ ), that column is removed from service, the second column becomes the lead column, the third column becomes the middle column, and the fresh, standby column becomes the third, or guard, column. The Cs-loaded CST from the first column is then sluiced with water into the Loaded Resin Tank where it is combined with the fines from the fines filter. Excess sluicing water is removed to produce a $10 \mathrm{wt} \%$ CST slurry in water. The excess water is sent to the Recycle Blend Tank. The CST/water slurry is transferred to the DWPF. 
Before being loaded into a column, the CST must undergo two treatments. First, the CST is loaded into the Column Preparation Tank, similar in dimensions to an IX column bed. The CST is then backflushed with water to float off the fines. These fines are removed by a filter for disposal as Industrial Waste. The second treatment involves a 24-hour caustic soak. The as-received CST is partially in the hydrogen form and partially in the sodium form. It is converted to the sodium form by circulating a $\mathrm{NaOH}$ solution through the bed for 24 hours. The material is then ready to load into an empty standby column by sluicing with water.

Prior to placing the freshly loaded standby column in service, the water must be displaced by a $2 \mathrm{M} \mathrm{NaOH}$ solution. If this is not done, aluminum may precipitate from the initial salt solution feed as the $\mathrm{pH}$ is reduced by mixing with the residual water. (Water must be maintained in the bed to exclude air which might cause channeling in the bed.) A similar $\mathrm{NaOH}$ flush is required after the bed is removed from service and before the CST is sluiced from the bed with water.

\subsubsection{Results}

\subsubsection{Introduction}

The decontamination of SRS salt solution is to be performed with a non-elutable ion exchange resin, crystalline silicotitanate (CST). This section presents the Flowsheet Team commitments outlined in the modified work scope matrix for the flowsheet team per HLW-SDT-980071, revision 1. These commitments include resin loading properties, sizing of the ion exchange columns, the expected baseline performance of these columns, factors that effect column performance, and CST/Cs disposition issues.

\subsubsection{Resin Loading Properties}

The adsorption of $\mathrm{Cs}^{+}$ion onto crystalline silicotitanate exchanges a $\mathrm{Na}^{+}$ion for the cesium ion. Since this is truly an ion exchange process, the environment (the salt solution) has a profound effect on the equilibrium between the liquid and solid phases. SRS salt solutions are very concentrated - typically 5 to $7 \mathrm{M} \mathrm{Na}^{+}$- and ions such as $\mathrm{OH}^{-}$, $\mathrm{NO}_{3}^{-}$, and $\mathrm{NO}_{2}^{-}$, exert influence primarily through ionic strength (chemical activity). Also, while CST is highly specific for cesium, there are other ions that are also exchanged onto the CST and, therefore, compete with cesium. Most notably, these are potassium, strontium, and rubidium. All these factors affect the capacity of CST to adsorb cesium; thus impacting both column size and CST usage. The composition of SRS waste can vary considerably (See Appendix C), so it is necessary to evaluate the impact the various waste compositions can have on the capacity of the CST. The Texas A\&M CST equilibrium model (Reference 27) was used to assess these impacts and results have been confirmed by tests at SRTC (Reference 28). The results are summarized with a more detailed presentation in Section A.16.1. 
$\mathrm{Na}^{+}$- Most of the soluble salts in SRS wastes are sodium salts. Sodium is the primary indicator of total ionic strength. In general, the higher the ionic strength, the lower the distribution coefficient $\left(\mathrm{K}_{\mathrm{d}}\right)$. This is one of the reasons the salt solution feed is diluted to $5.6 \mathrm{M} \mathrm{Na}^{+}$for the CST case.

$K^{+}$- Potassium competes weakly with cesium for adsorption onto the CST. In some DOE wastes (e.g., Hanford), the $\left[\mathrm{K}^{+}\right]$can be as high as $0.5 \mathrm{M}$. As a result, the Cs $\mathrm{K}_{\mathrm{d}} \mathrm{s}$ in these wastes is relatively low. Initially, there was a concern that some SRS wastes might have as high as 0.1 to $0.15 \mathrm{M} \mathrm{K}$. However, estimates indicate the blended SRS wastes will only be 0.009 to $0.022 \mathrm{M} \mathrm{K}$; thus the impact of potassium on CST capacity will be small. This small impact is accounted for by using a $\mathrm{Cs}$ isotherm that includes the effect of potassium.

$\mathrm{Sr}^{+2}$ and $\mathrm{Rb}^{+}-$There is essentially no rubidium in SRS waste. Also, because of the very high $\mathrm{pH}\left(\left[\mathrm{OH}^{-}\right]>1.5 \mathrm{M}\right)$, most of the strontium is precipitated. What little strontium remaining in solution is then removed by MST.

$\mathrm{OH}$ and $\mathrm{NO}_{3}{ }^{-}$- In addition to their contribution to ionic strength, these anions also affect the equilibrium between the liquid and the solid. Isotherm development at the waste composition extremes (high hydroxide and high nitrate) show that high hydroxide waste has a lower $K_{d}$ while the $K_{d}$ for high nitrate is approximately the same as for average waste.

Temperature - Temperature also affects the Cs $\mathrm{K}_{\mathrm{d}}$. For example, an increase from $25^{\circ} \mathrm{C}$ to $35^{\circ} \mathrm{C}$, decreases the $\mathrm{K}_{\mathrm{d}}$, and thus CST capacity, for average SRS waste by about $20 \%$.

Granular CST dilution factor - The powdered form of CST is too fine (in the micron range) to use in an IX bed - the pressure drop across such a bed would be excessive. The manufacturer has produced an engineered form which binds the powder into nearly spherical particles which are $>250$ microns in diameter. As-received, the granular CST contains the binder and some intra-particle moisture. This results in a bead that is only partially CST. This means the Cs capacity for the powder is greater than for the granular material since the granular material is "diluted" by the binder and the intra-particle moisture. As discussed in Section A.16 of Appendix A, a dilution factor of 0.70 is used to account for the binder and moisture. However, recent SRTC tests indicate this factor may be closer to 0.87 to 0.90 (Reference 28). These tests show that previous results indicating a dilution factor of 0.7 may be attributable to a pre-production batch of CST (batch 38B). Production batches $(1,2$, and 4$)$ used in these tests had significantly higher $K_{d} s$ than did batch 38B. If proven correct, this would mean increased CST capacity resulting in about $25 \%$ longer cycle times and lower CST usage.

Two waste compositions were used for the Phase III material balances. The distribution coefficient was estimated for each of twelve salt solution batches using the TAMU model (CSTIEXV). The average $\mathrm{K}_{\mathrm{d}}$ was $1808 \pm 156$. The two compositions chosen for material balances were years 2014 and 2016. Year 2016 had the lowest $K_{d}$ (1480) which will 
result in the shortest column cycles and the highest CST usage. Year 2014 had the highest $\mathrm{K}_{\mathrm{d}}$ (2070) which will produce the longest cycle time with the lowest CST usage.

\subsubsection{Equipment Sizing}

The Phase II calculations (Reference 1) designed a two-train ion exchange column arrangement based on a recommended superficial velocity $(2.5 \mathrm{~cm} / \mathrm{min})$, an engineering aspect ratio $(\mathrm{L} / \mathrm{D}=2)$, and a salt work-off rate $\left(13.2\right.$ gallons/minute $\left.@ 6.44 \mathrm{M} \mathrm{Na}^{+}\right)$. This earlier calculation resulted in two 3 -column trains, with each column 4 feet in diameter and 8 feet long. This design yielded 48 total feet of 4 -foot diameter column. Phase III calculations expand on this design by incorporating mass transfer concepts. Incorporating mass transfer concepts requires the simulation of an ion exchange column model tuned by experimental breakthrough curves (Reference 29) and equilibrium resin loading data.

Phase III ion exchange column design followed three independent tracks for ion exchange column simulation. These various models are highlighted in Section A.16 of Appendix A. In summary, three models were used to design an ion exchange column arrangement for SRS waste: a model from Purdue University (Reference 31), a model from Texas A\&M University (Reference 30), and a model from the Salt Disposition Flowsheet Team (Reference 32) (SDFT). Model results include the size of column required to perform the desired decontamination and the cycle time, indicating how often the lead column contents should be taken off-line for removal to the DWPF. Design parameters include the expected flowrate through the column and the expected variation in SRS waste composition most sensitive to ion exchange column design (High $\mathrm{OH}^{-1}$ and High $\mathrm{NO}_{3}^{-1}$ ).

The column length is defined to be the length of mass transfer zone: the length of column required to contain the $\mathrm{Cs}^{+}$wavefront from $\mathrm{C}=0.9 \mathrm{C}_{\mathrm{o}}$ to $\mathrm{C}=1.3 \times 10^{-3} \mathrm{mg} / \mathrm{L}$. By defining the column length to be the mass transfer zone length, the process control strategy confines the cesium wavefront to a single column. The cesium concentration is measured exiting the first column (lead). When the output of the lead column reaches $90 \%$ of its entry feed, this column is taken out of service. At that time, the cesium wavefront is completely contained in the second column. Table 3.4-1 summarizes the findings of the three design tracks. All designs show that for a nominal SRS waste and a work-off rate of $15 \mathrm{GPM}$, a 4 foot diameter 16 feet long column is sufficient to contain the mass transfer zone. For work off rates of 25 GPM, all designs show the required column length to be approximately 26-27 feet. Variations in salt composition affect the mass transfer zone length due to changing the CST adsorption capacity, see Section A.16 of Appendix A:. The Purdue and Texas A\&M models indicate that high $\mathrm{OH}^{-1}$ variations to SRS waste decrease the mass transfer zone length, indicating shorter columns. The Purdue and Texas A\&M models also indicate that high $\mathrm{NO}_{3}{ }^{-1}$ variations in SRS waste yield longer mass transfer zone lengths or longer column lengths. The Salt Disposition Flowsheet Team model is incapable of determining the dependency of mass transfer zone 
length on waste composition (this model addresses waste composition variance with cycle times only). The Salt Disposition Flowsheet Team model provides a bound on the mass transfer zone length. Critical comparison of the Salt Disposition Flowsheet Team model with the Purdue and Texas A\&M models is included in the Section A.16 of Appendix A.

The ion exchange column arrangement for Phase III consists of a single train with 3 columns. Each column is 5 feet in diameter and 16 feet long. Based on Purdue report (Reference 31 ), the mass transfer zone length is directly proportional to the superficial velocity: inversely proportional to the square of column diameter. Therefore, the results in Table 3.4-1 are scaled to Phase III column dimensions and work-off rates. The scaled values are shown bolded. After scaling the column lengths to account for differences in work-off rate and column diameter, all designs indicate that 16 feet is sufficient to contain the cesium wavefront for both nominal SRS waste and the variations to SRS waste. 
Table 3.4-1: Comparison of column lengths required for decontamination of SRS average waste, high $\mathrm{OH}^{-1}$ waste, and high $\mathrm{NO}_{3}^{-1}$ waste. Purdue and Texas A\&M results are for 4-foot diameter columns processing 15 and 25 GPM of solution. The column design for Phase III is set to 5-foot diameter columns processing 20GPM of salt solution. In order to compare the Phase III design with the work of Purdue and Texas A\&M, their results need to be scaled with respect to flow rate and column diameter. First, the 15GPM columns are multiplied by 20GPM/15GPM to scale with respect to work-off rate. Second, the 4-foot diameter column lengths are multiplied by the ratio $4^{2} \mathrm{ft}^{2} / 5^{2} \mathrm{ft}^{2}$ to account for the Phase III column diameter. The combined scaling factor is $(20 / 15) *(16 / 25)=0.853$.

\begin{tabular}{|c|c|c|c|c|c|}
\hline Feed Type & $\begin{array}{c}\text { Flowrate } \\
\text { (GPM) }\end{array}$ & $\begin{array}{l}\text { Column } \\
\text { Diameter } \\
(\mathrm{ft})\end{array}$ & $\begin{array}{c}\text { Column } \\
\text { Length (ft) } \\
\text { Texas A\&M } \\
\text { (Ref.30) }\end{array}$ & $\begin{array}{l}\text { Column Length } \\
\text { (ft) Purdue } \\
\text { (Ref. 31) }\end{array}$ & $\begin{array}{l}\text { Column Length } \\
\text { (ft) SDFT } \\
\text { (Ref. 32) }\end{array}$ \\
\hline \multirow[t]{2}{*}{ High $\mathrm{OH}^{-1}$} & 15 & 4 & 7.41 & 7.3 & 16.1 \\
\hline & 25 & 4 & 12.3 & 12.2 & 27.0 \\
\hline \multirow[t]{2}{*}{ Average } & 15 & 4 & 16.3 & 15.6 & 16.1 \\
\hline & 25 & 4 & 27.2 & 25.7 & 27.0 \\
\hline \multirow[t]{2}{*}{$\mathrm{High} \mathrm{NO}_{3}{ }^{-1}$} & 15 & 4 & 18.6 & 18.3 & 16.1 \\
\hline & 25 & 4 & 31.0 & 30.5 & 27.0 \\
\hline High $\mathbf{O H}^{-1}$ & 20 & 5 & 6.3 & 6.2 & 13.7 \\
\hline Average & 20 & 5 & 13.9 & 13.3 & 13.7 \\
\hline High $\mathrm{NO}_{3}{ }^{-1}$ & 20 & 5 & 15.9 & 15.6 & 13.7 \\
\hline
\end{tabular}

\subsubsection{Expected Performance}

After the mass transfer zone length is established, the next issue in column design reflects the speed at which the zone moves through the column. An ion exchange column that loads with high efficiency results from a slow-moving mass transfer zone. An ion exchange column operated inefficiently (very high work-off rates or increased temperatures) results in a fast-moving mass transfer zone, low breakthrough times, and large CST flowrates downstream of the ion exchange columns. All three ion exchange models report two measures of column efficiency: 
1). Cesium loading (mg Cs/g CST) relative to that predicted by the isotherm at entry cesium concentration and

2). The column breakthrough time or cycle time.

\section{CST Loading Efficiency}

Table 3.4-2 compares the CST loading efficiency predicted by the Texas A\&M model, the Purdue model, and the SDFT model. Both the Texas A\&M and Purdue models indicate very high loading of the first column prior to breakthrough. This high loading efficiency produces long cycle times and low CST flow rates down stream. The SDFT model is not capable of loading as efficiently as the Texas A\&M and Purdue models. This low loading efficiency translates into higher CST flow rates to DWPF. The low loading predicted by the SDFT is inherent to the model and does not reflect true uncertainty in the ability of CST to load cesium in the column.

Table 3.4-2: Comparison of CST loading efficiencies for the three models used in the preliminary design for Phase III. Both the Texas A\&M model and Purdue model predict very high loading of cesium on the CST relative to that predicted at entry cesium concentrations. The SDFT model predicts a lower loading efficiency (lack of detailed mass transfer mechanism). This lower loading efficiency translates into shorter breakthrough times and higher CST flow rates to DWPF, Table 3.4-5.

\begin{tabular}{|c|c|c|}
\hline $\begin{array}{c}\text { CST Loading } \\
\text { Efficiency }\end{array}$ & $\begin{array}{c}\text { CST Loading } \\
\text { Efficiency } \\
\text { Texas A\&M (Ref. 33) }\end{array}$ & $\begin{array}{c}\text { CST Loading } \\
\text { Efficiency } \\
\text { Purdue (Ref. 34) }\end{array}$ \\
\hline$>95 \%$ & $98.8 \%$ & $70 \%$ \\
\hline
\end{tabular}

\section{Cycle Time}

The second measure of column performance is the breakthrough time on the column. If the column is operated inefficiently (very high work-off rates or increased temperatures), the mass transfer zone can spread out resulting in early breakthrough. Therefore, long breakthrough times are desired. Tables 3.4-3, 3.4-4, and 3.4-5 show the breakthrough times predicted by the Texas A\&M, Purdue, and SDFT models. The Texas A\&M and Purdue models were simulated with different column diameters, column lengths, and salt work-off rates. In order to present all results on an identical basis, the Texas A\&M and Purdue results were scaled according to space velocity or residence time (Reference 30 ). Therefore, all results from Texas A\&M and Purdue were adjusted to 20GPM, 5ft diameter, and 16ft long columns. 
After scaling, the Texas A\&M model results predict the range of CST flow rates to DWPF to be between 8 and $11 \mathrm{lb} / \mathrm{hr}$. After scaling, the Purdue model results predict the average CST flow rate to DWPF to be $8.2 \mathrm{lb} / \mathrm{hr}$. The SDFT model over-predicts the CST flow rate to DWPF based primarily on:

1). The lower loading efficiency presented in Table 3.4-2 and

2). Because the model was tuned for early, $10 \%-50 \%$, breakthrough behavior and not late breakthrough behavior (cycle time is triggered at $90 \%$ breakthrough of lead column).

A complete comparison of the SDFT model with the Texas A\&M and Purdue models is included in Section A.16 of Appendix A. As in the previous section, the SDFT model results are meant to provide an independent validation of the more complex models. The column efficiency calculations exploit the weaknesses of the SDFT model. Therefore, the Salt Disposition Flowsheet Team presents the Texas A\&M and Purdue results as being the accurate representation of the CST flow rate to DWPF. Because of this issue, material balances for this variation were completed using an Excel spreadsheet (Appendix I). 
Table 3.4-3: Texas A\&M results for cycle times or breakthrough times for decontamination of SRS average waste and two variations about the average. Original Texas $A \& M$ results were designated for column diameters set to 4 feet. The last three rows in the table indicate expected cycle times and CST flow rates to DWPF for the Phase III column design. The original results were scaled with respect to the space velocity (Reference 30) or residence time. CST density is assumed $53 \mathrm{lb} / \mathrm{ft}^{3}$.

\begin{tabular}{|c|c|c|c|c|c|c|}
\hline Feed Type & $\begin{array}{l}\text { Flowrate } \\
\text { (GPM) }\end{array}$ & $\begin{array}{l}\text { Column } \\
\text { Diameter } \\
(\mathrm{ft})\end{array}$ & $\begin{array}{l}\text { Column } \\
\text { Length } \\
\text { (ft) }\end{array}$ & $\begin{array}{l}\text { Column } \\
\text { Volume } \\
\left(\mathrm{ft}^{3}\right)\end{array}$ & 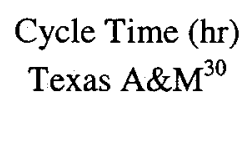 & $\begin{array}{c}\text { CST Flow Rate } \\
\text { to DWPF } \\
(\mathrm{lb} / \mathrm{hr})\end{array}$ \\
\hline \multirow[t]{2}{*}{$\mathrm{High} \mathrm{OH}^{-1}$} & 15 & 4 & 7.41 & 93.5 & 600 & 8.3 \\
\hline & 25 & 4 & 12.3 & 156 & 600 & 13.8 \\
\hline \multirow[t]{2}{*}{ Average } & 15 & 4 & 16.3 & 206 & 1800 & 6.0 \\
\hline & 25 & 4 & 27.2 & 343 & 1800 & 10.1 \\
\hline \multirow[t]{2}{*}{$\mathrm{High} \mathrm{NO}_{3}{ }^{-1}$} & 15 & 4 & 18.6 & 234 & 1800 & 6.9 \\
\hline & 25 & 4 & 31.0 & 390 & 1800 & 11.5 \\
\hline High $\mathrm{OH}^{-1}$ & 20 & 5 & 16.0 & 314 & 1518 & 11.0 \\
\hline Average & 20 & 5 & 16.0 & 314 & 2071 & 8.0 \\
\hline $\mathrm{High} \mathrm{NO}_{3}{ }^{-1}$ & 20 & 5 & 16.0 & 314 & 1815 & 9.2 \\
\hline
\end{tabular}


Table 3.4-4: Purdue University results for cycle times or breakthrough times for decontamination of SRS average waste. Original Purdue University results were designated for column diameters set to $\mathbf{4}$ feet and 5.2 feet. The last row in the table indicates expected cycle times and CST flow rates to DWPF for the Phase III column design. The original results were scaled with respect to the space velocity (Reference 30) or residence time. CST density is assumed $53 \mathrm{lb} / \mathrm{ft}^{3}$.

\begin{tabular}{|c|c|c|c|c|c|c|}
\hline Feed Type & $\begin{array}{c}\text { Flowrate } \\
(\mathrm{GPM})\end{array}$ & $\begin{array}{c}\text { Column } \\
\text { Diameter } \\
(\mathrm{ft})\end{array}$ & $\begin{array}{c}\text { Column } \\
\text { Length } \\
(\mathrm{ft})\end{array}$ & $\begin{array}{c}\text { Column } \\
\text { Volume } \\
\left(\mathrm{ft}^{3}\right)\end{array}$ & $\begin{array}{c}\text { Cycle Time (hr) } \\
\text { Purdue }^{31}\end{array}$ & $\begin{array}{c}\text { CST Flow Rate } \\
\text { to DWPF } \\
(\mathrm{lb} / \mathrm{hr})\end{array}$ \\
\hline Average & 15 & 4 & 16.0 & 201.1 & 1728 & 6.2 \\
\hline & 25 & 5.2 & 16.0 & 339.8 & 1728 & 10.4 \\
\hline Average & $\mathbf{2 0}$ & $\mathbf{5}$ & $\mathbf{1 6 . 0}$ & $\mathbf{3 1 4}$ & 2025 & 8.2 \\
\hline
\end{tabular}

Table 3.4-5: SDFT model results for cycle times or breakthrough times for decontamination of SRS average waste and two variations about the average. The column diameter is set at 5 feet. CST density is assumed $53 \mathrm{lb} / \mathrm{ft}^{3}$.

\begin{tabular}{|c|c|c|c|c|c|c|}
\hline Feed Type & $\begin{array}{c}\text { Flowrate(G } \\
\mathrm{PM})\end{array}$ & $\begin{array}{c}\text { Column } \\
\text { Diameter } \\
(\mathrm{ft})\end{array}$ & $\begin{array}{c}\text { Column } \\
\text { Length } \\
(\mathrm{ft})\end{array}$ & $\begin{array}{c}\text { Column } \\
\text { Volume } \\
\left(\mathrm{ft}^{3}\right)\end{array}$ & $\begin{array}{c}\text { Cycle Time (hr) } \\
\text { SDFT }^{32}\end{array}$ & $\begin{array}{c}\text { CST Flow Rate } \\
\text { to DWPF } \\
(\mathrm{lb} / \mathrm{hr})\end{array}$ \\
\hline High $\mathrm{OH}^{-1}$ & 20 & 5 & 16.0 & 314 & 724 & 23 \\
\hline Average & 20 & 5 & 16.0 & 314 & 760 & 22 \\
\hline${\mathrm{High} \mathrm{NO}_{3}^{-1}}^{-10}$ & 5 & 16.0 & 314 & 1040 & 16 \\
\hline
\end{tabular}

\subsubsection{Phase III Bases Changes}

During the interim between Phase II and Phase III, both the salt work-off rate and $\mathrm{Na}^{+}$ molarity changed for the ion exchange column design. First, the salt work-off rate was increased from 13.2GPM to 17.5GPM (see Section 2.4 Salt Processing Rates) to cut the life cycle cost for the project. This increase in flow rate results in a longer mass transfer zone through the column and adds length to the design. Table 3.4-1 provides the basis for the column length increase. Second, the $\mathrm{Na}^{+}$molarity was decreased from $6.4 \mathrm{M}$ to $5.6 \mathrm{M}$ (by dilution) to allow a more favorable (higher loading) isotherm (Reference 36) and a less viscous contaminated salt stream through the column (where pressure drop was a concern). The Salt Disposition Flowsheet Team also had more information at 5.6M 
than at $6.4 \mathrm{M}$. Therefore, the ion exchange column design prepared for a contaminated salt stream at $20.1 \mathrm{GPM}$ and $5.6 \mathrm{M} \mathrm{Na}^{+}$. Understanding of how the sodium ion concentration effected the CST loading capacity lead the Salt Disposition Flowsheet Team to address the effect of other ion in solution. The CST loading efficiency, as a function of various ions and temperature changes, was reported earlier (Reference 36).

\subsubsection{Material Balance Results}

The material balances for the two CST cases (years 2014 and 2016) were performed as follows:

- The stoichiometric MST plus $10 \%$ was added and the MST/sludge filtered out.

- The MST/sludge was washed to $0.5 \mathrm{M} \mathrm{Na}^{+}$with the wash water plus filter cleaning solutions added back into the salt solution stream. The washed MST/sludge is a DWPF feed stream.

- Water is added to clarified salt solution to produce the $5.6 \mathrm{M} \mathrm{Na}^{+}$feed for CST IX.

- Using the feed-specific isotherms, the 0.70 granular CST dilution factor, and loading of $90 \%$ equilibrium with the inlet feed composition, the Cs loading on the CST was calculated.

- The column cycle time was calculated based on the Cs loading, the total CST in a column, and the Cs feed rate.

- The cycle time was used to calculate the average sluicing water and pre- and posttreatment $\mathrm{NaOH}$ as specified in the Appendix. These were added to the salt solution feed in the Recycle Blend Tank prior to feeding to the IX train.

- In the IX train, the cesium is removed from the salt solution onto the CST.

- The decontaminated salt solution flows to Saltstone where it is mixed with premix and poured into vaults.

- The Cs-loaded CST flows to the DWPF where it is combined with washed sludge, the washed MST/sludge stream, and frit to make glass.

The results of the material balances are summarized in Table 3.4-6.

Table 3.4-6

Summary of Material Balance Results

\begin{tabular}{|l|c|c|}
\hline & Year 2014 & Year 2016 \\
\hline Fresh waste feed -gal/min & 17.5 & 17.5 \\
\hline $\mathrm{Na}^{+}$in fresh waste $-\mathrm{M}$ & 6.59 & 5.94 \\
\hline $\mathrm{Na}_{2} \mathrm{U}_{2} \mathrm{O}_{7}$ in fresh waste $-\mathrm{lbs} / \mathrm{hr}$ & 4.7 & 0.3 \\
\hline Washed MST/sludge - lbs/hr & 268 & 103 \\
\hline Fraction sludge in MST/sludge solids & 0.37 & 0.93 \\
\hline $\mathrm{Na}^{+}$in Saltstone feed -M & 5.42 & 5.33 \\
\hline
\end{tabular}




\begin{tabular}{|l|c|c|}
\hline & Year 2014 & Year 2016 \\
\hline Decon salt soln to Saltstone - gal/min & 21.31 & 19.59 \\
\hline Grout production - gal/min & 35.31 & 32.63 \\
\hline Cs loading on CST - mg Cs/g CST & 13.82 & 20.05 \\
\hline Column cycle time - hours & 2113 & 1562 \\
\hline CST rate to DWPF - lbs/hr & 9.28 & 12.55 \\
\hline Activity of CST slurry - Ci/gal* & 105 & 161 \\
\hline CST (dry basis) in glass - wt \% & 4.22 & 6.13 \\
\hline Total $\mathrm{TiO}_{2}$ in glass - wt \% & 2.68 & 2.09 \\
\hline Fraction of $\mathrm{TiO}_{2}$ from CST & 0.51 & 0.96 \\
\hline PCCS calculations & & \\
\hline Durability - In NL(B) g/L & -6.12 & -5.52 \\
\hline Viscosity - cp & 43.5 & 50.1 \\
\hline Liquidus - ${ }^{\circ} \mathrm{C}$ & 995 & 1007 \\
\hline
\end{tabular}

*assuming $10 \mathrm{wt} \%$ slurry of CST in water

There are several items in the previous table that warrant some discussion.

$M S T$ - The Year 2014 feed contains high quantities of alpha as $\mathrm{Na}_{2} \mathrm{U}_{2} \mathrm{O}_{7}$. This results in the high MST/sludge rate to DWPF and also in the high total $\mathrm{TiO}_{2}$ in the glass.

Grout production - At a given fresh waste feed rate and sodium molarity, the waste with the shorter cycle time would produce somewhat more saltstone because of increased dilution by sluicing water and pre- and post-treatment $\mathrm{NaOH}$. However, the opposite is the case above because the year 2016 feed is more dilute to begin with - so less dilution water is added prior to CST IX resulting in a lower flow rate to Saltstone.

$M S T$ - The Year 2014 feed contains high quantities of alpha as $\mathrm{Na}_{2} \mathrm{U}_{2} \mathrm{O}_{7}$. This results in the high MST/sludge rate to DWPF and also in the high total $\mathrm{TiO}_{2}$ in the glass.

\section{Ci/gal in CST slurry to DWPF - The Ci/gal Cs-137 ranges from 100 to 160 .}

Cycle time - The times show how cycle times can vary depending on waste composition - from 1560 to 2100 hours. The year 2016 cycle time is likely to be the shortest of all the feeds because of its low $\mathrm{K}_{\mathrm{d}}$ and high Cs concentration.

Total Cs-137 Ci/batch - The total Cs-137 accumulated in a column during the batch cycle ranges from 2.4 to $3.7 \mathrm{M} \mathrm{Ci}$.

CST usage rate - The CST usage rate ranges from 9.3 to $12.6 \mathrm{lbs} / \mathrm{hr}$ which is consistent with estimate from Texas A\&M and Purdue. If recent SRTC results are correct, this usage could drop to 7 to $9.5 \mathrm{lbs} / \mathrm{hr}$. This would, of course, result in lower CST concentration in the glass. 
CST loading in glass - Loading in glass is shown to be from 4 to $6 \mathrm{wt} \%$. One of the previous concerns was that if Cs-137 in the salt solutions was high ( $>5 \mathrm{Ci} / \mathrm{gal}$ ), the CST generation rate might exceed the current limit of $10 \mathrm{wt} \%$ in the glass. The waste blending calculations indicated this would not be a problem.

$\mathrm{TiO}_{2}$ in the glass - The total $\mathrm{TiO}_{2}$ in the glass ranges from 2.1 to $2.7 \mathrm{wt} \%$. The contribution from CST to this total is 1.4 to $2.0 \mathrm{wt} \%$.

PCCS calculations - The PCCS estimates (durability, viscosity, liquidus) performed by Speedup ${ }^{\mathrm{TM}}$ indicate good glass processability and durability.

\subsubsection{CST Disposition Issues}

Decontamination of the salt solution originates with the ion exchange columns and concludes with the vitrification of the CST/Cs. The vitrification of the CST/Cs adds a level of complexity to melter chemistry in that a new glass formulation is needed to account for CST components (Reference 37). A new glass formulation might require a new frit. This section of the document summarizes the effect CST is expected to have on glass making in the DWPF melter. This section concludes with a discussion of campaigning (Reference 38) the CST/Cs with sludge and advantages/disadvantages of constructing a new vitrification facility.

\section{CST Results}

SRTC has tested glass compositions corresponding to a range of CST loading from 2-14 wt $\%$ oxide basis and from $22-30$ wt $\%$ sludge oxides. Frit (ground glass containing glass formers) provides the balance of the mass.

Compositions of the glasses tested and results are discussed in Reference 39.

The predicted melt viscosities were acceptable for all test glasses. Based on the test results, the current property models predict the viscosity reasonably well.

All of the glasses had predicted Liquidus temperatures (the maximum temperature at which separate crystalline phases can form in glass) below the acceptance limit of 1050 Celsius. However, two of the glasses had Liquidus temperatures above 1000 Celsius. The test glasses were annealed at 1000 Celsius and examined by X-ray diffraction. Crystal phases were not detected, even for the two glasses predicted to have them. Thus, the Liquidus temperature model appears to be conservative.

Further, TiO2 concentration exceeds the current $1 \mathrm{wt} \%$ limits. This limit is based on the range of known technology. The concern is that $\mathrm{TiO} 2$ will exceed its solubility and crystallize and seed other crystalline phases. This did not happen with the test glasses, but further study is indicated. 
All of the glasses were predicted to exceed the durability of the benchmark glass ("EA" or Environmental glass). All of these glasses were better than EA glass, but four of them were less durable than the glasses DWPF has typically made. The leach rates were under-predicted by current models. Therefore, new durability models are needed.

A typical frit composition used to make these glasses is in Table 3.4-7 below. It is very similar to frits already specified and manufactured for DWPF and should be no problem to procure. Frit 202, used with sludge / salt coupled feed during DWPF Startup Testing is shown for comparison.

Table 3.4-7

Typical CST Frit Composition

\begin{tabular}{|c|c|c|}
\hline & CST Frit & Frit 202 \\
\hline $\mathrm{B} 2 \mathrm{O} 3$ & 10 & 8 \\
\hline $\mathrm{Li2O}$ & 9 & 7 \\
\hline $\mathrm{Na} 2 \mathrm{O}$ & 6 & 6 \\
\hline $\mathrm{SiO} 2$ & 75 & 77 \\
\hline $\mathrm{MgO}$ & 0 & 2 \\
\hline
\end{tabular}

The trade CST component is already oxidized, and is unlikely to affect the feed preparation chemistry. It may lead to some slight increase in the decomposition rate of formic acid, producing some hydrogen. However, the increase is within the existing DWPF design basis.

Element X's concentration can be measured at the levels expected using current DWPF analytical techniques (Reference 40).

\section{CST-New Vitrification Facility}

An option for the CST-Only campaign is to decouple the CST glass from DWPF by constructing a melter dedicated to CST only. The only difference between this option and the Sludge-Only/CST-Only campaign would be in the deletion of the transition time from one campaign to another. The CST-Only melter must make the same number of canisters (387-1263). Since the four-week campaign transition time had little effect on the cost for the Sludge-Only/CST-Only campaign, the cost of vitrifying the CST-Only glass in a dedicated melter is similar to the campaign option. 
Table 3.4-8 Summary of Glass Campaign Options

\begin{tabular}{|l|c|c|c|c|}
\hline Campaign & $\begin{array}{c}\text { Waste } \\
\text { Loading }\end{array}$ & Frt Loading & CST Loading & $\begin{array}{c}\text { Total } \\
\text { Canisters }\end{array}$ \\
\hline $\begin{array}{l}\text { Sludge-Only } \\
\text { Glass }\end{array}$ & $\begin{array}{c}28-30 \mathrm{wt} \% \\
\text { sludge oxides }\end{array}$ & $70-72 \mathrm{wt} \%$ frit oxides & 0 & $\begin{array}{c}5200^{3} @ 200- \\
250 \mathrm{cans} / \mathrm{year}\end{array}$ \\
\hline $\begin{array}{l}\text { CST-Only } \\
\text { Glass }\end{array}$ & 0 & $\begin{array}{c}37 \mathrm{wt} \% \text { frit oxides } \\
\text { (minimum) }\end{array}$ & $\begin{array}{c}63 \mathrm{wt} \% \text { waste } \\
\text { oxides } \\
\text { (maximum) }\end{array}$ & $387-1263^{4}$ \\
\hline $\begin{array}{l}\text { Sludge/CST } \\
\text { Glass }\end{array}$ & $\begin{array}{c}28 \mathrm{wt} \% \text { sludge } \\
\text { oxides }\end{array}$ & $62 \mathrm{wt} \%$ frit oxides & $\begin{array}{c}10 \mathrm{wt} \% \mathrm{CST} \\
\text { oxides }\end{array}$ & $\begin{array}{c}5200^{5} @ 200- \\
250 \mathrm{cans} / \mathrm{year}\end{array}$ \\
\hline
\end{tabular}

Table 3.4-9 Canisters Required for CST-Only Glass as a Function of Final Canister Location.

\begin{tabular}{|c|c|c|c|c|c|c|}
\hline (4) & Elmit & wis & $S_{2}$ & $\begin{array}{l}\text { Max } \\
\text { ketrom }\end{array}$ & Maxs & Totalcans \\
\hline Class C & $\begin{array}{l}{ }^{137} \mathrm{Cs}: 4600 \mathrm{Ci} / \mathrm{m}^{3} \\
\alpha: 100 \mathrm{nCi} / \mathrm{g}\end{array}$ & 0.54 & 2.55 & 3.20 & 15.3 & 38,100 \\
\hline GWSB & 460 watts/can & 16.0 & 2.60 & 95.0 & 460 & 1263 \\
\hline $\begin{array}{l}\text { HLW } \\
\text { rep. }\end{array}$ & 1500 watts/can & 46.8 & 2.90 & 310 & 1500 & 387 \\
\hline Max CST & $63 \mathrm{wt} \% \mathrm{CST}$ & 63.0 & 3.03 & 435 & 2100 & 276 \\
\hline
\end{tabular}

Bases for table:

1. Assume DWPF canisters which hold $4000 \mathrm{lbs}$ glass at $\mathrm{Sg}=2.65$

2. $1.55 \mathrm{Ci} / \mathrm{gal}$ in salt solution and $0.225 \mathrm{~g}{ }^{137} \mathrm{Cs} / \mathrm{g}$ total $\mathrm{Cs}$

3. $75 \%$ of maximum loading on CST $=17.0 \mathrm{mg} \mathrm{Cs} / \mathrm{g} \mathrm{CST} \mathrm{(even} \mathrm{@} 100 \%$ loading, answer is the same just lower \%CST in the canister), and

$120 \mathrm{M}$ total $\mathrm{Ci}$ of ${ }^{137} \mathrm{Cs}$.

\subsubsection{Conclusions}

- An ion exchange column carousel with three 5X16 columns operated at 20GPM produces a mass transfer zone length less than 16 feet.

- The first (lead) column in the carousel will load cesium at efficiencies greater than $90 \%$ predicted by the isotherm and entry cesium concentrations.

\footnotetext{
${ }^{3}$ System Plan, Revision 9.

${ }^{4}$ Pending the temporary canister storage standards (HLW Repository or current GWSB) as shown in Table 3.4-8.

${ }^{5} \mathrm{CST}$ oxides replace frit oxides in the material balance resulting in no change in total canisters required.
} 
- The ion exchange process will meet the required decontamination and produce between 8 and $11 \mathrm{lb} / \mathrm{hr}$ of CST to DWPF.

- The performance of the ion exchange is dependent on flow rates through the columns, deviations in SRS waste from nominal, and loading efficiency loss between CST powdered form and pellet form.

- Ci/gal in CST slurry to DWPF - The Ci/gal Cs-137 ranges from 100 to 160.

- Cycle time - The times show how cycle times can vary depending on waste composition - from 1560 to 2100 hours. The year 2016 cycle time is likely to be the shortest of all the feeds because of its low $\mathrm{K}_{\mathrm{d}}$ and high Cs concentration.

- Total Cs-137 Ci/batch - The total Cs-137 accumulated in a column during the batch cycle ranges from 2.4 to $3.7 \mathrm{M} \mathrm{Ci}$.

- CST usage rate - The CST usage rate ranges from 9.3 to $12.6 \mathrm{lbs} / \mathrm{hr}$ which is consistent with estimate from Texas A\&M and Purdue. If recent SRTC results are correct, this usage could drop to 7 to $9.5 \mathrm{lbs} / \mathrm{hr}$. This would, of course, result in lower CST concentration in the glass.

- CST loading in glass - Loading in glass is shown to be from 4 to $6 \mathrm{wt} \%$. One of the previous concerns was that if Cs-137 in the salt solutions was high ( $>5 \mathrm{Ci} / \mathrm{gal}$ ), the CST generation rate might exceed the current limit of $10 \mathrm{wt} \%$ in the glass. The waste blending calculations indicated this would not be a problem.

- $\mathrm{TiO}_{2}$ in the glass - The total $\mathrm{TiO}_{2}$ in the glass ranges from 2.1 to $2.7 \mathrm{wt} \%$. The contribution from CST to this total is 1.4 to $2.0 \mathrm{wt} \%$.

\section{CST-DWPF Model (SPEEDUP)}

The DWPF model used for the CST options was the same as that used for the solvent extraction option with the exception of changes made specifically for CST. These included:

CST composition, including a placeholder called "X10" and "X20" used to represent proprietary materials. These materials were introduced to the model using the vector positions normally used for $\mathrm{BaO}$ and $\mathrm{ZrO}_{2}$, materials not present in the CST calculation. A nominal molecular weight and free energy were provided for the proprietary constituents. A nominal molecular weight and free energy were also provided for the proprietary constituents.

Input to the DWPF model was provided by the Design Team. This included two source vectors: a CST slurry containing adsorbed cesium from the ion exchange column, and an MST slurry containing alpha constituents stripped from the source salt stream. 
A special CST frit composition was used for the glass calculation.

The high titanium content from both the CST and the MST input vectors required disabling the titanium limit in the PCCS calculation.

Results from the DWPF model are given as yearly average values. The values are determined by discarding the first 600 hours of the calculation and averaging over the remaining 2400 hours of a transient calculation. This avoids including startup effects in the yearly averages.

\subsubsection{Equipment}

\subsubsection{Building Layout}

Building layout based on shielding and function area sizes of the Non-Elutable Ion Exchange alternative compared to equivalent DWPF facility layouts are provided below in Table 3.4-8. Major process equipment consists of chemical storage and feed tanks, a large alpha sorption tank, transfer pumps, agitators, 1 set of crossflow filters, wash and concentration tanks, filter cleaning tanks, cesium removal ion exchange columns, resin hold tanks, mercury removal ion exchange columns and product hold tanks.

Table 3.4-8 Non-Elutable Ion Exchange

\begin{tabular}{|c|c|c|c|}
\hline & DWPF & CST & $\begin{array}{c}\text { CST } \\
\% \text { DWPF }\end{array}$ \\
\hline AREA (SQ.FT) & & & \\
\hline SHIELDED & 16,278 & 9,761 & $60 \%$ \\
\hline UNLOADING WELL & 2,175 & 2,100 & $97 \%$ \\
\hline LOW SHIELD & & 3,900 & \\
\hline OPERATING CORRIDOR & 59,029 & 32,594 & $55 \%$ \\
\hline CRANE OPERATING & 18,457 & 18,819 & $102 \%$ \\
\hline & & & \\
\hline TOTAL & 95,939 & 67,174 & $70 \%$ \\
\hline VOLUME(CU.FT) & & & \\
\hline SHIELDED & 640,344 & 430,697 & $67 \%$ \\
\hline UNLOADING WELL & 86,348 & 100,800 & $117 \%$ \\
\hline LOW SHIELD & & 187,200 & \\
\hline OPERATING CORRIDOR & $1,081,583$ & 782,256 & $72 \%$ \\
\hline CRANE OPERATING & 700,261 & 706,635 & $101 \%$ \\
\hline & & & \\
\hline & $2,508,536$ & $2,207,588$ & $88 \%$ \\
\hline TOTAL & & &
\end{tabular}




\subsubsection{Tanks}

Table 3.4-9 Tanks for Non-Elutable Ion Exchange Alternative

\begin{tabular}{|l|c|l|}
\hline \multicolumn{1}{|c|}{ Tank } & Tank Size & \multicolumn{1}{c|}{ Sizing Assumption } \\
\hline $\begin{array}{l}\text { Loaded Resin Hold } \\
\text { Tank }\end{array}$ & 15,000 gallons & $\begin{array}{l}\text { Sized for one batch storage of loaded resin to de-couple } \\
\text { the CST Facility from DWPF. }\end{array}$ \\
\hline Ba-137 Decay Tanks & 2 tanks each \\
2500 gallons & $\begin{array}{l}\text { Allows one tank to be filled while the second tank is } \\
\text { checked for }{ }^{137} \text { Cs and pumped forward. The tanks are } \\
\text { sized for approximately three hours of storage. }\end{array}$ \\
\hline Resin Make-up Tank & 2000 gallons & $\begin{array}{l}\text { Sized to allow make-up of one column of resin in } \\
\text { preparation for resin changeout. }\end{array}$ \\
\hline Caustic Feed Tank & 5000 gallons & $\begin{array}{l}\text { Sized to support pre-treatment of CST resin columns as } \\
\text { well as GT-73 resin columns in preparation for resin } \\
\text { changeout. }\end{array}$ \\
\hline $\begin{array}{l}\text { Mercury Removal } \\
\text { Feed Tank }\end{array}$ & 2500 gallons & $\begin{array}{l}\text { Sized to receive one Ba-137 Decay Tank batch. The } \\
\text { Mercury Removal System will be used if the mercury } \\
\text { concentration in the salt stream exceeds the Saltstone } \\
\text { Waste Acceptance Criteria. }\end{array}$ \\
\hline DSS Hold Tanks & 200,000 gallons & $\begin{array}{l}\text { sized to allow five days of hold-up of the material to } \\
\text { verify mercury removal, if applicable, meets the } \\
\text { Saltstone Waste Acceptance Criteria. The tanks also } \\
\text { allow hold-up of material during the time that the } \\
\text { Saltstone Facility is de-staffed and somewhat de-couple } \\
\text { the Saltstone Facility from the CST Facility. Two tanks } \\
\text { will allow filling of one tank while waiting for sample } \\
\text { results of the second. NOTE: These tanks allow for five } \\
\text { days of product storage from the CST Facility. This } \\
\text { five days of product is less than two days of operation } \\
\text { of the Saltstone Facility assuming two-shift operation. }\end{array}$ \\
\hline Resin Hold Tank & 10,000 gallons & $\begin{array}{l}\text { Sized to provide a make-up to the SRAT during } \\
\text { processing. }\end{array}$ \\
\hline Process Water Tank & 20,000 gallons & $\begin{array}{l}\text { Sized to support the make-up of CST resin columns, } \\
\text { make-up of GT-73 resin columns, cooling water } \\
\text { system, and chemical addition tanks. }\end{array}$ \\
\hline Sodium Nitrate Tank & 200 gallons & $\begin{array}{l}\text { Sized to make-up one GT-73 resin column for mercury } \\
\text { removal. }\end{array}$ \\
\hline Spent Resin Tank & 3000 gallons & $\begin{array}{l}\text { Sized to treat one GT-73 resin column. } \\
\text { Sized to treat one GT-73 resin column. }\end{array}$ \\
\hline
\end{tabular}




\begin{tabular}{|l|c|l|}
\hline \multicolumn{1}{|c|}{ Tank } & Tank Size & \multicolumn{1}{c|}{ Sizing Assumption } \\
\hline $\begin{array}{l}\text { Resin Loading and } \\
\text { Wash Overflow Tank }\end{array}$ & 3000 gallons & Sized to treat one column of GT-73 resin. \\
\hline MST Storage Tank & 400 gallons & Sized for approximately four weeks of storage. \\
\hline Alpha Sorption Tank & 100,000 gallons & Sized to hold one batch of salt solution. \\
\hline Recycle Blend Tank & 100,000 gallons & \\
\hline $\begin{array}{l}\text { Sludge Solids Receipt } \\
\text { Tank }\end{array}$ & 10,000 gallons & $\begin{array}{l}\text { Sized to receive multiple filter cleaning cycles as well } \\
\text { as sludge solids prior to pumping to DWPF. }\end{array}$ \\
\hline $\begin{array}{l}\text { Oxalic Acid Feed } \\
\text { Tank }\end{array}$ & 200 gallons & Sized to hold the solution to clean one cross-flow filter. \\
\hline Caustic Feed Tank & 500 gallons & Sized hold the solution to clean one cross-flow filter. \\
\hline $\begin{array}{l}\text { Cleaning Solution } \\
\text { Dump Tank }\end{array}$ & 1000 gallons & $\begin{array}{l}\text { Sized to circulate material to clean the cross-flow } \\
\text { filters. }\end{array}$ \\
\hline
\end{tabular}

\subsubsection{Transfer Lines}

Fresh Waste will be pumped to Tank 50. The salt solution will either be sampled and 'qualified' prior to being pumped to Tank 50 or will be sampled while in Tank 50 prior to transfer to the new CST Ion Exchange Facility.

The salt solution will then be pumped to the new CST Ion Exchange Facility via the existing interarea transfer line, which will be modified. The new CST Ion Exchange Facility will be located near the current Late Wash Facility. A section of new interarea transfer line will be needed to connect the current interarea transfer line to the new Facility. This tie-in will be near the Late Wash Facility.

The salt solution in the new CST Ion Exchange Facility will be treated using Monosodium Titanate (MST) to remove uranium, plutonium, and strontium from the salt solution. The salt solution is then filtered to remove the sludge solids and the MST solids. After washing to remove soluble salts, these solids will be pumped to the Low Point Pump Pit Precipitate Tank (LPPPPT) via a new interarea transfer line. This new interarea transfer line can tie into the 'abandoned' precipitate line from the Late Wash Facility.

The MST solids and sludge solids will then be transferred from the LPPPPT to a new MST/Sludge Tank located in the SPC. This transfer will occur via the existing interarea transfer line. 
The Loaded Resin will be transferred from the new CST Ion Exchange Facility to a new Pump Pit via a new interarea transfer line. This new Pump Pit will be in the vicinity of the current Low Point Pump Pit (LPPP) in the Defense Waste Processing Facility (DWPF).

A new interarea transfer line will be required between the new Pump Pit and the DWPF Salt Processing Cell (SPC). The Loaded Resin will be pumped via this new interarea transfer line to a Loaded Resin Tank located in the SPC. The Loaded Resin will then be pumped to the Sludge Receipt and Adjustment Tank (SRAT).

The decontaminated salt solution will be pumped via a new interarea transfer line to a valve box near the current Low Point Drain Tank (LPDT). The valve box will allow the Saltstone Facility to receive material from ETF or the new CST Ion Exchange Facility.

The ETF Bottoms will be transferred to a new 50,000-gallon ETF Bottoms Tank via a new interarea transfer line. The new interarea transfer line is needed because the current line will be used to transfer high activity salt solution to the new CST Ion Exchange Facility. The new ETF Bottoms Tank will hold approximately 4-5 months of ETF Evaporator Bottoms based on current production rates. The ETF Bottoms can then be campaigned when a new salt solution batch is being sampled.

The new valve box will then be used to transfer either the decontaminated salt solution or the ETF Bottoms to the Saltstone Facility via the current interarea transfer line at the Low Point Drain Tank. See Figure 3.4-2. 


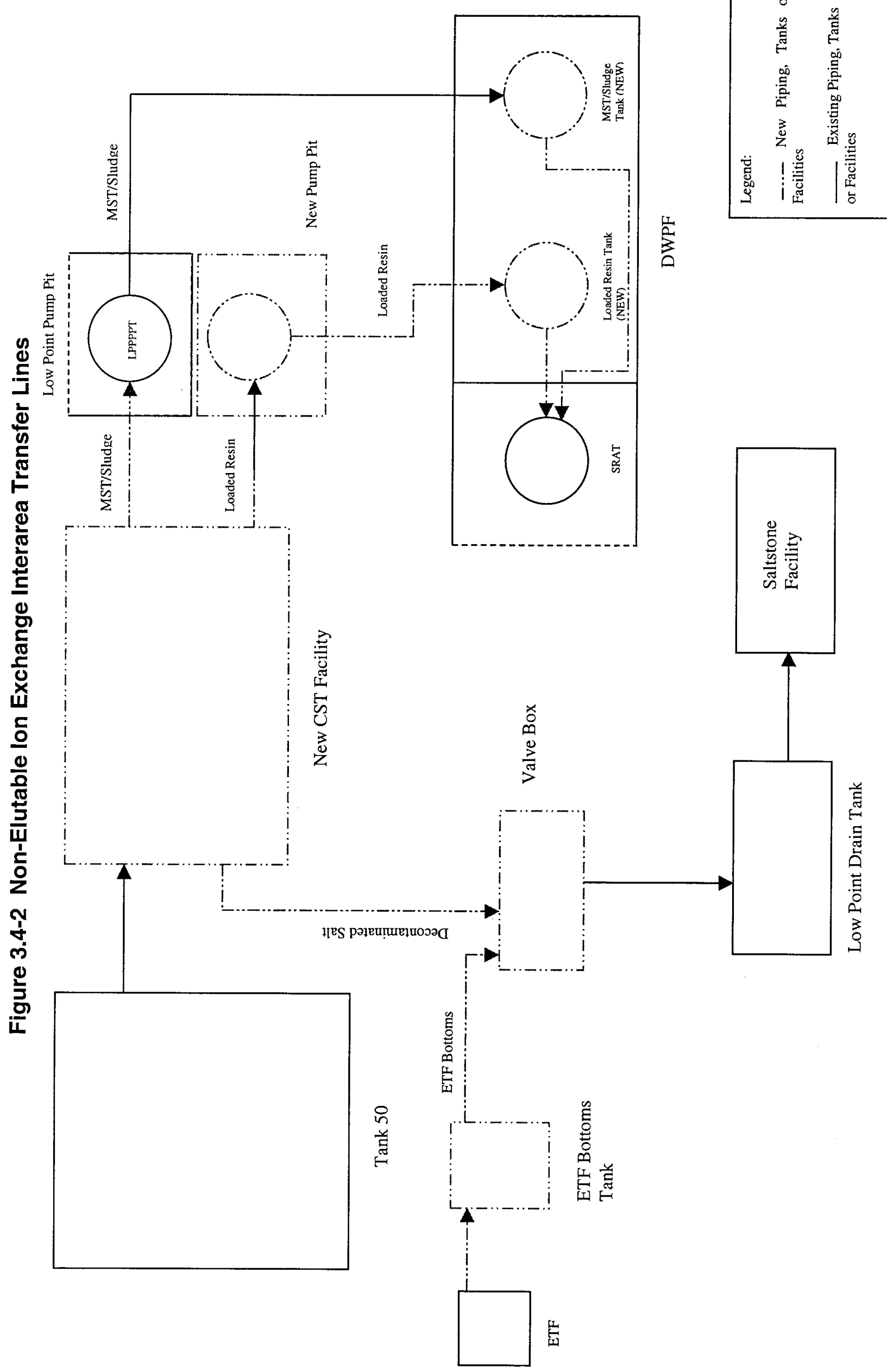




\subsubsection{Jumpers}

Table 3.4-10 Summary of Jumper Usage for Non-Elutable Ion Exchange Alternative

\begin{tabular}{|l|c|}
\hline \multicolumn{1}{|c|}{ Jumper Application } & Number of Jumpers \\
\hline Process Jumpers & 139 \\
\hline Process Jumpers with MOVs & 13 \\
\hline 3-way Process Jumpers & 4 \\
\hline 3-way Process Jumpers w/2 MOVs & 1 \\
\hline Electrical Jumpers & 42 \\
\hline Instrumentation Jumpers & 39 \\
\hline TOTAL & 238 \\
\hline
\end{tabular}




\subsection{Alternative Variations}

The High Level Waste Salt Disposition Team carried forward variations to the four alternative flowsheets chosen in Phase II. These variations to the base alternatives were to be reviewed during Phase III to determine feasibility and to be incorporated into the base case alternatives, where appropriate. The Flowsheet Team has made considerable progress in understanding the process design of all four base case options, since they were selected. Several of the alternatives appear to be infeasible and are no longer being controlled based on the analysis below. Some of the variations will be included as input to subsequent preliminary designs and estimates. The variations are keyed to the Workscope Matrix for phase III (Reference 3).

\subsection{Feed Clarification (Common Issue \#13)}

Direct Grouting, Ion Exchange (CST) and Solvent Extraction require a feed that has dissolved alpha contamination, strontium and sludge removed prior to processing. For the base case, this operation is to be done in a new facility. One variation would use Tank 48 to strike the salt solution with MST (the strontium and alpha adsorbent solid) and to filter this and residual sludge from the slurry using existing cross-flow filters. The clarified feed would be stored in Tank 49. Attributes of this alternative are:

- Eliminates new facilities with the corresponding reduction in capital cost (2 each 100,000-gallon tanks, filters, controls, feeds and cleaning equipment).

- Reduces the Tank Farms operating space by two million gallons by not returning Tanks 48 and 49 to waste storage use.

- Requires a dedicated doubly contained waste transfer line to DWPF if the MST and residual sludge cannot be blended with the sludge feed to DWPF prior to its acceptance.

- Requires additional design for filtrate handling facilities.

- (A new facility would be easier to operate, adjacent to and as part of the facilities for the base options.) Requires some additional staff to operate the Tank 48 / 49 alternative.

The lost value of the waste storage should be included as part of any cost savings anticipated from implementing this variation.

Recommendation: Complete the cost estimating of the existing flowsheet with feed clarification located in the new facility. HLW Program Management will perform the System Plan evaluation and Screening Economic Analyses of this variation. To facilitate this screening analyses, a revised layout for the direct disposal as grout without the alpha removal facilities is provided in Appendix $\mathbf{J}$. 


\subsection{Small Tank Precipitation - ITP Filter Building for Precipitation and Late Wash for Washing (Small Tank Matrix \#18)}

The concept of this variation is to maximize the use of the existing Late Wash facility for precipitate washing and expand the current ITP Facility to allow installation of the precipitation tanks. P-PG-H-8115, Rev A and C-CX-H-0063, Rev A (See Appendix K), provide layout and site plans for this concept.

Constructing the facilities for this concept is difficult since:

- The Safety Grade Nitrogen System piping must be relocated prior to construction and the piping will be 2 to 3 times longer.

- The existing ETF to Tank 50 line must be re-routed.

- The new cells require substantial excavation in the congested area near Tank 50.

- The hill must be lengthened about 110'.

Further:

- There is no provision for remote equipment handling, or decontamination.

- If a large carbon steel tank is used for filtrate storage, the regimen of inhibitor addition must continue. This increases the volume of filtrate by $\sim 10 \%$.

- Operating corridors will not hold all of the necessary instruments and these will be exposed to the elements.

- Truck access for filter removal will be difficult in the small area available.

- The benefits of using remote processing cells are lost. This alternative separates the process cells and contact maintenance areas by shield covers only. Process utility will decrease and operating cost will increase.

- A third filter cannot be accommodated at ITP; therefore the utility may be less than $75 \%$ due to the down time for filter cleaning.

- Earlier studies show that Late Wash's capacity only supports 200 canister per year production in DWPF at $75 \%$ attainment. It is likely that a somewhat higher rate could be supported if the wash water can be transferred to a nitrogen blanketed Type III tank, because the lengthy analysis for residual benzene can be eliminated. However, Late Wash will remain a bottleneck, when the down time for melter change out is included and will not produce sufficient feed to support the Site Treatment Plan.

Recommendation: The production rate of this variation does not meet the Site Treatment Plan requirements; therefore, no further study is necessary. Construction of the modified facility would also be difficult. 


\subsection{Small Tank Precipitation - Vortex Mixers at Late Wash (Small Tank Matrix \#20)}

For this options, feed clarification must be completed in tanks 48 and 49 , so the analysis for Common Issue \#13, above, applies.

The largest tank that can be put in the Late Wash Cells (12' X 12') while allowing transfer lines to drain properly is about 5000 gallons. Even assuming that a hold up time of 6 hours is adequate (versus the design basis of 24 hours for precipitation with TPBand sorption on MST), the tank required is too large ( 6000 gallons) to fit in a LW cell.

The LW filter throughput still limits the feed preparation capacity to that which supports only 200 DWPF canisters per year.

Recommendation: The equipment will not fit, and the required production rate can not be supported, no further evaluation is needed.

Note: Vortex Mixers may be used in the base case to increase reaction rates.

\subsection{Small Tank Precipitation - MST Sorption in Tank 48, Precipitation Adjacent to ITP, LW for Washing (Matrix Item \# 21)}

This approach uses a 1 million-gallon waste tank to sorb strontium and plutonium. The advantages and disadvantages of this option are the same as combining Common Issue \#13 and Small Tank Matrix \#18, as above. The layout is shown in Appendix K.

Since Small Tank ITP provides for filtering MST and this option offers little opportunity to take advantage of some possible reduction in reaction time (precipitation kinetics control, rather than sorption), there is little incentive to use Tank 48 for sorption.

Recommendation: The production rate does not meet the Site Treatment Plan requirements, therefore, no further study is necessary. Construction of the modified facility would also be difficult.

\subsection{Solvent Extraction - Located in Late Wash or in the Salt Processing Cell (Solvent Extraction Matrix \# 15)}

The maximum diameter for a vessel in either location is $\sim 12$ '. The required tank size is about 17' diameter. Also, centrifugal contactors will use the entire SPC, leaving no room for the other tankage. Appendix K shows an equipment layout with the SPC envelope superimposed. The equipment does not fit. Further, the LW cells are smaller, so the equipment cannot fit there either.

Recommendation: No further evaluation is needed. 


\subsection{Solvent Extraction - Located in H-Canyon (Solvent Extraction Matrix \# 14)}

The contactors and other solvent extraction equipment can be fit in the Hot Canyon in $\mathrm{H}$ Area with some room left for feed clarification (see Appendix K). However, the equipment already installed will be difficult to dismantle and rearrange. The availability of high activity waste transfer lines in and out of the Canyon is also uncertain.

H-Canyon's current commitments last until $1^{\text {st }}$ Quarter, FY 2004.

Recommendation: Because H-Canyon is not available in time to allow for D\&D, installation, and testing of new equipment, no further evaluation is needed.

\subsection{Crystalline Silicotitanate - Located in either Late Wash or the Salt Processing Cells (CST Matrix \#22)}

The equipment for this option will not fit in either the SPC(see Appendix K) or Late Wash, which is smaller.

Recommendation: No further evaluation is needed.

\subsection{Crystalline Silicotitanate - Cask Transfer of Solids to DWPF (CST Matrix \# 29, see HLW-SDT-980071)}

Rather than slurrying loaded resin to DWPF, it could be put in carriers compatible with the DWPF canister handling systems, shipped in the Shielded Canister Transporter, transferred into the Weld Test Cell and back into the Canister Decon Cell and flown, with the MPC from there to the Salt Processing Cell. There it could be unloaded and fed to the SRAT. This operation would be done about once per week. This method appears impractical. Therefore, a facility to slurry for transfer into DWPF would be needed.

X-PG-H-0004, Rev. A of Appendix K shows a CST facility with load-out capability. Unloading facilities would have to be installed in the SPC, similar to the loading facility, if the CST containers are brought in through the SPC. If a facility to slurry and transfer the solids into the SPC can be made to work, the slurry transfer, which is used in the base case, will work.

Recommendation: This variation should be pursued as a design study for implementation, if CST slurry transfer proves impractical. 


\subsection{Direct Grout Product Put in Licensed Shippable Container and Disposed of Offsite}

P-PG-Z-0001, Rev. A of Appendix $\mathrm{K}$ is a layout showing a facility which produces grout and puts it in Multi-Use, High Integrity Container (MUC-HICTM), rather than pumping it to an on-site vault. A minimum of 61,000 of the largest (88"x110"x120") of these would be filled.

Emplacement cost at a licensed offsite facility is estimated at $\$ 14$ billion, based on the current charges of $\$ 350$ per cubic foot at Chem-Nuclear's Barnwell site. The containers can be purchased for less than $\$ 200$ million.

Recommendation: Because of its excessive cost, no further evaluation is needed. 


\subsection{SUMMARY OF ALTERNATIVE RESULTS}

The modeling and material balances for the technology options selected for the short list salt disposition alternatives have been completed. A summary of the results for all of the options is presented in Tables 5-1 through 5-2. Table 5-1 contains the $100 \%$ attainment values each of the options for the year selected for material balances. Table 5-2 represents the $75 \%$ attainment results. The models and material balances are based on the assumptions and bases presented in Appendix A. The results can be assumed to be accurate to approximately $\pm 25 \%$. The complete material balance and flow sheet diagrams are included in Appendix I. The material balances were used to develop plant layouts and jumper specifications. The layouts and jumper specifications are shown in Appendices $\mathrm{J}$ and $\mathrm{B}$, respectively. The raw materials consumed are shown on the material balances shown in Appendix I. The results for each option have been discussed in more detail previously. 


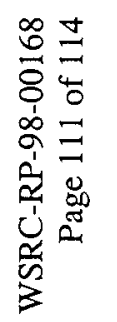
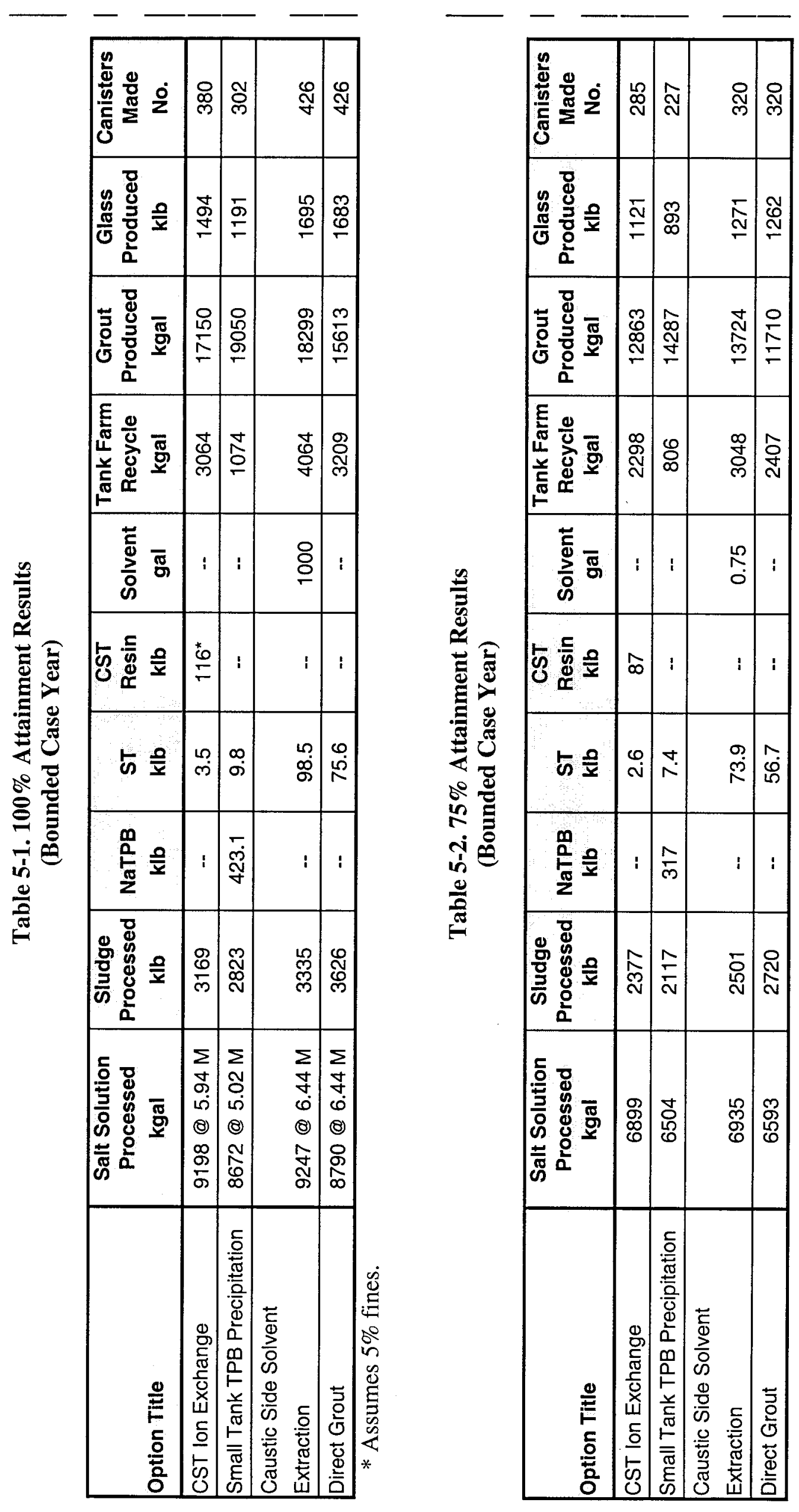

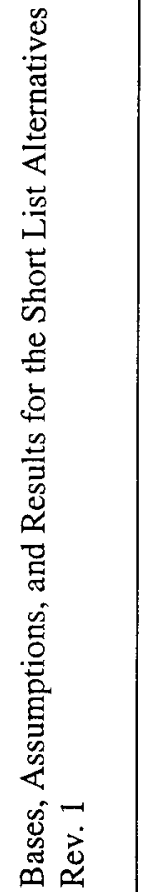




\subsection{REFERENCES}

1 WSRC-RP-98-00166, Bases, Assumptions, and Results of Flowsheet Calculations for the Initial Eighteen Salt Disposition Alternatives, Rev. 1.

2 Charter for the SRS High Level Waste Salt Disposition Systems Engineering Team.

3 HLW-SDT-980071, High Level Waste Salt Disposition Systems Engineering Team Scope Of Work Matrix, Revision 1.

4 S. Beck, Ion Exchange Model for CST Column Sizing (U), WSRC-RP-98-01053.

5 Rayford G. Anthony and Zhixin Zheng, CST Ion Exchange Version 5 (CSTIXE5), Department of Chemical Engineering, Texas A\&M University, College Station.

6 N. H. Linda Wang, Review of CST Ion Exchange Data and Preliminary Carousel Designs for Cesium Removal from SRS Wastes, School of Chemical Engineering, Purdue University, September 1998.

7 H. H. Elder, CST Glass Composition and Frit Formulations, HLW-SDT-98-0086, September 10, 1998.

8 N. R. Davis and M. N. Wells, HLW System Plan - Revision 9, HLW-OVP-98-0037, April 1998.

9 M. B. Bronikowski, D. T. Hobbs, W. R. Wilmarth, Preliminary Report on Monosodium Titanate Adsorption Kinetics (U), WSRC-TR-98-00347, Rev. 0, October, 1998.

10 SRT-WHM-98-18, W. B. Van Pelt and M. W. Greeting, Salt Disposition Filtration Studies Using The Filtration Research Engineering Demonstration (FRED) at the University of South Carolina, October 1, 1998

11 W. B. Van Pelt, Salt Disposition Filtration Studies Using the Parallel Rheology Experimental Filter (PREF), SRT-WHM-98-17, October 1, 1998

12 M. A. Shadday, "Heat Transfer Modeling of the Saltstone Pouring and Curing Process (U)," WSRC-TR-93-528, November 1993.

13 M. A. Shadday, Thermal Modeling of the Saltstone Pouring and Curing Process (U), September 1998

14 C. Langton, Direct Grout Stabilization of High Cesium Salt Waste: Salt Waste Alternative Phase III Feasability Study (U), WSRC-98-00337, September 30, 1998. 
15 J. R. Cook, Effect of "Grout-it-All" Alternative on Saltstone Performance Assessment, SRT-WED-98-0119, September 18, 1998.

16 D. D. Walker, "Low Temperature Decomposition Rates for Tetraphenylborate Ion," WSRC-TR-98-00342, Rev. 0, October 5,1998.

17 M. J. Barnes, "Cesium Precipitation Studies," WSRC-TR-98-00367, Rev.0, October 5,1998 .

18 D. T. Hobbs, et. al., "Preliminary Report on Monosodium Titanate Adsorption Kinetics,"WSRC-TR-98-00347, October 5,1998.

19 Octave Levenspiel, Chemical Reaction Engineering, John Wiley \& Sons, 1962, pages 101-104.

20 WSRC-TR-98-00347, Preliminary Report on Monosodium Titanate Adsorption Kinetics, October 5, 1998.

21 R. A. Leonard and M. C. Regalbuto, "A Spreadsheet Algorithm for Stagewise Solvent Extraction", Solvent and Ion Exchange, 12(5), 909-930 (1994).

22 WSRC-TR-98-000368, R.A. Peterson and F. F. Fowler, "High Level Waste Testing of Solvent Extraction Process, October 2, 1998

23 Conner, et. al. Batch Testing at ANL, October 2, 1998

24 Moyer, et. al. Summary Report, October 2, 1998

25 WSRC-TR-98-00371, Radiation Stability of Calixarene Based Solvent System, C. L. Crawford, F. F. Fondeur, R. A. Peterson, and T. L. White, October 2, 1988.

26 R. A. Jacobs, CST Equilibrium Dependence on Temperature (U). HLW-SDT-980160, October 1998.

27 Reference to TAMU model

28 WSRC-TR-98-00334

29 D. D. Walker, Modeling of Crystalline Silicotitanate Ion Exchange Columns, WSRC-TR-00343, Rev. 0, October 2, 1998.

30 M. E. Huckman, I. M. Latheef, and R. G. Anthony, Treating Savannah River Waste Using UOP IONSIV IE911, Texas A\&M University, Department of Chemical Engineering, Kinetics, Catalysis, and Reaction Engineering Group, September 24, 1998. 
31 B. Hritzko and N. H. Wang, Design of a Carousel process for Removing Cesium from SRS Waste Using Crystalline Silicotitanate Ion Exchanger, School of Chemical Engineering, Purdue University, West Lafayette, Indiana, September 30, 1998.

32 WSRC-RP-98-01053, S. Beck, Ion Exchange Model for CST Column Sizing (U).

33 M. E. Huckman, I. M. Latheef, and R. G. Anthony, Treating Savannah River Waste Using UOP IONSIV IE911, Texas A\&M University, Department of Chemical Engineering, Kinetics, Catalysis, and Reaction Engineering Group, September 24, 1998.

34 B. Hritzko and N. H. Wang, Design of a Carousel process for Removing Cesium from SRS Waste Using Crystalline Silicotitanate Ion Exchanger, School of Chemical Engineering, Purdue University, West Lafayette, Indiana, September 30, 1998.

35 WSRC-RP-98-01053, S. Beck, Ion Exchange Model for CST Column Sizing (U).

36 D. Walker, J. Walker, P. Taylor, and D. Hendrickson, Environmental Progress, 1997, 16, pp 251-262.

37 H. Elder, CST Glass Compositions and Frit Formulations, DRAFT.

38 S. Beck, Impact of Sludge-Only/CST-Only Campaign Transitions, WSRC-SDT-980088, Rev. A

39 WSRC-RP-98-01142, M. K. Andrews et. al., Results of the CST/Sludge Variability Study, October 1, 1998.

40 R. W. Winge, Inductively Coupled Plasma-Atomic Emission Spectroscopy, Elsevis, 1998. 
APPENDIX A

\section{BASES}




\section{APPENDIX A TABLE OF CONTENTS}

Section

Title

Page

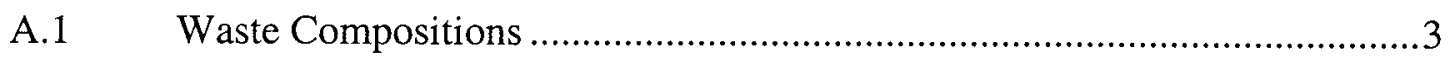

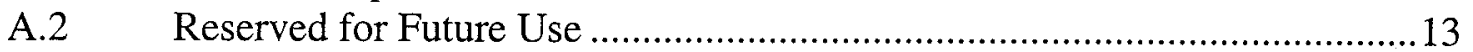

A.3 Alpha Decontamination by Monosodium Titantate Addition ......................14

A.4 Cs Decontamination by Tetraphenylborate Precipitation ..............................17

A.5 Radiolysis of Water and Salt Solutions ...................................................19

A.6 Radiolysis of Tetraphenylborate .........................................................19

A.7 Benzene Generation from Chemical Decomposition of TPB ......................20

A.8 Benzene Depletion in the Small Tank Facility ..........................................23

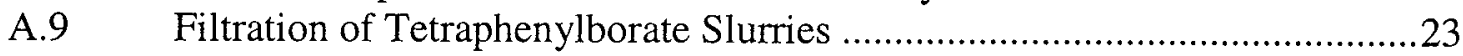

A.10 Saltstone Product Bases .........................................................................22

A.11 DWPF Salt Processing Cell Bases _.........................................................25

A.12 DWPF Chemical Cell Bases ..............................................................22

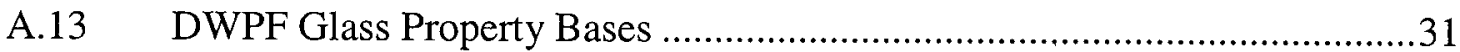

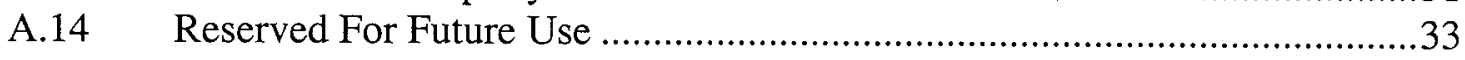

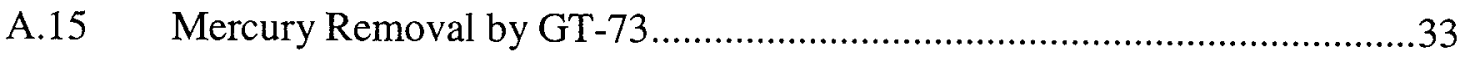

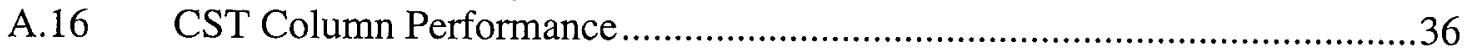

A.17 Crystalline Silicotitanate Final Disposal Forms ……....................................

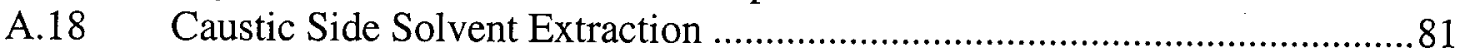

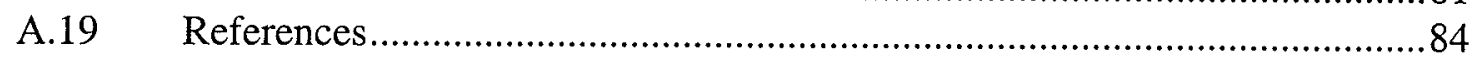




\section{APPENDIX A - BASES}

The following sections summarize the bases and assumptions used in the flowsheet calculations.

\section{A.1 Waste Compositions}

To provide a common basis for the various salt pretreatment options, the compositions of blend sludge and blend salt/supernate feeds have been estimated using the WCSystem database as of 4/1/98 and the integrated HLW Chemical Process Evaluation System (CPES) computer model. This section briefly describes the database, the model, and the bases and assumptions used to calculate the blend feed compositions.

\section{A.1.1 Database}

The WCSystem database describes the present HLW inventory at SRS based on both sampling and historical data, and is maintained by HLW Engineering. It contains information on the volumes and compositions of sludge, salt and supernate in each tank in an Excel ${ }^{\circledR}$ spreadsheet. The chemical compositions of nonradioactive species are given in an elemental, ionic or compound form, while those of radionuclides are given in curies for each isotope. The average level of ${ }^{137} \mathrm{Cs}$ in supernate is currently specified as $22.56 \%$ of all Cs isotopes by weight. This database is updated monthly as more sampling data and/or historical data become available. The compositions of blend waste feeds described in this section are based on database information on $4 / 1 / 98$. The total inventory and composition is summarized in Tables A.1-1 to A.1-4.

The total salt volume to be treated varies with treatment process. For example, some flowsheets allow treatment of salt solutions containing undissolved salts and can be treated at sodium concentrations of 6.5 molar while others can be treated as saturated solutions $(6.44$ molar sodium) and still others require dilution to 4.5 molar to improve the kinetics of selected treatment steps.

The total volume to be treated is a function of the amount of sodium in the tank farm and the required dilution. As noted in the Table A.1-4, the total volume at 6.44 molar sodium is 76.3 million gallons, further reduction results in:

- Total Solution Volume @ 5.5 $\mathrm{M}\left[\mathrm{Na}^{+}\right]=(1.866 \mathrm{E} 09$ moles $) /[(5.5 \mathrm{moles} / \mathrm{L})(3.785 \mathrm{~L} / \mathrm{gal})]=90$ million gallons.

- Total Solution Volume @ $5.0 \mathrm{M}\left[\mathrm{Na}^{+}\right]=(1.866 \mathrm{E} 09$ moles $) /[(4.5 \mathrm{moles} / \mathrm{L})(3.785 \mathrm{~L} / \mathrm{gal})]=99$ million gallons.

- Total Solution Volume @ 4.5 $\mathrm{M}\left[\mathrm{Na}^{+}\right]=(1.866 \mathrm{E} 09$ moles $) /[(4.5 \mathrm{moles} / \mathrm{L})(3.785 \mathrm{~L} / \mathrm{gal})]=110$ million gallons. 
Table A.1-1 Old Style Tank Inventory

\begin{tabular}{|c|c|c|c|c|c|c|c|c|}
\hline Tank & Tank Type & $\begin{array}{c}\text { Total } \\
\text { Waste } \\
\text { Volume } \\
\text { (gal) }\end{array}$ & $\begin{array}{c}\text { Sludge } \\
\text { Volume } \\
\text { (gal) }\end{array}$ & $\begin{array}{c}\text { Salt } \\
\text { Volume } \\
\text { (gal) }\end{array}$ & $\begin{array}{c}\text { Free } \\
\text { Supernate } \\
\text { Vol. (gal) }\end{array}$ & $\begin{array}{c}\text { Interstitial } \\
\text { Sludge } \\
\text { Supernate } \\
\text { Vol. (gal) }\end{array}$ & $\begin{array}{c}\text { Interstitial } \\
\text { Salt } \\
\text { Supernate } \\
\text { Vol. (gal) }\end{array}$ & $\begin{array}{c}\text { Total } \\
\text { Supernate Vol. } \\
\text { (gal) }\end{array}$ \\
\hline 1 & I & 505957 & 7000 & 480000 & 18957 & 4900 & 105600 & 129457 \\
\hline 2 & I & 540103 & 4000 & 536000 & 103 & 2800 & 117920 & 120823 \\
\hline 3 & I & 540374 & 4000 & 536000 & 374 & 2800 & 117920 & 121094 \\
\hline 4 & I & 508667 & 127000 & 34000 & 347667 & 88900 & 7480 & 444047 \\
\hline 5 & I & 28726 & 18078 & 10648 & & & & \\
\hline 6 & I & 344983 & 25000 & & 319983 & 17500 & & 337483 \\
\hline 7 & I & 366934 & 209000 & & 157934 & 146300 & & 304234 \\
\hline 8 & I & 138210 & 86973 & 51237 & & & & \\
\hline 9 & I & 542000 & 4000 & 538000 & & 2800 & 118360 & 121160 \\
\hline 10 & I & 217342 & 4000 & 213000 & 342 & 2800 & 46860 & 50002 \\
\hline 11 & I & 340647 & 140000 & & 200647 & 98000 & & 298647 \\
\hline 12 & I & 112465 & 82693 & 29772 & & & & \\
\hline 13 & II & 882000 & 223000 & & 659000 & 156100 & & 815100 \\
\hline 14 & II & 173950 & 17950 & 156000 & & 18900 & 34320 & 53220 \\
\hline 15 & II & 210000 & 142849 & 67151 & & & & \\
\hline 16 & II & & & & & & & \\
\hline 17 & IV & & & & & & & \\
\hline 18 & IV & 350106 & 42000 & & 308106 & 29400 & & 337506 \\
\hline 19 & IV & 276828 & 7560 & 13000 & 256268 & 5292 & 2860 & 264420 \\
\hline 20 & IV & & & & & & & \\
\hline 21 & IV & 130626 & 14000 & & 116626 & 9800 & & 126426 \\
\hline 22 & IV & 936330 & 21000 & & 915330 & 14700 & & 930030 \\
\hline 23 & IV & 719647 & 43000 & & 676647 & 30100 & & 706747 \\
\hline 24 & IV & 274704 & & & 274704 & & & 274704 \\
\hline & & & & & & & & \\
\hline Total & & 8140599 & 1223103 & 2664808 & 4252688 & 631092 & 551320 & 5435100 \\
\hline
\end{tabular}

* Bulk waste was removed from Tank 19 in 1986 . Waste heel remains to be removed. 
Table A.1-2 Type III Waste Tank Inventory

\begin{tabular}{|c|c|c|c|c|c|c|c|}
\hline Tank & $\begin{array}{c}\text { Total } \\
\text { Waste } \\
\text { Volume } \\
\text { (gal) }\end{array}$ & $\begin{array}{c}\text { Sludge } \\
\text { Volume } \\
\text { (gal) }\end{array}$ & $\begin{array}{c}\text { Salt } \\
\text { Volume } \\
\text { (gal) }\end{array}$ & $\begin{array}{c}\text { Free } \\
\text { Supernate } \\
\text { Vol. (gal) }\end{array}$ & $\begin{array}{c}\text { Interstitial } \\
\text { Sludge } \\
\text { Supernate } \\
\text { Vol. (gal) }\end{array}$ & $\begin{array}{c}\text { Interstitial } \\
\text { Salt } \\
\text { Supernate } \\
\text { Vol. (gal) }\end{array}$ & $\begin{array}{c}\text { Total } \\
\text { Supernate Vol. } \\
\text { (gal) }\end{array}$ \\
\hline 25 & 1269567 & & 1108000 & 161567 & & 243760 & 405327 \\
\hline 26 & 648297 & 281000 & & 367297 & 196700 & & 563997 \\
\hline 27 & 1268093 & & 463000 & 805093 & & 101860 & 906953 \\
\hline 28 & 1217268 & & 1032000 & 185268 & & 227040 & 412308 \\
\hline 29 & 1274060 & & 1000000 & 274060 & & 220000 & 494060 \\
\hline 30 & 1154053 & 500 & 65988 & 1087565 & 350 & 14517 & 1102432 \\
\hline 31 & 1258335 & & 1014000 & 244335 & & 223080 & 467415 \\
\hline 32 & 1212494 & 182871 & & 1029623 & 128010 & & 1157633 \\
\hline 33 & 457704 & 39000 & 227000 & 191704 & 27300 & 49940 & 268944 \\
\hline 34 & 1157949 & 25000 & 212000 & 920949 & 17500 & 46640 & 985089 \\
\hline 35 & 1203930 & 64584 & & 1139346 & 45209 & & 1184555 \\
\hline 36 & 1277745 & 150 & 1094000 & 183595 & 105 & 240680 & 424380 \\
\hline 37 & 1237275 & & 973000 & 264275 & & 214060 & 478335 \\
\hline 38 & 891540 & & 870480 & 21060 & & 191506 & 212566 \\
\hline 39 & 1045278 & 92664 & & 952614 & 64865 & & 1017479 \\
\hline 40 & 1243242 & 173000 & & 1070242 & 121100 & & 1191342 \\
\hline 41 & 1240083 & & 1231000 & 9083 & & 270820 & 279903 \\
\hline 42 & 527202 & 261900 & & 265302 & 209520 & & 474822 \\
\hline 43 & 1026956 & 58756 & 123084 & 845116 & 41129 & 27078 & 913323 \\
\hline 44 & 1268865 & & 989000 & 279865 & & 217580 & 497445 \\
\hline 45 & 1263249 & & 1130000 & 133249 & & 248600 & 381849 \\
\hline 46 & 892067 & & 4000 & 888067 & & 880 & 888947 \\
\hline 47 & 1258160 & 248000 & 868000 & 142160 & 173600 & 190960 & 506720 \\
\hline 48 & 245068 & & & 245068 & & & 245068 \\
\hline 49 & 114286 & & & 114286 & & & 114286 \\
\hline 50 & 384556 & & & 384556 & & & 384556 \\
\hline 51 & 233766 & 232766 & & 1000 & 186213 & & 187213 \\
\hline & & & & & & & \\
\hline Total & 26271086 & 1660191 & 12404552 & 12206343 & 1211600 & 2729001 & 16146945 \\
\hline & & & & & & & \\
\hline
\end{tabular}


Table A.1-3 Total Tank Farm Inventory

\begin{tabular}{|c|c|c|c|c|c|c|c|}
\hline Tank & $\begin{array}{c}\text { Total } \\
\text { Waste } \\
\text { Volume } \\
\text { (gal) }\end{array}$ & $\begin{array}{c}\text { Sludge } \\
\text { Volume } \\
\text { (gal) }\end{array}$ & $\begin{array}{c}\text { Salt } \\
\text { Volume } \\
\text { (gal) }\end{array}$ & $\begin{array}{c}\text { Free } \\
\text { Supernate } \\
\text { Vol. (gal) }\end{array}$ & $\begin{array}{c}\text { Interstitial } \\
\text { Sludge } \\
\text { Supernate } \\
\text { Vol. (gal) }\end{array}$ & $\begin{array}{c}\text { Interstitial } \\
\text { Salt } \\
\text { Supernate } \\
\text { Vol. (gal) }\end{array}$ & $\begin{array}{c}\text { Total } \\
\text { Supernate } \\
\text { Vol. (gal) }\end{array}$ \\
\hline $\begin{array}{c}\text { Type I, II, } \\
\text { and IV } \\
\text { Inventory }\end{array}$ & 8140599 & 1223103 & 2664808 & 4252688 & 631092 & 551320 & 5435100 \\
\hline $\begin{array}{c}\text { Type III } \\
\text { Tank } \\
\text { Inventory }\end{array}$ & 26271086 & 1660191 & 12404552 & 12206343 & 1211600 & 2729001 & 16146945 \\
\hline $\begin{array}{c}\text { Total } \\
\text { Tank Farm } \\
\text { Inventory }\end{array}$ & 34411685 & 2883294 & 15069360 & 16459031 & 1842692 & 3280321 & 21582045 \\
\hline
\end{tabular}


Table A.1-4 Projected Salt Inventory to Be Processed

\begin{tabular}{|c|c|c|c|c|c|c|c|c|}
\hline Waste Species & $\begin{array}{l}\text { Molecular } \\
\text { Weight }\end{array}$ & $\begin{array}{c}\text { Current } \\
\text { Inventory } \\
\text { Supernate } \\
\text { (kg) }\end{array}$ & $\begin{array}{c}\text { Current } \\
\text { Inventory } \\
\text { Salt Cake } \\
(\mathrm{kg})\end{array}$ & $\begin{array}{c}\text { Future } \\
\text { Additions } \\
\text { Supernate } \\
\text { (kg) }\end{array}$ & $\begin{array}{l}\text { Current } \\
\text { Inventory } \\
\text { Supernate } \\
\text { (moles) }\end{array}$ & $\begin{array}{c}\text { Current } \\
\text { Inventory } \\
\text { Salt Cake } \\
\text { (moles) }\end{array}$ & $\begin{array}{c}\text { Future } \\
\text { Additions } \\
\text { Supernate } \\
\text { (moles) }\end{array}$ & $\begin{array}{c}\text { Total } \\
\text { Sodium } \\
\text { Salts } \\
\text { (moles) }\end{array}$ \\
\hline Water & 18.020 & $6.249 \mathrm{E}+07$ & (c) & $3.670 \mathrm{E}+08$ & $3.468 \mathrm{E}+09$ & (c) & $2.037 \mathrm{E}+07$ & \\
\hline$\overline{\mathrm{CsOH}}$ & 149.910 & $6.605 \mathrm{E}+03$ & (d) & $2.970 \mathrm{E}+02$ & $4.406 \mathrm{E}+04$ & (d) & $1.982 \mathrm{E}+00$ & \\
\hline $\mathrm{KNO}_{3}$ & 101.103 & & $8.271 E+04$ & & & $8.181 E+05$ & & \\
\hline $\mathrm{KOH}$ & 56.106 & $2.279 \mathrm{E}+05$ & & $2.581 \mathrm{E}+03$ & $4.061 E+06$ & & $4.600 \mathrm{E}+04$ & \\
\hline $\mathrm{NaAl}(\mathrm{OH})_{4}$ & 118.001 & $3.690 \mathrm{E}+06$ & $7.483 \mathrm{E}+06$ & $9.512 \mathrm{E}+05$ & $3.127 \mathrm{E}+07$ & $6.341 \mathrm{E}+07$ & $8.061 E+06$ & $1.027 E+08$ \\
\hline $\mathrm{Na}_{2} \mathrm{C}_{2} \mathrm{O}_{4}$ & 133.999 & $9.239 \mathrm{E}+04$ & $4.302 \mathrm{E}+05$ & $4.687 \mathrm{E}+03$ & $6.895 E+05$ & $3.210 \mathrm{E}+06$ & $3.498 \mathrm{E}+04$ & $7.869 \mathrm{E}+06$ \\
\hline $\mathrm{Na}_{2} \mathrm{CO}_{3}$ & 105.989 & $2.113 E+06$ & $3.311 \mathrm{E}+06$ & $1.115 \mathrm{E}+05$ & $1.994 \mathrm{E}+07$ & $3.124 \mathrm{E}+07$ & $1.052 \mathrm{E}+06$ & $1.045 \mathrm{E}+08$ \\
\hline $\mathrm{Na}_{2} \mathrm{CrO}_{4}$ & 161.973 & $9.668 \mathrm{E}+04$ & $6.250 \mathrm{E}+04$ & $4.702 \mathrm{E}+03$ & $5.969 E+05$ & $3.858 \mathrm{E}+05$ & $2.903 E+04$ & $2.023 \mathrm{E}+06$ \\
\hline $\mathrm{Na}_{2} \mathrm{MoO}_{4}$ & 205.917 & & $1.212 \mathrm{E}+04$ & $8.159 E+02$ & $0.000 \mathrm{E}+00$ & $5.885 E+04$ & $3.962 \mathrm{E}+03$ & $1.256 \mathrm{E}+05$ \\
\hline $\mathrm{Na}_{2} \mathrm{SiO}_{3}$ & 122.033 & $1.316 \mathrm{E}+04$ & $1.307 \mathrm{E}+05$ & $4.016 \mathrm{E}+03$ & $1.078 \mathrm{E}+05$ & $1.071 \mathrm{E}+06$ & $3.291 E+04$ & $2.423 \mathrm{E}+06$ \\
\hline $\mathrm{Na}_{2} \mathrm{SO}_{4}$ & 142.043 & $4.462 \mathrm{E}+05$ & $6.377 E+06$ & $9.823 \mathrm{E}+04$ & $3.141 E+06$ & $4.489 \mathrm{E}+07$ & $6.916 E+05$ & $9.745 \mathrm{E}+07$ \\
\hline $\mathrm{Na}_{3} \mathrm{PO}_{4}$ & 163.941 & $1.670 \mathrm{E}+05$ & $2.488 \mathrm{E}+05$ & $1.209 \mathrm{E}+04$ & $1.019 \mathrm{E}+06$ & $1.517 \mathrm{E}+06$ & $7.373 E+04$ & $7.829 \mathrm{E}+06$ \\
\hline $\mathrm{NaAg}(\mathrm{OH})_{2}$ & 164.873 & $3.125 \mathrm{E}+01$ & $1.862 \mathrm{E}+02$ & $1.049 \mathrm{E}+00$ & $1.895 \mathrm{E}+02$ & $1.129 \mathrm{E}+03$ & $6.363 \mathrm{E}+00$ & $1.325 \mathrm{E}+03$ \\
\hline $\mathrm{NaCl}$ & 58.443 & $4.946 \mathrm{E}+04$ & $4.195 \mathrm{E}+05$ & $7.419 \mathrm{E}+03$ & $8.462 \mathrm{E}+05$ & $7.177 \mathrm{E}+06$ & $1.269 \mathrm{E}+05$ & $8.151 E+06$ \\
\hline $\mathrm{NaF}$ & 41.988 & $3.981 \mathrm{E}+04$ & $3.970 \mathrm{E}+05$ & $1.043 \mathrm{E}+03$ & $9.481 \mathrm{E}+05$ & $9.455 \mathrm{E}+06$ & $2.484 \mathrm{E}+04$ & $1.043 E+07$ \\
\hline $\mathrm{NaHgO}(\mathrm{OH})$ & 256.587 & $9.122 \mathrm{E}+03$ & $2.570 \mathrm{E}+03$ & $6.299 \mathrm{E}+02$ & $3.555 E+04$ & $1.002 \mathrm{E}+04$ & $2.455 \mathrm{E}+03$ & $4.802 \mathrm{E}+04$ \\
\hline $\mathrm{NaNO}_{2}$ & 68.995 & $6.028 \mathrm{E}+06$ & $5.183 \mathrm{E}+06$ & $3.778 \mathrm{E}+05$ & $8.736 \mathrm{E}+07$ & $7.511 \mathrm{E}+07$ & $5.476 \mathrm{E}+06$ & $1.680 \mathrm{E}+08$ \\
\hline $\mathrm{NaNO}_{3}$ & 84.995 & $1.173 \mathrm{E}+07$ & $4.830 \mathrm{E}+07$ & $1.206 \mathrm{E}+06$ & $1.380 \mathrm{E}+08$ & $5.682 \mathrm{E}+08$ & $1.419 \mathrm{E}+07$ & $7.205 \mathrm{E}+08$ \\
\hline $\mathrm{NaOH}$ & 39.997 & $1.398 \mathrm{E}+07$ & $9.723 \mathrm{E}+06$ & $1.434 \mathrm{E}+06$ & $3.496 \mathrm{E}+08$ & $2.431 \mathrm{E}+08$ & $3.585 \mathrm{E}+07$ & $6.285 \mathrm{E}+08$ \\
\hline $\mathrm{NH}_{4} \mathrm{NO}_{3}$ & 80.043 & & $1.012 \mathrm{E}+04$ & $5.057 \mathrm{E}+02$ & $0.000 \mathrm{E}+00$ & $1.264 \mathrm{E}+05$ & $6.318 \mathrm{E}+03$ & \\
\hline $\mathrm{CaSO}_{4}$ & 136.142 & $2.971 \mathrm{E}+02$ & $9.806 \mathrm{E}+02$ & $4.600 \mathrm{E}-01$ & $2.182 \mathrm{E}+03$ & $7.203 E+03$ & $3.379 \mathrm{E}+00$ & \\
\hline Other Salts & (a) & $5.847 \mathrm{E}+04$ & $3.283 \mathrm{E}+05$ & & & & & \\
\hline Insol. Solids & (b) & $1.231 \mathrm{E}+03$ & $2.135 \mathrm{E}+05$ & & & & & \\
\hline Total Solids & & $3.875 \mathrm{E}+07$ & $8.271 \mathrm{E}+07$ & $4.217 \mathrm{E}+06$ & $6.377 \mathrm{E}+08$ & $1.050 \mathrm{E}+09$ & $6.570 \mathrm{E}+07$ & $1.860 \mathrm{E}+09$ \\
\hline Liq. Vol, gal & & $2.065 \mathrm{E}+07$ & -- & $9.714 \mathrm{E}+07$ & $2.708 \mathrm{E}+07$ & $4.647 \mathrm{E}+07$ & $2.775 \mathrm{E}+06$ & $7.6 \mathrm{E}+7$ \\
\hline$[\mathrm{Na}+], \mathrm{M}$ & & 8.45 & dry solid & 0.18 & 6.44 & 6.44 & 6.44 & 6.44 \\
\hline
\end{tabular}

(a) Includes soluble salts of trace metals (e.g., $\mathrm{Ba}, \mathrm{Cd}, \mathrm{Cu}, \mathrm{Pd}, \mathrm{Sn}, \mathrm{Tc}, \mathrm{Rh}, \mathrm{Ru}$, lanthanides, actinides).

(b) Represents entrained sludge solids; will vary, depending on settling time prior to transfer.

(c) Water in salt tanks included with interstitial supernate; salt cake inventory is based on dry salt.

(d) Bounding total $\mathrm{CsOH}$ concentration; based on Total $\mathrm{Ci}$ of ${ }^{137} \mathrm{Cs}$ transferred to the waste tanks.

\section{A.1.2 CPES Model}

The computational tool used to estimate the blend waste feed compositions was the integrated HLW flowsheet model built on the Chemical Process Evaluation System (CPES) software; it is commonly called the CPES model. It is a steady state model, and describes the entire HLW processing operations at SRS, including the DWPF and Tank Farms. Currently, the CPES model tracks 183 individual chemical species in 1,900 streams connecting 750 unit operation 
blocks. The blending of washed sludge, pretreated salt and glass forming frit is optimized in each CPES run by setting the blending ratio at the value specified by the Product Composition Control System (PCCS) run iteratively. Instantaneous mass flow rates represent the timeaveraged values required for each unit operation to meet the specified glass production rate for a given cycle time.

\section{A.1.3 Bases and Assumptions}

The composition of the blend salt/supernate feed was calculated by taking the weighted average of the entire salt, including both dry saltcake and interstitial supernate in the salt layer, and free supernate inventory documented in the WCSystem database. The composition of the blend sludge feed was calculated in two steps. First, the weighted average composition of the HM sludge inventory was calculated, which was then followed by the aluminum dissolution step in the Extended Sludge Processing (ESP) Facility. Next, the aluminumdissolved HM sludge was combined with the weighted average of the PUREX sludge inventory before the washing step. Some of the key bases and assumptions used are:

- $76.6 \mathrm{wt} \%$ of the total aluminum in the weighted-average HM sludge was removed during the Al-dissolution step in the ESP. This has resulted in the concentration of $\mathrm{Al}_{2} \mathrm{O}_{3}$ in the final blend glass at $4.3 \mathrm{wt} \%$.

- The combined PUREX and Al-dissolved HM sludge was washed in a straight one-tank washing mode, as opposed to the two-tank cowash. The total sodium content in the washed sludge was $7 \mathrm{wt} \%$ on a dry basis.

- The washed sludge was then blended with the current Tank 42 sludge (Batch 1B) before storage.

- The blend sludge was then stored on the average for one year before being fed to DWPF, which is equivalent to the average total duration of two years for each batch. This has increased the total sodium level in the final sludge feed to DWPF to $7.7 \mathrm{wt} \%$ due to atmospheric $\mathrm{CO}_{2}$ absorption and subsequent inhibitor addition during storage.

- The total salt in the blend salt/supernate feed was adjusted to $33.5 \mathrm{wt} \%$.

- The spent wash and decant from ESP and the DWPF recycle were sent to the evaporator, and the evaporator concentrate was split into salt and sludge, which were then recycled back to ITP and ESP, respectively. 
Since the chemical forms of some of the species tracked in the CPES model are different from those used in the SPEEDUP model (Input Vector), the following conversion was done to preserve the total mass balance:

- $\mathrm{NaAl}(\mathrm{OH})_{4} \rightarrow \mathrm{NaAlO}_{2}+2 \mathrm{H}_{2} \mathrm{O}$

- $\mathrm{Al}_{2} \mathrm{O}_{3}+3 \mathrm{H}_{2} \mathrm{O} \rightarrow 2 \mathrm{Al}(\mathrm{OH})_{3}$

- $\mathrm{Fe}_{2} \mathrm{O}_{3}+3 \mathrm{H}_{2} \mathrm{O} \rightarrow 2 \mathrm{Fe}(\mathrm{OH})_{3}$

- $2 \mathrm{UO}_{2}(\mathrm{OH})_{2}+2 \mathrm{NaOH} \rightarrow \mathrm{Na}_{2} \mathrm{U}_{2} \mathrm{O}_{7}+3 \mathrm{H}_{2} \mathrm{O}$

- $\mathrm{Na}_{2} \mathrm{PuO}_{2}(\mathrm{OH})_{4} \rightarrow \mathrm{PuO} 2$ (alpha) $+2 \mathrm{NaOH}+2 \mathrm{OH}$ (misc. salt)

- $\mathrm{Na}(\mathrm{HgO}(\mathrm{OH})) \rightarrow \mathrm{NaOH}+\mathrm{HgO}$

- $6 \mathrm{MnO}_{2} \rightarrow 6 \mathrm{MnO}+3 \mathrm{O}_{2}$ (misc. salt)

All the species present in the CPES model but not in the SPEEDUP model were included in either the misc. salt or the misc. sludge. 


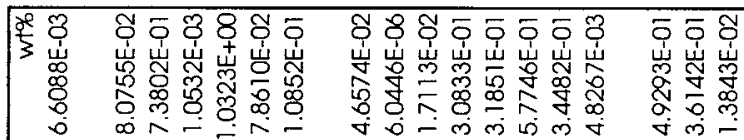

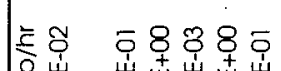

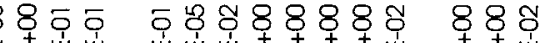

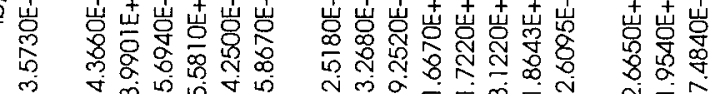

ร

3

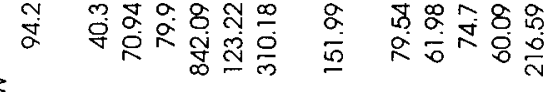

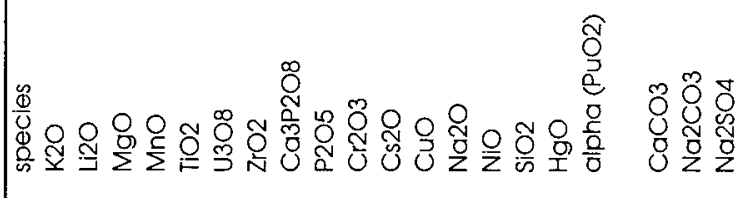

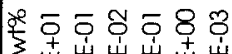

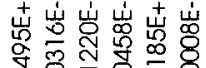

舟

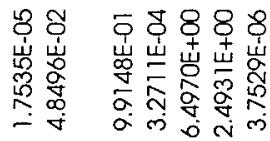

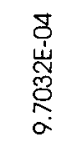

ํํำ ชิ 88 ชิ

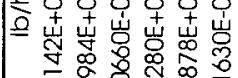

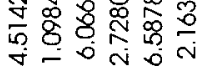

우우 8 우웅

岁岩岁岕苫岕岁

总令

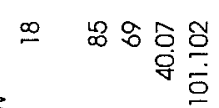

只

\begin{tabular}{llll}
8 & 0 & 0 & 0 \\
4 & 8 & \multicolumn{1}{c}{}
\end{tabular}

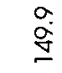

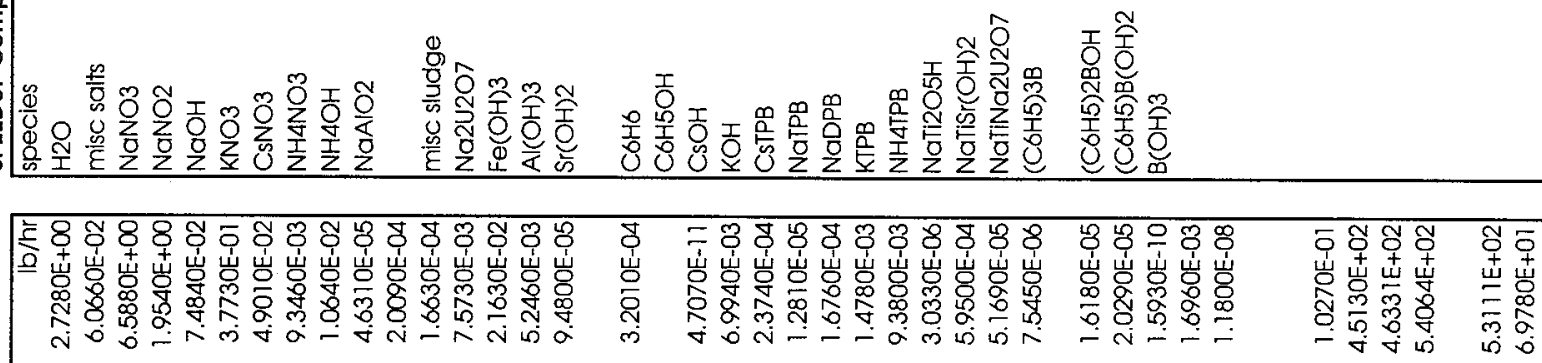

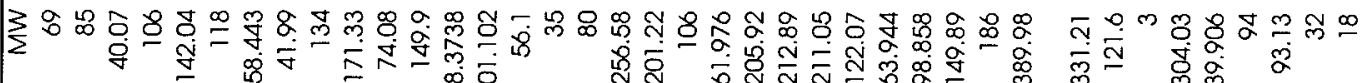

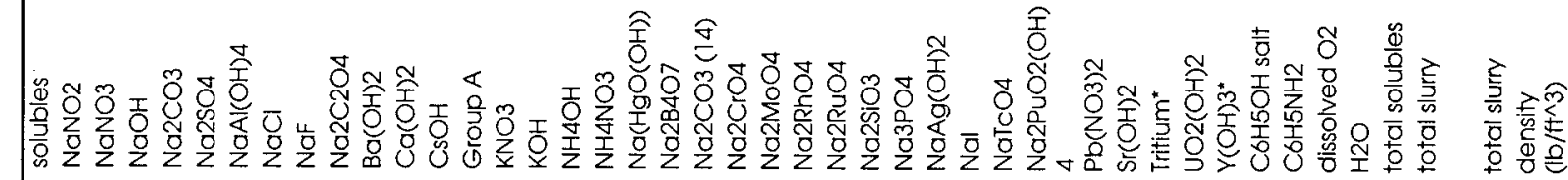

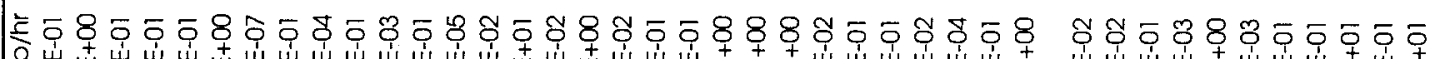

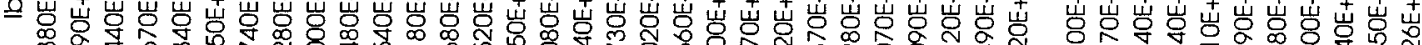

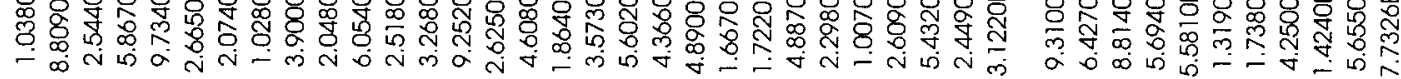

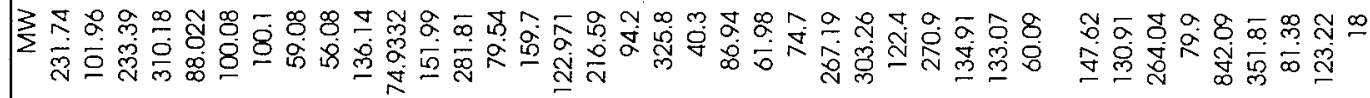




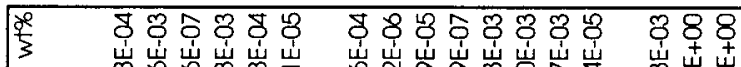

㟧岕岕岕岕岕

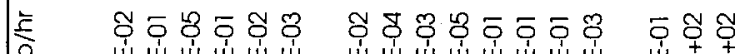

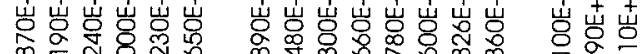

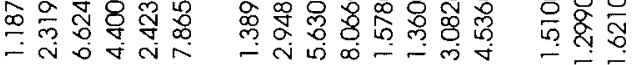

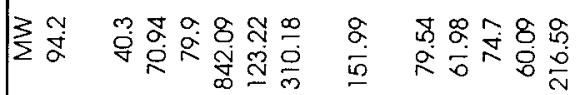

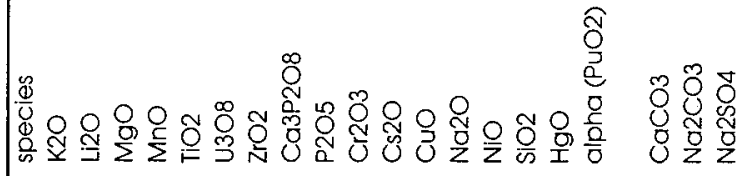

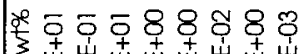

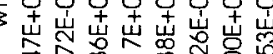

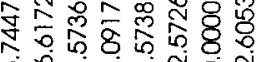

$8 \%$

ชิ

岃 岩岁岩岩岩

峲崖

sㅎำ

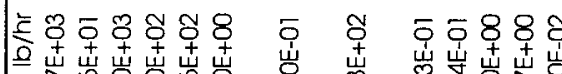

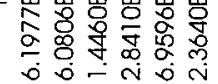

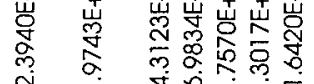

후웅

岁岁豈

要总员

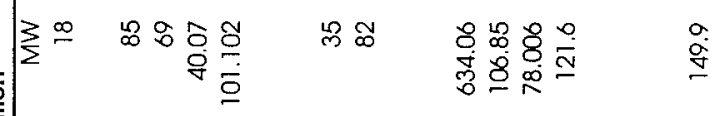

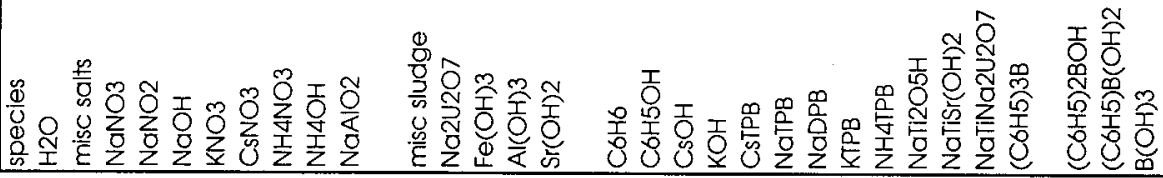

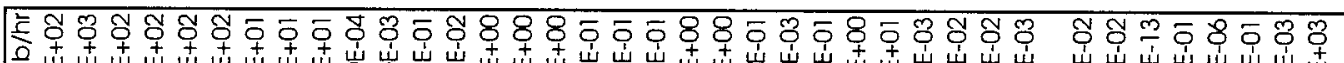

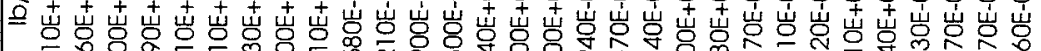

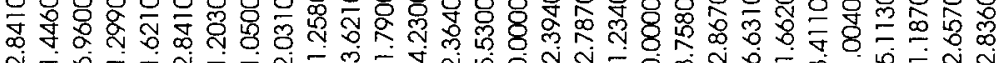

岁耑㟧岩岩岩岩吉

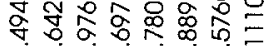

\%о̄

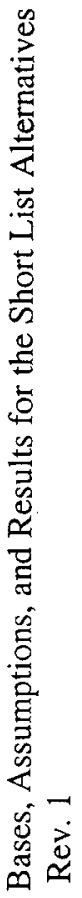

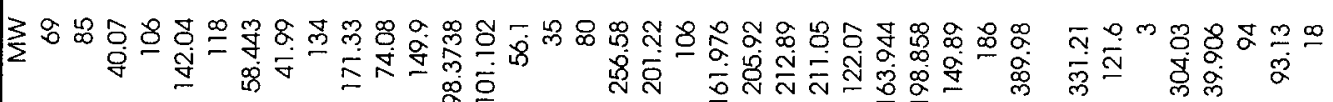

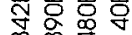

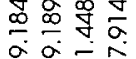

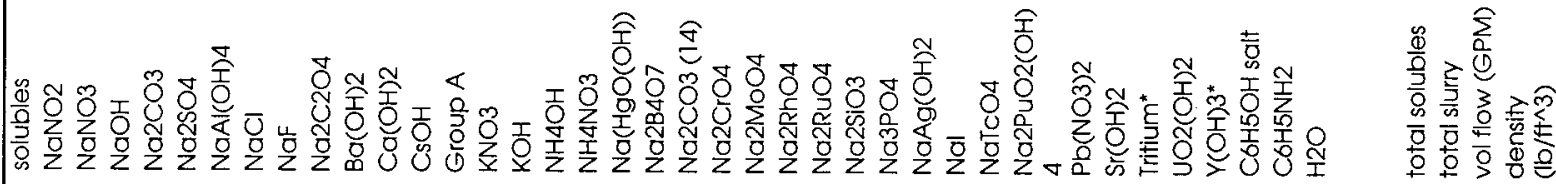

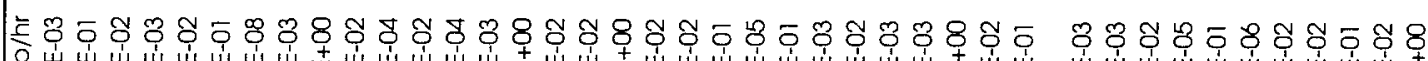

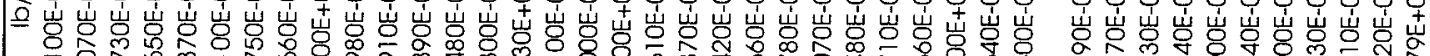

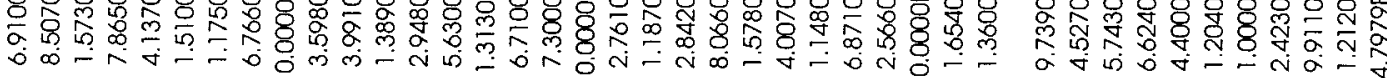

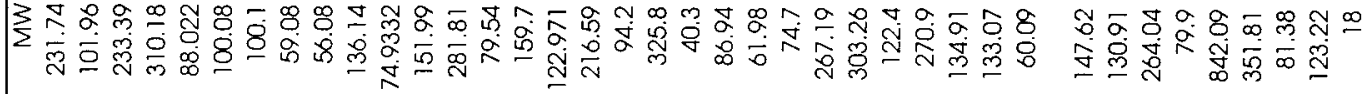

ิิ 


\section{A.1.4 Process Chemistry Bases}

Chemical reactions that apply for the various process alternatives are summarized in applicable sections. In these reactions, any solid species that are not included in the input vector (which may include water of hydration identified as $\mathrm{H}_{2} \mathrm{O}_{(\text {hyd) }}$ ) is represented by "[algebraic sum of input components to yield an equivalent chemical formula + $\left.\mathrm{H}_{2} \mathrm{O}_{\text {(hyd) }}\right]_{\text {solid." }}$ Principle soluble salts excluded from the input vector are represented by "[algebraic sum of input components to yield an equivalent chemical formula $]_{\text {aqueous." }}$

Key reactions that will occur, but cannot be constructed from the components in the input vector, will simply be based on chemistry of components known to be present in the actual waste. Components that can not be constructed from those included in the input vector are shown in italics. Insoluble reactants or products in these reactions are underlined.

The reactions provide the stoichiometry to be used for material balance purposes for the list of components used in the input vector to represent mass flows. Reactions are assumed to go to $100 \%$ completion unless the last product shown is followed by a percentage in parentheses. The percentage represents the extent of reaction based on the reactant shown. All soluble components react first; products from these reactions may undergo further reactions, as appropriate. For material balance purposes, listed reactions should be done sequentially, since products of preceding reactions can undergo subsequent reaction according to following reaction.

Because of the limited list of components used in modeling these processes, the equations do not necessarily represent the actual species that are present in any of the streams. For example, the addition of a solution of $\mathrm{Sr}(\mathrm{OH})_{2}$ to a solution of $\mathrm{Na}_{2} \mathrm{CO}_{3}$ would precipitate solid $\mathrm{SrCO}_{3}$. This reaction would normally be shown as follows:

$$
\mathrm{Sr}(\mathrm{OH})_{2}+\mathrm{Na}_{2} \mathrm{CO}_{3} \rightarrow \mathrm{SrCO}_{3}+2 \mathrm{NaOH}
$$

Because $\mathrm{SrCO}_{3}$ is not included in the list of components, this reaction would be represented stoichiometrically as follows:

$\frac{\text { Reactants }}{\mathrm{Sr}(\mathrm{OH})_{2}+\mathrm{Na}_{2} \mathrm{CO}_{3}}$

$\frac{\text { Products }}{\left[\mathrm{SrO}+\mathrm{Na}_{2} \mathrm{CO}_{3}-\mathrm{Na}_{2} \mathrm{O}\right]_{\text {solid }}+2 \mathrm{NaOH}}$

\section{A.1.5 Cold Feed Solutions}

Several of the proposed alternatives require the addition of an acid to the salt solution feed to achieve a certain $\mathrm{pH}$ or acid concentration prior to performing unit operations that separate components into different outlet streams. Several of the ion-exchange alternatives may also use acid to elute $\mathrm{Cs}$ and regenerate the resin for reuse. For material balance and stream flows that require the addition of an acidic solution, $50 \mathrm{wt} \%$ nitric acid $\left(\mathrm{HNO}_{3}\right)$ is assumed. Properties of this solution are summarized below: 


$\begin{array}{ll}\text { Wt \% HNO3 } & 50 \\ \text { Specific gravity } & 1.32 \\ \text { Molarity (moles/L) } & 10.5\end{array}$

The quantity of $\mathrm{HNO}_{3}$ added is based on that required to satisfy the stoichiometry of reactions specified for a given alternative plus any additional quantity needed to achieve the desired acid concentration or $\mathrm{pH}$.

Any acidic stream generated in the course of processing must be treated with sodium hydroxide to yield a minimum $\mathrm{pH}$ of 12 before sending the solution to either a HLW storage tank or to Z Area for conversion to saltstone. For material balance and stream flows that require the addition of a caustic, $48-50$ wt \% sodium hydroxide $(\mathrm{NaOH})$ is assumed. Properties of this solution are summarized below:

$\begin{array}{ll}\mathrm{Wt} \% \mathrm{NaOH} & 48 \\ \text { Specific gravity } & 1.51 \\ \text { Molarity (moles/L) } & 18.1\end{array}$

\section{A.2 Reserved for Future Use}




\section{A.3 Alpha Decontamination by Monosodium Titanate Addition}

\section{A.3.1 Chemical Bases for the Four Alternatives}

In all four alternatives, salt solution containing suspended sludge solids is treated in the Alpha Sorption Tank (AST) with a slurry containing nominally $125 \mathrm{~g}$ monosodium titanate per liter to adsorb soluble strontium and TRU contaminants. To maintain filtration rates in the cross-flow filter units, the filters are periodically cleaned using solutions of sodium hydroxide and oxalic acid. Sufficient MST slurry must be added to at least satisfy the following chemical stoichiometry (plus a $10 \%$ excess to account for analytical uncertainties):

Reactants

Strontium removal:

$\mathrm{Sr}(\mathrm{OH})_{2}+2 \mathrm{H}\left(\mathrm{NaTi}_{2} \mathrm{O}_{5}\right)$

TRU removal:

$\mathrm{Na}_{2} \mathrm{U}_{2} \mathrm{O}_{7}+4 \mathrm{H}\left(\mathrm{NaTi}_{2} \mathrm{O}_{5}\right)$

$\mathrm{Na}_{2} \mathrm{PuO}_{2}(\mathrm{OH})_{4}+2 \mathrm{H}\left(\mathrm{NaTi}_{2} \mathrm{O}_{5}\right)$

$\mathrm{NpO}_{2}(\mathrm{OH})+\mathrm{H}\left(\mathrm{NaTi}_{2} \mathrm{O}_{5}\right)$

$\mathrm{AmO}_{2}(\mathrm{OH})+\mathrm{H}\left(\mathrm{NaTi}_{2} \mathrm{O}_{5}\right)$

$\underline{\text { Reactants }}$

\section{Products}

$\mathrm{Sr}\left(\mathrm{NaTi}_{2} \mathrm{O}_{5}\right)_{2}+2 \mathrm{H}_{2} \mathrm{O}$
$2 \mathrm{UO}_{2}\left(\mathrm{NaTi}_{2} \mathrm{O}_{5}\right)_{2}+2 \mathrm{NaOH}+\mathrm{H}_{2} \mathrm{O}$

$\mathrm{PuO}_{2}\left(\mathrm{NaTi}_{2} \mathrm{O}_{5}\right)_{2}+2 \mathrm{NaOH}+2 \mathrm{H}_{2} \mathrm{O}$

$\mathrm{NpO}_{2}\left(\mathrm{NaTi}_{2} \mathrm{O}_{5}\right)+\mathrm{H}_{2} \mathrm{O}$

$\mathrm{AmO}_{2}\left(\mathrm{NaTi}_{2} \mathrm{O}_{5}\right)+\mathrm{H}_{2} \mathrm{O}$

Addition of Filter Cleaning Solutions to the AST:

$2 \mathrm{NaOH}+\mathrm{H}_{2} \mathrm{C}_{2} \mathrm{O}_{4}$

$\mathrm{Na}_{2} \mathrm{C}_{2} \mathrm{O}_{4}+\mathrm{H}_{2} \mathrm{O}$

Because Sr and TRU contaminants compete for adsorption sites on the MST, an equilibrium distribution constant $\left(k_{d}\right)$ is needed for each contaminant to account for the relative adsorption efficiency and determine the quantity of MST slurry needed to adequately remove $\mathrm{Sr}$ and TRU contaminants. The equilibrium distribution constants are related to the decontamination factor ( $\mathrm{DF}=$ initial concentration / final concentration) by the following equation:

$$
\mathrm{k}_{\mathrm{d}}=\{\mathrm{M}\}_{\mathrm{ads}} /[\mathrm{M}]=(\mathrm{DF}-1) /[\mathrm{MST}]
$$

where: $\{\mathrm{M}\}_{\mathrm{ads}}=$ equilibrium concentration of adsorbing species, $\mathrm{M}$, on the MST in $\mathrm{mmol} / \mathrm{ml}$

[M] = equilibrium solution concentration of adsorbing species in $\mathrm{mmol} / \mathrm{ml}$

$[\mathrm{MST}]=$ concentration of MST in $\mathrm{g} / \mathrm{ml}$.

The equilibrium distribution constants for $\mathrm{Sr}, \mathrm{U}$, and $\mathrm{Pu}$, determined experimentally, are $1.2 \times 10^{5}, 2 \times 10^{3}$, and $4.8 \times 10^{4} \mathrm{ml}$ of salt solution per gram of metal, respectively (Reference 4). For all four alternatives, the $k_{d}$ measured for $U$ is used to determine the quantity of MST needed, since using the lowest measured $k_{d}$ is conservative. Laboratory studies show that $\mathrm{Sr}-90$ equilibrium is reached within $24 \mathrm{hrs}$ under well mixed conditions. 
At the end of Phase II, Kinetic data did not exist for TRU contaminants. A reaction time of 24 hours, based on ${ }^{90} \mathrm{Sr}$ kinetics, is assumed for AST processing for all four alternatives in the material balances for Phase III.

\section{A.3.2 Process Bases for Direct Disposal as Grout, CST Ion Exchange, and Solvent Extraction Alternatives}

The MST treatment is described separately in Section 3.2.1 for the Small Tank TPB Precipitation (STTP) alternative, since it includes a separate precipitation step prior to filtration. For Direct Disposal as Grout (DDG), CST Ion Exchange (CST), and Solvent Extraction (SE) alternatives, an identical MST sorption and filtration process is assumed.

\section{$\underline{\text { MST Treatment }}$}

For these three alternatives, up to 100,000 gallons of salt solution containing suspended sludge solids is transferred at an average rate of $130 \mathrm{gpm}$ to the Alpha Sorption Tank (AST). The salt solution is diluted with process water, if necessary, and about 75 gallons of MST slurry is then added to the AST. The resulting slurry is mixed for 24 hours to assure adequate adsorption of ${ }^{90} \mathrm{Sr}$ and TRU contaminants. The slurry is then sampled, filtered and analyzed to confirm adequate alpha decontamination to be within Class A disposal limits ([TRU] $<18 \mathrm{nCi} / \mathrm{g}$ ). For the DDG alternative, the filtered sample is also analyzed for mercury to determine if mercury removal is necessary before processing into grout (NOTE: Clarified solution with $[\mathrm{Hg}]<260 \mathrm{mg} / \mathrm{L}$ does not require $\mathrm{Hg}$ removal). If blending during waste removal can reduce $[\mathrm{Hg}$ ] to less than $260 \mathrm{mg} / \mathrm{L}$, then mercury removal is not required for any alternative. Analysis is required to validate the feed to MST treatment with respect to mercury contamination.

\section{Filtering}

Using one of two cross-flow filter units, the slurry is then filtered at a rate of $50 \mathrm{gpm}$ to yield about 100,000 gallons of clarified salt solution for further processing. A heel of about 10,000 gallons of more concentrated slurry of residual insoluble solids remains in the AST at the end of filtration. The insoluble solids (Table A.3.2-1) from four consecutive batches are allowed to accumulate in the AST before further processing.

For the DDG alternative, clarified salt solution is transferred from one of the two filter units to the Mercury Removal Feed Tank (MRFT) for further processing. If prior analysis shows mercury removal is unnecessary, the clarified salt solution is simply transferred from the MRFT to the Salt Solution Hold Tank (SSHT), bypassing the Mercury Removal Columns.

For the CST and SE alternatives, clarified salt solution is transferred directly to the Clarified Salt Solution Tank to provide feed for the next process operation ${ }^{137} \mathrm{Cs}$ decontamination by either CST or SE). If mercury removal is necessary, for these two alternatives that process operation is completed after ${ }^{137} \mathrm{Cs}$ is removed from the salt solution. 


\section{$\underline{\text { Residual Solids Washing }}$}

After the MST and sludge solids from four salt solution batches have accumulated in the heel contained in the AST, the 10,000 gallon heel is transferred to the Sludge Solids Receipt Tank ( SSRT). The solids are then continuously washed by adding process water at $50 \mathrm{gpm}$ while simultaneously filtering to yield clarified wash water at the rate of 50 gpm. Washing continues until the sodium concentration is reduced to $<0.5 \mathrm{M}$ in the solution.

For the DDG alternative, clarified wash water is transferred at $50 \mathrm{gpm}$ from the filter unit to the MRFT and on to SSHT for processing into grout. After washing is complete, the 10,000 gallons of MST/sludge slurry in a $<0.5 \mathrm{M}$ sodium solution is sampled for analysis to establish the insoluble solids content and composition. The slurry is then transferred at 130 gpm to a tank located in the DWPF for incorporation into glass.

\section{Filter Unit Cleaning}

To maintain optimum filtration rates, the cross-flow filter units must be cleaned periodically. A filter cleaning operation is assumed to be required after processing 200,000 gallons of salt solution, corresponding to a cleaning operation after two $100,000-$ gallon batches of feed solution have been processed through the AST. For a filter cleaning cycle, these steps and volumes of solution or water are assumed:

(1) Two hundred gallons of about $1 \mathrm{M} \mathrm{NaOH}$ are prepared by adding 189 gallons of process water and 11 gallons of $50 \mathrm{wt} \%$ sodium hydroxide (s.g. $=1.525$ ) from the Caustic Storage Tank to the Cleaning Solution Dump Tank (CSDT).

(2) The $1 \mathrm{M} \mathrm{NaOH}$ solution is circulated through the filter unit while periodically backpulsing the filter unit to dislodge any accumulated solids.

(3) The $\mathrm{NaOH}$ solution in the filter unit and CSDT is transferred to the AST.

(4) To reduce the residual $\mathrm{NaOH}$ concentration remaining in the filter unit and CSDT, 200 gallons of process water is added to the CSDT and circulated through the filter unit while periodically back-pulsing the filter unit.

(5) The water rinse is transferred from the CSDT and filter unit to the AST.

(6) Two hundred gallons of about 2 wt $\%$ oxalic acid $(\mathrm{s.g.}=1.014)$ are prepared in the Oxalic Acid Feed Tank.

(7) The oxalic acid is transferred to the CSDT and circulated through the filter unit while periodically back-pulsing the filter unit.

(8) The oxalic acid is transferred from the filter unit and the CSDT to the AST, where it reacts with excess $\mathrm{NaOH}$ to produce sodium oxalate.

(9) Two hundred gallons of about $1 \mathrm{M} \mathrm{NaOH}$ is prepared by adding 189 gallons of process water and 11 gallons of $50 \mathrm{wt} \% \mathrm{NaOH}$ from the Caustic Storage Tank to the CSDT. 
(10) The $\mathrm{NaOH}$ solution in the CSDT is circulated through the filter unit to condition the filter. Circulation of the solution is stopped and the filter unit is left filled with the caustic solution until placed in service for processing either salt solution from the AST or wash water from the SSRT.

Table A.3.2-1

\begin{tabular}{|l|}
\hline Insoluble Species \\
\hline $\mathrm{Fe}(\mathrm{OH})_{3}$ \\
\hline $\mathrm{Al}(\mathrm{OH})_{3}$ \\
\hline $\mathrm{NaTi}_{2} \mathrm{O}_{5} \mathrm{H}$ \\
\hline $\left.\mathrm{NaTiSr}_{(\mathrm{OH}}\right)_{2}$ \\
\hline $\mathrm{NaTiNa}_{2} \mathrm{U}_{2} \mathrm{O}_{7}$ \\
\hline $\mathrm{Al}_{2} \mathrm{O}_{3}$ \\
\hline $\mathrm{B}_{2} \mathrm{O}_{3}$ \\
\hline $\mathrm{Cr}_{2} \mathrm{O}_{3}$ \\
\hline $\mathrm{CuO}$ \\
\hline $\mathrm{Fe} \mathrm{O}_{3}$ \\
\hline $\mathrm{HgO}$ \\
\hline $\mathrm{K}_{2} \mathrm{O}$ \\
\hline $\mathrm{NiO}$ \\
\hline $\mathrm{SiO}_{2}$ \\
\hline $\mathrm{TiO}_{2}$ \\
\hline $\mathrm{U}_{3} \mathrm{O}_{8}$ \\
\hline $\mathrm{ZrO}_{2}$ \\
\hline
\end{tabular}

\section{A.4 Cs Decontamination by Tetraphenylborate Precipitation}

\section{$\underline{\text { Solubilities }}$}

The salt solution is decontaminated by the addition of sodium tetraphenylborate (NaTPB). The tetraphenylborate (TPB) ion in solution then reacts with potassium, cesium and ammonium to form highly insoluble solids. The presence of high salt concentrations reduces the solubility for these species as well as the parent NaTPB.

The reaction stoichiometry for the tetraphenylborate reactions with $\mathrm{Cs}, \mathrm{K}, \mathrm{Na}$, and $\mathrm{NH}_{4}$ are shown below:

$$
\begin{aligned}
& \mathrm{Cs}^{+}+\mathrm{TPB}^{-} \stackrel{\mathrm{ksp}}{\rightleftharpoons} \mathrm{CsTPB} \\
& \mathrm{K}^{+}+\mathrm{TPB}^{-} \stackrel{\mathrm{ksp}}{\rightleftharpoons} \mathrm{KTPB} \\
& \mathrm{Na}^{+}+\mathrm{TPB}^{-} \stackrel{\mathrm{ksp}}{\rightleftharpoons} \mathrm{NaTPB} \\
& \mathrm{NH}_{4}{ }^{+}+\mathrm{TPB}^{-} \stackrel{\mathrm{ksp}}{\rightleftharpoons} \mathrm{NH}_{4} \mathrm{TPB} .
\end{aligned}
$$


The activity coefficients (Reference 1 ) were determined using commercially available software as:

$$
\begin{aligned}
& \gamma_{\mathrm{Cs}}=0.0258 \mathrm{I}_{\mathrm{m}}{ }^{2}-0.160 \mathrm{I}_{\mathrm{m}}+0.783 \\
& \gamma_{\mathrm{k}}=0.0284 \mathrm{I}_{\mathrm{m}}{ }^{2}-0.219 \mathrm{I}_{\mathrm{m}}+0.777 \\
& \gamma_{\mathrm{Na}}=0.0088 \mathrm{I}_{\mathrm{m}}{ }^{2}-0.0701 \mathrm{I}_{\mathrm{m}}+0.701 \\
& \gamma_{\mathrm{TPB}}=1.91 \mathrm{I}_{\mathrm{m}}{ }^{3}-4.54 \mathrm{I}_{\mathrm{m}}{ }^{2}+5.48 \mathrm{I}_{\mathrm{m}}+0.712
\end{aligned}
$$

where $\gamma$ is the activity coefficient and $I_{m}$ is the molar scale ionic strength of the solution:

$I_{m}=0.5\left\{\left(Z_{a}^{2} \times M_{a}\right)+\left(Z_{b}^{2} \times M_{b}\right)+\left(Z_{c}^{2} \times M_{c}\right)+\ldots\right\}$

Where $\mathrm{Z}$ is the ionic charge of the ions and $\mathrm{m}$ is the molar concentration (moles $/ 1000 \mathrm{~g}$ solvent).

Cesium or potassium concentrations in solution can then be determined by rearranging:

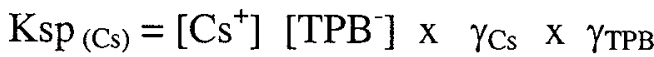

$$
\begin{aligned}
& \mathrm{Ksp}_{(\mathrm{k})}=\left[\mathrm{K}^{+}\right]\left[\mathrm{TPB}^{-}\right] \times \gamma_{\mathrm{k}} \times \gamma_{\mathrm{TPB}}
\end{aligned}
$$

Since the sodium ion concentration is so high, sources the TPB in solution is determined by rearranging:

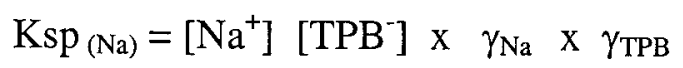

The activity of an ionic species is solved by:

$$
\mathrm{Ksp}=\left(\mathrm{a}_{\mathrm{m}+)}\left(\mathrm{a}_{\mathrm{x}-}\right)\right.
$$

where ' $a$ ' is the activity of the ionic species and

$$
\mathrm{a}_{\mathrm{m}}=\gamma_{\mathrm{m}}[\mathrm{M}]
$$

After Reference 3 was issued the solubility of TPB in high salt concentrations containing potassium was questioned. Subsequent laboratory tests (Reference 5) indicated that the mass action thermodynamic approach described above overpredicts the TPB solubility. The degree of overprediction is a function of salt concentration and the initial TPB/K ratio. Limited solubility data is provided in this reference for 4.0 to 4.5 molar salt solution over a range of TPB/K ratios. The TPB solubility was about $100 \mathrm{mg} / \mathrm{L}$ when a $33 \%$ stoichiometric molar excess was used in a 4.3 molar salt solution. These conditions are used as the bases for all precipitation alternatives. 


\section{$\underline{\text { Kinetics }}$}

Kinetic studies indicate that the equilibrium of TPB solubility is reached in the precipitation reactions within one hour (Reference 2) when $33 \%$ stoichiometric molar excess was used and mixing was good.

When precipitation is conducted in agitated tanks, the residence time is set to 12 hours.

When the excess TPB is depleted a re-precipitation should be made. The TPB concentration should be returned to that present right after the initial precipitation. The cycle time for this operation is based on the amount of addition, addition rate and analytical times for the specific facility.

\section{A.5 Radiolysis of Water and Salt Solutions}

The radiolysis of water forms hydrogen. The formation of hydrogen by radiolysis is expressed in terms of a $\mathrm{G}$ value. The $\mathrm{G}$ value is expressed as the number of molecules of hydrogen formed per $100 \mathrm{eV}$ of radiation energy.

The $G$ value for hydrogen in water is generally accepted as 0.46 molecules of hydrogen formed per $100 \mathrm{eV}$ of radiation energy.

The $G$ value for hydrogen in salt solutions can be calculated using the following equations (Reference 3 ):

$$
\begin{aligned}
& \mathrm{G}=0.4597-0.3803 *\left(\left[\mathrm{NO}_{3}^{-}\right]+0.5 *\left[\mathrm{NO}_{2}^{-}\right]\right)^{1 / 3} \\
& \text { when: }\left(\left[\mathrm{NO}_{3}{ }^{-}\right]+0.5 *\left[\mathrm{NO}_{2}{ }^{-}\right]\right)^{1 / 3} \leq 1 \\
& \text { and } \mathrm{G}=0.1199-0.0504 *\left(\left[\mathrm{NO}_{3}{ }^{-}\right]+0.5^{*}\left[\mathrm{NO}_{2}^{-}\right]\right)^{1 / 3} \\
& \text { when: } 1<\left(\left[\mathrm{NO}_{3}{ }^{-}\right]+0.5^{1 / 3}\left[\mathrm{NO}_{2}{ }^{-}\right]\right)^{1 / 3} \leq 2 .
\end{aligned}
$$

\section{A.6 Radiolysis of Tetraphenylborate}

Tetraphenylborate also decomposes radiolytically. The radiolytic decomposition stoichiometry can be modeled using the following reaction:

$$
1.25\left(\mathrm{C}_{6} \mathrm{H}_{5}\right)_{4} \mathrm{~B} \stackrel{\text { Radiolysis }}{\longrightarrow} 2 \mathrm{C}_{6} \mathrm{H}_{6}+\mathrm{C}_{6} \mathrm{H}_{5} \mathrm{OH}+\mathrm{C}_{12} \mathrm{H}_{10} \text { (biphenyl) }+\mathrm{B} \text {. }
$$

The measured product split for the radiolytic decomposition of TPB is $50 \%$ benzene, 25 $\%$ phenol, and $25 \%$ biphenyl (Reference 4 ). As can be seen this exact product split 
cannot be expressed stoichiometrically. The above equation approximates the experimental results.

The $G$ value for the formation of benzene from the radiolytic decomposition of TPB is $0.71 \pm 35 \%$ molecules of benzene formed per $100 \mathrm{eV}$ radiation dose to 10 weight percent slurry. A bounding value of 0.96 has been used in prior authorization bases for the ITP facility. This bounding value is applied for all precipitation cases.

The amount of benzene generation varies with the specific activity of the slurries. Given the energy from Cs decay as 4.84 watts $/ \mathrm{kCi}$, and the conversion factor of $1 \mathrm{eV} / \mathrm{sec}$ is $1.6 \mathrm{E}-19$ watts, the baseline benzene generation rate from radiolysis is:

$=\frac{0.96 \text { molecules }}{100 \mathrm{eV}} \frac{4.84 \text { watts }}{1000 \mathrm{Ci}} \frac{1 \mathrm{eV} / \mathrm{sec}}{1.6 \mathrm{E}-19 \text { watts }} \frac{25 \mathrm{Ci}}{\text { gal }} \frac{1 \mathrm{gal}}{3.8 \mathrm{~L}} \quad \frac{78,120 \mathrm{mg}}{6.02 \mathrm{E} 23 \text { molecules }} \quad \frac{3600 \mathrm{sec}}{\mathrm{hr}}$

$=0.9 \mathrm{mg} / \mathrm{L}-\mathrm{hr}$

\section{A.7 Benzene Generation from Chemical Decomposition of Tetraphenylborate}

\section{Benzene Generation and TPB Decomposition}

Laboratory studies have indicated that tetraphenylborate decomposes in a series of reactions given below:

$\left(\mathrm{C}_{6} \mathrm{H}_{5}\right)_{3} \mathrm{~B}\left(\mathrm{C}_{6} \mathrm{H}_{5}\right)^{-}+\mathrm{H}_{2} \mathrm{O} \rightarrow\left(\mathrm{C}_{6} \mathrm{H}_{5}\right)_{3} \mathrm{~B}+\mathrm{C}_{6} \mathrm{H}_{6}+\mathrm{OH}^{-}$

$\left(\mathrm{C}_{6} \mathrm{H}_{5}\right)_{3} \mathrm{~B}+\mathrm{OH}^{-}+\mathrm{H}_{2} \mathrm{O} \rightarrow\left(\mathrm{C}_{6} \mathrm{H}_{5}\right)_{2} \mathrm{~B}(\mathrm{OH})_{2}^{-}+\mathrm{C}_{6} \mathrm{H}_{6}$

$\left(\mathrm{C}_{6} \mathrm{H}_{5}\right)_{2} \mathrm{~B}(\mathrm{OH})_{2}{ }^{-}+\mathrm{H}_{2} \mathrm{O} \rightarrow\left(\mathrm{C}_{6} \mathrm{H}_{5}\right) \mathrm{B}(\mathrm{OH})_{3}{ }^{-}+\mathrm{C}_{6} \mathrm{H}_{6}$

$\left(\mathrm{C}_{6} \mathrm{H}_{5}\right) \mathrm{B}(\mathrm{OH})_{3}{ }^{-}+\mathrm{H}_{2} \mathrm{O} \rightarrow \mathrm{B}(\mathrm{OH})_{4}{ }^{-}+\mathrm{C}_{6} \mathrm{H}_{6}$

Each mole of TPB or intermediate produces one mole of benzene. Other reaction paths also exist depending upon the presence or absence of oxygen and resulting in the production of phenol instead of benzene. This study assumes $100 \%$ production of benzene.

The classic kinetic model expected takes the following form:

$\underline{\mathrm{d}[4 \mathrm{~PB}]}=-\mathrm{k}_{1}[4 \mathrm{~PB}]-$ Radiolysis

$\mathrm{dt}$

$\underline{\mathrm{d}}[3 \mathrm{~PB}]=\mathrm{k}_{1}[4 \mathrm{~PB}]-\mathrm{k}_{2}[3 \mathrm{~PB}]$

$\mathrm{dt}$ 


$$
\begin{aligned}
& \frac{\mathrm{d}[2 \mathrm{~PB}]}{\mathrm{dt}}=\mathrm{k}_{2}[3 \mathrm{~PB}]-\mathrm{k}_{3}[2 \mathrm{~PB}] \\
& \frac{\mathrm{d}[1 \mathrm{~PB}]}{\mathrm{dt}}=\mathrm{k}_{3}[2 \mathrm{~PB}]-\mathrm{k}_{4}[1 \mathrm{~PB}]
\end{aligned}
$$

Where:

[4PB], [3PB], [2PB], [1PB] are the molar concentrations of $\left(\mathrm{C}_{6} \mathrm{H}_{5}\right)_{3} \mathrm{~B}\left(\mathrm{C}_{6} \mathrm{H}_{5}\right)$, $\left(\mathrm{C}_{6} \mathrm{H}_{5}\right)_{3} \mathrm{~B},\left(\mathrm{C}_{6} \mathrm{H}_{5}\right)_{2} \mathrm{~B}(\mathrm{OH})_{2}{ }^{-}$and $\left(\mathrm{C}_{6} \mathrm{H}_{5}\right) \mathrm{B}(\mathrm{OH})_{3}$ respectively.

Radiolysis is the loss of TPB associated with the radiolytic destruction of KTPB solids

$\mathrm{k}_{1}, \mathrm{k}_{2}, \mathrm{k}_{3}$, and $\mathrm{k}_{4}$ are the sequential rate constants for each of the decomposition reactions.

These rate constants have been determined to be a function of catalyst type, ionic strength, temperature and potentially other factors.

\section{Decomposition when KTPB is Present}

For this study, the overall benzene generation rate was varied in order to distinguish between the various precipitation alternatives. In order to meet this objective the TPB decomposition rate equation was set to zero order (constant decomposition rate). The rate constant $\left(\mathrm{k}_{1}\right)$ is then defined as the desired rate $/ 4$ expressed as mMoles/L-hr. For example, the basecase assumes an overall benzene generation rate of $7 \mathrm{mg} / \mathrm{L}-\mathrm{hr}$ of this tetraphenylborate decomposition is responsible for $1 / 4$ of the total benzene production and converting to mmoles yields $0.0224 \mathrm{mMoles} / \mathrm{L}-\mathrm{hr}$.

Since the decomposition of TPB has been set, the formation of 3PB is also set at $\mathrm{k}_{1}$ (0.0224 mMoles/L-hr, in the basecase). A material balance around 3PB results in the following equation for the rate of change of $3 \mathrm{~PB}$ :

$$
\mathrm{d}[3 \mathrm{~PB}] / \mathrm{dt}=\mathrm{k}_{1}-\mathrm{k}_{2 \mathrm{Pd}} *[3 \mathrm{~PB}]-\mathrm{k}_{2 \mathrm{Cu}} *[3 \mathrm{~PB}]
$$

where the rate constants are based on laboratory studies and provided by the following (Reference 5):

$$
\begin{aligned}
& \mathrm{k}_{2 \mathrm{Pd}}=1224 *[\mathrm{Na}]^{4.59} *[\mathrm{Pd}]^{0.905} * \mathrm{e}^{-5985.42 / \mathrm{T}} \\
& \mathrm{k}_{2 \mathrm{Cu}}=3.1 \times 10^{7} *[\mathrm{Cu}]^{0.36} *[\mathrm{OH}]^{-0.72} * \mathrm{e}^{-7867.23 / \mathrm{T}} \\
& \mathrm{T}=\text { temperature },{ }^{\circ} \mathrm{K}
\end{aligned}
$$


A material balance around $2 \mathrm{~PB}$ results in the following expression for the rate of change of 2PB:

$$
\mathrm{d}[2 \mathrm{~PB}] / \mathrm{dt}=\mathrm{k}_{2 \mathrm{Pd}} *[3 \mathrm{~PB}]+\mathrm{k}_{2 \mathrm{Cu}} *[3 \mathrm{~PB}]-\mathrm{k}_{3} *[2 \mathrm{~PB}]
$$

where the rate constants are based on laboratory studies and provided by the following (Reference 9):

$$
\mathrm{k}_{3}=6.17 \times 10^{8} *[\mathrm{OH}]^{0.28} *[\mathrm{Cu}]^{0.3} * \mathrm{e}^{-7923.7 / \mathrm{T}} .
$$

A material balance around $1 \mathrm{~PB}$ results in the following expression for the rate of change of 1PB:

$$
\mathrm{d}[1 \mathrm{~PB}] / \mathrm{dt}=\mathrm{k}_{3} *[2 \mathrm{~PB}]-\mathrm{k}_{4} *[1 \mathrm{~PB}]
$$

where the rate constants are based on laboratory studies and provided by the following (Reference 9):

$$
\mathrm{k}_{4}=5.09 \times 10^{10} *[\mathrm{OH}]^{0.26} *[\mathrm{Cu}]^{0.8} * \mathrm{e}^{-9087.6 / \mathrm{T}} .
$$

\section{Decomposition in Filtrate}

The decomposition rates for TPB and 3PB are much slower in filtrate systems which do not contain KTPB and sludge solids. For these systems the catalytic decomposition rate is set to the copper only catalyzed rates. This is justified since the copper catalyst is soluble and will pass through the filter to promote decomposition. For these systems a material balance 4PB becomes

$$
\frac{\mathrm{d}[4 \mathrm{~PB}]}{\mathrm{dt}}=-\mathrm{k}_{1}[4 \mathrm{~PB}][\mathrm{Cu}]-\text { Radiolysis }
$$

where the rate constants are based on laboratory studies and provided by the following (Reference 6):

$$
\begin{aligned}
& \ln \left(\mathrm{K}_{1}\right)=35.4-1.10 \mathrm{E} 4 / \mathrm{T} \\
& \mathrm{T}=\text { temperature, }{ }^{\circ} \mathrm{K}
\end{aligned}
$$

The rate constant for the remaining species are the same as the copper catalyzed reactions noted above:

$$
\begin{aligned}
& \mathrm{k}_{2}=\mathrm{k}_{2 \mathrm{Cu}} \\
& \mathrm{k}_{2 \mathrm{Cu}}=3.1 \times 10^{7} *[\mathrm{Cu}]^{0.36} *[\mathrm{OH}]^{-0.72} * \mathrm{e}^{-7867.23 / \mathrm{T}} \\
& \mathrm{k}_{3}=6.17 \times 10^{8} *[\mathrm{OH}]^{0.28} *[\mathrm{Cu}]^{0.3} * \mathrm{e}^{-7923.7 / \mathrm{T}} \\
& \mathrm{k}_{4}=5.09 \times 10^{10} *[\mathrm{OH}]^{0.26} *[\mathrm{Cu}]^{0.8} * \mathrm{e}^{-9087.6 / \mathrm{T}}
\end{aligned}
$$




\section{A.8 Benzene Depletion in the Small Tank Facility}

In the small tank facility, all of the tanks are well agitated. Under these conditions, the release rate of benzene is equal to the generation rate. A small nitrogen purge maintaining the tanks at positive pressure will remove generated benzene to the Process Vessel Vent System.

\section{A.9 Filtration of Tetraphenylborate Slurries}

The ITP process and the LWF use Mott ${ }^{\mathrm{tm}}$ cross-flow filters with a 0.2 micron pore size to filter the slurries prepared in the referenced processes. The ITP facility contains two filters, and the LWF contains one. The performance of these filters has been previously modeled with the filter flux represented by the following equation (Reference 7):

$$
\mathrm{F}=5325 * \mathrm{~N} *\{10 * \mathrm{Y} 2-\mathrm{Y} 1+[\mathrm{Y} 1-\mathrm{Y} 2] * \mathrm{~W}\}
$$

Where :

$$
\begin{aligned}
& \mathrm{F}=\text { Filtrate flow rate, } \mathrm{L} / \mathrm{hr} \\
& \mathrm{N}=\text { Number of filters in operation } \\
& \mathrm{Y} 1=\text { Filtration rate for } 10 \mathrm{Wt} \% \text { slurry, } 0.03317 \\
& \mathrm{Y} 2=\text { Filtration rate for } 1 \mathrm{Wt} \% \text { slurry, } 0.3317 \\
& \mathrm{~W}=\text { Current percent solids }
\end{aligned}
$$

The filtrate flow rate is dependent on the pressure drop across the filter. The equations are based on data from laboratory filter testing and actual in-plant testing at ITP prior to ITP startup (Reference 8). The filter is assumed to be $100 \%$ efficient for retention of insoluble species contained in the slurry. This would include any TPB solids, sludge, and MST. The efficiency of the filter is maintained by a backpulse system. The amount of water added to the ITP system by the backpulse system is negligible and does not require modeling at this time. For the purposes of the base case and those options that use the ITP or LWF filters, accumulated solids are returned to the feed tank in the filter return to the feed tank: Tank 48 for ITP and the Precipitate Reactor Tank at the LWF.

\section{A.10 Saltstone Product Bases}

Saltstone is a solid waste form that is the product of chemical reactions between a salt solution and a blend of cementitious materials (slag, flyash, and a lime source). An acceptable saltstone product can be produced over a broad range of these four components. The chemical composition of the dry materials used in the production of saltstone are shown in Table A.10-1 (Reference 9). The demonstrated range of acceptability for each component with respect to physical properties and resistance to contaminant leaching is shown in Table A.10-2 (Reference 10). As presently formulated, saltstone is comprised of about $47 \mathrm{wt} \%$ salt solution, $25 \mathrm{wt} \%$ of Grade 120 slag (ASTM C989-82), $25 \mathrm{wt} \%$ of Class F fly ash (ASTM C618-85) and $3 \mathrm{wt} \%$ of type II cement (ASTM C150-85A). Calcium hydroxide can be used as a substitute for the cement to 
function as a lime source in the dry blend. The dry materials are blended to form a premix of dry solids which is then combined with salt solution to produce a grout.

Saltstone grout is formulated to minimize bleed water from the grout during curing. An acceptable saltstone product, from the standpoint of physical properties, has been demonstrated with salt solution ranging from about 20 wt $\%$ to 32 wt $\%$ salt, corresponding to a specific gravity ranging from about 1.18 to 1.32 with a sodium molarity of ranging from about $4 \mathrm{M}$ to $6 \mathrm{M}$. Bleed water is controlled by controlling the water-to-premix mass ratio in the range of 0.52 to 0.60 (presently set at 0.57 ). The density of cured saltstone ranges between 1.70 and $1.80 \mathrm{~kg} / \mathrm{L}$ (References 11 and 12).

Table A.10-1. Composition of Saltstone Cementitious Materials

\begin{tabular}{|c|c|c|c|}
\hline Component & $\begin{array}{l}\text { Cement Type II } \\
\text { Santee }(\mathrm{Wt} \%)\end{array}$ & $\begin{array}{c}\text { Slag Grade } 120 \\
\text { NEWCEM }^{a} \\
\text { (Wt\%) }\end{array}$ & $\begin{array}{l}\text { Fly Ash Class F } \\
\text { Low CaO } \\
\left(\mathrm{Wt}_{\mathrm{t}} \%\right)\end{array}$ \\
\hline $\mathrm{SiO}_{2}$ & 21.10 & 34.70 & 52.17 \\
\hline $\mathrm{Al}_{2} \mathrm{O}_{3}$ & 4.66 & 10.70 & 27.60 \\
\hline $\mathrm{TiO}_{2}$ & 0.23 & 0.51 & 1.98 \\
\hline $\mathrm{Fe}_{2} \mathrm{O}_{3}$ & 4.23 & 0.41 & 4.36 \\
\hline $\mathrm{MgO}$ & 1.21 & 11.90 & 0.61 \\
\hline $\mathrm{CaO}$ & 64.55 & 39.37 & 0.96 \\
\hline $\mathrm{MnO}$ & 0.016 & 0.539 & 0.014 \\
\hline $\mathrm{BaO}$ & 0.02 & 0.05 & 0.10 \\
\hline $\mathrm{Na}_{2} \mathrm{O}$ & 0.11 & 0.25 & 0.26 \\
\hline $\mathrm{K}_{2} \mathrm{O}$ & 0.34 & 0.55 & 1.53 \\
\hline $\mathrm{P}_{2} \mathrm{O}_{5}$ & 0.31 & $<0.05$ & 0.12 \\
\hline $\mathrm{SO}_{3}$ & 2.25 & & 0.33 \\
\hline $\mathrm{SrO}$ & & & 0.04 \\
\hline LOI $\left(900^{\circ} \mathrm{C}\right)$ & 1.35 & $1.34^{b}$ & 9.92 \\
\hline Totals & 100.40 & 100.36 & 100.00 \\
\hline
\end{tabular}

a Also referred to as Atlantic

$b$ The loss-on-ignition (LOI) values for slag is negative indicating the existence of sulfur as free sulfur or metal sulfides (i.e., FeS) rather than $\mathrm{SO}_{3}$ (i.e., samples gained weight on heating). 
Table A.10-2. Demonstrated Range of Acceptability

\begin{tabular}{l|c|c}
\hline \multicolumn{1}{|c|}{ Saltstone Component } & $\begin{array}{c}\text { Nominal Blend } \\
(\mathbf{W t} \%)\end{array}$ & $\begin{array}{c}\text { Range } \\
\text { (Wt \%) }\end{array}$ \\
\hline Lime Source $^{a}$ & 3 & 0 to 10 \\
\hline Fly Ash & 25 & 10 to 40 \\
\hline Slag & 25 & 10 to 40 \\
\hline Salt Solution & 47 & 40 to 55 \\
\hline
\end{tabular}

${ }^{a}$ Either Portland Class II cement or $\mathrm{Ca}(\mathrm{OH})_{2}$.

\section{A.11 DWPF Salt Processing Cell Bases}

The bases for the SPC operating cycle times and parameters were developed experimentally (Reference 13) and are documented (Reference 14). The chemical additions and cycle times are based on hydrolyzing sodium tetraphenyl borate completely (removing all four phenyl groups to produce four benzene molecules) and to reduce the level of organic (principally phenylboric acid) to $<53 \mathrm{ppm}$ in the aqueous product (PHA). Further, the mercury level is to be reduced to $<260 \mathrm{ppm}$ as diphenylmercury.

$\underline{\text { Reactants }}$

$$
\begin{aligned}
& \mathrm{CsB}\left(\mathrm{C}_{6} \mathrm{H}_{5}\right)_{4}+\mathrm{HCOOH} \\
& \mathrm{KB}\left(\mathrm{C}_{6} \mathrm{H}_{5}\right)_{4}+\mathrm{HCOOH} \\
& \mathrm{NaB}\left(\mathrm{C}_{6} \mathrm{H}_{5}\right)_{4}+\mathrm{HCOOH} \\
& \mathrm{NH}_{4} \mathrm{~B}\left(\mathrm{C}_{6} \mathrm{H}_{5}\right)_{4}+\mathrm{HCOOH} \\
& \left.\mathrm{HB} \mathrm{C}_{6} \mathrm{H}_{5}\right)_{4}+2 \mathrm{H}_{2} \mathrm{O} \\
& \mathrm{HB}\left(\mathrm{C}_{6} \mathrm{H}_{5}\right)_{4}+\mathrm{H}_{2} \mathrm{O}+\mathrm{NaNO}_{3} \\
& \mathrm{HB}\left(\mathrm{C}_{6} \mathrm{H}_{5}\right)_{4}+3 \mathrm{H}_{2} \mathrm{O} \\
& \mathrm{HB}\left(\mathrm{C}_{6} \mathrm{H}_{5}\right)_{4}+2 \mathrm{H}_{2} \mathrm{O}+2 \mathrm{NaNO}_{3} \\
& 3 \mathrm{C}_{6} \mathrm{H}_{5} \mathrm{~B}(\mathrm{OH})_{2} \\
& \mathrm{Hg}\left(\mathrm{C}_{6} \mathrm{H}_{5}\right)_{2}+\mathrm{HCOOH}
\end{aligned}
$$

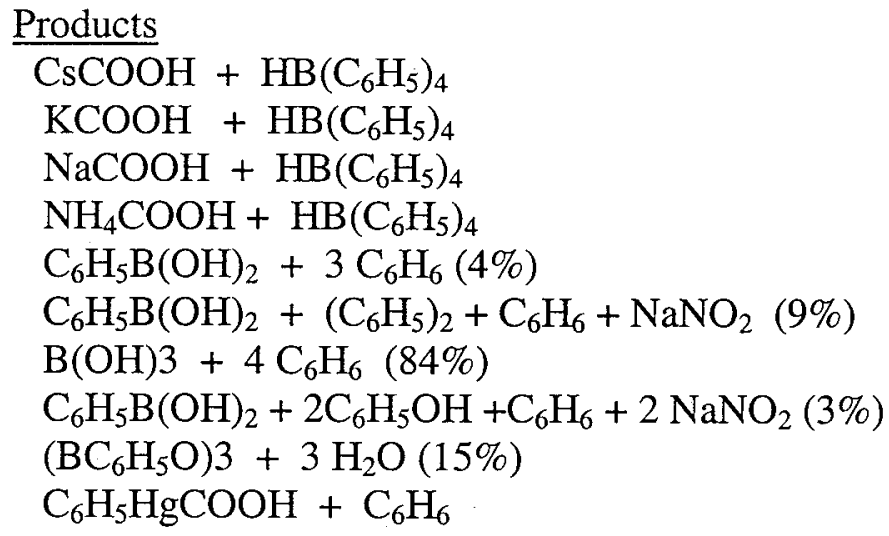


The bases for the DWPF parameters are:

Target acid (after neutralizing base equivalents of carbonate, hydroxide, TPBand nitrite) $-0.25 \mathrm{M}$ in PHA

Copper II catalyst target - 950 ppm in PHA

PR Temperature during feeding $-90^{\circ} \mathrm{C}$

Post Feed Reaction Period at $90^{\circ} \mathrm{C}-5$ hours

Aqueous Boil Period $\geq 5$ hours

Total Aqueous Boiled Volume - > 10,000 gallons

Modeling Bases - The simplified reaction scheme shown below was used to model the hydrolysis reactions in the salt cell. Benzene is the only organic species tracked in the model.

$\underline{\text { Reactants }} \quad \underline{\text { Products }}$

$\mathrm{CsB}\left(\mathrm{C}_{6} \mathrm{H}_{5}\right)_{4}+\mathrm{HCOOH}+3 \mathrm{H}_{2} \mathrm{O} \quad \mathrm{CsCOOH}+\mathrm{B}(\mathrm{OH})_{3}+4 \mathrm{C}_{6} \mathrm{H}_{6}$

$\mathrm{KB}\left(\mathrm{C}_{6} \mathrm{H}_{5}\right)_{4}+\mathrm{HCOOH}+3 \mathrm{H}_{2} \mathrm{O} \quad \mathrm{KCOOH}+\mathrm{B}(\mathrm{OH})_{3}+4 \mathrm{C}_{6} \mathrm{H}_{6}$

$\mathrm{NaB}\left(\mathrm{C}_{6} \mathrm{H}_{5}\right)_{4}+\mathrm{HCOOH}+3 \mathrm{H}_{2} \mathrm{O} \quad \mathrm{NaCOOH}+\mathrm{B}(\mathrm{OH})_{3}+4 \mathrm{C}_{6} \mathrm{H}_{6}$

$\mathrm{NH}_{4} \mathrm{~B}\left(\mathrm{C}_{6} \mathrm{H}_{5}\right)_{4}+\mathrm{HCOOH}+3 \mathrm{H}_{2} \mathrm{O} \quad \mathrm{NH}_{4} \mathrm{COOH}+\mathrm{B}(\mathrm{OH})_{3}+4 \mathrm{C}_{6} \mathrm{H}_{6}$

Fixed volumes of formic acid and copper catalyst were added to each PR batch:

167 gallons of $90 \mathrm{wt} \%$ formic acid and

255 gallons of $5 \mathrm{wt} \%$ copper nitrate.

Time delays were used in the model to match the nominal salt cell operating time. Two salt cell batches were run for every chemical cell batch processed. The OE was not modeled since benzene separation was essentially complete in the PR boiling. Temperature is not tracked, since energy balances are not performed. 


\section{A.12 DWPF Chemical Cell Bases}

\section{A.12.1 Bases for HNO3 / HCOOH addition and F-N basis}

Technical Bases - Acid adjustment in the SRAT is partially completed by adding nitric acid to yield an acid $\mathrm{pH}$. The aqueous product from the acid hydrolysis, which contains an excess of $\mathrm{HCOOH}$, is then fed to the SRAT. Feeding of some formic acid would be required for any of the alternatives, since the $\mathrm{HCOOH}$ is added to reduce mercury(II) compounds to mercury $(0)$. The mercury is then steam-stripped from the sludge slurry to minimize the quantity sent to the melter. Only those reactions that involve a species in the salt solution are included, since reactions of sludge components are not generally affected by the various alternatives.

\begin{tabular}{|c|c|}
\hline Reactants & Products \\
\hline $\mathrm{NaOH}+\mathrm{HNO}_{3}$ & $\mathrm{NaNO}_{3}+\mathrm{H}_{2} \mathrm{O}$ \\
\hline $\mathrm{NH}_{4} \mathrm{OH}+\mathrm{HNO}_{3}$ & $\mathrm{NH}_{4} \mathrm{NO}_{3}+\mathrm{H}_{2} \mathrm{O}$ \\
\hline $\mathrm{NaAlO}_{2}+4 \mathrm{HNO}_{3}$ & $\mathrm{Al}\left(\mathrm{NO}_{3}\right)_{3}+\mathrm{NaNO}_{3}+2 \mathrm{H}_{2} \mathrm{O}$ \\
\hline $\mathrm{CsOH}+\mathrm{HNO}_{3}$ & $\mathrm{CsNO}_{3}+\mathrm{H}_{2} \mathrm{O}$ \\
\hline $\mathrm{Na}_{2} \mathrm{U}_{2} \mathrm{O}_{7}+6 \mathrm{HNO}_{3}$ & $2 \mathrm{UO}_{2}\left(\mathrm{NO}_{3}\right)_{2}+2 \mathrm{NaNO}_{3}+3 \mathrm{H}_{2} \mathrm{O}$ \\
\hline $\mathrm{SrCO}_{3}+2 \mathrm{HNO}_{3}$ & $\mathrm{Sr}\left(\mathrm{NO}_{3}\right)_{2}+\mathrm{H}_{2} \mathrm{O}+\mathrm{CO}_{2}$ \\
\hline $\mathrm{CoO}+2 \mathrm{HNO}_{3}$ & $\mathrm{Co}\left(\mathrm{NO}_{3}\right)_{2}+\mathrm{H}_{2} \mathrm{O}(70 \%)$ \\
\hline $\mathrm{HgO}+\mathrm{HCOOH}$ & $\mathrm{Hg}+\mathrm{H}_{2} \mathrm{O}+\mathrm{CO}_{2}(99 \%)$ \\
\hline $2 \mathrm{Ag}_{2} \mathrm{O}+2 \mathrm{HCOOH}$ & $2 \mathrm{Ag}+\mathrm{H}_{2} \mathrm{O}+\mathrm{CO}_{2}(99 \%)$ \\
\hline $\mathrm{PdO}+\mathrm{HCOOH}$ & $\mathrm{Pd}+\mathrm{H}_{2} \mathrm{O}+\mathrm{CO}_{2}(99 \%)$ \\
\hline $\mathrm{RhO}_{2}+2 \mathrm{HCOOH}$ & $\mathrm{Rh}+2 \mathrm{H}_{2} \mathrm{O}+2 \mathrm{CO}_{2}(99 \%)$ \\
\hline
\end{tabular}

The method for calculating acid addition and the balance between formate ion and nitrate ion are based on laboratory work (Reference 15) and DWPF cold runs and operating experience.

1. Calculate the total acid required to neutralize or react with materials in the feed. One mole acid is needed for each mole of $\mathrm{HgO}, \mathrm{NaOH}$, and $\mathrm{KOH}$. Two moles acid are needed for $\mathrm{Ca}(\mathrm{OH}) 2, \mathrm{Ba}(\mathrm{OH}) 2, \mathrm{Mg}(\mathrm{OH}) 2$ and carbonate $(\mathrm{CO} 3)--$. One quarter mole is needed for each mole of nitrite (NO2-) and 0.4 moles are needed for each mole of $\mathrm{MnO} 2$.

2. Multiply this "stoichiometric" amount by 1.25 . This is the total amount of acid to be added.

3. Assume that $40 \%$ of the formic acid is lost in the SRAT cycle. Based on this, calculate how much formic acid is required such that the [formate]-[nitrate] (" $\mathrm{F}$ minus N") will be $0.4 \mathrm{M}$ in the SME - normalized to $45 \mathrm{wt} \%$ solids in the SME. Assume that 100 gallons $90 \%$ formic acid will be added to the SME to provide part to the formate needed. 
Modeling Bases - Acid addition to the SRAT and SME use fixed volumes representative of plant operating practice. For each SRAT batch are added:

200 gallons of $50 \mathrm{wt} \%$ nitric acid

150 gallons of $90 \mathrm{wt} \%$ formic acid

If some nitric acid enters the SRAT through the salt feed stream (as was the case in some of the alternative salt processing schemes) the 200 gallon volume is reduced by the amount in the input stream.

In each SME batch 100 gallons of $90 \mathrm{wt} \%$ formic acid are added. The F-N redox value is calculated in the SME using the equation:

$$
\mathrm{F}-\mathrm{N}=0.227 * \text { (liquid density) } *(0.646 *[\text { Formate }]-1.403 *[\text { Nitrate }])
$$

Some formic acid will be removed in the SRAT cycle during the evaporation. The amount of acid lost is calculated by an ideal solution estimate of the vapor composition and may not be the nominal $40 \%$.

Mercury is removed from the solution in the SRAT and collected as a side stream. The mercury is tracked as $\mathrm{HgO}$ throughout the process.bb

\section{Bases for $\mathrm{NaOH}$ and $\mathrm{NaNO} 2$ to RCT}

\section{$\underline{\text { Technical Bases }}$}

\section{$\underline{\text { Reactants }}$ \\ $\mathrm{HCOOH}+4 \mathrm{NaOH}$ \\ $\mathrm{Pu}(\mathrm{COOH}) 4+4 \mathrm{NaOH}$ \\ $\mathrm{UO}_{2}(\mathrm{COOH})_{2}+2 \mathrm{NaOH}$ \\ $\mathrm{HCl}+\mathrm{NaOH}$ \\ $\mathrm{HF}+\mathrm{NaOH}$ \\ $\mathrm{HgCl}_{2}+2 \mathrm{NaOH}$ \\ $\mathrm{Hg}_{2} \mathrm{Cl}_{2}+2 \mathrm{NaOH}$ \\ $\mathrm{Hg}_{2} \mathrm{I}_{2}+2 \mathrm{NaOH}$ \\ $\mathrm{KCOOH}+\mathrm{NaNO} 3$ \\ $\mathrm{NH} 4 \mathrm{COOH}+\mathrm{NaNO} 3$ \\ $\mathrm{CsCOOH}+\mathrm{NaNO} 3$ \\ $\mathrm{CsCl}+\mathrm{NaNO} 3$ \\ $\mathrm{Cs}_{2} \mathrm{O}+2 \mathrm{NaNO} 3+\mathrm{H}_{2} \mathrm{O}$}

\author{
Products \\ $\mathrm{NaCOOH}+\mathrm{H}_{2} \mathrm{O}$ \\ $\mathrm{PuO}_{2}+4 \mathrm{NaCOOH}+2 \mathrm{H}_{2} \mathrm{O}$ \\ $\mathrm{UO}_{2}(\mathrm{OH})_{2}+2 \mathrm{NaCOOH}$ \\ $\mathrm{NaCl}+\mathrm{H}_{2} \mathrm{O}$ \\ $\mathrm{NaF}+\mathrm{H}_{2} \mathrm{O}$ \\ $\mathrm{HgO}+2 \mathrm{NaCl}$ \\ $\mathrm{Hg}+\mathrm{HgO}+2 \mathrm{NaCl}+\mathrm{H}_{2} \mathrm{O}$ \\ $\mathrm{Hg}+\mathrm{HgO}+2 \mathrm{NaI}+\mathrm{H}_{2} \mathrm{O}$ \\ $\mathrm{KNO} 3+\mathrm{NaCOOH}$ \\ $\mathrm{NH} 4 \mathrm{NO} 3+\mathrm{NaCOOH}$ \\ $\mathrm{CsNO} 3+\mathrm{NaCOOH}$ \\ $\mathrm{CsNO} 3+\mathrm{NaCl}$ \\ $\mathrm{CsNO} 3+\mathrm{NaOH}$
}

The quantities of caustic and nitrite added to the RCT are based on the Waste Acceptance Specification and operating experience. This is to assure that the inhibitors required to prevent corrosion of the carbon steel waste tanks are present. 
Modeling Bases - Caustic and inhibitor are added to the RCT to produce a recycle solution that is

$$
0.5 \mathrm{M} \mathrm{NaOH} \text { and } 0.045 \mathrm{M} \mathrm{NaNO}_{2}
$$

Water evaporated in the SRAT, SME and melter goes directly to the RCT in the simplified Speedup model.

\section{Bases for NOx Produced in the Melter}

Technical Bases - In the melter, $50 \%$ of the nitrate salts and all of the nitrite salts react with sodium formate to form nitric oxide (NO). The balance of the nitrate salts react to form nitrogen $\left(\mathrm{N}_{2}\right)$. Subsequently, the NO reacts with oxygen in the air to form nitrogen dioxide $\left(\mathrm{NO}_{2}\right)$.

Reactants

$4 \mathrm{NaNO}_{3}+8 \mathrm{NaCOOH}$

$4 \mathrm{NaNO}_{2}+2 \mathrm{NaCOOH}$

$4 \mathrm{Al}\left(\mathrm{NO}_{3}\right)_{3}+24 \mathrm{NaCOOH}$

$12 \mathrm{H}_{2} \mathrm{O}$
Products

$6 \mathrm{Na}_{2} \mathrm{O}+2 \mathrm{NO}+\mathrm{N}_{2}+8 \mathrm{CO}_{2}+4 \mathrm{H}_{2} \mathrm{O}$

$3 \mathrm{Na}_{2} \mathrm{O}+4 \mathrm{NO}+2 \mathrm{CO}_{2}+\mathrm{H}_{2} \mathrm{O}(100 \%)$

$2 \mathrm{Al}_{2} \mathrm{O}_{3}+12 \mathrm{Na}_{2} \mathrm{O}+6 \mathrm{NO}+3 \mathrm{~N}_{2}+24 \mathrm{CO}_{2}+$

Modeling Bases - The reactions shown below as the Modeling Bases for Vitrification, closely approximate the $\mathrm{NO}_{2}$ emission. Since complete oxidation is assumed, carbon monoxide and hydrogen in the melter off-gas are not accounted for. 


\section{Bases for Vitrification in the Melter}

\section{$\underline{\text { Technical Bases }}$}

In addition to reactions with nitrate and nitrite salts, formate salts either react with other oxidizing species in the melter feed or thermally decompose to generate carbon monoxide, carbon dioxide, hydrogen, water and oxides of metal ion species. Oxalate salts and other compounds that are thermally unstable at melter temperature also decompose (e.g., $\mathrm{CaC}_{2} \mathrm{O}_{4}, \mathrm{HgO}$ ).

Reactants

$4 \mathrm{Al}\left(\mathrm{NO}_{3}\right)_{3}+18 \mathrm{NaCOOH}$

$2 \mathrm{Na}_{2} \mathrm{SO}_{4}+2 \mathrm{NaCOOH}$

$4 \mathrm{Fe}_{2} \mathrm{O}_{3}+2 \mathrm{NaCOOH}$

$2 \mathrm{NaCOOH}$

$2 \mathrm{KCOOH}$

$4 \mathrm{NH}_{4} \mathrm{COOH}+3 \mathrm{O}_{2}$

$\mathrm{Mn}(\mathrm{COOH})_{2}$

$\mathrm{Ni}(\mathrm{COOH})_{2}$

$\mathrm{Ca}(\mathrm{COOH})_{2}$

$\mathrm{UO}_{2}(\mathrm{COOH})_{2}+\mathrm{O}_{2}$

$\mathrm{Cu}(\mathrm{COOH})_{2}$

$\mathrm{Co}(\mathrm{COOH})_{2}$

$\mathrm{Zn}(\mathrm{COOH})_{2}$

$\mathrm{Mg}(\mathrm{COOH})_{2}$

$\mathrm{Sr}(\mathrm{COOH})_{2}$

$2 \mathrm{CsCOOH}$

$\mathrm{Na}_{2} \mathrm{C}_{2} \mathrm{O}_{4}$

$\mathrm{CaC}_{2} \mathrm{O}_{4}$

$\mathrm{CaF}_{2}+\mathrm{Na}_{2} \mathrm{O}$

$\mathrm{Sr}(\mathrm{OH})_{2}$

$\mathrm{HgO}$

$\mathrm{Hg}$

$\mathrm{Cs}_{2} \mathrm{O}$

$2 \mathrm{MnO}_{2}$

$\mathrm{Pd}\left(\mathrm{NO}_{3}\right)_{2}$

$2 \mathrm{PuO}_{2}\left(\mathrm{NaTi}_{2} \mathrm{O}_{5}\right)_{2}$

$\mathrm{Sr}\left(\mathrm{NaTi}_{2} \mathrm{O}_{5}\right)_{2}$

$2 \mathrm{H}\left(\mathrm{NaTi}_{2} \mathrm{O}_{5}\right)$
Products

$$
\begin{aligned}
& 2 \mathrm{Al}_{2} \mathrm{O}_{3}+9 \mathrm{Na}_{2} \mathrm{O}+12 \mathrm{NO}+18 \mathrm{CO}_{2}+9 \mathrm{H}_{2} \mathrm{O} \\
& 3 \mathrm{Na}_{2} \mathrm{O}+2 \mathrm{SO}_{2}+2 \mathrm{CO}_{2}+\mathrm{H}_{2} \mathrm{O} \\
& 4 \mathrm{FeO}+\mathrm{Na}_{2} \mathrm{O}+2 \mathrm{CO}_{2}+7 \mathrm{H}_{2} \mathrm{O} \\
& \mathrm{Na}_{2} \mathrm{O}+\mathrm{CO}+\mathrm{CO}_{2}+\mathrm{H}_{2} \\
& \mathrm{~K}_{2} \mathrm{O}+\mathrm{CO}+\mathrm{CO}_{2}+\mathrm{H}_{2} \\
& 2 \mathrm{~N}_{2}+8 \mathrm{H}_{2} \mathrm{O}+2 \mathrm{CO}+2 \mathrm{CO}_{2}+2 \mathrm{H}_{2} \\
& \mathrm{MnO}+\mathrm{CO}+\mathrm{CO}_{2}+\mathrm{H}_{2} \\
& \mathrm{NiO}+\mathrm{CO}+\mathrm{CO}_{2}+\mathrm{H}_{2} \\
& \mathrm{CaO}+\mathrm{CO}+\mathrm{CO}_{2}+\mathrm{H}_{2} \\
& \mathrm{U}_{3} \mathrm{O} 8+\mathrm{CO}+\mathrm{CO}_{2}+\mathrm{H}_{2} \\
& \mathrm{CuO}+\mathrm{CO}+\mathrm{CO}_{2}+\mathrm{H}_{2} \\
& \mathrm{CoO}+\mathrm{CO}+\mathrm{CO}_{2}+\mathrm{H}_{2} \\
& \mathrm{ZnO}+\mathrm{CO}+\mathrm{CO}_{2}+\mathrm{H}_{2} \\
& \mathrm{MgO}+\mathrm{CO}+\mathrm{CO}_{2}+\mathrm{H}_{2} \\
& \mathrm{SrO}+\mathrm{CO}+\mathrm{CO}_{2}+\mathrm{H}_{2} \\
& \mathrm{Cs} \mathrm{O}+\mathrm{CO}+\mathrm{CO}_{2}+\mathrm{H}_{2} \\
& \mathrm{Na} \mathrm{C}_{2}+\mathrm{CO}+\mathrm{CO}_{2} \\
& \mathrm{CaO}+\mathrm{CO}+\mathrm{CO} \\
& \mathrm{CaO}+2 \mathrm{NaF} \\
& \mathrm{SrO}+\mathrm{H}_{2} \mathrm{O} \\
& \mathrm{Hg}(\mathrm{v})+\mathrm{O}_{2} \\
& \mathrm{Hg}(\mathrm{v}) \\
& \mathrm{Cs} \mathrm{O}(\mathrm{v})(10 \%) \\
& \mathrm{MnO}+\mathrm{O}_{2} \\
& \mathrm{Pd}+2 \mathrm{NO}+2 \mathrm{O}_{2} \\
& 2 \mathrm{PuO}+8 \mathrm{TiO}_{2}+2 \mathrm{Na}_{2} \mathrm{O}+\mathrm{O}_{2} \\
& \mathrm{SrO}+4 \mathrm{TiO}+\mathrm{Na}_{2} \mathrm{O} \\
& \mathrm{H} \mathrm{O}+4 \mathrm{TiO}+\mathrm{Na}_{2} \mathrm{O} \\
&
\end{aligned}
$$


Modeling Bases - The following simplified oxidation reactions were used to convert metal salts and other compounds into oxides in the glass melter:

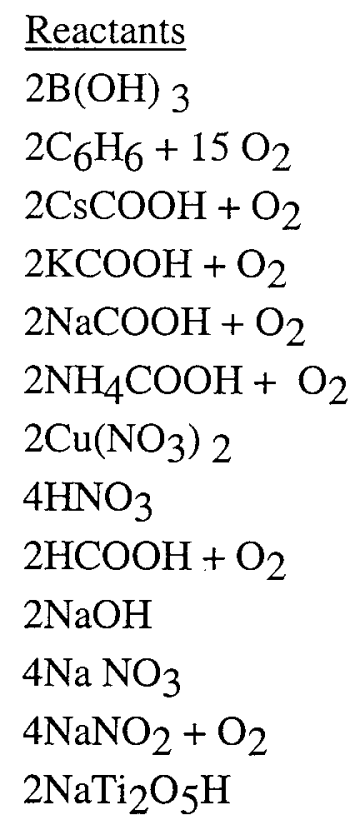

$$
\begin{aligned}
& \mathrm{B}_{2} \mathrm{O}_{3}+3 \mathrm{H}_{2} \mathrm{O} \\
& 12 \mathrm{CO}_{2}+6 \mathrm{H}_{2} \mathrm{O} \\
& \mathrm{Cs}_{2} \mathrm{O}+2 \mathrm{CO}_{2}+\mathrm{H}_{2} \mathrm{O} \\
& \mathrm{K}_{2} \mathrm{O}+2 \mathrm{CO}_{2}+\mathrm{H}_{2} \mathrm{O} \\
& \mathrm{Na}_{2} \mathrm{O}+2 \mathrm{CO}_{2}+\mathrm{H}_{2} \mathrm{O} \\
& 2 \mathrm{NH}_{3}+2 \mathrm{CO}_{2}+2 \mathrm{H}_{2} \mathrm{O} \\
& 2 \mathrm{CuO}+4 \mathrm{NO}_{2}+\mathrm{O}_{2} \\
& 4 \mathrm{NO}_{2}+2 \mathrm{H}_{2} \mathrm{O}+\mathrm{O}_{2} \\
& 2 \mathrm{CO}_{2}+2 \mathrm{H}_{2} \mathrm{O} \\
& \mathrm{Na}_{2} \mathrm{O}+\mathrm{H}_{2} \mathrm{O} \\
& 2 \mathrm{Na}_{2} \mathrm{O}+4 \mathrm{NO}_{2}+\mathrm{O}_{2} \\
& 2 \mathrm{Na}_{2} \mathrm{O}+4 \mathrm{NO}_{2} \\
& \mathrm{Na}_{2} \mathrm{O}+4 \mathrm{TiO}_{2}+\mathrm{H}_{2} \mathrm{O}
\end{aligned}
$$

\section{Bases for Water additions and Recycle:}

Modeling Bases - Water evaporated from SRAT and SME is recycled through SMECT to RCT.

All water fed to the melter goes to the Offgas Condensate Tank and thence to the RCT

Steam Atomized Scrubbers and Film Cooler add 1000 pph water to offgas stream. This water is condensed and recycled. Decon waste adds another $340 \mathrm{pph}$ water to the RCT.

\section{A.13 DWPF Glass Property Bases}

The Technical and Modeling Bases for estimating glass properties are identical and are described below.

The glass' resistance to leaching determines its quality. This is measured by the Product Consistency Test for glass waste forms (Method ASTM C 1285-94). It can be estimated from the composition of the SME product. The elemental weight percentages of SME product constituents are converted to an oxide basis ("glass basis"). The number of moles of each oxide per 100 grams of glass is calculated and multiplied by its molar free energy of hydration (Table A.13.1, below). The sum of these molar free energies of hydration is used to estimate leach rate by:

[Boron], $\mathrm{g} / \mathrm{l}=10^{\wedge}(-0.1812 *(\Sigma($ molar free energy $) *($ moles per $100 \mathrm{~g}))-1.9014)$. 
The benchmark glass ("Environmental Assessment" Glass) has a leach rate of $16 \mathrm{~g} / \mathrm{l}$. However, model and analytical measurement uncertainties associated with this calculation requires a statistical offset to assure that glass will meet these limits. For the purpose of the simple model, a leach rate $<2.25 \mathrm{~g} / 1$ will be used.

The equivalent expressions and limits for lithium and sodium are (Reference 23):

[Lithium], $g / l=10^{\wedge}\left(-0.1468^{*}\left(\Sigma(\text { molar free energy })^{*}(\right.\right.$ moles per $\left.\left.100 \mathrm{~g})\right)-1.5459\right)$. leach rate $<1.84 \mathrm{~g} / 1$

[Sodium], $\mathrm{g} / \mathrm{l}=10^{\wedge}\left(-0.1710^{*}(\Sigma(\right.$ molar free energy $) *($ moles per $\left.100 \mathrm{~g}))-1.8012\right)$. leach rate $<2.28 \mathrm{~g} / \mathrm{l}$

Table A.13-1

Molar Free Energy of Hydration for Glass Oxides

\begin{tabular}{|c|c|}
\hline $\mathrm{Al} 2 \mathrm{O} 3$ & 37.68 \\
\hline $\mathrm{B} 2 \mathrm{O} 3$ & -10.43 \\
\hline $\mathrm{CaO}$ & -13.79 \\
\hline $\mathrm{Cr} 2 \mathrm{O} 3$ & 11.95 \\
\hline $\mathrm{CuO}$ & -4.95485 \\
\hline $\mathrm{Fe} 2 \mathrm{O} 3$ & 14.56 \\
\hline $\mathrm{K} 2 \mathrm{O}$ & -76.41 \\
\hline $\mathrm{Li2O}$ & -24.04 \\
\hline $\mathrm{MgO}$ & -6.57 \\
\hline $\mathrm{MnO}$ & -24.44 \\
\hline $\mathrm{Na} 2 \mathrm{O}$ & -53.09 \\
\hline $\mathrm{NiO}$ & 0.37 \\
\hline $\mathrm{SiO} 2$ & 4.05 \\
\hline $\mathrm{TiO} 2$ & 16.27 \\
\hline $\mathrm{U} 3 \mathrm{O} 8$ & -23.77 \\
\hline $\mathrm{ZrO} 2$ & 17.49 \\
\hline
\end{tabular}

The temperature below which glass will form a separate crystalline phase is the "liquidus". A minimum liquidus of $1050^{\circ} \mathrm{C}$ is required because the DWPF melter operates at around $1100^{\circ} \mathrm{C}$ and there are cooler zones about $50^{\circ} \mathrm{C}$ below the bulk temperature. Again model and measurement uncertainties require that the calculated liquidus be lower $\left(1015^{\circ} \mathrm{C}\right)$. The equation for liquidus is (Reference 16):

$\begin{aligned} \text { Liquidus, }{ }^{\circ} \mathrm{C}= & 2276.8723 *(-134 *[\mathrm{Fe} 2 \mathrm{O} 3] /(-155.6 *[\mathrm{SiO} 2]-(-3 \\ & 59.88 *[\mathrm{Al} 2 \mathrm{O} 3])))+803.8696\end{aligned}$

All concentrations are in moles per 100 grams of glass. 
The viscosity of the glass melt must not be too low, which leads to uncontrollable pouring or too high, which leads to low pour rate. The limits are from 20 to 100 poise (at $1150^{\circ} \mathrm{C}$ ). However, the calculated range which is acceptable is from 24 to 90 poise, because of model and measurement uncertainty. Viscosity is calculated from (Reference 17):

Viscosity, poise $=10^{\wedge}((-1.5342 *(2 *([\mathrm{Fe} 2 \mathrm{O} 3]-$ $[\mathrm{A} 12 \mathrm{O} 3]+[\mathrm{Cs} 2 \mathrm{O}]+[\mathrm{Li} 2 \mathrm{O}]+[\mathrm{K} 2 \mathrm{O}]+[\mathrm{Na} 2 \mathrm{O}])+[\mathrm{B} 2 \mathrm{O} 3]) /[\mathrm{SiO} 2])-0.6103+4472.4453 / 1150)$

All concentrations are in moles per 100 grams of glass.

\section{A.14 This Section is reserved for future use.}

\section{A.15 Mercury Removal by GT-73}

\section{A.15.1 Background}

Most of the alternatives proposed for evaluation retain processing and disposal of salt solution as saltstone in Z-Area. One condition of the Z-Area disposal permit issued by the South Carolina Department of Health and Environmental Control (SCDHEC) requires that monthly saltstone samples be subjected to Toxicity Characteristic Leach Procedure (TCLP) to show saltstone is properly categorized as a non-hazardous, solid industrial waste (Reference 18). Based on analyses of soluble radioactive waste samples and process history for the separation areas, chromium and mercury are the only two hazardous metals that are present in significant concentrations in soluble waste. Chromium $(\mathrm{Cr})$ is present as sodium chromate $\left(\mathrm{Na}_{2} \mathrm{CrO}_{4}\right)$, while mercury $(\mathrm{Hg})$ may be present either as an ionic species $\left(\mathrm{Hg}_{2}{ }^{+2}\right.$ or $\mathrm{Hg}^{+2}$ ) or as dissolved metal $\left(\mathrm{Hg}^{0}\right)$ (References 19 and 20). Leaching of these hazardous metals from the saltstone waste form is mitigated by reaction with slag used in the dry material formulation for the production of saltstone. Based on laboratory tests and regulatory requirements, $\mathrm{Hg}$ is limited to 250 $\mathrm{mg} / \mathrm{L}(0.0012 \mathrm{moles} / \mathrm{L})$ and $\mathrm{Cr}$ is limited to $1000 \mathrm{mg} / \mathrm{L}(0.019 \mathrm{moles} / \mathrm{L})$ in salt solution sent to Z-Area for processing into saltstone (References 21 and 22). The overall blended average concentrations for these two species are well within the limits specified for feed to Z-Area.

\section{A.15.1.1 Soluble Mercury}

Soluble $\mathrm{Hg}$ concentration in the overall salt solution blend is about $30 \mathrm{mg} / \mathrm{L}$, which is well within the Saltstone limit of $250 \mathrm{mg} / \mathrm{L}$. However, the maximum $\mathrm{Hg}$ concentration found in samples of both fresh supernate and concentrated supernate in H-Area waste is about $340 \mathrm{mg} / \mathrm{L}$, which exceeds the Saltstone limit. Furthermore, about $10 \%$ of the $\mathrm{HgO}$ contained in HM HAW sludge was observed to dissolve during Aluminum dissolution and subsequent washing operations, and waste recycled from the DWPF could also contain relatively high concentrations of soluble mercury compared to the total salt solids 
in the recycle stream. Thus various sludge feed preparation steps and solution evaporation performed in the tank farm could yield a substantial volume of salt solution with $\mathrm{Hg}$ concentrations exceeding the Saltstone limit. The ITP process precipitates soluble $\mathrm{Hg}$ as diphenylmercury, and $\mathrm{Hg}$ is not a concern for Saltstone in this process option. Other options will require either careful blending or a separate unit operation to remove $\mathrm{Hg}$ to assure the $\mathrm{Hg}$ concentration in salt solutions sent to $\mathrm{Z}$-Area is within the limit of $250 \mathrm{mg} / \mathrm{L}$. Ion exchange using Duolite ${ }^{\mathrm{TM}} \mathrm{GT}-73$ resin, described below, provides the necessary unit operation to reduce the $\mathrm{Hg}$ concentration in salt solution sent to Z-Area if mercury removal is required.

\section{A.15.1.2 Soluble Chromium}

Soluble Cr concentration in the overall salt solution blend is about $170 \mathrm{mg} / \mathrm{L}$, which is well within the Z-Area limit of $1000 \mathrm{mg} / \mathrm{L}$. The maximum $\mathrm{Cr}$ concentration found in a concentrated supernate sample is about $680 \mathrm{mg} / \mathrm{L}$, which is also well within the Z-Area limit. This solution was also about $12 \mathrm{M}^{\text {in }} \mathrm{Na}^{+}$, and would be further reduced through dilution and blending with other salt solutions in any of the alternative treatment processes. Thus, treatment to remove or reduce the $\mathrm{Cr}$ concentration in salt solution beyond blending is unnecessary.

\section{A.15.1.3 Hg Ion Exchange Process Description}

Duolite $^{\mathrm{TM}}$ GT-73 is the resin of choice for mercury removal from SRS salt solution (References $23,24,25$ ). The resin has been demonstrated effective with simulated and radioactive salt solutions. This resin is presently used at the F/H Effluent Treatment Facility (ETF) and the TNX ETF. Spent resin from processing actual HLW salt solution can be washed with a solution of sodium nitrate to remove residual radioactivity to yield a waste containing less than $1 \mathrm{nCi} / \mathrm{g}$ of residual ${ }^{137} \mathrm{Cs}$ activity. The washed spent resin was shown to pass the TCLP leach tests for mercury, lead, silver and chromium (Reference 26). Thus, the spent resin would not be classified as hazardous waste and, after dewatering, can be sent to the burial ground for disposal as solid LLW waste.

A preliminary technical data summary for mercury removal from salt solution feed to ITP has been previously described (Reference 27). For the $\mathrm{Hg}$ ion exchange process, a 2column system will be used. Filtered salt solution flows into the first column. The second column is placed in series as a guard bed. When the resin in the first column is fully loaded, feed is diverted to the second column and there will be no guard bed until the first column has been replenished with fresh resin and returned to service as a guard bed. This mode of operation is justified in light of the high capacity $(\sim 1450$ column bed volumes, CBV) of the GT-73 resin. In addition, mercury removal is not required on all of the salt waste to be within Z-Area limits of $250 \mathrm{mg} / \mathrm{L}$.

The GT-73 resin will be used only once. Fresh resin must be preconditioned for 24 hours by slurrying with $2 \mathrm{M} \mathrm{NaOH}$ in a separate resin slurry makeup tank prior to loading the resin into a column. This is necessary because the resin, which is shipped in the acid 
form, swells approximately $40 \%$ when converted to the sodium form. The resin slurry is then transferred to the column using water. Relative volumes needed for this operation is $5 \mathrm{CBV} 2 \mathrm{M} \mathrm{NaOH}$ and $20 \mathrm{CBV}$ water.

After a column has been loaded with $\mathrm{Hg}$, the resin is washed with 5 bed volumes of $2 \mathrm{M}$ $\mathrm{NaNO}_{3}$ to remove any residual ${ }^{137} \mathrm{Cs}$ from the resin. The resin is then slurried from the column with $25 \mathrm{CBV}$ of water, dewatered (drained), and packaged for disposal as nonhazardous LLW.

\section{A.15.2.1 Column Sizing}

The mercury removal columns can be as large as practical for available space and handling to minimize resin changes. Flux through the columns should not exceed 8 $\mathrm{gpm} / \mathrm{ft}^{2}$ of column area (Reference 28). Column diameter is sized by assuming $50 \%$ of the recommended maximum flux $-4 \mathrm{gpm} / \mathrm{ft}^{2}$. For purposes of this evaluation, two columns containing 250 gallons of resin each are assumed, providing a processing capacity of 362,250 gallons (250 gallons x 1450 column bed volumes) of salt solution before a resin change would be needed. At an assumed flowrate of $42 \mathrm{gpm}$ and flux of 4 $\mathrm{gpm} / \mathrm{ft}^{2}$, the cross-sectional area of the column needs to be $10.5 \mathrm{ft}^{2}$, corresponding to an internal column diameter of 44 inches and a resin bed height of 38 inches.

\section{A.15.2.2 Flowrates for Various Streams}

The flowrates of various solutions and materials corresponding to 300,000 gallons of salt solution feed to saltstone are summarized below:

- GT-73 Resin

- 250 gallon column bed volume @ 4.8 lbs. resin/gal of bed volume = $1200 \mathrm{lbs}$. resin/cycle

- $\quad$ resin used $=1200 \mathrm{lbs} / 300,000$ gal salt solution $=0.00400 \mathrm{lbs}$ resin $/$ gal salt solution

- cycle time $=300,000 \mathrm{gal} / 2520 \mathrm{gal} / \mathrm{hr}=119 \mathrm{hr}=4.96$ days ( $24 \mathrm{hr}$ operation)

- 48 hrs to replace spent resin in one column

- condition with $2 \mathrm{M} \mathrm{NaOH}=1250$ gallons per cycle

- slurry conditioned resin into column with water $=5000$ gallons per cycle

- rinse spent resin with $2 \mathrm{M} \mathrm{NaNO}_{3}=1250$ gallons per cycle

- slurry spent resin from column with water $=6250$ gallons per cycle, but reuse 5 cycles before returning liquid to upstream feed tank (6250 gallons sent to feed tank every fifth cycle). Average is 1250 gallons/cycle.

- Stream destinations:

- Decontaminated salt solution to next process unit operation

- All liquid waste streams from column loading, resin conditioning, resin washing sent forward to next unit operation (1250 gal $2 \mathrm{M} \mathrm{NaOH}$ plus 5000 gallons water plus 1250 gallons $2 \mathrm{M} \mathrm{NaNO}_{3}$ )

- Liquid waste stream from spent resin processing returned to feed tank $(6250$ gallons water every fifth cycle). 


\section{A.15.2.3 Stoichiometry}

Reactants

\section{Resin Pretreatment}

$\mathrm{H}_{2}$ \{SRES $\}+2 \mathrm{NaOH}$

2. Filtrate ion exchange

$[\mathrm{HgO}+\mathrm{NaOH}]_{\text {aqueous }}+\mathrm{Na}_{2}\{$ SRES $\}+\mathrm{H}_{2} \mathrm{O}$
Products

$\mathrm{Na}_{2}\{\operatorname{SRES}\}+\mathrm{H}_{2} \mathrm{O}$

$3 \mathrm{NaOH}+H g\{\operatorname{SRES}\}(25 \%)$

\section{A.16 CST Column Performance}

\section{A.16.1 Ion Exchange Column Model}

Introduction

The separation of cesium from the contaminated salt solution is to be performed by a crystalline silicotitanate (CST) resin. The absorption of cesium onto the resin, for a film resistance-controlling mass transfer model, is a function of the local concentration driving force in the column and a proportionality constant (mass transfer coefficient). The concentration driving force is the difference between the bulk solution cesium concentration and the interfacial cesium concentration that is in equilibrium with the CST. The concentration driving force depends on the mass transfer (diffusion from the bulk solution to the CST surface) and the convective transfer (contaminated salt solution flowrate) of cesium through the column. Therefore, the solution to a dynamic ionexchange column calculation involves both temporal and spatial integrations. In Phase II (Reference 29), an exact dynamic model of the ion-exchange column was not sought, and the resin loading was assumed to be $75 \%$ of the equilibrium loading at entry Cs concentrations. The following sections describe the dynamic ion-exchange model and logic used for Phase III Bases calculations.

Designing an ion-exchange column for the removal of cesium from contaminated salt solution requires a dynamic model of an ion-exchange column. The ion-exchange column model must provide a mechanism for the dynamic transport of cesium from the bulk solution to the exchange site on the resin, and the model must capture the steadystate capacity of the resin to load cesium. A model that adequately describes these mechanisms is then capable of determining the correct column length and cycle times for breakthrough. The combination of column size and cycle time identifies how much CST must be processed by DWPF into glass in order to maintain the desired decontamination. This section of the Phase III Bases will provide details of the CST ion-exchange column modeling logic, isotherm development, preliminary column sizing, and SPEEDUP modeling for Phase III material balances.

Modeling Summary/Logic

In order to size an ion-exchange column, a model is needed that relates both kinetic data and equilibrium-loading data, see Figure A.16-1. Figure A.16-1 provides the ion- 
exchange model approach that is utilized by the Salt Disposition Flowsheet Team. Purdue and Texas A\&M have been employed to provide more extensive column design information in later reports. Purdue and Texas A\&M utilize identical approaches, but they differ from the Salt Disposition Flowsheet Team in the complexity of the ionexchange column model. The Salt Disposition Flowsheet Team chose to use a simple ionexchange column model available from Transport Phenomena by Bird, Stewart, and Lightfoot (Reference 30) for preliminary design/evaluation until results are made available with the SPEEDUP model.

The Salt Disposition Flowsheet Team calculation utilizes an equilibrium cesium loading correlation from Texas A\&M (referred to as the TAMU loading (Kd) model, Reference 31) and breakthrough curves from several non-SRS wastes (References 32 and 33) to arrive at a "lumped" or overall mass transfer coefficient capable of describing the ionexchange behavior of these wastes. The key assumption in this preliminary design is that the "lumped" mass transfer coefficient determined from non-SRS waste can be used with SRS waste, and the only differences will be due to the various isotherms for SRS waste predicted by the TAMU loading model. The isotherm or loading capacity (g Cs/g CST vs [Cs]) of the CST is dependent upon several key parameters: cesium concentration, strontium concentration, potassium concentration, hydroxide concentration, sodium concentration, and temperature. In order to account for the compositional variances expected with SRS waste, the TAMU model is used to predict the CST loading capacity (isotherm) for perturbations to average SRS waste that are expected to bound the design. Without the TAMU model, extensive batch loading experiments would need to be performed to determine the CST loading capacity as a function of the above parameters.

The model used by the Salt Disposition Flowsheet Team is the simplest of all ionexchange models: linear isotherm, 1D solution (cesium varies with column length only), an overall "lumped" mass transfer coefficient, and no exchanged cesium in the column at time zero. The model description and preliminary column design were presented in earlier work (Reference 34). The linear model used in the earlier analysis was shown to yield conservative (bounded) column lengths due to prohibiting the "self-sharpening" that normally occurs with breakthrough curves (Reference 35 ). 

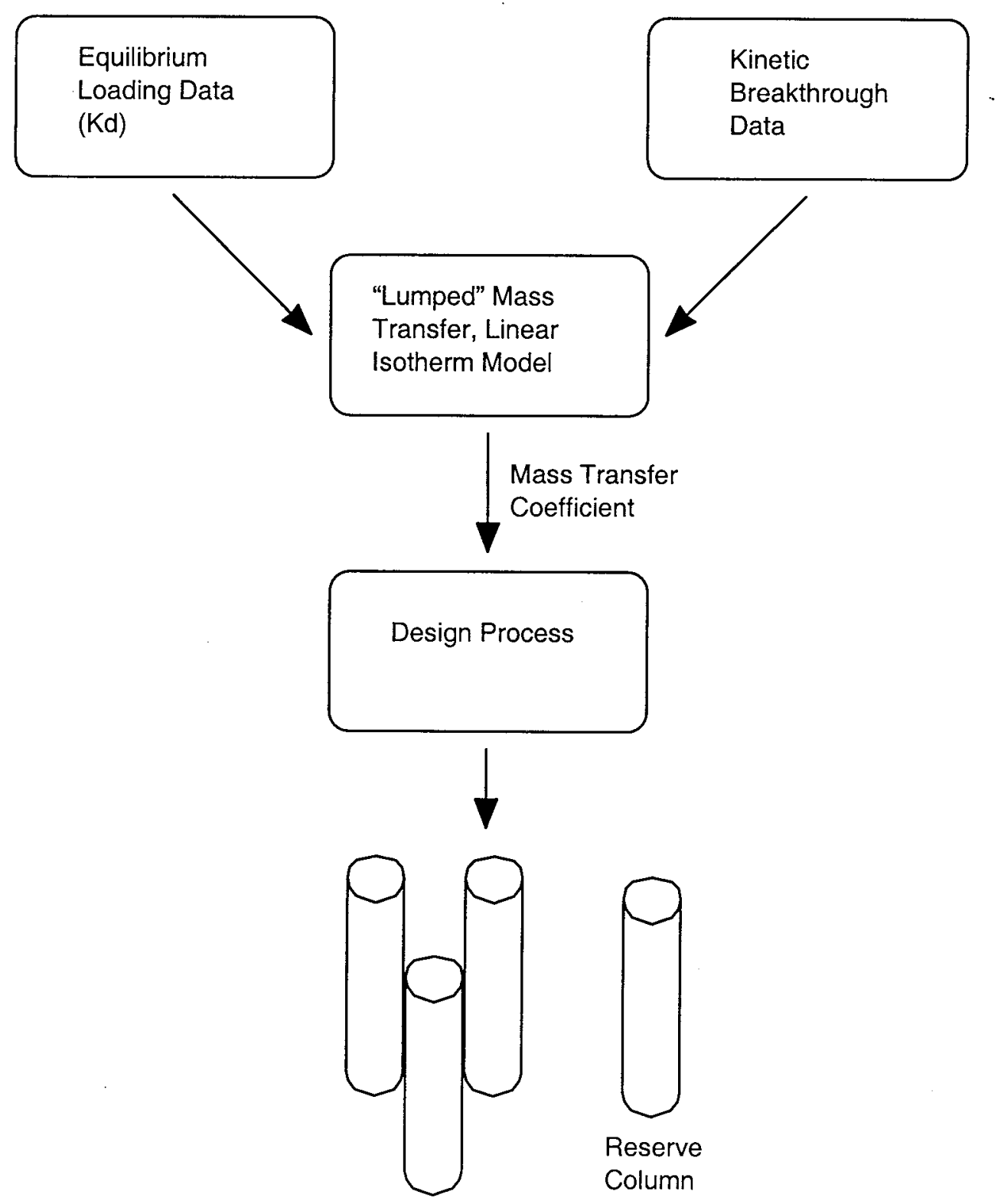

3 Column

Carousel

Figure A.16-1 Schematic showing the approach for designing the IX columns. Equilibrium loading information is obtained from the TAMU model. Breakthrough information is obtained from recent CST bench-scale column runs with non-SRS waste. Both information sets are required in order to derive mass transfer coefficients. Once the mass transfer coefficient is obtained from the data, columns can be scaled to meet design requirements. 
The Salt Disposition Flowsheet Team has decided to design a 3-column carousel for the ion-exchange option. The carousel arrangement works as follows:

1. Contaminated salt solution enters the first of three columns in series.

2. The cesium activity is measured for the solution exiting the first column.

3 . When the exiting cesium concentration from the first column reaches $90 \%$ of its entry value, the first column is taken off-line when exit of the $2^{\text {nd }}$ column reaches $20 \mathrm{nCi} / \mathrm{g}$.

4. The second column is rotated into the first position.

5. The third column is rotated into the second position.

6. The reserve column is placed into the third position.

7. The carousel arrangement has been designed so that $90 \%$ breakthrough on the first column maintains the required $\mathrm{DF}$ on the solution exiting the second column. The third column is for guard purposes only.

$\underline{\text { Ion-Exchange Column Basics }}$

As contaminated waste solution passes through the column, a cesium wavefront is established, see Figure A.16-2. Figure A.16-2 presents preliminary ion-exchange column results from the Salt Disposition Flowsheet Team (SDFT) ion-exchange column model (Reference 34). The cesium wavefront is also referred to as the mass transfer zone (MTZ). The cesium wavefront has been defined as beginning with $\mathrm{x}_{\mathrm{A}} / \mathrm{x}_{\mathrm{A}_{0}}=0.9$ and extending to $\mathrm{x}_{\mathrm{A}} / \mathrm{x}_{\mathrm{Ao}}=1 / 40000$, with $\mathrm{x}_{\mathrm{A}}$ equal to the cesium concentration as a function of both time and column position and $\mathrm{x}_{\mathrm{Ao}}$ equal to the initial cesium concentration entering the $1^{\text {st }}$ column. The output of the first column is sampled for breakthrough. When the first column reaches $90 \%$ of inlet cesium concentration $\left(\mathrm{x}_{\mathrm{A}} / \mathrm{x}_{\mathrm{Ao}}=0.9\right)$, the leading edge of the cesium wavefront must be contained within the second column. Therefore, the mass transfer zone determines the column length. A $5 \times 16$ foot column processing $20 \mathrm{GPM}$ of contaminated SRS waste would yield a mass transfer zone length of 13.8 feet.

The speed at which the cesium wavefront passes through the column will determine the cycle time by determining when the first column is taken off-line, see Figure A.16-3. Figure A.16-3 shows the dependency of cycle time on column throughput. A 5 X16 foot column processing $20 \mathrm{GPM}$ of contaminated SRS waste would require change out every 700 hours.

Figure A.16-2 and Figure A.16-3 provide the basic column response for designing ionexchange columns. First, the ion-exchange column is simulated with nominal flowrates and waste compositions. Second, the cesium bulk concentration is plotted throughout the column length. Third, the mass transfer zone length is determined, and individual columns are sized to contain this mass transfer zone. Finally, the cycle time is calculated in order to determine how much CST is required maintain the decontamination factor. Performing the previous calculations requires modeling two key aspects of an ionexchange column: the equilibrium loading capacity of the resin and the rate at which the resin can reach that capacity. The following section explains these two important aspects of the modeling effort. 


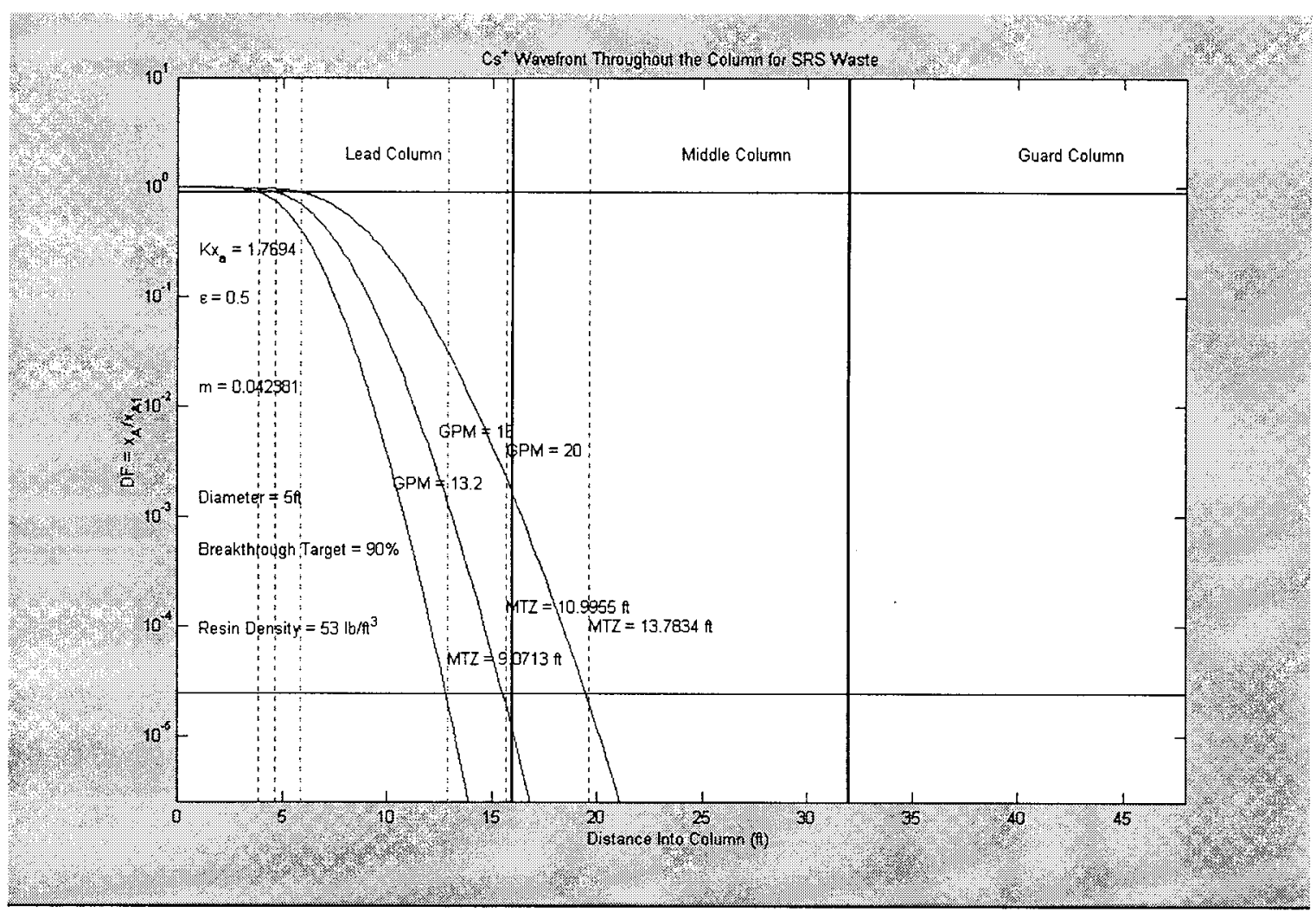

Figure A.16-2. A three-column carousel has been modeled as three columns in series, each column is 5 feet in diameter. The first column is represented from 1-16 feet. The second column is represented from 16-32 feet. This figure demonstrates the location of the cesium wavefront, at a given time, as a function of flowrate through the columns. The dotted vertical lines denote the beginning and ending of each mass transfer zone. This figure indicates that processing 20GPM of contaminated salt solution through the column will result in a mass transfer zone (MTZ) 13.8 feet long. 


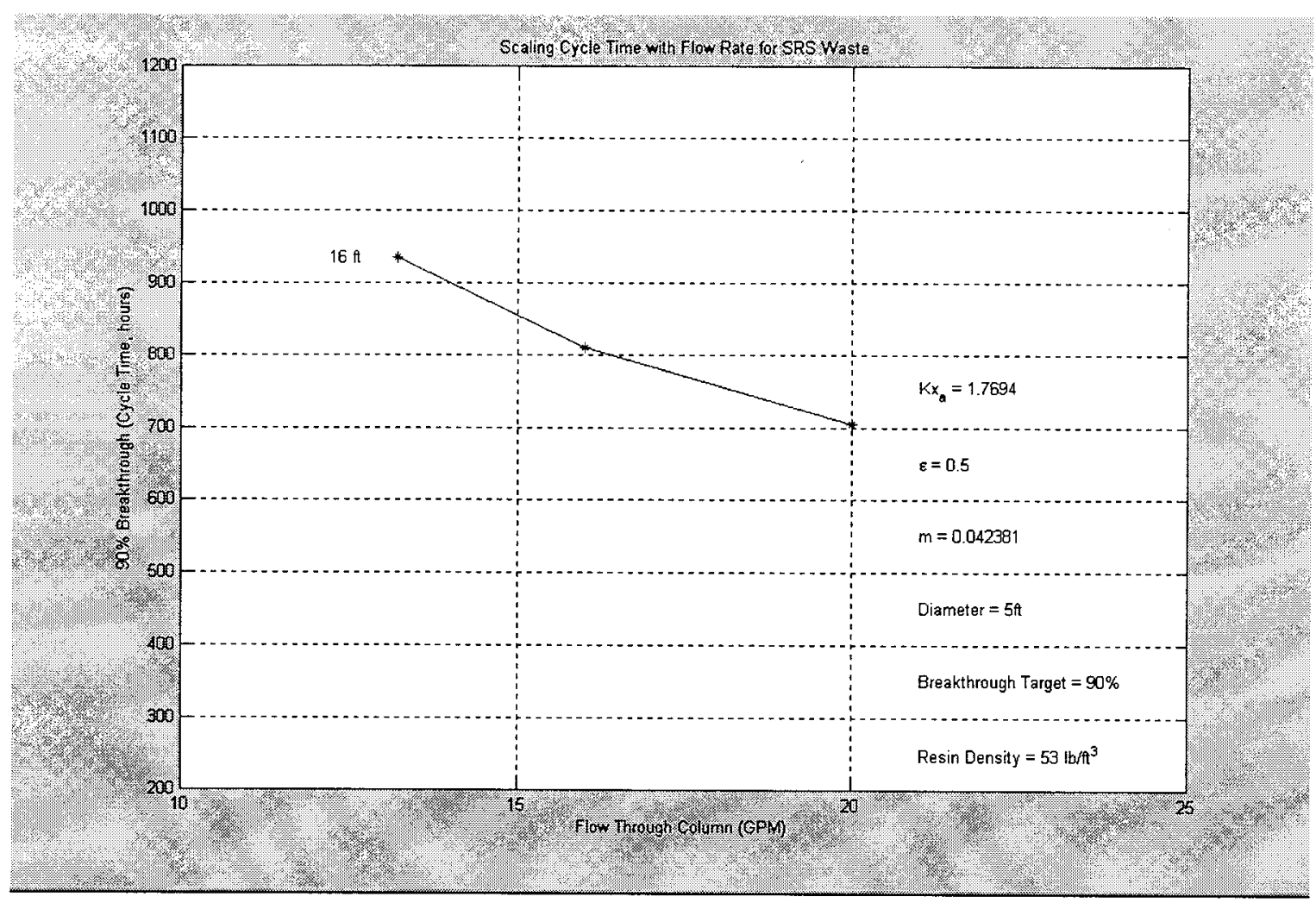

Figure A.16-3. This figure shows the time required for the lead column to breakthrough as a function of flow rate through the column. As the flow rate increases, the mass transfer zone length increases resulting in early breakthrough behavior. This early breakthrough behavior results in a high flow rate of CST to DWPF for processing into glass. 


\section{$\underline{\text { Key Aspects of all Ion-Exchange Column Models }}$}

\section{TAMU Isotherm}

The capacity of CST to load cesium is normally measured by batch experiments where a given amount of resin is contacted with a given amount of contaminated salt solution. After a fixed amount of time, the cesium remaining is solution is measured with the difference being assumed loaded onto the resin. The experiment is repeated for varying amounts of cesium in the contaminated solution. The relationship of loading to final cesium concentration is referred to as an isotherm. The isotherm can be directly proportional to cesium concentration in which case it is referred to as a linear isotherm. Normally, the isotherm is only linear over small concentration ranges, and for SRS waste the isotherm is non-linear. The non-linearity occurs at high cesium concentrations, because the CST becomes "saturated". The isotherm description in the section titled "Isotherm Development" discusses the isotherms used in the ion-exchange column models and how this isotherm varies with SRS waste variations.

\section{Overall Mass Transfer Coefficient}

The transport of cesium from the bulk solution to the exchange site on the resin is a complicated process. The cesium ion must navigate from the bulk, to the surface of resin, to a pore, diffuse through the pore, and finally exchange with a sodium ion. Each segment of the transport process has associated with it a resistance to mass transfer. The Salt Disposition Flowsheet Team decided to use a model which consolidates all resistances into a single term similar to how one might lump all heat transfer resistances into a single heat transfer coefficient. The driving force for mass transfer, when film resistance dominates, is the concentration difference between the bulk cesium concentration and the cesium concentration on the surface of the resin. The surface cesium concentration is provided by the isotherm information discussed in the previous section. Therefore, cesium will transfer to the surface of the resin at a rate that is controlled by the concentration driving force and a proportionality constant: the mass transfer coefficient. Because the Salt Disposition Flowsheet Team decided to lump all resistances into a single term, the mass transfer coefficient is referred to as a "lumped" or overall mass transfer coefficient.

In order to determine the mass transfer coefficient, column breakthrough information is needed. At the time of this preliminary design, column breakthrough data with SRS waste had not been made available. Therefore, the mass transfer coefficient was determined from non-SRS waste. Mass transfer coefficients are calculated by solving the material balance equations for both the cesium in the bulk solution and the cesium on the resin. Solving these equations leads to a breakthrough curve as a function of the mass transfer coefficient and column operating conditions. A sum of squares minimization (regression) is performed so that the model predicted breakthrough curve is very similar to the actual column breakthrough response. 
Utilization of both isotherm information and mass transfer coefficient yields a model capable a designing an ion-exchange column. The model is capable of determining the length of mass transfer zone needed to size the columns on the carousel. The model is also capable of predicting when the first column of the carousel will break through and require unloading of the CST/Cs to DWPF. The frequency of this operation determines how much CST DWPF needs to incorporate into glass.

\section{Modeling Effort Applied to Phase III Calculations}

At present, four ion-exchange models are currently being used to provide information to the Phase III decision. The ion-exchange models offer varying degrees of complexity from the very simple to the state-of-the-art. The goal of the Salt Disposition Flowsheet Team was to provide an ion-exchange column design that would be validated by the more complex models. Purdue University and Texas A\&M University are providing the more complicated models for ion-exchange column design. The purpose of this section is to briefly outline the models used in providing the ion-exchange flowsheets to the Salt Disposition Team. Provided that the non-elutable ion-exchange candidate makes the Phase III decision, the ion-exchange column model used by the Salt Disposition Flowsheet Team could be upgraded to include more of the concepts accounted for in the Purdue and Texas A\&M models.

Table A.16-1 summarizes the four models currently in use by the Salt Disposition Flowsheet Team (SDFT), Salt Disposition Modeling Team (SDMT), Purdue University (PU), and Texas A\&M University (A\&M). The SDFT model is the simplest ionexchange model in that the column is modeled as a long tube and the non-linear isotherm is linearized over the entire cesium concentration range for mathematical simplification. This model has a tendency to predict a conservative mass transfer zone and a nonconservative cycle time and CST loading due to the linearization of the non-linear isotherm. The SDMT model is latest revision to the SDFT model in that the non-linear isotherm and carousel arrangement are accounted for. The non-linear isotherm should eliminate the lack of conservatism in cycle time. The SDMT also provides a new piece of information not available to the SDFT: the cycle time of the second column after partial loading. The cycle time is important, because all columns after the very first will be partially loaded with cesium upon rotation to the lead position. This cycle time is certainly smaller than that predicted by the unloaded column, the exact decrease is unknown. The Purdue and Texas A\&M models are the most complex due to the various mass transfer mechanisms employed. The Purdue and Texas A\&M models also offer the ability to track more than cesium through the column: multi-phase isotherms.

The purpose in utilizing four ion exchange models was to provide varying degrees of complexity to an identical problem. Each model provided a measure of checks and balances to the other models. Table A.16-1 provides the primary purpose of each model. 
Table A.16-1. Summary of models used in preliminary ion-exchange column design.

\begin{tabular}{|c|c|c|}
\hline Contributor & Ion-Exchange Column Model Description & Purpose \\
\hline $\begin{array}{l}\text { Salt Disposition Flowsheet } \\
\text { Team simulated this model } \\
\text { using MATLAB }{ }^{\text {TM. }} \text { (SDFT) }\end{array}$ & $\begin{array}{l}\text { 1. "Lumped Resistance" mechanism, } \\
\text { 2. Linear Isotherm } \\
\text { 3. Single Long Column } \\
\text { 4. Constant feed composition } \\
\text { 5. Zero cesium loaded initially } \\
\text { 6. Mass transfer coefficient calculated } \\
\text { from bench-scale non-SRS wastes. }\end{array}$ & $\begin{array}{l}\text { - Check on preliminary sizing } \\
\text { - Compare/validate other } \\
\text { models: PU and A\&M }\end{array}$ \\
\hline $\begin{array}{l}\text { Salt Disposition Modeling } \\
\text { Team simulated this model } \\
\text { using SPEEDUP. (SDMT) }\end{array}$ & $\begin{array}{ll}\text { 1. } & \text { "Lumped Resistance" mechanism, } \\
\text { 2. Non-Linear Isotherm } \\
\text { 3. } 3 \text { Column Carousel } \\
\text { 4. Variable feed composition } \\
\text { 5. Calculates cycle time for partially } \\
\text { loaded column. } \\
\text { 6. } \\
\text { Mass transfer coefficient calculated } \\
\text { from bench-scale non-SRS wastes. }\end{array}$ & $\begin{array}{l}\text { - Provide material balances } \\
\text { Compare/validate other } \\
\text { models: PU and A\&M }\end{array}$ \\
\hline $\begin{array}{l}\text { Purdue University has } \\
\text { developed the numerical } \\
\text { techniques required to solve this } \\
\text { system of equations. (PU) }\end{array}$ & $\begin{array}{l}\text { 1. Various mass transfer mechanisms, } \\
\text { 2. Non-Linear Isotherm } \\
\text { 3. } 3 \text { Column Carousel } \\
\text { 4. Variable feed composition } \\
\text { 5. Mass transfer coefficient calculated } \\
\text { from pilot-scale non-SRS wastes. }\end{array}$ & $\begin{array}{l}\text { Perform column sizing } \\
\text { evaluation } \\
\text { Cross check WSRC models: } \\
\text { SDFT and SDMT }\end{array}$ \\
\hline $\begin{array}{l}\text { Texas A\&M University has } \\
\text { developed the numerical } \\
\text { techniques required to solve this } \\
\text { system of equations. (A\&M) }\end{array}$ & $\begin{array}{l}\text { 1. Various mass transfer mechanisms, } \\
\text { 2. Non-Linear Isotherm } \\
\text { 3. Single Long Column } \\
\text { 4. Variable feed composition } \\
\text { 5. Mass transfer coefficient calculated } \\
\text { from pilot-scale non-SRS wastes. }\end{array}$ & $\begin{array}{l}\text { Perform column sizing } \\
\text { evaluation } \\
\text { Cross check WSRC models: } \\
\text { SDFT and SDMT }\end{array}$ \\
\hline
\end{tabular}

\section{Conclusions}

The purpose of the modeling/logic section of this document is to explain the basics of ion-exchange column design, to identify where the different aspects of the calculation come from, and to identify what organizations are currently working on evaluating an ion-exchange column for SRS waste. At a minimum, an ion-exchange model must account for the equilibrium loading capacity of CST and the rate at which the CST is able to achieve this capacity. The current ion-exchange column design utilized in SPEEDUP is based on the equilibrium loading capacity predicted by the Texas A\&M loading model and the mass transfer coefficient derived from four bench-scale column runs with nonSRS waste. Both Purdue and Texas A\&M are using their own models to design an ionexchange column for SRS-waste.

\section{$\underline{\text { Isotherm Development }}$}

A basic requirement for modeling mass transfer is to quantify the equilibrium driving force for mass transfer. For ion exchange systems, the equilibrium between the solution concentration of the ion of interest and its concentration on the solid is known as an isotherm. In some cases, the equilibrium ratio is directly proportional to the solution concentration thus producing a linear isotherm. In other cases, the ratio varies with 
solution concentration thus requiring equilibrium data as a function of solution concentration. Normally, this data is produced by a series of experiments. However, in the case of CST, a very detailed model of cesium/CST equilibrium has been developed by the chemical engineering department at Texas A\&M University (References 36 and 37)

The model simulates the results of an experiment to determine the distribution coefficient $\left(\mathrm{K}_{\mathrm{d}}\right)$ for the powdered form of CST. In a $\mathrm{K}_{\mathrm{d}}$ experiment, a quantity of solution is placed in contact with a quantity of ion exchange material. After reaching equilibrium, the concentrations of various cations (in the case of a cation resin) are measured. The ending solution concentrations for each cation are used to calculate the $\mathrm{K}_{\mathrm{d}}$ for that cation, the loading on the resin, and the equilibrium ratio between the ending solution concentration and the resin. A series of final solution concentrations versus resin concentrations define the equilibrium curve or isotherm.

The TAMU model requires the input of the principal cations and anions. These include the ions that comprise the bulk of the ionic strength as well as those which compete for sites on the CST. In SRS wastes, potassium and strontium are cations present in relatively low concentrations, which significantly affect the Cs/CST isotherm. Strontium is, however, removed by MST. As discussed later, care has been taken to use bounding potassium concentrations during our evaluations. In addition to the cation and anion concentrations, the other inputs required for the model are temperature, form of the CST (sodium or hydrogen), quantity of solution, quantity of CST, and solution density.

\section{Model Validation}

Isotherms generated using the TAMU model have been used extensively during the Phase III evaluation so it is necessary to validate the model to ensure the integrity of the evaluations. Three sources have been used. First, Reference 1 contains many examples showing excellent agreement between actual and predicted for a wide range of Cscontaining DOE wastes. Second, the results of experiments performed by McCabe (Reference 38) are compared to those predicted by the model (discussion below). Third, SRTC has performed additional $\mathrm{K}_{\mathrm{d}}$ experiments at bounding waste compositions (Reference 39); these experimental results will be compared to the TAMU model predictions. 
In 1994, McCabe performed experiments with powdered CST using a simulant of typical SRS wastes. The simulant composition was as follows:

Table A.16-2

SRS SIMULANT INPUT TO MODEL

\begin{tabular}{|l|c|}
\hline \multicolumn{1}{|c|}{ Component } & $\begin{array}{c}\text { Concentration } \\
\text { (M) }\end{array}$ \\
\hline $\mathrm{Na}^{+}$ & 5.55 \\
\hline $\mathrm{Cs}^{+}$ & $2.124 \mathrm{E}-04$ \\
\hline $\mathrm{H}^{+}$ & $7.25 \mathrm{E}-15$ \\
\hline $\mathrm{Rb}^{+}$ & 0.0 \\
\hline $\mathrm{K}^{+}$ & 0.015 \\
\hline $\mathrm{Sr}^{++}$ & 0.0 \\
\hline & \\
\hline $\mathrm{OH}^{-}$ & 1.38 \\
\hline $\mathrm{NO}_{3}{ }^{-}$ & 2.355 \\
\hline $\mathrm{NO}_{2}^{-}$ & 0.71 \\
\hline $\mathrm{SO}_{4}{ }^{-}$ & 0.17 \\
\hline $\mathrm{CO}_{3}{ }^{-}$ & 0.20 \\
\hline $\mathrm{Al}^{-}(\mathrm{OH})_{4}^{-}$ & 0.38 \\
\hline
\end{tabular}

The results of the model runs are included with the measured data from Reference 38:

Table A.16-3

\section{POWDERED CST: EXPERIMENTAL AND MODEL RESULTS}

\begin{tabular}{|c|c|c|c|}
\hline \multicolumn{2}{c|}{ MEASURED } & \multicolumn{2}{c|}{ PREDICTED } \\
$\mathbf{C}$ & $\mathbf{Q}$ & $\mathbf{C}$ & $\mathbf{Q}$ \\
(mg Cs/L) & (mg Cs/g CST) & (mg Cs/L) & (mg Cs/g CST) \\
\hline 5.86 & 11.42 & 5.98 & 11.35 \\
\hline 10.01 & 19.73 & 11.36 & 19.00 \\
\hline 12.49 & 24.73 & 15.15 & 23.39 \\
\hline 16.02 & 28.77 & 19.00 & 27.38 \\
\hline 36.92 & 40.39 & 37.61 & 40.14 \\
\hline 46.32 & 45.76 & 48.24 & 44.79 \\
\hline
\end{tabular}


The plotted results are:

\section{Figure A.16-4 \\ POWDERED EXPERIMENTAL AND MODEL RESULTS}

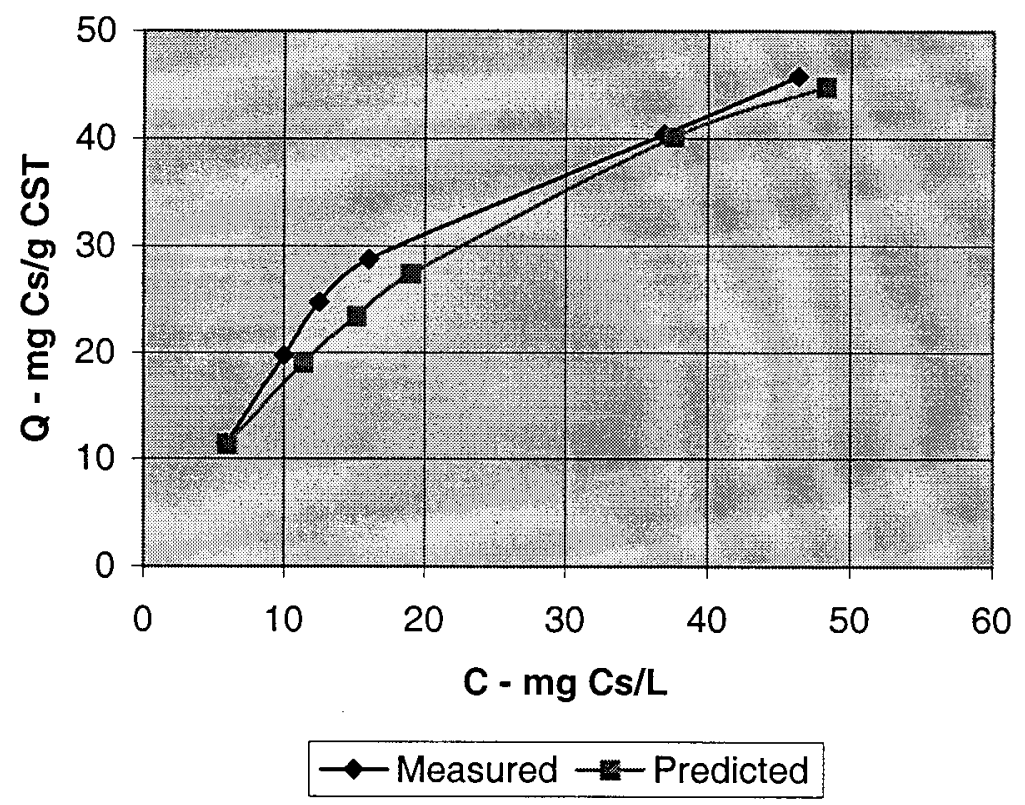

Figure A.16-4 indicates close agreement between the measured and predicted values.

Recent SRTC $\mathrm{K}_{\mathrm{d}}$ measurements confirm the accuracy of the TAMU model (Reference 40). On average, the ratio of measured $K_{d}$ to predicted $K_{d}$ was close to 1.0 when the moisture content of the granular resin was taken into account.

\section{Granular CST}

The powdered form of CST is much too fine (in the micron range) to use in an IX bed the pressure drop across such a bed would be excessive. The manufacturer has produced an engineered form which binds the powder into nearly spherical particles which are $>$ 250 microns in diameter. As-received, the granular CST contains the binder and some intra-particle moisture. This results in a bead that is only partially CST. This means the Cs loading (Q) in $\mathrm{mg}$ Cs/g CST predicted by the TAMU model (for powdered CST) is greater than for the granular resin since the granular material is "diluted" by the binder and the intra-particle moisture. Therefore, it is necessary to include a CST "dilution factor" when using the CST loading predicted by the model.

The concentration of binder is proprietary. However, the aggregate effect of the binder and moisture can be estimated from the difference between predictions for the powdered CST and measurements made on the granular CST using the same solution matrix. McCabe repeated the experiments using granular CST (Reference 41) that were performed with powdered CST (Reference 38). These results are: 
Table A.16-4

GRANULAR CST: EXPERIMENTAL AND MODEL RESULTS

\begin{tabular}{|c|c|c|c|}
\hline \multicolumn{2}{|c|}{ MEASURED } & \multicolumn{2}{|c|}{ PREDICTED } \\
\hline$\underset{(m g ~ C s / L)}{C}$ & $\begin{array}{c}\mathrm{Q} \\
(\mathrm{mg} \mathrm{Cs} / \mathrm{g} \text { CST) }\end{array}$ & $\begin{array}{c}\mathrm{C} \\
(\mathrm{mg} \mathrm{Cs} / \mathrm{L})\end{array}$ & $\begin{array}{c}\mathrm{Q} \\
\text { (mg Cs } / \mathrm{g} \text { CST) }\end{array}$ \\
\hline 4.87 & 7.31 & 3.77 & 7.58 \\
\hline 9.75 & 17.24 & 9.94 & 17.14 \\
\hline 15.22 & 19.28 & 12.16 & 20.07 \\
\hline 30.66 & 26 & 20.47 & 28.57 \\
\hline 48.16 & 30.24 & 28.71 & 34.95 \\
\hline 66.09 & 32.38 & 36.81 & 39.74 \\
\hline 90.38 & 33.17 & 46.38 & 44.12 \\
\hline
\end{tabular}

Figure A.16-5

GRANULAR CST: EXPERIMENTAL AND MODEL RESULTS

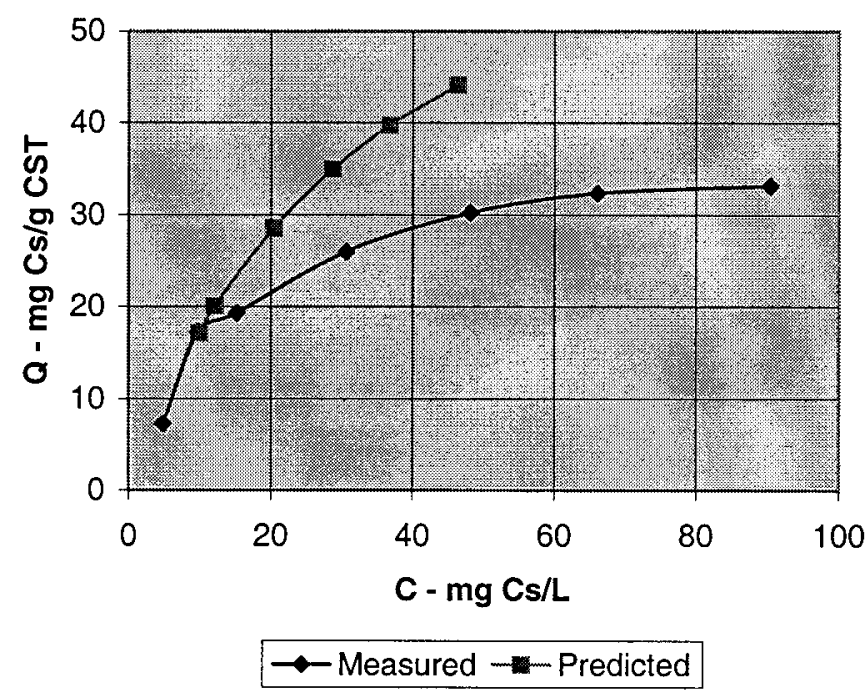

Graphical evaluation of the ratio between measured Q over predicted Q from 20 to $50 \mathrm{mg}$ $\mathrm{Cs} / \mathrm{L}$ in the solution gives values that range from 0.77 at $20 \mathrm{mg} \mathrm{C} / \mathrm{L}$ to 0.67 at $50 \mathrm{mg}$ $\mathrm{Cs} / \mathrm{L}$. In addition, Wang, et al., evaluated the difference between powdered and granular for other wastes and obtained values between 0.56 and 0.66 (Reference 42). Finally, based on proprietary information provided by the manufacturer, the value of inert material in the engineered resin should be approximately $30 \%$. Therefore, a dilution factor of 0.7 has been used for IX column modeling of the granular form of CST.

\section{$\underline{\text { Non-SRS Waste Isotherms }}$}

Isotherms for non-SRS wastes were provided for use by Beck for preliminary column sizing using the lumped-parameter model and for evaluation of literature CST column data by Wang and Anthony. The isotherms are DSSF simulant (Reference 43), MVST-27 
and MVST-29 (References 44 and 45), and Tank 241-AW-101 (Ref. 44). The compositions used and isotherms are :

Note: The units used in the tables vary from table to table.

Table A.16-5

INPUT - DSSF

\begin{tabular}{|l|c|} 
Component & $\begin{array}{c}\text { Concentration } \\
\text { (M) }\end{array}$ \\
\hline $\mathrm{Na}^{+}$ & 3.9 \\
\hline $\mathrm{Cs}^{+}$ & $7.0 \mathrm{E}-05$ \\
\hline $\mathrm{H}^{+}$ & $7.7 \mathrm{E}-15$ \\
\hline $\mathrm{Rb}^{+}$ & $8.56 \mathrm{E}-05$ \\
\hline $\mathrm{K}^{+}$ & 0.09 \\
\hline & \\
\hline $\mathrm{OH}^{-}$ & $1.3+0.01502$ \\
\hline $\mathrm{NO}_{3}{ }^{-}$ & 1.23 \\
\hline $\mathrm{NO}_{2}{ }^{-}$ & 0.34 \\
\hline $\mathrm{SO}_{4}{ }^{-}$ & 0.12 \\
\hline $\mathrm{CO}_{3}{ }^{-}$ & 0.16 \\
\hline $\mathrm{Al}(\mathrm{OH})_{4}{ }^{-}$ & 0.34 \\
\hline $\mathrm{F}$ & 0.07 \\
\hline
\end{tabular}

Table A.16-7

INPUT - MVST-27

\begin{tabular}{|l|c|}
\multicolumn{1}{|c|}{ Component } & $\begin{array}{c}\text { Concentration } \\
(\mathbf{M})\end{array}$ \\
\hline $\mathrm{Na}^{+}$ & $4.913+0.3346$ \\
\hline $\mathrm{Cs}^{+}$ & $7.0 \mathrm{E}-06$ \\
\hline $\mathrm{H}^{+}$ & $5 \mathrm{E}-14$ \\
\hline $\mathrm{Rb}^{+}$ & $1.3 \mathrm{E}-05$ \\
\hline $\mathrm{K}^{+}$ & 0.263 \\
\hline $\mathrm{Sr}^{++}$ & $4.6 \mathrm{E}-04$ \\
\hline $\mathrm{Ca}^{++}$ & $2.23 \mathrm{E}-03$ \\
\hline & \\
\hline $\mathrm{OH}^{+}$ & 0.2 \\
\hline $\mathrm{NO}_{3}{ }^{+}$ & 5.194 \\
\hline $\mathrm{NO}_{2}{ }^{-}$ & -- \\
\hline $\mathrm{SO}_{4}{ }^{+}$ & 0.016 \\
\hline $\mathrm{Cl}^{-}$ & 0.09 \\
\hline
\end{tabular}

Table A.16-6

RESULTS - DSSF

\begin{tabular}{|c|c|}
\hline $\begin{array}{c}\mathbf{C} \\
\text { (mg Cs/L) }\end{array}$ & $\begin{array}{c}\mathbf{Q} \\
\text { (mg Cs/g CST) }\end{array}$ \\
\hline 20.5 & 32.7 \\
\hline 2.63 & 6.68 \\
\hline 0.356 & 0.974 \\
\hline 0.106 & 0.293 \\
\hline 0.0177 & 0.0488 \\
\hline 0.00247 & 0.00683 \\
\hline 0.000352 & 0.000978 \\
\hline
\end{tabular}

Table A.16.8

RESULTS - MVST-27

\begin{tabular}{|c|c|}
\hline $\begin{array}{c}\mathbf{C} \\
\text { (mg Cs/L) }\end{array}$ & $\begin{array}{c}\mathbf{Q} \\
\text { (mg Cs/g CST) }\end{array}$ \\
\hline 2.50 & 0.323 \\
\hline 0.874 & 0.113 \\
\hline 0.250 & 0.0325 \\
\hline 0.0500 & 0.00649 \\
\hline 0.00874 & 0.00114 \\
\hline 0.00125 & 0.000162 \\
\hline
\end{tabular}


Table A.16-9

INPUT - MVST-29

\begin{tabular}{|l|c|}
\hline Component & $\begin{array}{c}\text { Concentration } \\
\text { (M) }\end{array}$ \\
\hline $\mathrm{Na}^{+}$ & 4.15 \\
\hline $\mathrm{Cs}^{+}$ & $1.0 \mathrm{E}-05$ \\
\hline $\mathrm{H}^{+}$ & $2.08 \mathrm{E}-13$ \\
\hline $\mathrm{Rb}^{+}$ & $3.86 \mathrm{E}-05$ \\
\hline $\mathrm{K}^{+}$ & 0.38 \\
\hline $\mathrm{Sr}^{++}$ & $1.37 \mathrm{E}-05$ \\
\hline $\mathrm{Ca}^{++}$ & $8.23 \mathrm{E}-05$ \\
\hline & \\
\hline $\mathrm{OH}^{-}$ & 0.048 \\
\hline $\mathrm{NO}_{3}^{-}$ & $4.0+0.28224$ \\
\hline $\mathrm{NO}_{2}^{-}$ & 0.20 \\
\hline
\end{tabular}

Table A.16-11

INPUT - 241-AW-101

\begin{tabular}{|l|c|}
\hline \multicolumn{1}{|c|}{ Component } & $\begin{array}{c}\text { Concentration } \\
\text { (M) }\end{array}$ \\
\hline $\mathrm{Na}^{+}$ & 5.513 \\
\hline $\mathrm{Cs}^{+}$ & $1 \mathrm{E}-05$ \\
\hline $\mathrm{H}^{+}$ & $3.7 \mathrm{E}-15$ \\
\hline $\mathrm{Rb}^{+}$ & -- \\
\hline $\mathrm{K}^{+}$ & 0.506 \\
\hline & \\
\hline $\mathrm{OH}^{-}$ & $2.690-0.1595$ \\
\hline $\mathrm{NO}_{3}{ }^{-}$ & 1.531 \\
\hline $\mathrm{NO}_{2}{ }^{-}$ & 1.274 \\
\hline $\mathrm{SO}_{4}{ }^{-}$ & 0.003 \\
\hline $\mathrm{Al}^{+}(\mathrm{OH})_{4}^{-}$ & 0.574 \\
\hline $\mathrm{PO}_{4}{ }^{-}$ & 0.006 \\
\hline $\mathrm{F}^{-}$ & 0.033 \\
\hline $\mathrm{Cl}$ & 0.088 \\
\hline
\end{tabular}

Table A.16-10

RESULTS - MVST-29

\begin{tabular}{|c|c|}
\hline $\begin{array}{c}\mathbf{C} \\
\text { (mmol Cs/L) }\end{array}$ & $\begin{array}{c}\mathbf{Q} \\
\text { (mmol Cs/g CST) }\end{array}$ \\
\hline $8.84 \mathrm{E}-01$ & $3.11 \mathrm{E}-01$ \\
\hline $1.49 \mathrm{E}-01$ & $1.02 \mathrm{E}-01$ \\
\hline $2.86 \mathrm{E}-02$ & $2.28 \mathrm{E}-02$ \\
\hline $7.08 \mathrm{E}-03$ & $5.83 \mathrm{E}-03$ \\
\hline $1.41 \mathrm{E}-03$ & $1.17 \mathrm{E}-03$ \\
\hline $2.83 \mathrm{E}-04$ & $2.35 \mathrm{E}-04$ \\
\hline $5.65 \mathrm{E}-05$ & $4.70 \mathrm{E}-05$ \\
\hline $1.13 \mathrm{E}-05$ & $9.40 \mathrm{E}-06$ \\
\hline $2.12 \mathrm{E}-06$ & $1.76 \mathrm{E}-06$ \\
\hline
\end{tabular}

Table A.16-12

RESULTS - 241-AW-101

\begin{tabular}{|c|c|}
\hline $\mathbf{C}$ & $\begin{array}{c}\mathbf{Q} \\
\text { (mg Cs/L) }\end{array}$ \\
\hline 1.84 & 2.15 \\
\hline 0.606 & 0.724 \\
\hline 0.121 & 0.145 \\
\hline 0.0362 & 0.0436 \\
\hline 0.00602 & 0.00728 \\
\hline 0.00181 & 0.00218 \\
\hline 0.000362 & 0.000436 \\
\hline
\end{tabular}




\section{$\underline{\text { Average and Bounding SRS Wastes }}$}

In addition to the previous isotherms, Beck, Anthony, and Wang required isotherms for SRS wastes. SRS salt wastes fall into three categories: average, high hydroxide, and high nitrate. Each waste type is also evaluated at very conservative concentrations of $\mathrm{K}^{+}$and $\mathrm{Cs}^{+}$. The compositions used for this study are based on Table 5.1-4 of the Salt Team Assumptions and Bases document (Reference 29) and more detail on how the bounding values were chosen are in Reference 46.

\section{Average SRS Salt Waste}

Table A.16-13

INPUT

\begin{tabular}{|l|c|c|}
\hline \multicolumn{1}{|c|}{ Component } & $\begin{array}{c}\text { Nominal } \\
(\mathbf{M})\end{array}$ & $\begin{array}{c}\text { Bounding } \\
(\mathbf{M})\end{array}$ \\
\hline $\mathrm{Na}^{+}$ & 5.6 & 5.465 \\
\hline $\mathrm{Cs}^{+}$ & $1.4 \mathrm{E}-04$ & $7.0 \mathrm{E}-04$ \\
\hline $\mathrm{H}^{+}$ & $5.24 \mathrm{E}-15$ & $5.24 \mathrm{E}-15$ \\
\hline $\mathrm{K}^{+}$ & 0.015 & 0.150 \\
\hline & & \\
\hline $\mathrm{OH}^{-}$ & $1.91+0.00414$ & $1.91+0.00470$ \\
\hline $\mathrm{NO}_{3}{ }^{-}$ & $2.164 *$ & $2.164 *$ \\
\hline $\mathrm{NO}_{2}{ }^{-}$ & 0.52 & 0.52 \\
\hline $\mathrm{Al}_{(}(\mathrm{OH})_{4}{ }^{-}$ & 0.31 & 0.31 \\
\hline $\mathrm{CO}_{3}{ }^{-}$ & 0.16 & 0.16 \\
\hline $\mathrm{SO}_{4}{ }^{-}$ & 0.15 & 0.15 \\
\hline $\mathrm{Cl}^{-}$ & 0.025 & 0.025 \\
\hline $\mathrm{F}^{-3}$ & 0.032 & 0.032 \\
\hline $\mathrm{PO}_{4}^{-3}$ & 0.010 & 0.010 \\
\hline \multicolumn{2}{|c|}{ *includes $\mathrm{C}_{2} \mathrm{O}_{4}{ }^{-}$and $\mathrm{SiO}_{3}{ }^{-}=2 *(0.008+0.004)$} \\
\end{tabular}

Table A.16-14

RESULTS

\begin{tabular}{|c|c|c|c|}
\hline \multicolumn{2}{|c|}{ Nominal } & \multicolumn{2}{c|}{ Bounding } \\
\hline $\begin{array}{c}\mathbf{C} \\
(\mathbf{m m o l} \mathbf{~ C s} / \mathbf{L})\end{array}$ & $\begin{array}{c}\mathbf{Q} \\
(\mathbf{m m o l} \mathbf{C s} / \mathbf{g} \mathbf{C S T})\end{array}$ & $\begin{array}{c}\mathbf{C} \\
(\mathbf{m m o l} \mathbf{C s} / \mathbf{L})\end{array}$ & $\begin{array}{c}\mathbf{Q} \\
(\mathbf{m m o l} \mathbf{C s} / \mathbf{g} \mathbf{C S T})\end{array}$ \\
\hline $6.31 \mathrm{E}-01$ & $4.19 \mathrm{E}-01$ & 2.75 & $5.10 \mathrm{E}-01$ \\
\hline $7.30 \mathrm{E}-02$ & $1.34 \mathrm{E}-01$ & $5.31 \mathrm{E}-01$ & $3.38 \mathrm{E}-01$ \\
\hline $1.90 \mathrm{E}-02$ & $4.20 \mathrm{E}-02$ & $9.29 \mathrm{E}-02$ & $1.14 \mathrm{E}-01$ \\
\hline $4.61 \mathrm{E}-03$ & $1.08 \mathrm{E}-02$ & $1.73 \mathrm{E}-02$ & $2.54 \mathrm{E}-02$ \\
\hline $9.14 \mathrm{E}-04$ & $2.17 \mathrm{E}-03$ & $3.41 \mathrm{E}-03$ & $5.18 \mathrm{E}-03$ \\
\hline $1.82 \mathrm{E}-04$ & $4.35 \mathrm{E}-04$ & $6.80 \mathrm{E}-04$ & $1.04 \mathrm{E}-03$ \\
\hline $3.65 \mathrm{E}-05$ & $8.71 \mathrm{E}-05$ & $1.70 \mathrm{E}-04$ & $2.60 \mathrm{E}-04$ \\
\hline $9.12 \mathrm{E}-06$ & $2.18 \mathrm{E}-05$ & $3.40 \mathrm{E}-05$ & $5.20 \mathrm{E}-05$ \\
\hline $1.82 \mathrm{E}-06$ & $4.35 \mathrm{E}-06$ & $6.80 \mathrm{E}-06$ & $1.04 \mathrm{E}-05$ \\
\hline
\end{tabular}




\section{High Hydroxide SRS Waste}

Table A.16-15

INPUT

\begin{tabular}{|l|c|c|}
\hline \multicolumn{1}{|c|}{ Component } & $\begin{array}{c}\text { Nominal } \\
(\mathbf{M})\end{array}$ & $\begin{array}{c}\text { Bounding } \\
(\mathbf{M})\end{array}$ \\
\hline $\mathrm{Na}^{+}$ & 5.6 & 5.48 \\
\hline $\mathrm{Cs}^{+}$ & $3.7 \mathrm{E}-04$ & $7.0 \mathrm{E}-04$ \\
\hline $\mathrm{H}^{+}$ & $3.25 \mathrm{E}-15$ & $3.25 \mathrm{E}-15$ \\
\hline $\mathrm{K}^{+}$ & 0.030 & 0.150 \\
\hline & & \\
\hline $\mathrm{OH}^{-}$ & $3.05+0.00237$ & $3.05+.00270$ \\
\hline $\mathrm{NO}_{3}{ }^{-}$ & 1.124 & 1.124 \\
\hline $\mathrm{NO}_{2}{ }^{-}$ & 0.74 & 0.74 \\
\hline $\left.\mathrm{Al}_{(\mathrm{OH}}\right)_{4}^{-}$ & 0.27 & 0.27 \\
\hline $\mathrm{CO}_{3}{ }^{-}$ & 0.17 & 0.17 \\
\hline $\mathrm{SO}_{4}{ }^{-}$ & 0.030 & 0.030 \\
\hline $\mathrm{Cl}^{-}$ & 0.010 & 0.010 \\
\hline $\mathrm{F}^{-}$ & 0.010 & 0.010 \\
\hline $\mathrm{PO}_{4}{ }^{-3}$ & 0.008 & 0.008 \\
\hline \multicolumn{2}{|c|}{ *includes $\mathrm{C}_{2} \mathrm{O}_{4}{ }^{-}$and $\mathrm{SiO}_{3}{ }^{=}=2 *(0.008+0.004)$}
\end{tabular}

Table A.16-16

RESULTS

\begin{tabular}{|c|c|c|c|}
\hline \multicolumn{2}{|c|}{ Nominal } & \multicolumn{2}{|c|}{ Bounding } \\
\hline $\begin{array}{c}\mathrm{C} \\
(\mathrm{mmol} \mathrm{Cs} / \mathrm{L})\end{array}$ & $\frac{\mathrm{Q}}{(\mathrm{mmol} \mathrm{Cs} / \mathrm{g} \text { CST) }}$ & $\begin{array}{c}\mathrm{C} \\
(\mathrm{mmol} \mathrm{Cs} / \mathrm{L})\end{array}$ & $\begin{array}{c}\text { Q } \\
(\mathrm{mmol} \mathrm{Cs} / \mathrm{g}\end{array}$ \\
\hline $7.70 \mathrm{E}-01$ & $4.60 \mathrm{E}-01$ & 2.74 & $5.23 \mathrm{E}-01$ \\
\hline $2.19 \mathrm{E}-01$ & $3.03 \mathrm{E}-01$ & $5.16 \mathrm{E}-01$ & $3.68 \mathrm{E}-01$ \\
\hline $4.60 \mathrm{E}-02$ & $1.08 \mathrm{E}-01$ & $8.53 \mathrm{E}-02$ & $1.29 \mathrm{E}-01$ \\
\hline $8.38 \mathrm{E}-03$ & $2.32 \mathrm{E}-02$ & $1.56 \mathrm{E}-02$ & $2.89 \mathrm{E}-02$ \\
\hline $1.64 \mathrm{E}-03$ & $4.71 \mathrm{E}-03$ & $3.05 \mathrm{E}-03$ & $5.90 \mathrm{E}-03$ \\
\hline $3.27 \mathrm{E}-04$ & $9.45 \mathrm{E}-04$ & $6.08 \mathrm{E}-04$ & $1.18 \mathrm{E}-03$ \\
\hline $8.18 \mathrm{E}-05$ & $2.36 \mathrm{E}-04$ & $1.52 \mathrm{E}-04$ & $2.96 \mathrm{E}-04$ \\
\hline $1.64 \mathrm{E}-05$ & $4.73 \mathrm{E}-05$ & $3.04 \mathrm{E}-05$ & $5.93 \mathrm{E}-05$ \\
\hline 4.09E-06 & $1.18 \mathrm{E}-05$ & $7.59 \mathrm{E}-06$ & $1.48 \mathrm{E}-05$ \\
\hline
\end{tabular}




\section{High Nitrate SRS Waste}

Table A.16-17

INPUT

\begin{tabular}{|l|c|c|}
\multicolumn{1}{|c|}{ Component } & $\begin{array}{c}\text { Nominal } \\
(\mathbf{M})\end{array}$ & $\begin{array}{c}\text { Bounding } \\
(\mathbf{M})\end{array}$ \\
\hline $\mathrm{Na}^{+}$ & 5.6 & 5.4541 \\
\hline $\mathrm{Cs}^{+}$ & $1.4 \mathrm{E}-04$ & $7.0 \mathrm{E}-04$ \\
\hline $\mathrm{H}^{+}$ & $8.55 \mathrm{E}-15$ & $5.24 \mathrm{E}-15$ \\
\hline $\mathrm{K}^{+}$ & 0.0041 & 0.150 \\
\hline & & \\
\hline $\mathrm{OH}^{-}$ & $1.17+0.00024$ & $1.17+0.00080$ \\
\hline $\mathrm{NO}_{3}^{-}$ & 2.864 & 2.864 \\
\hline $\mathrm{NO}_{2}^{-}$ & 0.37 & 0.37 \\
\hline $\mathrm{Al}^{-}(\mathrm{OH})_{4}^{-}$ & 0.32 & 0.32 \\
\hline $\mathrm{CO}_{3}{ }^{-}$ & 0.16 & 0.16 \\
\hline $\mathrm{SO}_{4}{ }^{-}$ & 0.22 & 0.22 \\
\hline $\mathrm{Cl}^{-}$ & 0.040 & 0.040 \\
\hline $\mathrm{F}^{-}$ & 0.050 & 0.050 \\
\hline $\mathrm{PO}_{4}^{-3}$ & 0.010 & 0.010 \\
\hline
\end{tabular}

*includes $\mathrm{C}_{2} \mathrm{O}_{4}{ }$ and $\mathrm{SiO}_{3}{ }{ }=2 *(0.008+0.004)$

Table A.16-18

RESULTS

\begin{tabular}{|c|c|c|c|}
\hline $\begin{array}{c}\mathbf{C} \\
(\mathbf{m m o l} \mathbf{C s} / \mathbf{L})\end{array}$ & $\begin{array}{c}\mathbf{Q} \\
\text { (mmol Cs/g CST) }\end{array}$ & $\begin{array}{c}\mathbf{C} \\
(\mathbf{m m o l} \\
\mathbf{C s} / \mathbf{L})\end{array}$ & $\begin{array}{c}\mathbf{Q} \\
\text { (mmol Cs/g CST) }\end{array}$ \\
\hline $6.39 \mathrm{E}-01$ & $4.01 \mathrm{E}-01$ & 2.75 & $4.98 \mathrm{E}-01$ \\
\hline $7.78 \mathrm{E}-02$ & $1.24 \mathrm{E}-01$ & $5.42 \mathrm{E}-01$ & $3.16 \mathrm{E}-01$ \\
\hline $1.53 \mathrm{E}-02$ & $2.95 \mathrm{E}-02$ & $9.82 \mathrm{E}-02$ & $1.04 \mathrm{E}-01$ \\
\hline $2.99 \mathrm{E}-03$ & $6.02 \mathrm{E}-03$ & $1.86 \mathrm{E}-02$ & $2.29 \mathrm{E}-02$ \\
\hline $7.44 \mathrm{E}-04$ & $1.51 \mathrm{E}-03$ & $3.66 \mathrm{E}-03$ & $4.67 \mathrm{E}-03$ \\
\hline $1.49 \mathrm{E}-04$ & $3.03 \mathrm{E}-04$ & $7.31 \mathrm{E}-04$ & $9.38 \mathrm{E}-04$ \\
\hline $2.97 \mathrm{E}-05$ & $6.05 \mathrm{E}-05$ & $1.83 \mathrm{E}-04$ & $2.35 \mathrm{E}-04$ \\
\hline $4.96 \mathrm{E}-06$ & $1.01 \mathrm{E}-05$ & $3.65 \mathrm{E}-05$ & $4.69 \mathrm{E}-05$ \\
\hline & & $7.31 \mathrm{E}-06$ & $9.39 \mathrm{E}-06$ \\
\hline
\end{tabular}




\section{Preliminary Sizing}

$\underline{\text { Introduction }}$

This section is divided into two subsections: model description and SRS column design. The first section derives the simple ion-exchange column model and how the isotherms from the TAMU model are applied. The first section describes the necessary mathematical simplifications for generating an analytical solution. The first section concludes with the derivation of the mass transfer coefficient from various bench scale column runs using non-SRS waste. The second section describes the SRS column design by first explaining the mass transfer zone length and cycle time calculation. This section concludes with a comparison between the analytical solution in Matlab to the numerical solution in SPEEDUP.

\section{$\underline{\text { Ion-Exchange Model }}$}

Figure A.16-6 shows the ion-exchange column modeled as two phases: fluid and solid. Solution enters the top of the ion-exchange column at a molar flow rate of $W_{B}$. As the solution moves down the column, the ion-exchange media slowly removes $\mathrm{Cs}^{+}$from the solution at a rate that is proportional to difference between the bulk $\mathrm{Cs}^{+}$concentration and interface $\mathrm{Cs}^{+}$concentration. The proportionality constant is the "lumped" or overall mass transfer coefficient. The driving force for mass transfer decreases throughout the column due to the bulk $\mathrm{Cs}^{+}$concentration decreasing by material balance.

\section{Equations}

Equations 1 and 2 constitute material balances over a differential element for both the solid and fluid phases in the column, Figure A.16-6. These two equations state that the uptake of $\mathrm{Cs}^{+}$on the resin is entirely a function of mass transfer from the liquid phase to the solid phase, and the loss of $\mathrm{Cs}^{+}$from the bulk is entirely the result of the same mass transfer. Equations 3 and 4 represent the boundary conditions for the system of equations. The first boundary condition states that at time $=0$ the ion-exchange material has loaded no $\mathrm{Cs}^{+}$. The second boundary condition states that the starting concentration at $\mathrm{z}=0$ is the bulk $\mathrm{Cs}^{+}$concentration. 


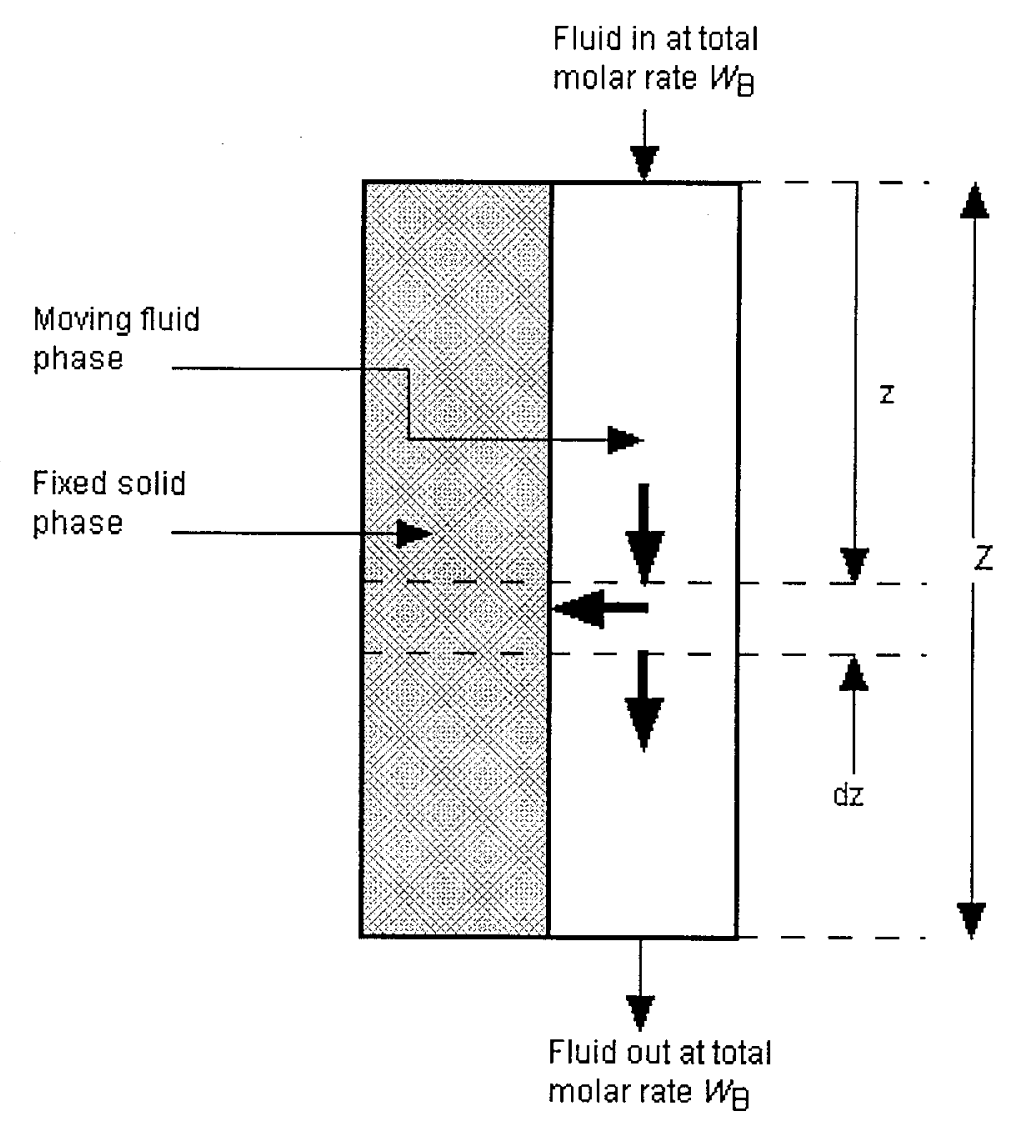

Figure A.16-6 Schematic showing the material balance over a differential element of fluid and resin. Cs moves down the column and the resistance to mass transfer is lumped into a single coefficient. 


$$
\underbrace{(1-\varepsilon) S d z \frac{\partial c_{A s}}{\partial t}}_{\text {[rate of } \mathrm{C}^{+}{ }^{+} \text {uptake on the resin] }}=\underbrace{\left(k_{x a}\right)\left(x_{A}-x_{A 0}\right) S d z}_{\text {[mass transfer rate] }}
$$

$$
\underbrace{\varepsilon S c \frac{\partial x_{A}}{\partial t}}_{\text {[rate of } \mathrm{Cs}^{+} \text {change in the fluid] }}=\underbrace{-\mathcal{W}_{B} \frac{\partial x_{A}}{\partial z}}_{\text {[flow } \mathrm{C}_{\varepsilon^{+}}^{+} \text {(in) - flow } \mathrm{Cs}^{+} \text {(out)] }} \underbrace{-S\left(k_{x a}\right)\left(x_{A}-x_{A o}\right)}_{\text {[mass transfer rate] }}
$$

B.C. 1: at $t=0, c_{A s}=0$ for all $z>0$

$$
\text { B.C. 2: at } z=0, x_{A}=x_{A 1} \text { for all } t>0
$$

Table A.16-19 defines the parameters used in Equations 1 through 4. An analytical solution to the above equations exists as long as the above equations are recast into a different form. The following manipulations recast the above equations into the appropriate form. The manipulations consist of two time scalings and one distance scaling. The first step in solving this problem is to scale time with respect to the time necessary for solution to travel to the end of the column, Equation 5. Equation 5 states that time zero is relative to the first moment resin sees waste solution.

Table A.16-19. Ion-Exchange Model Parameters

\begin{tabular}{|l|l|l|}
\hline Symbol & Definition & Units \\
\hline$\Pi$ & volume fraction of column occupied by liquid & $\%$ \\
\hline $\mathrm{S}$ & cross sectional area of empty column & $\mathrm{cm}^{2}$ \\
\hline $\mathrm{C}_{\mathrm{As}}$ & moles of A absorbed per unit volume of solid phase & $\mathrm{moles} / \mathrm{cm}^{3}$ \\
\hline $\mathrm{x}_{\mathrm{A}}$ & bulk mole fraction of A in fluid phase & $\%$ \\
\hline $\mathrm{X}_{\mathrm{Ao}}$ & Interfacial mole fraction of A in fluid phase in equilibrium $\mathrm{with} \mathrm{c}_{\mathrm{As}}$ & $\%$ \\
\hline $\mathrm{k}_{\mathrm{xa}}$ & fluid phase mass transfer coefficient & $\mathrm{moles} / \mathrm{hr} / \mathrm{cm}^{3}$ \\
\hline $\mathrm{W}_{\mathrm{B}}$ & molar flow rate of solution through resin & $\mathrm{moles} / \mathrm{hr}$ \\
\hline $\mathrm{M}$ & slope of linearized isotherm & $(\%) \mathrm{cm}^{3} / \mathrm{moles}^{3}$ \\
\hline $\mathrm{C}$ & total molar concentration & $\mathrm{moles} / \mathrm{cm}^{3}$ \\
\hline $\mathrm{Z}$ & Distance into column & $\mathrm{Cm}$ \\
\hline $\mathrm{x}_{\mathrm{A} 1}$ & entry mole fraction of A in fluid phase & $\%$ \\
\hline
\end{tabular}




$$
t^{\prime}=t-z\left(\frac{\varepsilon S_{C}}{\mathcal{W}_{B}}\right)
$$

\section{Adjustment for Scaled Time}

Equations 6 through 12 represent the utilization of Equation 5 in Equations 1 through 4 . This system of equations is not coupled until a relationship is defined for the interphase equilibrium distribution, Equation 8 . The interphase equilibrium distribution relates how much cesium is on the resin based on the interface cesium concentration. This relationship is derived from batch loading $(\mathrm{Kd})$ experiments where the ending cesium concentration is assumed to be in equilibrium with the cesium loaded onto the resin. All of the loading information used in this work resulted from the TAMU model. Equation 8 reflects a linear isotherm. The cesium concentration in SRS waste will span non-linear regions of the isotherm. The reader should also note that the equilibrium loading is a function of cesium concentration only. In complicated systems, the isotherms could be a function of numerous other ions resulting in a multiphase isotherm. The model, as it exists today, is incapable of handling a multiphase isotherm.

$$
\begin{gathered}
\left(\frac{\partial c_{A s}}{\partial t^{\prime}}\right)_{z}=\frac{\left(k_{x a}\right)}{1-\varepsilon}\left(x_{A}-x_{A o}\right) \\
\left(\frac{\partial x_{A}}{\partial z}\right)_{t^{\prime}}=\frac{S\left(k_{x a}\right)}{\mathcal{W}_{B}}\left(x_{A}-x_{A o}\right) \\
x_{A o}=m c_{A s}
\end{gathered}
$$

Substituting the interphase equilibrium distribution into the continuity/mass transfer equations results in a set of coupled partial differential equations. The goal of scaling the system of equations is to convert the mathematics into a set of equations with a known solution. The following section performs the last conversion to dimensionless time and space. 


$$
\begin{gathered}
\left(\frac{\partial c_{A s}}{\partial t^{\prime}}\right)_{z}=\frac{\left(k_{x a}\right)}{1-\varepsilon}\left(x_{A}-m c_{A s}\right) \\
\left(\frac{\partial x_{A}}{\partial z}\right)_{t^{\prime}}=\frac{S\left(k_{x a}\right)}{\mathcal{W}_{B}}\left(x_{A}-m c_{A s}\right)
\end{gathered}
$$

B.C. 1: at $t^{\prime}=0, c_{A s}=0$ for all $z>0$

B.C. 2: at $z=0, x_{A}=x_{A 1}$ for all $t^{\prime}>0$

\section{Adjustment for Dimensionless Time and Distance}

The ion-exchange model equations have an analytical solution, Equation 21, provided the problem can be cast into Equations 13 through 16. Utilization of a reduced fluid $\mathrm{Cs}^{+}$ concentration (Equation 17), reduced resin loading (Equation 18), reduced column length (Equation 19), and reduced time (Equation 20) provides the necessary scaling to apply the known analytical solution, Equation 21. Equations $17-20$ provide insight into the relationships among the various model parameters. One should notice that the "Iumped" or overall mass transfer coefficient is used to scale both column length and time in the column. The "lumped" mass transfer coefficient has the most effect in changing the shape of the breakthrough curve due to its relationship with column length and time. Other model parameters simply shift the breakthrough behavior in time. 


$$
\begin{gathered}
\frac{\partial X}{\partial \zeta}=-(X-Y) \\
\frac{\partial Y}{\partial \tau}=(X-Y)
\end{gathered}
$$

B.C. 1: at $\tau=0, Y=0$ for all $\zeta$

B.C. 2: at $\zeta=0, X=1$ for all $\tau$

$$
X=\frac{x_{A}}{x_{A 1}}
$$

$$
Y=\frac{m c_{A s}}{x_{A 1}}
$$

$$
\begin{gathered}
\zeta=\frac{z S\left(k_{x a}\right)}{W_{B}} \\
\tau=\frac{m t^{\prime}\left(k_{x a}\right)}{1-\varepsilon}
\end{gathered}
$$




\section{Ion-Exchange Model Solution}

Equation 21 represents the solution of the coupled partial differential equations, 13-16 (Reference 30 ). This equation expresses how the bulk $\mathrm{Cs}^{+}$concentration will vary as a function of both column position $(\Theta)$ and time $(\beta)$. This equation can be solved with a spreadsheet or any software package capable of evaluating a zero-order Bessel function of the first kind, $\mathrm{J}_{0}(\mathrm{ix})$. MATLAB ${ }^{\mathrm{TM}}$ was chosen due to the author's experience. The integral must be evaluated numerically, and a trapezoidal numerical integration was used with the column length divided into 10000 increments. In order to calculate solutions from this equation, one picks a column length and evaluates the integral at various times of interest.

$$
X(\zeta, \tau)=1-\int_{0}^{\zeta} \exp (-\tau-\zeta) J_{o}(i \sqrt{4 \tau \zeta}) d \zeta
$$

The remaining discussion in this section focuses on the information provided to this model and the calculations required to convert this information into a form usable by the model.

Once the experimental column breakthrough information is provided to the model along with the appropriate isotherm, the only parameter to fit is the "lumped" mass transfer coefficient. The goal of this analysis is to extract "lumped" mass transfer coefficients from various experimental column breakthrough curves and apply these mass transfer coefficients to the proposed SRS column design and waste. The ion-exchange model approach used here is very similar to designing a heat exchanger by knowing an overall heat transfer coefficient. As long as the chief mechanism for heat transfer does not change during the design, an overall heat transfer coefficient is valid. If the design changes so that another resistance mechanism is dominating, the overall heat transfer coefficient will lead to only approximate exchanger lengths. The same conditions hold for the utilization of this ion-exchange model. Provided that the mechanism for mass transfer remains intra-particle, the overall mass transfer coefficient will capture most of the important dynamics for column design. If a design parameter changed the resistance mechanism, the overall mass transfer coefficient would not reflect this.

\section{Equilibrium $\mathrm{Cs}^{+}$Loading from TAMU Model}

The primary use of the TAMU model is to calculate the equilibrium $\mathrm{Cs}^{+}$loading as a function of the various waste constituents in DSSF-5 (Reference 43), MVST W-29, Hanford, and MVST W-27 (Reference 47). Understanding how the various waste stream components effect the equilibrium loading is critical in comparing breakthrough curves from these wastes to SRS waste. The primary transient constituent is cesium. As waste 
solution passes down the column, the ion-exchange resin captures cesium such that the waste cesium concentration decreases with column length. To successfully model the ionexchange process, one needs to quantify the equilibrium loading as a function of cesium concentration. Other ions also effect the equilibrium loading: strontium and potassium. Therefore, to adequately model an ion-exchange column, one needs to understand how changes in $\mathrm{Cs}^{+}, \mathrm{Sr}^{++}$, and $\mathrm{K}^{+}$concentrations effect the maximum cesium loading on the resin. The TAMU model also serves to standardize the breakthrough curves from the various DOE waste streams so that general observations can be made. Prior to the TAMU model, comparing different breakthrough curves from different waste streams was very difficult. General conclusions could not be made due to not knowing the effects of column operating conditions and isotherm behavior.

Utilization of TAMU results required converting units primarily from molarity to mole fraction for incorporation into the ion-exchange column model. The following section describes this unit conversion. Once the units are consistent with the ion-exchange model, the isotherms were linearized to obtain the isotherm slope required in Equation 8. The linearization is performed by a simple linear regression routine in MATLAB ${ }^{\mathrm{TM}}$. Table A.16-20 lists the isotherm slopes for the various wastes utilized in the ion-exchange | column design.

Table A.16-20. Linearized isotherm slopes for various wastes.

\begin{tabular}{|l|l|}
\hline Waste & Isotherm Slope \\
\hline SANDIA DSSF-5 & 0.012782 \\
\hline ORNL: MVST W-29 & 0.042469 \\
\hline Hanford 241-AW-101 & 0.016997 \\
\hline ORNL: MVST W-29 & 0.16788 \\
\hline SRS: 5.6M & 0.033277 \\
\hline SRS: $6.4 \mathrm{M}$ & 0.036106 \\
\hline SRS: avg & 0.027679 \\
\hline SRS: high $\mathrm{OH}^{-1}$ & 0.027002 \\
\hline SRS: high $\mathrm{NO}_{3}^{-1}$ & 0.020231 \\
\hline SRS: high $\mathrm{K}^{+1}$ & 0.037482 \\
\hline SRS: avg $+\mathrm{Sr}^{+2}$ & 0.037183 \\
\hline SRS: high $\mathrm{K}^{+1}+\mathrm{Sr}^{+2}$ & 0.257016 \\
\hline SRS: high $\mathrm{OH}^{-1}+\mathrm{Sr}^{+2}$ & 0.029667 \\
\hline
\end{tabular}

\section{$\underline{\text { Unit Conversion Calculation }}$}

Before calculations can be performed with the ion-exchange model, the output information from the TAMU model must be converted from concentration units to mole fraction units. This conversion utilizes a 1 liter basis and the calculated solution density in order to determine the total number of moles of each waste constituent and water. The 
total mass of solution, $\mathrm{M}_{\mathrm{T}}$, is calculated by multiplying the density by the 1 liter basis. The mass of each constituent, $\mathrm{M}_{\mathrm{i}}$, is determined by multiplying the concentration of each constituent at the end of the batch $\mathrm{K}_{\mathrm{d}}$ experiment, $\mathrm{c}_{\mathrm{i}}$ (moles/liter), by its molecular weight. The difference between the total mass and the constituent mass is the mass of water, $\mathrm{M}_{\mathrm{H} 20}$, contained in the 1 liter basis. The calculation of $\mathrm{Cs}^{+}$mole fraction, $\mathrm{x}_{\mathrm{A}}$, is now accomplished by summing both water and constituent moles and dividing this amount into the moles of cesium. The TAMU output for the four non-SRS waste streams is presented in the "Isotherm Development" section.

$$
\begin{gathered}
M_{T}[\mathrm{~kg}]=\left(\rho \frac{\mathrm{kg}}{\mathrm{m}^{3}}\right)\left(\frac{1 \mathrm{~m}^{3}}{1000 \mathrm{~L}}\right)(1 \text { liter }) \\
M_{i}[\mathrm{~kg}]=\left(c_{i}\right)\left(\mathrm{MW}_{i}\right)(1 \text { liter })\left(\frac{1 \mathrm{~kg}}{1000 \mathrm{~g}}\right) \\
M_{\mathrm{H}_{2} \mathrm{o}}[\mathrm{kg}]=M_{T}-\sum_{i=1}^{n} M_{i} \\
m_{\mathrm{H}_{2} \mathrm{o}}[\mathrm{moles}]=M_{\mathrm{H}_{2} 0}\left(\frac{1000 \mathrm{~g}}{1 \mathrm{~kg}}\right)\left(\frac{1 \mathrm{~mole} \mathrm{H}_{2} \mathrm{O}}{18 \mathrm{~g} \mathrm{H}_{2} \mathrm{O}}\right) \\
x_{A}=\frac{m_{\mathrm{Cos}^{+}}}{m_{\mathrm{H}_{2} 0}+\sum_{i=1}^{n} m_{i}} \\
m_{i}\left[\mathrm{moles}=\left(c_{i}\right)(1 \text { liter })\right.
\end{gathered}
$$

\section{Mass Transfer Coefficient Derivation}

The purpose of modeling the DSSF-5 (Reference 43), MVST W-29 (Reference 33), Hanford (Reference 33), and MVST W-27 (Reference 33) column runs is to tune the 
model to experimental breakthrough curves by varying the model parameters: mass transfer coefficient $\left(k_{x a}\right)$, liquid void fraction $(\Pi)$, and isotherm slope $(m)$. Although the slope of the linearized isotherm has been calculated from the TAMU model, a slightly different slope might yield much better model/column comparisons. Allowing the slope to change slightly is justified considering the fact that the linearization region is arbitrary and all mass transfer mechanisms have been lumped into a single term. Routines to minimize model/column differences by varying model parameters did not exist and were created (Reference 34 ). MATLAB ${ }^{\mathrm{TM}}$ provides a toolbox for performing this optimization (curve fit) once a penalty function $(\mathrm{F})$ is defined. Equation 28 describes the penalty function used to drive the optimization routine in MATLAB $^{\mathrm{TM}}$. This function inputs the isotherm slope $(m)$, mass transfer coefficient $\left(k_{x a}\right)$, and liquid volume fraction $(\Pi)$. The output of the function is the average relative percent difference between the model and column data at $10 \%$ and $50 \%$ breakthrough. The optimization could have included more data points for comparison, but two data points provides enough information to center the ion-exchange model output onto the column breakthrough data (Reference 43). Therefore, the decision was made to fit the "lumped" parameter ion-exchange model to the mid-breakthrough behavior (10\% and $50 \%)$.

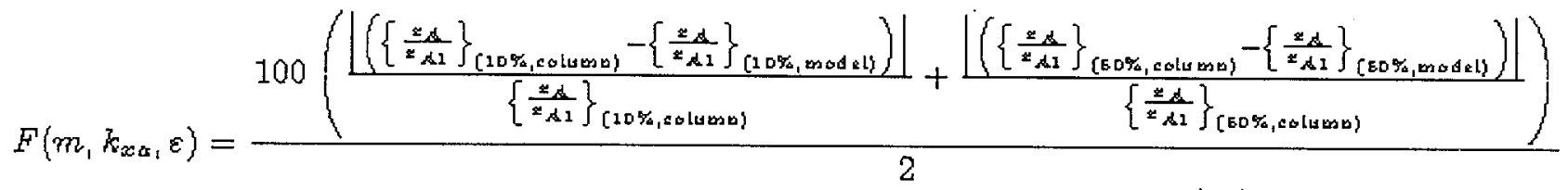

Figures A.16-7, Figure A.16-8, Figure A.16-9, and Figure A.16-10 compare the predicted model breakthrough curves against experimental data. Table A.16-21 and show column operating parameters and breakthrough information used in the four bench-scale column runs. Table A.16-23 shows the final isotherm slope, mass transfer coefficient, and liquid volume fraction arrived at by the optimization routine. The SRS column design will utilize the average mass transfer coefficient in Table A.16-23. Figure 11 shows that the final and initial isotherm slopes were close on all of the bench scale run except the MVST $\mathrm{W}-27$. The right-hand graph in Figure 11 plots the liquid volume fraction arrived at by the optimization routine. The MVST W-27 bench scale run provided the most trouble in terms of the differences between initial parameter guesses and final optimized values. The optimization routine was very slow and time consuming, so that time constraints played a role in the degree of fit. The optimization routine could run longer for better results. The benefit of this extended optimization search must be weighed against the regression improvement. The goal of this work was to determine the mass transfer zone length by calculating a mass transfer coefficient. Fine-tuning of this coefficient should be left to the more complicated models. 


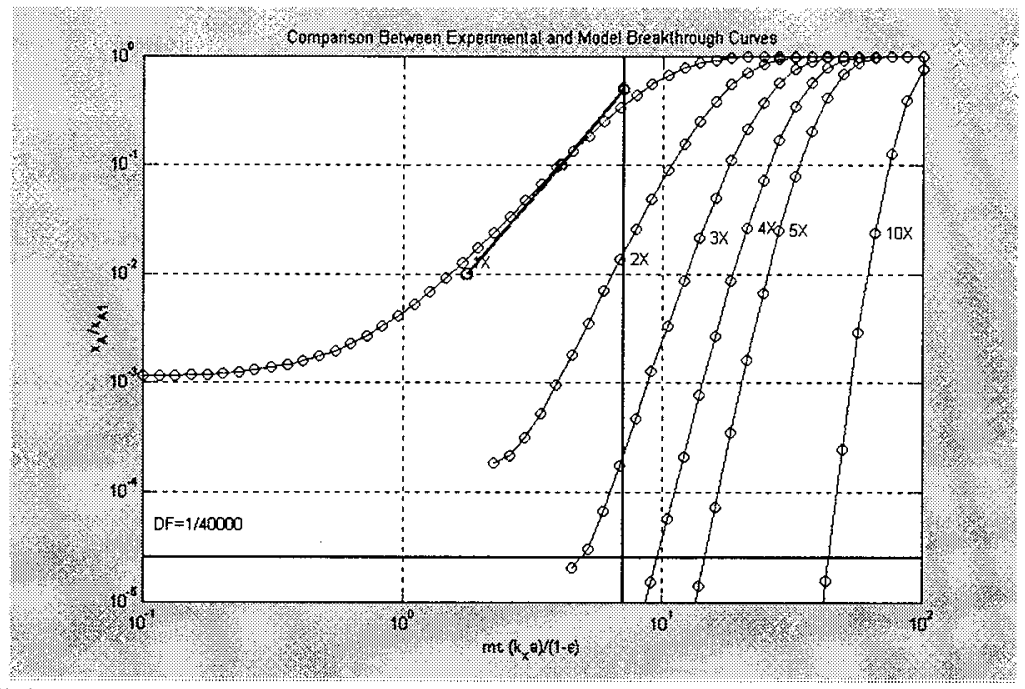

Figure A.16-7 Column breakthrough curves presented on a reduced timescale for DSSF-5 Simulant at $3.75 \mathrm{CV} / \mathrm{hr}$ and room temperature are shown with 3 data points. Model results for the original column and subsequent column lengths are labeled at $1 \mathrm{X}, 2 \mathrm{X}, 3 \mathrm{X}, \mathbf{4 X}, 5 \mathrm{X}$, and 10X. The $\mathrm{x}$-axis label represents the right-hand side of Equation 20.

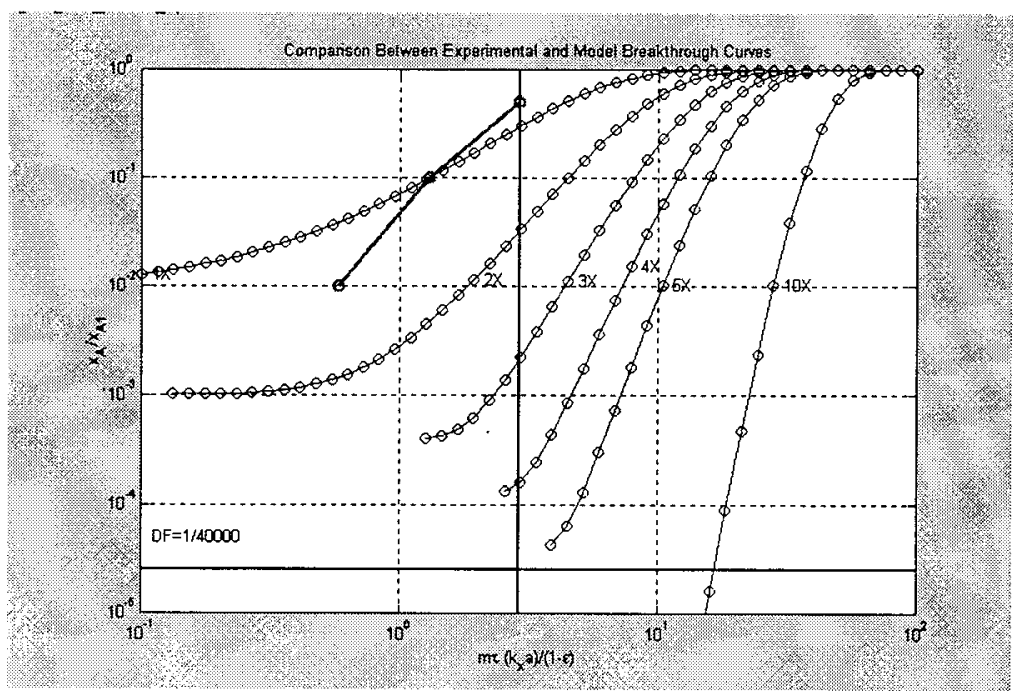

Figure A.16-8 Column breakthrough curves presented on a reduced timescale for MVST W$29, \mathrm{pH} 12.6, \mathrm{Cs}=4.4 \mathrm{E}-6 \mathrm{M}, 6.0 \mathrm{CV} / \mathrm{hr}$, and room temperature are shown with 3 data points. Model results for the original column and subsequent column lengths are labeled at $1 \mathrm{X}, 2 \mathrm{X}$, $3 \mathrm{X}, 4 \mathrm{X}, 5 \mathrm{X}$, and $10 \mathrm{X}$. The $\mathrm{X}$-axis label represents the right-hand side of Equation 20. 


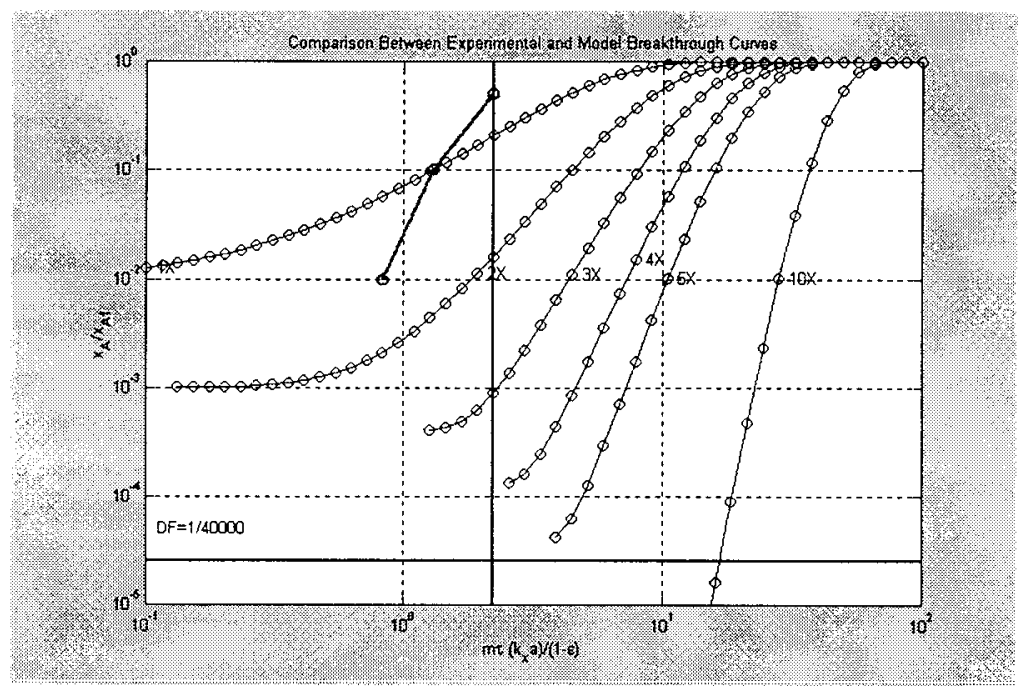

Figure A.16-9 Column breakthrough curves presented on a reduced timescale for Hanford 241-AW-101, Cs=0.00001N , 6.3 CV/hr, and room temperature are shown with 3 data points. Model results for the original column and subsequent column lengths are labeled at $1 X, 2 X, 3 X, 4 X, 5 X$, and 10X. The $X$-axis label represents the right-hand side of Equation 20.

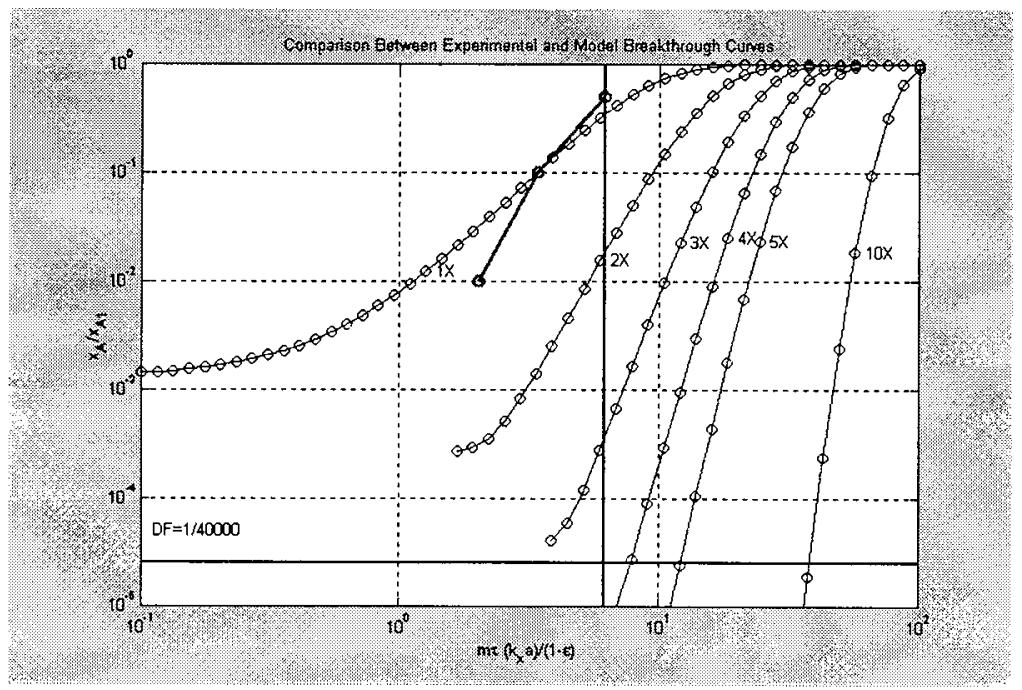

Figure A.16-10 Column breakthrough curves presented on a reduced timescale for MVST$27, \mathrm{pH} 13.3,3 \mathrm{CV} / \mathrm{hr}$, and room temperature are shown with 3 data points. Model results for the original column and subsequent column lengths are labeled at $1 \mathrm{X}, 2 \mathrm{X}, 3 \mathrm{X}, 4 \mathrm{X}, 5 \mathrm{X}$, and 10X. The X-axis label represents the right-hand side of Equation 20. 


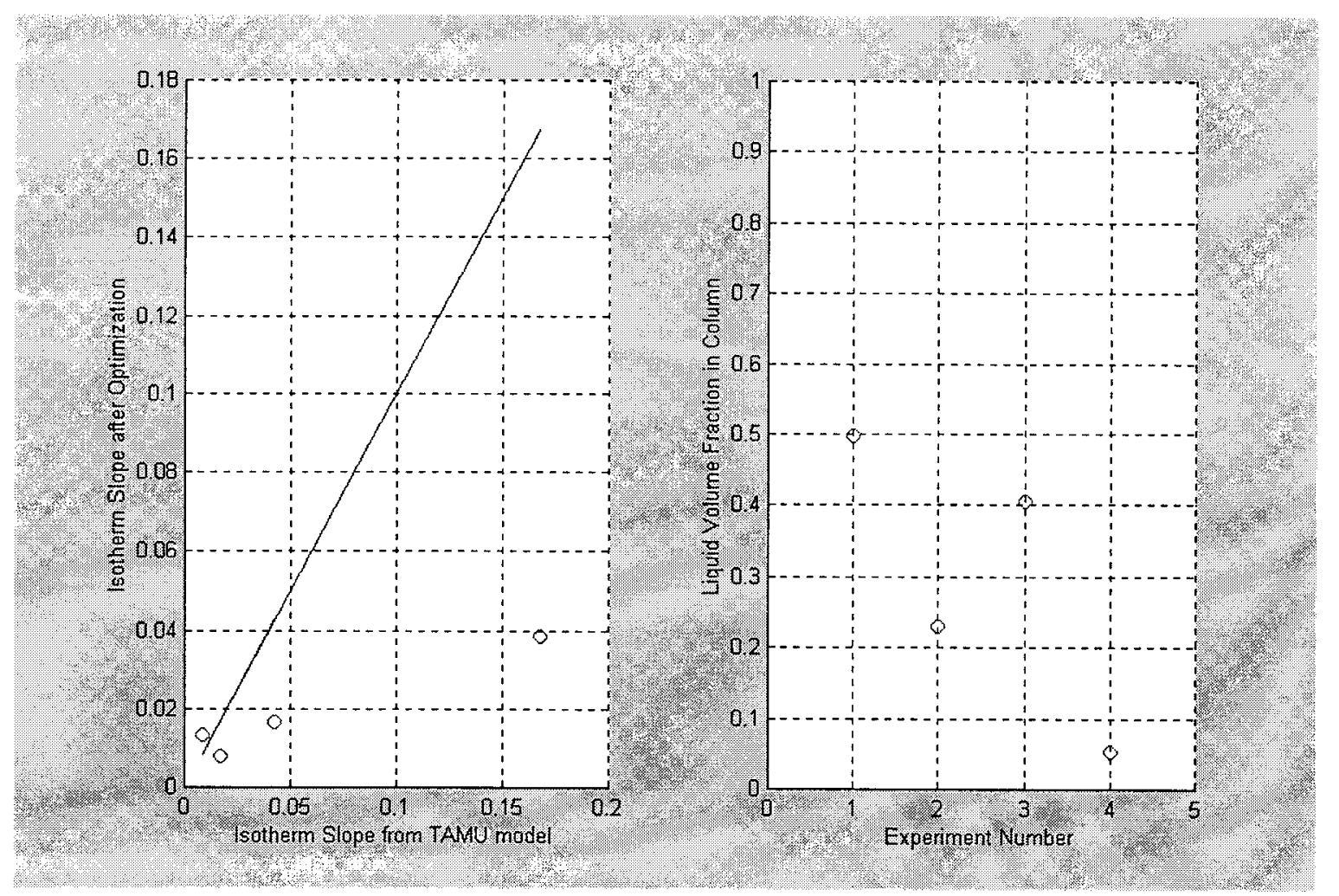

Figure A.16-11. The model is fit to the experimental data by varying the mass transfer coefficient $\left(\mathrm{k}_{\mathrm{xa}}\right)$, the slope of the linear isotherm (m), and the liquid volume fraction in the column (II). The left figure compares the original slopes versus what the optimization routine converged on. Perfect convergence would place all data points on the reference line with slope equal to one. The right figure shows the liquid volume fractions converged on by the optimization routine. The last data point (MVST W-27) on both curves clearly is unacceptable, and work is underway to constrain the optimization search to realistic values. 
Figure A.16-7 shows the breakthrough curves for the column experiment performed at SANDIA (Reference 43) with DSSF-5 waste. Model/column comparison is excellent at $1 \%, 10 \%$, and $50 \%$. The $50 \%$ breakthrough line (vertical) shows that $1 / 40000$ is not reached until 3-4 columns. Figure A.16-8 shows the breakthrough curves for the column experiment performed at Oak Ridge with MVST W-29 waste. Model/column comparison is acceptable at $10 \%$ breakthrough. The $50 \%$ breakthrough line (vertical) shows that $1 / 40000$ is not reached until approximately 5 column lengths. Figure A.16-9 compares model breakthrough data to column data. The Hanford data represents the most challenging comparison with the model only passing through the $10 \%$ breakthrough point. It is worth mentioning that the optimization routine required excessive time to fit model output to experimental data. If longer times had been allowed, the fit most likely would have improved. The goal of this work was to arrive at an overall mass transfer coefficient representative of experimental data. Based on the level of optimization performed, the Hanford experiment would have required 5 columns to obtain a $\mathrm{DF}=40000$. If one assumes that the optimization would have turned the solution counterclockwise eventually, one might suggest that 3-4 columns would be required. Figure A.16-10 shows the model/column comparison for Oak Ridge's MVST W-27 waste. The model offers good agreement with the $10 \%$ and $50 \%$ breakthrough points. Based on the model results, the required DF would occur between 3-4 columns.

Table A.16-21. Four experimental columns were used to obtain a mass transfer coefficient. This table describes the physical setup of each column where $\mathrm{CV}=$ column volume.

\begin{tabular}{|l|l|l|l|l|l|}
\hline & $\begin{array}{l}\text { Column } \\
\text { Diameter }\end{array}$ & $\begin{array}{l}\text { Column } \\
\text { Length }\end{array}$ & Flowrate & Bed Density & Resin \\
\hline Experiment & {$[\mathrm{cm}]$} & {$[\mathrm{cm}]$} & {$[\mathrm{CV} / \mathrm{hr}]$} & {$\left[\mathrm{lb} / \mathrm{ft}^{3}\right]$} & CST Info \\
\hline SANDIA (Ref 43) & 1 & 15.3 & 3.75 & 53.0 & $07398-38 \mathrm{~B}$ \\
\hline $\begin{array}{l}\text { ORNL: MVST W-29 } \\
\text { Ref. 33) }\end{array}$ & 1.5 & 5.9 & 6 & 53.0 & \\
\hline Hanford (Ref. 33) & 1 & 10 & 6.3 & 53.0 & \\
\hline ORNL: W-27 (Ref. 33) & 1.5 & 6.8 & 3 & 53.0 & \\
\hline
\end{tabular}


Table A.16-22. Table showing breakthrough information for each of the four experimental columns. | The ion-exchange model only required limited breakthrough information to perform regressions on mass transfer coefficients. CV corresponds to column volume.

\begin{tabular}{|l|l|l|l|}
\hline & $1 \%$ Breakthrough & $10 \%$ Breakthrough & $50 \%$ Breakthrough \\
\hline Experiment & {$[\mathrm{CV}]$} & {$[\mathrm{CV}]$} & {$[\mathrm{CV}]$} \\
\hline SANDIA (Ref. 43) & 130 & 300 & 525 \\
\hline $\begin{array}{l}\text { ORNL: MVST W-29 } \\
\text { (Ref. 33) }\end{array}$ & 100 & 226 & 505 \\
\hline Hanford (Ref. 33) & 260 & 410 & 700 \\
\hline ORNL: W-27 (Ref. 33) & 114 & 192 & 350 \\
\hline
\end{tabular}

Table A.16-23. Mass transfer coefficients determined by the tuning the IX column model to experimental column breakthrough curves. All mass transfer mechanisms were lumped into a film resistance term weighted by the mass transfer coefficient. The driving force was characterized by the bulk cesium concentration and the surface cesium concentration given by the TAMU loading model

\begin{tabular}{|l|l|l|l|}
\hline Experiment & Mass Transfer Coefficient & Isotherm Slope & Liquid Volume Fraction \\
\hline SANDIA (Ref. 43) & 1.99 & 0.0134 & 0.49 \\
\hline $\begin{array}{l}\text { ORNL: MVST W-29 } \\
\text { (Ref. 33) }\end{array}$ & 1.69 & 0.0165 & 0.23 \\
\hline Hanford (Ref. 33) & 1.88 & 0.00818 & 0.66 \\
\hline ORNL: W-27 (Ref. 33) & 1.52 & 0.0394 & 0.11 \\
\hline
\end{tabular}




\section{CST Ion-Exchange Column Calculations Based on Model Output}

Solution to the ion-exchange column model reveals the bulk cesium concentration as a function of both position and time. Both dependencies are important in determining the length of mass transfer zone and the cycle time for the column.

Figure A.16-12 offers the reader three key pieces of information. First, the length of the mass transfer zone is derived from the breakthrough data by taking a snapshot of the bulk cesium concentration at various column lengths. Second, the ion-exchange column cycle times can be calculated by measuring the time for the first column to reach $90 \%$ breakthrough. Finally, the analytical solution (MATLAB ${ }^{\mathrm{TM}}$ ) contained in Equation 21 is compared with the numerical solution to Equations 9-12 (SPEEDUP). The SPEEDUP model is discussed in following sections. The last calculation in this section discusses the effect of waste composition on the breakthrough or cycle times. 


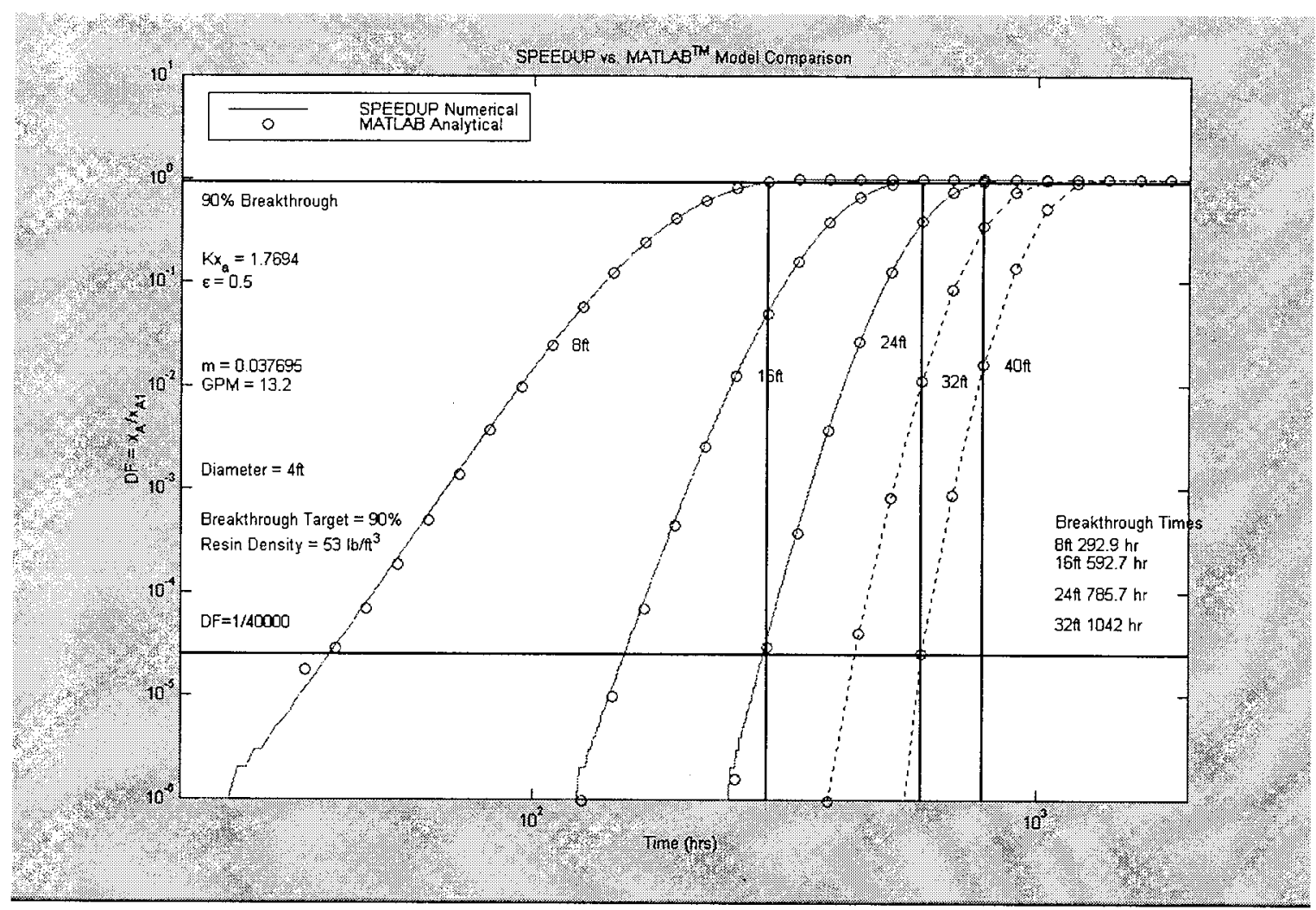

Figure A.16-12. The above figure has three purposes: validate both the MATLAB ${ }^{\text {TM }}$ and SPEEDUP versions of the ion-exchange column model, describe how the column length is determined, and describe how the cycle time is determined. 


\section{Ion-exchange Column Length Determination}

The column length is determined by the length of the mass transfer zone which is defined as the length of column required to contain the cesium wavefront from a DF $=0.9$ $1 / 40000$.

Figure A.16-12 shows the DF range by two horizontal lines marked by "90\% | Breakthrough" and "DF=1/40000". Calculating the mass transfer zone length is accomplished by determining how many feet of column separate these two extremes.

Figure A.16-12 also shows when the 8, 16, and 24-foot sections of column reach $90 \%$ breakthrough with the three vertical lines at 293, 593, and 786 hours. If one looks at the $90 \%$ breakthrough point at 8 feet into the column, one notices that the $\mathrm{DF}=1 / 40000$ is exactly maintained at 24 feet into the column. Therefore, the mass transfer zone length is $24-8=16$ feet. One can double-check this calculation by observing the $90 \%$ breakthrough behavior at 16 feet (593 hours). In order to maintain the DF of $1 / 40000$, one must proceed down the column to 32 feet. Again, the mass transfer zone length is equal to 16 feet.

This validation case in Figure A.16-12 was run using the isotherm for powdered CST resin. Recent isotherm work (Reference 46) has revealed that the engineered form does not load as efficiently. This loss in efficiency is relatively constant over the cesium concentration range.

Figure A.16-13 shows the breakthrough behavior of SRS waste with a reduced loading isotherm. The mass transfer zone length continues to be 16 feet. The column diameter is set to 4 feet for comparison with Purdue and Texas A\&M designs. 


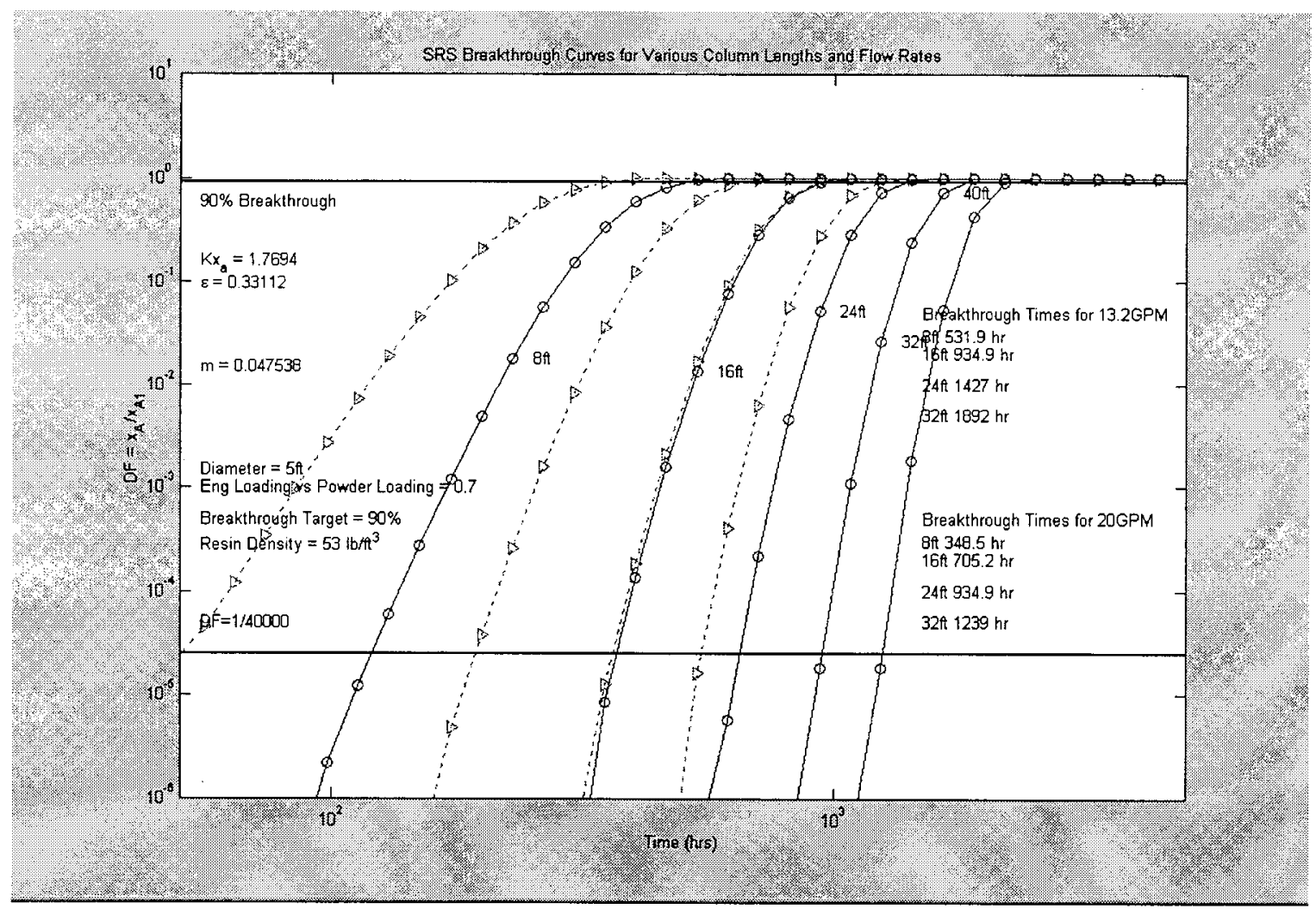

Figure A.16-13. This figures shows the predicted breakthrough of SRS waste when the engineered resin is used rather than the powdered resin in the previous figure. The early breakthrough behavior is different, but the $90 \%$ breakthrough times on the $16 \mathrm{ft}$ column are essentially identical. The mass transfer zone length continues to be approximately $16 \mathrm{ft}$. 


\section{Ion-exchange Column Cycle Time Determination}

Cycle times are determined by how long it takes for the lead column to breakthrough. For the SRS design, column lengths have been set at 16 feet. When the lead column reaches $90 \%$ breakthrough, this column is taken offline for CST removal. The amount of resin in the column is fixed. Therefore, the amount of CST sent to the DWPF is controlled by the $90 \%$ breakthrough time of the lead column. The ion-exchange column model predicts that the first 16 feet of column will breakthrough at 593 hours, for the powdered CST.

Figure A.16-13 shows that the 16 foot column will breakthrough in 564 hours, for the engineered CST. These times are representative of the cycle time of the ion-exchange column carousel. The current analytical solution does not allow for the rotation of the columns on the carousel due to the constraint of zero cesium loaded on the column at time equal to zero. The numerical SPEEDUP solution can calculate the cycle time of the second column after rotation, and this cycle time should be less than the one calculated here due to the fact that the second column has already loaded a finite amount of cesium. Therefore, cycle times representative of partially loaded columns will be determined by the SPEEDUP version of the ion-exchange model.

\section{Sensitivity to Variations in Waste Composition}

The variation of SRS waste can lead to a variety of column performances. The ionexchange column design should identify certain waste variations that result in long mass transfer zone lengths and/or short cycle times. The variation in waste composition can be handled two ways: design columns long enough to handle the "worst" waste or blend the waste upstream of the columns to insure the "worst" waste composition never reaches the columns.

Figure A.16-14 provides the first attempt at bounding the cycle times and CST flow rates to DWPF. The figure relates the cycle time to CST flow rate as a function of various column lengths and waste compositions. Previous figures showed how to determine breakthrough times. If one bounds the SRS waste perturbations to include all reasonable variations of hydroxide, nitrate, and sodium molarity, the 5X16 foot column (20GPM) will breakthrough between 3.3 and 6.2 weeks resulting in CST flow rates of 16-30 lb/hr. 


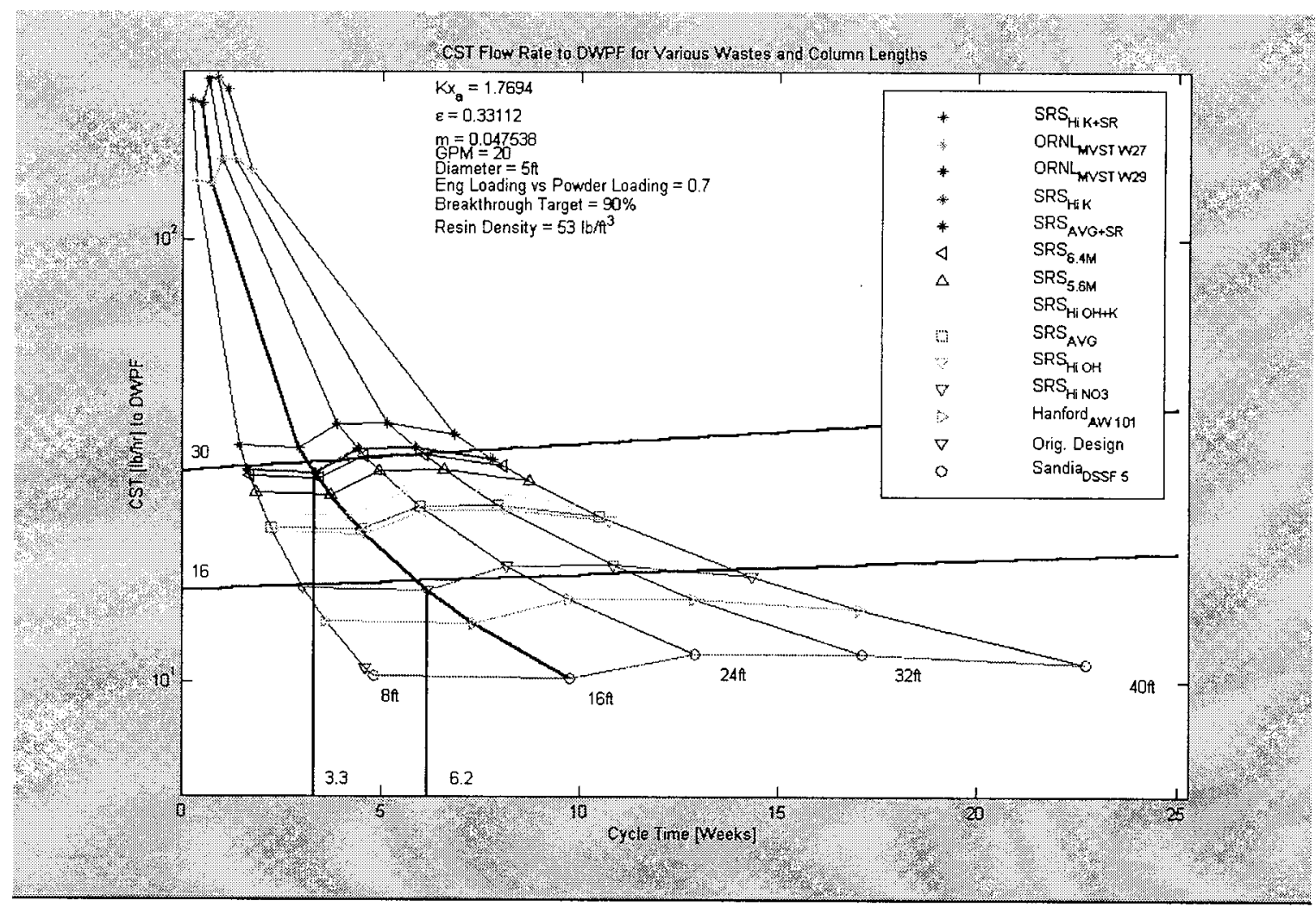

Figure A.16-14. This figure shows the expected cycle times of various column lengths with various perturbations to SRS waste. Due to the column size being fixed, cycle times translate into CST flow rates to DWPF. This figure bounds the SRS waste streams in terms of cycle times (3.3.7-6.2 weeks) and CST mass flow rates (16-30 lb/hr). 


\section{$\underline{\text { Conclusions }}$}

A simplified ion-exchange column model has been used to provide preliminary column sizing and cycle times to the Phase III decision. This 5 foot diameter column model yielded mass transfer zone of 9.1 and 13.8 feet at column flow rates of 13.2 and 20 GPM respectively. Cycle times for the 2 flow rates were 930 hours (5.5 weeks) and 700 hours (4.2 weeks) respectively. Variations in waste composition could expand the mass transfer zone lengths and reduce the column cycle times. Preliminary calculations for a 5-foot diameter column, 20GPM, reveal the likely spread in cycle times to be 3.3-6.2 weeks indicating that compositional variance can account for performance changes comparable to 13-20 GPM flowrate change. This range of cycle times corresponds to CST flow rates of $16-30 \mathrm{lb} / \mathrm{hr}$.

\section{SPEEDUP Modeling}

\section{Speedup Model Functionality}

1) Two feed compositions will be chosen based on the blended feed calculations. The feed composition will be diluted to $5.6 \mathrm{M} \mathrm{Na}^{+}$and the TRU and sludge components removed. The feed rate will be provided in gal $/ \mathrm{min}$.

2) Certain batch operations will be performed each time a column is emptied and inventoried. These will be added to the above feed stream at an average rate based on the cycle time (as determined by the CST column model). The basis for the additions are

- water to inventory column $=20 \mathrm{col}$ vols $=47,100$ gallons $/ \mathrm{cycle} 2 \mathrm{M} \mathrm{NaOH}$ pretreatment $=5 \mathrm{col}$ vols $=11,750$ gallons $/$ cycle

- $\quad 2 \mathrm{M} \mathrm{NaOH}$ post-treatment $=5 \mathrm{col}$ vols $=11,750$ gallons $/$ cycle excess water to slurry resin from col $=25,950$ gallons $/$ cycle $^{*}$

*Based on $20 \mathrm{col}$ vols less the water to produce a $10 \mathrm{wt} \%$ CST slurry.

The ion exchange reaction of Cs onto the CST is modeled using the standard lumpedparameter, film-controlled mass transfer model used by Beck and adapted to SPEEDUP by Dimenna and Hang. In addition to the feed composition and feed rate, the model requires a feed-specific, liquid-solid equilibrium isotherm.

3) The feed-specific isotherm for CST powder (as developed by the TAMU model) with a granular CST dilution factor already included will be provided. (The granular CST includes a binder and moisture which in essence dilutes the powder.) The dilution factor used will be 0.7 .

4) The IX train is three columns in series with each containing a bed that is $5 \mathrm{ft}$ diameter by $16 \mathrm{ft}$ long $\left(314.16 \mathrm{ft}^{3}\right)$. (There is a fourth column which is loaded with fresh resin and 
in standby to be used when the first column is loaded.) The granular CST has a dry bulk density of $1.0 \mathrm{~g} / \mathrm{ml}$ so a column contains $19,600 \mathrm{lbs}$ of CST.

5) The beginning of a cycle is when feed is started to a column which has been rotated from the second position to the first. The end of a cycle will be when either of the following criteria is satisfied:

- $c / c_{o}$ for $C s$ in the liquid at the exit of the first column reaches 0.9 , or

- the Cs concentration in the liquid at the exit of the second column reaches 1.3 micrograms $\mathrm{Cs} / \mathrm{L}$ (or $20 \mathrm{nCi} / \mathrm{g}$ )

At that time, the first column is taken off line and unloaded, the second becomes the first, the third becomes second, and the fresh spare becomes the third. When the column is unloaded, 20 column volumes of water is used. A $10 \mathrm{wt} \%$ CST slurry in water goes to DWPF (21,150 gallons) with the rest as described in (2).

6) Two reactions which occur in the IX bed are ignored because they are inconsequential to the material balance. The $\mathrm{Cs}^{+}$is exchanged for a $\mathrm{Na}^{+}$which then goes with the decontaminated salt solution. A small amount of $\mathrm{K}^{+}$exchanges onto the resin and goes with the CST to the DWPF. This is estimated to be less than $2.5 \mathrm{lbs} / \mathrm{hr}$.

There are, of course, two product streams: Decontaminated Salt Solution and CST slurry.

7) The decontaminated salt solution is simply the column feed stream less the Cs removed by the column.

8) The CST slurry contains one column volume of CST (19,600 lbs) along with the Cs removed during the cycle and sufficient water to produce a $10 \mathrm{wt} \%$ slurry $(21,150$ gallons). This is fed to DWPF at a rate of $196,000 \mathrm{lbs}$ divided by the cycle time as determined in (5) above.

The DWPF portion of the Speedup model needs additional inputs.

9) In addition to the CST slurry stream, there are three other inputs required:

- the MST/sludge stream from alpha removal matching the salt work-off rate,

- the washed, average sludge feed rate, and

- the CST-specific frit.

The washed, average sludge rate and frit rate/composition will be supplied based on a DWPF recipe developed by Hank Elder. He will also supply the CST composition with the proprietary component designated as $\mathrm{XO}$. The molecular weight and free energy of hydration for XO will also be specified. 
10) By virtue of the composition information provided for the CST and frit, the PCCS algorithms in the DWPF model should provide reasonable information. However, if there are any built-in constraints or adjustments based on the PCCS calculations, these should turned off - especially anything associated with high $\mathrm{TiO}_{2}$ in the glass.

10) The following Speedup outputs are required including stream compositions:

- 5.6 M CST IX feed stream

- water and $\mathrm{NaOH}$ added to the feed

- decontaminated salt solution

- CST slurry stream

- CST cycle time

- loading of Cs on CST (mg Cs/g CST) in the CST slurry

- DWPF feed streams (CST slurry, MST/sludge, washed sludge, frit)

- glass product stream

- $\mathrm{TiO}_{2}$ in the glass including contribution from MST

- results of PCCS calculations

\section{$\underline{\text { Feed Compositions }}$}

Two feeds are chosen for evaluation. The feed with the highest $K_{d}$ will provide the longest mass transfer zone and the feed with the lowest $\mathrm{K}_{\mathrm{d}}$ will provide the highest rate of CST to the DWPF. Blended feeds were estimated for the CST option for years 2007 through 2018. Table A.16-24 shows the major feed constituents and the computed $\mathrm{K}_{\mathrm{d}}$ value for each of the feeds. The compositions for years 2014 and 2016 were selected for Speedup modeling.

Table A.16-24

Blended Salt Solution Feeds to CST Ion Exchange $5.60 \mathrm{M} \mathrm{Na}^{+}$

\begin{tabular}{|c|c|c|c|c|c|c|c|}
\hline Year & $\mathbf{K d ~ ( m V / g )}$ & $\mathbf{C s}(\mathbf{C i} /$ gal) & $\mathbf{O H}^{-}(\mathbf{M})$ & $\mathbf{N O}_{\mathbf{3}} \mathbf{( M )}$ & $\mathbf{N O}_{\mathbf{2}}^{-}(\mathbf{M})$ & $\mathbf{C s}^{+}(\mathbf{M})$ & $\mathbf{K}^{+}(\mathbf{M})$ \\
\hline 2007 & 1810 & 0.97 & 1.60 & 2.52 & 0.38 & 0.000098 & 0.012 \\
\hline 2008 & 2020 & 1.01 & 2.03 & 1.94 & 0.68 & 0.000101 & 0.013 \\
\hline 2009 & 1890 & 0.71 & 1.50 & 2.52 & 0.42 & 0.000072 & 0.009 \\
\hline 2010 & 1850 & 0.69 & 1.45 & 2.55 & 0.44 & 0.000069 & 0.011 \\
\hline 2011 & 1870 & 1.48 & 2.41 & 1.71 & 0.66 & 0.000149 & 0.022 \\
\hline 2012 & 1720 & 1.54 & 2.10 & 2.14 & 0.43 & 0.000155 & 0.020 \\
\hline 2013 & 1690 & 1.19 & 1.53 & 2.60 & 0.32 & 0.000120 & 0.014 \\
\hline 2014 & 2070 & 0.93 & 2.31 & 1.79 & 0.67 & 0.000094 & 0.019 \\
\hline 2015 & 1830 & 0.63 & 1.71 & 2.57 & 0.22 & 0.000064 & 0.019 \\
\hline 2016 & 1480 & 2.12 & 1.74 & 2.40 & 0.36 & 0.000214 & 0.018 \\
\hline 2017 & 1710 & 1.82 & 2.03 & 1.98 & 0.67 & 0.000183 & 0.013 \\
\hline 2018 & 1750 & 1.70 & 1.90 & 2.03 & 0.67 & 0.000172 & 0.010 \\
\hline
\end{tabular}


The full stream vector is shown diluted to 5.6 $\mathrm{M} \mathrm{Na}$ in Table A.16-25 and the composition-specific isotherms for both streams is shown in Table A.16-26.

Table A.16-25

Stream Vectors

Flow $=20.1 \mathrm{gal} / \mathrm{min}$

\begin{tabular}{|c|c|c|c|c|}
\hline & \multicolumn{2}{|r|}{2014} & \multicolumn{2}{|r|}{2016} \\
\hline Component & $\mathbf{M}$ & Mass Fraction & $\mathbf{M}$ & Mass Fraction \\
\hline $\mathrm{H} 20$ & & 0.7162 & & 0.7009 \\
\hline $\mathrm{NaNO}_{3}$ & 1.790 & 0.1239 & 2.396 & 0.1632 \\
\hline $\mathrm{NaOH}$ & 2.292 & 0.07464 & 1.720 & 0.05511 \\
\hline $\mathrm{KOH}$ & 0.019 & 0.000854 & 0.018 & 0.000808 \\
\hline $\mathrm{Na}_{2} \mathrm{CO}_{3}$ & 0.125 & 0.01083 & 0.186 & 0.01580 \\
\hline Misc Na salts & 0.128 & 0.006043 & 0.125 & 0.005808 \\
\hline $\mathrm{NaNO}_{2}$ & 0.670 & 0.03766 & 0.357 & 0.01972 \\
\hline $\mathrm{KNO}_{3}$ & 0.000 & 0.0 & 0.000 & 0.0000039 \\
\hline $\mathrm{NaAlO}_{2}$ & 0.250 & 0.01666 & 0.254 & 0.01668 \\
\hline $\mathrm{CsOH}$ & 0.000094 & 0.0000114 & 0.000214 & 0.0000257 \\
\hline $\mathrm{Na}_{2} \mathrm{SO}_{4}$ & 0.110 & 0.01268 & 0.188 & 0.02142 \\
\hline $\mathrm{HgO}$ & & 0.0000303 & & 0.0000185 \\
\hline Density & & $10.224 \mathrm{lbs} / \mathrm{gal}$ & & $10.410 \mathrm{lbs} / \mathrm{gal}$ \\
\hline
\end{tabular}

Table A.16-26

Isotherms

Includes CST Dilution Factor $=\mathbf{0 . 7 0}$

\begin{tabular}{|c|c|c|c|}
\hline \multicolumn{2}{|r|}{2014} & \multicolumn{2}{|r|}{2016} \\
\hline $\begin{array}{c}\mathrm{C} \\
(\mathrm{mol} \text { frac Cs})\end{array}$ & $\begin{array}{c}\mathbf{Q} \\
\left(\mathrm{mol} \mathrm{Cs} / \mathrm{cm}^{3}\right)\end{array}$ & $\underset{(\mathrm{mol} \text { frac } \mathrm{Cs})}{\mathrm{C}}$ & $\begin{array}{c}\mathbf{Q} \\
\left(\mathrm{mol} \mathrm{Cs} / \mathrm{cm}^{3}\right)\end{array}$ \\
\hline $1.767 \mathrm{E}-06$ & $9.996 \mathrm{E}-05$ & $4.795 \mathrm{E}-06$ & $1.690 \mathrm{E}-04$ \\
\hline $8.522 \mathrm{E}-07$ & $5.688 \mathrm{E}-05$ & $2.286 \mathrm{E}-06$ & $1.083 \mathrm{E}-04$ \\
\hline $2.545 \mathrm{E}-07$ & $1.928 \mathrm{E}-05$ & $6.653 \mathrm{E}-07$ & $4.064 \mathrm{E}-05$ \\
\hline $4.980 \mathrm{E}-08$ & $3.933 \mathrm{E}-06$ & $1.267 \mathrm{E}-07$ & $8.568 \mathrm{E}-06$ \\
\hline $9.886 \mathrm{E}-09$ & $7.914 \mathrm{E}-07$ & $2.695 \mathrm{E}-08$ & $1.850 \mathrm{E}-06$ \\
\hline $9.886 \mathrm{E}-10$ & $7.914 \mathrm{E}-08$ & $4.460 \mathrm{E}-09$ & $3.088 \mathrm{E}-07$ \\
\hline $9.886 \mathrm{E}-11$ & 7.914E-09 & $4.460 \mathrm{E}-10$ & $3.088 \mathrm{E}-08$ \\
\hline $9.886 \mathrm{E}-12$ & $7.914 \mathrm{E}-10$ & $4.460 \mathrm{E}-11$ & $3.088 \mathrm{E}-09$ \\
\hline
\end{tabular}


Critical Comparison of Salt Disposition Flowsheet Team Model to Purdue and Texas A\&M IX Column Models

Four models were used to size the ion exchange column carousel used in Phase III. The two models from Texas A\&M and Purdue contained extensive mass transfer concepts and are considered state-of-the-art. Two additional models were developed at WSRC to provide validation of the Purdue and Texas A\&M results. These models had limited mass transfer mechanisms, but they provided a means of adjusting column geometry, work-off rates, and isotherm information. Upon review of the final reports from Texas A\&M (Reference 48) and Purdue (Reference 49), the simple WSRC model can be critiqued against the state-of-the-art. The WSRC models consisted of the SDFT model and the SDMT revision. These models captured the basics of ion exchange column design and were successful in designing the column length to contain the mass transfer zone length. These models suffered in predicting larger mass transfer zone velocities through the column. This over-prediction resulted in shorter column cycle times and larger CST flow rates to DWPF. This section aims at describing the difference between the models developed in house and the two models from Texas A\&M and Purdue. The following list describes why the simple SDFTmodel yields different results.

1. The SDFT model was tuned to four non-SRS experimental bench-scale column runs only. The Texas A\&M model has been tested and tuned on SRS waste.

2. The SDFT model was tuned to the $10 \%$ and $50 \%$ breakthrough information only. The breakthrough trigger was set to $90 \%$. The SDFT model was forced to extrapolate, leading to error.

3. In all four cases, the SDFT model predicted a broader breakthrough curve than the experimental data. Broader breakthrough curves yield decreased loading and shorter cycle times. The simple SDFT model should always predict lower loading of the resin due to the lack of complex mass transfer mechanisms.

4. The mass transfer coefficient used by the SDFT model was the average of the four bench-scale experiments. Both Purdue and Texas A\&M tuned their models on individual pilot-scale and bench-scale column runs. Texas A\&M reported that one of the four non-SRS waste columns produced a diffusivity more than twice the other three. Therefore, it is possible that the four bench scale experiments are not consistent enough to take an average.

5. Finally, no effort was made to improve on the mass transfer coefficient derivation. More breakthrough curve comparisons could have lead to better overall mass transfer coefficients. 


\section{A.17 Crystalline Silicotitanate Final Disposal Forms}

CST is a non-elutable resin that is used as the ion exchange medium for sorbing ${ }^{137} \mathrm{Cs}$. The composition of CST is the proprietary property of the manufacturer, UOP. According to the Material Safety Data Sheet (MSDS) (Reference 50), the composition is shown in Table A.17-1.

Table A.17-1

\begin{tabular}{|l|c|}
\hline Component & Wt \% \\
\hline $\mathrm{SiO}_{2}$ & $15-25$ \\
\hline $\mathrm{TiO}_{2}$ & $20-40$ \\
\hline $\mathrm{Na}_{2} \mathrm{O}$ & $5-20$ \\
\hline $\begin{array}{l}\text { Trade secret } \\
\text { material }\end{array}$ & $15-25$ \\
\hline $\begin{array}{l}\text { Trade secret } \\
\text { metal oxide }\end{array}$ & $0-25$ \\
\hline $\mathrm{Al}_{2} \mathrm{O}_{3}$ & $0-10$ \\
\hline $\mathrm{CuO}$ & $0-2$ \\
\hline $\mathrm{CaO}$ & $0-2$ \\
\hline $\mathrm{Cr} \mathrm{O}_{3}$ & $0-2$ \\
\hline $\mathrm{MgO}$ & $0-2$ \\
\hline
\end{tabular}

\section{A.17.1 CST/Sludge Glasses}

The CST is fed to the DWPF where it is combined with sludge and frit to produce a borosilicate glass. The most critical component in the CST for DWPF glass is the $\mathrm{TiO}_{2}$ concentration. DWPF currently has a limit of $1 \mathrm{wt} \% \mathrm{TiO}_{2}$ in the glass (Reference 51). M. K. Andrews has shown that sludge/CST glasses containing up to $10 \mathrm{wt} \%$ CST pass the PCT test and make glass which has been qualitatively judged acceptable for viscosity (Reference 52). J. R. Harbour has advised using a concentration of $33 \mathrm{wt} \% \mathrm{TiO}_{2}$ in the $\mathrm{CST}$. Therefore, at $10 \mathrm{wt} \% \mathrm{CST}$, the current $\mathrm{TiO}_{2}$ limit is exceeded by more than a factor of three.

A key operating strategy for the DWPF involves the use of first-principles correlations which predict liquidus, viscosity, and glass durability based on melter feed composition (Reference 53). These correlations have been developed for a specific range of glass compositions. They have been incorporated into the Speedup HLW model (RIFM) to ensure the resulting melter feed composition meets the constraints for liquidus and viscosity while making durable glass meeting the WAPS requirements. The compositions tested by Andrews are outside the range of glass compositions used to develop the correlations. Therefore, the built-in checking of liquidus, viscosity, and durability cannot be used. 
Andrews' tests have produced "good" glass (passes PCT) using various sludge compositions generally at $28 \mathrm{wt} \%$ sludge oxides in glass and with CST concentrations up to and including $10 \mathrm{wt} \%$ CST (Reference Error! Bookmark not defined.). The remainder of the feed is borosilicate glass formers. The exact composition of the glass formers is different than current DWPF frit (Frits 200 and 202) but has not been documented.

The specified flowsheet option includes two sources of titanium: (1) the CST, and (2) the MST added to remove $\mathrm{Sr}, \mathrm{Pu}$, and $\mathrm{U}$. Tests have not been conducted to prove that titanium from MST is equivalent to and is soluble in glass in the same proportions as titanium from CST. However for the purposes of these calculations, assumed they are equivalent. At $3.33 \mathrm{wt} \% \mathrm{TiO}_{2}$ in the glass, the [Ti] is $2.00 \mathrm{wt} \%$.

For this option, any glass that falls within tested ranges will be considered "good". The following constraints are used to specify "good" glass for this option:

- CST is considered a discrete component.

- Glass composition is to be $\leq 10$ wt $\%$ CST with $\leq 28$ wt $\%$ oxides from sludge with the balance being "frit".

- Total Ti (from CST and MST) $\leq 2.00 \mathrm{wt} \%$ in the glass. Add frit if necessary to meet this requirement. ( $\mathrm{Ti}$ from $\mathrm{CST}$ and $\mathrm{Ti}$ from MST are assumed equivalent.)

- These constraints are assumed to produce melt with satisfactory liquidus and viscosity.

\section{A.17.2 CST Only Glass}

Andrews, et al., have also tested a number of CST-only glasses containing up to 70 wt \% CST with borosilicate glass formers (Reference 54). A glass formulation with 65 wt \% CST passed the PCT but was marginal for crystallinity. A maximum concentration of 61 to 64 wt \% was recommended. The same document also included specific gravities for various glass compositions.

Extremely large volume reduction can be achieved at such CST loadings. On the other hand, a typical Cs concentration on CST will produce a glass with relatively high thermal and dose output. Processing, storing, and retrieving such glass would require a balance among glass volume, cooling requirements, and shielding requirements.

\section{A.18 Caustic Side Solvent Extraction}

The basis for the development of caustic side solvent extraction is laboratory testing from Oak Ridge National Laboratory (References 55, 56, 57, \& 58). The lab testing measured the single contact distribution ratio for cesium using the proposed solvent. These tests used a typical SRS High Level Waste salt solution composition containing $7 \mathrm{M}$ sodium salts. The solvent consisted of: 
$0.01 \mathrm{M}$ BoBCalixC6 extractant

$0.2 \mathrm{M}$ Cs-5 modifier

Isopar L diluent (balance)

Equal parts solvent and salt solution were contacted and then separated and the concentration of cesium in each stream were determined. These measurements were then used to determine the distribution coefficient:

$$
D=\frac{C s_{o r g}}{C s_{a q}}
$$

The solvent extraction process consists of three processing segments, aqueous extraction extraction, solvent scrubbing and solvent stripping segments. Each segment is comprised of multiple stages of aqueous-organic contacting and separation. Therefore, in addition to contacting the salt solution, the scrub solution and the strip solution were also contacted with the solvent and distribution ratios were measured. These measurements were:

\begin{tabular}{|c|c|c|c|}
\hline & Extraction & Scrub & Strip \\
\hline $\mathrm{D}(\mathrm{Cs})$ & $8\left(25^{\circ} \mathrm{C}\right)$ & $0.6\left(25^{\circ} \mathrm{C}\right)$ & $0.2\left(30^{\circ} \mathrm{C}\right)$ \\
\hline
\end{tabular}

Using this data, a proposed flowsheet for the extraction of cesium from typical $(2.7 \mathrm{e}-4$ molar cesium) waste can be developed using the Excel macro SASSE developed by Ralph Leonard at Argonne National Laboratory. This flowsheet assumed a feed of 17.5 gpm at a concentration of $6.44 \mathrm{M}$ sodium (with the balance primarily $\mathrm{OH}, \mathrm{NO}_{3}$, and $\mathrm{NO}_{2}$ ). In addition, the flowsheet targeted a raffinate cesium concentration of less than 40 $\mathrm{nCi} / \mathrm{g}$.

The spreadsheet output for the rates for the various streams are:

\begin{tabular}{|c|c|c|c|c|c|}
\hline $\begin{array}{c}\text { Salt } \\
\text { Feed } \\
(\mathrm{gpm})\end{array}$ & $\begin{array}{c}\text { Scrub Feed } \\
(\mathrm{gpm})\end{array}$ & $\begin{array}{c}\text { Strip Feed } \\
(\mathrm{gpm})\end{array}$ & $\begin{array}{c}\text { Aqueous Raffinate } \\
(\mathrm{gpm})\end{array}$ & $\begin{array}{c}\text { Strip Effluent } \\
(\mathrm{gpm})\end{array}$ & $\begin{array}{c}\text { Solvent } \\
(\mathrm{gpm})\end{array}$ \\
\hline 17.5 & 1.14 & 1.5 & 18.7 & 1.5 & 5.7 \\
\hline
\end{tabular}

The effluent would contain $<.01 \mathrm{M} \mathrm{Na},<0.001 \mathrm{M}$ of other metals.

This flowsheet assumes 16 stages of extraction, 2 stages of scrubbing and 16 stages of stripping. This number of stages was employed to achieve an approximate 12 fold increase in the Cs concentration of the effluent over the feed. Use of additional stages can produce an increase in the concentration achieved while use of few stages results in lower concentration increases. 
This flowsheet was developed under the assumption of equilibrium stages (a relatively accurate assumption for centrifugal contactors as indicated by testing at ANL, Reference 59). A further assumption was of minimal other phase carry over. This assumption implies that good phase disengagement is achieved. Phase disengagement was confirmed during testing at ANL (Reference 84). Significant other phase carryover would likely significantly reduce the efficiency of the process.

Cesium material balances can be determined for each stage $\mathrm{n}$ as follows:

Cs In = Cs Out

$$
\mathrm{M}_{\mathrm{aq}} *\left[\mathrm{Aq}_{\mathrm{n}+1}\right]+\mathrm{M}_{\mathrm{org}} *\left[\operatorname{Org}_{\mathrm{n}}\right]=\mathrm{M}_{\mathrm{aq}} *\left[\mathrm{Aq}_{\mathrm{n}}\right]+\mathrm{M}_{\mathrm{org}} *\left[\operatorname{Org}_{\mathrm{n}-1}\right]
$$

Where: $M_{\mathrm{aq}}$ is the mass flowrate of the aqueous phase $\mathrm{M}_{\mathrm{org}}$ is the mass flowrate of the organic phase

$\left[\mathrm{Aq}_{\mathrm{n}+1}\right]$ is the $\mathrm{Cs}$ concentration in the aqueous phase entering this stage [Org ${ }_{n}$ ] is the Cs concentration in the organic phase exiting this stage $\left[\mathrm{Aq}_{\mathrm{n}}\right]$ is the $\mathrm{Cs}$ concentration in the aqueous phase exiting this stage [Org $\left.{ }_{n-1}\right]$ is the Cs concentration in the organic phase entering this stage

Since each stage is in equilibrium the distribution coefficient relationship above allows the determination of a single unknown for each stage.

The glass product bases remain the same as for the current DWPF (See Section A.13). 


\section{A.19 REFERENCES}

1 D. J. McCabe, "Cesium, Potassium, and Sodium Tetraphenylborate Solubility in Salt Solution”, WSRC-TR-96-0384, December 1996.

2 S. M. Serkiz, "Tetraphenylborate Solubility in High Ionic Strength Salt Solutions," WSRC-TR-98-00103, April 3, 1998.

3 C. L. Crawford and D. D. Walker, "Hydrogen Generation by Radiolysis of Tetraphenylborate Solutions and Slurries (U)," WSRC-TR-96-0109, June 19, 1996.

4 D. D. Walker, "Benzene Distribution in Product Streams from In-Tank Processing," DPST-86-390, January 15, 1987.

5 R. A. Peterson and T. B. Edwards, "Statistical Investigation into the Decomposition of Tetraphenylborate and its Daughter Compounds", WSRC-TR-97-00403, December 1997.

6 M. J. Barnes and T. B. Edwards, "Copper Catalyzed Sodium Tetraphenylborate Decomposition Kinetic Studies”, WSRC-TR-96-0351, November 1996.

7 D. D. Walker and T. Hang, "ITP Process Dynamic Benzene Material Balance Computer Model Part 2: Model Development (U)," WSRC-RP-93-595, April 21, 1993.

8 "Test Summary Report Simulant Runs Phase 3B Integrated Tests," ITP-TSR-103, September 15, 1994.

9 R. I. A. Malek, D. M. Roy, P. H. Licastro and C. A. Langton. "Saltstone Starting Materials Characterization.”, 1985.

10 R. W. Heckrotte, "Project S-1780 - Savannah River Plant - 200-S Area Defense Waste Processing Facility - Sludge Plant Request to Modify the DWPF Saltstone Industrial Solid Waste Permit", PP-0001183.

11 "Radiological Performance Assessment for the Z-Area Saltstone Disposal Facility." WSRC-RP-92-1360, December 1992.

12 "DWPF Process Description". DPSOP 257-1, Rev. 0, February 2, 1987.

13 W. G. Ramsey et al, "Prediction of Copper Precipitation in the DWPF Melter from the Melter Feed Formate and Nitrate Content", WSRC-TR-92-385, Rev. 0, November 30, 1994.

14 C. J. Bannochie and D. P. Lambert, Technical Bases for the Precipitate Hydrolysis Operating Parameters, WSRC-TR-92-458 (Rev. 1), November 9, 1992. 
15 C. W. Hsu, "Nitric Acid Requirements for Treating Sludge", WSRC-RP-92-1056, September 4, 1992.

16 Jantzen, C. M "Relationship of Glass Composition to Glass Viscosity, Resistivity, Liquidus Temperature, and Durability: First Principles Process-Product Models for Vitrification of Nuclear Wastes", Ceramic Transactions, 23, American Ceramic Society, Westerville, OH, 37-51 (1991).

17 Jantzen, C. M. "The Relationship Between Glass Viscosity and Composition: A First Principles Model for Vitrification of Nuclear Waste," US DOE Report WSRC-MS90-41, Westinghouse Savannah River Co., Aiken, SC (April 1991).

18 "Industrial Waste Permit \# 025500-1603, Savannah River Plant Z-Area Saltstone Disposal Facility," SCDHEC, 2600 Bull St., Columbia, SC 29201 (May 1996).

19 J. R. Fowler, "Estimate of Soluble Mercury in Feed to Stage II of the DWPF," Internal Report DPST-81-648, E. I. Du Pont de Nemours \& Co., Inc., Savannah River Laboratory, Aiken, SC (August 13, 1981).

20 D. D. Walker and J. R. Fowler, "Chromium Levels in Savannah River Plant Soluble Waste," Internal Report DPST-87-210, E. I. Du Pont de Nemours \& Co., Inc., Savannah River Laboratory, Aiken, SC (January 7, 1987).

21 C. A. Langton, "Guidance on Z-Area Salt Solution Toxic Metal Concentrations Based on EP Toxicity Tests for Saltstone (U)," Internal Report DPST-89-314, E. I. du Pont de Nemours \& Co., Inc., Savannah River Laboratory, Aiken, SC (February 22, 1989).

22 C. A. Langton and E. L. Wilhite, "Revised Mercury Limit for Z-Area Salt Solution Based on Groundwater Protection Criteria (U)," WSRC-RP-89-1375, Westinghouse Savannah River Company, Savannah River Laboratory, Aiken, SC (January 17, 1990).

23 J. R. Fowler, "Preliminary Design Bases for Ion Exchange Processing to Decontaminate High Activity Soluble Waste (U)," WSRC-RP-90-1123, Westinghouse Savannah River Company (September 25, 1990).

24 E. F. Duhn, "Ion Exchange Technology Assessment Report (U)," WSRC-RP-921093TL, Westinghouse Savannah River Company (September 13, 1992).

25 J. P. Bibler and R. M. Wallace, "Mercury Removal from Supernate Using Ion Exchange," Internal Report DPST-84-848, E. I. Du Pont de Nemours \& Co., Inc., Savannah River Laboratory, Aiken, SC (October 30, 1984). 
26 J. P. Bibler, "TCLP Test Results for $\mathrm{Hg}, \mathrm{Cr}(\mathrm{III})$ and $\mathrm{Pb}$ on GT-73 Cation Exchange Resin," Internal Report DPST-87-811, E. I. Du Pont de Nemours \& Co., Inc., Savannah River Laboratory, Aiken, SC (November 13, 1987).

27 M. C. H. Fong, "Preliminary Technical Data Summary Mercury Removal from Supernate," DPSTD-85-117, E. I. Du Pont de Nemours \& Co., Inc., Savannah River Laboratory, Aiken, SC (April 8, 1985).

28 "IMAC-73 Complexing Resin, Technical Sheet," Duolite International, 1982. cf. "Duolite GT-73- Preliminary Technical Data Sheet." Rohm and Haas Company, 1983.

29 S. Beck, R. Dimenna, O. Duarte, H. Elder, J. Fowler, M. Gregory, T. Hang, R. Jacobs, P. Paul, P. Rutland, M. Shadday, F. Smith, and G. Taylor, Bases, Assumptions, and Results of the Flowsheet Calculations for the Initial Eighteen Salt Disposition Alternatives, WSRC-RP-98-00166.

30 R. Bird, W. Stewart, and E. Lightfoot, Transport Phenomena, John Wiley \& Sons, New York, 1960, pp 703-705.

31 Z. Zheng, R. G. Anthony, and J. Miller, Ind. Eng. Chem. Res., 1997, 36, pp 24272434.

32 J. Miller and N. Brown, SAND97-0771, Unlimited Release, 1997.

33 D. Walker, J. Walker, P. Taylor, and D. Hendrickson, Environmental Progress, 1997, 16, pp 251-262.

34 S. Beck, Ion Exchange Model for CST Column Sizing (U), WSRC-RP-98-01053.

35 CST IX Meeting at the Savannah River Company, 1998.

36 Z. Zheng, R. G. Anthony, and J. E. Miller, Modeling Multi-Component Ion Exchange Equilibrium Utilizing Hydrous Crystalline Silicotitanates by a Multiple Interactive Ion Exchange Site Model, Department of Chemical Engineering, Texas A\&M University, March 1997.

37 Rayford G. Anthony and Zhixin Zheng, CST Ion Exchange Version 5 (CSTIXE5), Department of Chemical Engineering, Texas A\&M University, College Station.

38 D. J. McCabe, Crystalline Silicotitanate Examination Results (U), WSRC-RP-941123, May 1995.

39 D. D. Walker, Scoping Tests for Crystalline Silicotitanate Flowsheet (U), WSRC-RP98-00372, August 1998. 
40 Reference from Bill King - in preparation.

41 D. J. McCabe, Examination of Crystalline Silicotitanate Applicability in Removal of Cesium from SRS High Level Waste (U), WSRC-TR-97-0016, April 1997.

42 N. H. Linda Wang, Review of CST Ion Exchange Data and Preliminary Carousel Designs for Cesium Removal from SRS Wastes, School of Chemical Engineering, Purdue University, September 1998.

43 J. E. Miller and N. E. Brown, Development and Properties of Crystalline Silicotitanate (CST) Ion Exchangers for Radioactive Waste Applications, SAND97. 0771, April 1997.

44 D. D. Lee, J. F. Walker, Jr., and P. A. Taylor, Cesium-Removal Flow Studies Using Ion Exchange, Environmental Progress, Winter 1997 (Vol. 16, No. 4).

45 J. F. Walker, Jr., et al., Cesium Removal Demonstration Utilizing Crystalline Silicotitanate Sorbent for Processing Melton Valley Storage Supernate: Final Report, ORNL/TM-13503, March 1998.

46 R. A. Jacobs, Powdered Crystalline Silicotitanate (CST) Isotherms for SRS Wastes (U), WSRC-RP-98-01051, September 1998.

47 D. Walker, J. Walker, P. Taylor, and D. Hendrickson, Environmental Progress, 1997, 16, pp 251-262.

48 M. E. Huckman, I. M. Latheef, and R. G. Anthony, Treating Savannah River Waste Using UOP IONSIV IE911, Texas A\&M University, Department of Chemical Engineering, Kinetics, Catalysis, and Reaction Engineering Group, September 24, 1998.

49 B. Hritzko and N. H. Wang, Design of a Carousel process for Removing Cesium from SRS Waste Using Crystalline Silicotitanate Ion Exchanger, School of Chemical Engineering, Purdue University, West Lafayette, Indiana, September 30, 1998.

50 Material Safety Data Sheet, Crystalline Silicotitanate, UOP, February 1995.

51 M. J. Plodinec and G. W. Wilds, "Long TermWaste Management Progress Report Role of TiO2 in SRP Waste Glass", DPST-78-358 (1978).

52 M. K. Andrews and P. J. Workman, "Glass Formulation Development for the Immobilization of High-Level Waste Coupled with Cesium-Loaded Crystalline Silicotitanate (CST) (U)", WSRC-MS-98-00328, May 1998.

53 C. M. Jantzen, et al., Process/Product Models for the Defense Waste Processing Facility (DWPF): Part I. Predicting Glass Durability from Composition Using A 
Thermodynamic Hydration Energy Reaction Model (THERMO) (U), WSRC-TR-93672, Rev. 0, April 1995 and Rev. 1, September 1995.

54 M. K. Andrews, Glass Formulation Development And Testing For The Vitrification Of Cesium-Loaded Crystalline Silicotitanate (CST), 97-MP23.05, for presentation at the Air \& Waste Management Association's $90^{\text {th }}$ Annual Meeting and Exhibition, June 8 - 13, 1997. Contained in WSRC-TR-97-00320, Fiscal Year 1997 Final Report For Task Plan SR-16WT-31 Task B, Vitrification Of Ion Exchange Material, September 1997.

55 R. A. Leonard, "Use of Electronic Worksheets for Calculation of Stagewise Solvent Extraction Processes," Sep. Sci. Technol. 22, 535-556 (1987).

56 R. A. Leonard, M. C. Regalbuto, D. B. Chamberlain, and G. F. Vandegrift, "A New Model for Solvent Extraction in Columns," Sep. Sci. Technol. 25, 1689-1707 (1990).

57 R. A. Leonard and M. C. Regalbuto, "A Spreadsheet Algorithm for Stagewise Solvent Extraction," Sol. Extr. and Ion Exch., 12(5), 909-930 (1994).

58 B. A. Moyer and P. Bonnesen, E-mail Communication to R. Peterson, 4/30/98.

59 R. A. Leonard, "ANL work on the alkaline-side csex solvent extraction process", presented at CSEX Review Meeting September 9-10, 1998. 
APPENDIX B

DETAILED JUMPER USAGE 


\section{APPENDIX B TABLE OF CONTENTS}

Section

Title

Page

B.1 DIRECT GROUT 3

B.2 SMALL TANK TPB

8

B. 3

SOLVENT EXTRACTION 12

B. 4

NON-ELUTABLE ION EXCHANGE 


\section{APPENDIX B - DETAILED JUMPER USAGE}

The following tables depict, in detail, the jumper usage for the four alternatives

\section{B.1 DIRECT GROUT}

\begin{tabular}{|c|c|}
\hline \multicolumn{2}{|c|}{ Table B-1 Detailed Jumper Usage for Direct Grout } \\
\hline Tank & Number of Jumpers and Jumper Connection \\
\hline \multirow[t]{13}{*}{ Alpha Sorption Tank } & 1 process jumper - from in cell sump pump \\
\hline & 1 process jumper - fresh waste feed \\
\hline & 1 process jumper - MST Tank \\
\hline & 2 process jumpers with MOVs - filter pumps to the filters \\
\hline & 2 process jumpers with MOVs - from filters to the tank \\
\hline & $\begin{array}{l}2 \text { process jumpers - from sludge pumps to the Sludge Solids } \\
\text { Receipt Tank }\end{array}$ \\
\hline & 1 process jumper - ventilation \\
\hline & 2 process jumpers - sampler and sample return \\
\hline & $\begin{array}{l}5 \text { process jumpers - prime water for each pump ( } 2 \text { filter pumps, } 2 \\
\text { sludge pumps, and } 1 \text { sample pump) }\end{array}$ \\
\hline & 1 process jumper - return from Salt Solution Feed Tank \\
\hline & 1 process jumper - from Cleaning Solution Dump Tank \\
\hline & $\begin{array}{l}6 \text { electrical jumpers - }(2 \text { filter pumps, } 2 \text { sludge pumps, } 1 \text { sample } \\
\text { pump, } 1 \text { agitator })\end{array}$ \\
\hline & $\begin{array}{l}2 \text { instrument jumpers - ( } 1 \text { level detection, } 1 \text { temperature detection } \\
\text { w/thermowell) }\end{array}$ \\
\hline \multirow{6}{*}{$\begin{array}{l}\text { Sludge Solids Receipt } \\
\text { Tank }\end{array}$} & 2 process jumpers - from the Alpha Sorption Tank \\
\hline & 2 process jumpers with MOVs - from cross-flow filters \\
\hline & 2 jumpers - sampler and sample return \\
\hline & 1 process jumper - from Process Water Tank \\
\hline & 1 process jumper - ventilation \\
\hline & $\begin{array}{l}4 \text { process jumpers - prime water for each pump ( } 2 \text { filter pumps, } 1 \\
\text { sample pump, and } 1 \text { sludge pump) }\end{array}$ \\
\hline
\end{tabular}




\begin{tabular}{|c|c|}
\hline \multicolumn{2}{|c|}{ Table B-1 Detailed Jumper Usage for Direct Grout } \\
\hline Tank & Number of Jumpers and Jumper Connection \\
\hline & 2 process jumpers with MOVs - from filter pumps \\
\hline & 1 jumper with MOV - to Sludge Solids Receipt Tank \\
\hline & 1 process jumper - from in cell sump pump \\
\hline & $\begin{array}{l}5 \text { electrical jumpers - ( } 2 \text { filter pumps, } 1 \text { sludge pumps, } 1 \text { sample } \\
\text { pump, } 1 \text { agitator })\end{array}$ \\
\hline & $\begin{array}{l}2 \text { instrument jumpers - ( } 1 \text { level detection, } 1 \text { temperature detection } \\
\text { w/thermowell) }\end{array}$ \\
\hline \multirow[t]{3}{*}{ Filter \#1 } & 2 process jumpers - one to and one from the Alpha Sorption Tank \\
\hline & 1 process jumper - from the backpulse chamber \\
\hline & 1 process jumper - to the Salt Solution Hold Tank \\
\hline \multirow[t]{3}{*}{ Filter \#2 } & 2 process jumpers - one to and one from the Alpha Sorption Tank \\
\hline & 1 process jumper - from the backpulse chamber \\
\hline & 1 process jumper - to the Salt Solution Hold Tank \\
\hline \multirow{9}{*}{$\begin{array}{l}\text { Cleaning Solution Dump } \\
\text { Tank }\end{array}$} & 2 process jumpers with MOVs - to cross-flow filters \\
\hline & 2 process jumpers with MOVs - from cross-flow filters \\
\hline & 3 process jumpers - prime water to each pump \\
\hline & 1 process jumper - to Alpha Sorption Tank \\
\hline & 1 process jumper - from Filter Cleaning Caustic Tank \\
\hline & 1 process jumper - from Oxalic Feed Tank \\
\hline & 1 jumper - ventilation \\
\hline & $\begin{array}{l}3 \text { electrical jumpers - }(2 \text { filter pumps, } 1 \text { pump to Alpha Sorption } \\
\text { Tank) }\end{array}$ \\
\hline & 2 instrument jumpers \\
\hline \multirow[t]{5}{*}{$\begin{array}{l}\text { Mercury Removal Feed } \\
\text { Tank }\end{array}$} & $\begin{array}{l}13 \text {-way process jumper with } 2 \text { MOVs - from filters to Mercury } \\
\text { Removal Feed Tank and Salt Solution Hold Tank }\end{array}$ \\
\hline & 1 process jumper - ventilation \\
\hline & 2 process jumpers - sampler and sample return \\
\hline & 1 process jumper - from in cell sump pump \\
\hline & 3 electrical jumpers \\
\hline
\end{tabular}




\begin{tabular}{|c|c|}
\hline \multicolumn{2}{|c|}{ Table B-1 Detailed Jumper Usage for Direct Grout } \\
\hline \multirow[t]{3}{*}{ Tank } & Number of Jumpers and Jumper Connection \\
\hline & 1 instrument jumper \\
\hline & $\begin{array}{l}13 \text {-way process jumper with } 2 \text { MOVs - from Mercury Removal } \\
\text { Feed Tank to header for columns }\end{array}$ \\
\hline \multirow[t]{9}{*}{$\begin{array}{l}\text { Mercury Removal } \\
\text { Columns }\end{array}$} & $\begin{array}{l}1 \text { process jumper - from column header to Hg Removal Header } \\
\# 1\end{array}$ \\
\hline & $\begin{array}{l}1 \text { process jumper - from column header to Hg Removal Header } \\
\# 2\end{array}$ \\
\hline & 2 process jumpers - process water to each column \\
\hline & $\begin{array}{l}2 \text { process jumpers - from Slurry Makeup Tank (one for each } \\
\text { column) }\end{array}$ \\
\hline & $\begin{array}{l}2 \text { process jumpers - from Sodium Nitrate Tank (one for each } \\
\text { column) }\end{array}$ \\
\hline & $\begin{array}{l}2 \text { process jumpers - to Salt Solution Hold Tank (one for each } \\
\text { column) }\end{array}$ \\
\hline & $\begin{array}{l}2 \text { process jumpers - to Mercury Removal Feed Tank (one for } \\
\text { each column) }\end{array}$ \\
\hline & $\begin{array}{l}2 \text { process jumpers - to Resin Loading and Wash Overflow Tank } \\
\text { (one for each column) }\end{array}$ \\
\hline & 2 process jumpers - to Spent Resin Tank (one for each column) \\
\hline \multirow{4}{*}{$\begin{array}{l}\text { Resin Loading and Wash } \\
\text { Overflow Tank }\end{array}$} & 2 electrical jumpers \\
\hline & 1 process jumper - prime water for the pump \\
\hline & 1 process jumper - to the Salt Solution Hold Tank \\
\hline & 1 instrument jumper - level detection \\
\hline \multirow[t]{6}{*}{ Spent Resin Tank } & 1 process jumper - prime water for the pump \\
\hline & 2 process jumpers - cooling water supply and return \\
\hline & 1 process jumper - ventilation \\
\hline & 1 process jumper - plant air for sparger \\
\hline & 1 process jumper - to Resin Loading and Wash Overflow Tank \\
\hline & $\begin{array}{l}1 \text { process jumper - to sparge resin to container for Solid Waste } \\
\text { Disposal }\end{array}$ \\
\hline
\end{tabular}




\begin{tabular}{|c|c|}
\hline \multicolumn{2}{|c|}{ Table B-1 Detailed Jumper Usage for Direct Grout } \\
\hline \multirow[t]{3}{*}{ Tank } & Number of Jumpers and Jumper Connection \\
\hline & 1 electrical jumper \\
\hline & $\begin{array}{l}2 \text { instrument jumpers - (1 level detection and } 1 \text { temperature } \\
\text { detection w/thermowell) }\end{array}$ \\
\hline \multirow[t]{11}{*}{ Salt Solution Hold Tank } & 1 process jumper - from in cell sump pump \\
\hline & 1 process jumper - ventilation \\
\hline & 2 process jumpers - sampler and sample return \\
\hline & 1 process jumper - from Flush Water Receipt Tank \\
\hline & 3 process jumpers - prime water for pumps \\
\hline & 4 electrical jumpers \\
\hline & 1 process jumper - from Resin Loading and Wash Overflow Tank \\
\hline & $\begin{array}{l}2 \text { process jumpers - from Mercury Removal Columns (one for } \\
\text { each column) }\end{array}$ \\
\hline & 1 process jumper - bypass around Mercury Removal Columns \\
\hline & 2 process jumpers - Salt Solution Hold Tank pumps to the mixers \\
\hline & 2 instrument jumpers \\
\hline \multirow{6}{*}{$\begin{array}{l}\text { Flush Water Receipt } \\
\text { Tank }\end{array}$} & 1 process jumper - to the Salt Solution Hold Tank \\
\hline & 5 electrical jumpers \\
\hline & 4 process jumpers - prime water for the pumps \\
\hline & 13-way process jumper with $2 \mathrm{MOVs}$ - to mixers \\
\hline & 1 process jumper - from in cell sump pump \\
\hline & 2 instrument jumpers \\
\hline \multirow[t]{5}{*}{ Saltstone Hold Tank } & 2 process jumpers - from Salt Solution Hold Tank \\
\hline & 1 process jumper - ventilation \\
\hline & 1 electrical jumper \\
\hline & 2 process jumpers - from mixers \\
\hline & 1 instrument jumper - level detection \\
\hline \multirow[t]{2}{*}{ Mixers } & 2 process jumpers - from Premix Feed Bins (one for each mixer) \\
\hline & 2 process jumpers - for Process Water Tank (one for each mixer) \\
\hline
\end{tabular}




\begin{tabular}{|c|c|}
\hline \multicolumn{2}{|c|}{ Table B-1 Detailed Jumper Usage for Direct Grout } \\
\hline Tank & Number of Jumpers and Jumper Connection \\
\hline & $\begin{array}{l}23 \text {-way process jumpers with } 2 \text { MOVs - from Salt Solution Hold } \\
\text { Tank and Flush Water Receipt Tank to Mixer }\end{array}$ \\
\hline & $\begin{array}{l}1 \text { 3-way process jumpers with } 2 \text { MOVs - from Mixers to } \\
\text { Saltstone Hold Tank }\end{array}$ \\
\hline & 2 process jumpers - grout samplers \\
\hline & 2 electrical jumpers \\
\hline & 2 process jumpers - ventilation \\
\hline \multirow[t]{7}{*}{ Transfer Pumps } & $\begin{array}{l}3 \text { 3-way process jumpers with } 2 \text { MOVs - from Saltstone Hold } \\
\text { Tank and Process Water Tank (for priming) to the First Stage } \\
\text { Transfer Pumps }\end{array}$ \\
\hline & $\begin{array}{l}3 \text { process jumpers - connect first stage pumps to second stage } \\
\text { pumps }\end{array}$ \\
\hline & 3 process jumpers - to grout header \\
\hline & 1 process jumper - to Flush Water Receipt Tank \\
\hline & 2 process jumpers - from pigging system \\
\hline & 6 electrical jumpers \\
\hline & 6 instrumentation jumpers \\
\hline Sumps & 6 electrical \& 6 instrumentation jumpers - one for each sump \\
\hline \multirow[t]{3}{*}{ Remote Decon Area } & 10 process jumpers \\
\hline & 5 electrical jumpers \\
\hline & 2 instrumentation jumpers \\
\hline \multirow[t]{3}{*}{ PVV Cell } & 10 process jumpers \\
\hline & 5 electrical jumpers \\
\hline & 6 instrumentation jumpers \\
\hline
\end{tabular}




\section{B.2 SMALL TANK TPB}

\begin{tabular}{|c|c|}
\hline \multicolumn{2}{|c|}{ Table B-2 Detailed Jumper Usage for Small Tank TPB } \\
\hline Tank & Number of Jumpers and Jumper Connection \\
\hline \multirow[t]{13}{*}{ Precipitation Tank \#1 } & 1 process jumper - nitrogen \\
\hline & $\begin{array}{l}3 \text { instrument jumpers }-(1 \text { level detection, } 1 \text { temperature } \\
\text { detection w/thermowell, } 1 \text { gas chromatograph })\end{array}$ \\
\hline & 2 process jumpers - supply and return for chilled water \\
\hline & 2 process jumpers - to Precipitation Hold Tank \#2 \\
\hline & 1 process jumper - from Filtrate Hold Tanks \\
\hline & 1 process jumper - fresh waste feed \\
\hline & 1 process jumper - from MST tank \\
\hline & 1 process jumper - from NaTPB Tank \\
\hline & 1 process jumper - from in cell sump pump \\
\hline & 3 electrical jumpers \\
\hline & 2 process jumpers - prime water for each pump \\
\hline & 1 process jumper - from Recycle Wash Hold Tank \\
\hline & 1 process jumper - ventilation \\
\hline \multirow[t]{7}{*}{ Precipitation Tank \#2 } & 1 process jumper - nitrogen supply \\
\hline & $\begin{array}{l}3 \text { instrument jumpers }-(1 \text { level detection, } 1 \text { temperature } \\
\text { detection w/thermowell, } 1 \text { gas chromatograph })\end{array}$ \\
\hline & 2 process jumpers - supply and return for chilled water \\
\hline & 2 process jumpers - to Concentrate Tank \\
\hline & 3 electrical jumpers \\
\hline & 2 process jumpers - prime water for each pump \\
\hline & 1 process jumper - ventilation \\
\hline \multirow[t]{4}{*}{ Concentrate Tank } & 1 process jumper - nitrogen supply \\
\hline & 2 process jumpers - from Precipitation Tank \#2 \\
\hline & 2 process jumpers - to Wash Tank \\
\hline & 2 process jumpers - supply and return for chilled water \\
\hline
\end{tabular}




\begin{tabular}{|c|c|}
\hline \multicolumn{2}{|c|}{ Table B-2 Detailed Jumper Usage for Small Tank TPB } \\
\hline \multirow[t]{7}{*}{ Tank } & Number of Jumpers and Jumper Connection \\
\hline & $\begin{array}{l}3 \text { instrument jumpers }-(1 \text { level detection, } 1 \text { temperature } \\
\text { detection w/thermowell, } 1 \text { gas chromatograph })\end{array}$ \\
\hline & 7 electrical jumpers \\
\hline & $\begin{array}{l}6 \text { process jumpers with MOVs - supply and return for the three } \\
\text { concentration filters }\end{array}$ \\
\hline & 1 process jumper - from in cell sump pump \\
\hline & 2 process jumpers - sampler and sample return \\
\hline & 1 process jumper - ventilation \\
\hline \multirow[t]{3}{*}{ Concentrate Filters } & 3 process jumpers - from backpulse tanks \\
\hline & 3 process jumpers - to Filtrate Hold Tanks \\
\hline & $\begin{array}{l}6 \text { process jumpers with MOVs - supply and return to Cleaning } \\
\text { Solution Dump Tank headers }\end{array}$ \\
\hline \multirow[t]{11}{*}{ Wash Tank } & 1 process jumper - nitrogen supply \\
\hline & 1 process jumper - ventilation \\
\hline & 2 process jumpers - supply and return for chilled water \\
\hline & 1 process jumper - from Process Water Tank \\
\hline & 2 process jumpers - from Concentrate Tank \\
\hline & 3 process jumpers with MOVs - to wash filters \\
\hline & 2 process jumpers - to Precipitate Surge Tank \\
\hline & 3 process jumpers with MOVs - from wash filters \\
\hline & 1 process jumper - from in cell sump pump \\
\hline & $\begin{array}{l}3 \text { instrument jumpers }-(1 \text { level detection, } 1 \text { temperature } \\
\text { detection w/thermowell, } 1 \text { gas chromatograph })\end{array}$ \\
\hline & 7 electrical jumpers \\
\hline \multirow[t]{3}{*}{$\begin{array}{l}\text { Cleaning Solution Dump } \\
\text { Tanks }\end{array}$} & $\begin{array}{l}2 \text { process jumpers - from Process Water Tank (one for each } \\
\text { tank) }\end{array}$ \\
\hline & 2 process jumpers - from Caustic Feed Tank (one for each tank) \\
\hline & 2 process jumpers - from Oxalic Acid Tank (one for each tank) \\
\hline
\end{tabular}




\begin{tabular}{|c|c|}
\hline \multicolumn{2}{|c|}{ Table B-2 Detailed Jumper Usage for Small Tank TPB } \\
\hline Tank & Number of Jumpers and Jumper Connection \\
\hline & $\begin{array}{l}23 \text {-way process jumpers - from Concentrate Tank filters (one } \\
\text { for each tank) }\end{array}$ \\
\hline & $\begin{array}{l}2 \text { 3-way process jumpers - from Wash Tank filters (one for each } \\
\text { tank) }\end{array}$ \\
\hline & 4 process jumpers with MOVs - to the Dump Tank Header \\
\hline & 4 instrument jumpers \\
\hline & 2 electrical jumpers \\
\hline \multirow[t]{8}{*}{ Precipitate Surge Tank } & 2 process jumpers - supply and return for chilled water \\
\hline & 1 process jumper - ventilation \\
\hline & 1 process jumper - nitrogen supply \\
\hline & $\begin{array}{l}13 \text {-way process jumper - from Precipitate Surge Tank pumps to } \\
\text { PRFT tie-in }\end{array}$ \\
\hline & 2 process jumpers - from Wash Tank \\
\hline & 1 process jumper - from in cell sump pump \\
\hline & $\begin{array}{l}5 \text { instrument jumpers }- \text { (1 level detection, } 3 \text { temperature } \\
\text { detection w/thermowell, } 1 \text { gas chromatograph })\end{array}$ \\
\hline & 3 electrical jumpers \\
\hline Sumps & 6 electrical \& 6 instrument jumpers - one for each in cell sump \\
\hline \multirow[t]{9}{*}{ Recycle Wash Hold Tank } & 2 process jumpers - supply and return for chilled water \\
\hline & 1 process jumper - nitrogen supply \\
\hline & 2 electrical jumpers \\
\hline & 2 instrument jumpers \\
\hline & 1 process jumper - prime water for the pump \\
\hline & $\begin{array}{l}13 \text {-way process jumper with } 2 \text { MOVs - from wash water header } \\
\text { to Recycle Hold Tank and Filtrate Hold Tanks }\end{array}$ \\
\hline & 1 process jumper - to Wash Tank header \\
\hline & 1 process jumper - to Concentrate Tank Header \\
\hline & 1 process jumpers - to Wash Tank Filters \\
\hline Remote Decon Area & 10 process jumpers \\
\hline
\end{tabular}




\begin{tabular}{|c|c|}
\hline \multicolumn{2}{|c|}{ Table B-2 Detailed Jumper Usage for Small Tank TPB } \\
\hline Tank & Number of Jumpers and Jumper Connection \\
\hline & 5 electrical jumpers \\
\hline & 2 instrumentation jumpers \\
\hline \multirow[t]{3}{*}{ PVV Cell } & 10 process jumpers \\
\hline & 5 electrical jumpers \\
\hline & 6 instrumentation jumpers \\
\hline
\end{tabular}




\section{B.3 SOLVENT EXTRACTION}

\begin{tabular}{|c|c|}
\hline \multicolumn{2}{|c|}{ Table B-3 Detailed Jumper Usage for Solvent Extraction } \\
\hline Tank & Number of Jumpers and Jumper Connection \\
\hline \multirow[t]{13}{*}{ Alpha Sorption Tank } & 1 process jumper - from in cell sump pump \\
\hline & 1 process jumper - fresh waste feed \\
\hline & 1 process jumper - MST Tank \\
\hline & 2 process jumpers with MOVs - filter pumps to the filters \\
\hline & 2 process jumpers with MOVs - from filters to the tank \\
\hline & $\begin{array}{l}2 \text { process jumpers - from sludge pumps to the Sludge Solids } \\
\text { Receipt Tank }\end{array}$ \\
\hline & 1 process jumper - ventilation \\
\hline & 2 process jumpers - sampler and sample return \\
\hline & $\begin{array}{l}5 \text { process jumpers - prime water for each pump ( } 2 \text { filter pumps, } 2 \\
\text { sludge pumps, and } 1 \text { sample pump) }\end{array}$ \\
\hline & 1 process jumper - return from Salt Solution Feed Tank \\
\hline & 1 process jumper - from Cleaning Solution Dump Tank \\
\hline & $\begin{array}{l}6 \text { electrical jumpers - ( } 2 \text { filter pumps, } 2 \text { sludge pumps, } 1 \text { sample } \\
\text { pump, } 1 \text { agitator })\end{array}$ \\
\hline & $\begin{array}{l}2 \text { instrument jumpers - (1 level detection, } 1 \text { temperature detection } \\
\text { w/thermowell) }\end{array}$ \\
\hline \multirow{9}{*}{$\begin{array}{l}\text { Sludge Solids Receipt } \\
\text { Tank }\end{array}$} & 2 process jumpers - from the Alpha Sorption Tank \\
\hline & 2 process jumpers with MOVs - from cross-flow filters \\
\hline & 2 jumpers - sampler and sample return \\
\hline & 1 process jumper - from Process Water Tank \\
\hline & 1 process jumper - ventilation \\
\hline & $\begin{array}{l}4 \text { process jumpers - prime water for each pump ( } 2 \text { filter pumps, } 1 \\
\text { sample pump, and } 1 \text { sludge pump) }\end{array}$ \\
\hline & 2 process jumpers with MOVs - from filter pumps \\
\hline & 1 jumper with MOV - to Sludge Solids Receipt Tank \\
\hline & 1 process jumper - from in cell sump pump \\
\hline
\end{tabular}




\begin{tabular}{|c|c|}
\hline \multicolumn{2}{|c|}{ Table B-3 Detailed Jumper Usage for Solvent Extraction } \\
\hline Tank & Number of Jumpers and Jumper Connection \\
\hline & $\begin{array}{l}5 \text { electrical jumpers - ( } 2 \text { filter pumps, } 1 \text { sludge pumps, } 1 \text { sample } \\
\text { pump, } 1 \text { agitator) }\end{array}$ \\
\hline & $\begin{array}{l}2 \text { instrument jumpers - (1 level detection, } 1 \text { temperature detection } \\
\text { w/thermowell })\end{array}$ \\
\hline \multirow[t]{3}{*}{ Filter \#1 } & 2 process jumpers - one to and one from the Alpha Sorption Tank \\
\hline & 1 process jumper - from the backpulse chamber \\
\hline & 1 process jumper - to the Salt Solution Feed Tank \\
\hline \multirow[t]{3}{*}{ Filter \#2 } & 2 process jumpers - one to and one from the Alpha Sorption Tank \\
\hline & 1 process jumper - from the backpulse chamber \\
\hline & 1 process jumper - to the Salt Solution Feed Tank \\
\hline \multirow{9}{*}{$\begin{array}{l}\text { Caustic Solvent Wash } \\
\text { Tank }\end{array}$} & 1 process jumper - from Caustic Feed Tank \\
\hline & 1 process jumper - ventilation \\
\hline & $\begin{array}{l}4 \text { electrical jumpers - (1 Aqueous Raffinate Stilling Tank pump, } 1 \\
\text { Re-alkaline Stage Pump, } 1 \text { agitator, } 1 \text { sample pump })\end{array}$ \\
\hline & 2 instrument jumpers \\
\hline & 2 process jumpers - sampler and sample return \\
\hline & 3 process jumpers - prime water for each pump \\
\hline & 1 process jumper - to Aqueous Raffinate Stilling Tank \\
\hline & 1 process jumper - to Re-alkaline stages \\
\hline & 1 process jumper - from Re-alkaline stages \\
\hline \multirow[t]{6}{*}{$\begin{array}{l}\text { Contactors and } \\
\text { Associated Equipment }\end{array}$} & $\begin{array}{l}6 \text { process jumpers - connect aqueous side of the contactor six } \\
\text { packs }\end{array}$ \\
\hline & 6 process jumpers - connect solvent side of the contactor six packs \\
\hline & 1 process jumper - from Scrub Feed Tank to Scrub stages \\
\hline & 1 process jumper - Re-alkaline stages to Solvent Hold Tank \\
\hline & $\begin{array}{l}13 \text {-way process jumper - connects scrub stages, Salt Solution } \\
\text { Feed Tank, and extraction stages }\end{array}$ \\
\hline & $\begin{array}{l}1 \text { process jumper - from Isopar Feed Tank to Raffinate Organic } \\
\text { Removal stages }\end{array}$ \\
\hline
\end{tabular}




\begin{tabular}{|c|c|}
\hline \multicolumn{2}{|c|}{ Table B-3 Detailed Jumper Usage for Solvent Extraction } \\
\hline \multirow[t]{4}{*}{ Tank } & Number of Jumpers and Jumper Connection \\
\hline & 1 process jumper - from Strip Feed Tank to Strip stages \\
\hline & $\begin{array}{l}1 \text { process jumper - from Isopar Feed Tank to Strip Organic } \\
\text { Removal stages }\end{array}$ \\
\hline & 42 electrical jumpers - one for each contactor \\
\hline \multirow[t]{4}{*}{ Kerosene Still } & 1 process jumper - from Strip stages \\
\hline & 1 process jumper - from Solvent Acid Wash stages \\
\hline & 1 process jumper - to Kerosene Condensate Tank \\
\hline & 1 instrument jumper \\
\hline \multirow{4}{*}{$\begin{array}{l}\text { Kerosene Condensate } \\
\text { Tank }\end{array}$} & 1 process jumper - to CIF Hold Tank \\
\hline & 1 instrument jumper \\
\hline & 1 process jumper - to vacuum pump \\
\hline & 2 process jumpers - chilled water supply and return \\
\hline \multirow[t]{9}{*}{ Solvent Wash Tank } & 1 process jumper - to Aqueous Raffinate Stilling Tank \\
\hline & 1 process jumper - from Solvent Solution Makeup Tank \\
\hline & 1 process jumper - ventilation \\
\hline & 3 process jumpers - prime water for each pump \\
\hline & 2 process jumpers - sampler and sample return \\
\hline & 1 process jumper - to Solvent Acid Wash stages \\
\hline & 1 process jumper - from Solvent Acid Wash stages \\
\hline & $\begin{array}{l}4 \text { electrical jumpers - ( } 1 \text { agitator, } 1 \text { sample pump, } 1 \text { solvent acid } \\
\text { wash pump, } 1 \text { aqueous raffinate pump) }\end{array}$ \\
\hline & 2 instrument jumpers \\
\hline \multirow[t]{2}{*}{ Sumps } & $\begin{array}{l}1 \text { electrical jumper \& } 1 \text { instrument jumper - Alpha Sorption Tank } \\
\text { cell sump pump (instrument jumper for level detection in the } \\
\text { sump) }\end{array}$ \\
\hline & $\begin{array}{l}1 \text { electrical jumper \& } 1 \text { instrument jumper - Salt Solution Feed } \\
\text { Tank cell sump pump (instrument jumper for level detection in the } \\
\text { sump) }\end{array}$ \\
\hline
\end{tabular}




\begin{tabular}{|c|c|}
\hline \multicolumn{2}{|c|}{ Table B-3 Detailed Jumper Usage for Solvent Extraction } \\
\hline Tank & Number of Jumpers and Jumper Connection \\
\hline & $\begin{array}{l}1 \text { electrical jumper \& } 1 \text { instrument jumper - Sludge Solids Receipt } \\
\text { Tank cell sump pump (instrument jumper for level detection in the } \\
\text { sump) }\end{array}$ \\
\hline & $\begin{array}{l}1 \text { electrical jumper \& } 1 \text { instrument jumper - Solvent cell sump } \\
\text { pump (instrument jumper for level detection in the sump) }\end{array}$ \\
\hline & $\begin{array}{l}1 \text { electrical jumper \& } 1 \text { instrument jumper - DWPF Salt Feed } \\
\text { Tank cell sump pump (instrument jumper for level detection in the } \\
\text { sump) }\end{array}$ \\
\hline \multirow[t]{10}{*}{ Solvent Hold Tank } & 1 process jumper - from Extractant Makeup Tank \\
\hline & 1 process jumper - from Modifier Makeup Tank \\
\hline & 1 process jumper - from Solvent Makeup Tank \\
\hline & 2 process jumpers - cooling coil supply and return \\
\hline & 2 process jumpers - sampler and sample return \\
\hline & 2 process jumpers - prime water for each pump \\
\hline & 3 electrical jumpers \\
\hline & $\begin{array}{l}2 \text { instrument jumper - (1 level detection and } 1 \text { temperature } \\
\text { detection w/thermowell) }\end{array}$ \\
\hline & $\begin{array}{l}13 \text {-way process jumper - from Solvent Hold Tank and Raffinate } \\
\text { Organic Removal stages to the extraction stages }\end{array}$ \\
\hline & 1 process jumper - ventilation \\
\hline \multirow[t]{10}{*}{ Salt Solution Feed Tank } & 1 process jumper - from Alpha Sorption Tank \\
\hline & 1 process jumper - to Alpha Sorption Tank \\
\hline & 3 process jumpers - prime water for pumps \\
\hline & 2 process jumpers - sampler and sample return \\
\hline & 1 process jumper - ventilation \\
\hline & 1 process jumper - to extraction stages \\
\hline & 1 process jumper - from Aqueous Raffinate Stilling Tank \\
\hline & 1 process jumper - from Ba-137 Decay Tanks \\
\hline & 1 process jumper - from in cell sump pump \\
\hline & 4 electrical jumpers \\
\hline
\end{tabular}




\begin{tabular}{|c|c|}
\hline \multicolumn{2}{|c|}{ Table B-3 Detailed Jumper Usage for Solvent Extraction } \\
\hline \multirow[t]{2}{*}{ Tank } & Number of Jumpers and Jumper Connection \\
\hline & $\begin{array}{l}2 \text { instrument jumpers - ( } 1 \text { level detection and } 1 \text { temperature } \\
\text { detection } w / \text { thermowell })\end{array}$ \\
\hline \multirow{7}{*}{$\begin{array}{l}\text { Strip Effluent Stilling } \\
\text { Tank }\end{array}$} & 1 process jumper - ventilation \\
\hline & 1 instrument jumper \\
\hline & 1 process jumper - from in cell sump pump \\
\hline & 1 process jumper - to DWPF Salt Feed Tank \\
\hline & 2 electrical jumpers \\
\hline & 2 process jumpers - prime water for each pump \\
\hline & $\begin{array}{l}13 \text {-way process jumper - from Strip Effluent Stilling Tank and } \\
\text { Strip Organic Removal to Strip stages }\end{array}$ \\
\hline \multirow{10}{*}{$\begin{array}{l}\text { Aqueous Raffinate } \\
\text { Stilling Tank }\end{array}$} & 1 process jumper - ventilation \\
\hline & 1 instrument jumper \\
\hline & 3 electrical jumpers \\
\hline & 1 process jumper - from Solvent Wash Tank \\
\hline & 1 process jumper - from Caustic Solvent Wash Tank \\
\hline & 1 process jumper - from Raffinate Organic Removal stages \\
\hline & $\begin{array}{l}13 \text {-way process jumper - from Raffinate Organic Removal stages } \\
\text { and Aqueous Raffinate Stilling Tank to the Extraction stages }\end{array}$ \\
\hline & $\begin{array}{l}1 \text { process jumper - from Aqueous Raffinate Stilling Tank to Salt } \\
\text { Solution Feed Tank }\end{array}$ \\
\hline & $\begin{array}{l}13 \text {-way process jumper - from Aqueous Raffinate Stilling Tank to } \\
\text { the Ba-137 Decay Tanks }\end{array}$ \\
\hline & 3 process jumpers - prime water for each pump \\
\hline \multirow[t]{5}{*}{ Ba-137 Decay Tanks } & 6 instrument jumpers -3 for each tank \\
\hline & 4 electrical jumpers -2 for each tank \\
\hline & 2 process jumpers - prime water for each pump \\
\hline & $\begin{array}{l}14 \text {-way process jumper - from Ba-137 Decay Tanks to Salt } \\
\text { Solution Feed Tank or Mercury Removal Tank }\end{array}$ \\
\hline & 2 process jumpers - ventilation \\
\hline
\end{tabular}




\begin{tabular}{|c|c|}
\hline \multicolumn{2}{|c|}{ Table B-3 Detailed Jumper Usage for Solvent Extraction } \\
\hline Tank & Number of Jumpers and Jumper Connection \\
\hline \multirow[t]{3}{*}{ Remote Decon Area } & 10 process jumpers \\
\hline & 5 electrical jumpers \\
\hline & 2 instrumentation jumpers \\
\hline \multirow[t]{3}{*}{ PVV Cell } & 10 process jumpers \\
\hline & 5 electrical jumpers \\
\hline & 6 instrumentation jumpers \\
\hline
\end{tabular}




\section{B.4 NON-ELUTABLE ION EXCHANGE}

\begin{tabular}{|c|c|}
\hline \multicolumn{2}{|c|}{ Table B-4 Detailed Jumper Usage for Non-Elutable Ion Exchange } \\
\hline Tank & Number of Jumpers and Jumper Connection \\
\hline \multirow[t]{13}{*}{ Alpha Sorption Tank } & 1 process jumper - from in cell sump pump \\
\hline & 1 process jumper - fresh waste feed \\
\hline & 1 process jumper - MST Tank \\
\hline & 2 process jumpers with MOVs - filter pumps to the filters \\
\hline & 2 process jumpers with MOVs - from filters to the tank \\
\hline & $\begin{array}{l}2 \text { process jumpers - from sludge pumps to the Sludge Solids } \\
\text { Receipt Tank }\end{array}$ \\
\hline & 1 process jumper - ventilation \\
\hline & 2 process jumpers - sampler and sample return \\
\hline & $\begin{array}{l}5 \text { process jumpers - prime water for each pump ( } 2 \text { filter pumps, } \\
2 \text { sludge pumps, and } 1 \text { sample pump) }\end{array}$ \\
\hline & 1 process jumper - return from Recycle Blend Tank \\
\hline & 1 process jumper - from Cleaning Solution Dump Tank \\
\hline & $\begin{array}{l}6 \text { electrical jumpers - ( } 2 \text { filter pumps, } 2 \text { sludge pumps, } 1 \text { sample } \\
\text { pump, } 1 \text { agitator })\end{array}$ \\
\hline & $\begin{array}{l}2 \text { instrument jumpers - }(1 \text { level detection, } 1 \text { temperature } \\
\text { detection w/thermowell })\end{array}$ \\
\hline \multirow{9}{*}{$\begin{array}{l}\text { Sludge Solids Receipt } \\
\text { Tank }\end{array}$} & 2 process jumpers - from the Alpha Sorption Tank \\
\hline & 2 process jumpers with MOVs - from cross-flow filters \\
\hline & 2 jumpers - sampler and sample return \\
\hline & 1 process jumper - from Process Water Tank \\
\hline & 1 process jumper - ventilation \\
\hline & $\begin{array}{l}4 \text { process jumpers - prime water for each pump ( } 2 \text { filter pumps, } \\
1 \text { sample pump, and } 1 \text { sludge pump) }\end{array}$ \\
\hline & 2 process jumpers with MOVs - from filter pumps \\
\hline & 1 jumper with MOV - to Sludge Solids Receipt Tank \\
\hline & 1 process jumper - from in cell sump pump \\
\hline
\end{tabular}




\begin{tabular}{|c|c|}
\hline \multirow[t]{3}{*}{ Tank } & Number of Jumpers and Jumper Connection \\
\hline & $\begin{array}{l}5 \text { electrical jumpers - ( } 2 \text { filter pumps, } 1 \text { sludge pumps, } 1 \text { sample } \\
\text { pump, } 1 \text { agitator) }\end{array}$ \\
\hline & $\begin{array}{l}2 \text { instrument jumpers - }(1 \text { level detection, } 1 \text { temperature } \\
\text { detection w/thermowell })\end{array}$ \\
\hline \multirow[t]{3}{*}{ Filter \#1 } & $\begin{array}{l}2 \text { process jumpers - one to and one from the Alpha Sorption } \\
\text { Tank }\end{array}$ \\
\hline & 1 process jumper - from the backpulse chamber \\
\hline & 1 process jumper - to the Recycle Blend Tank \\
\hline \multirow[t]{3}{*}{ Filter \#2 } & $\begin{array}{l}2 \text { process jumpers - one to and one from the Alpha Sorption } \\
\text { Tank }\end{array}$ \\
\hline & 1 process jumper - from the backpulse chamber \\
\hline & 1 process jumper - to the Recycle Blend Tank \\
\hline \multirow{9}{*}{$\begin{array}{l}\text { Cleaning Solution Dump } \\
\text { Tank }\end{array}$} & 2 process jumpers with MOVs - to cross-flow filters \\
\hline & 2 process jumpers with MOVs - from cross-flow filters \\
\hline & 3 process jumpers - prime water to each pump \\
\hline & 1 process jumper - to Alpha Sorption Tank \\
\hline & 1 process jumper - from Filter Cleaning Caustic Tank \\
\hline & 1 process jumper - from Oxalic Feed Tank \\
\hline & 1 jumper - ventilation \\
\hline & $\begin{array}{l}3 \text { electrical jumpers - ( } 2 \text { filter pumps, } 1 \text { pump to Alpha Sorption } \\
\text { Tank) }\end{array}$ \\
\hline & 2 instrument jumpers \\
\hline \multirow[t]{7}{*}{ Recycle Blend Tank } & 1 process jumper - from in cell sump pump \\
\hline & 2 process jumpers - from cross-flow filters \\
\hline & 2 process jumpers - sampler and sample return \\
\hline & 1 process jumper - ventilation \\
\hline & 2 instrument jumpers \\
\hline & 1 process jumper - return from sampling header \\
\hline & 5 electrical jumpers \\
\hline
\end{tabular}




\begin{tabular}{|c|c|}
\hline \multicolumn{2}{|c|}{ Table B-4 Detailed Jumper Usage for Non-Elutable Ion Exchange } \\
\hline Tank & Number of Jumpers and Jumper Connection \\
\hline & 4 process jumpers - prime water to pumps \\
\hline & 2 process jumpers - from Loaded Resin Hold Tanks \\
\hline & 1 process jumper - from Product Holdup Tank \\
\hline & 1 process jumper - to Alpha Sorption Tank \\
\hline & 2 process jumpers - to columns \\
\hline \multirow[t]{8}{*}{ Columns } & 8 process jumpers - interconnecting supply jumpers \\
\hline & $\begin{array}{l}43 \text {-way process jumpers - to allow sampling for radiation } \\
\text { measurement }\end{array}$ \\
\hline & 4 process jumpers - to Recycle Blend Tank \\
\hline & 4 process jumpers - from Column Preparation Tank \\
\hline & 4 process jumpers - from Caustic Feed Tank \\
\hline & 4 process jumpers - from Process Water Tank \\
\hline & 8 process jumpers - cooling water supply and return \\
\hline & 8 instrument jumpers - temperature measurement \\
\hline Sumps & $\begin{array}{l}5 \text { electrical jumpers \& } 5 \text { instrument jumpers - one for each in } \\
\text { cell sump }\end{array}$ \\
\hline \multirow[t]{11}{*}{ Loaded Resin Hold Tanks } & 1 process jumper - from in cell sump pump \\
\hline & 1 process jumper - from fines filter \\
\hline & 2 process jumpers - nitrogen supply (one for each tank) \\
\hline & $\begin{array}{l}4 \text { process jumpers - cooling water supply and return for each } \\
\text { tank }\end{array}$ \\
\hline & 2 process jumpers - plant air supply for each tank \\
\hline & 2 process jumpers - to Recycle Blend Tank (one for each tank) \\
\hline & 2 process jumpers - to Resin Hold Tank (one for each tank) \\
\hline & 2 process jumpers - ventilation (one for each tank) \\
\hline & $\begin{array}{l}43 \text {-way process jumpers with } 2 \text { MOVs - from columns to either } \\
\text { Loaded Resin Hold Tank }\end{array}$ \\
\hline & 4 process jumpers - prime water for each pump \\
\hline & 4 electrical jumpers \\
\hline
\end{tabular}




\begin{tabular}{|c|c|}
\hline & \\
\hline Tain & Number or Jumpers ana Jumper Connection \\
\hline & 8 instrument jumpers -4 for each tank \\
\hline & 1 process jumper - Process Water to the Fines filter \\
\hline \multirow[t]{8}{*}{ Product Holdup Tank } & 2 instrument jumpers \\
\hline & 4 electrical jumpers \\
\hline & 3 process jumpers - prime water for each pump \\
\hline & 1 process jumper - to Recycle Blend Tank \\
\hline & 1 process jumper - to DSS Hold tanks \\
\hline & 1 process jumper - ventilation \\
\hline & 1 process jumper $-\mathrm{N}_{2}$ supply \\
\hline & 1 process jumper - to online radiation monitor \\
\hline \multirow[t]{3}{*}{ Remote Decon Area } & 10 process jumpers \\
\hline & 5 electrical jumpers \\
\hline & 2 instrumentation jumpers \\
\hline \multirow[t]{3}{*}{ PVV Cell } & 10 process jumpers \\
\hline & 5 electrical jumpers \\
\hline & 6 instrumentation jumpers \\
\hline
\end{tabular}




\section{APPENDIX C}

Cross-Verification of ProdMod and TFARM Models 


\section{APPENDIX C TABLE OF CONTENTS}

Section

Title

Page

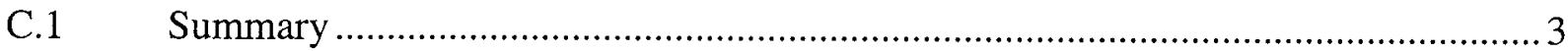

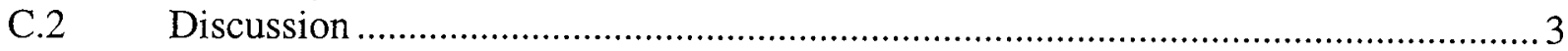

C.2.1 SPEEDUPTM Environment ..........................................................

C.2.2 ProdMod/TFARM Differences ........................................................

C.2.3 Verification Tests ........................................................................ 4

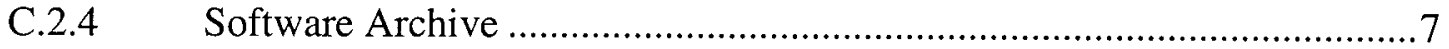

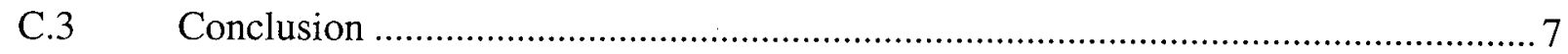




\section{C.1 Summary}

ProdMod (ref. 1) is the Production Planning Model which has been in routine use for generating High Level Waste System Plans. For the Salt Disposition Alternatives study, it is being used to define operating scenarios for taking each of the options to the clean tanks state. TFARM is a new dynamic model, created specifically for the Salt Disposition Alternatives study. It performs dynamic Tank Farm blending simulations that provide detailed temporal responses for the composition of the salt solution being fed to the four alternatives being studied. In order to provide a verification cross-check on these two computational tools, some comparisons of the integral results computed by the ProdMod and TFARM models have been made. The two models provide independent calculations of similar data, which can be used to verify the correctness of the two models. The results examined to date show variations of only a few percent between the two models, thus we have reasonable confidence in the computed results.

\section{C.2 Discussion}

\section{C.2.1 SPEEDUPTM Environment}

Both ProdMod and TFARM models were developed and executed under the SPEEDUP software environment, a product of Aspen Technology, Inc. SPEEDUP provides a very efficient dynamic simulation environment in which models can be quickly developed at the equation level. The software uses flowsheeting capabilities and automatic solution algorithm generators to solve a wide range of modeling problems. The solution capabilities of SPEEDUP were verified soon after its initial purchase by WSRC via several rigorous numerical benchmarks (refs. 2,3). In addition, SPEEDUP is in widespread current use throughout the international chemical process community (e.g., DuPont Co., Bayer AG, etc.) where it routinely supports multi-million dollar process design decisions.

\section{C.2.2 ProdMod/TFARM Differences}

Though both ProdMod and TFARM are SPEEDUP models, they represent very different solutions of the problem of interest. Their two equation sets are fundamentally different. ProdMod consists of a set of approximately 100,000 algebraic equations which represent time advancement only implicitly in the form of the equations. TFARM consists of a set of approximately 10,000 ordinary differential equations (with only a few algebraic equations) which are dynamically integrated with an automatic timestep selector. Thus we claim that the results we will be discussing are derived from two totally independent solutions and provide a valid verification of the two models, at least in an integral sense.

The common point between ProdMod and TFARM is the use of the same scenario of events (i.e., "the schedule"). This ensures two independent solutions of the same problem (which is 
the basis of the verification). In fact, the starting point for TFARM is the input of the production schedule generated by the output of a ProdMod run: that defines the sequence and timing of transfers within the tank farm, and the timing of blend compositions to be fed to the salt disposition alternative being studied.

There are sufficient differences between the ProdMod and TFARM models so that one would never expect exact agreement between the two. Most of the major operations are treated by the two models: tank-to-tank supernate transfers, direct evaporation from tanks, salt cake dissolution, fresh waste sources from the canyons, DWPF recycle and ESP spent wash sources to the tank farm. But there are differences in the details of implementation. The largest difference is the neglect in TFARM of wash water from those tanks that are being taken out of service, which takes on significance mostly in the last years of a scenario. In addition, the recycle and spent wash sources in TFARM are kept fixed at a given composition, rather than varying as the spent wash would during sludge washing. Plus, continued evaporation of tank contents is not modeled in TFRAM. On the other hand, the TFARM compositions are much more detailed (tracking 34 rather than the 4 chemical species in ProdMod), thus the tank composition database takes a totally different form (but hopefully is consistent) between the two models. In fact, the entire reason for creating TFARM was to predict the time response of all 34 constituents in the different blends being fed to the salt disposition alternatives. The purpose of TFARM is to highlight the maximum deviations from a uniform, average composition feed, while the purpose of ProdMod is to work through the entire multi-decade production schedule with a feasible scenario which leads to clean tanks.

\section{C.2.3 Verification Tests}

Due to the constraints of time, we are necessarily limited to the verification of the two models only in an integral sense. Thus for three of the salt disposition alternatives (the CST Option is omitted since its blending schedule is almost identical to the Solvent Extraction Option), we will report the volume of salt solution blended together, and the total volume of dilution water required to bring the individual blends to the $\mathrm{Na}$ molarity specification. These two volumes provide a gross, integral test of the two models in the sense that the former would identify any large discrepancies in the volume quantities blended together (i.e., an error in the schedule details), while the latter would identify any large discrepancy in the specific compositions of the volumes used in the blending (i.e., an error in the tank composition data). In addition, the blend details for one FY for one of the options (FY2006 in the Direct Grout option) will be broken down into its individual sub-volumes to provide one finer-than-integral test case.

\section{Direct Grout Option}

The Direct Grout Option results were examined in the most detail. Three variants of this case were analyzed. The first pass through this option was with the original schedule as defined 
prior to 9/21/98 (start date of Jan 2004). The integral comparison between TFARM and ProdMod yielded the following, where the difference is (ProdMod-TFARM)/ProdMod:

\begin{tabular}{|l|c|c|c|}
\hline & TFARM & ProdMod & difference \\
\hline $\begin{array}{l}\text { Total blend volume before } \\
\text { dilution }\end{array}$ & $57,562 \mathrm{kgal}$ & $58,324 \mathrm{kgal}$ & $1.3 \%$ \\
\hline $\begin{array}{l}\text { Total dilution added to get to } \\
6 \mathrm{M} \mathrm{Na}\end{array}$ & $19,955 \mathrm{kgal}$ & $20,397 \mathrm{kgal}$ & $2.2 \%$ \\
\hline $\begin{array}{l}\text { Total diluted blend } \\
\text { Volume (FY2016) }\end{array}$ & $77,517 \mathrm{kgal}$ & $79,135 \mathrm{kgal}$ & $2.0 \%$ \\
\hline
\end{tabular}

Following the above comparison, it was discovered that TFARM was treating the ESP spent wash returns to the tank farm as a stream with $\mathrm{spg}=1.0004$. The analysis was repeated with a better characterization of that stream's composition $(\mathrm{spg}=1.2)$ with a significantly improved result:

\begin{tabular}{|l|c|c|c|}
\hline & TFARM & ProdMod & difference \\
\hline $\begin{array}{l}\text { Total blend volume before } \\
\text { dilution }\end{array}$ & $57,569 \mathrm{kgal}$ & $58,324 \mathrm{kgal}$ & $1.3 \%$ \\
\hline $\begin{array}{l}\text { Total dilution added to get to } \\
6 \mathrm{M} \mathrm{Na}\end{array}$ & $20,500 \mathrm{kgal}$ & $20,397 \mathrm{kgal}$ & $-0.5 \%$ \\
\hline $\begin{array}{l}\text { Total diluted blend } \\
\text { Volume (FY2016) }\end{array}$ & $78,069 \mathrm{kgal}$ & $79,135 \mathrm{kgal}$ & $1.3 \%$ \\
\hline
\end{tabular}

A third variation of the Direct Grout option was run after that option's start date was moved up to March 2006 (both ProdMod and TFARM cases were rerun subsequent to this 9/21/98 change). The results for this third, delayed start, case were:

\begin{tabular}{|l|c|c|c|}
\hline & TFARM & ProdMod & difference \\
\hline $\begin{array}{l}\text { Total blend volume before } \\
\text { dilution }\end{array}$ & $58,142 \mathrm{kgal}$ & $58,815 \mathrm{kgal}$ & $1.1 \%$ \\
\hline $\begin{array}{l}\text { Total dilution added to get to } \\
6 \mathrm{M} \mathrm{Na}\end{array}$ & $19,589 \mathrm{kgal}$ & $18,608 \mathrm{kgal}$ & $-5.3 \%$ \\
\hline $\begin{array}{l}\text { Total diluted blend } \\
\text { Volume (FY2018) }\end{array}$ & $77,731 \mathrm{kgal}$ & $77,423 \mathrm{kgal}$ & $-0.4 \%$ \\
\hline
\end{tabular}

The above integral comparisons show differences between the two models of the order of a few percent. In addition, the change between the first and second variations shows a reduction 
in the differences when a known discrepancy was corrected. Those reasonable agreements suggest no gross errors in the models.

A more rigorous test is to examine the specific details of the blend composition for a single year rather than relying on the "macro" results provided by the integral comparisons. That has been done for the FY2006 blend for the Direct Grout Option (in the delayed start case), focusing specifically on the Na species, with the following results:

\begin{tabular}{|c|c|c|c|}
\hline & Volume, kgal & ProdMod & TFARM \\
\hline Supernate Decants & & Na: & \\
\hline Tank 43 & 362. & $5.80 \mathrm{M}$ & $7.13 \mathrm{M}$ \\
\hline Tank 26 & $400.72 \mathrm{M}$ \\
\hline Tank 30 & 300. & $10.77 \mathrm{M}$ & $9.17 \mathrm{M}$ \\
\hline Tank 47 & $149.76 \mathrm{M}$ \\
\hline Tank 41 & & $8.56 \mathrm{M}$ & $8.16 \mathrm{M}$ \\
\hline Tank 14 & 300. & Na: & $8.33 \mathrm{M}$ \\
\hline Tank 47 & 413. & $8.02 \mathrm{M}$ & $7.48 \mathrm{M}$ \\
\hline Dissolved Saltcake & 997. & $6.41 \mathrm{M}$ & $7.88 \mathrm{M}$ \\
\hline $\begin{array}{l}\text { Dilution H2O to achieve 6.0 } \\
\text { M Na }\end{array}$ & 2921. & $7.66 \mathrm{M}$ & $912 . \mathrm{kgal}$ \\
\hline
\end{tabular}

The above results illustrate several points of interest. First, the tank compositions differ between the two models, which may have several causes: differences in the initial tank composition database, differences in the effects of tank-to-tank transfers, modeling differences (e.g., Tank 43 is an evaporator feed tank - evaporator systems are handled very differently in the two models). Second, the differences in the supernate and saltcake regions tend in opposite directions, thus the net effect is minimized: the total blend $\mathrm{Na}$ content is roughly the same, thus the final composition of the two blends do not differ greatly. The result is that both models predict a dilution volume that agrees to within about $10 \%$. Third, the Na M value for the total blend in both models can be almost trivially calculated by hand, and is found to be in agreement with the data produced by the models. The ultimate conclusion is that on the "micro" level as well as on the "macro" level, both models are consistent to within the uncertainty on the basic tank farm data itself (typically larger than 10\%).

For completeness, we will go on to examine the two other options, reverting again to just looking at the integral comparisons.

\section{$\underline{\text { Small Tank Option }}$}

In the case of the Small Tank Option, we again compare the data generated by the analyses for the original schedule (i.e., pre-9/21/98). That integral data was found to be: 


\begin{tabular}{|l|c|c|c|}
\hline & TFARM & ProdMod & Difference \\
\hline $\begin{array}{l}\text { Total blend volume before } \\
\text { dilution }\end{array}$ & $58,714 \mathrm{kgal}$ & $60,156 \mathrm{kgal}$ & $2.4 \%$ \\
\hline $\begin{array}{l}\text { Total dilution added to get to } \\
6.44 \mathrm{M} \mathrm{Na}\end{array}$ & $14,524 \mathrm{kgal}$ & $11,538 \mathrm{kgal}$ & $-25.9 \%$ \\
\hline $\begin{array}{l}\text { Total diluted blend } \\
\text { Volume (FY2019) }\end{array}$ & $73,238 \mathrm{kgal}$ & $71,694 \mathrm{kgal}$ & $-2.2 \%$ \\
\hline
\end{tabular}

In this option, there is a significantly larger difference in the necessary dilution volume (which suggests differences in the specific tank compositions); however, that difference is compensated for by the blend volume, so that the net results are again within several percent of one another.

\section{Solvent Extraction Option}

Similarly, the Solvent Extraction Option case was examined for the pre-9/21/98 original schedule, with the results:

\begin{tabular}{|l|c|c|c|}
\hline & TFARM & ProdMod & Difference \\
\hline $\begin{array}{l}\text { Total blend volume before } \\
\text { dilution }\end{array}$ & $58,660 \mathrm{kgal}$ & $59,194 \mathrm{kgal}$ & $0.9 \%$ \\
\hline $\begin{array}{l}\text { Total dilution added to get to } \\
6.44 \mathrm{M} \text { Na }\end{array}$ & $13,465 \mathrm{kgal}$ & $15,981 \mathrm{kgal}$ & $15.7 \%$ \\
\hline $\begin{array}{l}\text { Total diluted blend } \\
\text { Volume (FY2019) }\end{array}$ & $72,127 \mathrm{kgal}$ & $75,175 \mathrm{kgal}$ & $4.1 \%$ \\
\hline
\end{tabular}

Again, the differences are of the same order as for the earlier cases.

\section{C.2.4 Software Archive}

All the computer records required to run the TFARM blending analyses have been archived on the Cray in the directory: /archive/t4148/blend. An appropriately named subdirectory (i.e., /grout, /grout2, /grout3, /smallt, /solvext, and /cstix) has been created for each of the cases.

\section{C.3 Conclusions}

An integral comparison has been made between TFARM and ProdMod model results for three of the Salt Disposition Alternative options. In addition, a single year of the Direct Grout Option has been examined in more detail. All the results suggest an agreement between the two independent models to within several percent, with the differences being ascribed to minor differences between the way operations are modeled, and to small differences due to 
the entirely different forms of the tank farm composition database used to drive the two models. This reasonable agreement can be considered to provide a cross-verification of the two models.

\section{References}

1. M.V. Gregory and P.K. Paul, "Functional Overview of the Production Planning Model (ProdMod)," WSRC-TR-95-0386, September 1995.

2. M.V. Gregory, "Numerical Benchmarking of SPEEDUP ${ }^{\mathrm{TM}}$ Against Point Kinetics Solutions," WSRC-RP-93-320, February 1993.

3. M.V. Gregory, "Code-to-Code Benchmarking of SPEEDUP' Versus WATFAM," WSRC-RP-93-381, March 1993. 
APPENDIX D

INITIAL TANK INVENTORY 


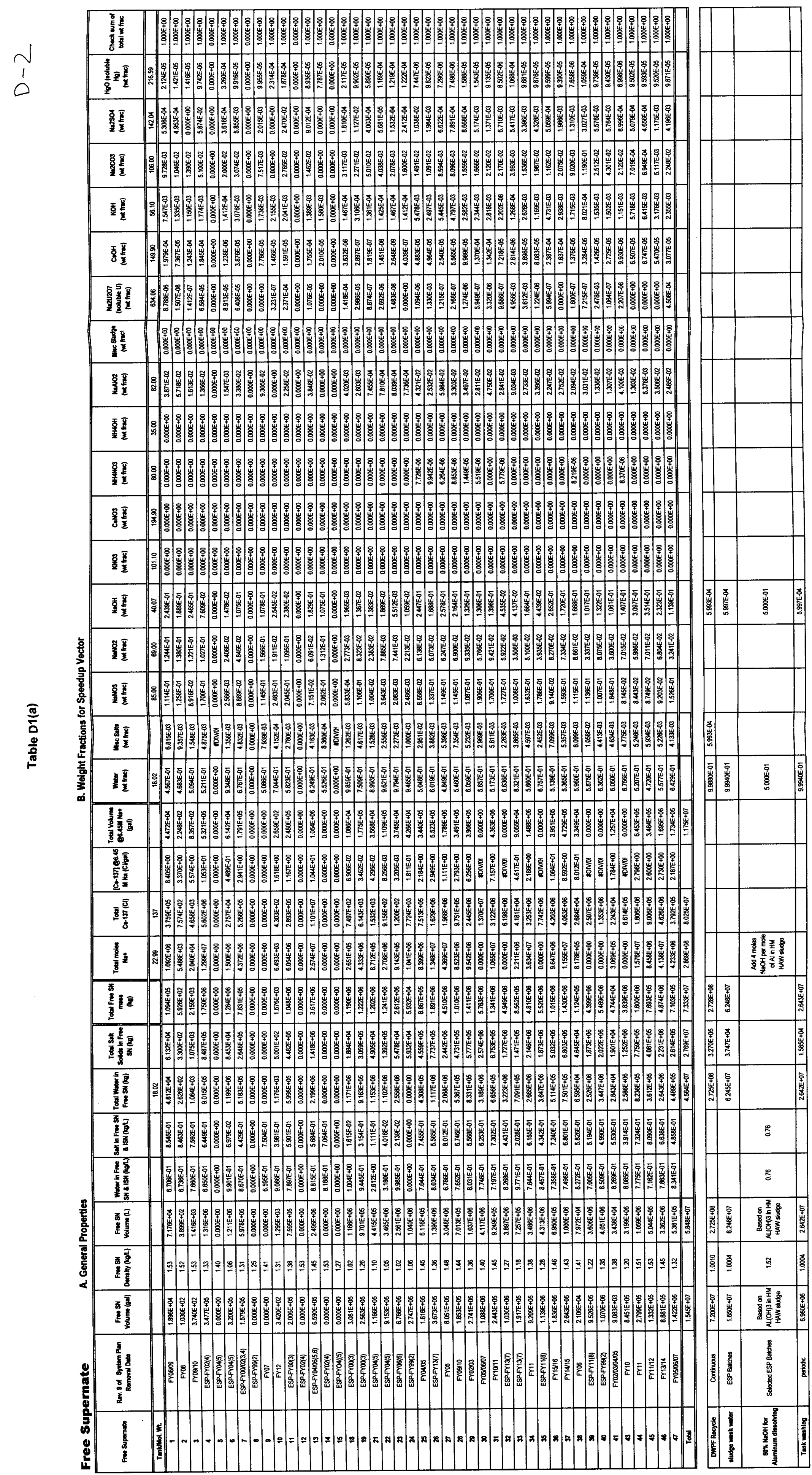




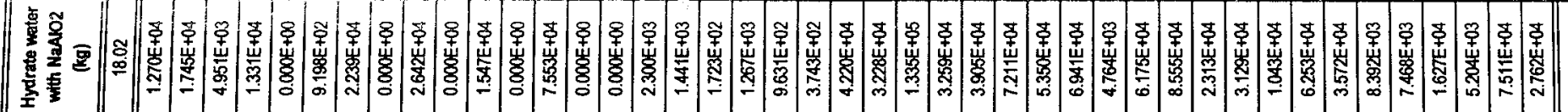

年 焉至

鼓意

害

每

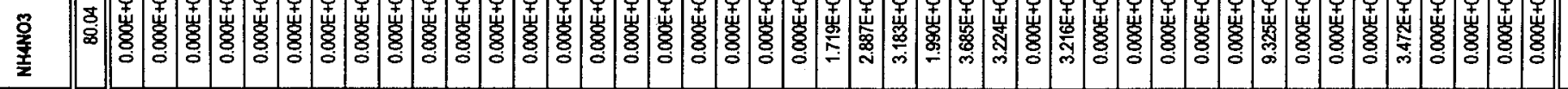

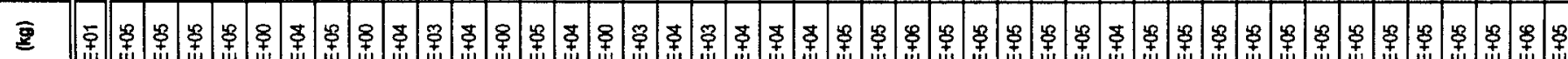

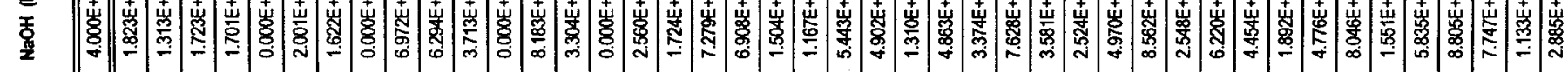

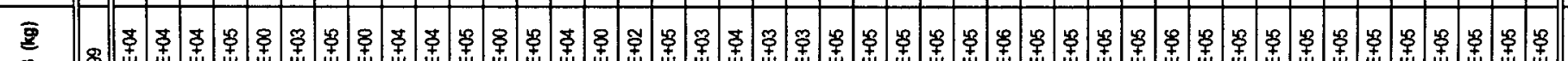

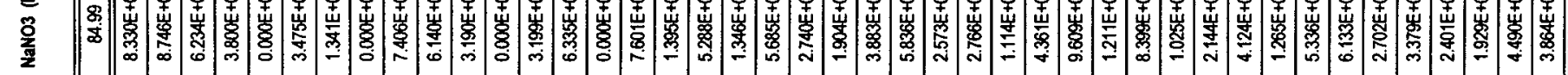

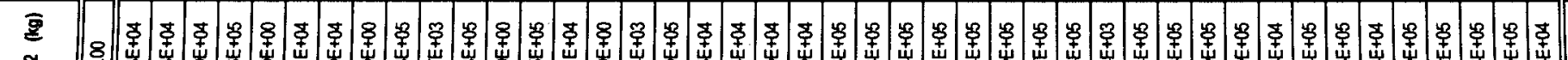

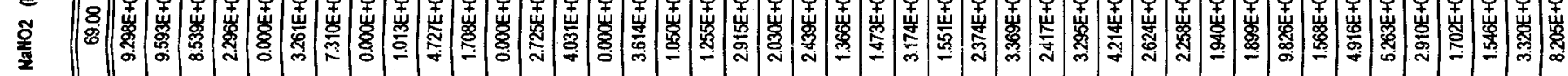

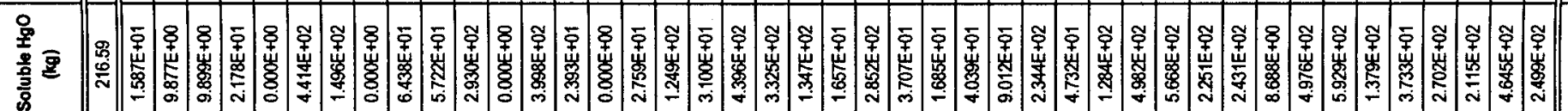

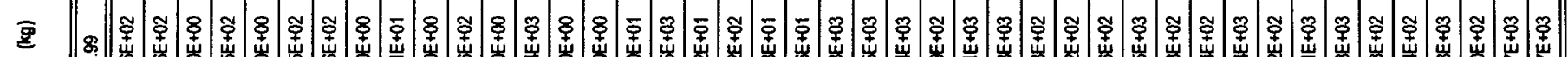

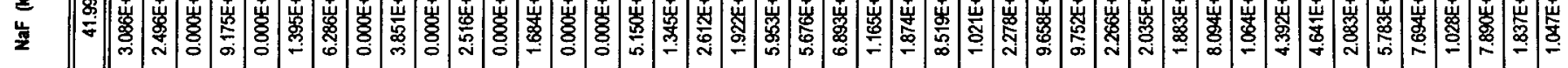

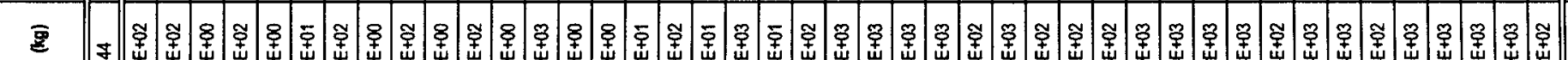

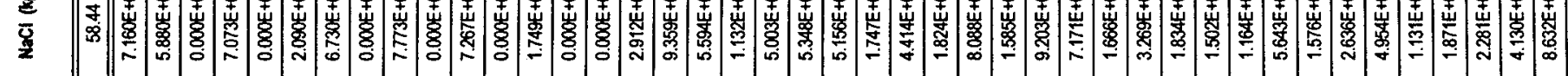

言

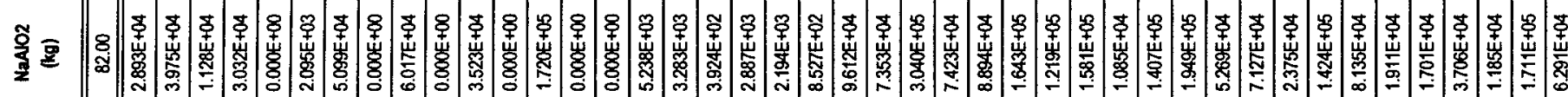

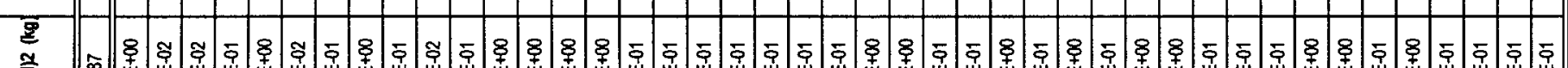

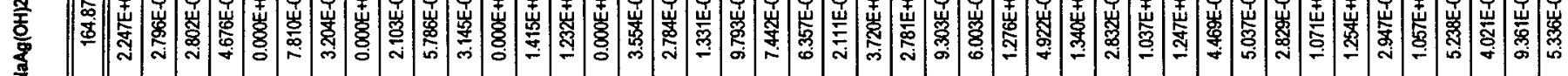

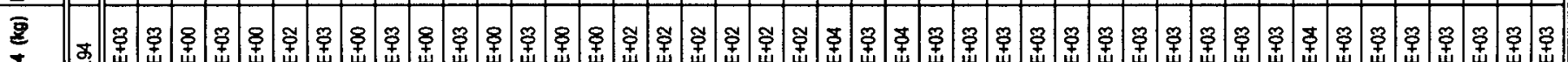

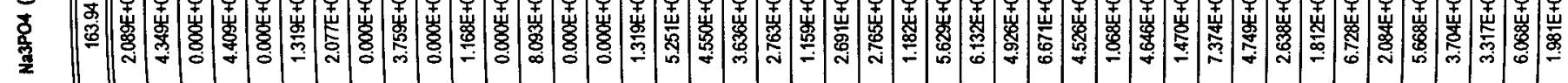

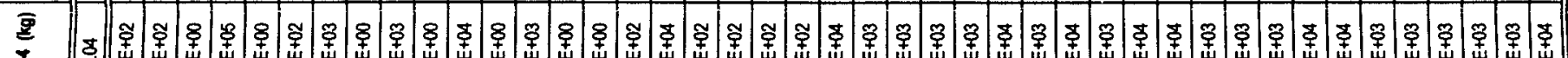

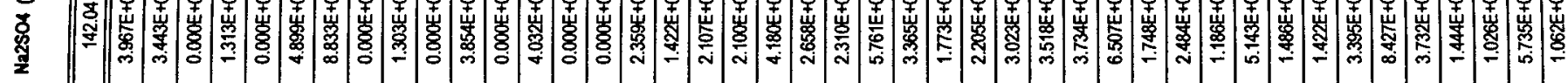

高

兽

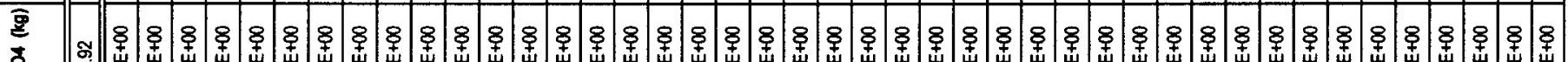

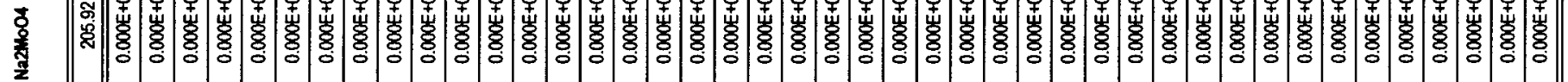

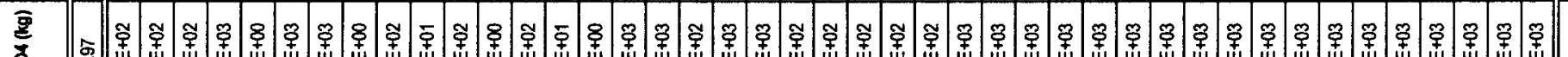

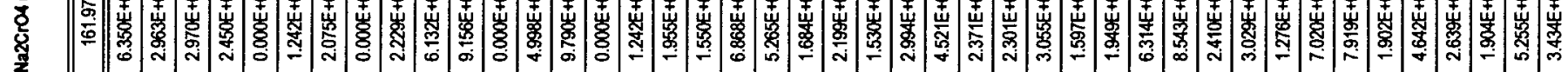

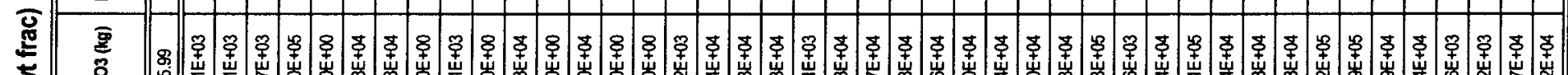

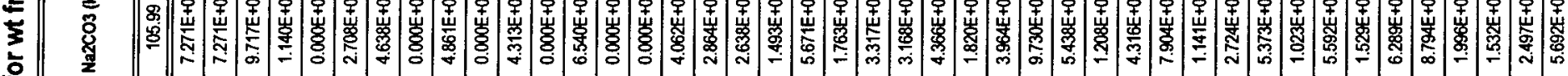

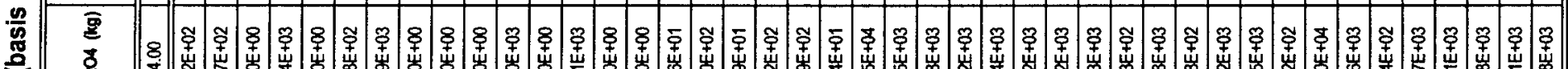

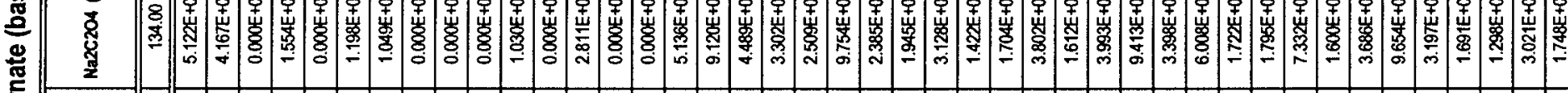

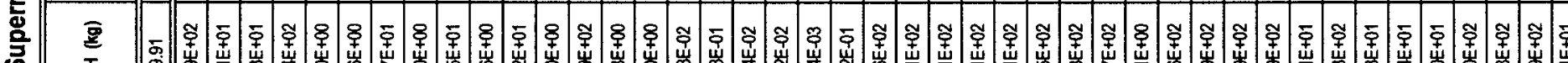

焉

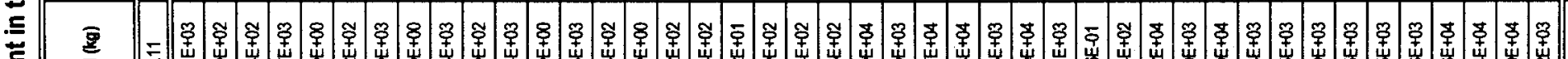

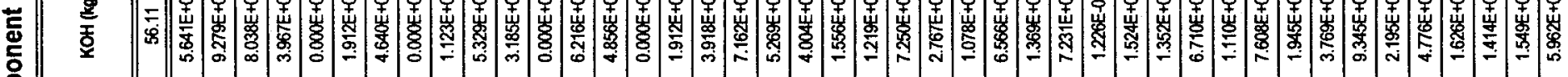

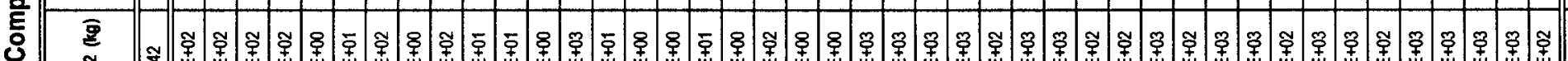

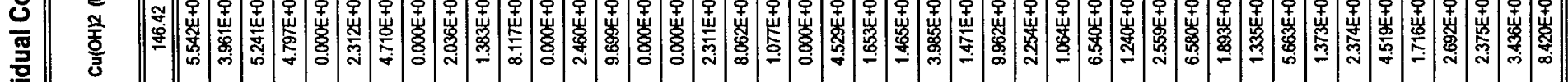

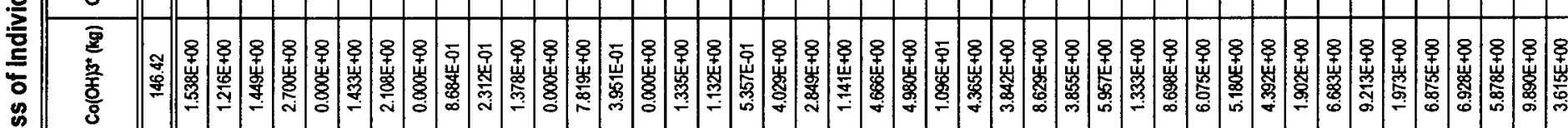

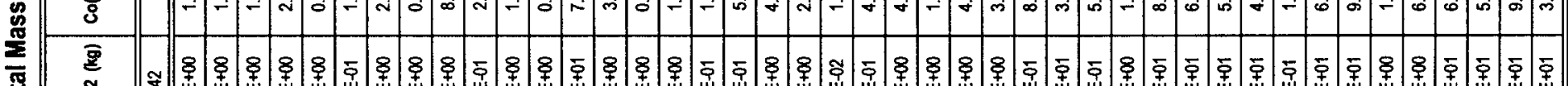

is

要

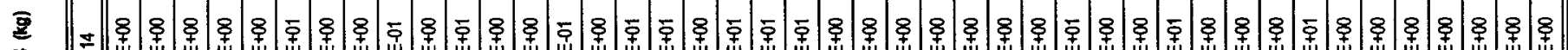

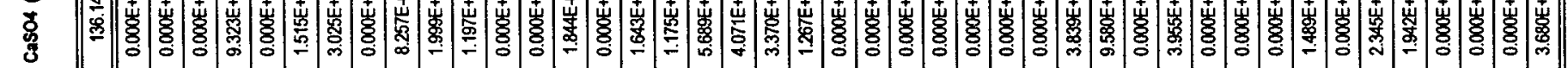

:

重 言

空

政

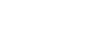




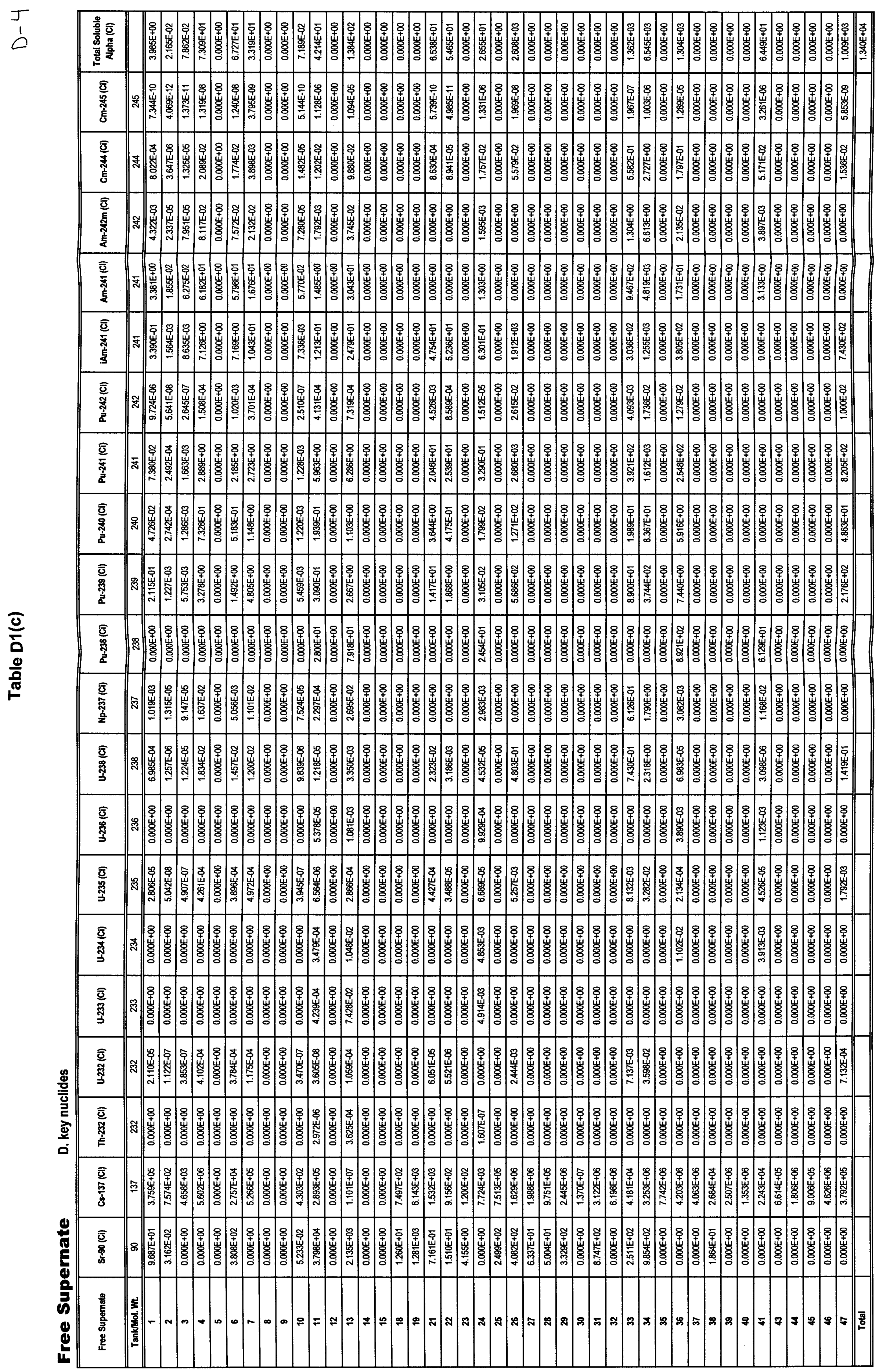




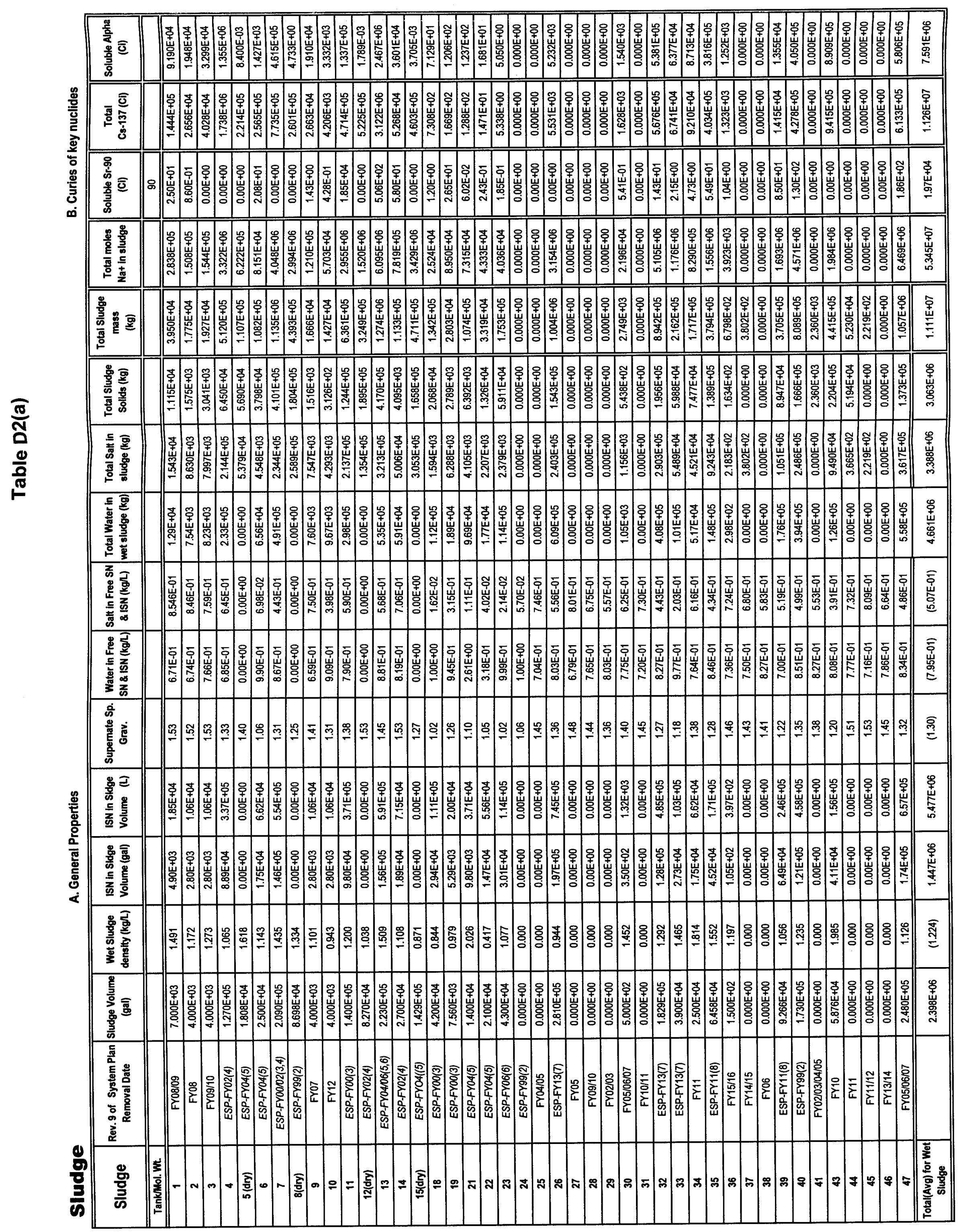




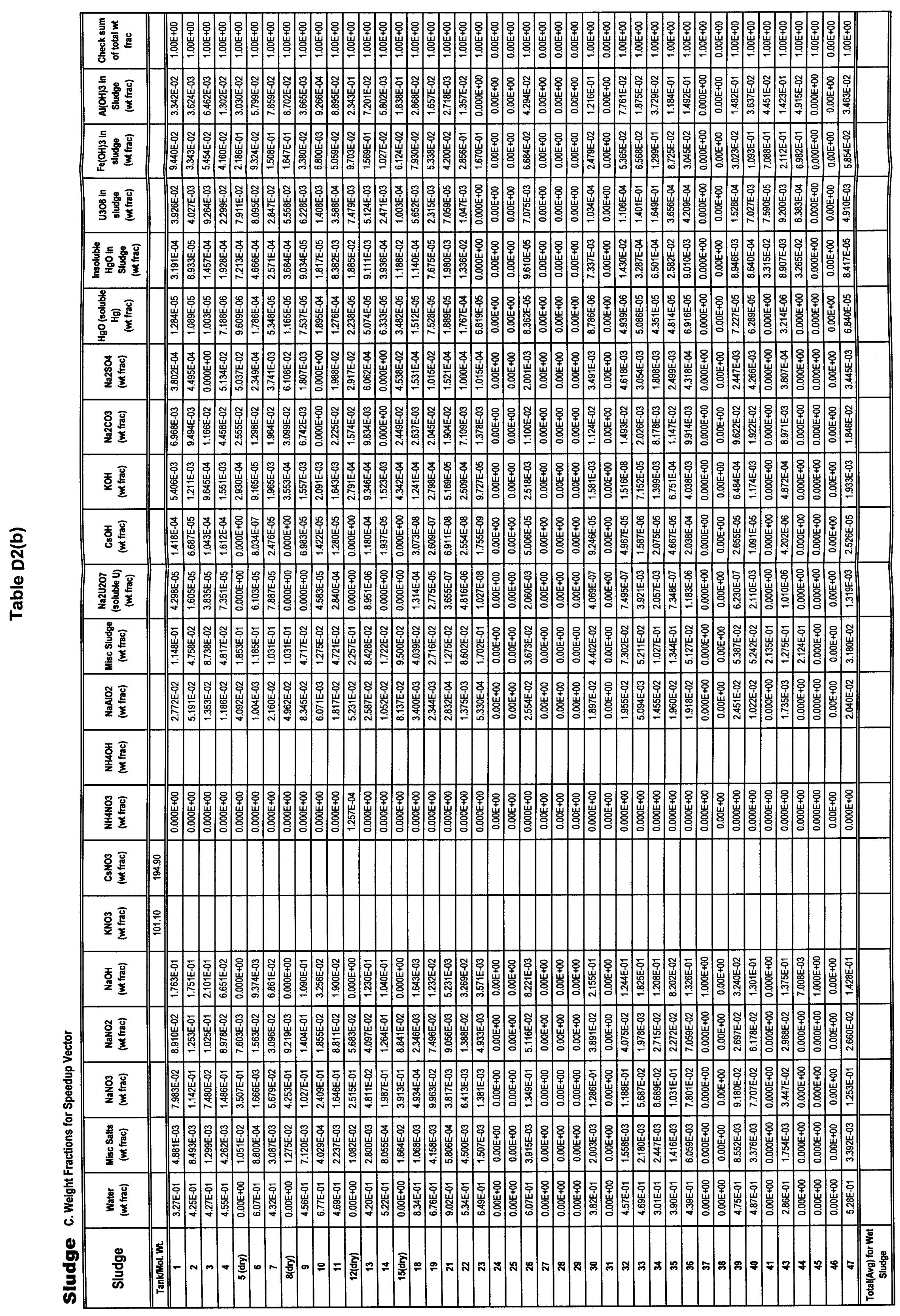




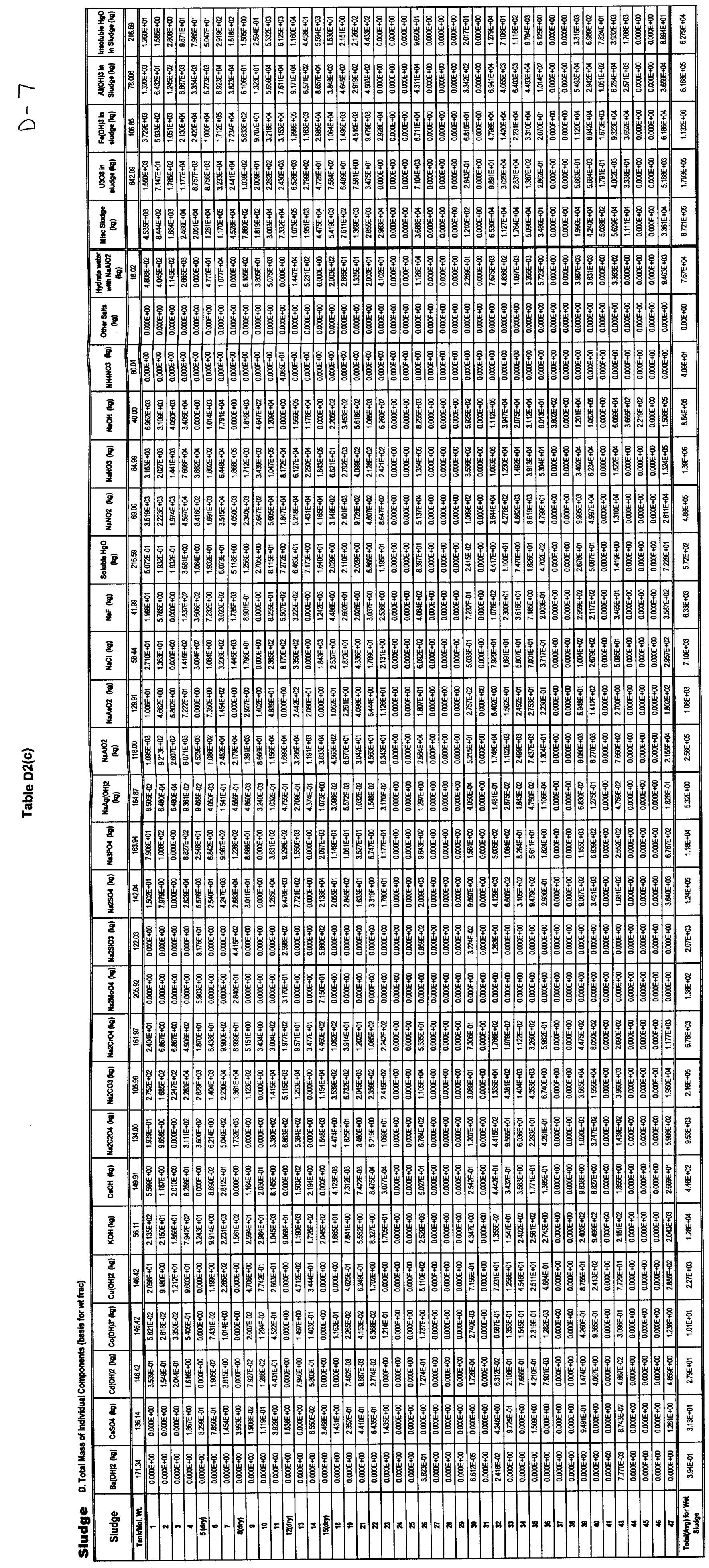




\begin{tabular}{|c|c|c|c|}
\hline 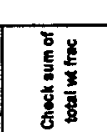 & 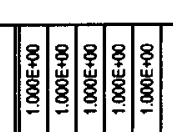 & 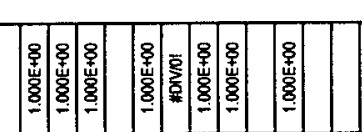 & 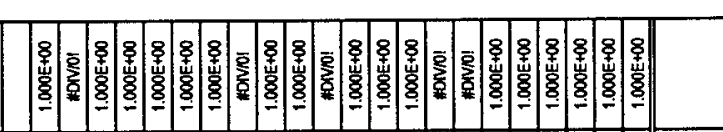 \\
\hline 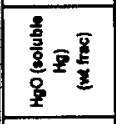 & 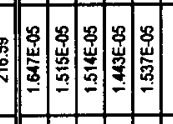 & 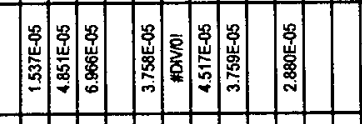 & 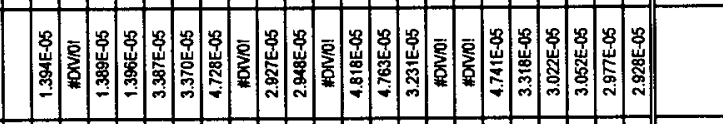 \\
\hline in & 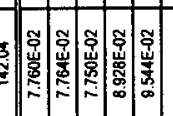 & 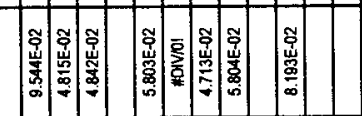 & 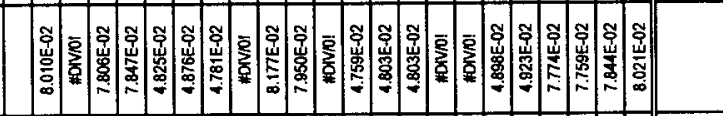 \\
\hline 嫼 & 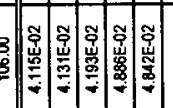 & 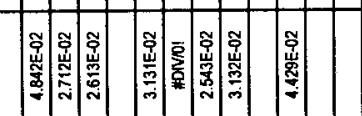 & 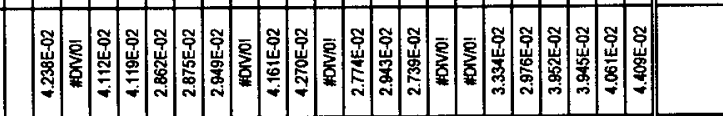 \\
\hline 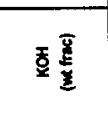 & 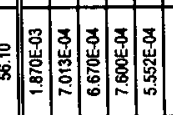 & 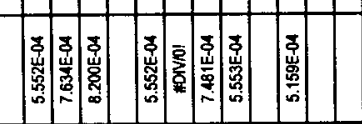 & 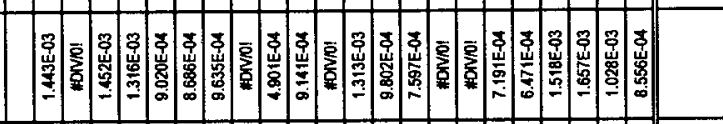 \\
\hline$\frac{8 \pi}{81}$ & 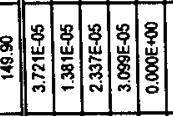 & 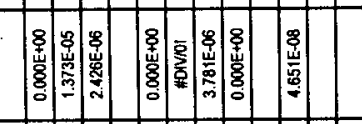 & 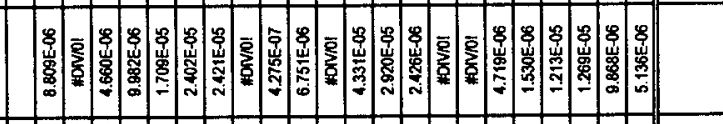 \\
\hline 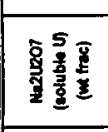 & 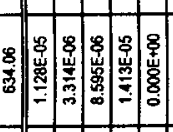 & 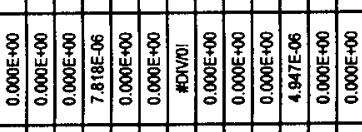 & 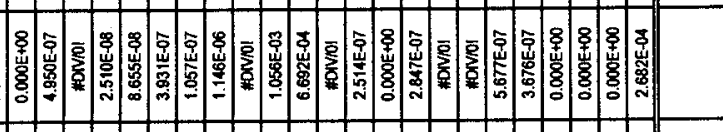 \\
\hline II & 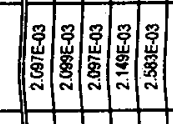 & 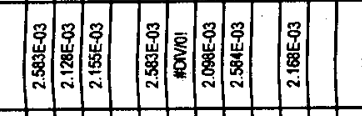 & 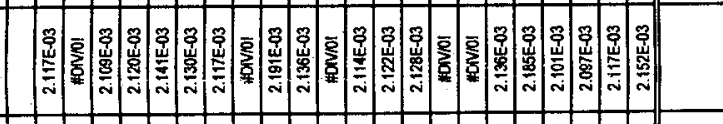 \\
\hline II & 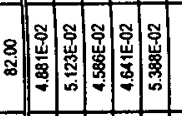 & 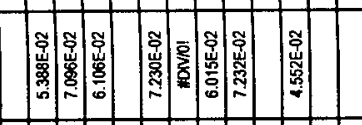 & 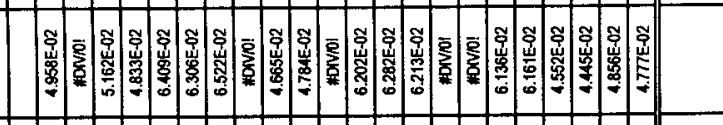 \\
\hline II & 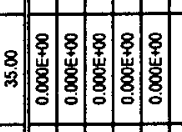 & 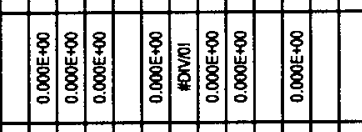 & 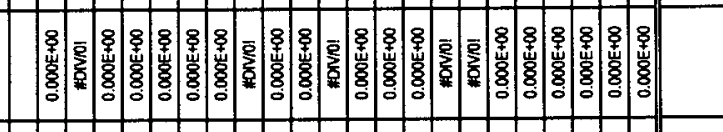 \\
\hline II & 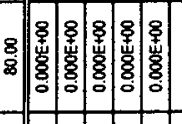 & 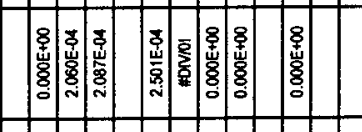 & 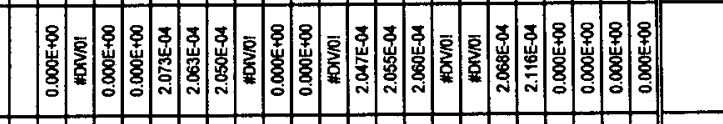 \\
\hline$\frac{81}{2}$ & 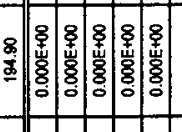 & 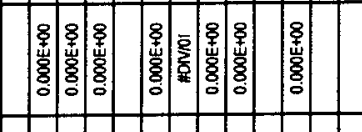 & 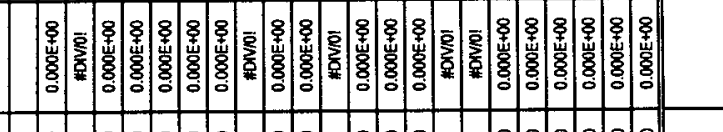 \\
\hline 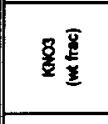 & 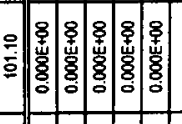 & 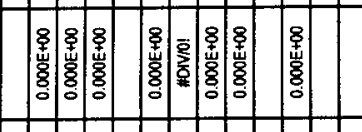 & 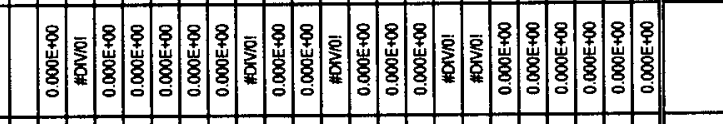 \\
\hline$\underline{\underline{15}}$ & 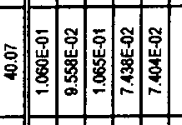 & 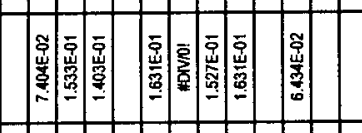 & 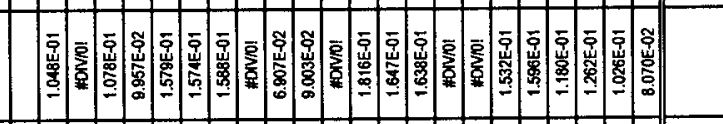 \\
\hline II & 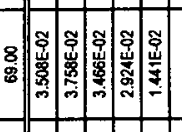 & 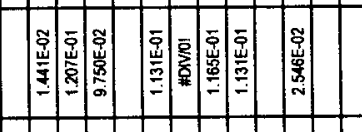 & 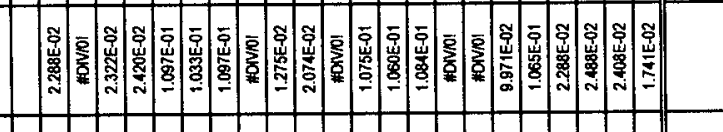 \\
\hline II & 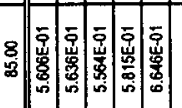 & 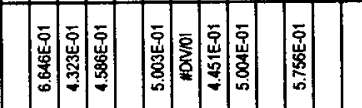 & 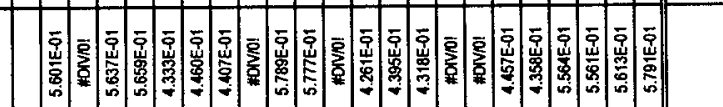 \\
\hline$\sqrt{11}$ & 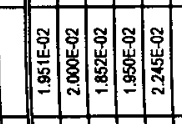 & 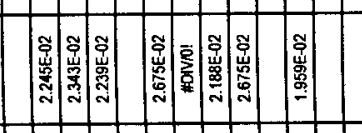 & 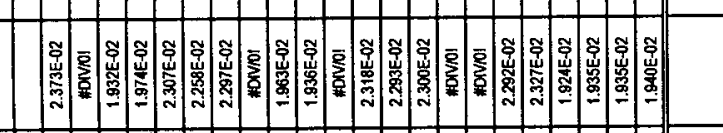 \\
\hline 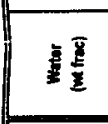 & 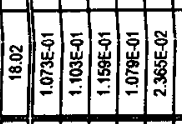 & 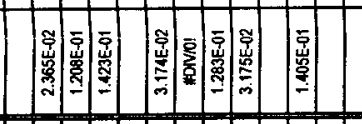 & 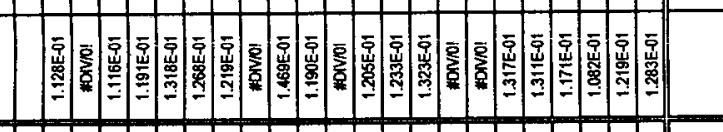 \\
\hline$\frac{15}{15}$ & 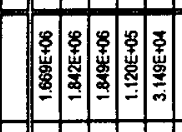 & 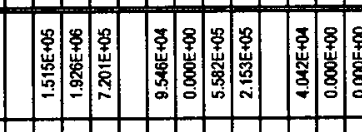 & 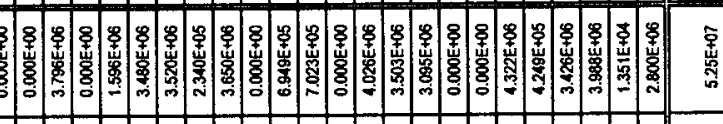 \\
\hline 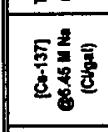 & 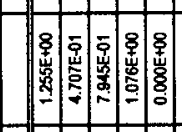 & 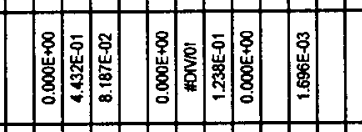 & 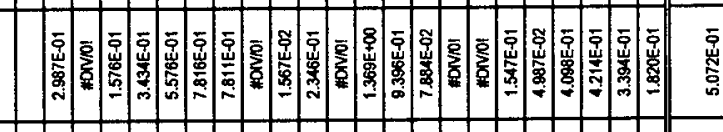 \\
\hline $\begin{array}{ll}\frac{3}{3 \frac{5}{2}} \\
\end{array}$ & 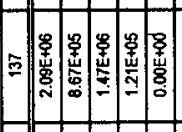 & 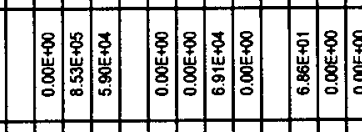 & 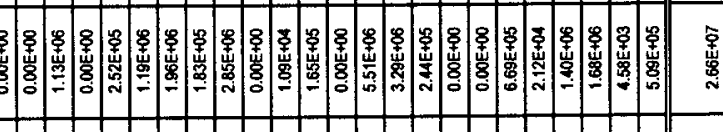 \\
\hline$\overline{i s}$ & 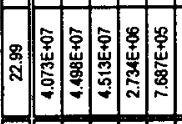 & 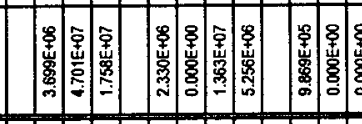 & 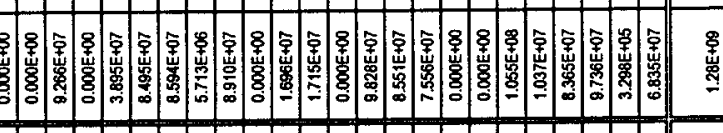 \\
\hline tis & 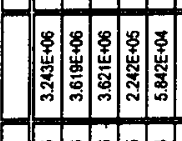 & 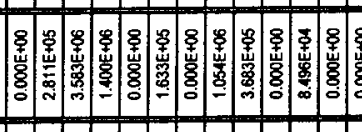 & 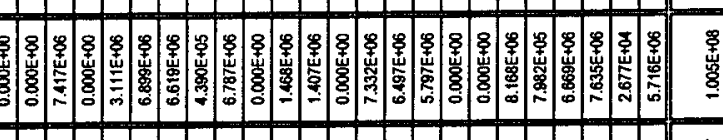 \\
\hline$\frac{1}{12}$ & 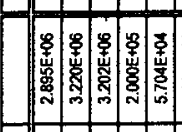 & 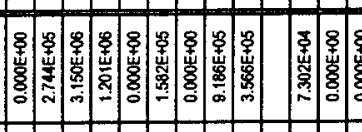 & 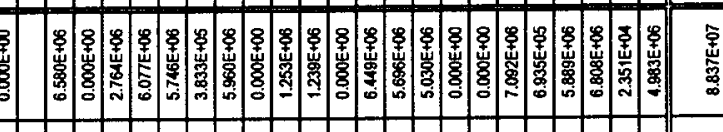 \\
\hline 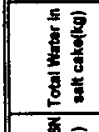 & 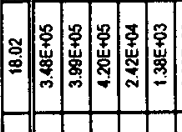 & 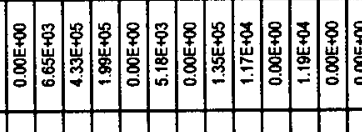 & 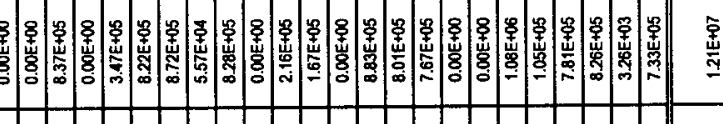 \\
\hline 醇 & 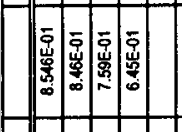 & 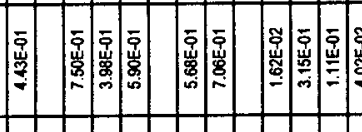 & 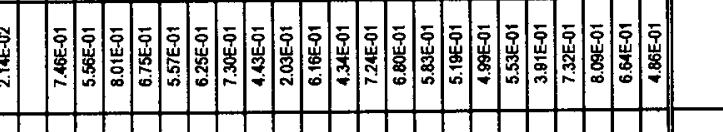 \\
\hline$\frac{15}{3}$ & 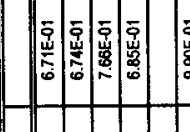 & 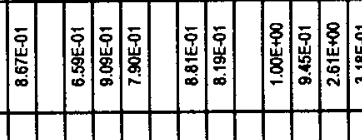 & 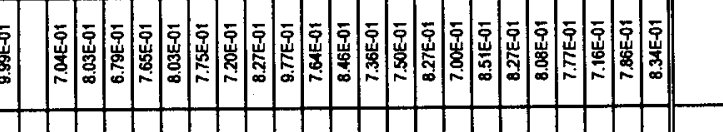 \\
\hline is & $2 \pm n=2$ & 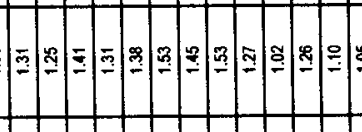 & 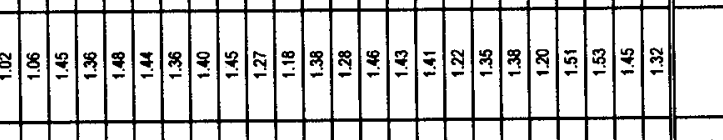 \\
\hline 垤 & 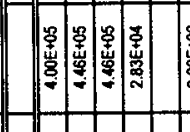 & 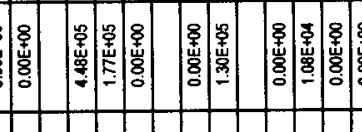 & 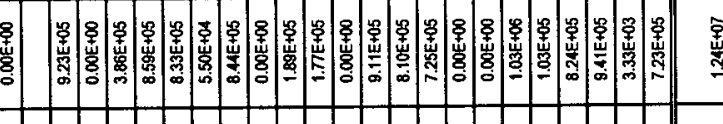 \\
\hline 䇺 & 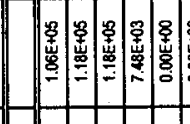 & 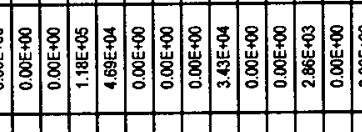 & 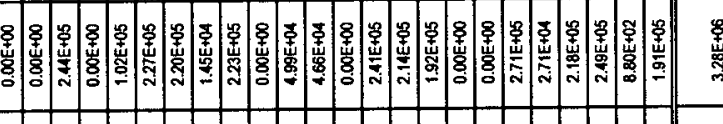 \\
\hline$\|_{1}^{2}$ & 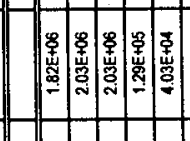 & 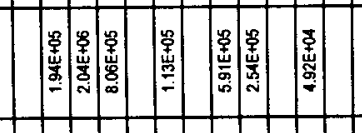 & 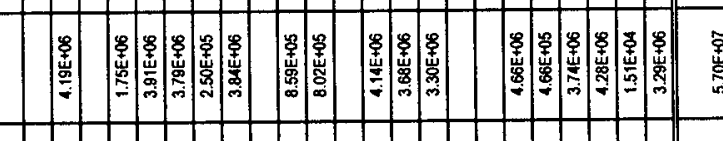 \\
\hline in & & 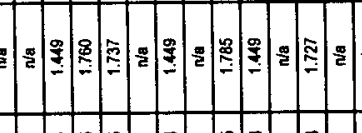 & 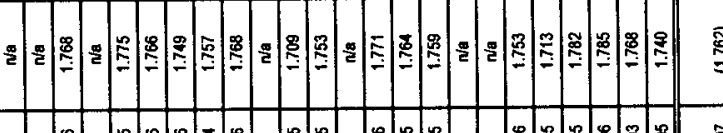 \\
\hline 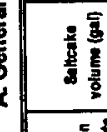 & 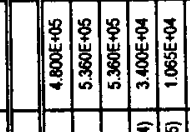 & 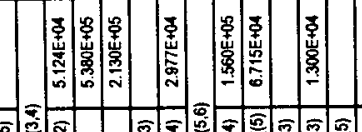 & 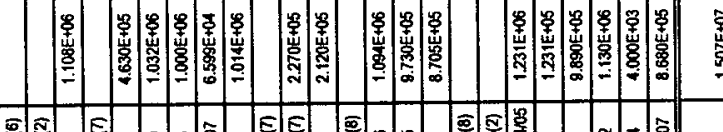 \\
\hline III & $\sqrt{n=1}$ & 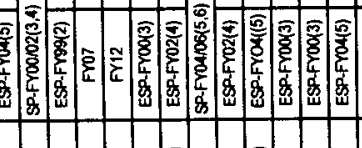 & 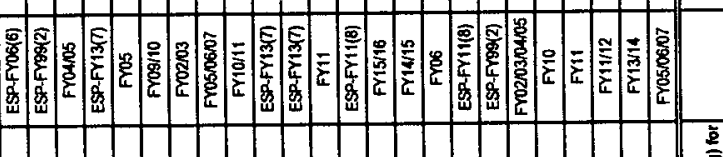 \\
\hline
\end{tabular}




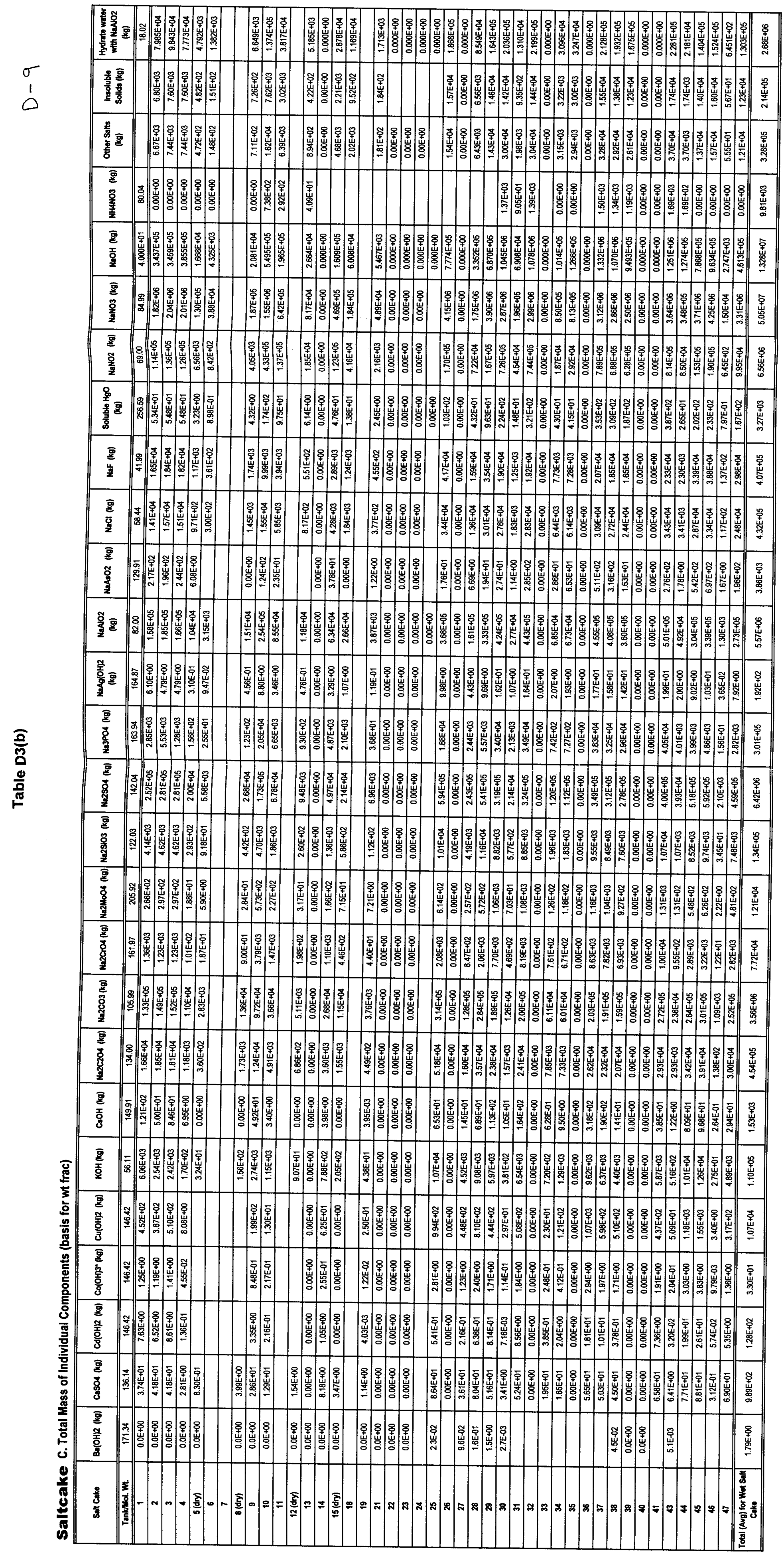




\begin{tabular}{|c|c|c|c|c|c|}
\hline (1) & & 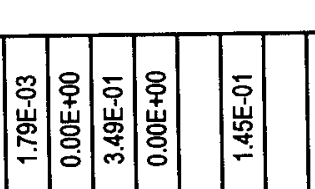 & & 圆 & \\
\hline 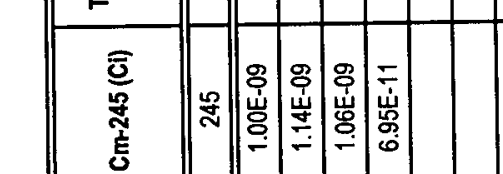 & 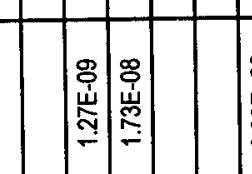 & 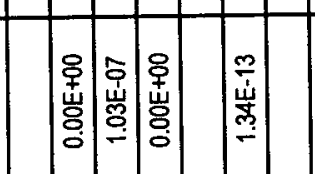 & & 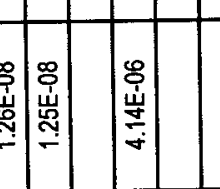 & 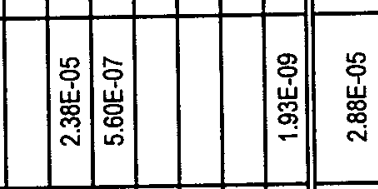 \\
\hline 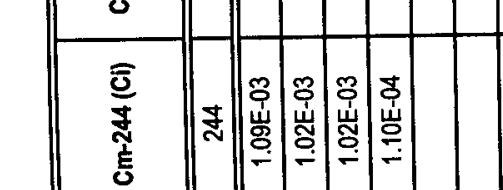 & 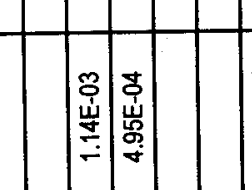 & 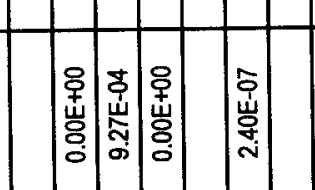 & & 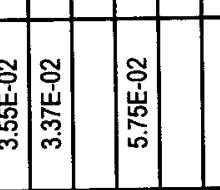 & 䧳 \\
\hline 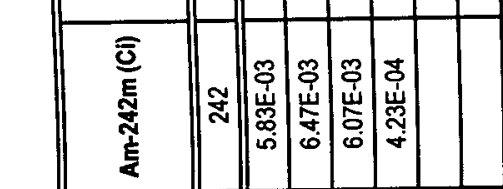 & IIIII & & 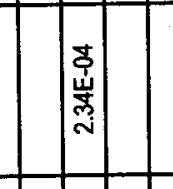 & 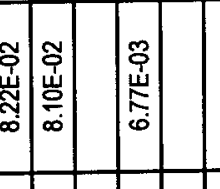 & 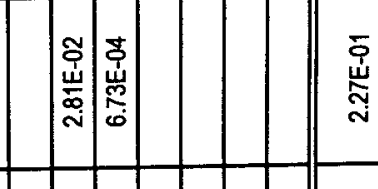 \\
\hline 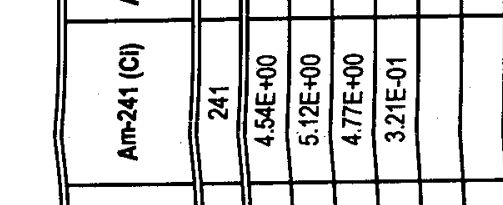 & 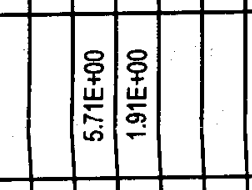 & & 国 & 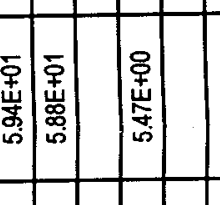 & 闇 \\
\hline 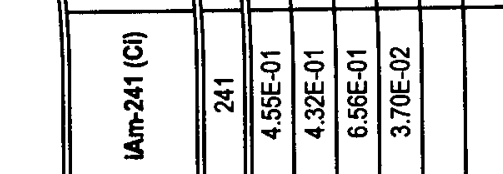 & 閏| & 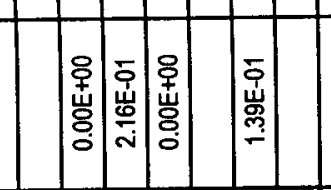 & in & 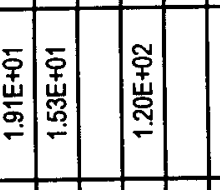 & 谙 \\
\hline 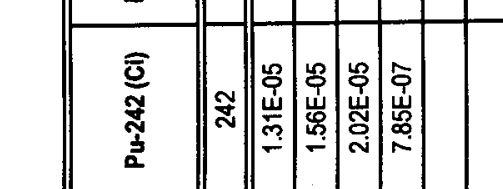 & 林| & 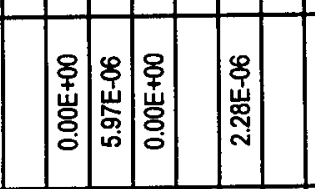 & & 武国 & 1 \\
\hline 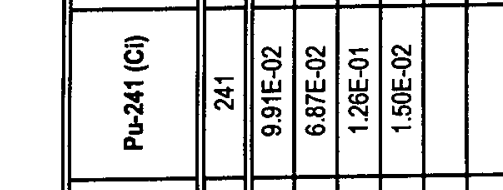 & 夙 & 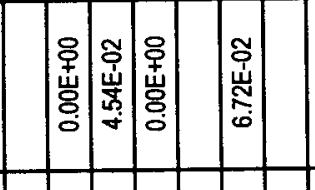 & 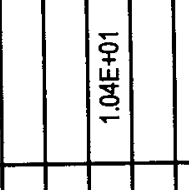 & 䨿国 & 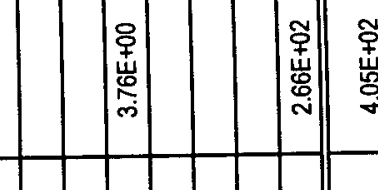 \\
\hline 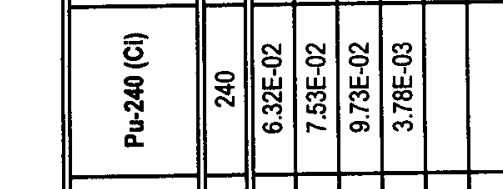 & 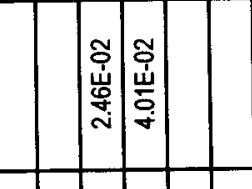 & 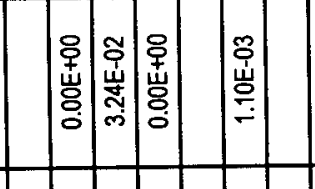 & 国 & 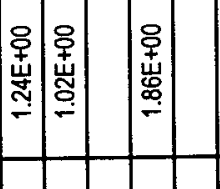 & \\
\hline 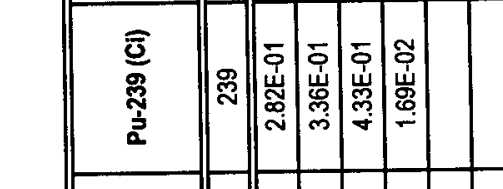 & 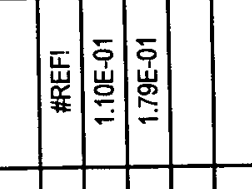 & 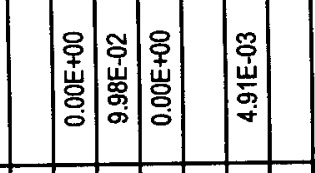 & 国 & 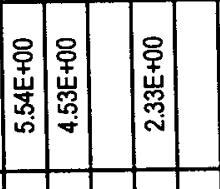 & 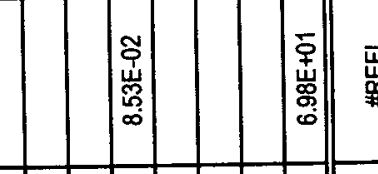 \\
\hline I: & i]II & & & 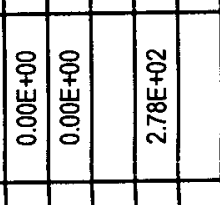 & 周闻 \\
\hline 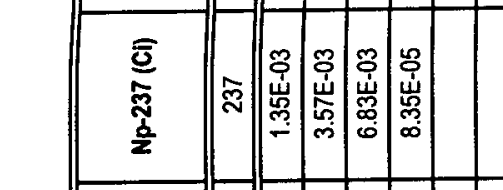 & 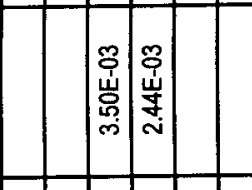 & & 圆 & 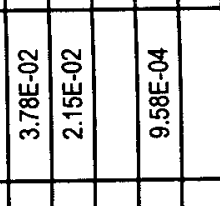 & 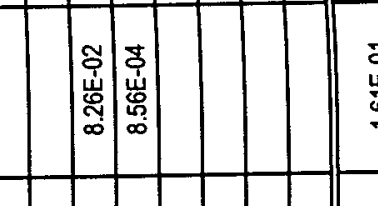 \\
\hline 要 & 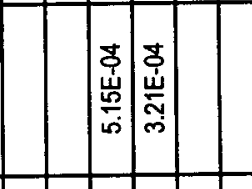 & 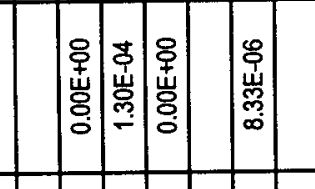 & 倍 & 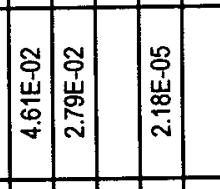 & 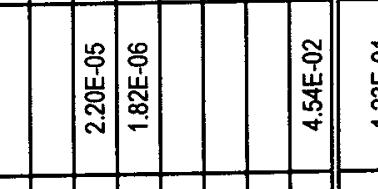 \\
\hline 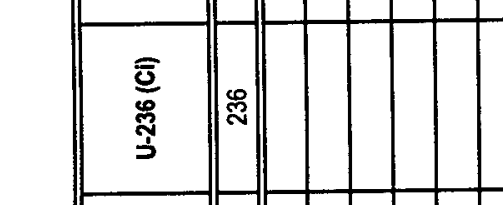 & |110 & 1010 & 语 & 10 & 周|| \\
\hline 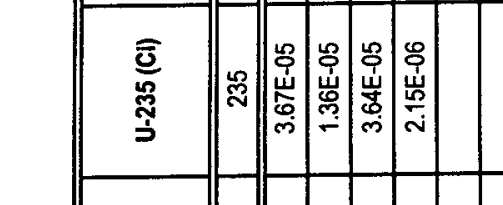 & 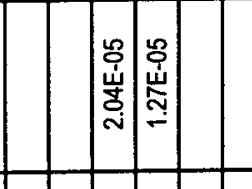 & 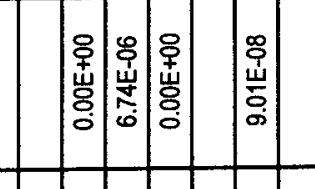 & 国 & 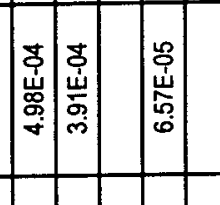 & \\
\hline 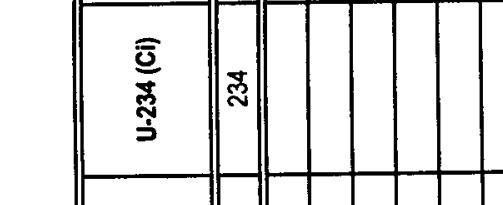 & $H$ & & 倍 & 110 & 成 \\
\hline$\frac{1}{3}=1$ & H & & & & \\
\hline 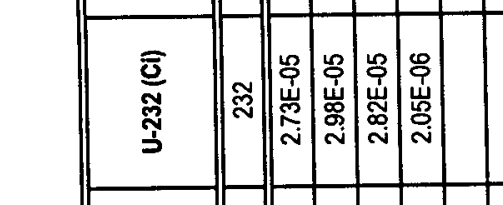 & 閳 & 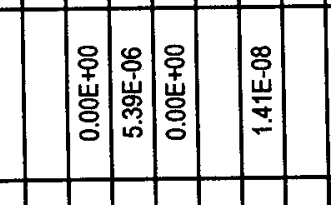 & & 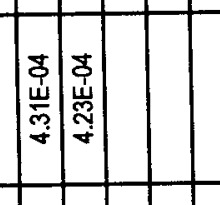 & \\
\hline 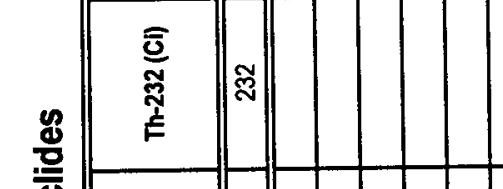 & 1111 & & & 111 & \\
\hline $\mid$ & |l| & 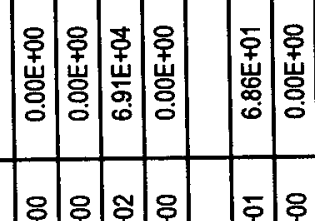 & & 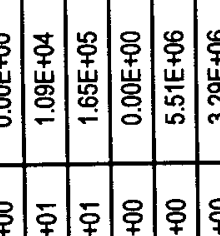 & \\
\hline $\mathrm{I}^{\frac{1}{1}}$ & 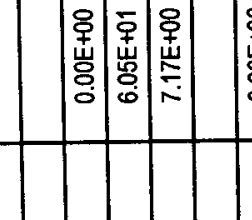 & 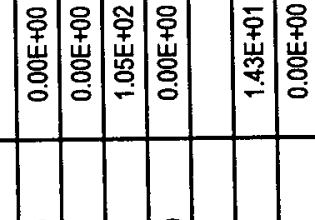 & & & \\
\hline 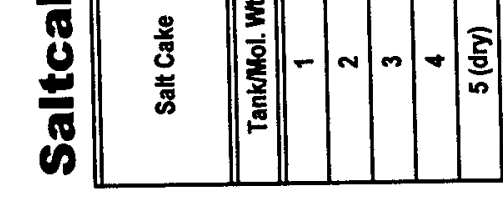 & & & & 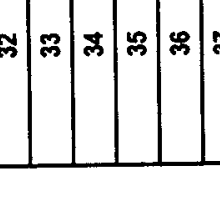 & \\
\hline
\end{tabular}




\section{APPENDIX E}

COMPARISON OF SOLVENT EXTRACTION MODELS 


\section{CORRESPONDENCE \#1}

To: Glenn Taylor

Subject: SPEEDUP Extraction Model

Author: Frank02 Smith at SRCCC08

Date: 7/23/98 1:04 PM

I have compared results from a version of our SPEEDUP solvent extraction model with the results reported for the SASSE calculations for the TRUEX process in the paper by Leonard and Regalbuto. I started with the SPEEDUP model exactly as it was used in the Phase II work and first stripped this down to just the extraction part of the model and modified the input for the TRUEX parameters given in the citation. The SPEEDUP results from this model compared well with most of the SASSE results although they were not in complete agreement. The original SPEEDUP model used a relatively simple representation of a countercurrent extraction stage with two input streams and two output streams for the aqueous and organic phases. As an improvement to this model (based on the suggestion in the SASSE article) I modified the SPEEDUP model to include carryover of the aqueous phase in the organic stream and of the organic phase in the aqueous stream. This roughly doubles the size of the model since it increased the number of flow streams by a factor of two. This enhancement improved the comparison of SPEEDUP results to those reported for SASSE. For the four main output streams from the process I get the following comparison:

\begin{tabular}{|c|c|c|c|c|}
\hline \multirow[b]{2}{*}{ Component } & \multicolumn{2}{|c|}{$\begin{array}{c}\text { Extraction stages } \\
\text { (raffinate) }\end{array}$} & \multicolumn{2}{|c|}{$\begin{array}{l}\text { Strip \#1 stages } \\
\text { (AM Product) }\end{array}$} \\
\hline & SASSE & SPEEDUP & SASSE & SPEEDUP \\
\hline 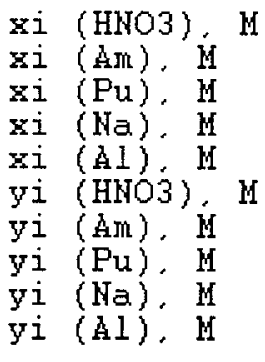 & $\begin{array}{l}1.09 \\
4 e-12 \\
3 e-16 \\
0.27 \\
0.43 \\
0.54 \\
1 e-10 \\
7 e-14 \\
5 e-3 \\
4 e-5\end{array}$ & $\begin{array}{l}1.09 \\
4 e-12 \\
2 e-16 \\
0.27 \\
0.43 \\
0.55 \\
1 e-10 \\
3 e-14 \\
5 e-3 \\
4 e-5\end{array}$ & $\begin{array}{l}0.86 \\
2 e-6 \\
8 e-9 \\
3 e-4 \\
4 e-6 \\
0.20 \\
1 e-5 \\
1 e-6 \\
5 e-6 \\
4 e-10\end{array}$ & $\begin{array}{l}0.85 \\
2 e-6 \\
8 e-9 \\
2 e-4 \\
2 e-7 \\
0.20 \\
1 e-5 \\
1 e-6 \\
4 e-6 \\
2 e-11\end{array}$ \\
\hline Component & $\begin{array}{l}\text { Strip } \\
\text { SASPE }\end{array}$ & $\begin{array}{l}\text { \#2 stages } \\
\text { Product) } \\
\text { SPEEDUP }\end{array}$ & $\begin{array}{r}\text { Strip } \\
\text { (So } \\
\text { SASE }\end{array}$ & $\begin{array}{l}\text { tages } \\
\text { t) } \\
\text { SPEEDUP }\end{array}$ \\
\hline 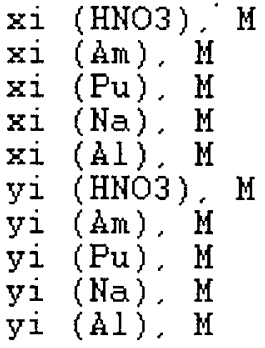 & $\begin{array}{l}0.05 \\
2 e-5 \\
5 e-6 \\
3 e-9 \\
9 e-14 \\
0.002 \\
4 e-6 \\
2 e-7 \\
6 e-11 \\
9 e-18\end{array}$ & $\begin{array}{l}0.05 \\
2 e-5 \\
5 e-6 \\
1 e-9 \\
0 \\
0.002 \\
4 e-6 \\
2 e-7 \\
3 e-11 \\
0\end{array}$ & $\begin{array}{l}0.05 \\
6 e-6 \\
9 e-8 \\
3 e-11 \\
4 e-17 \\
0.002 \\
1 e-6 \\
3 e-9 \\
5 e-13 \\
4 e-21\end{array}$ & $\begin{array}{l}0.05 \\
6 e-6 \\
7 e-8 \\
1 e-11 \\
0 \\
0.002 \\
1 e-6 \\
2 e-9 \\
2 e-13 \\
0\end{array}$ \\
\hline
\end{tabular}

$\mathrm{xi}$ - concentration in aqueous phase yi - concentration in organic phase all concentration are molar rounded off to the precision reported for the SASSE results

As can be seen from the above tables, SPEEDUP compares well with the SASSE code. This provides a somewhat crude validation of the SPEEDUP results calculated in Phase II. I didn't try to follow the SASSE implementation exactly but just used the existing SPEEDUP model and extended it to include carryover 
with my own formulation of the material balance equations. The different algorithms or machine precision may account for the differences in the two sets of results.

I think the SPEEDUP formulation would be easier to extend to handle additional modifications such as solvent cleanup or direct linking to pre and post processing steps for the salt streams than would the spreadsheet version. The steady-state SPEEDUP code runs very quickly on the VAX alpha machines. As I showed Glenn previously, the SPEEDUP code is very compact using just a model of a single extraction stage and a macro for separate parts of the extraction process (extraction, scrubbing, stripping, etc...) that builds the part using as many stages as are specified. If anyone is interested in having a copy of the SPEEDUP code or would like to discuss the work further just let me know. I will be on vacation all of next week but should have some (maybe limited) time to spend on this in August. 


\section{APPENDIX F}

ENGINEERING INTEGRATED COMMITMENT MATRIX 


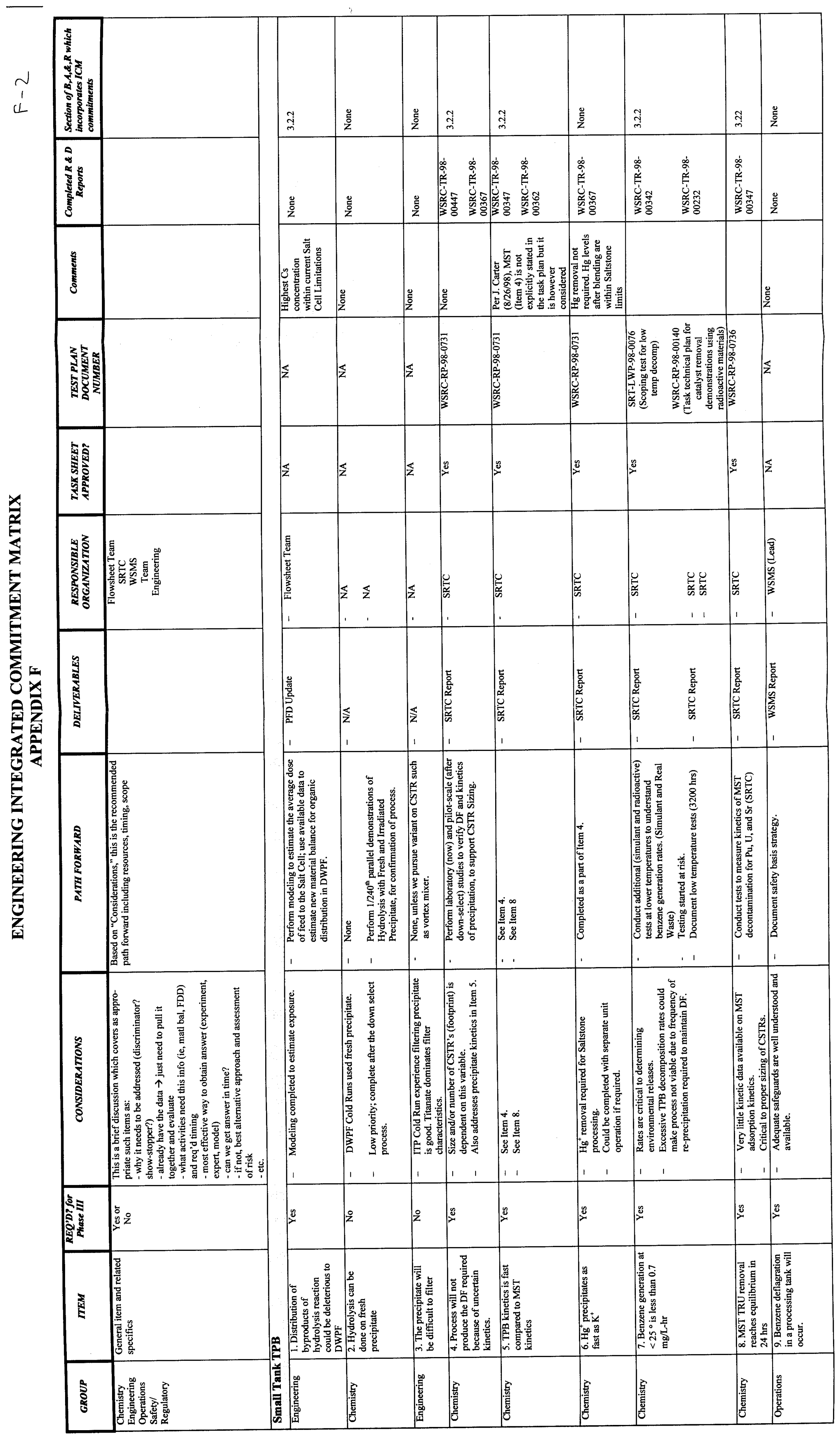




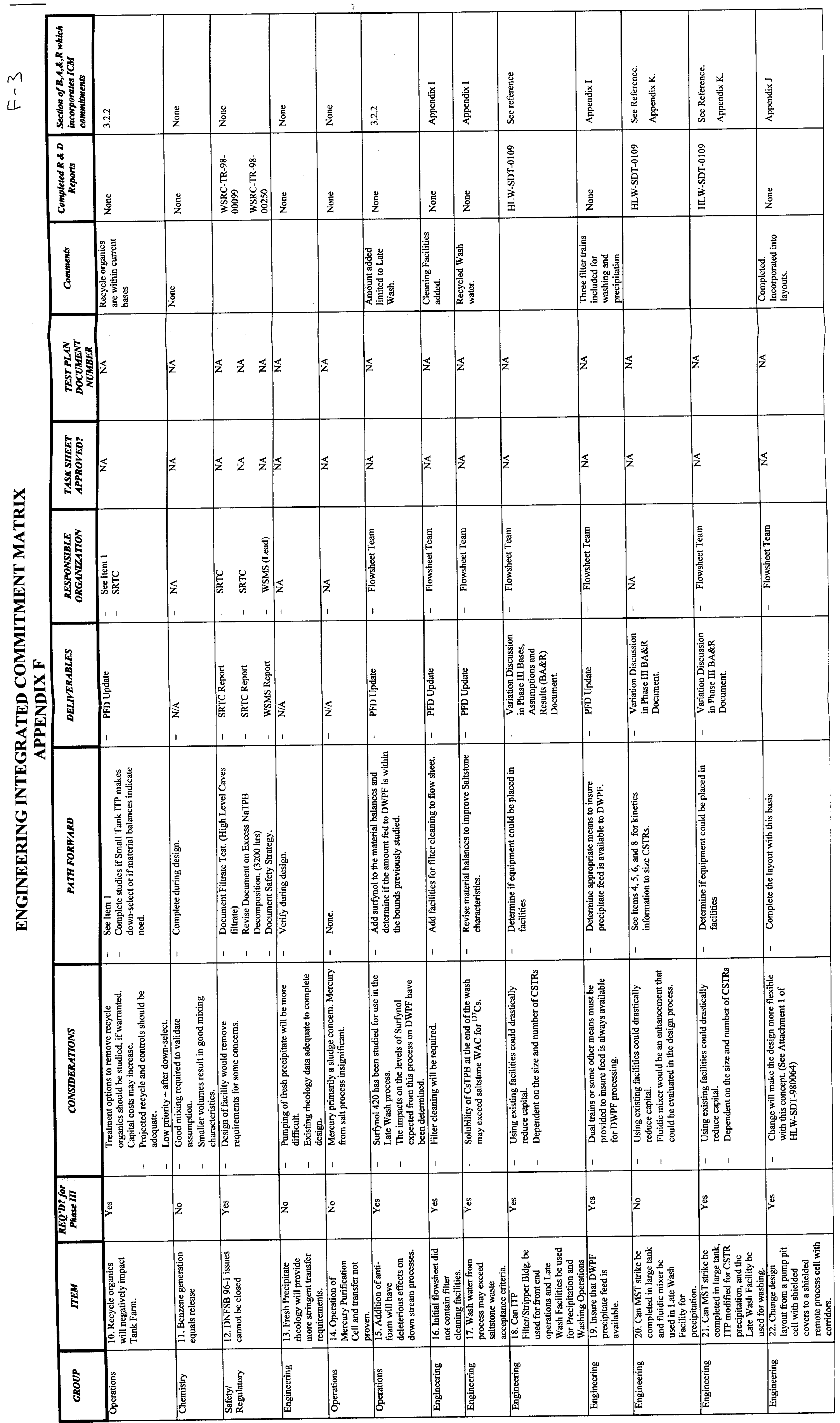




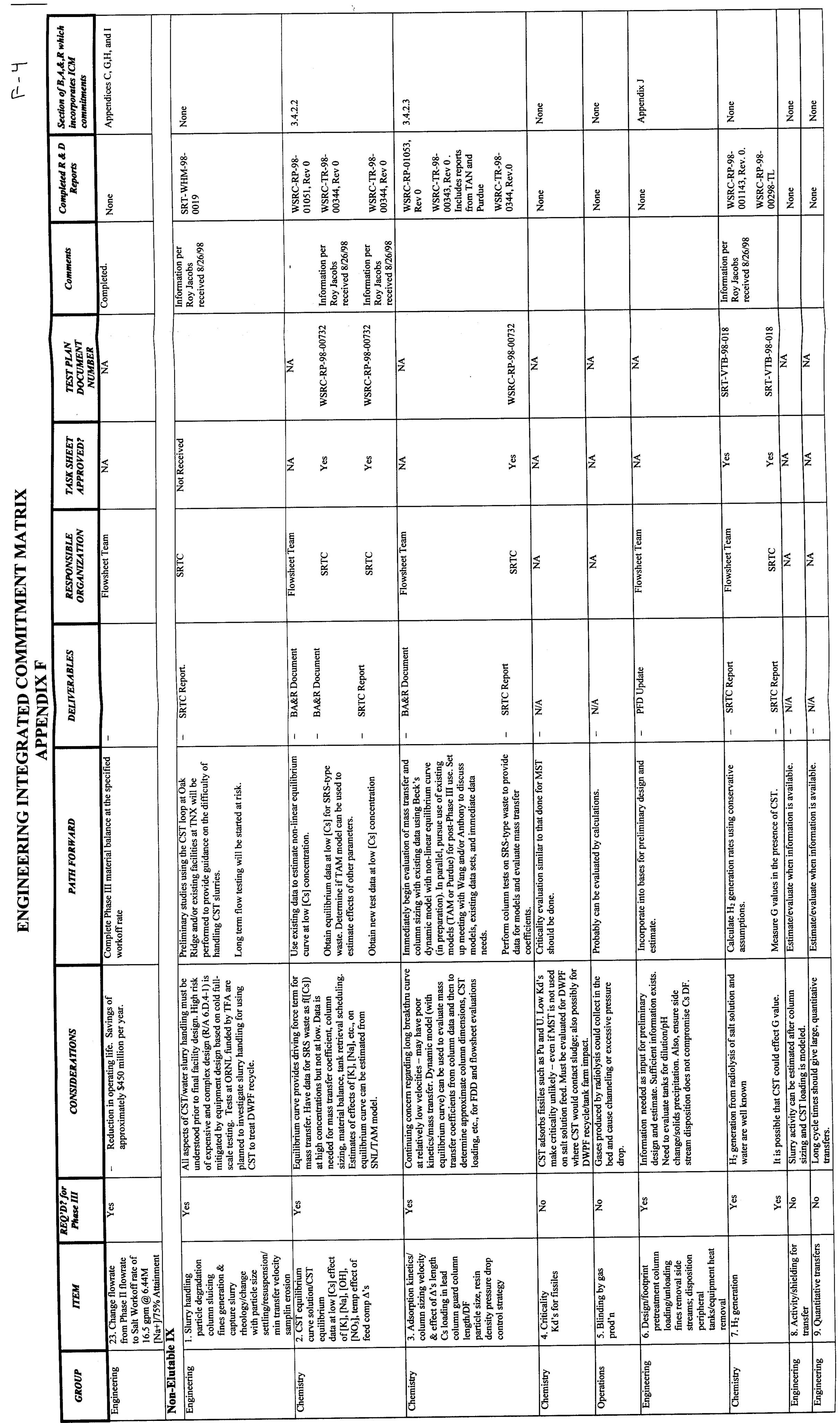




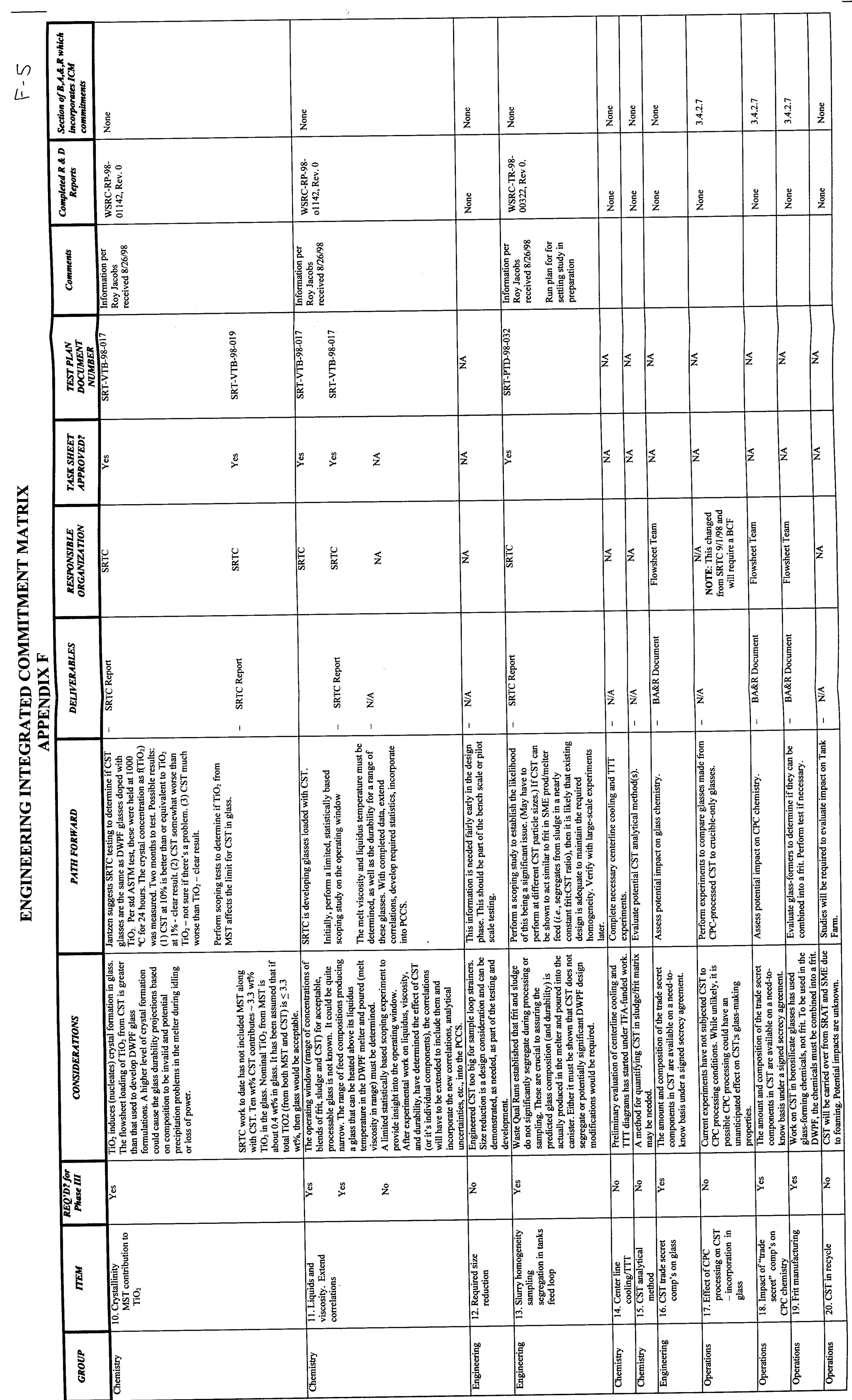




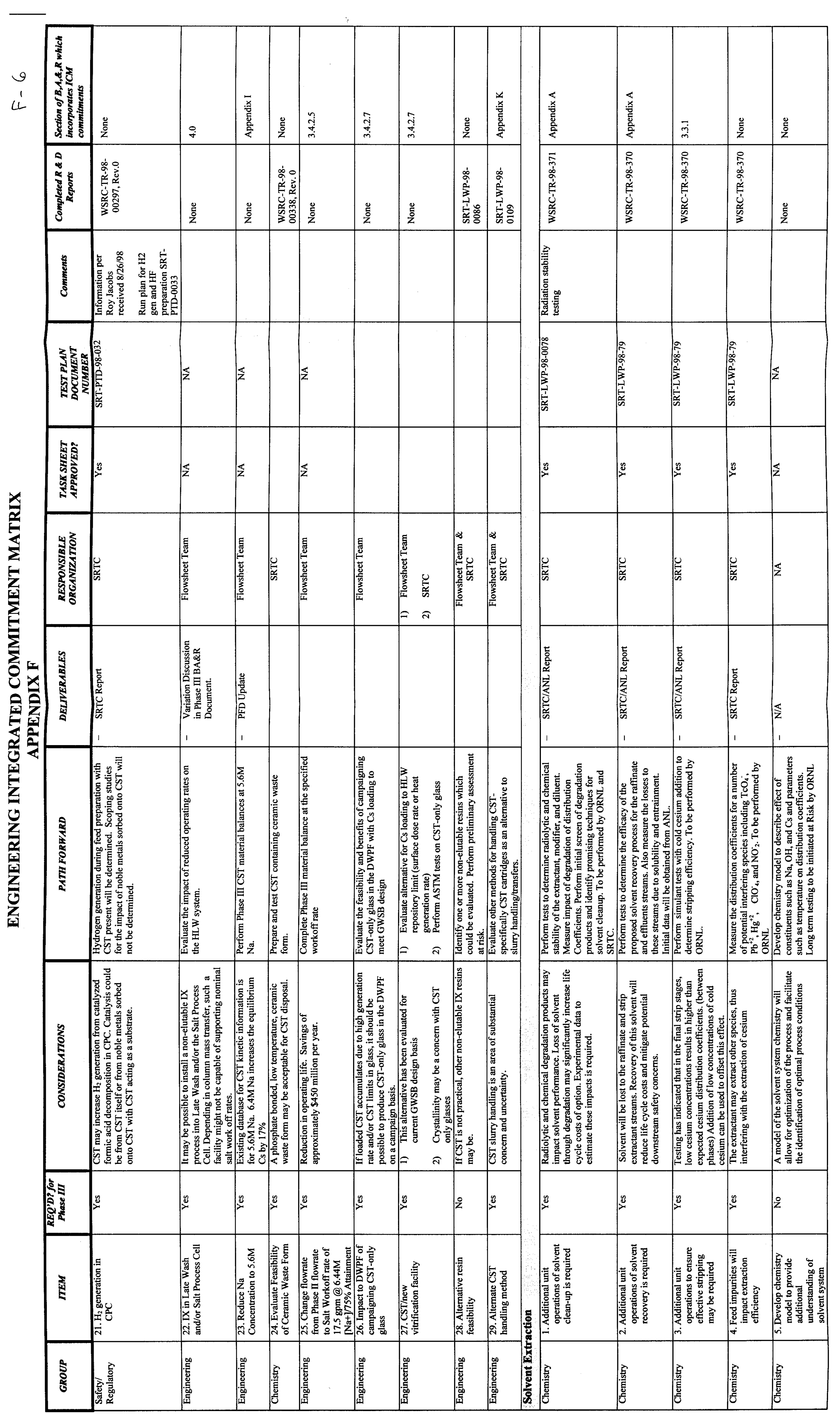




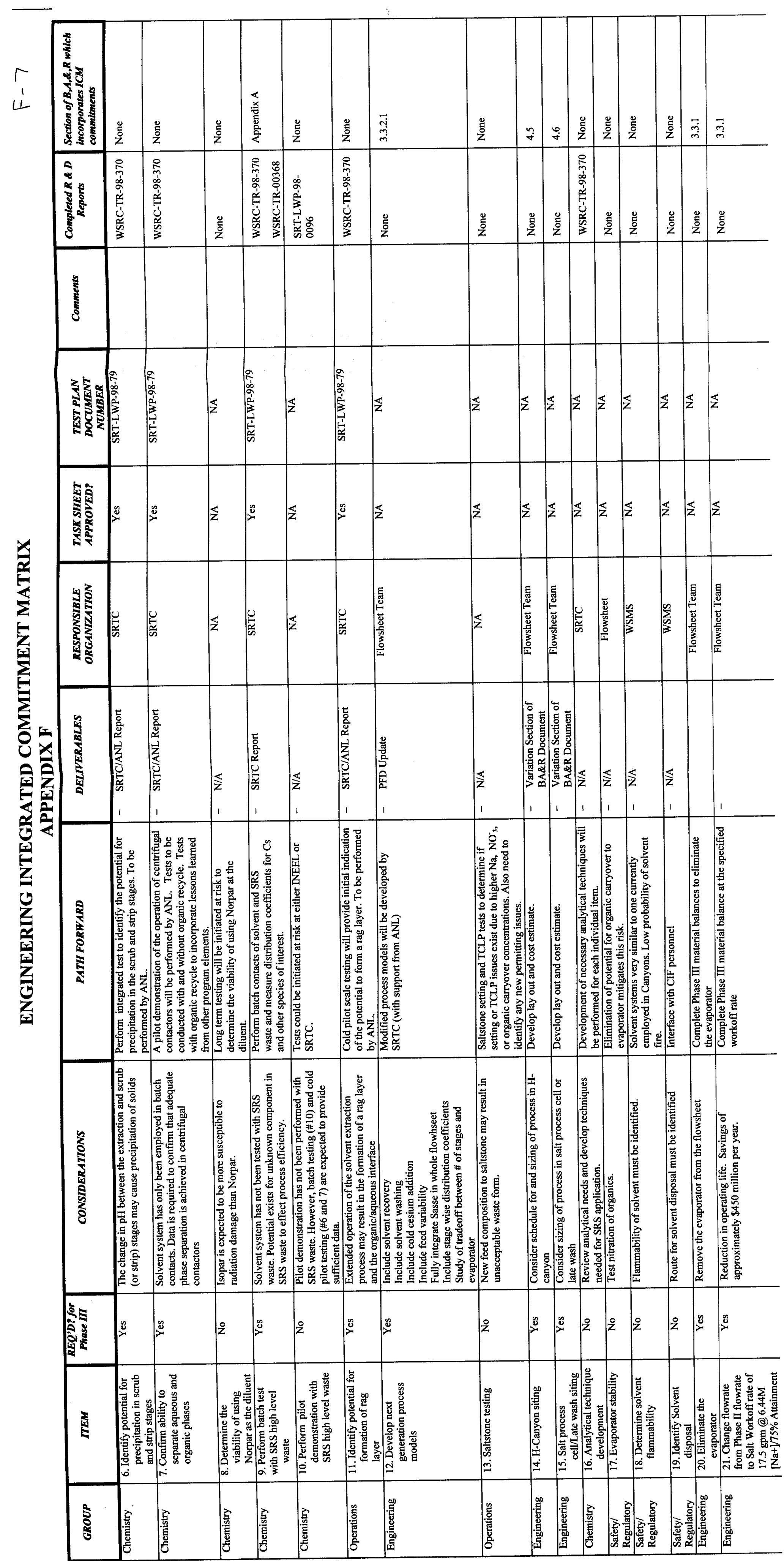




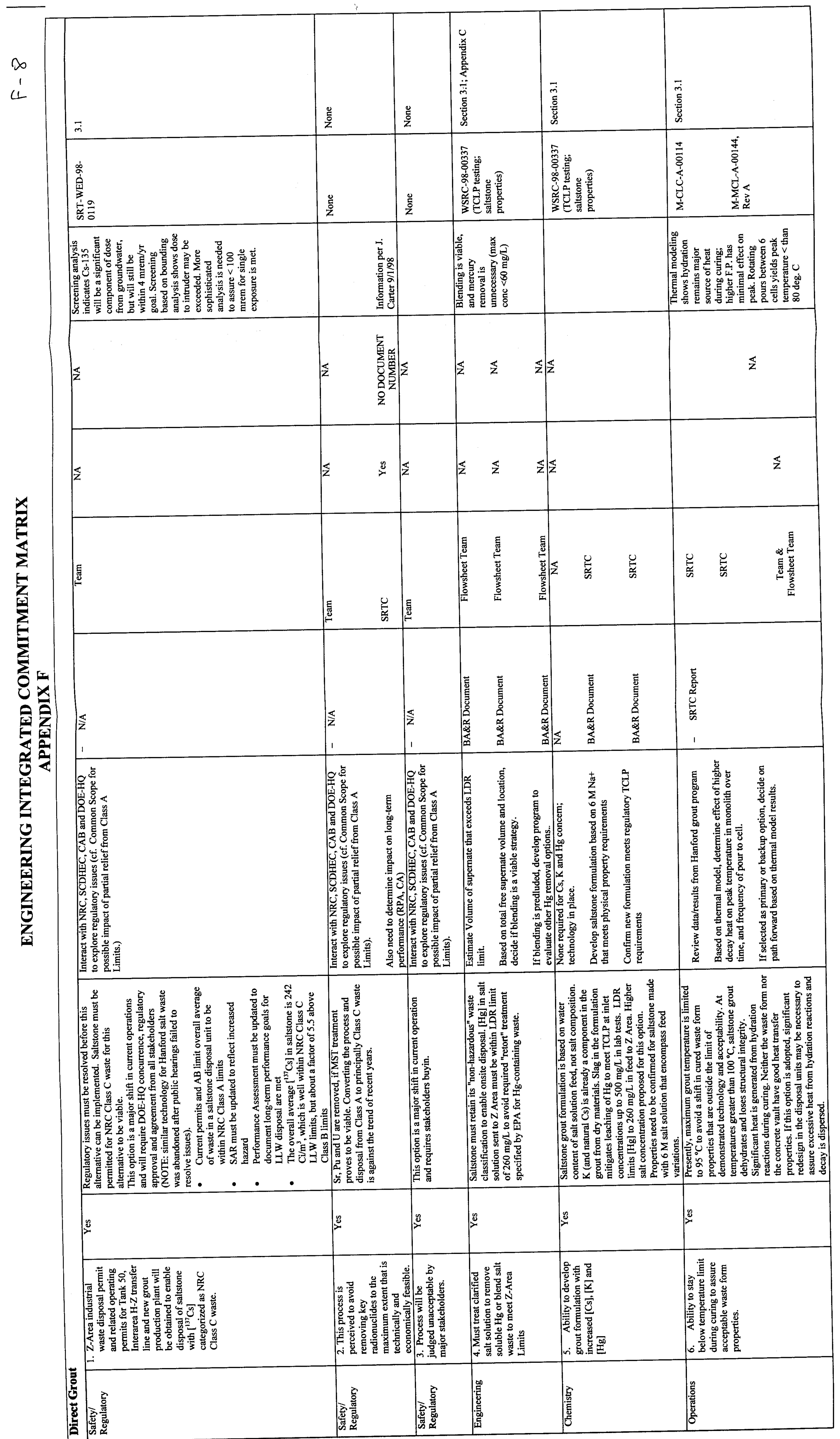




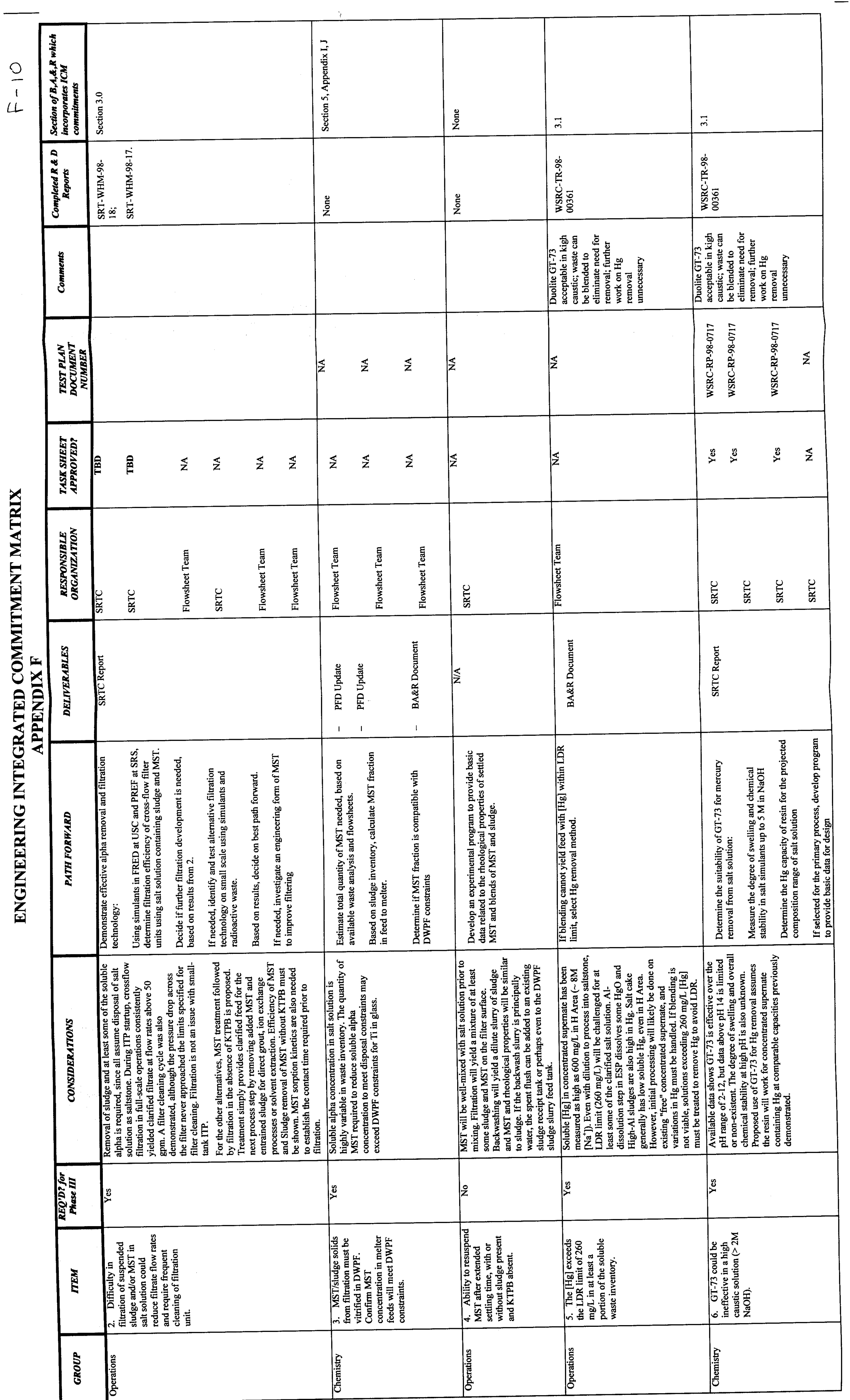




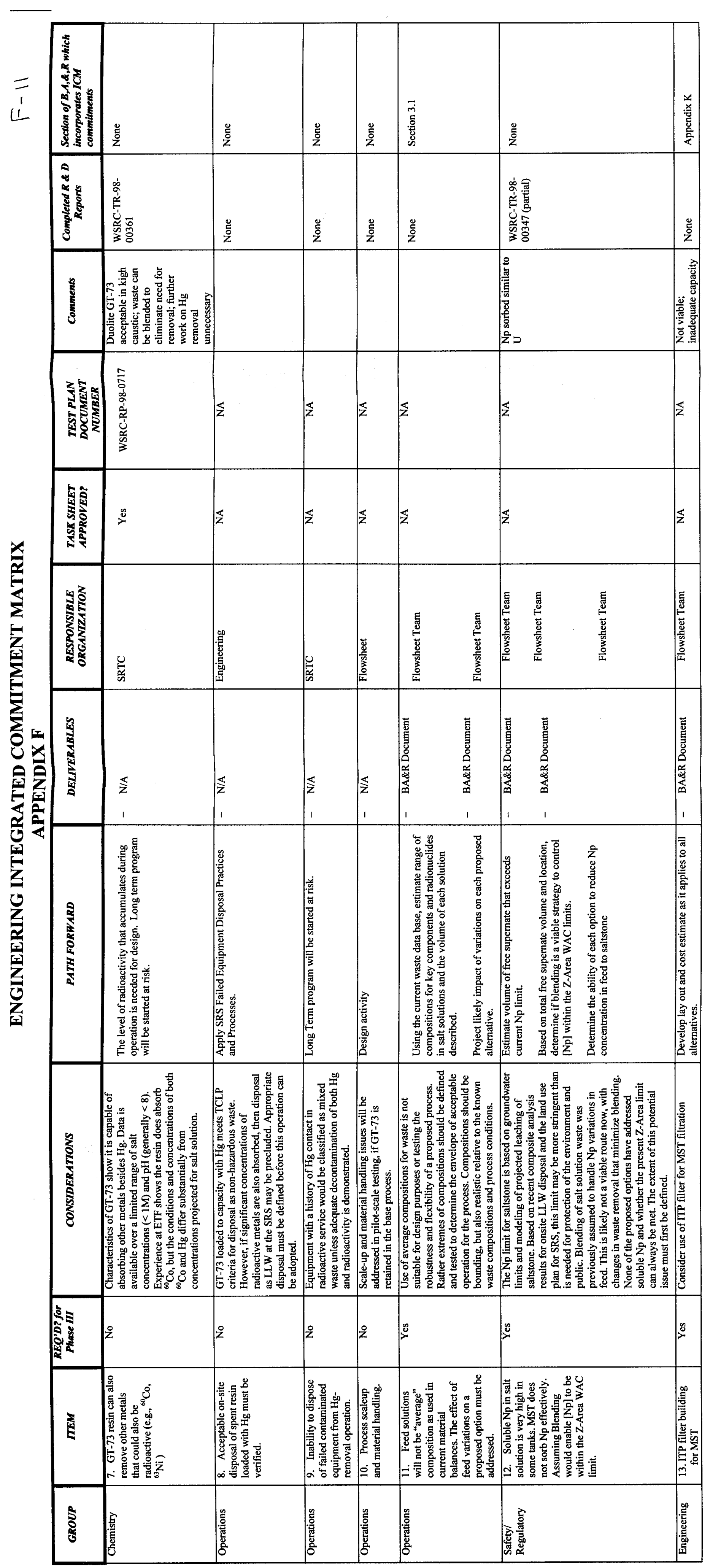


APPENDIX G

\section{YEARLY FEED STREAM COMPOSITION}




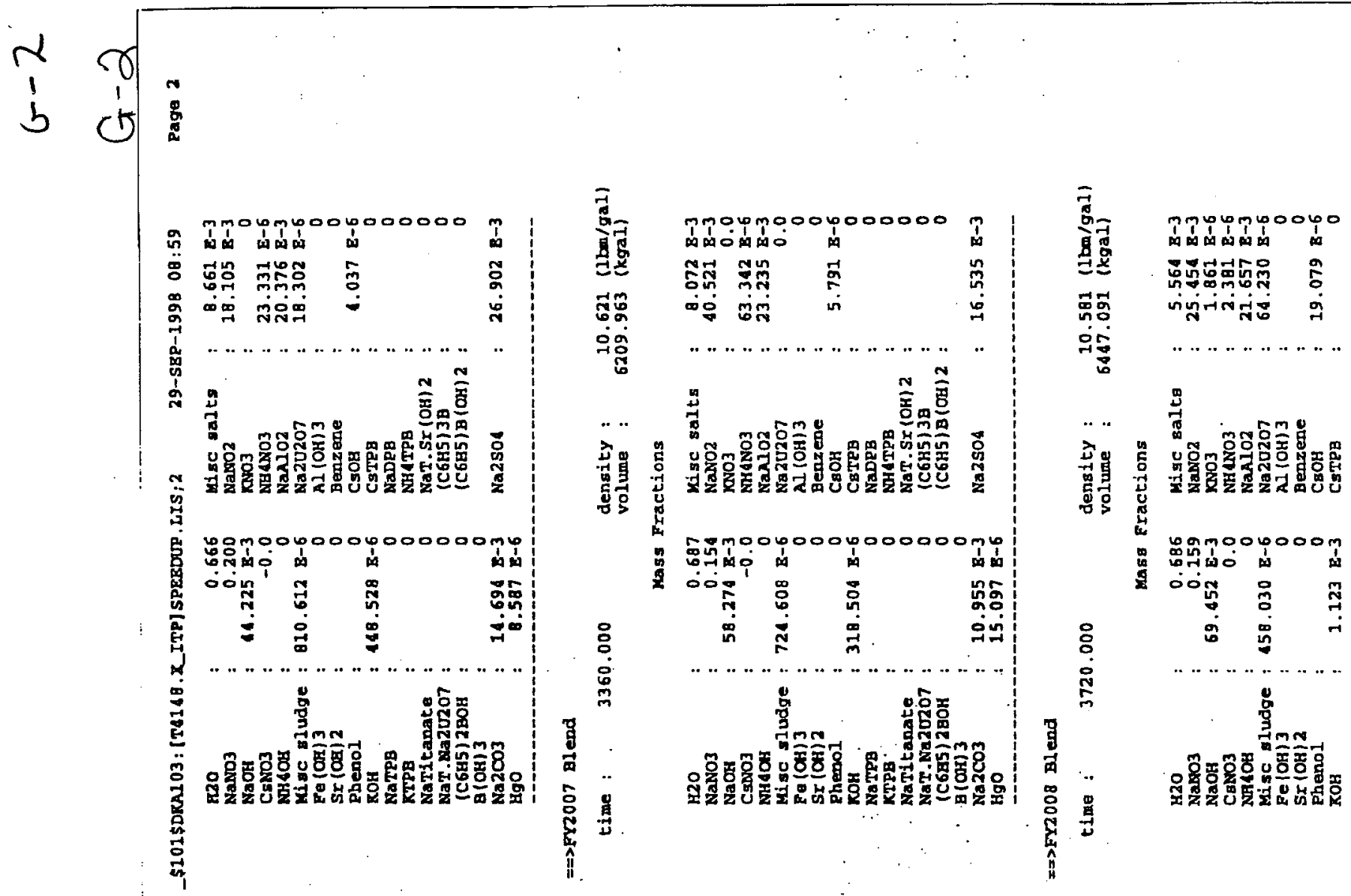

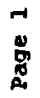
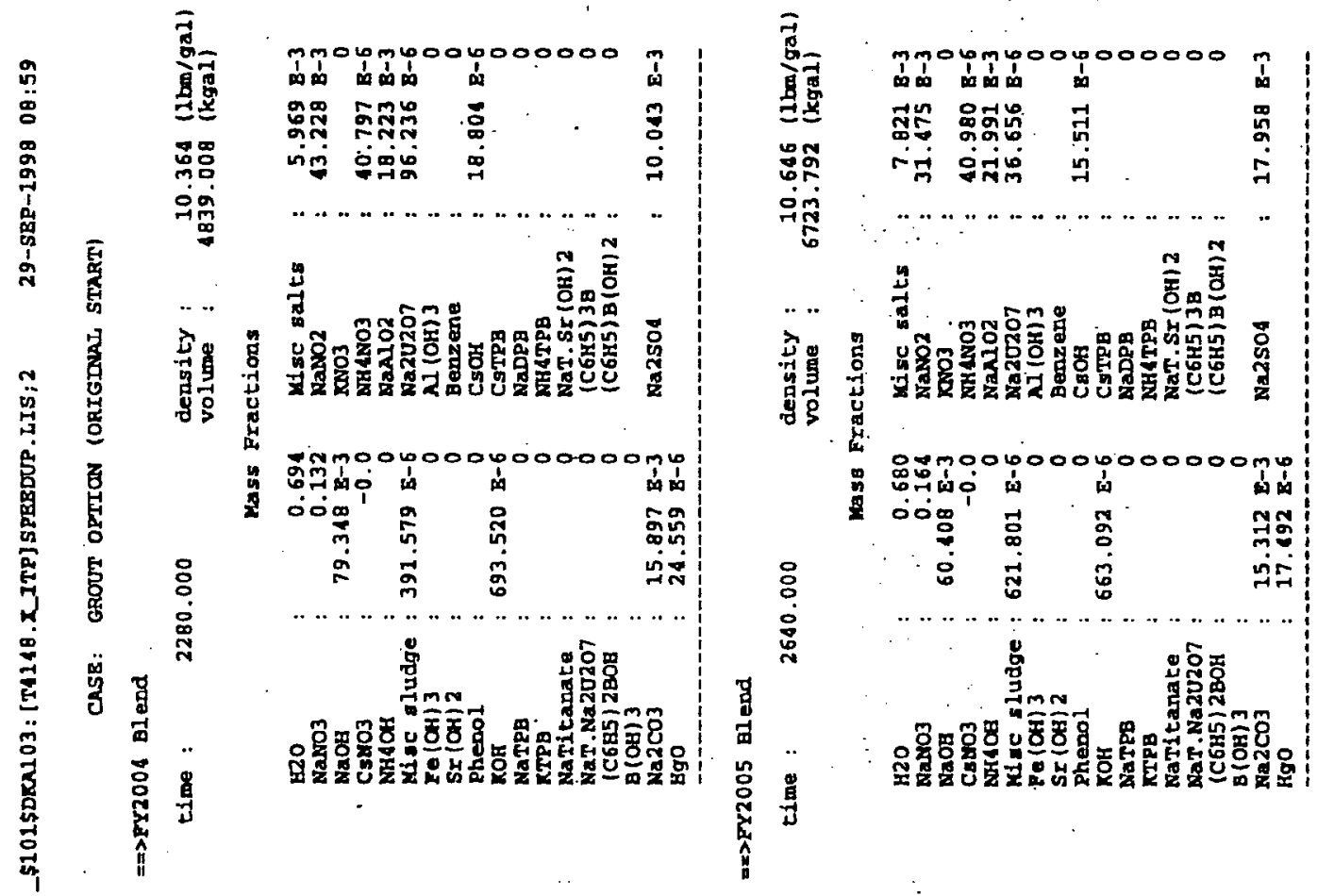

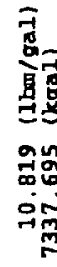

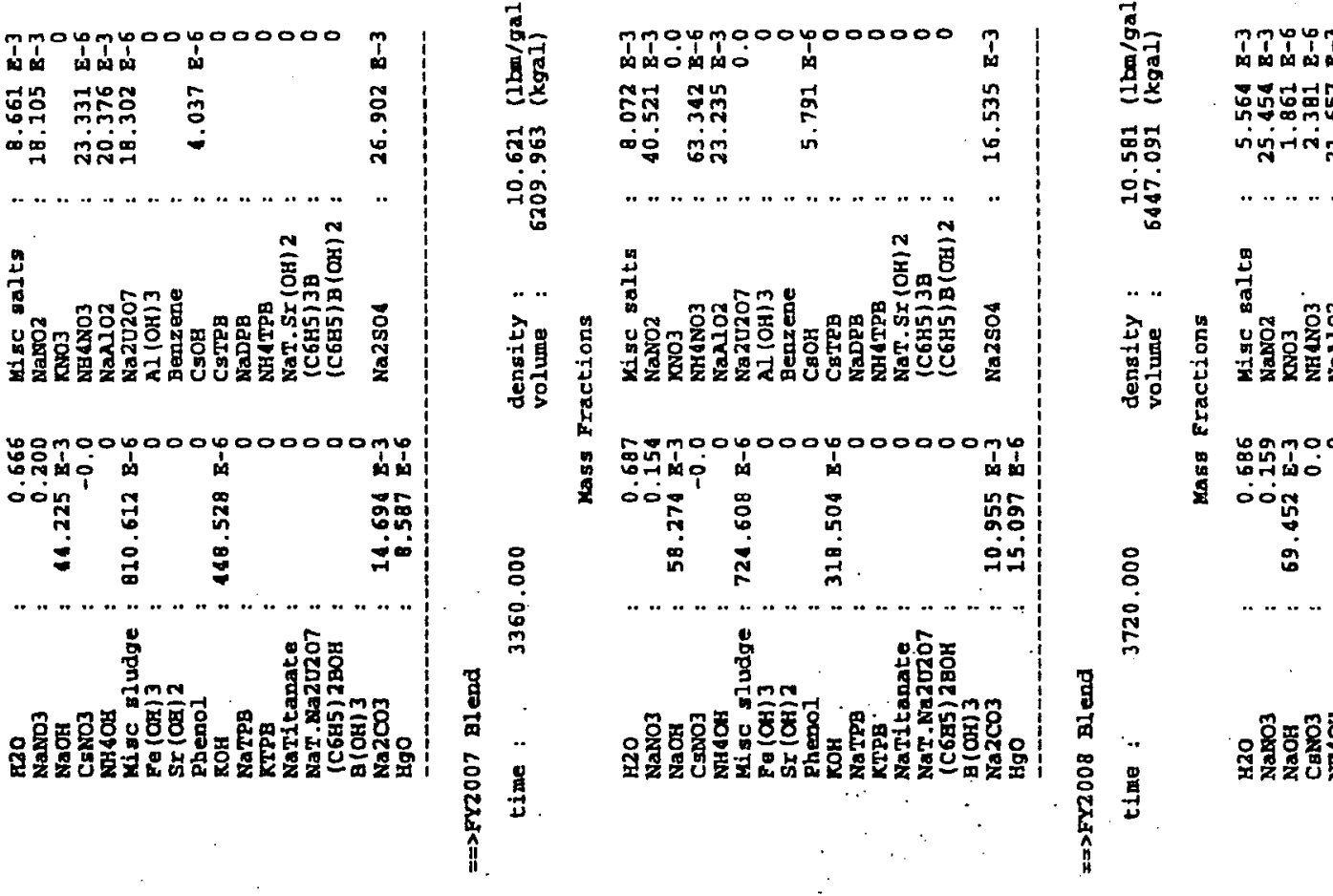

总筫

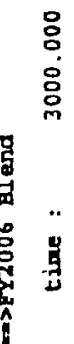



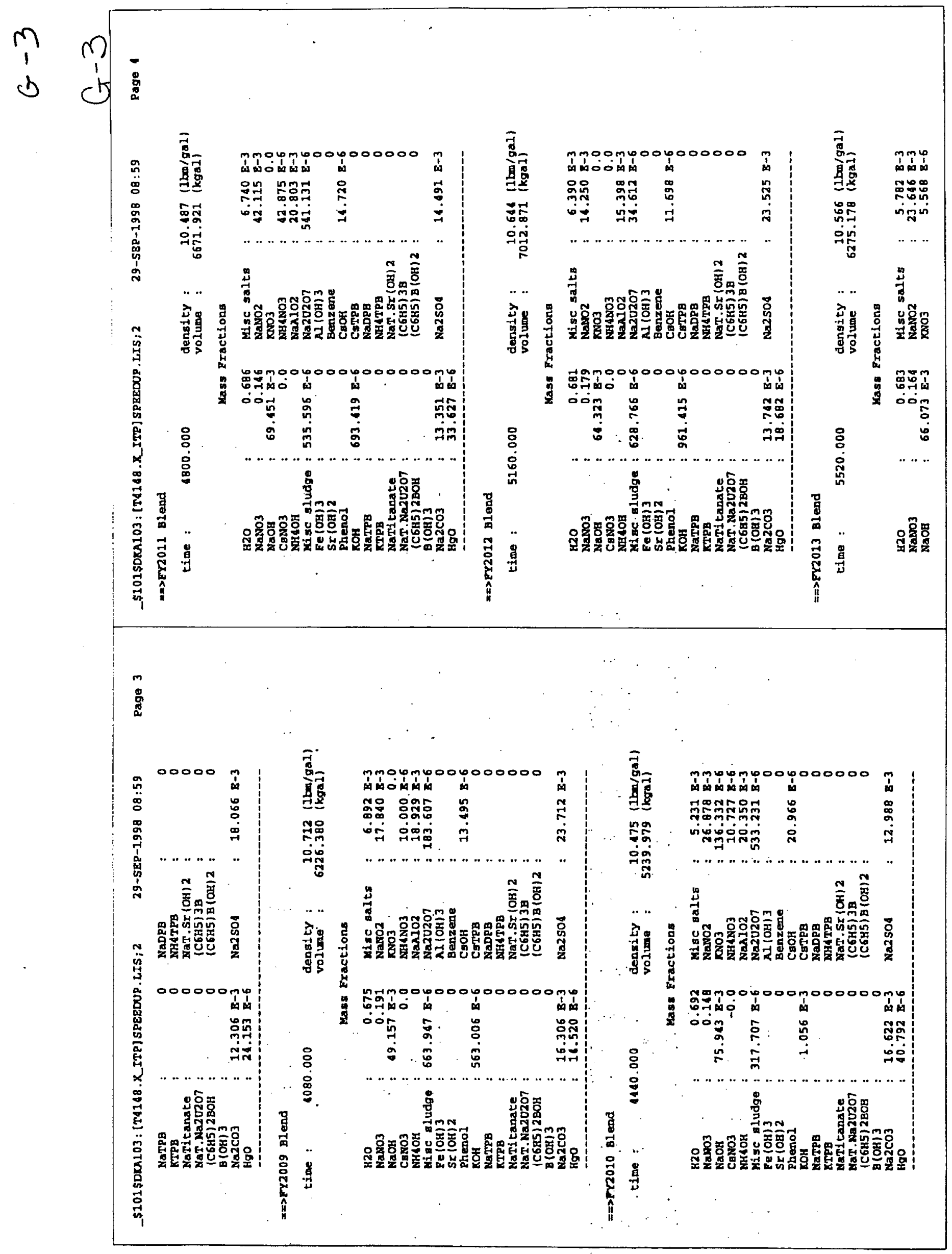
+
1
3
+

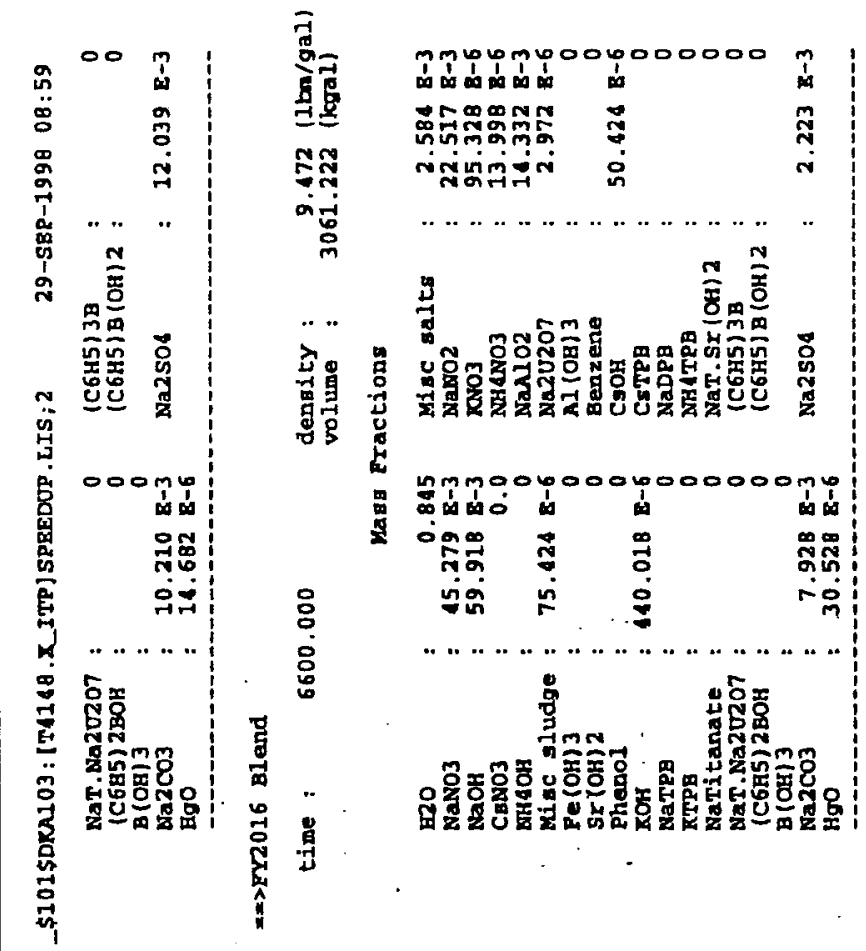

un

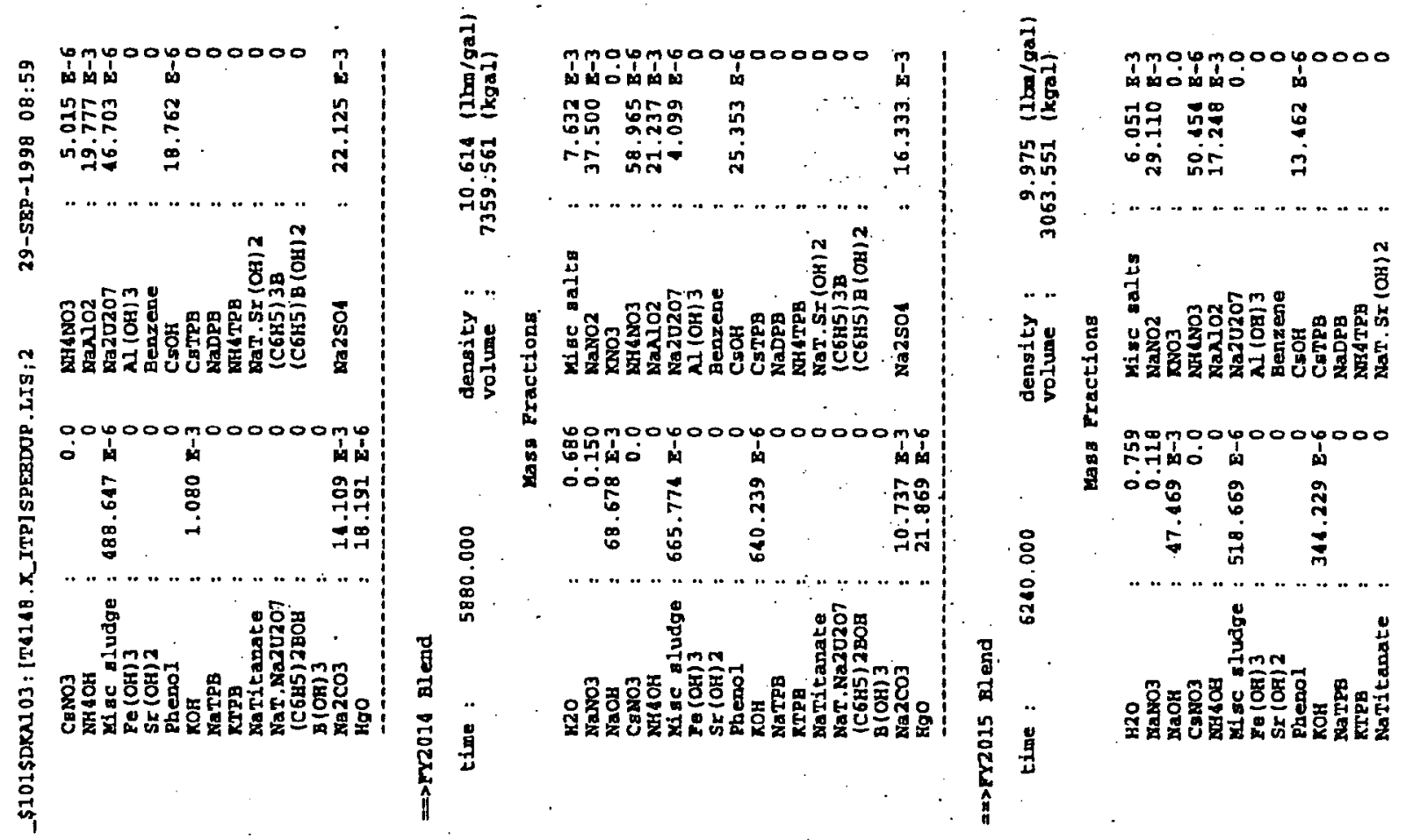


$n$
1
3

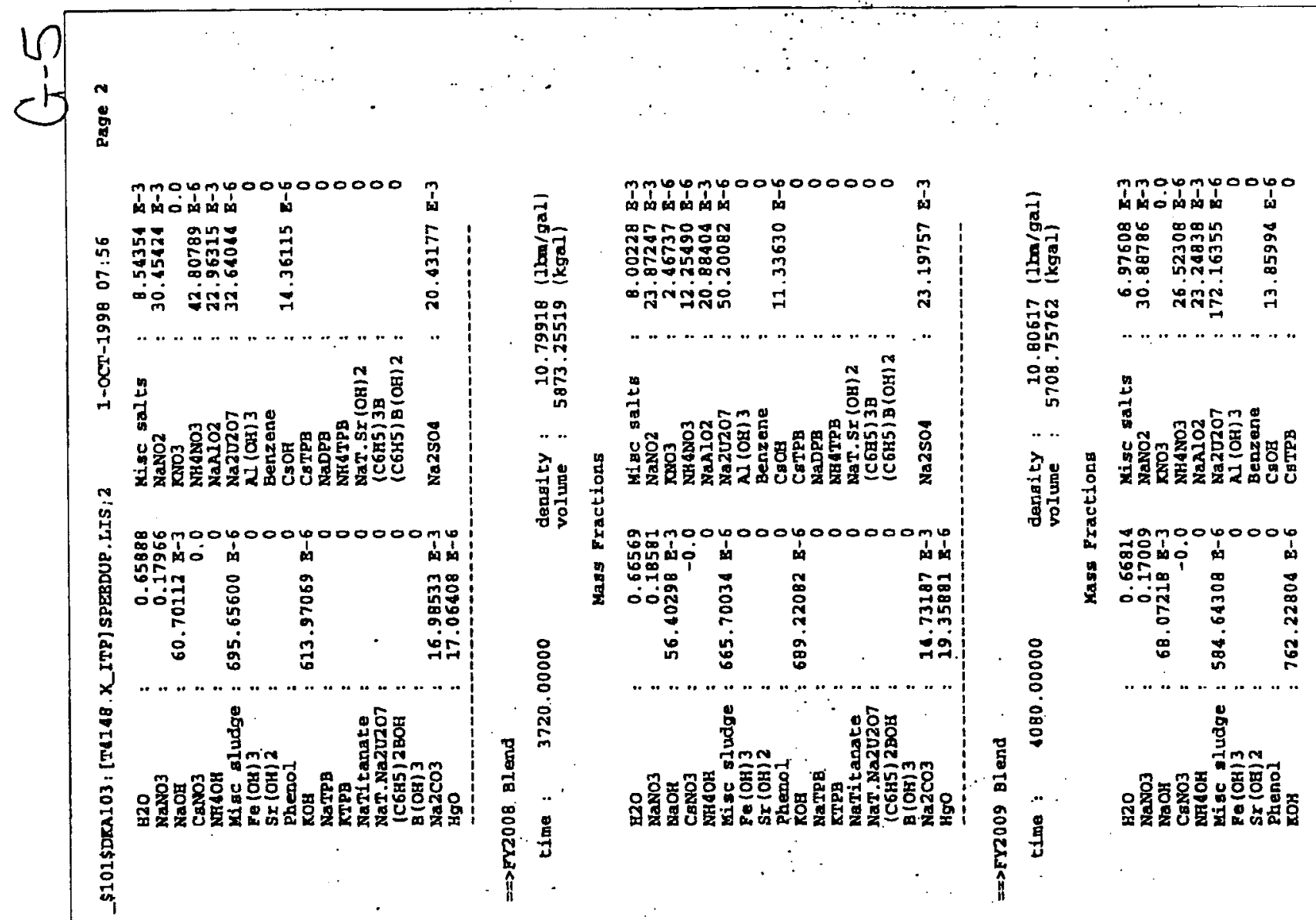

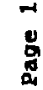
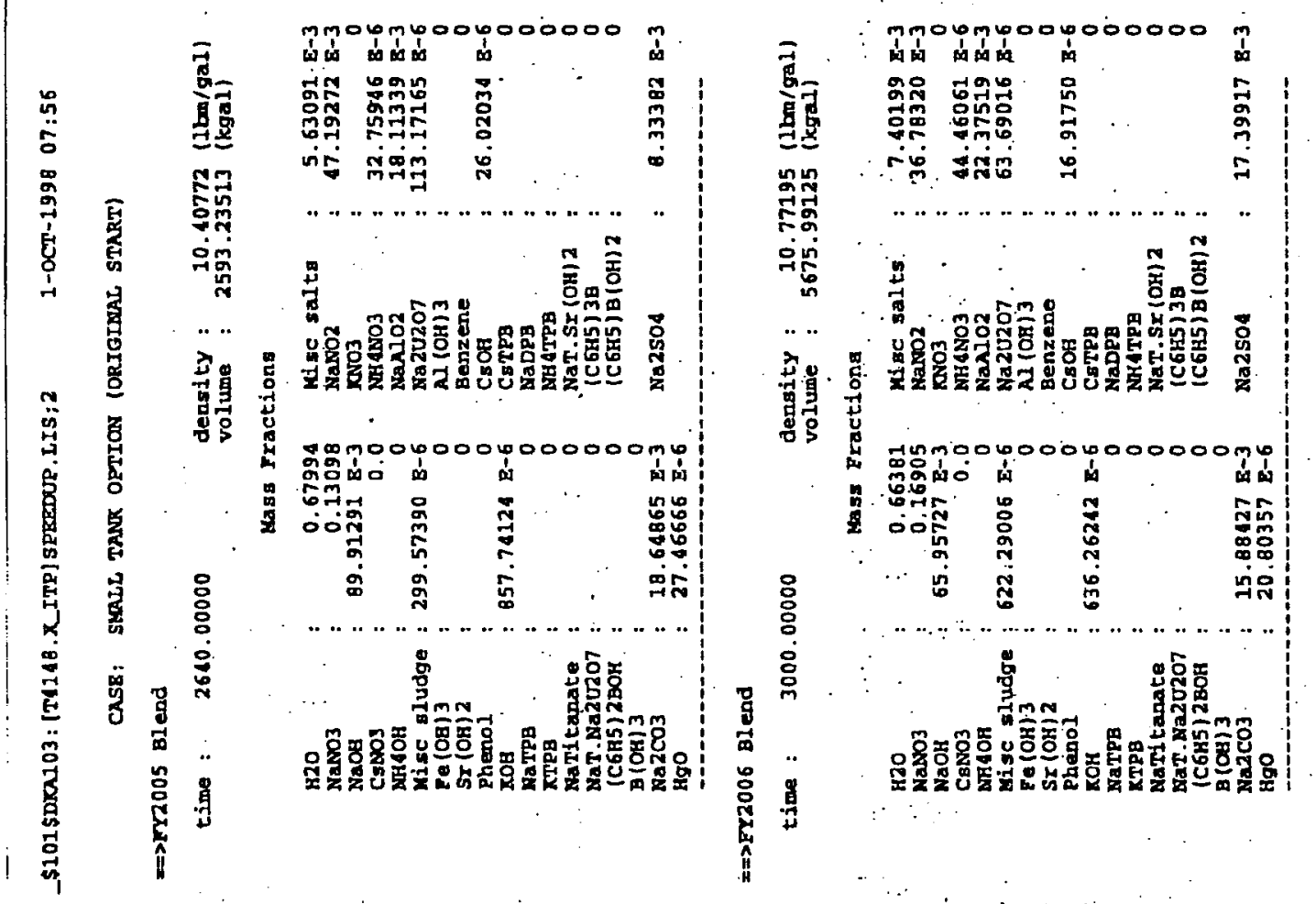

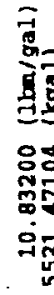

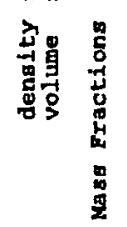

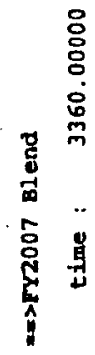


b

$\frac{9}{15}$
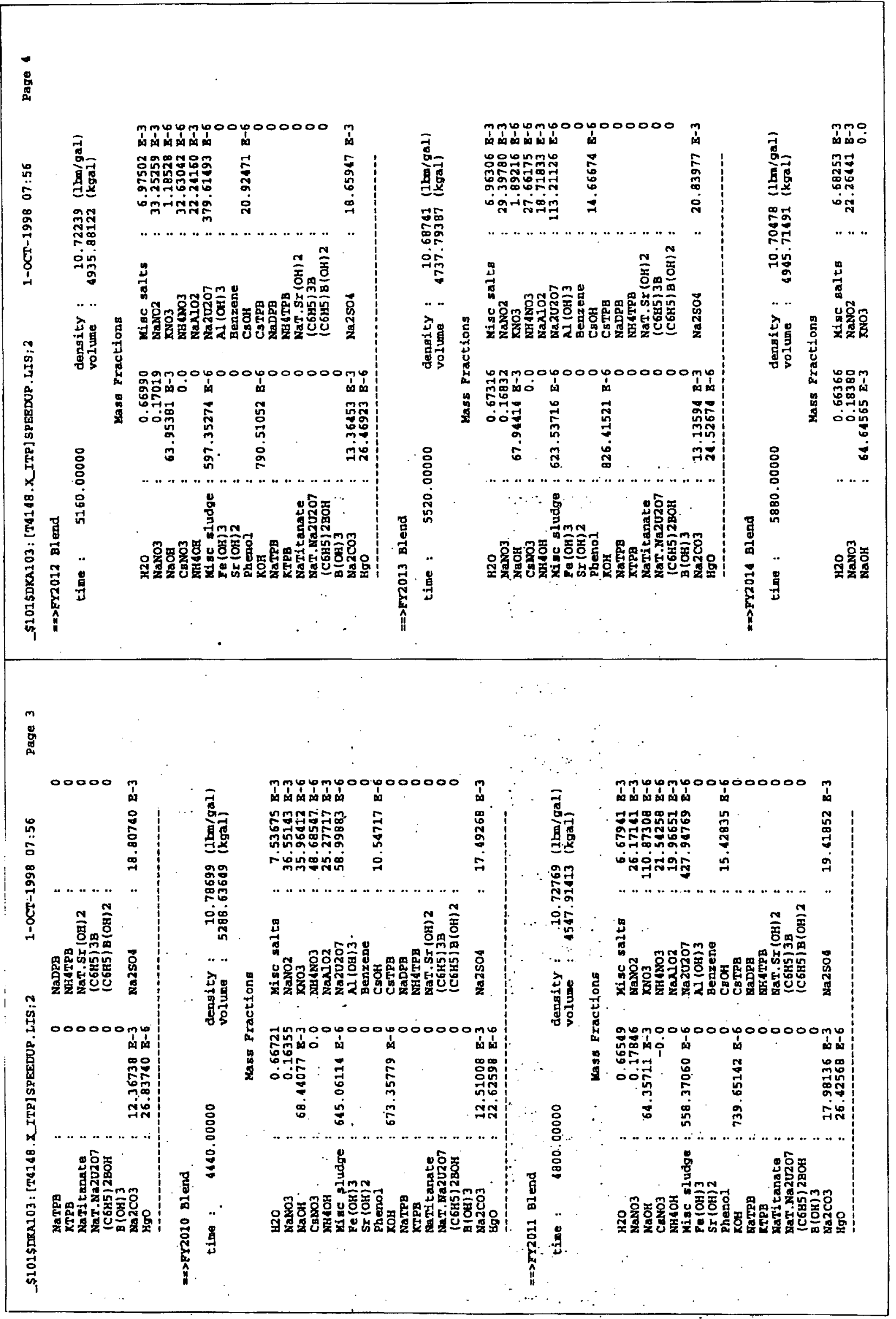


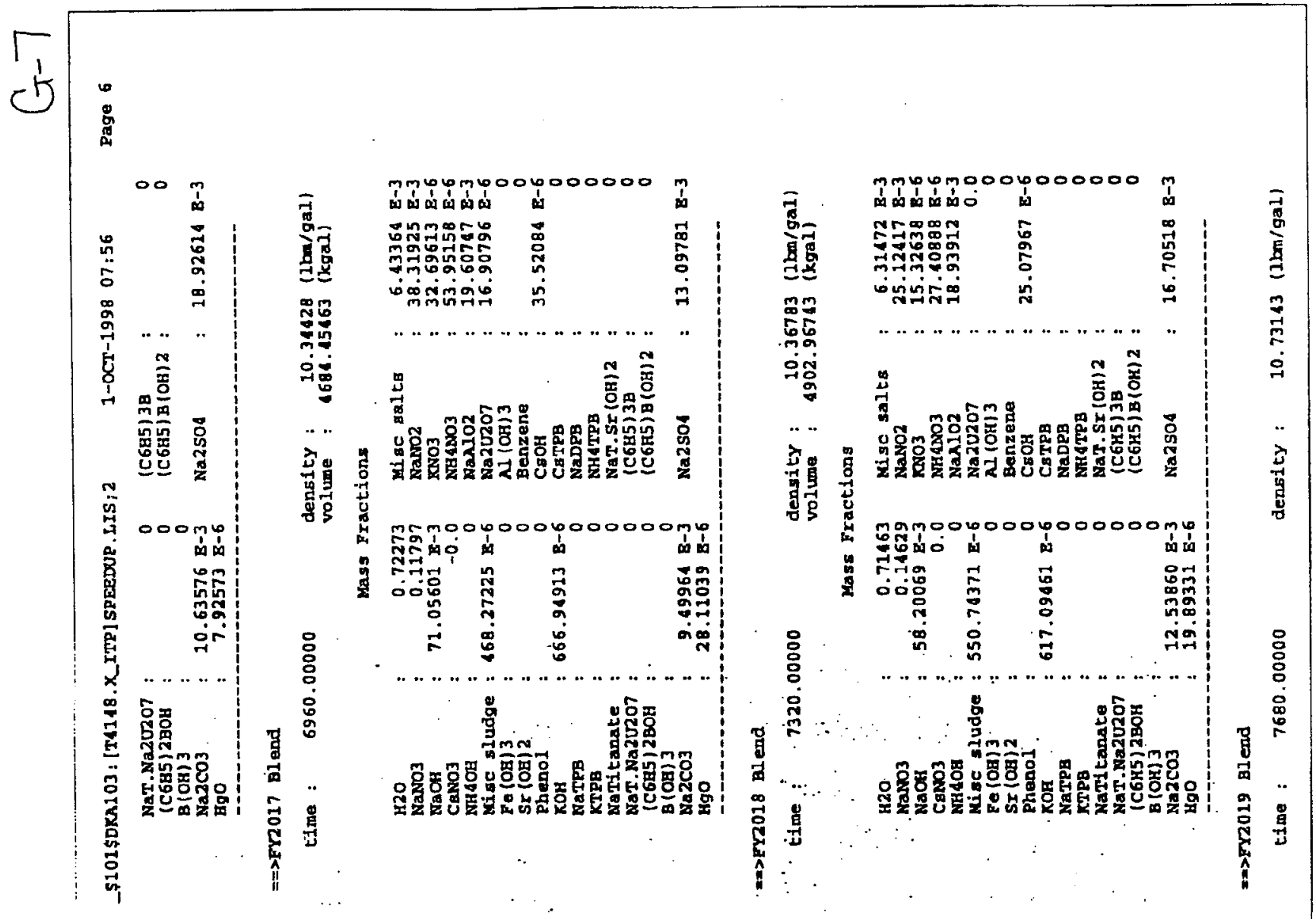

n
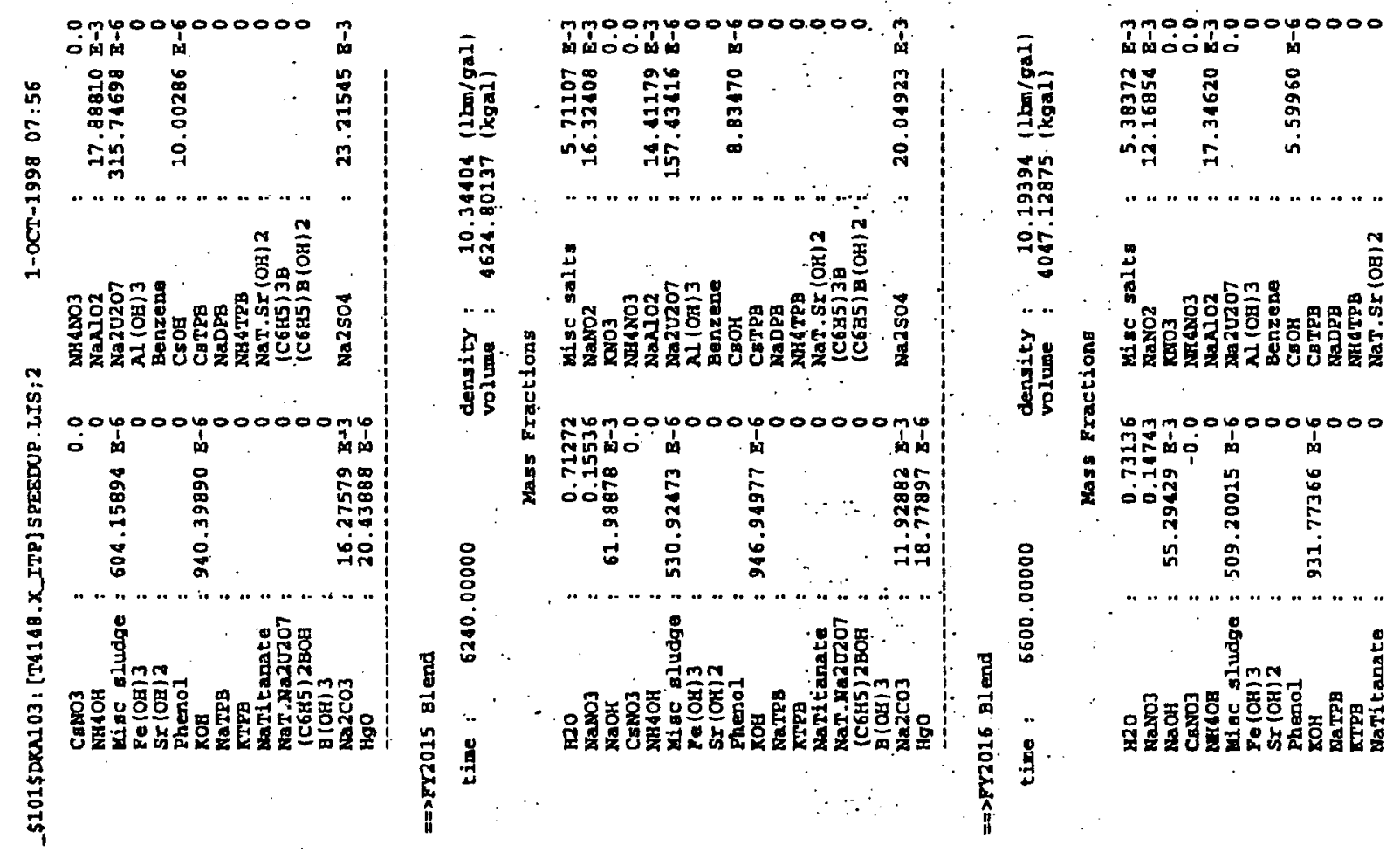


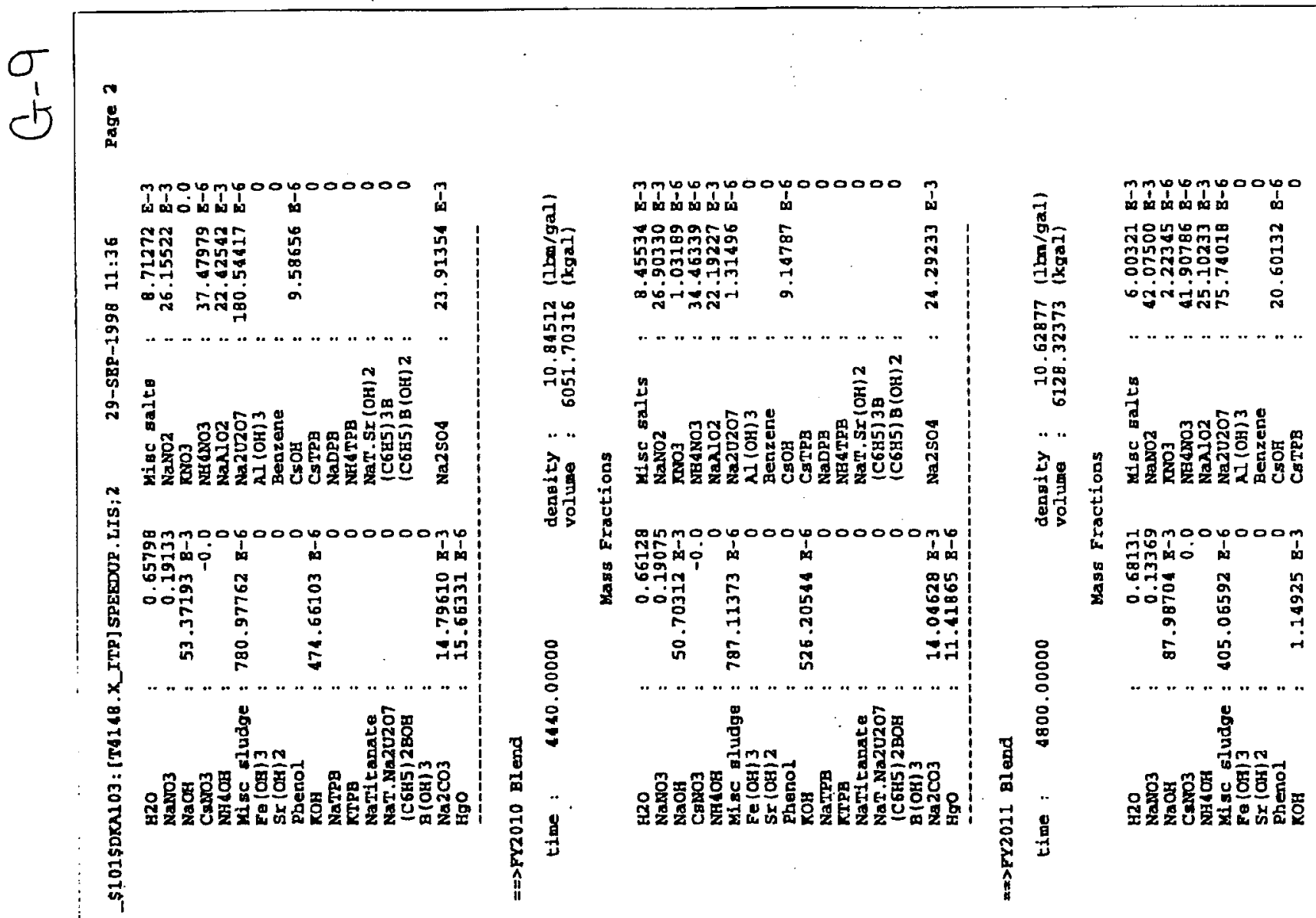

-
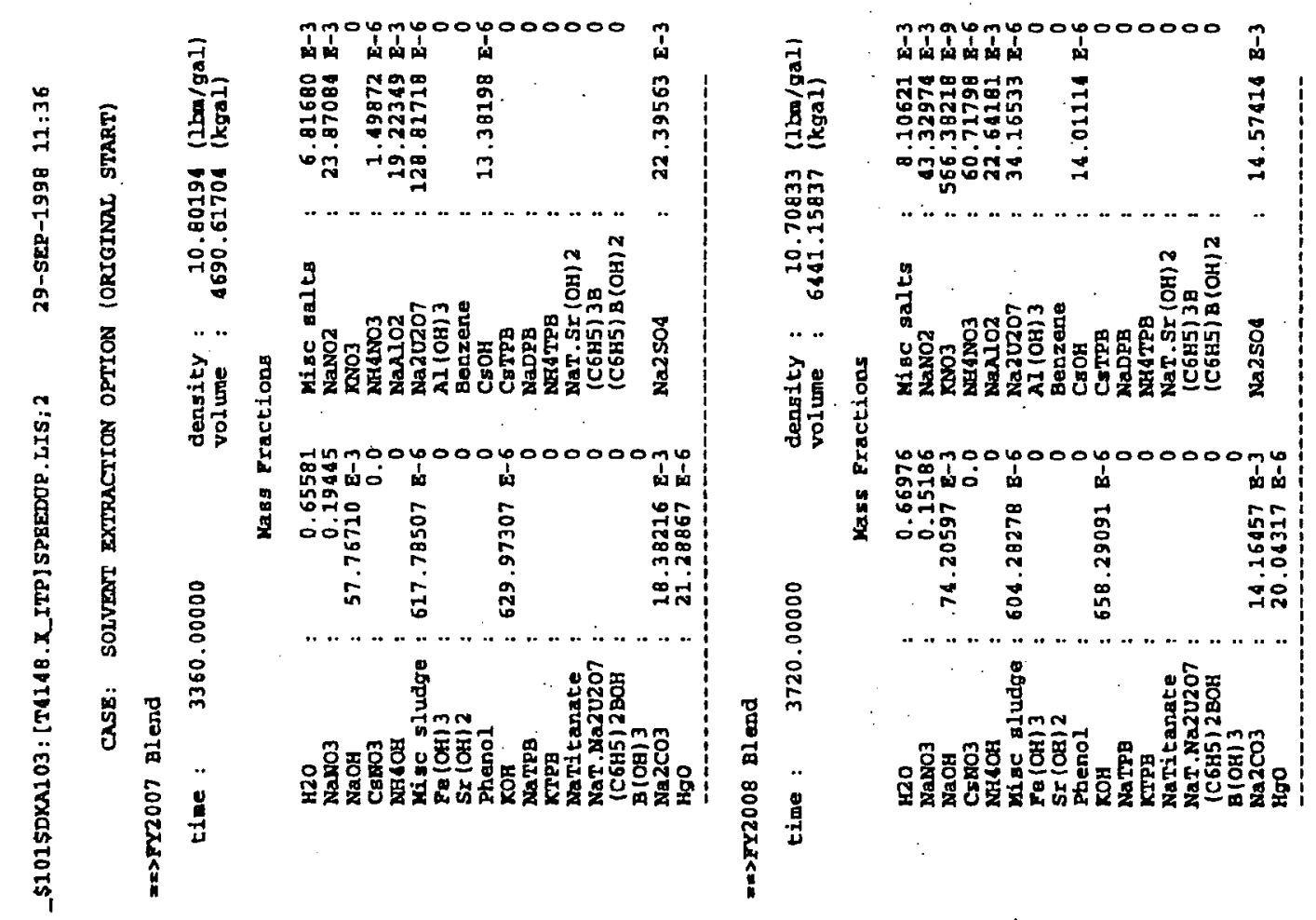

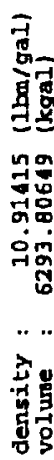

吾

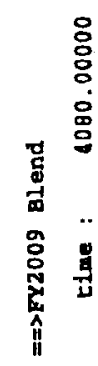


$\frac{e}{b}$

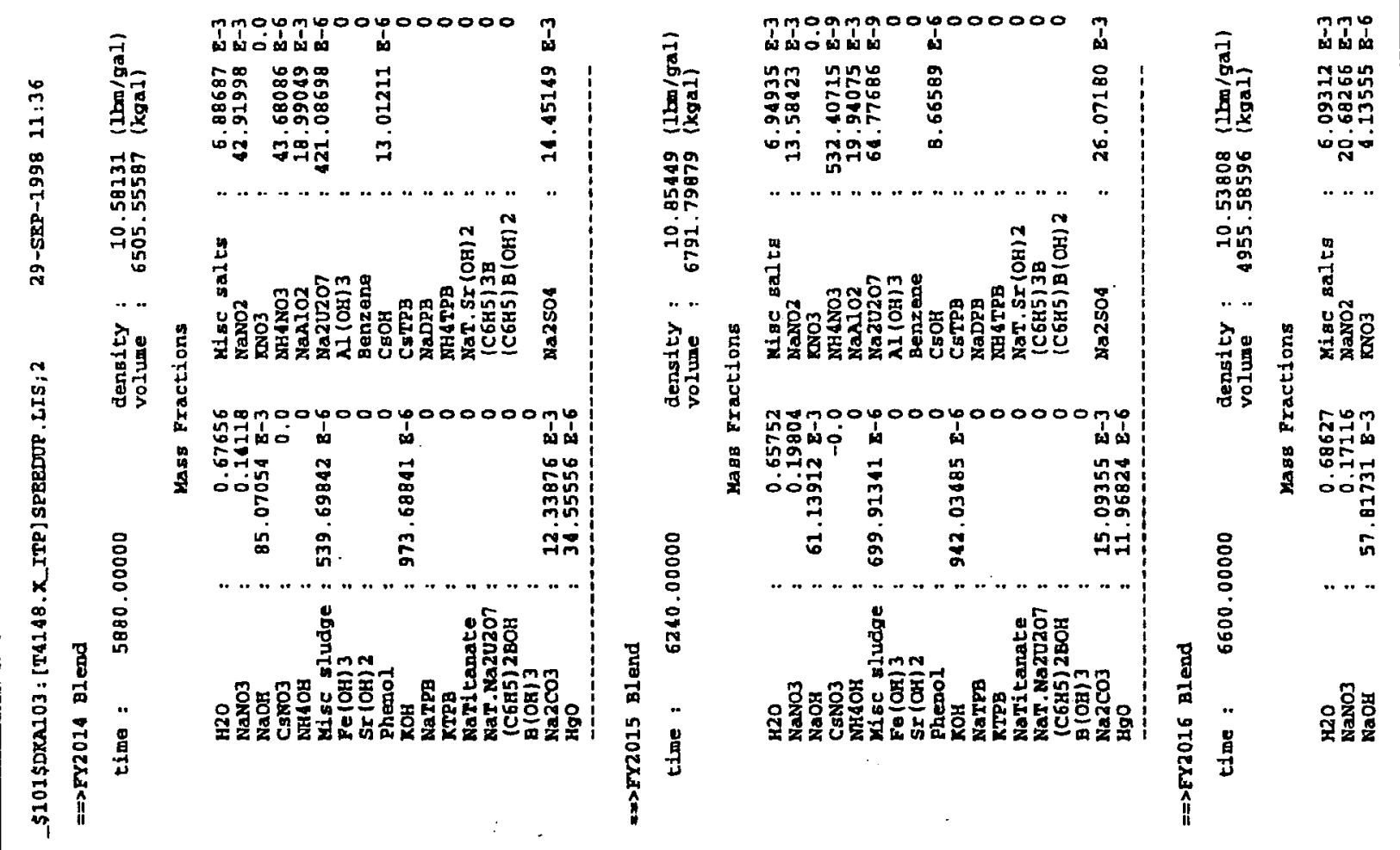

要
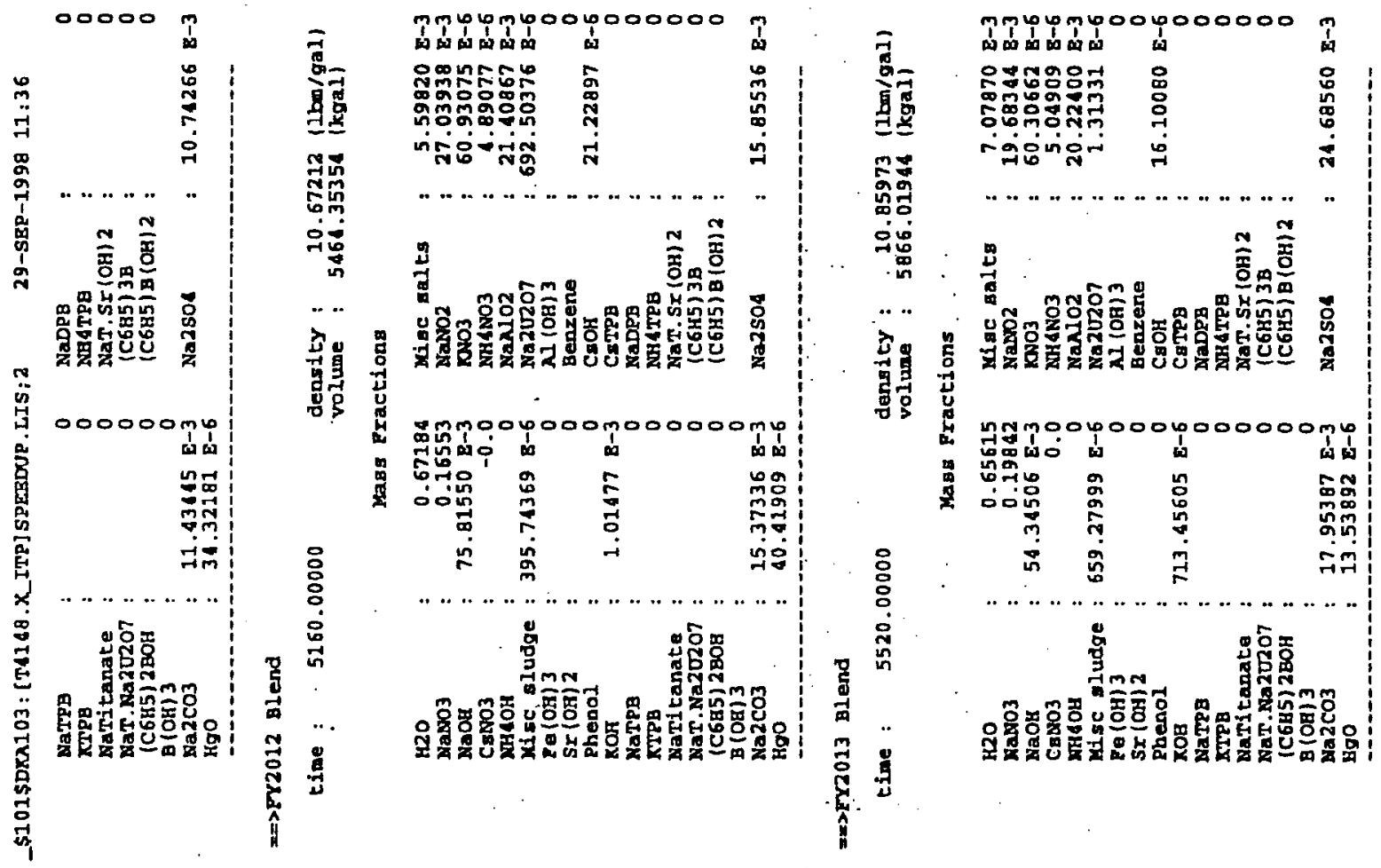


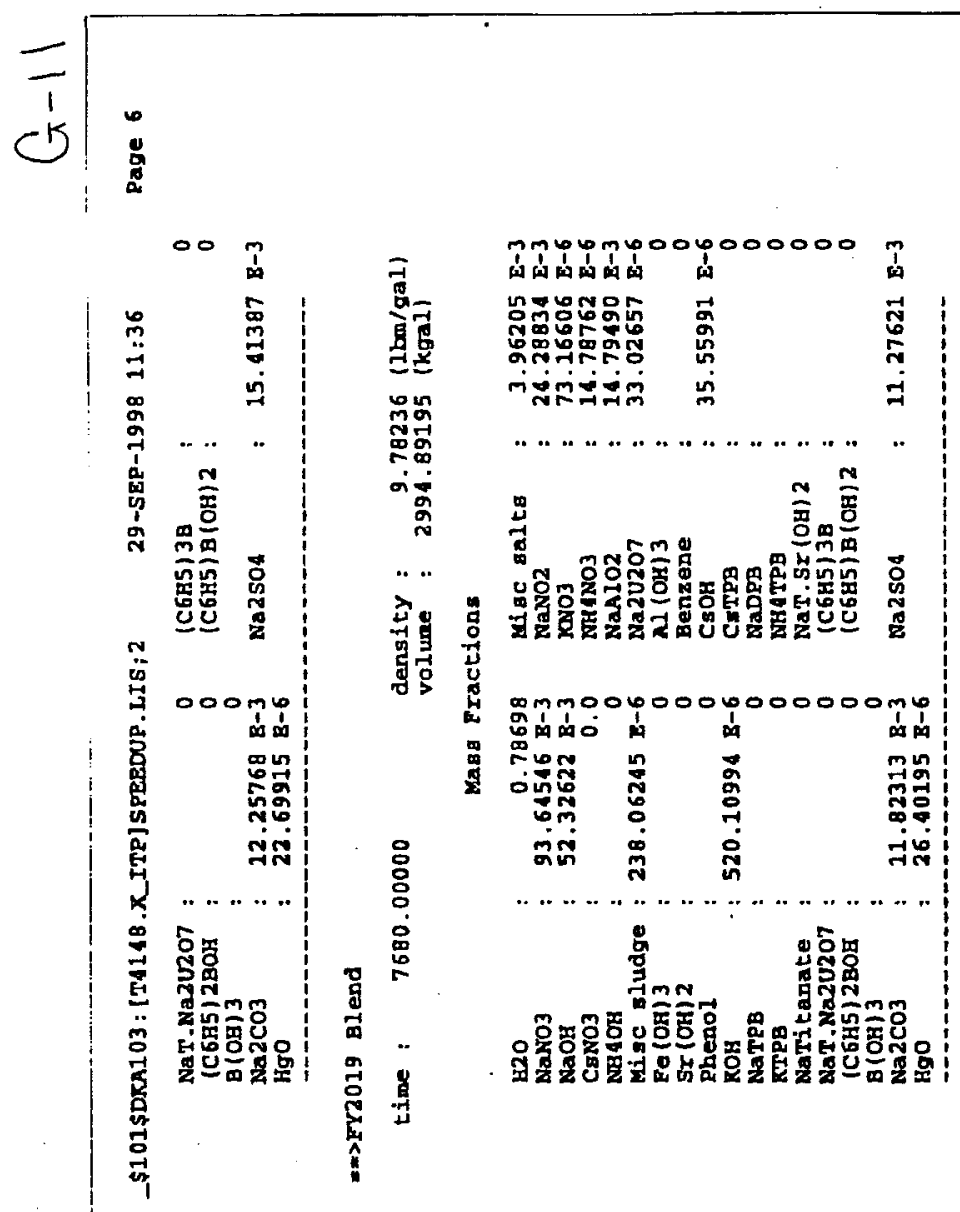

n
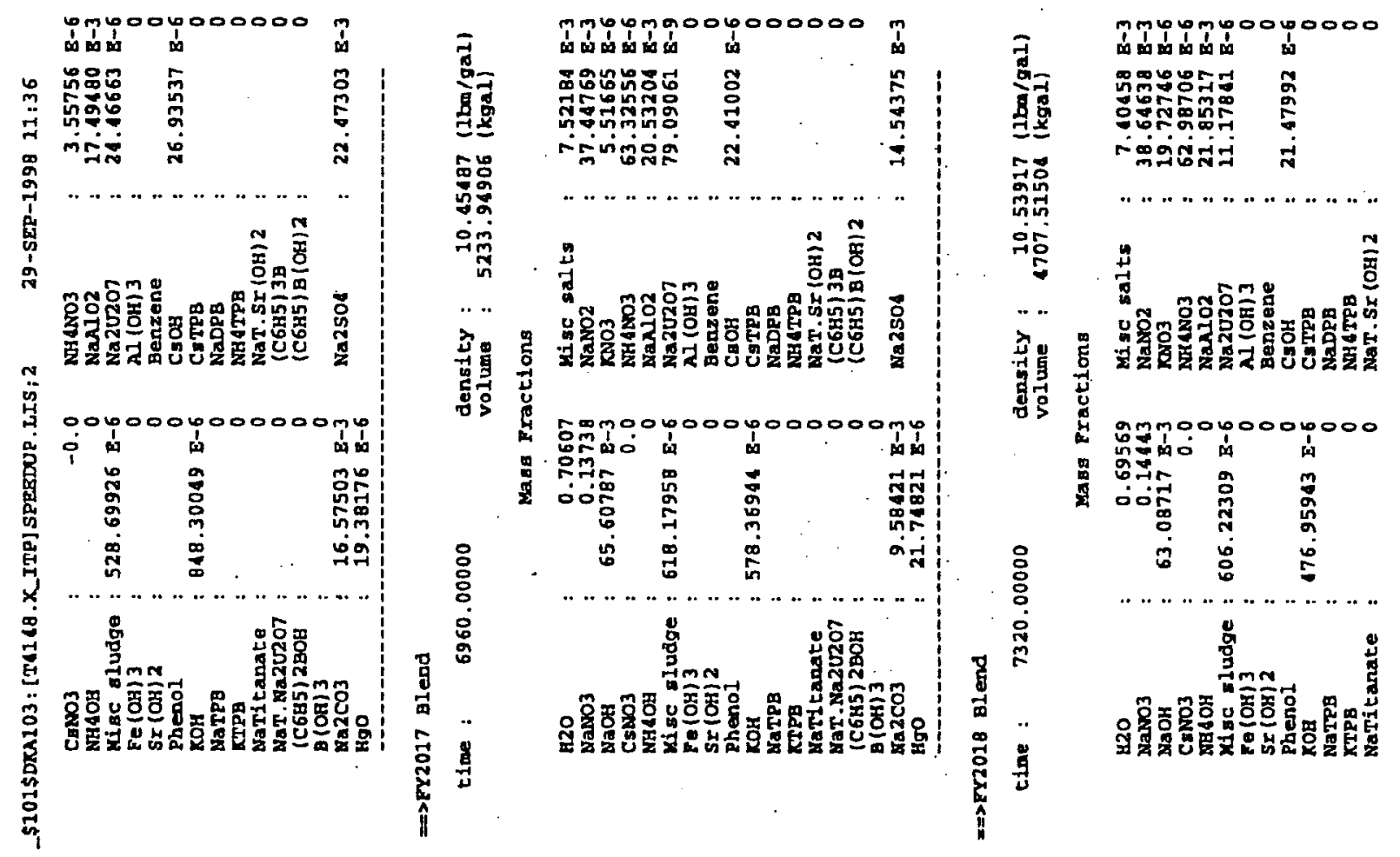


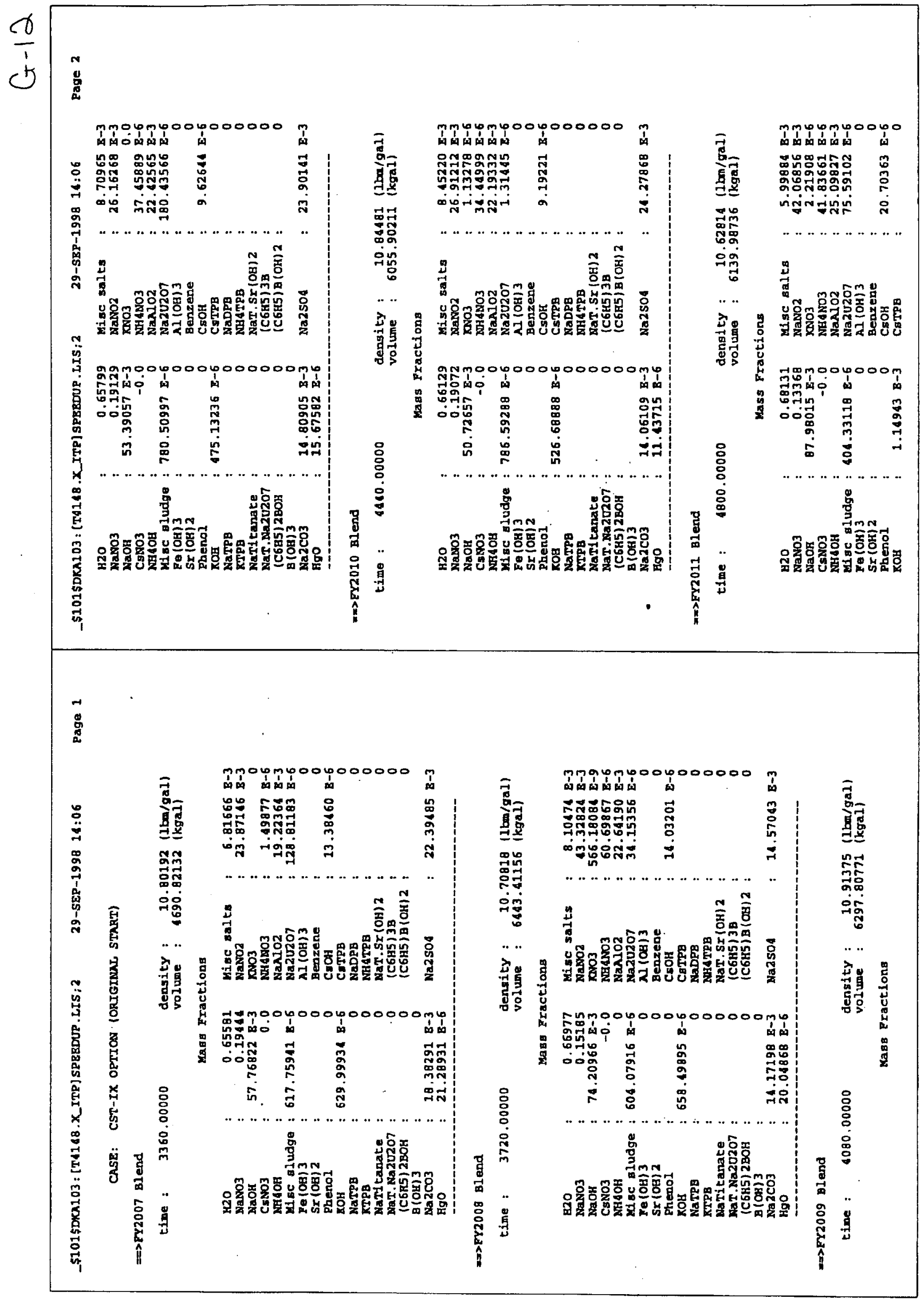




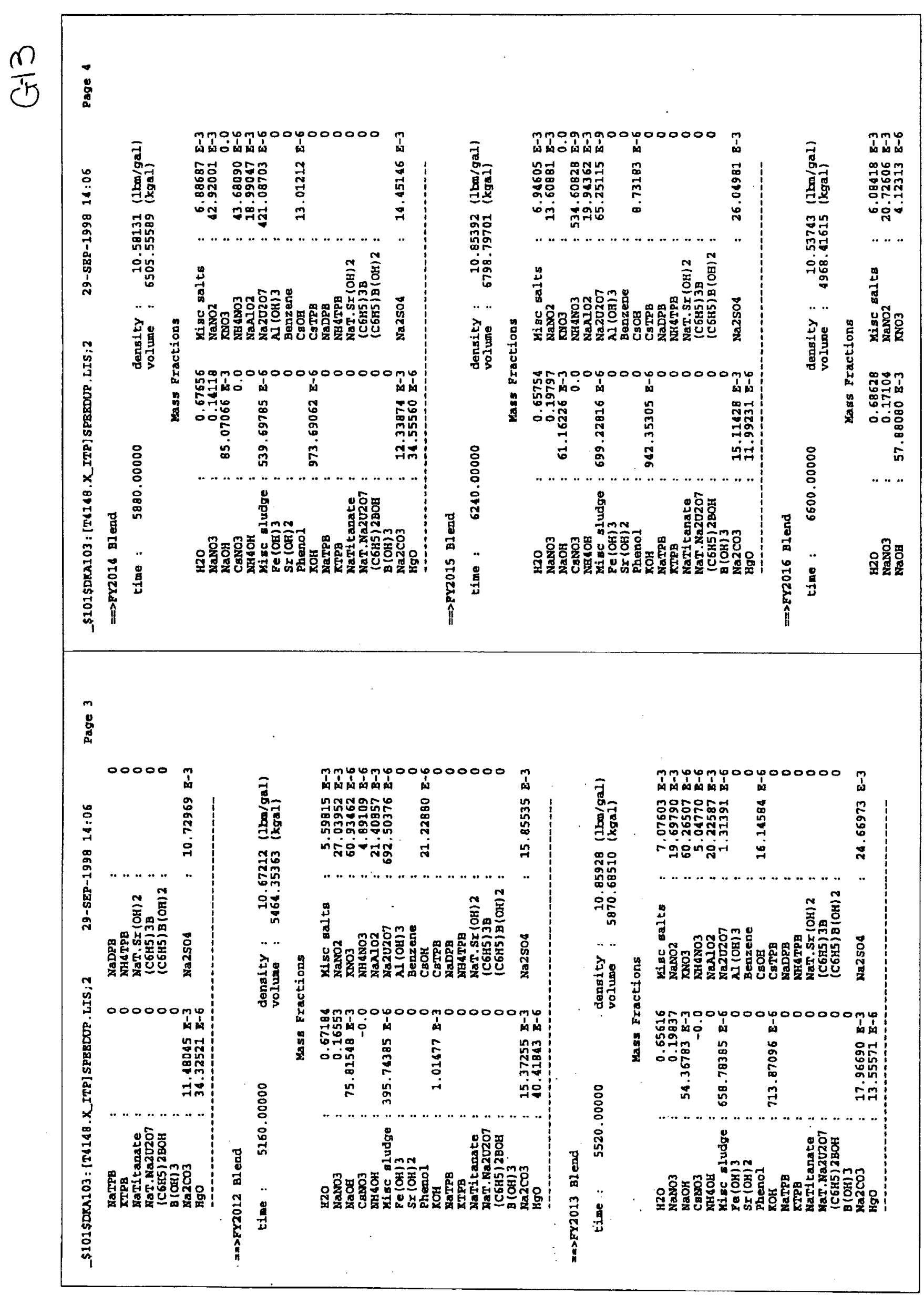




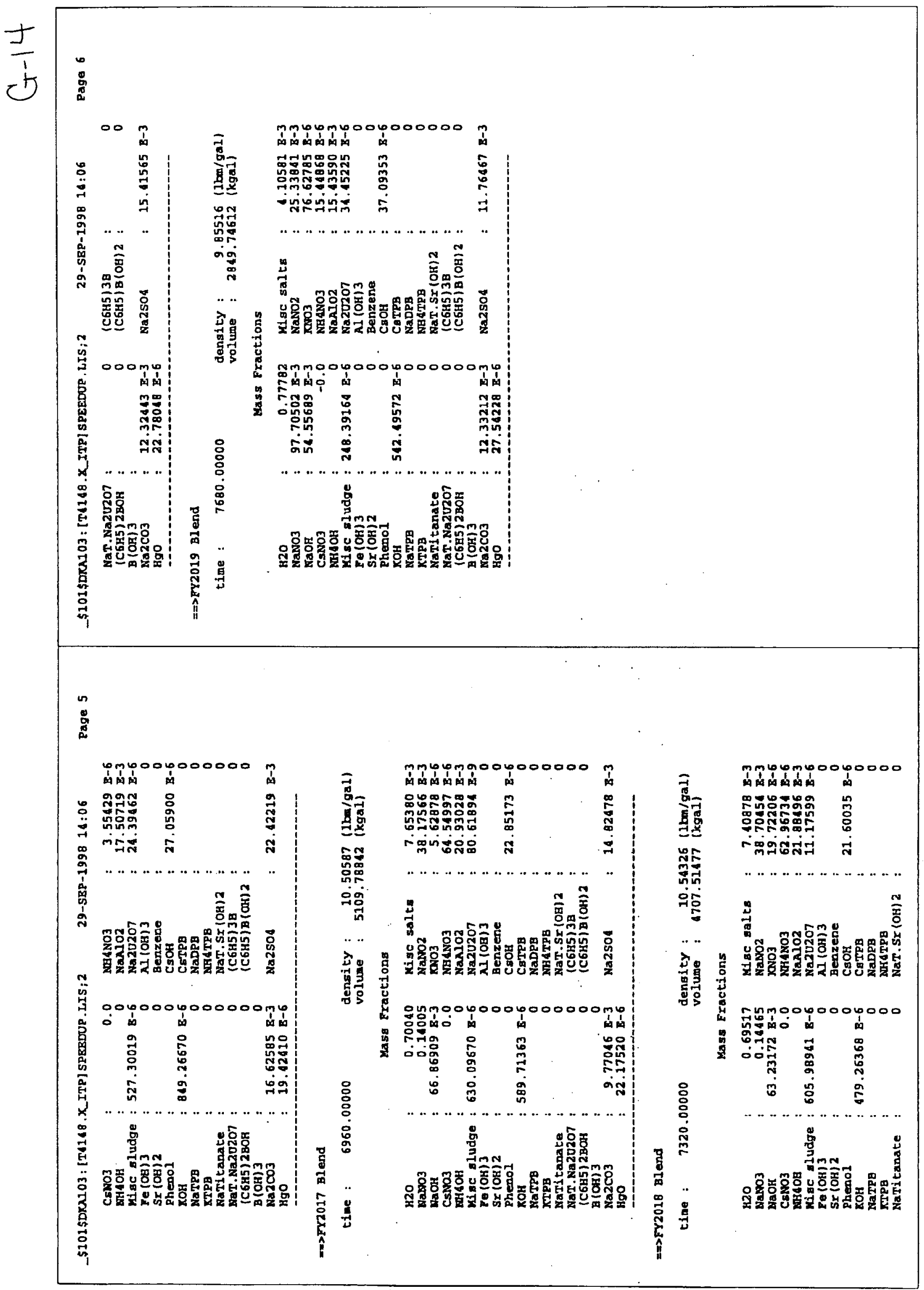


APPENDIX H

SPEEDUP TIME-SERIES PLOTS 
$\gamma$
1
\pm

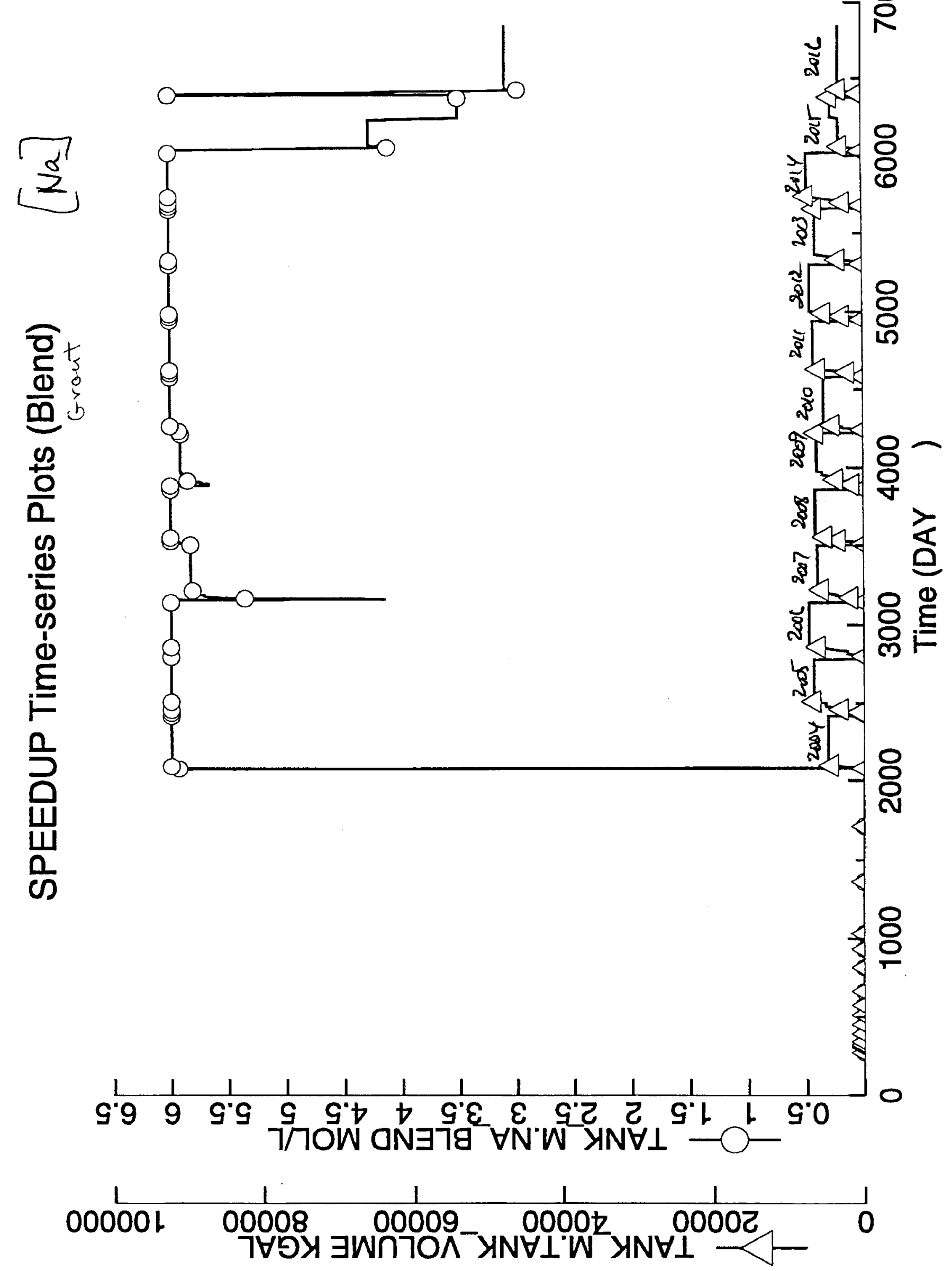


p

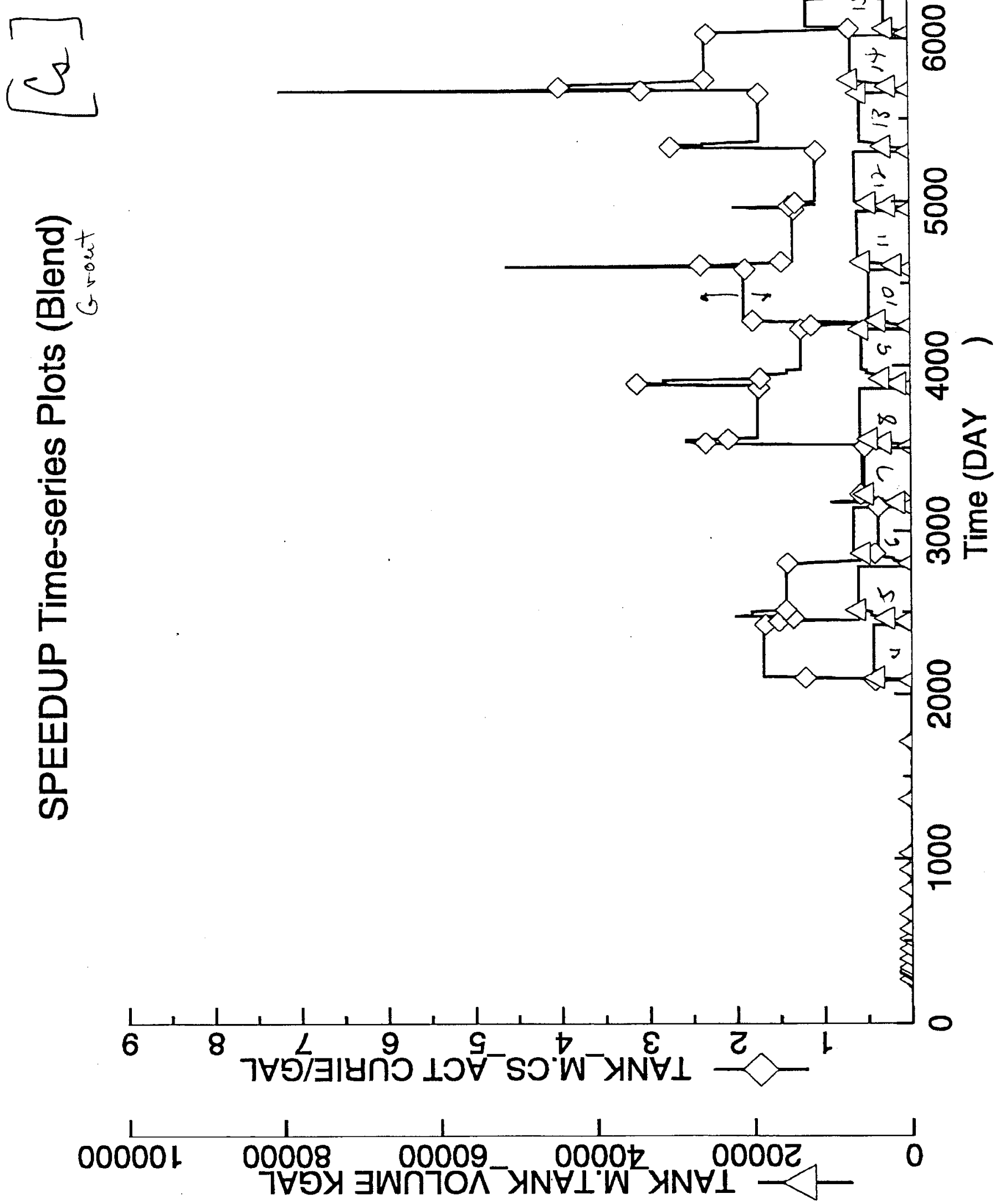


1
1
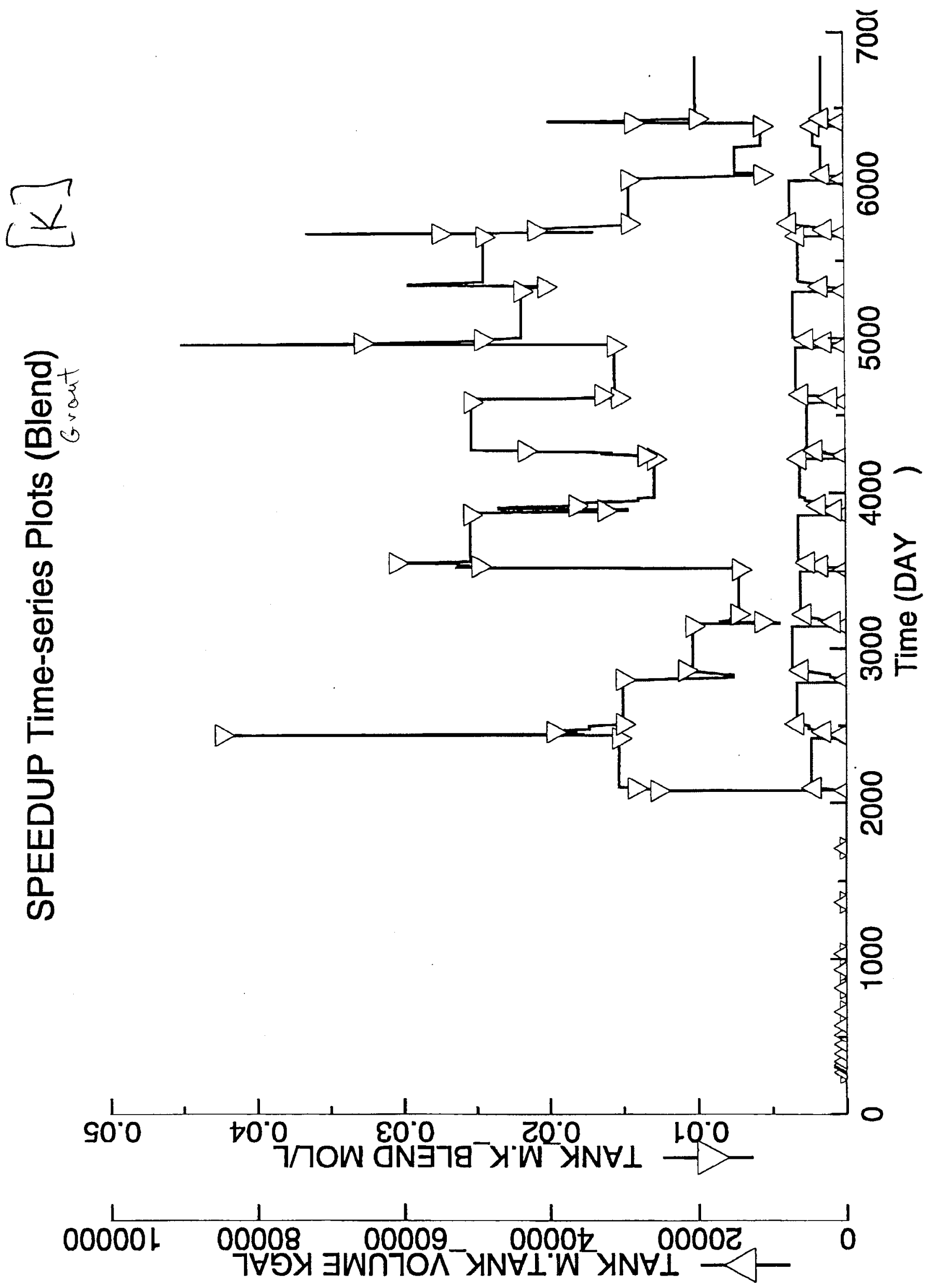
$\stackrel{n}{ \pm}$

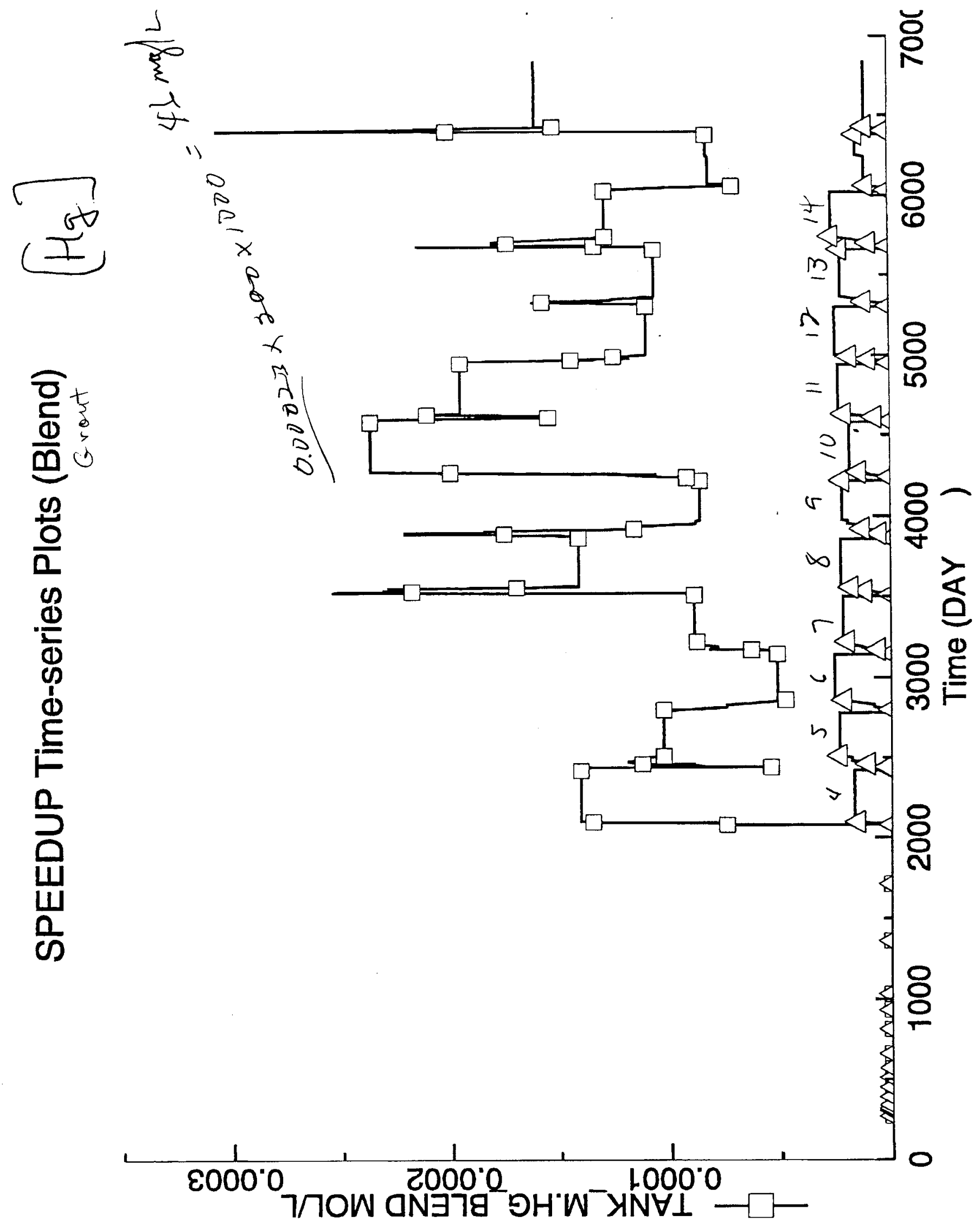

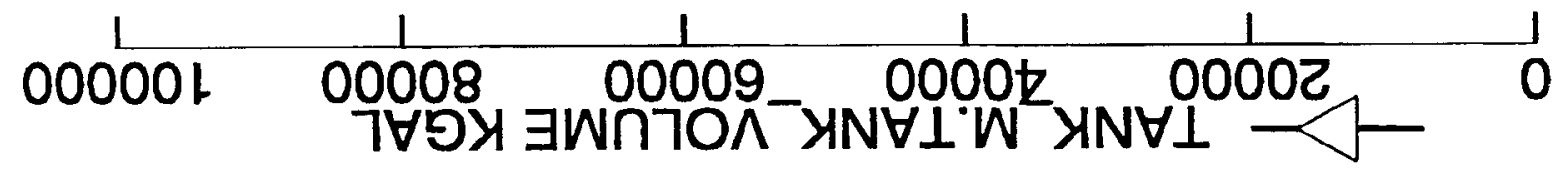



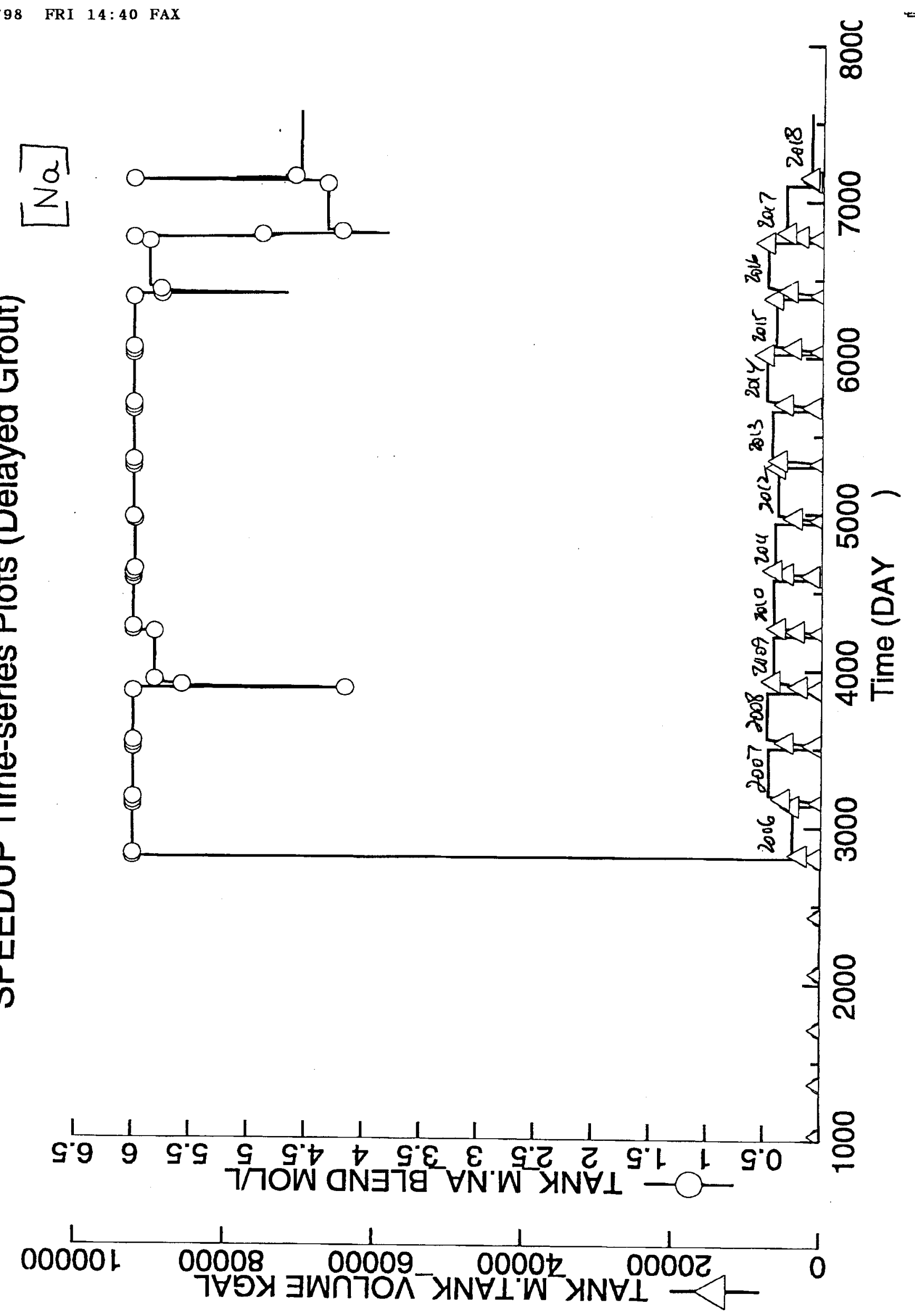
$09 / 25 / 98$ FRI 14:40 FAX

$\Gamma_{1}$

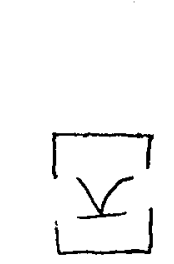

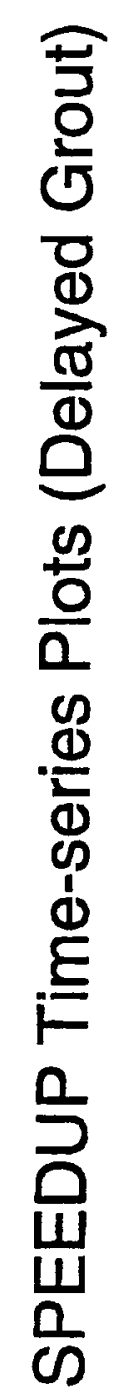

7 ๖
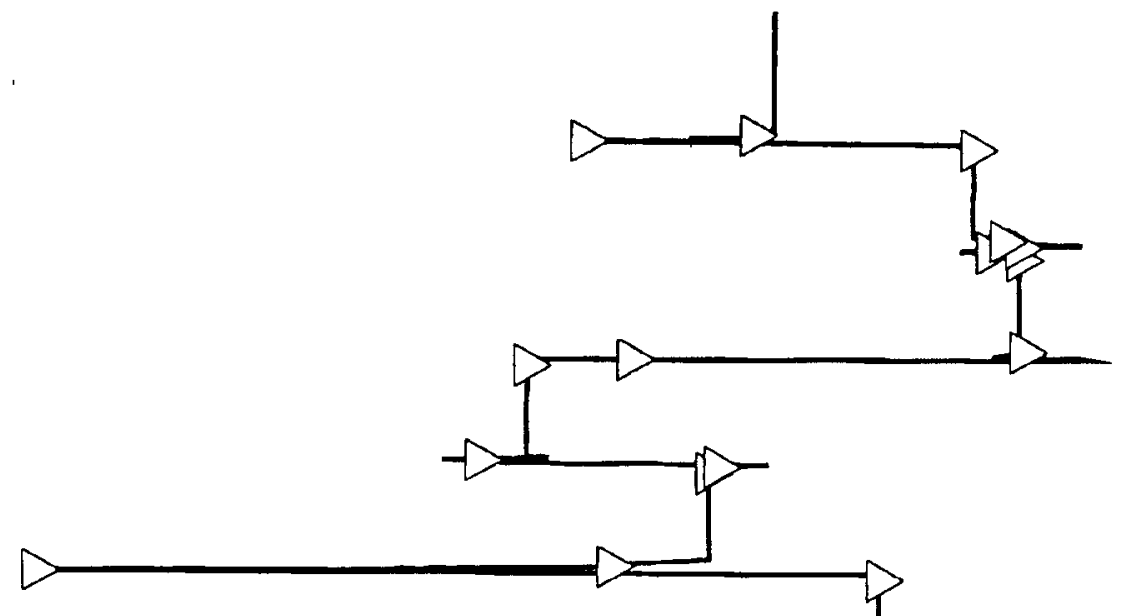

18

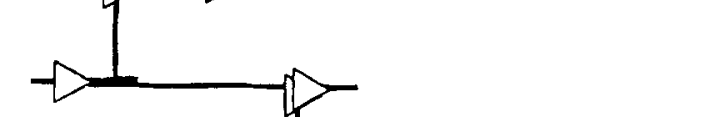

8
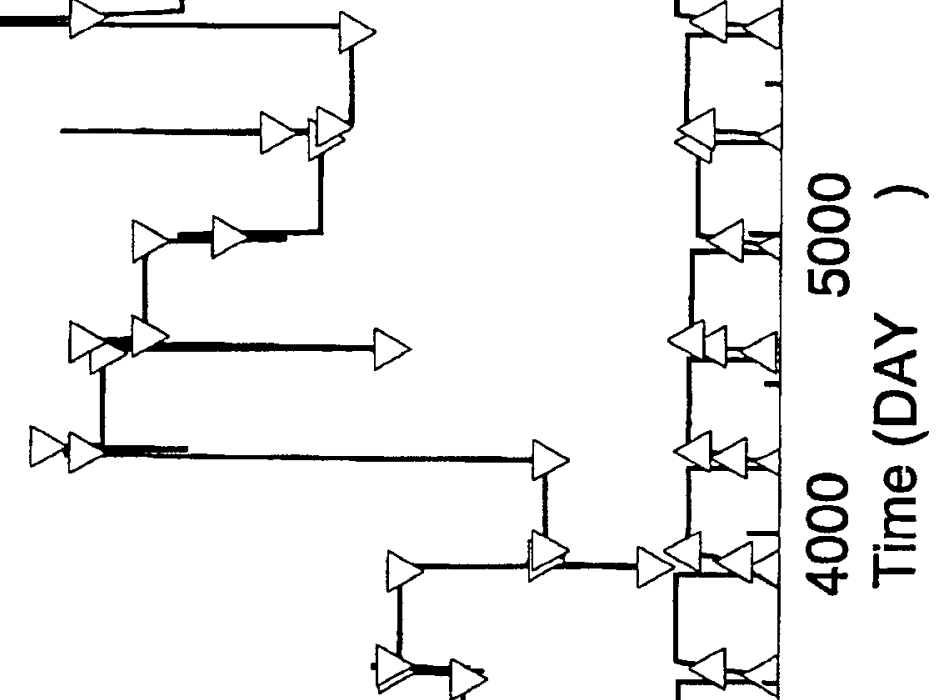

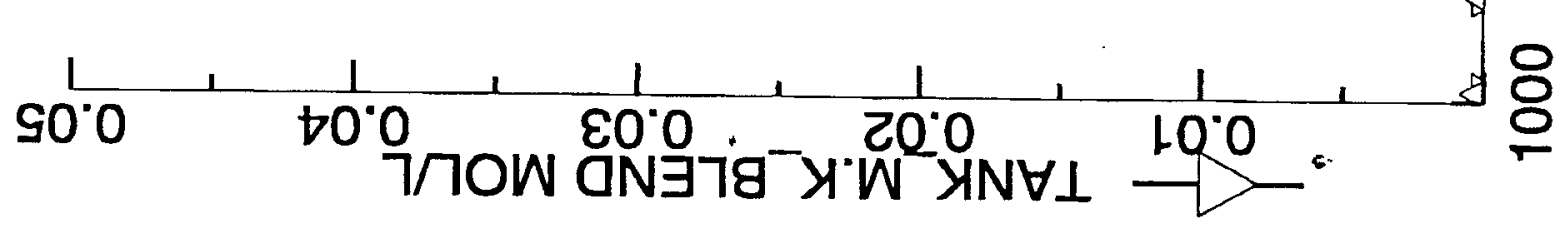

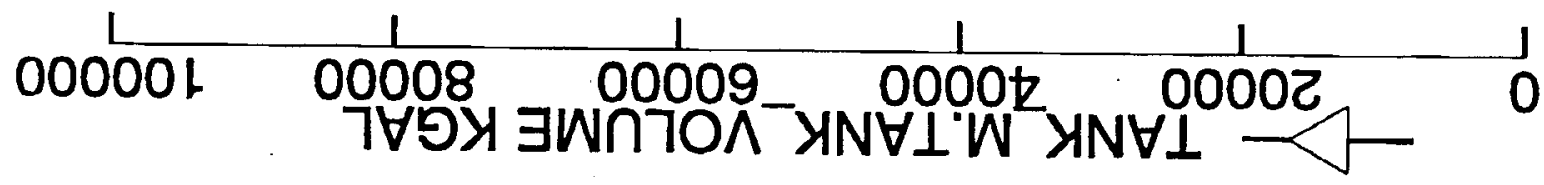


09/25/98 FRI 14:40 FAX

$\infty$

I

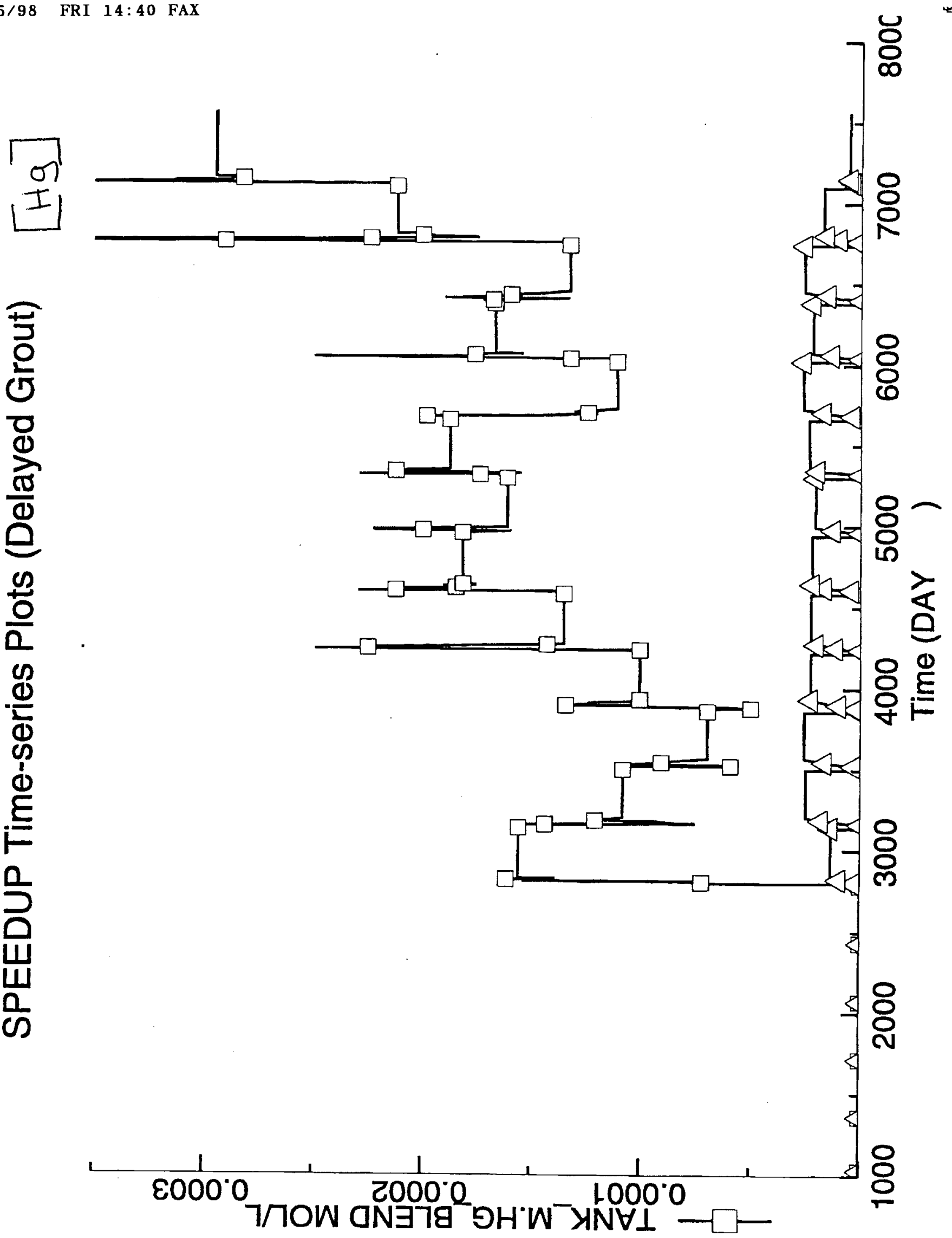

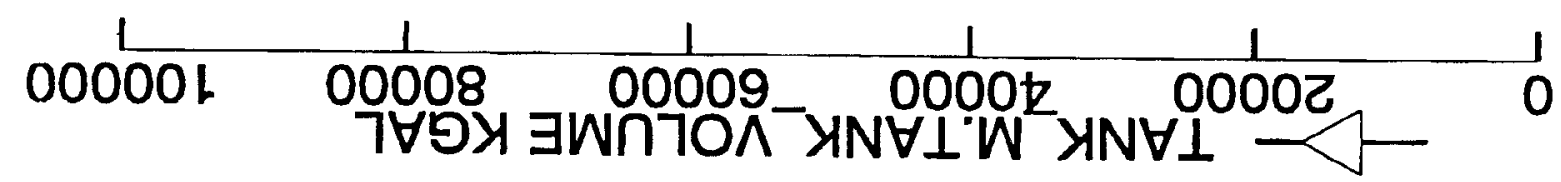


09/25/98 FRI 14:41 FAX

$\frac{\sigma}{1}$

Juบ

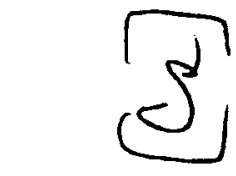

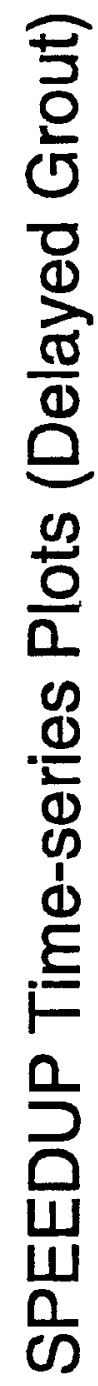

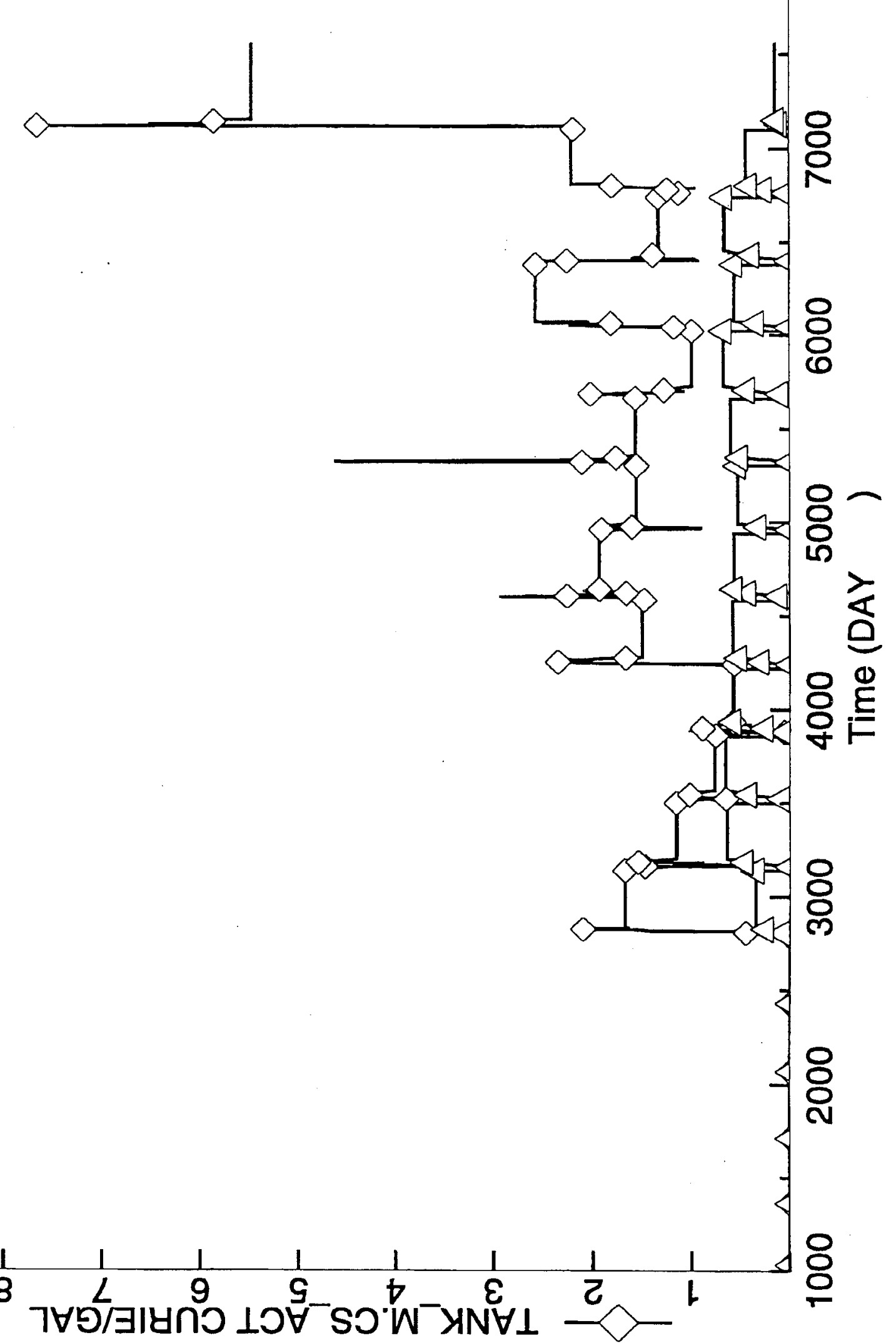

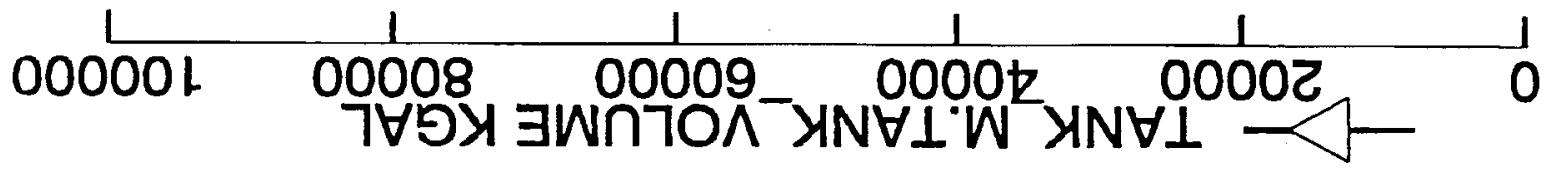




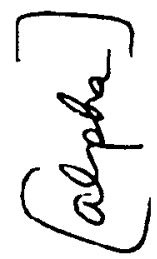

$\frac{5}{6}$
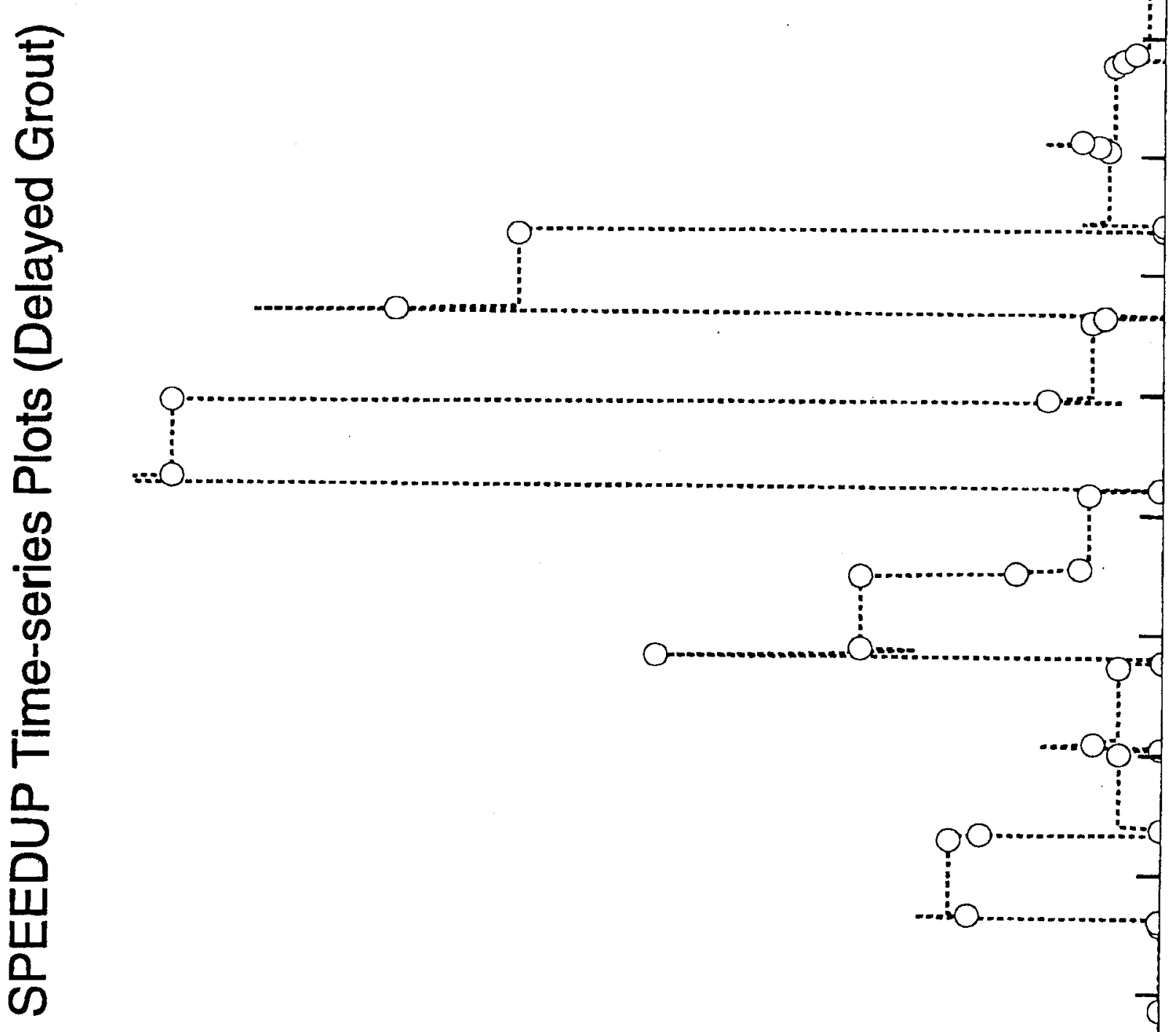

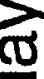

(1)

0

음<smiles>C=C[Co]</smiles>

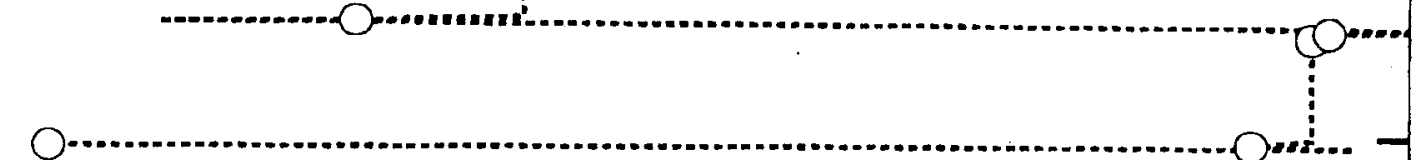

$\ldots$

.0
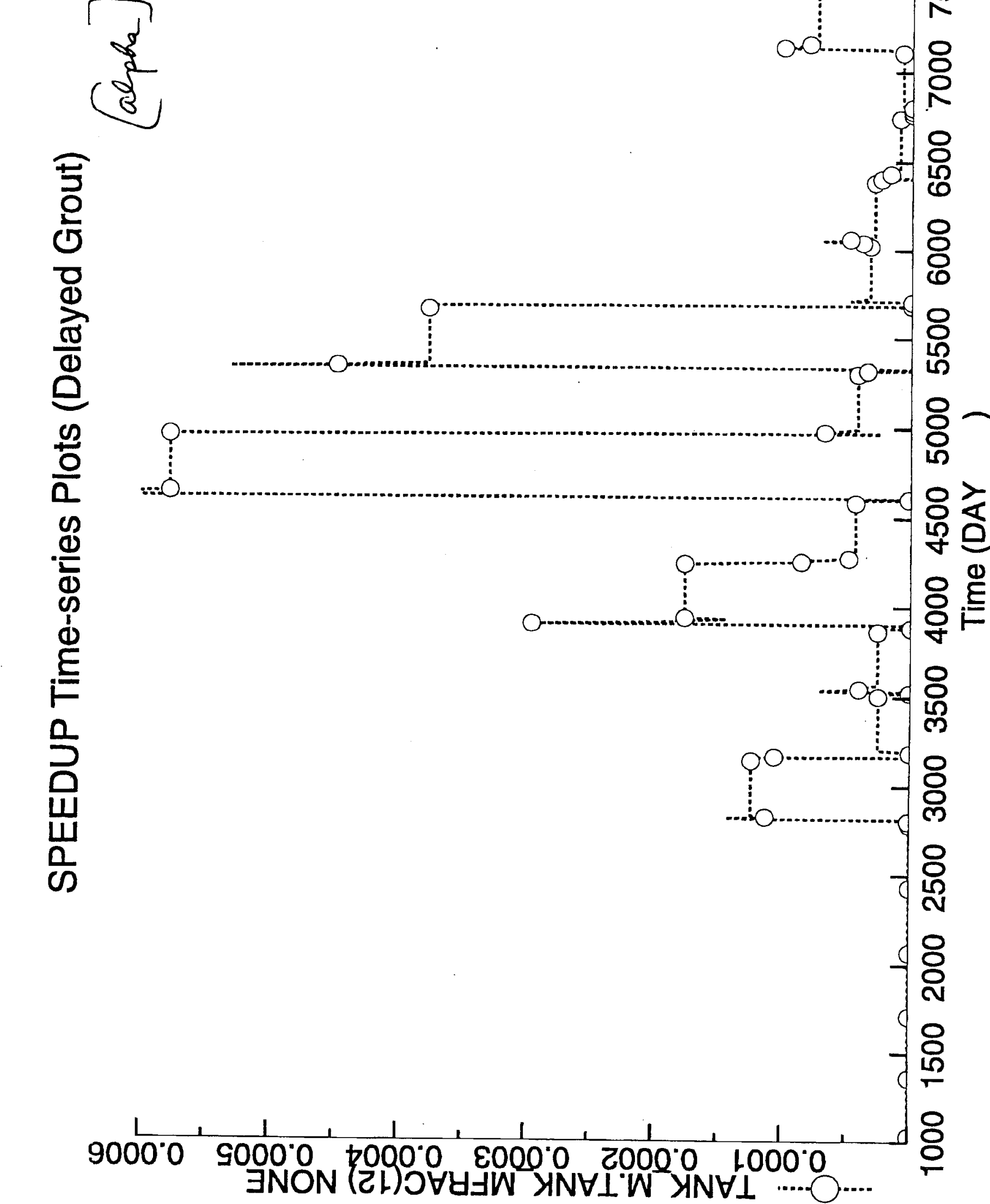
$\bar{I}$

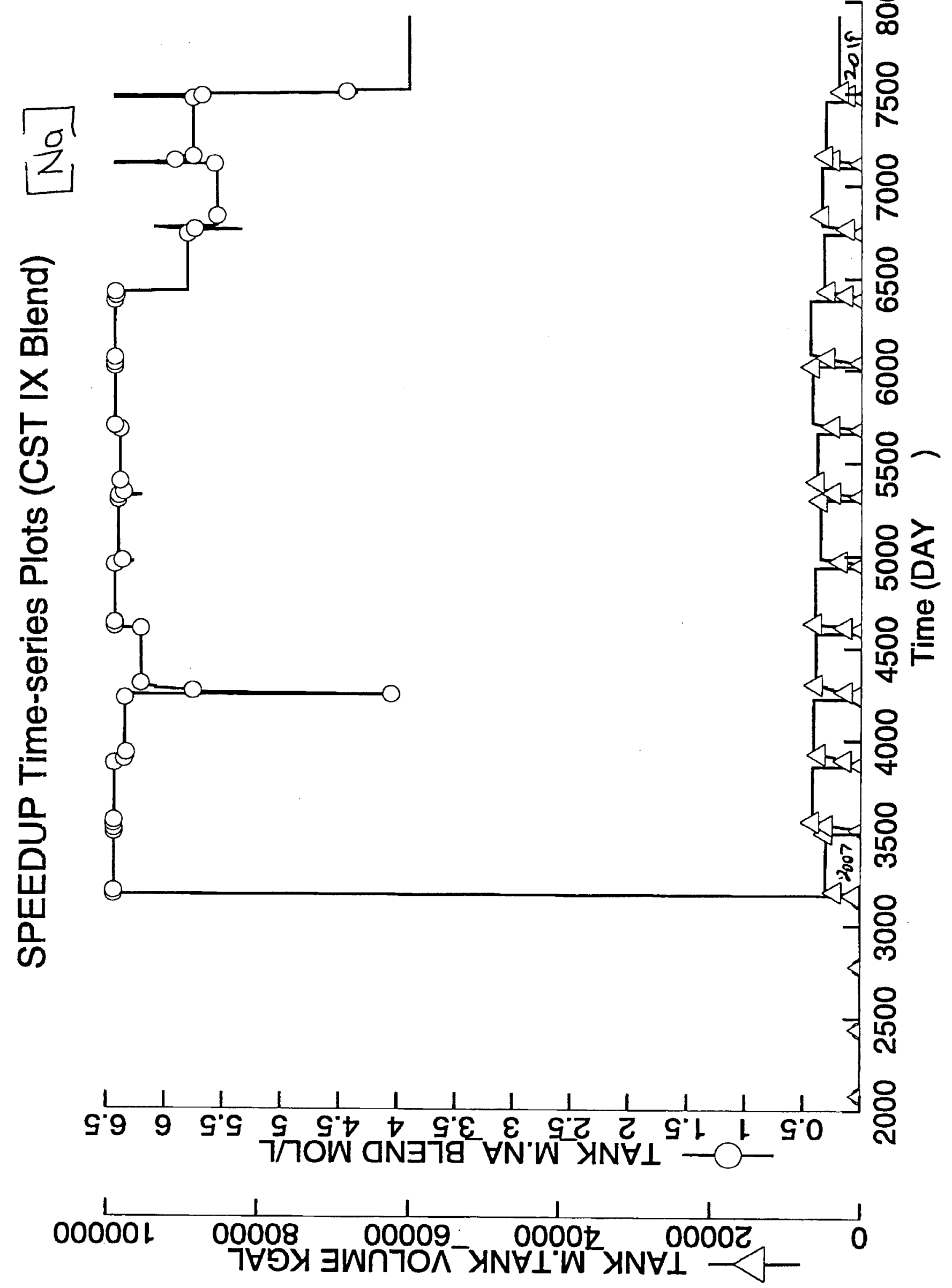


$\pm$

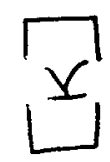

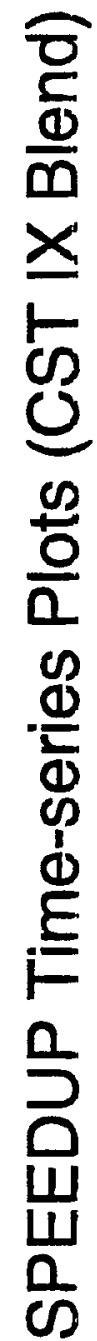

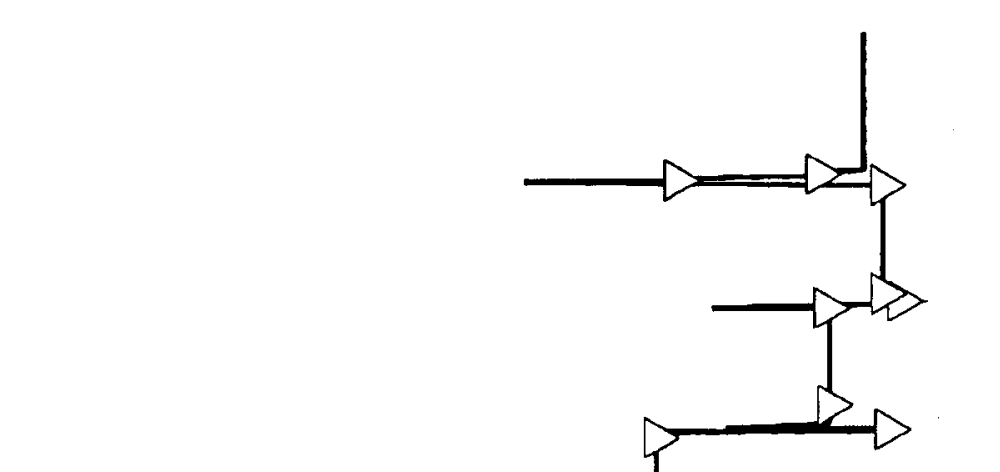

178
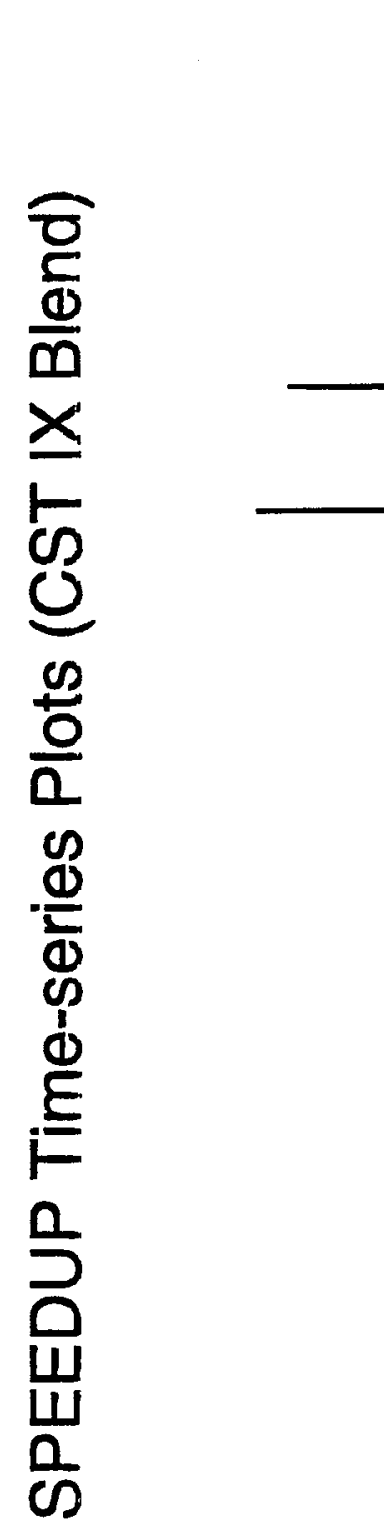
$\frac{n}{1}$

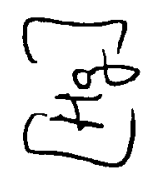

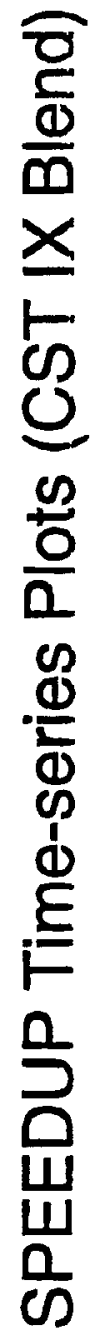

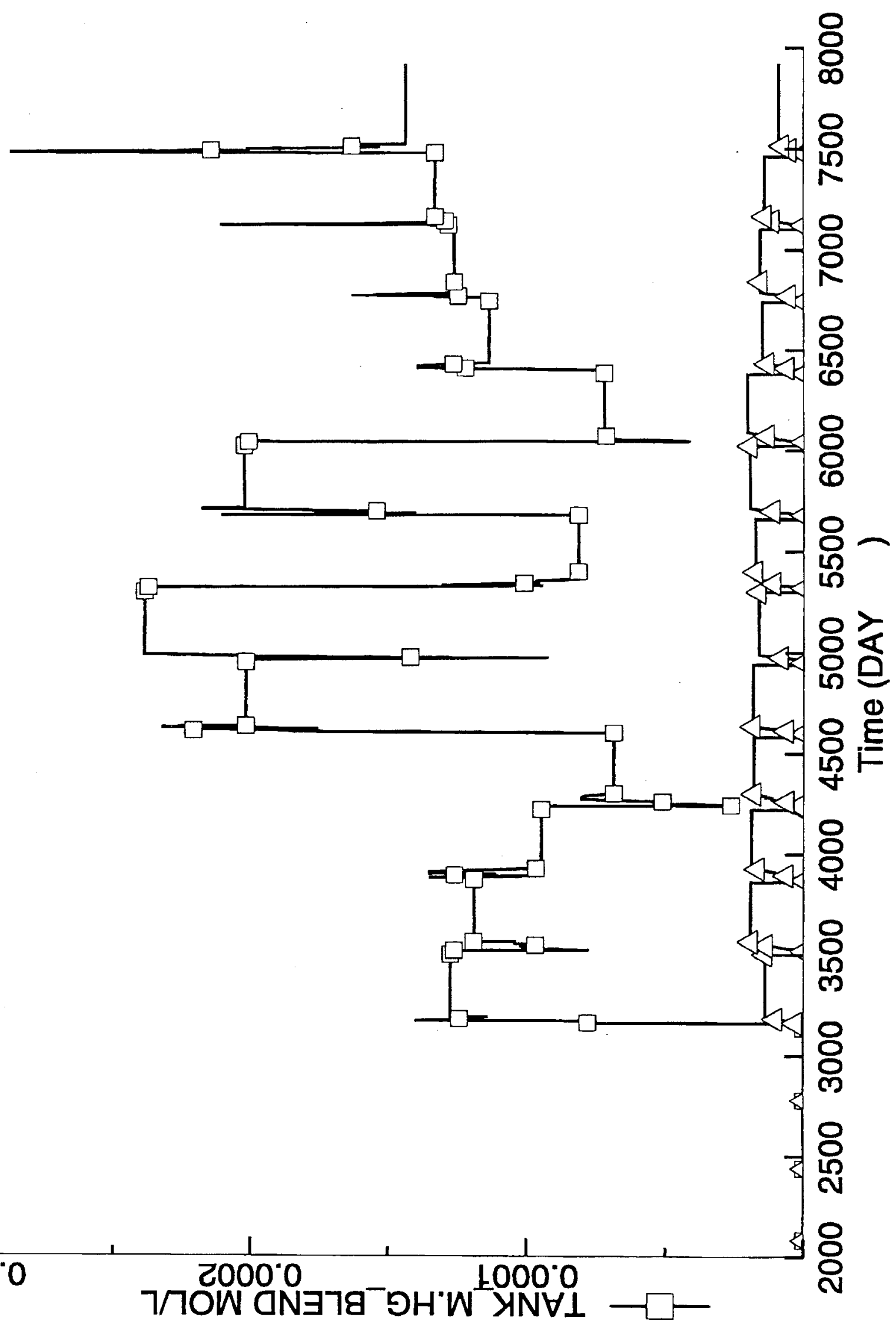

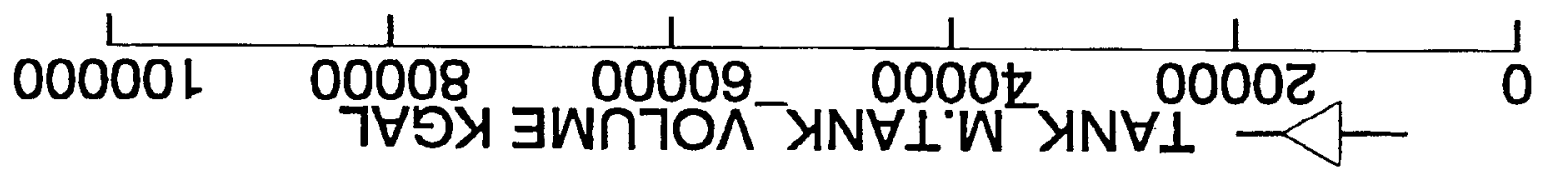



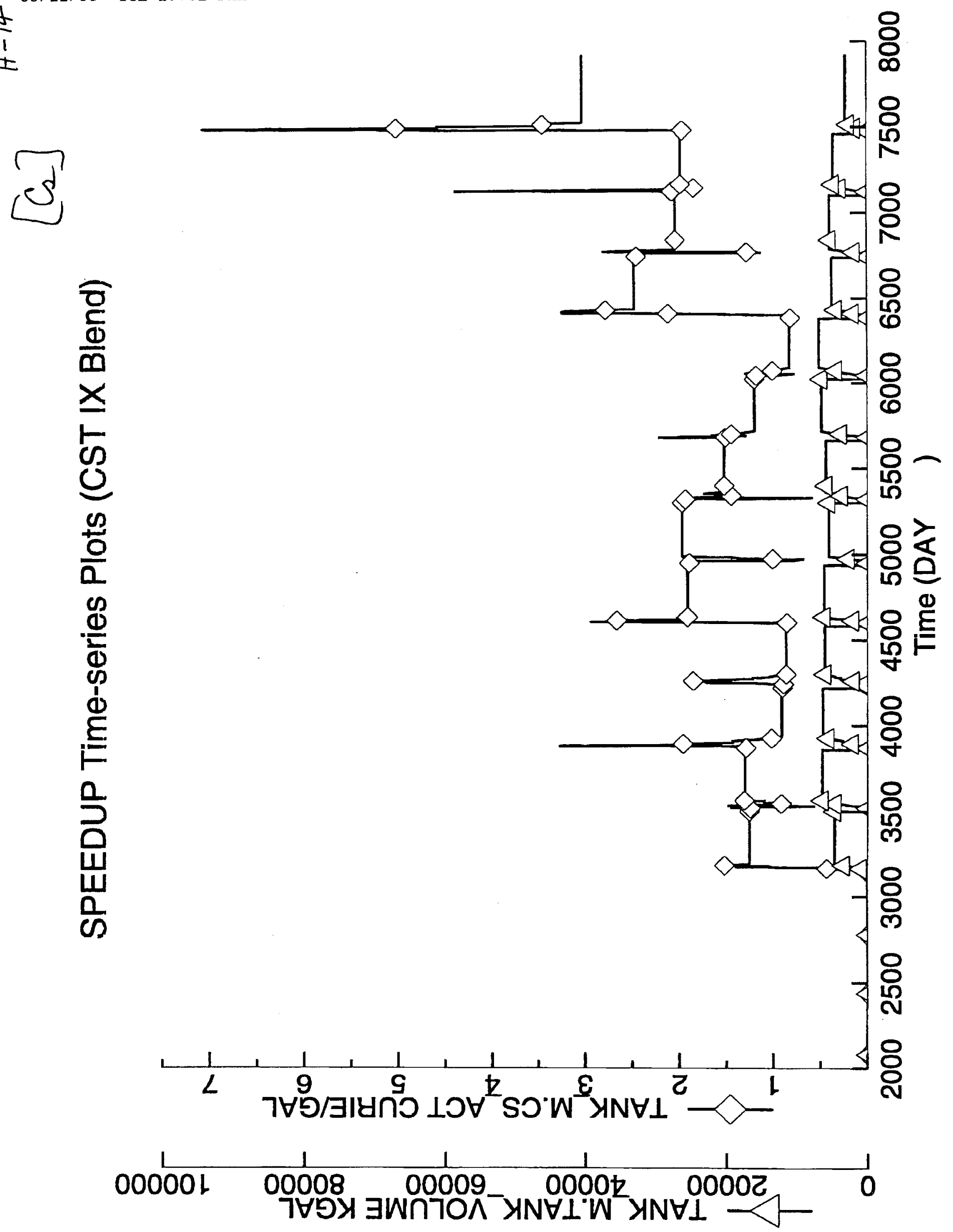
$n$
1
\pm

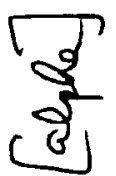

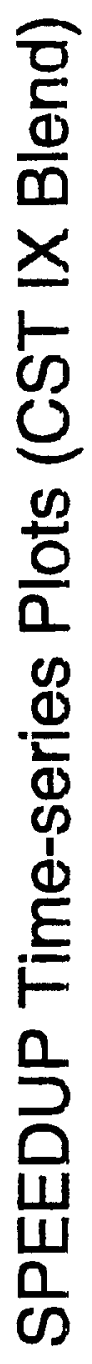
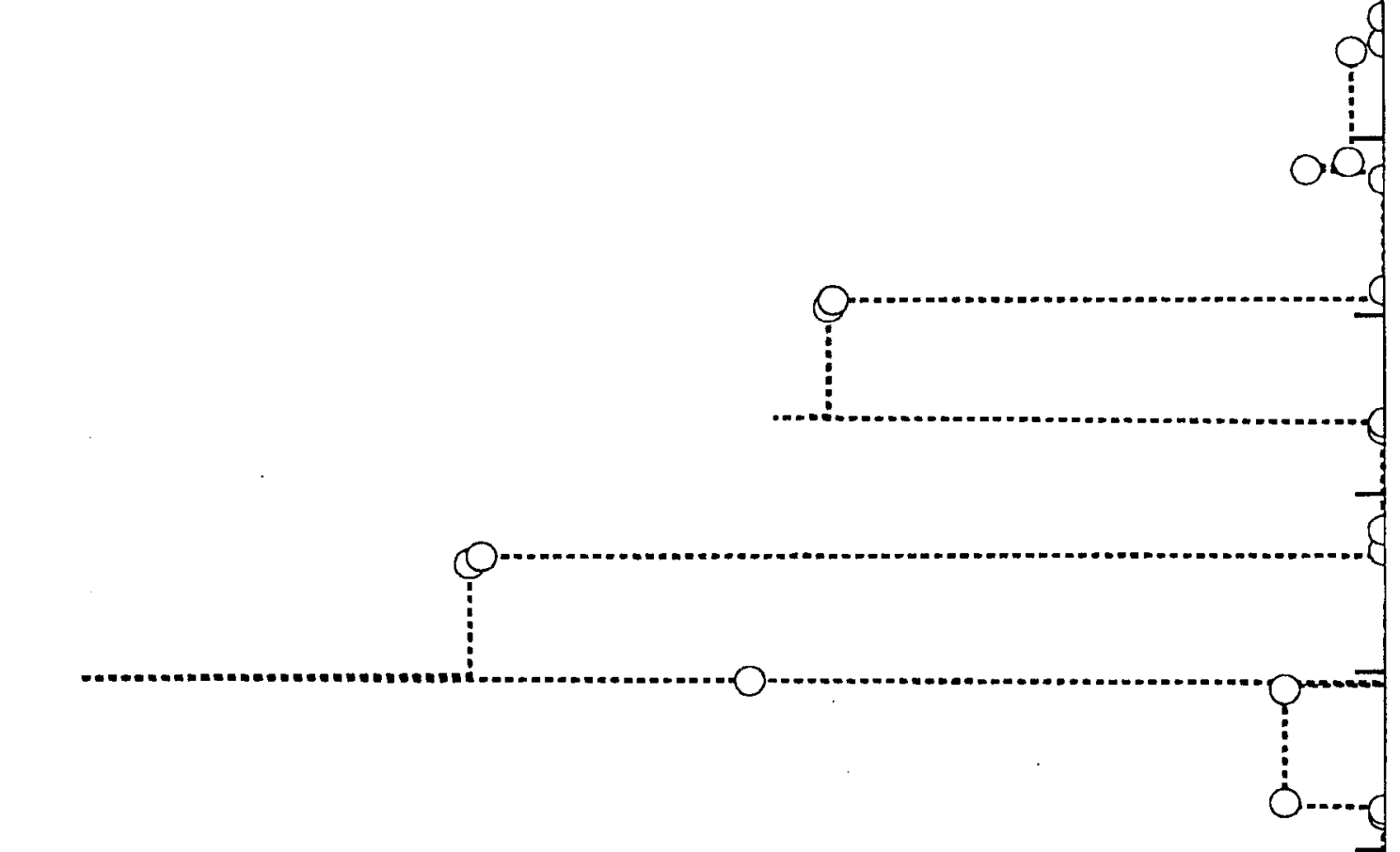

82

น

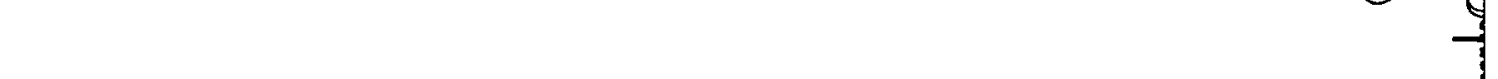

욜

$\checkmark$

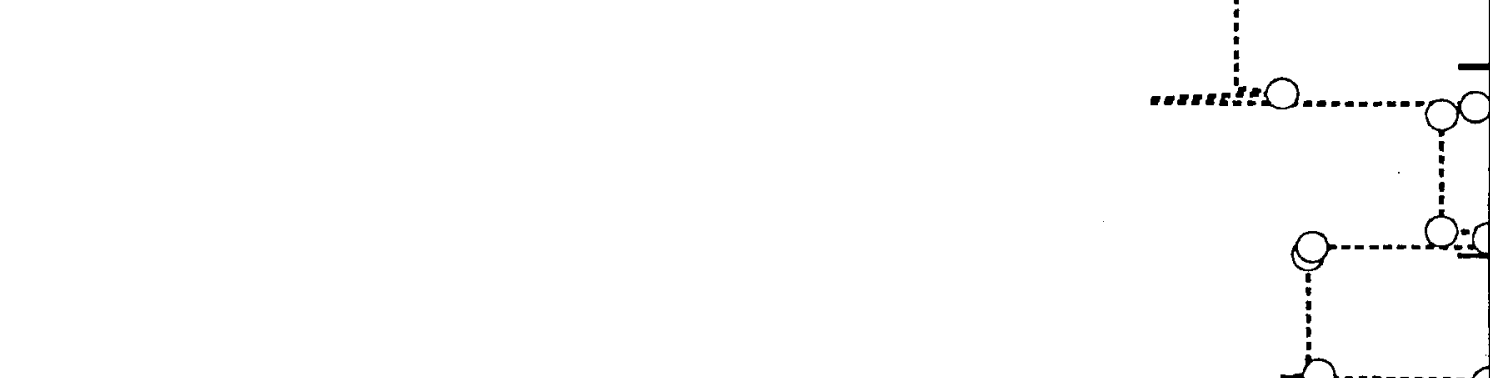

8

ณ

(5) 


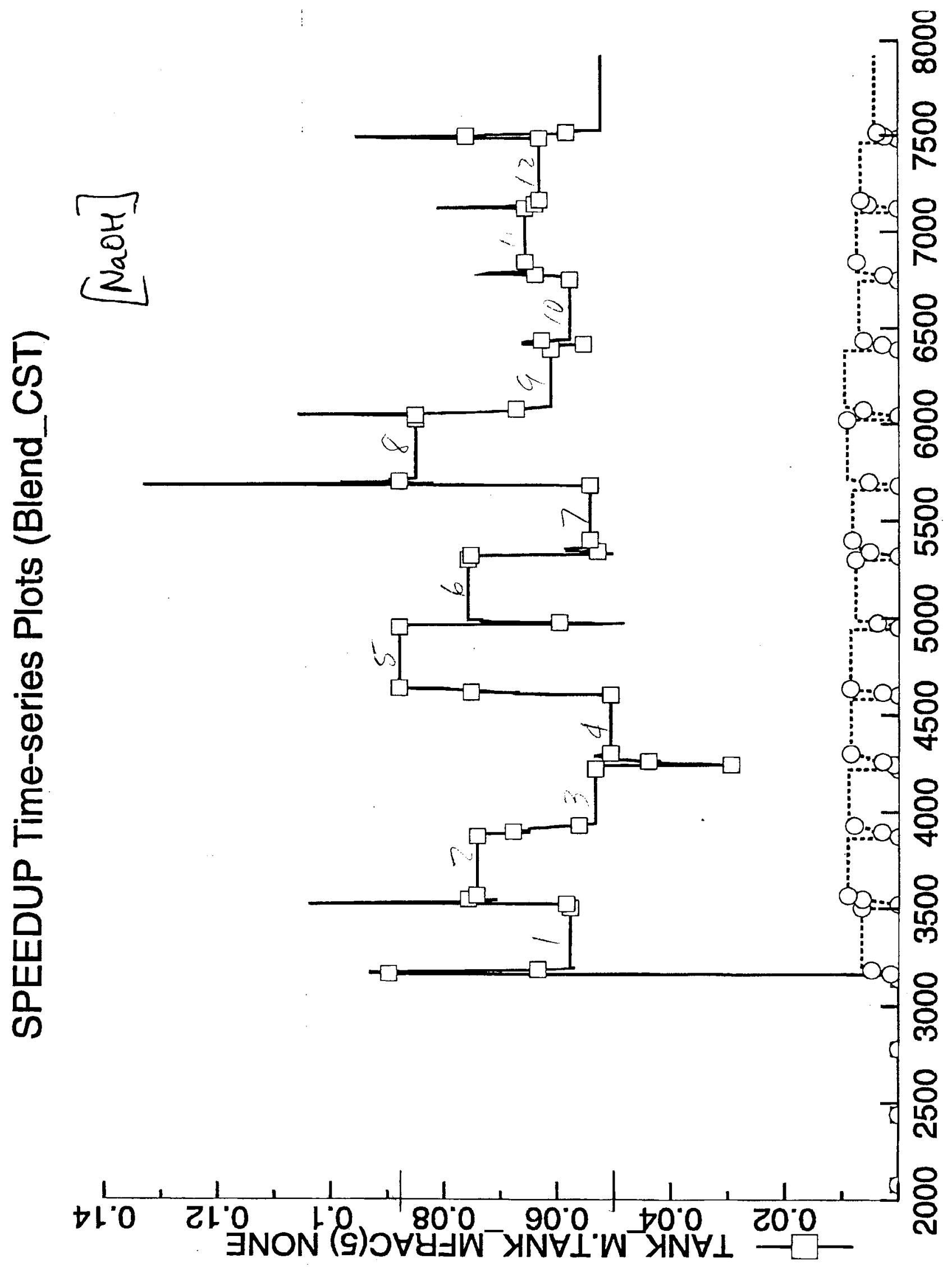

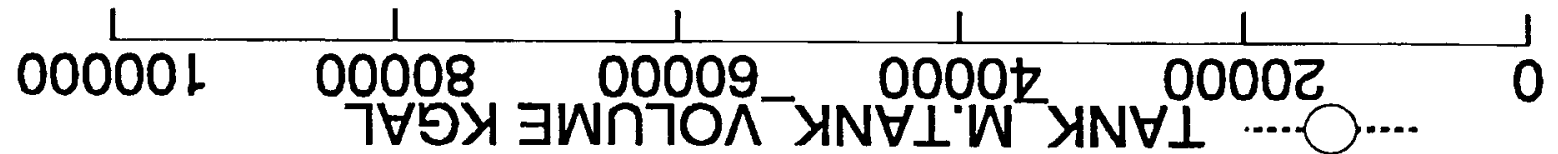


$\frac{1}{1}$

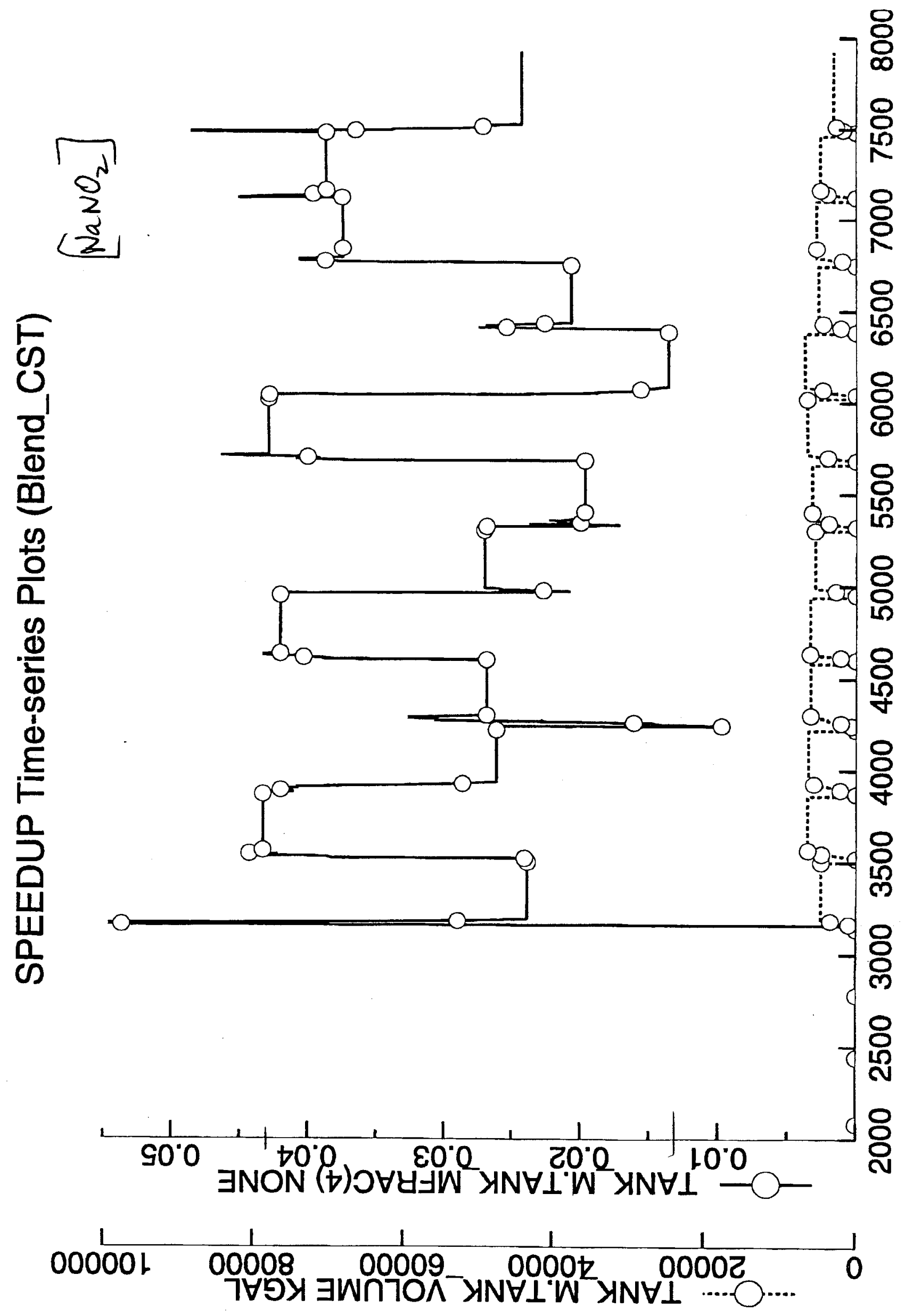


$\sum_{ \pm}^{\infty}$
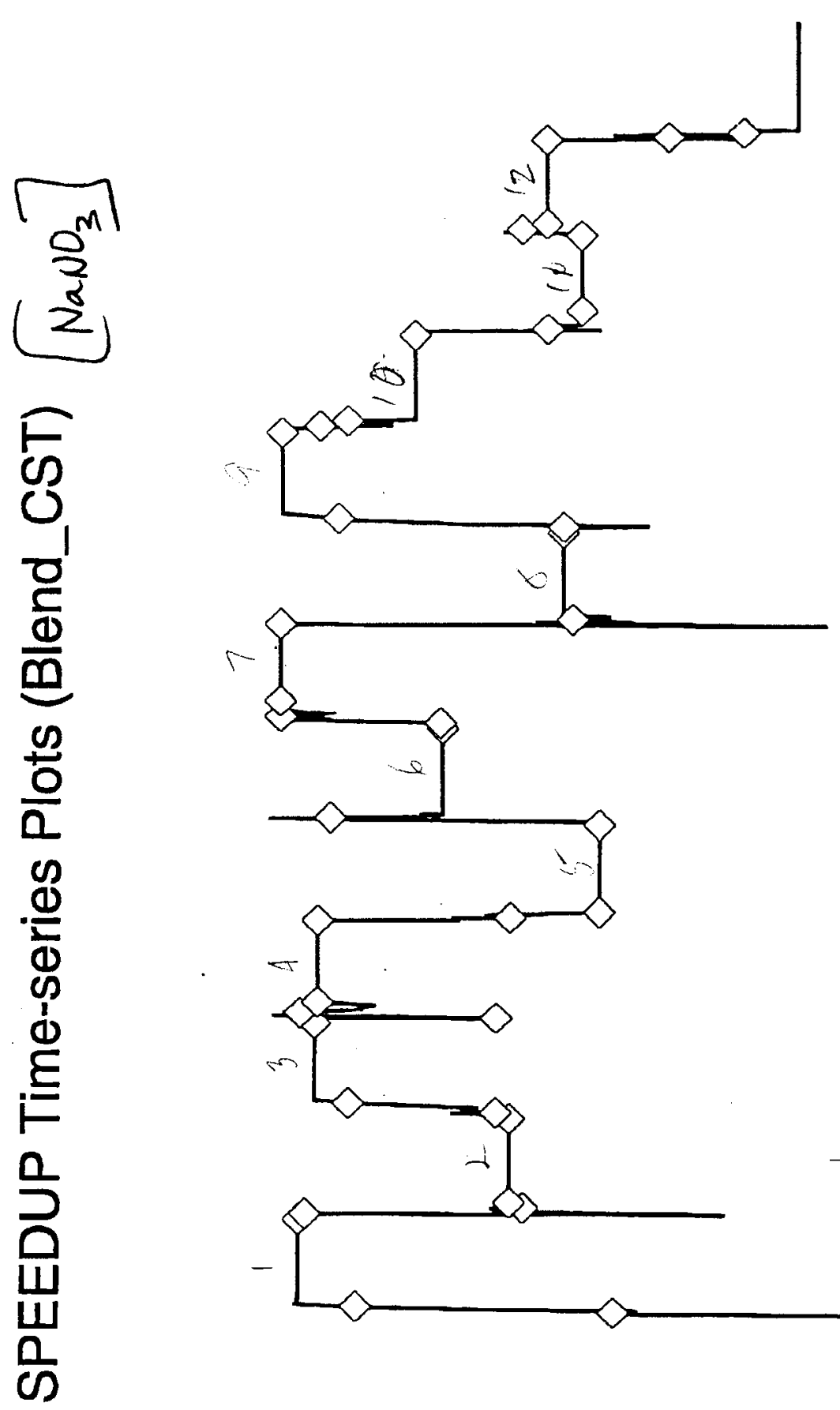

$-78$
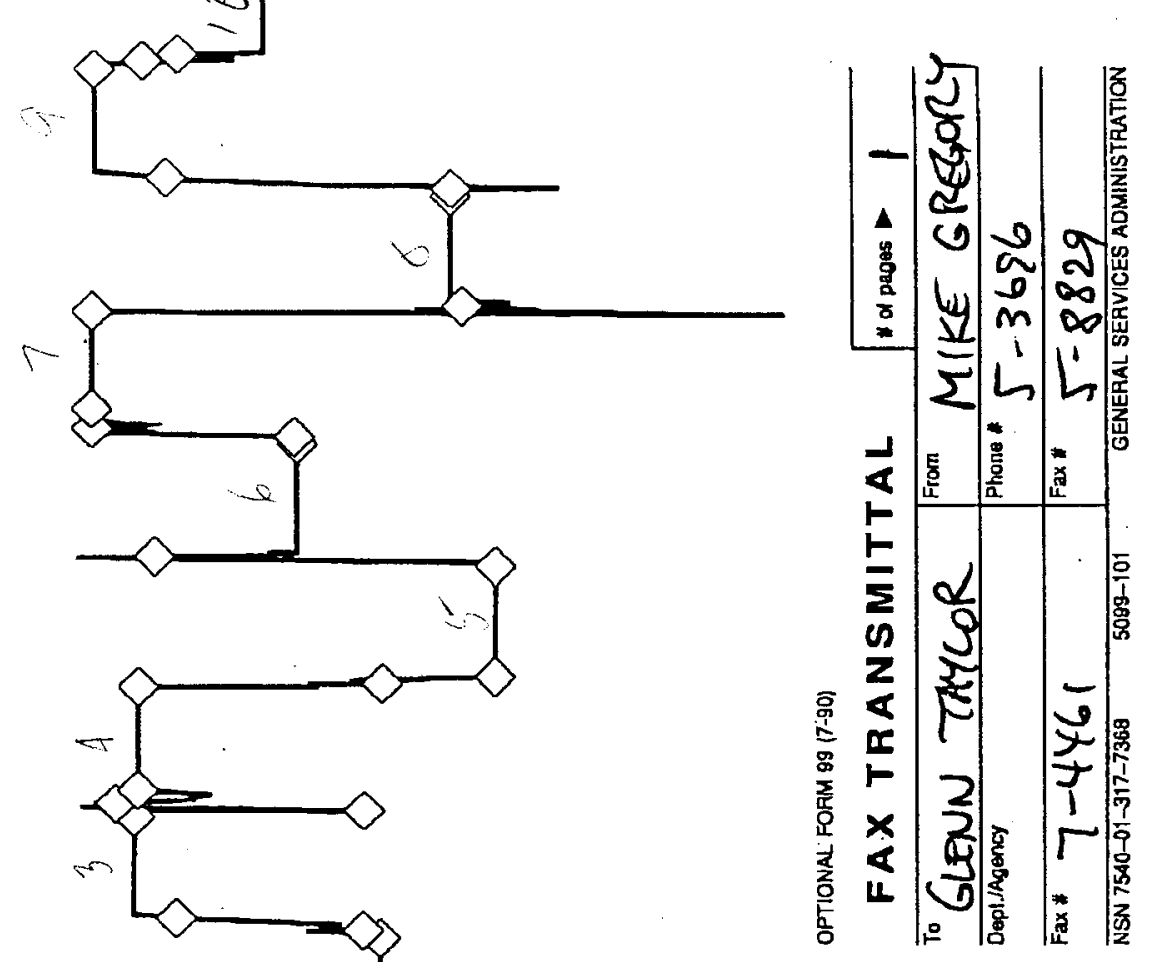

Q.:.

:

$\therefore O$

- 8

O=.

$=0$.

8
ถ
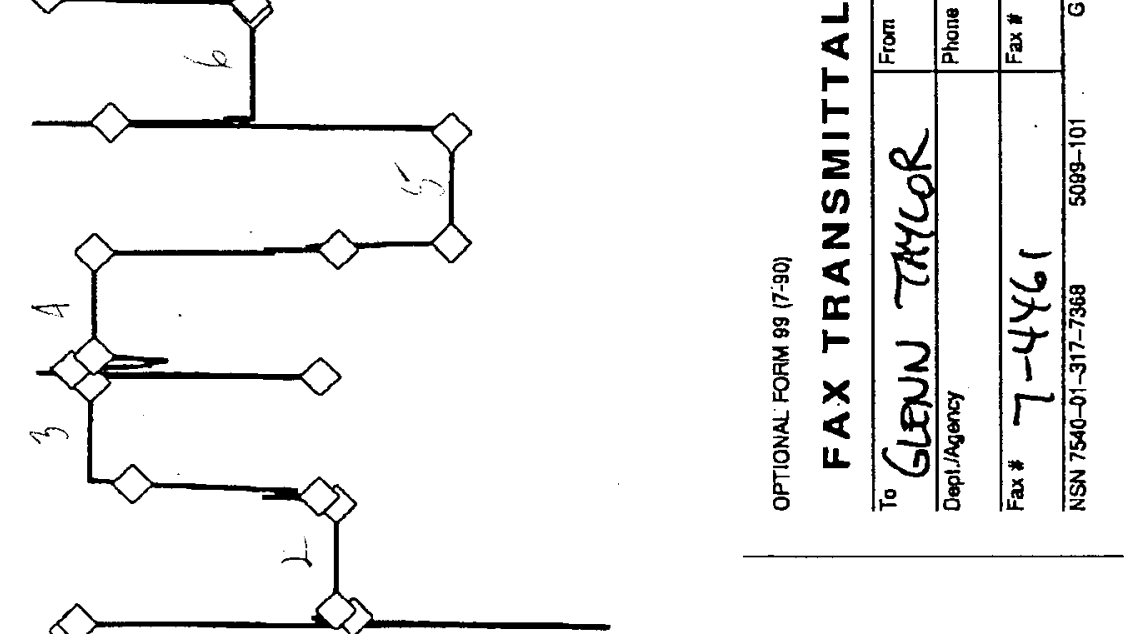

$\because \operatorname{8\pi } 2$

Qxo $8 E$
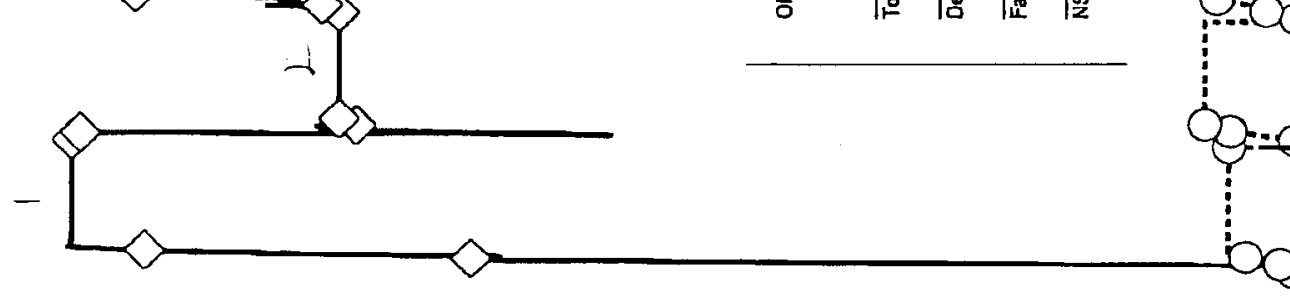

ณ

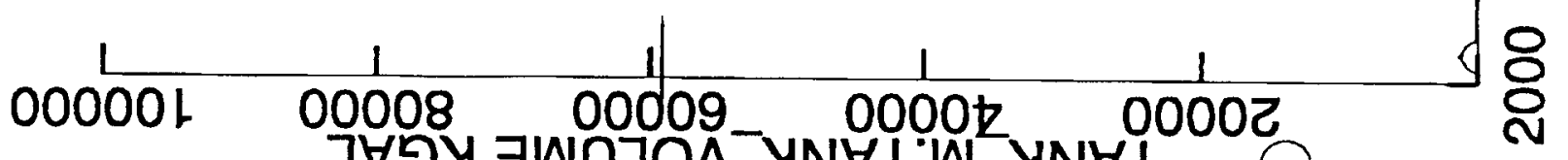

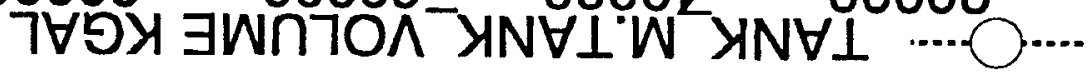

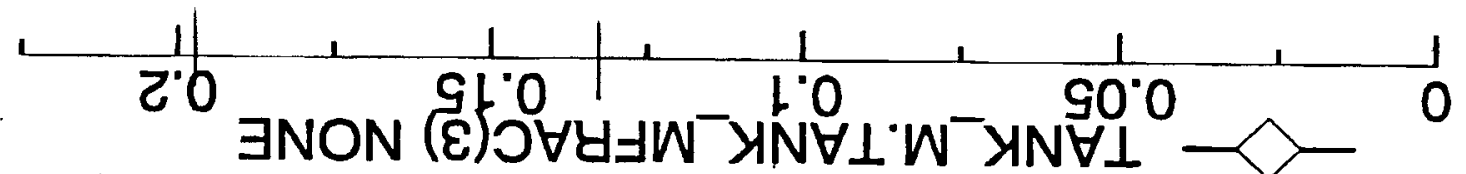


$\frac{0}{1}$

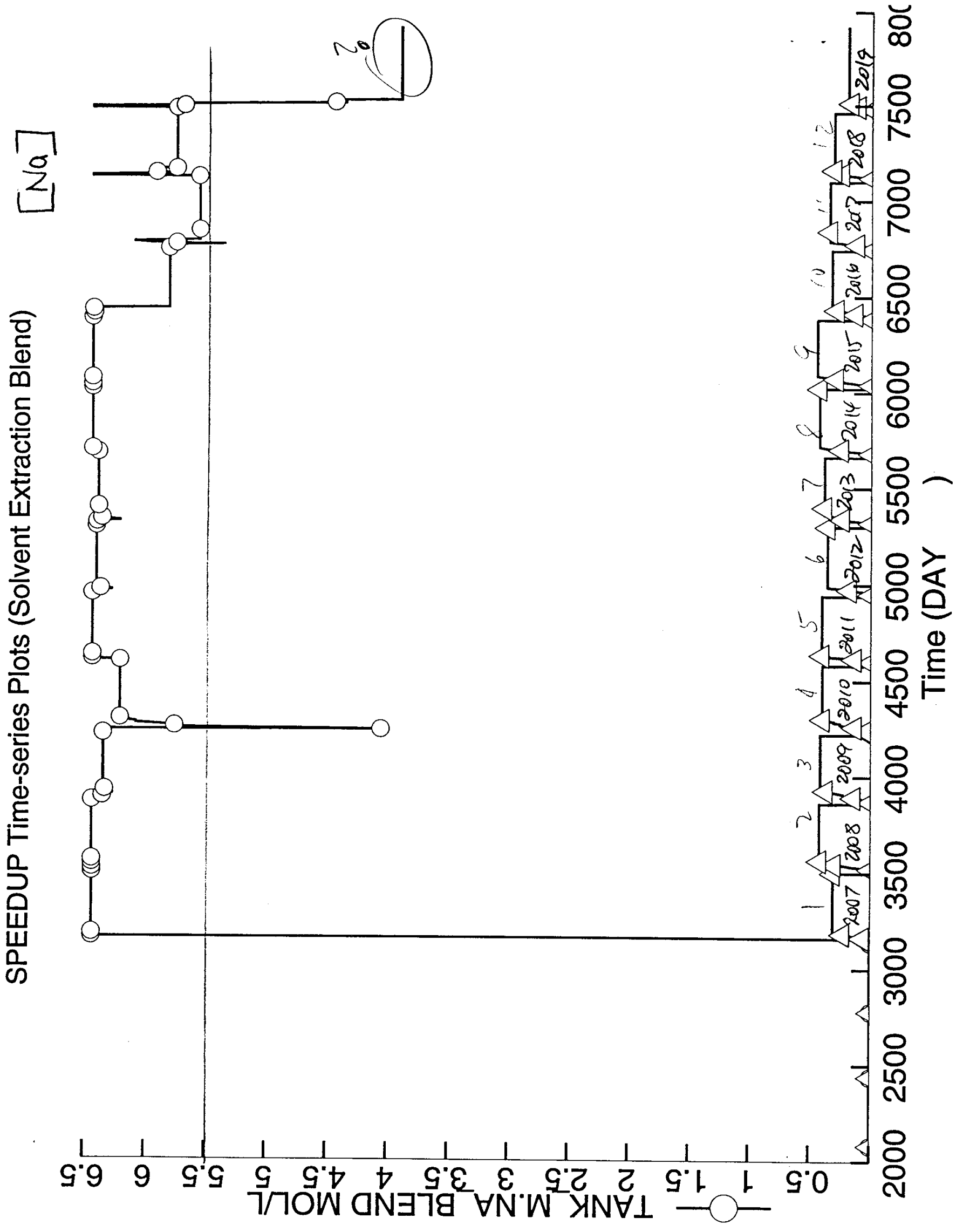

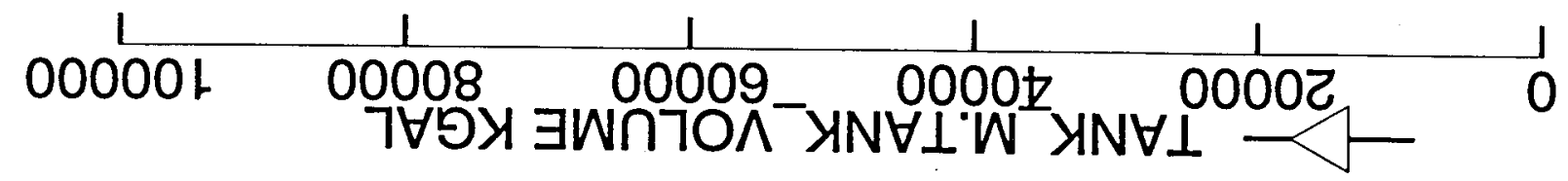


$\underset{T}{1}$

平

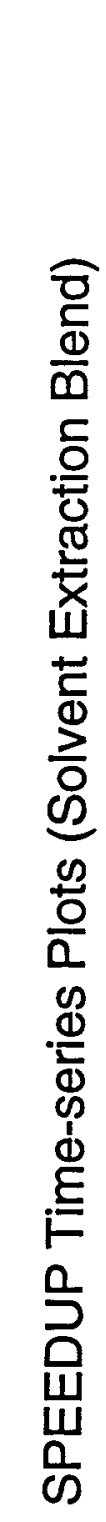

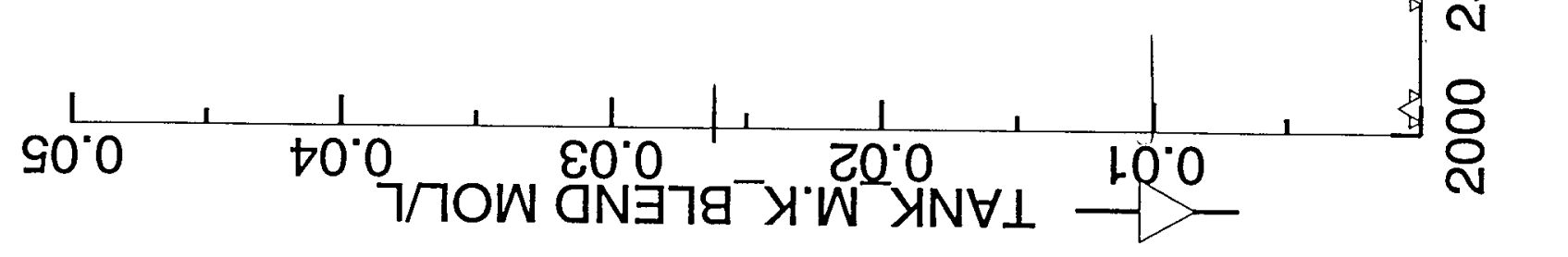

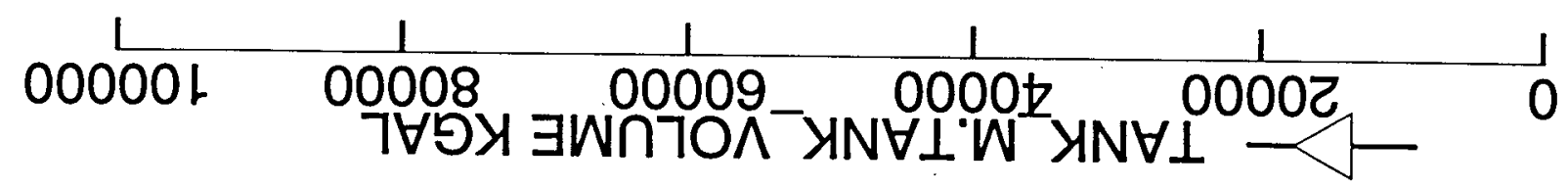


$\bar{\partial}$

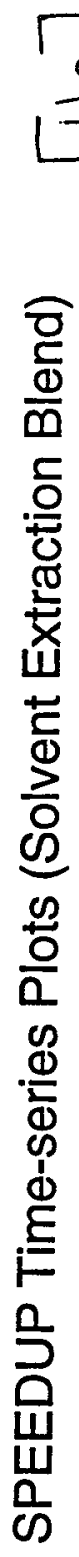
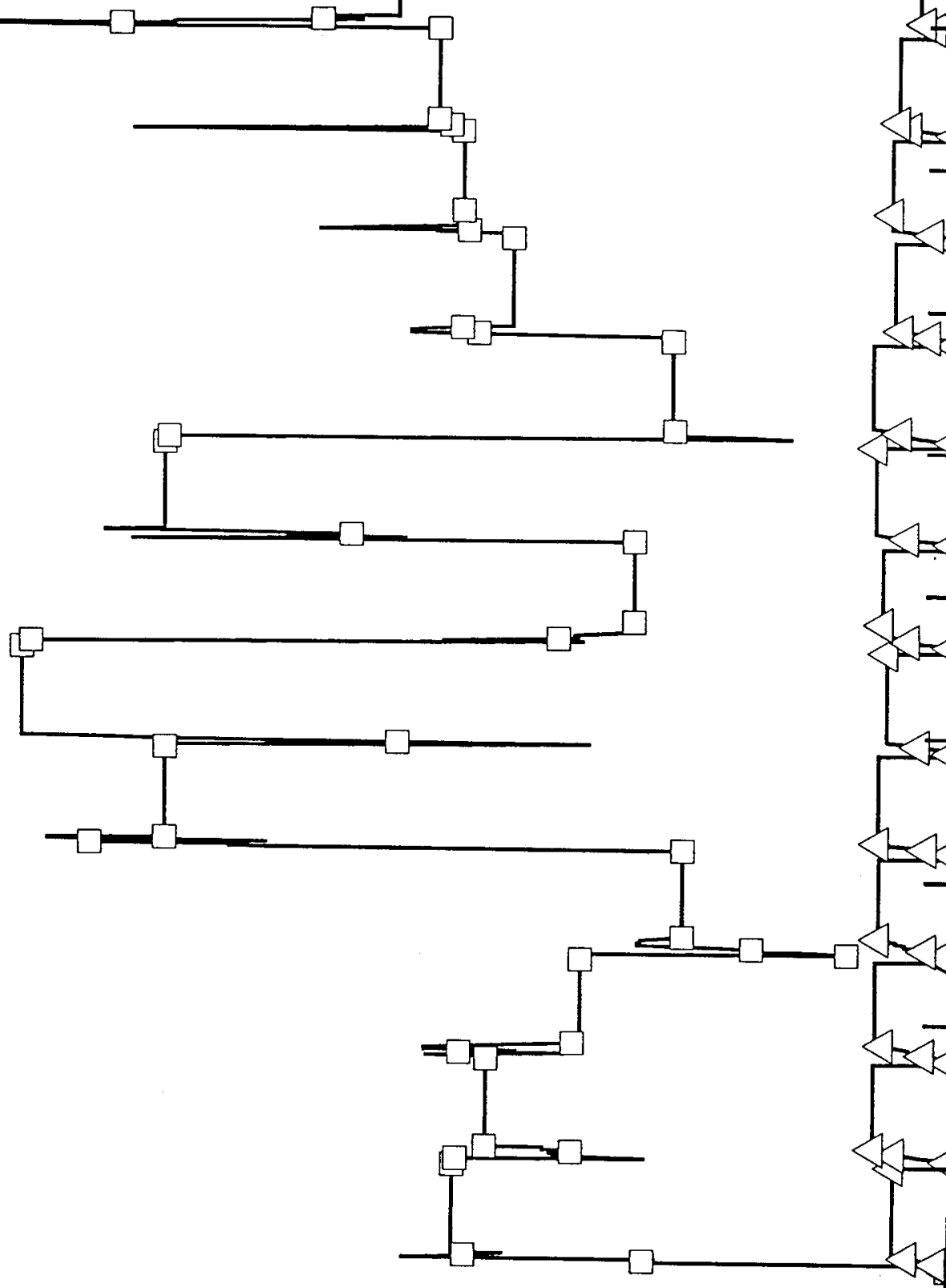

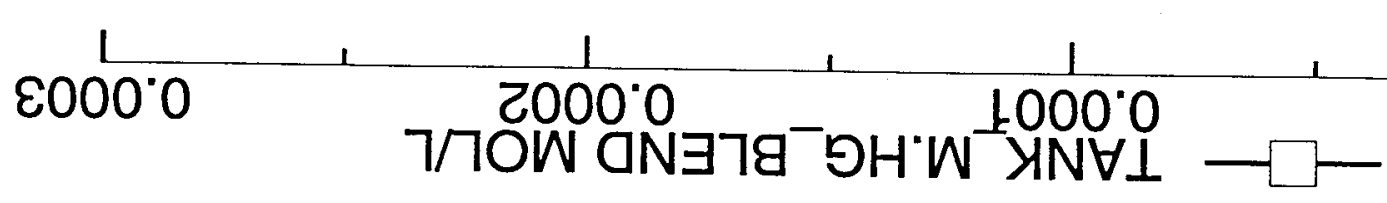

옹

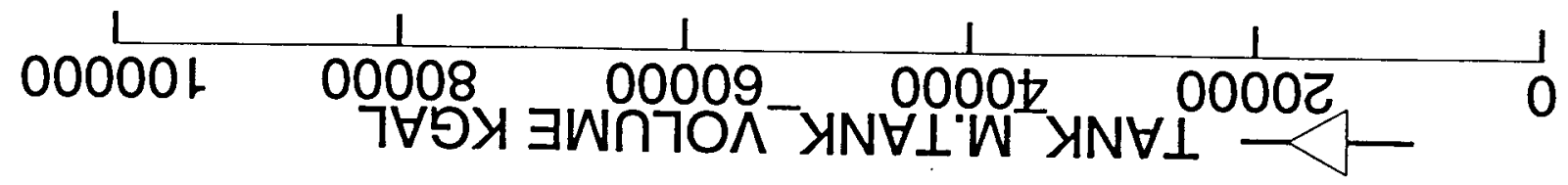


6
8
1
1

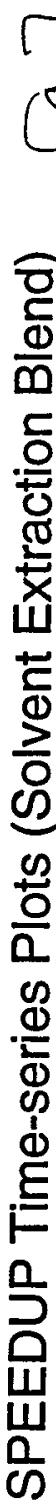
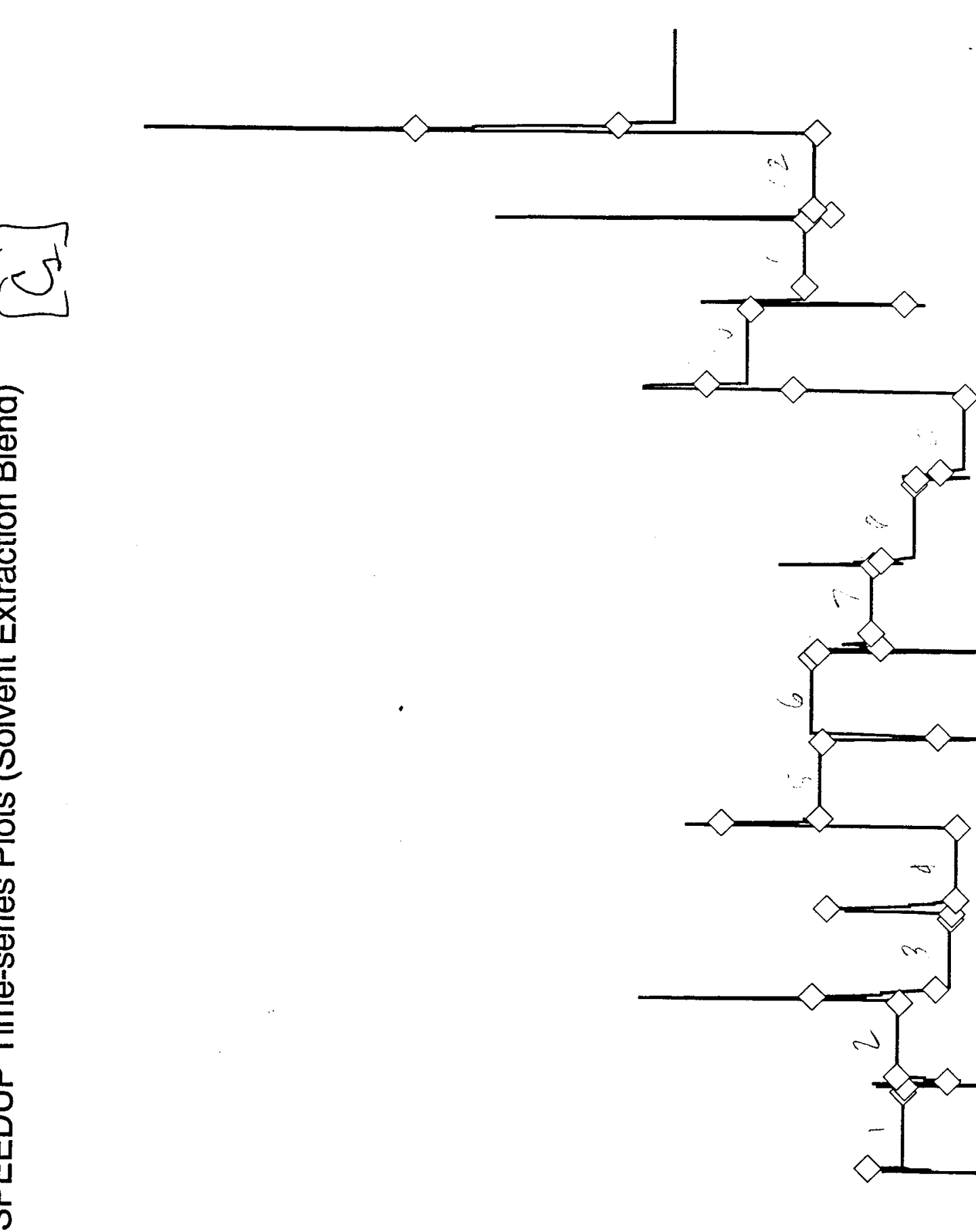

S

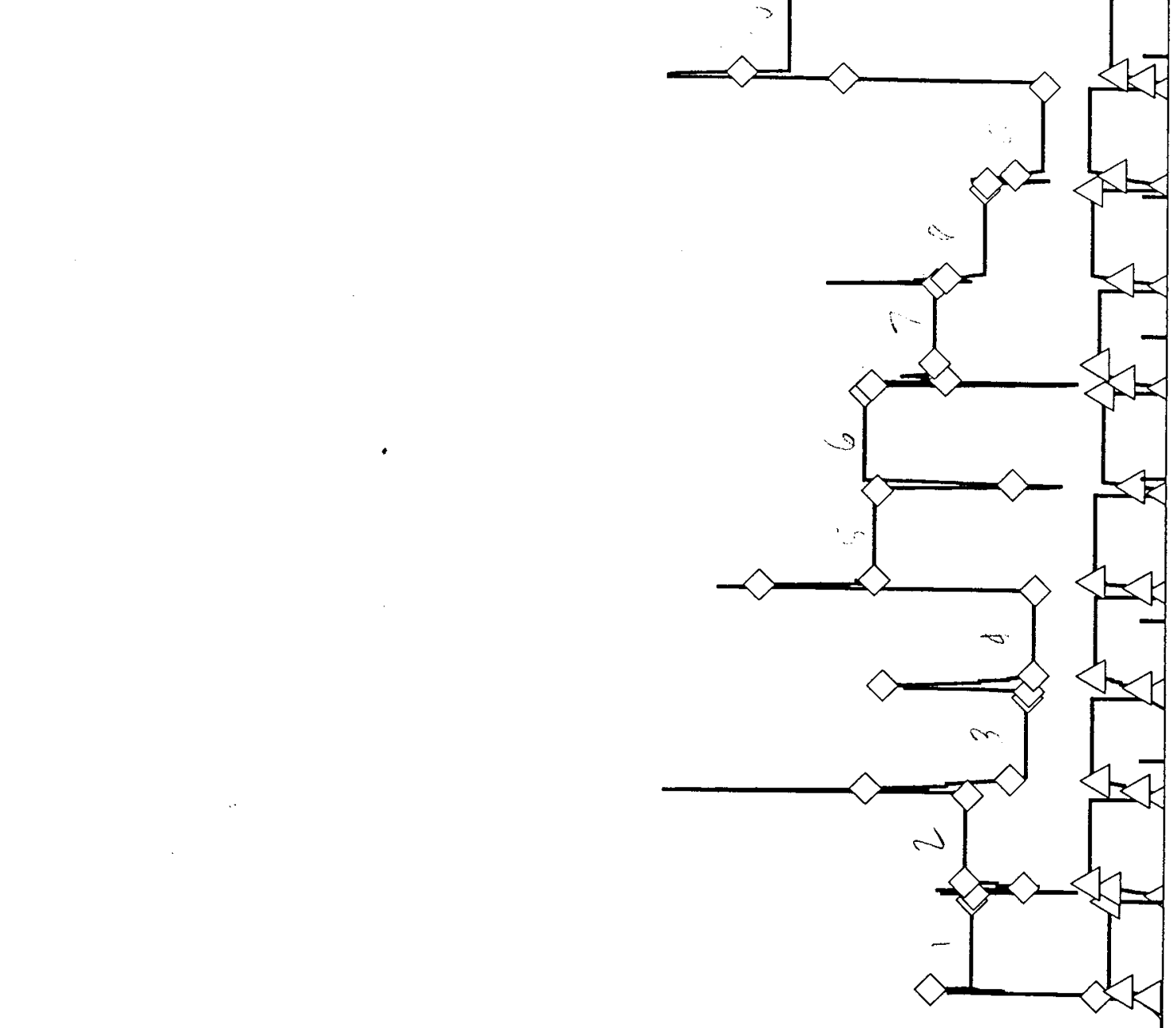

$-8$

ก

0
8
0

E

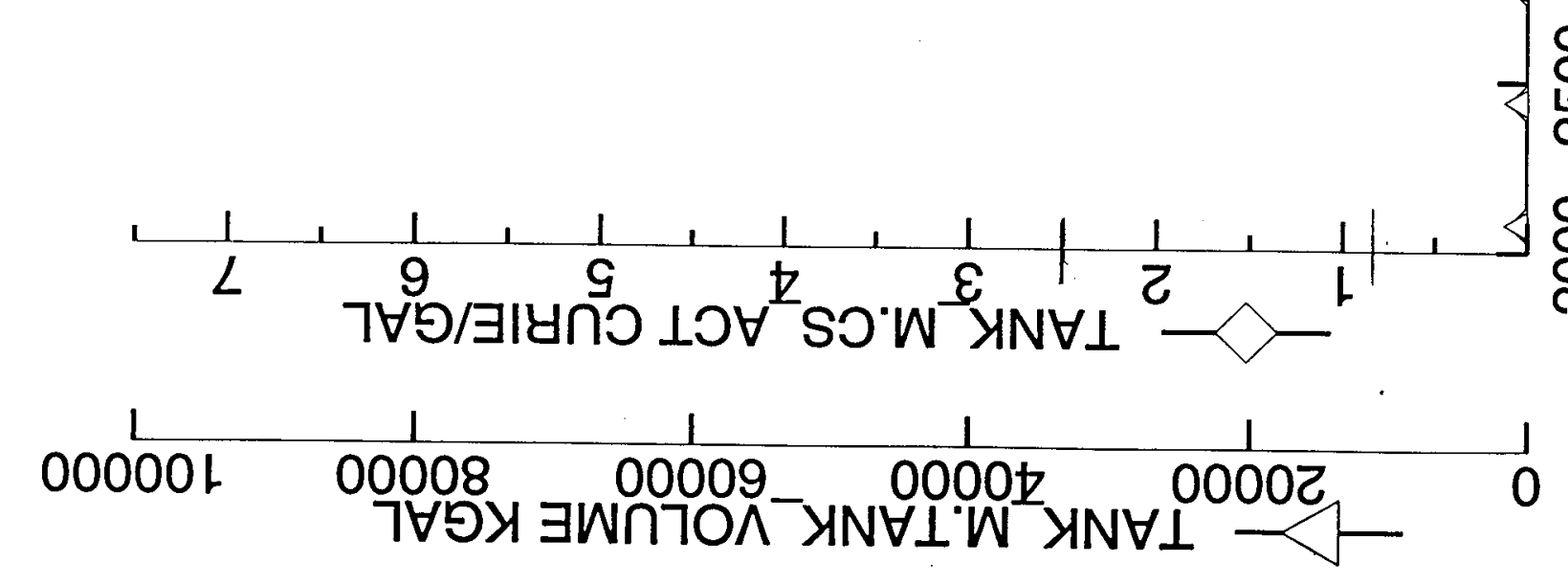


$m$
1
$I$

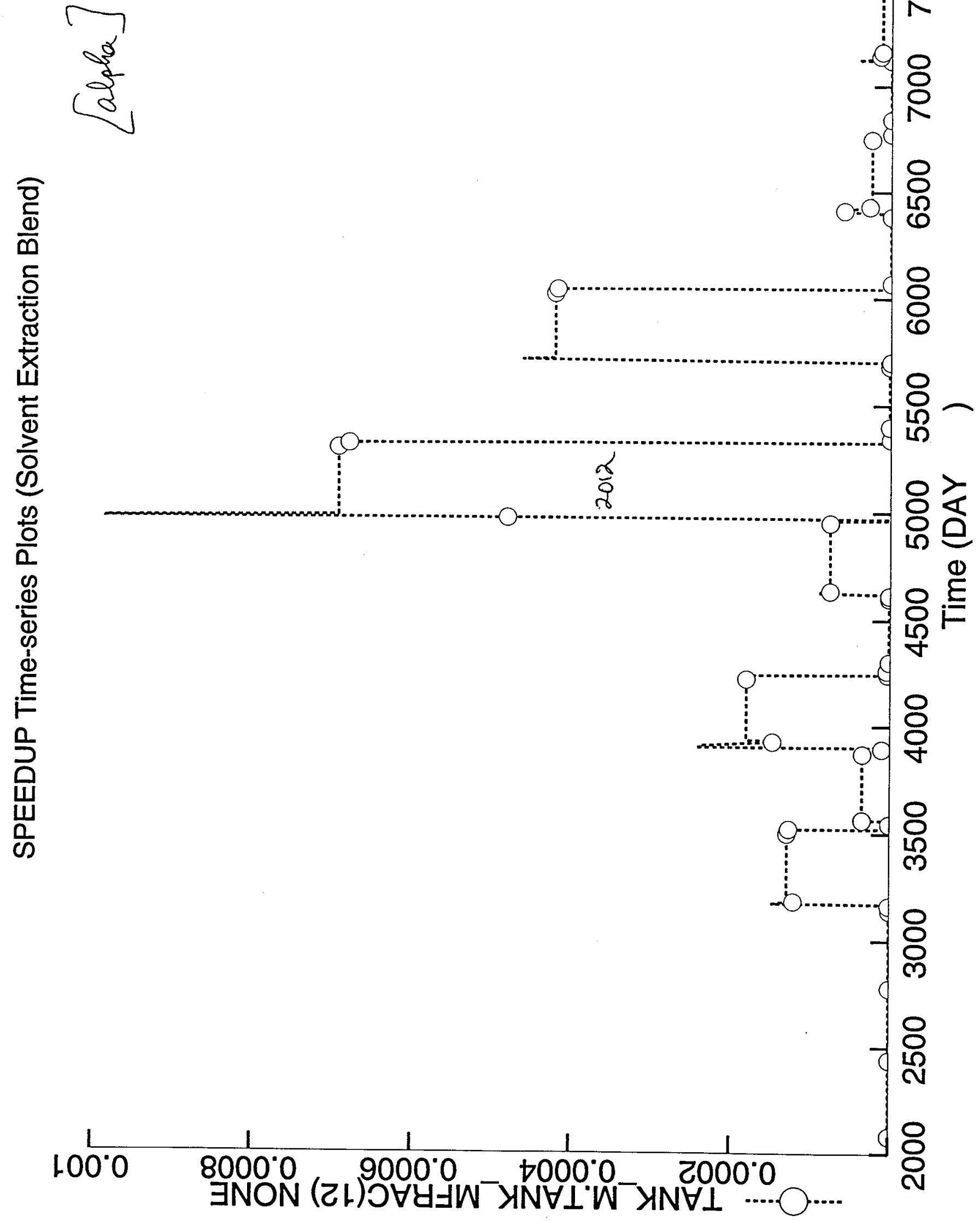




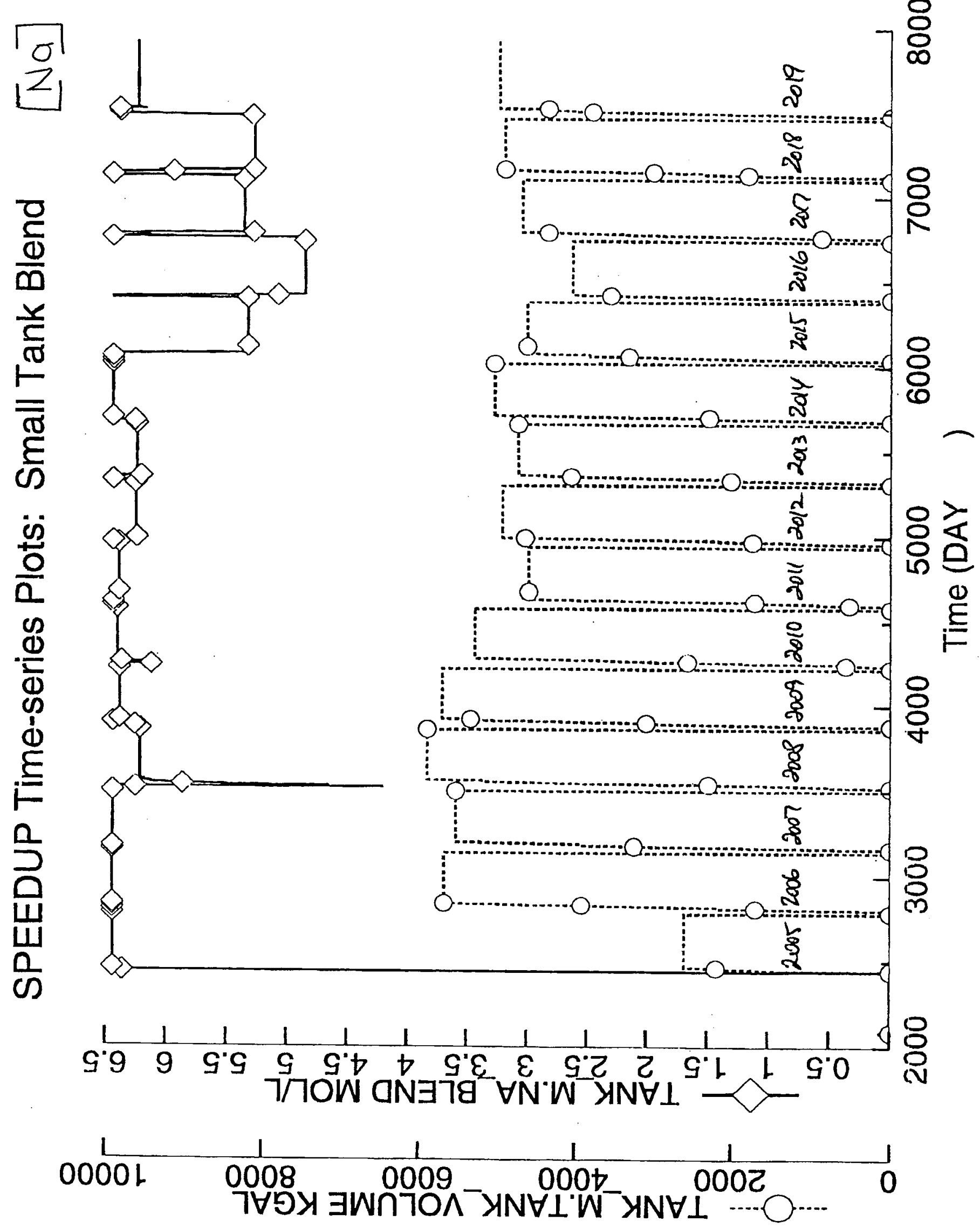


In

co $\pm$

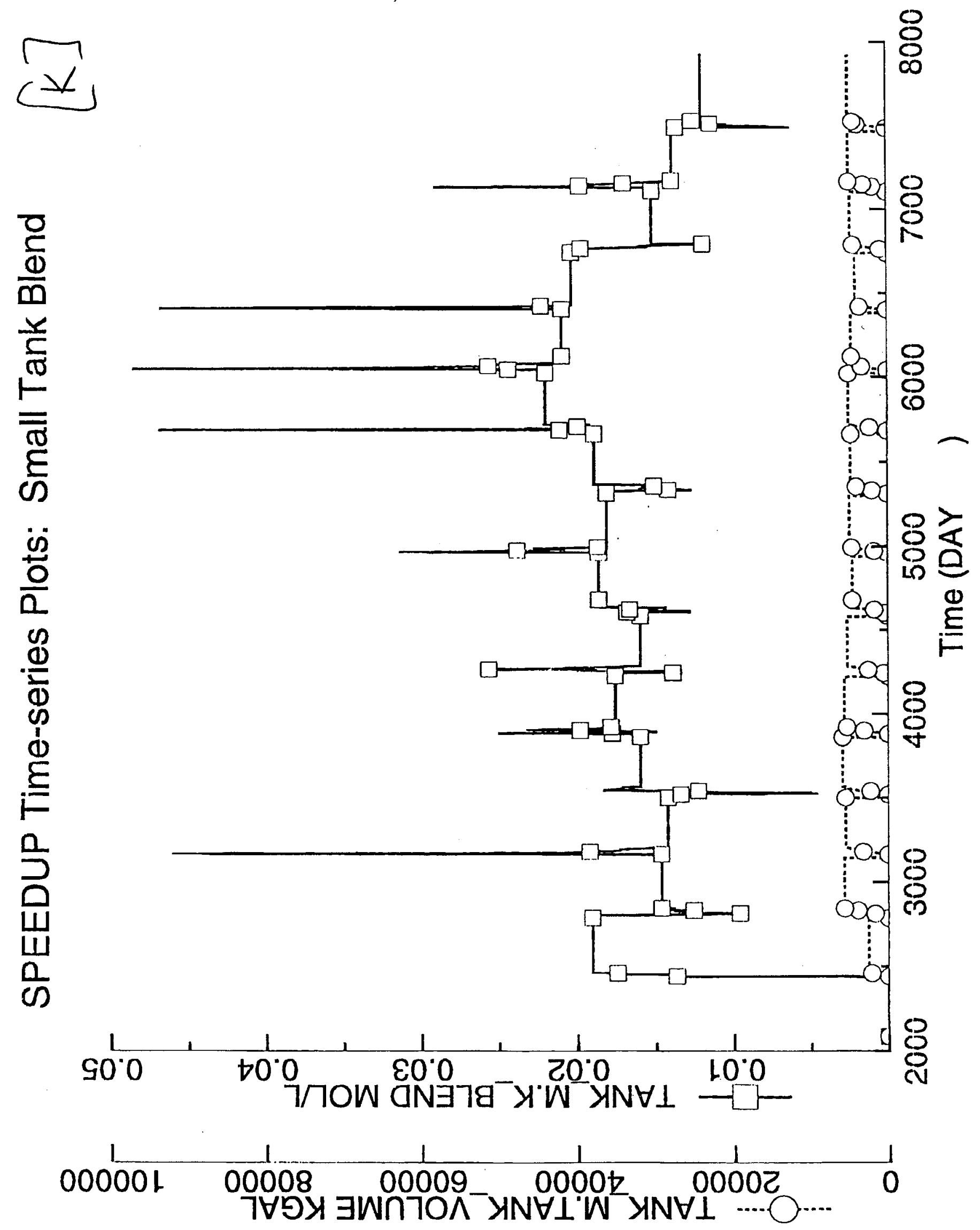


3
1
$x$

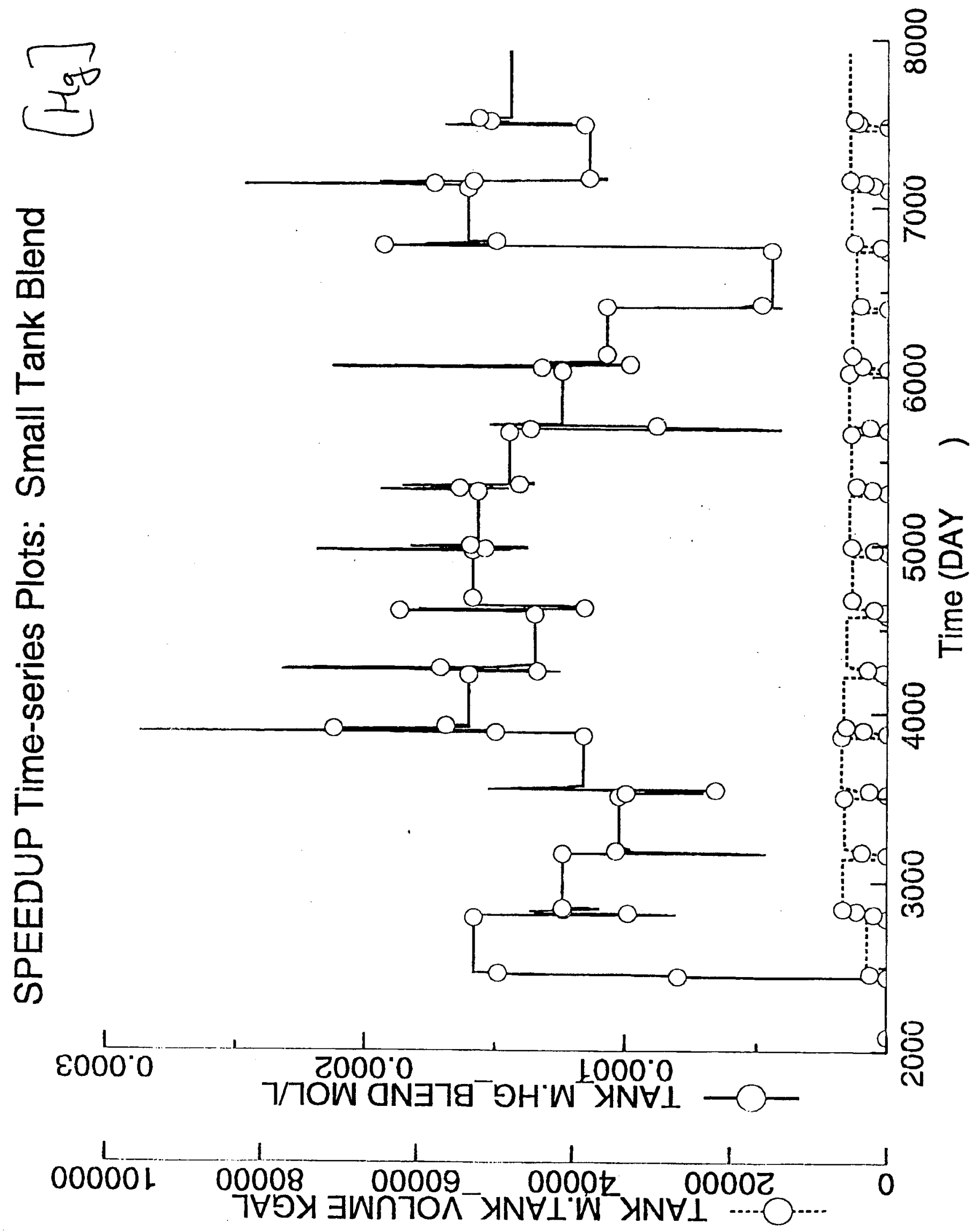


$n$
1

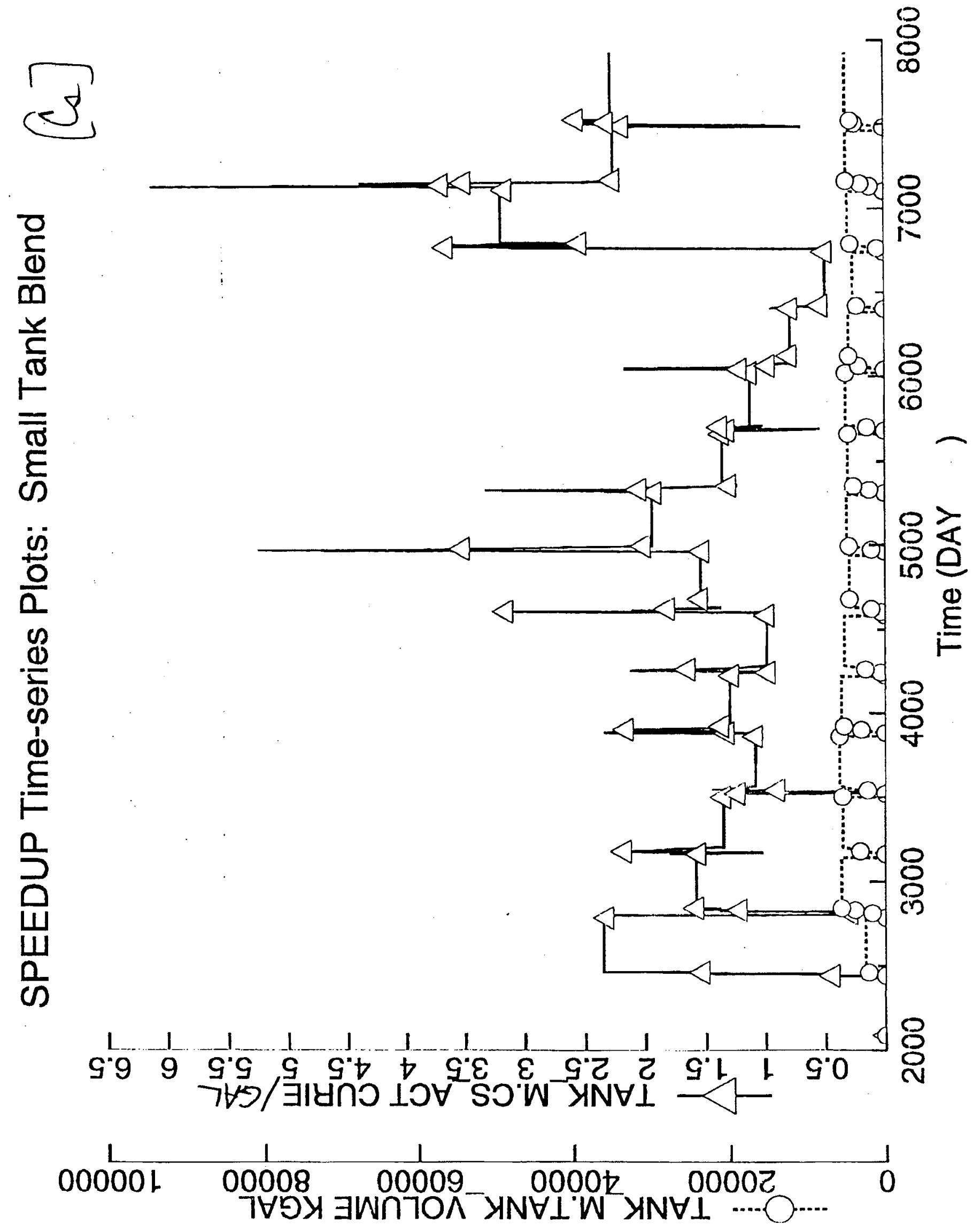




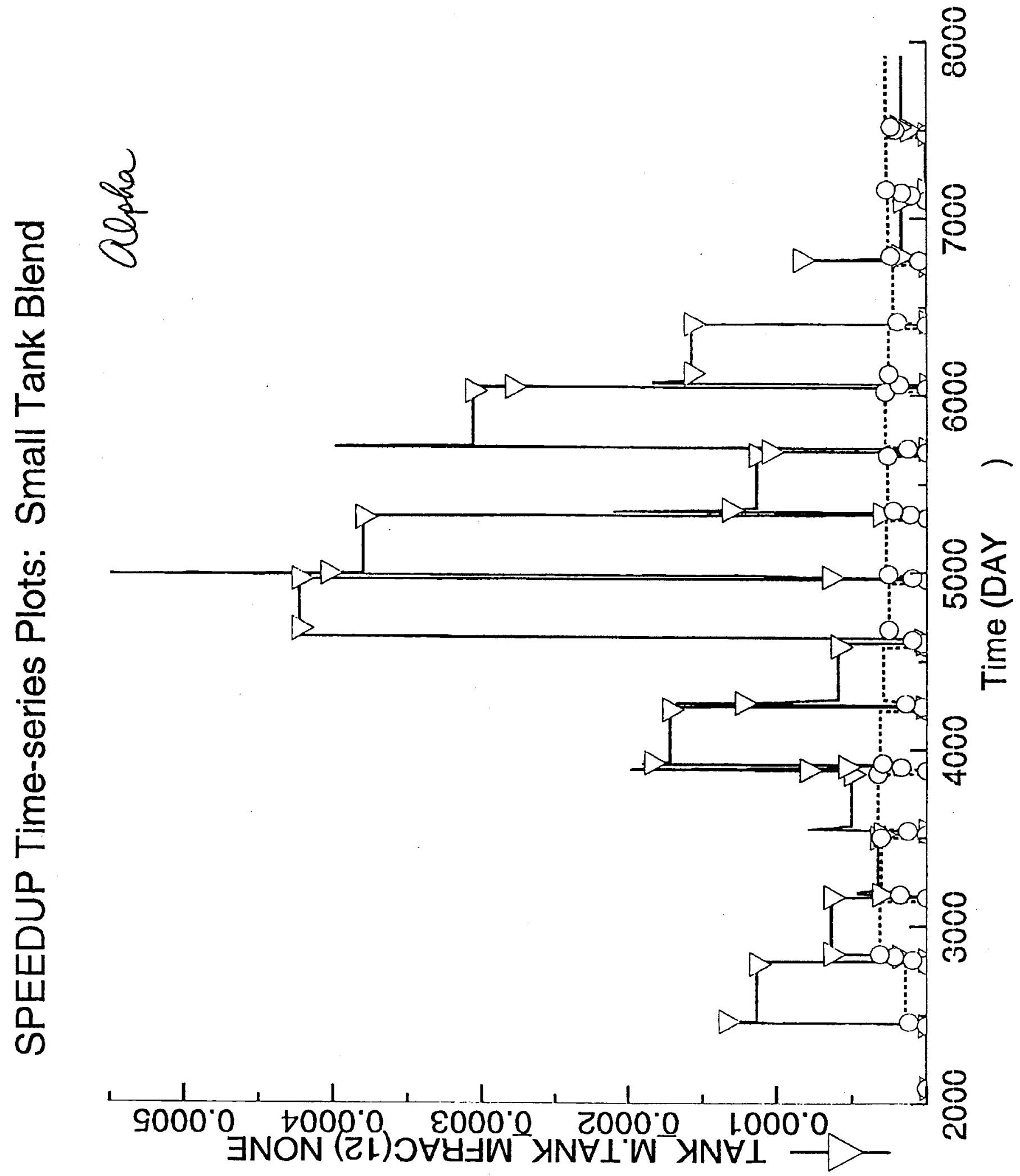




\section{APPENDIX I}

PROCESS FLOW DIAGRAMS 


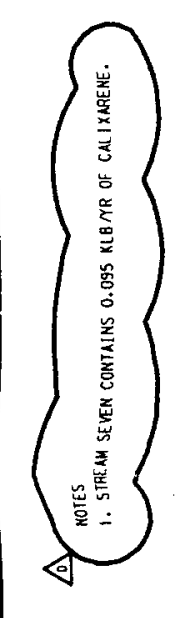

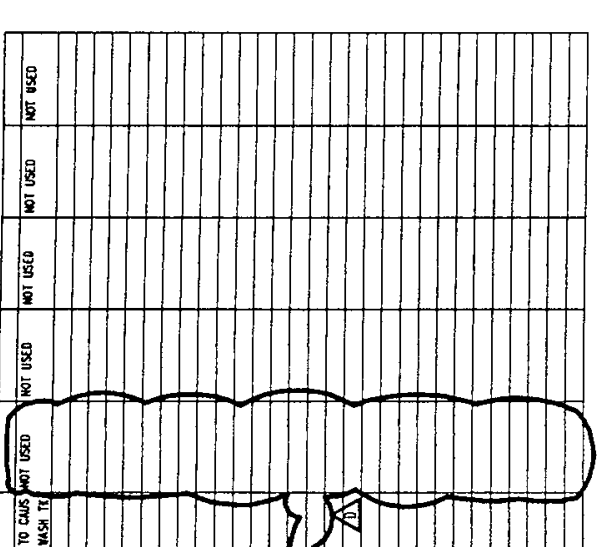

㰻

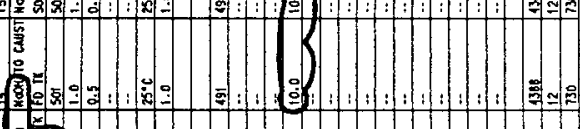

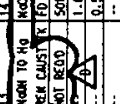
焉: 端

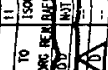

- 翡

(n)

壦

整

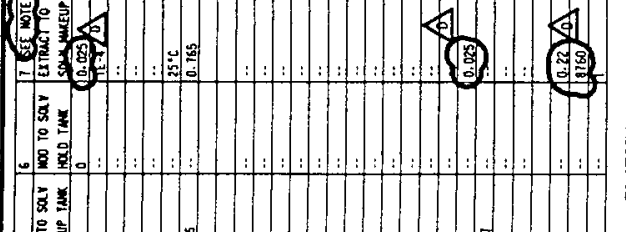

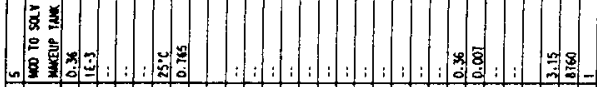

部

氧到:

:

到: 0

, ( 12

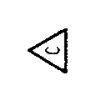
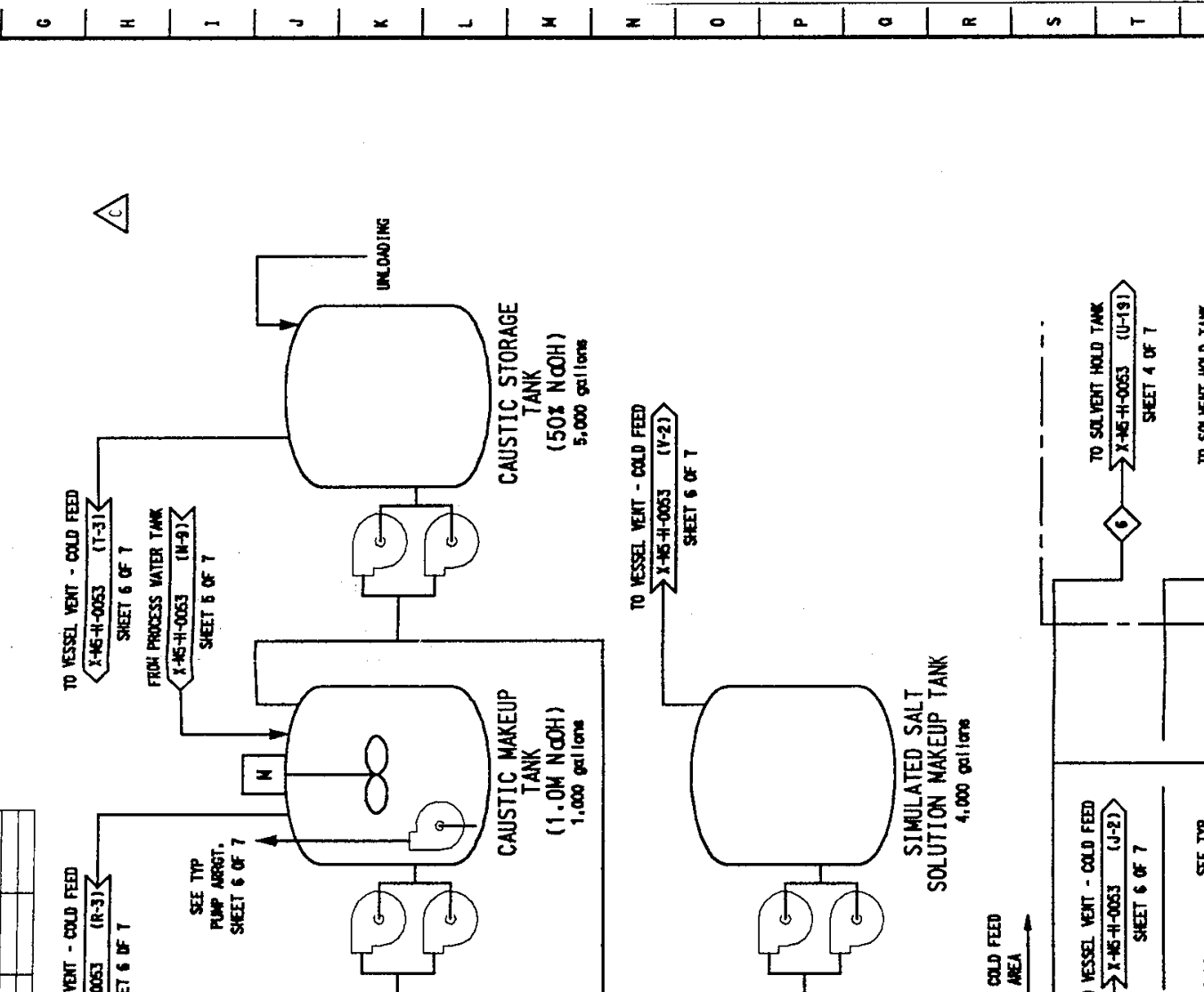

占国
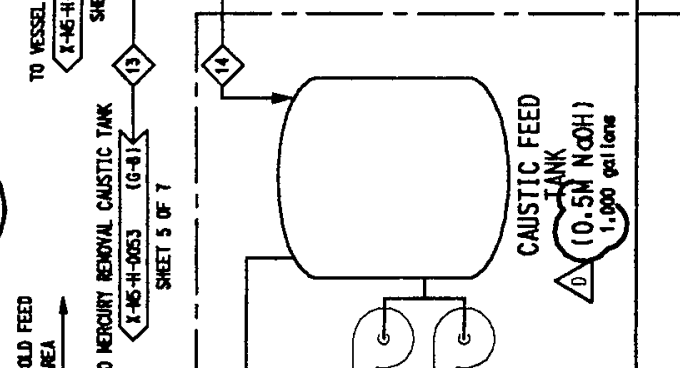

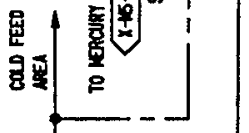

(2)

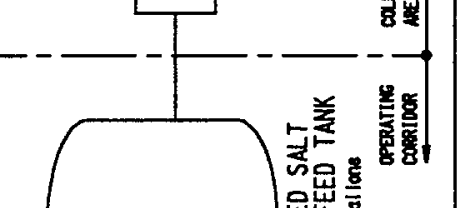

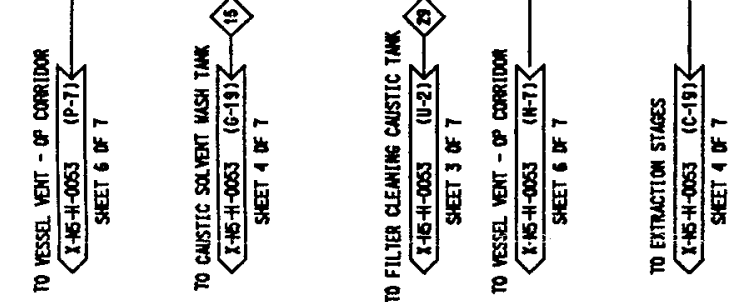
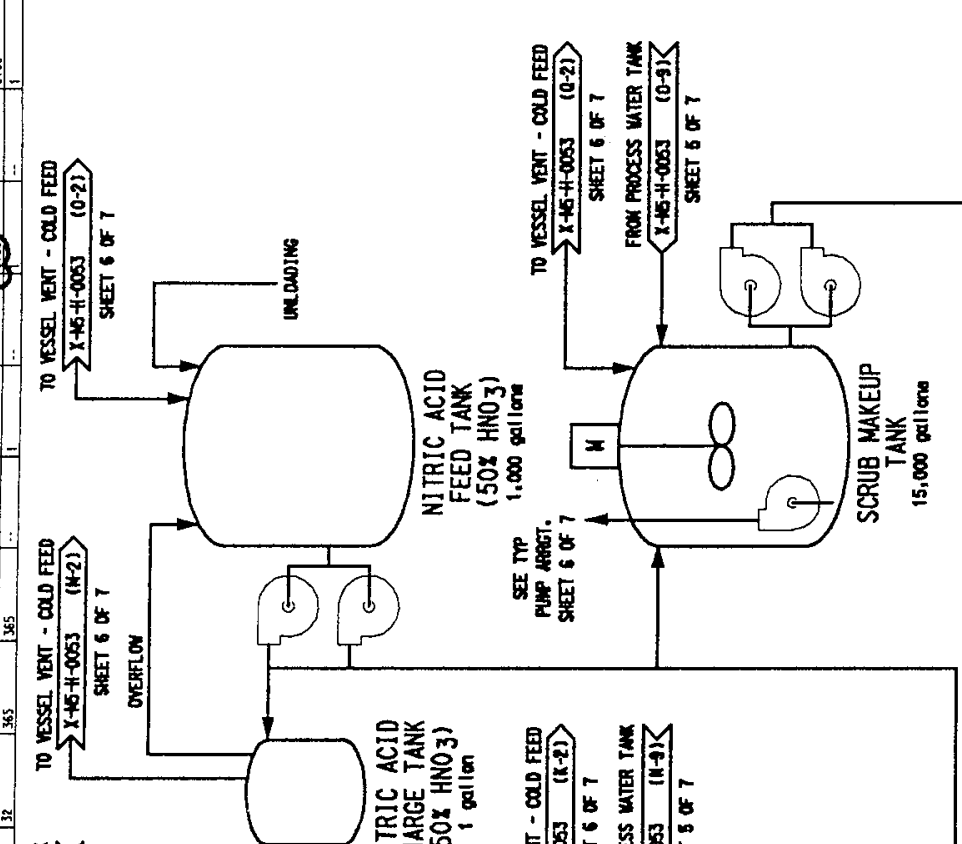

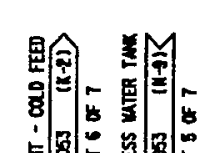

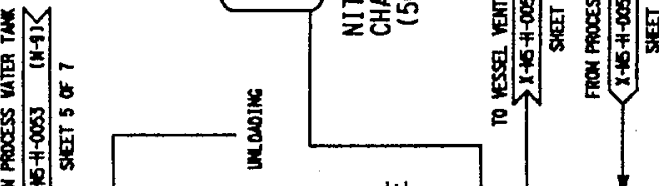
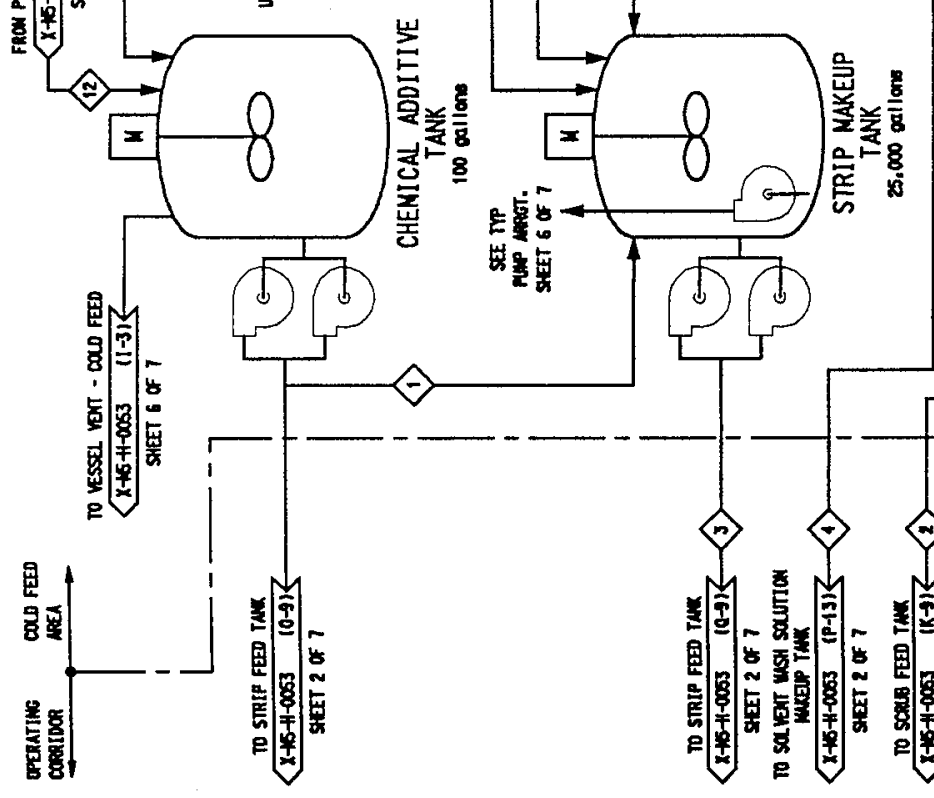

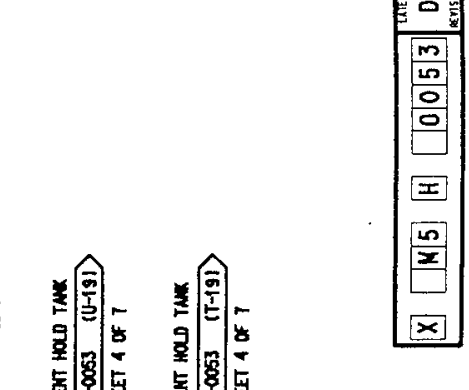

善部

等

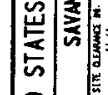

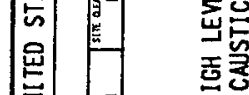

$\rightarrow \infty$

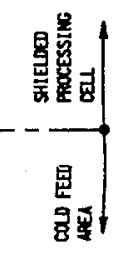

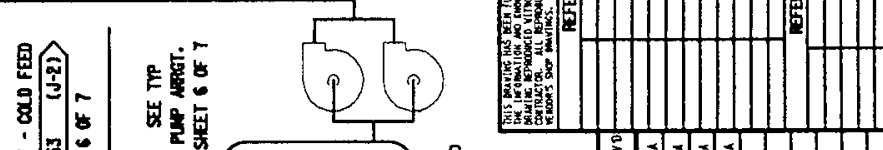
高

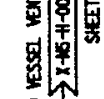

:

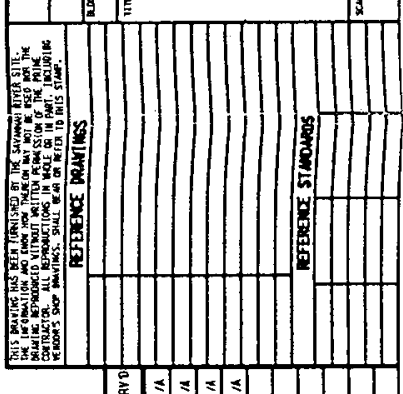

咅: $=2$

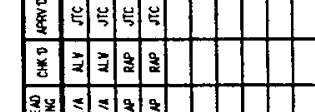

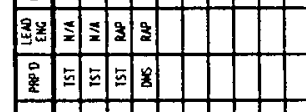

1 部

(5)
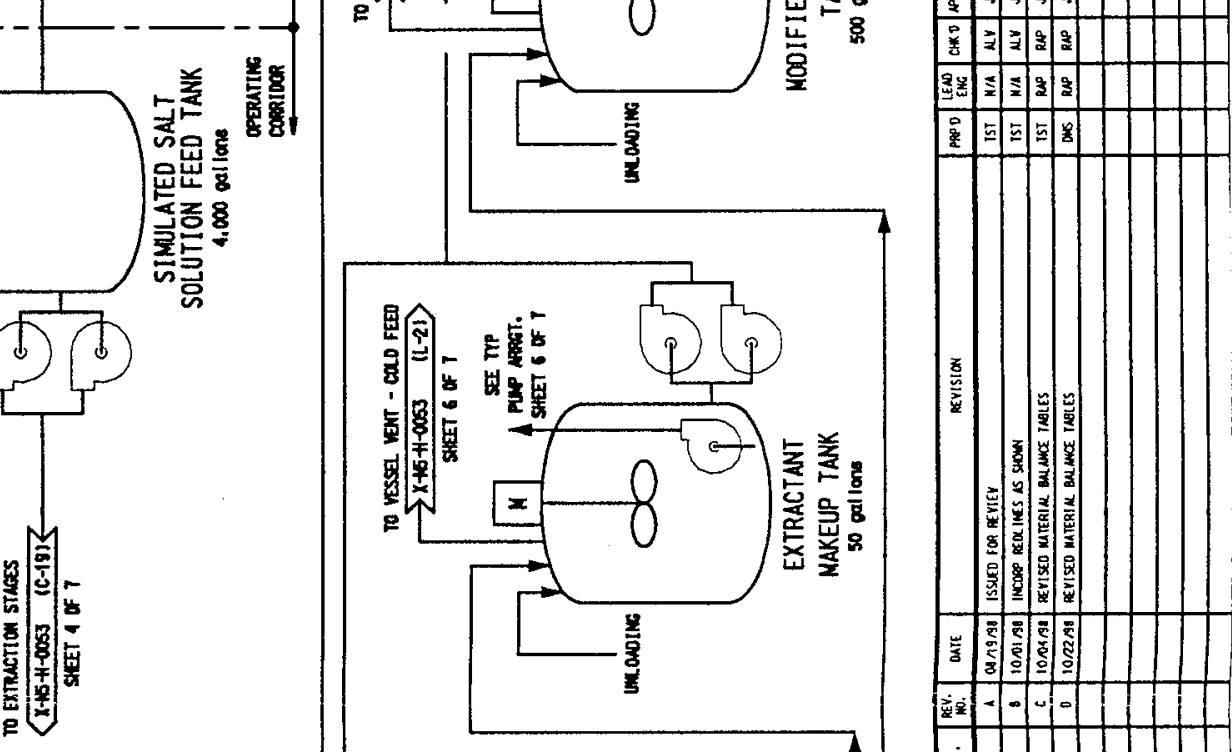

$\frac{5}{2}$

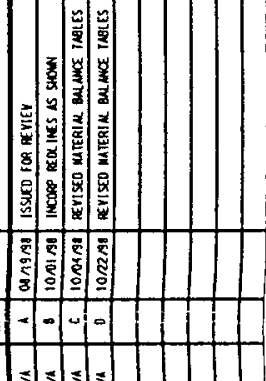

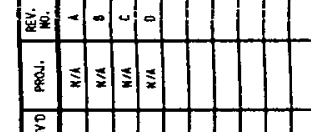

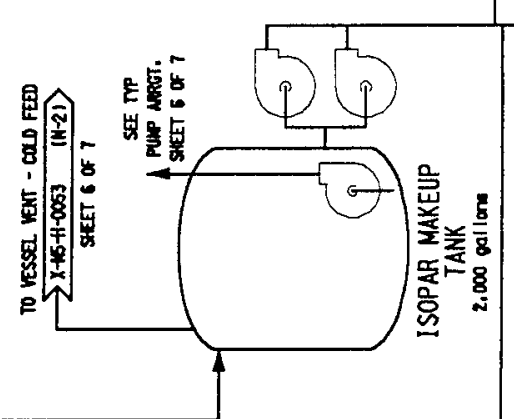

:

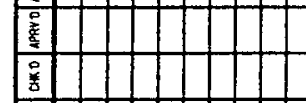

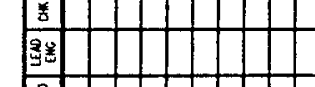

+

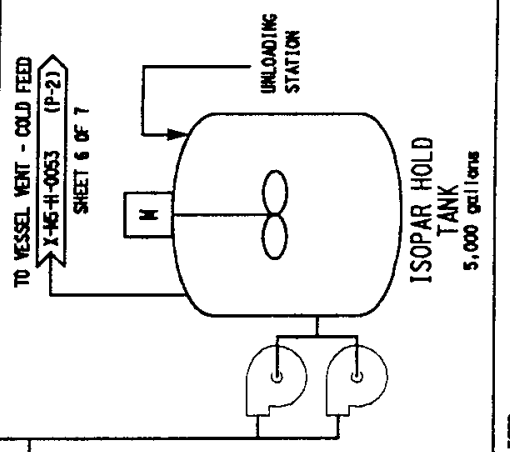

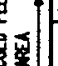

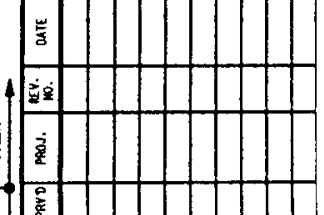
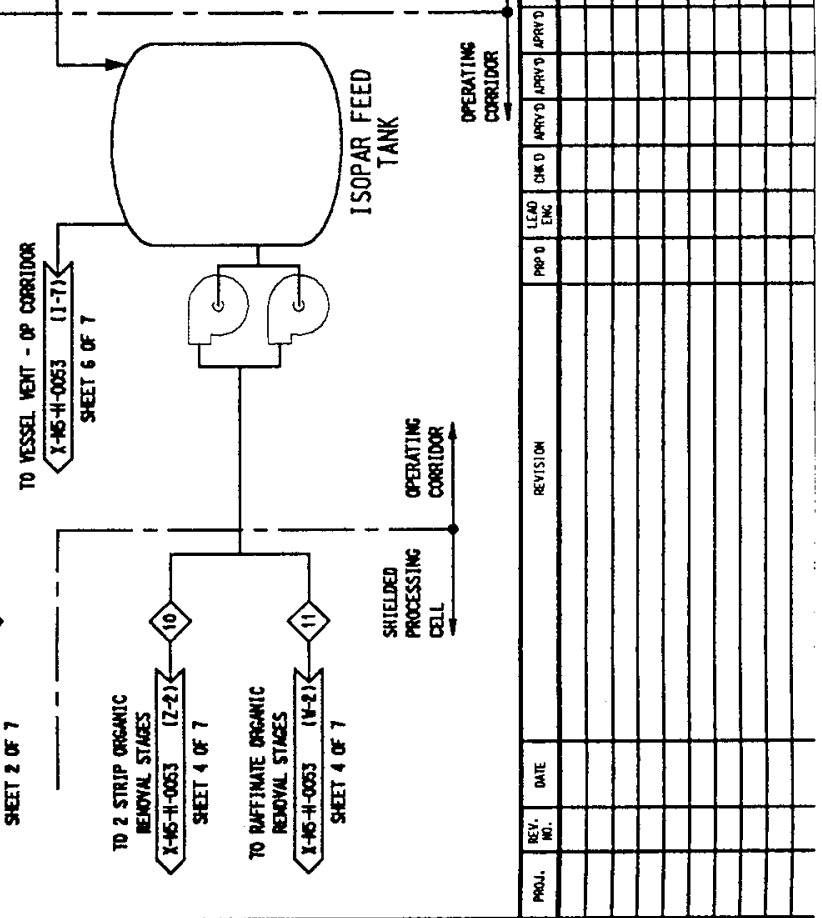


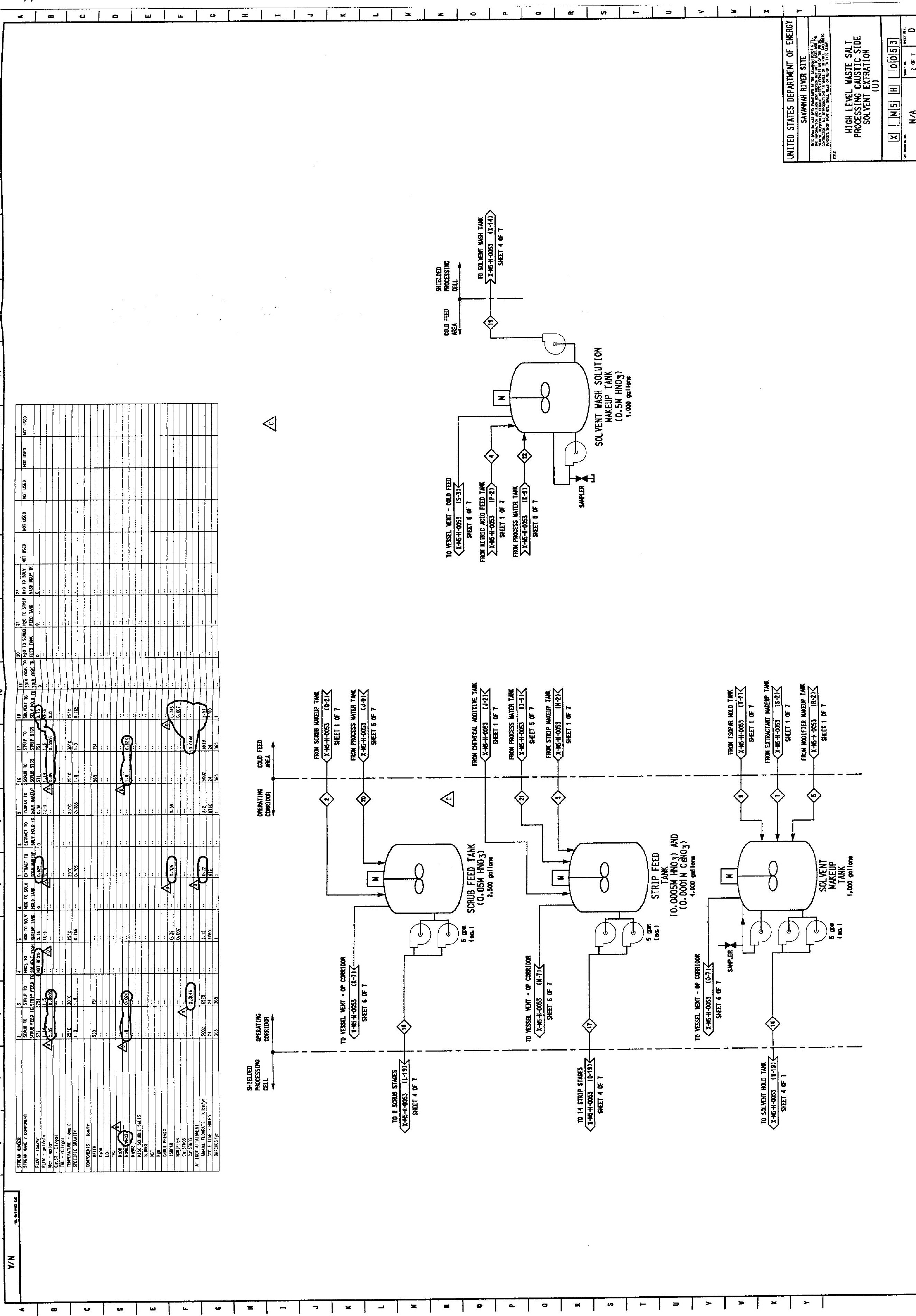


'ं

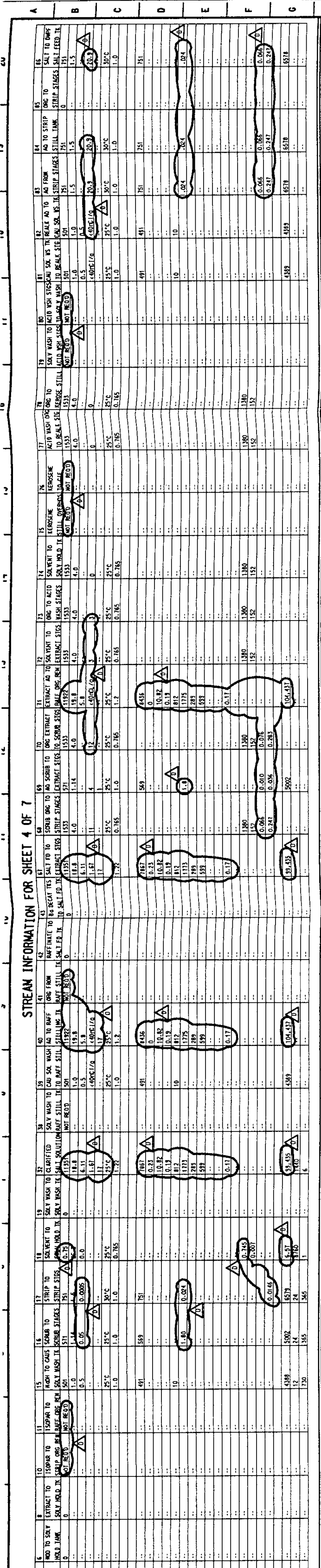

,

×

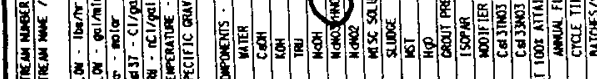

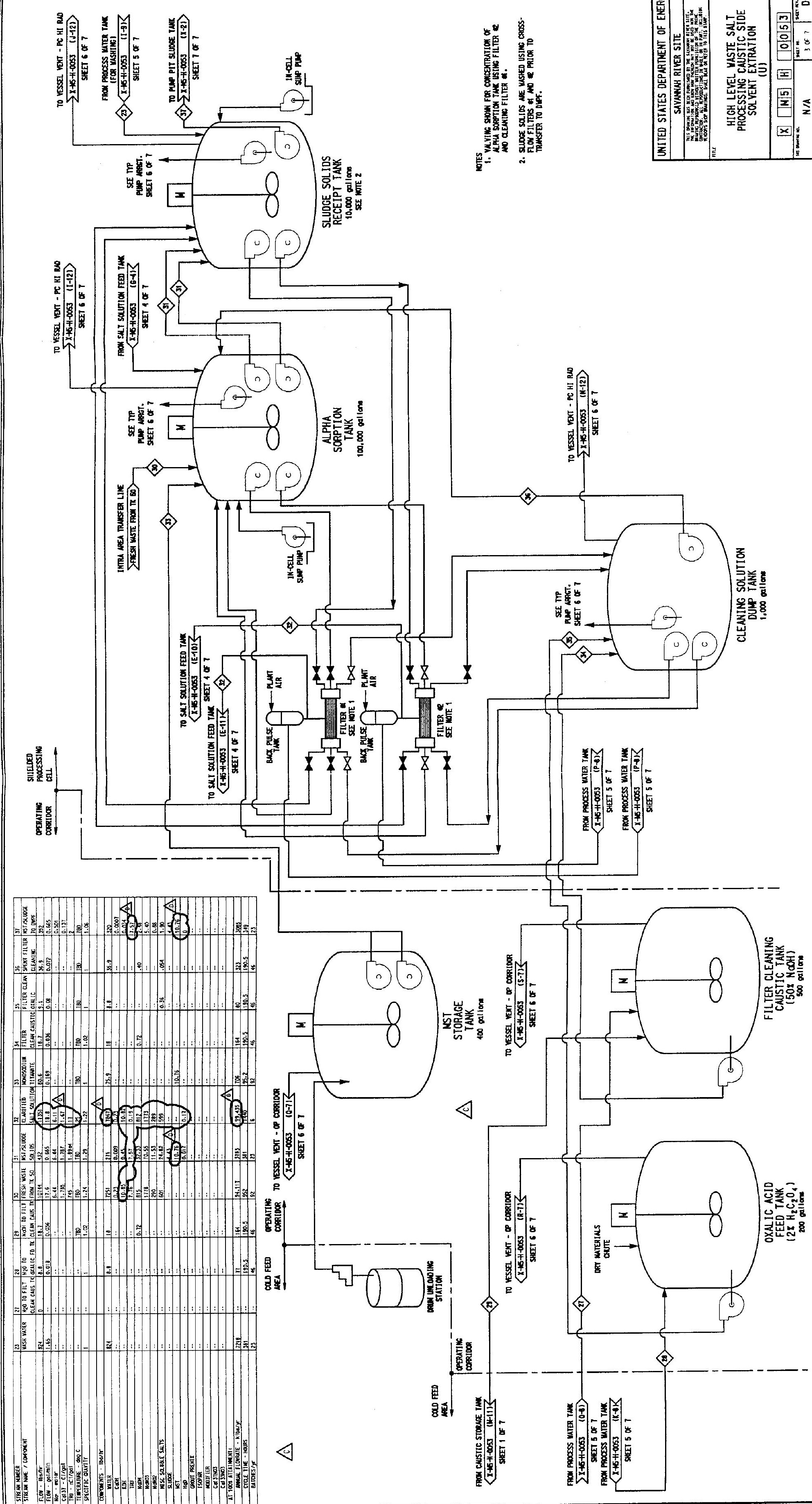




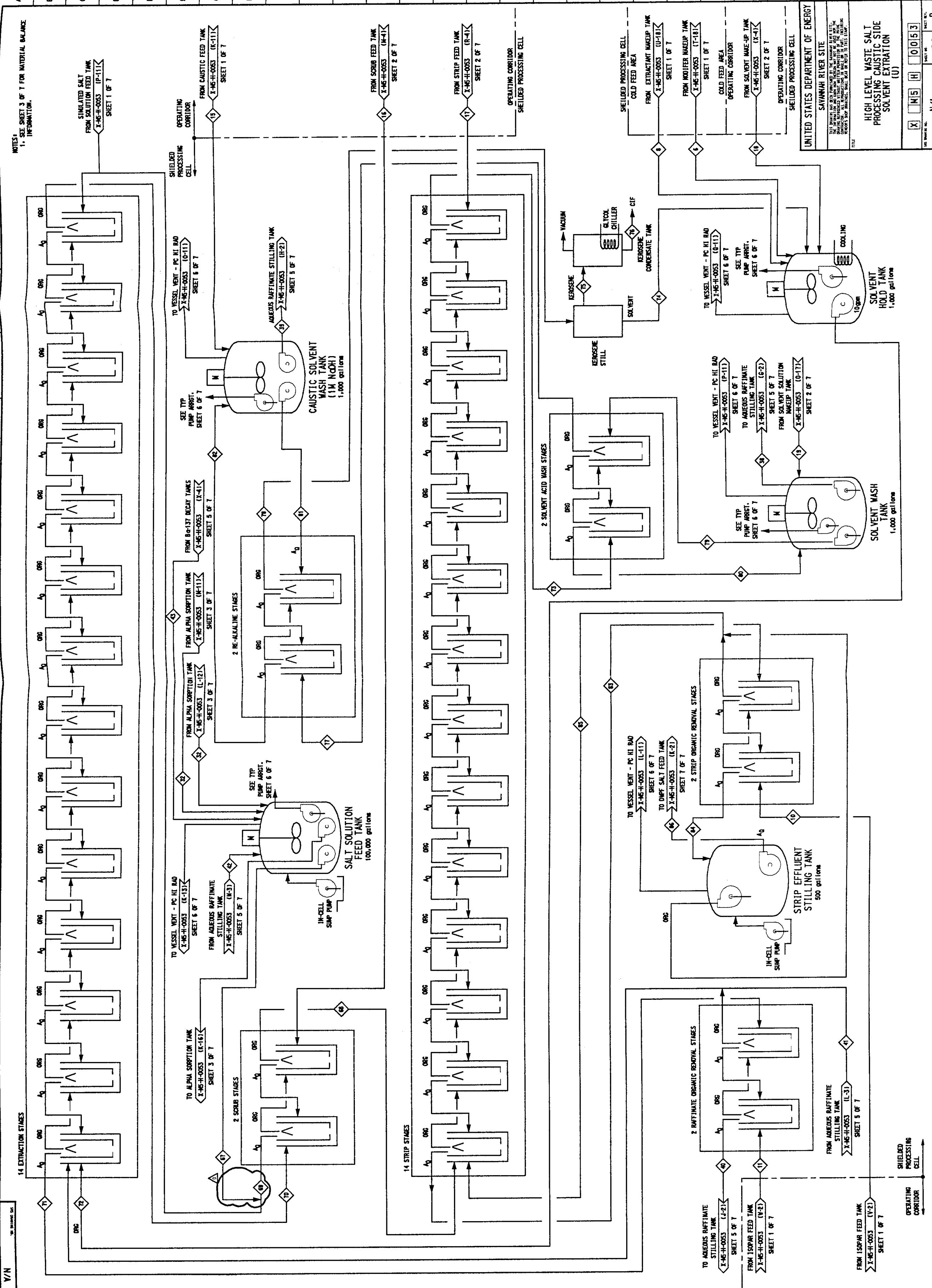




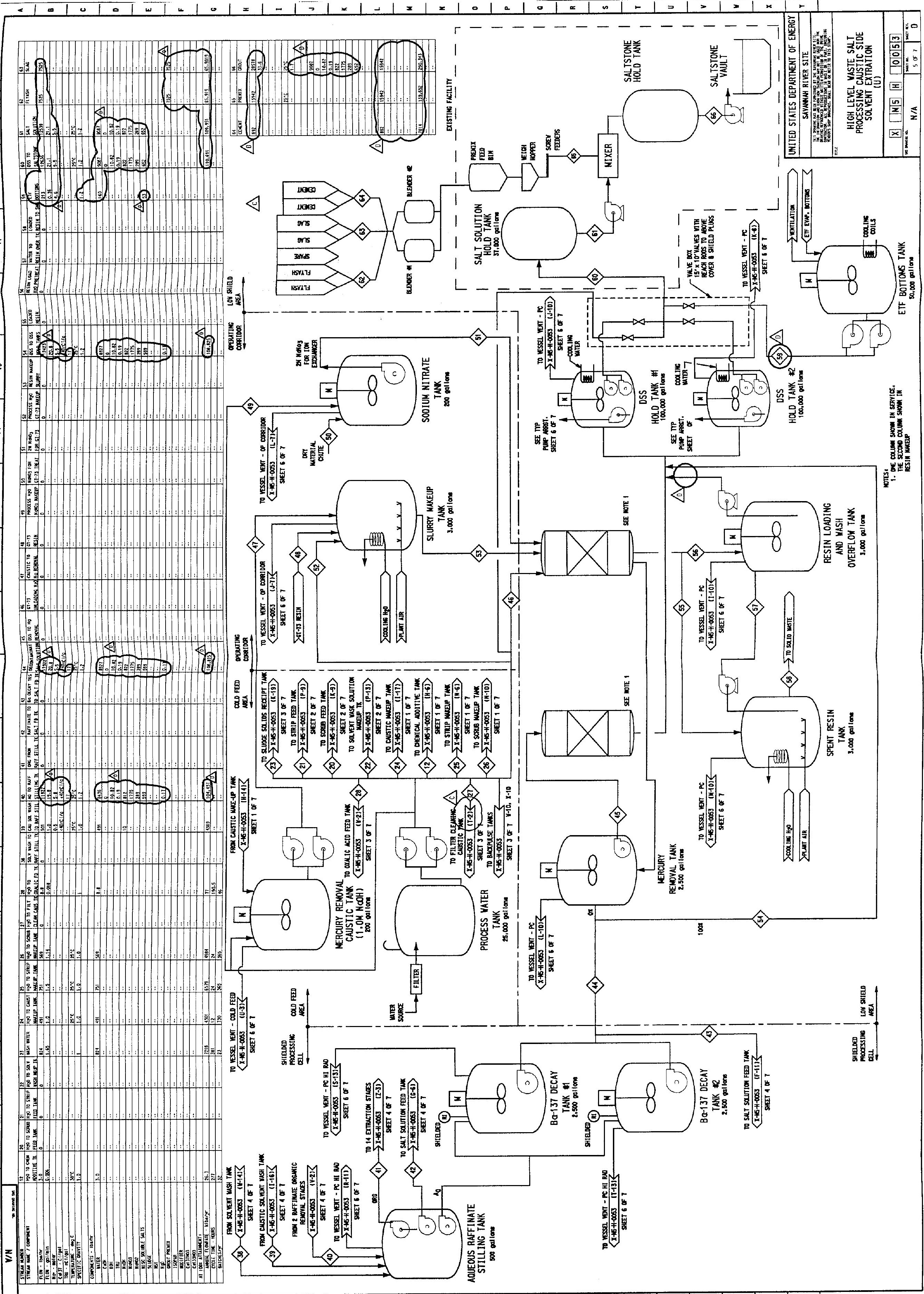



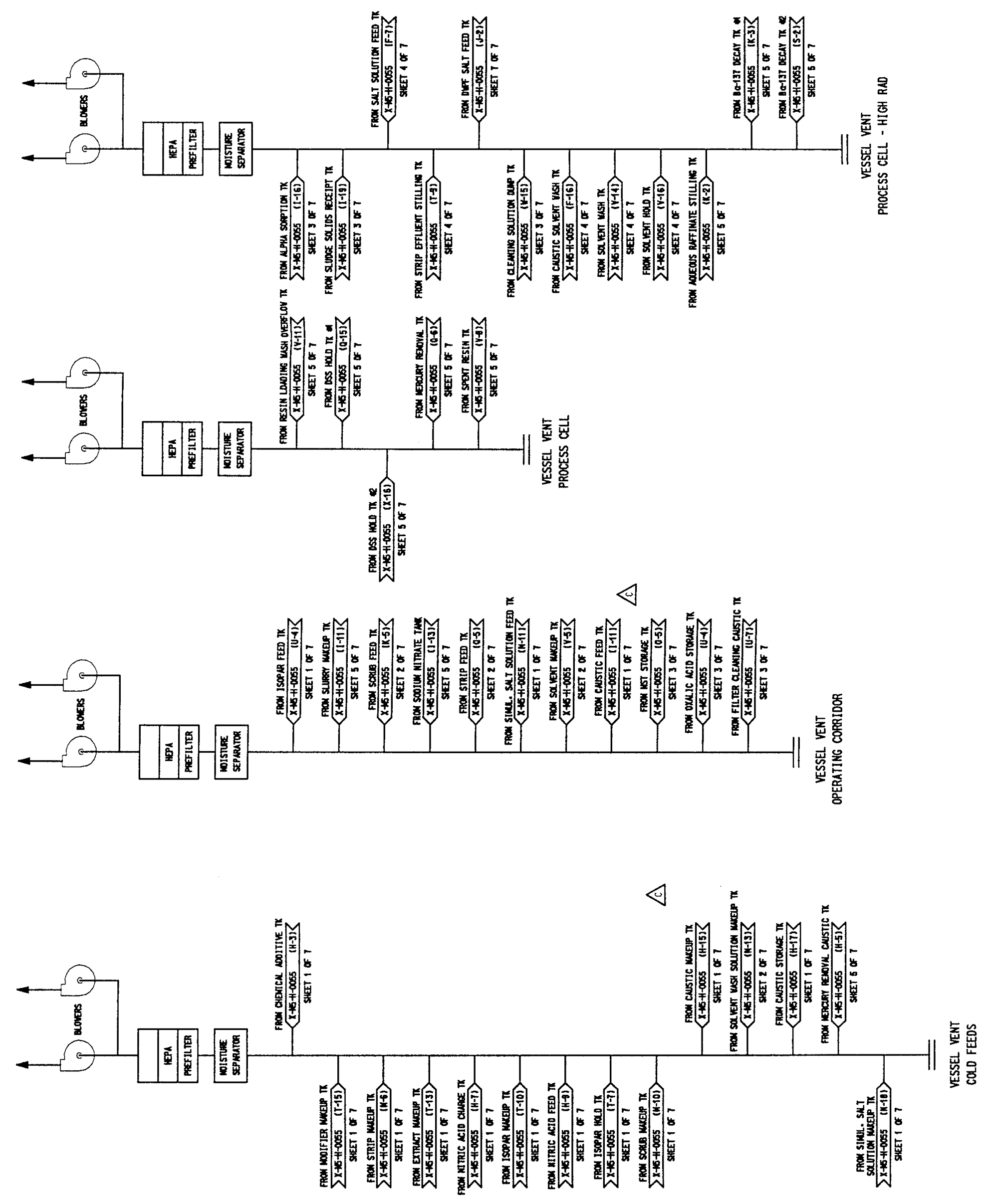


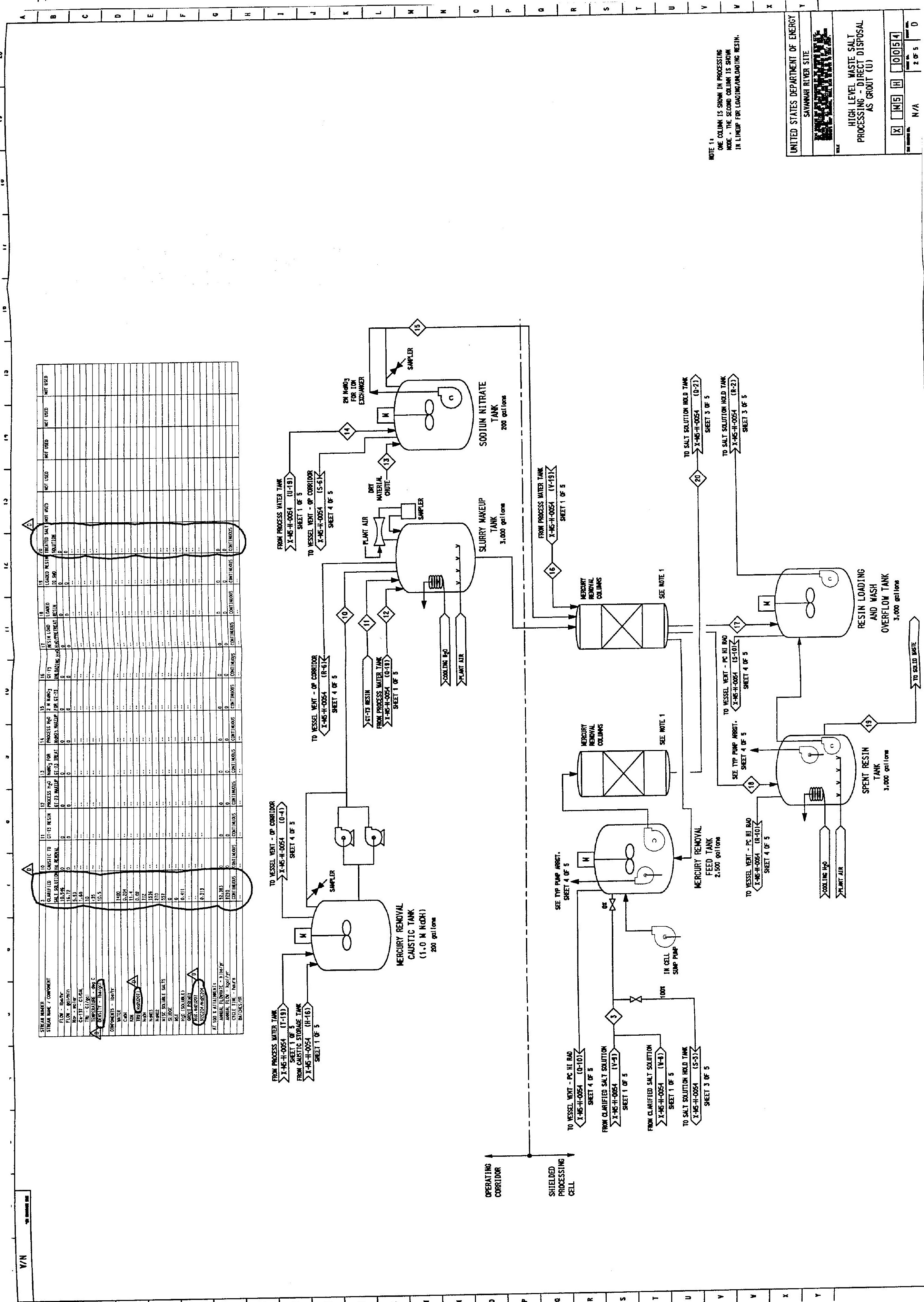




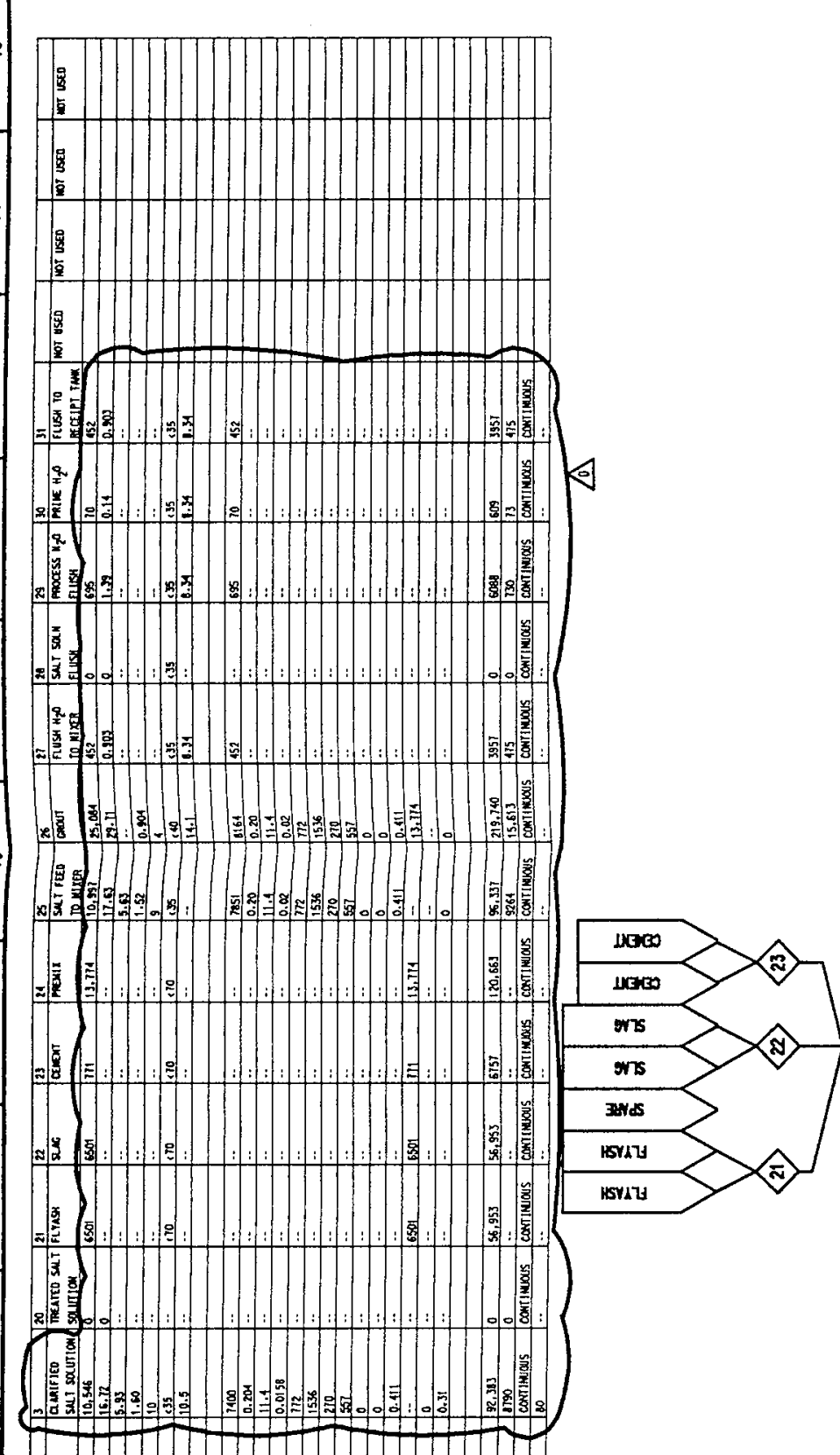

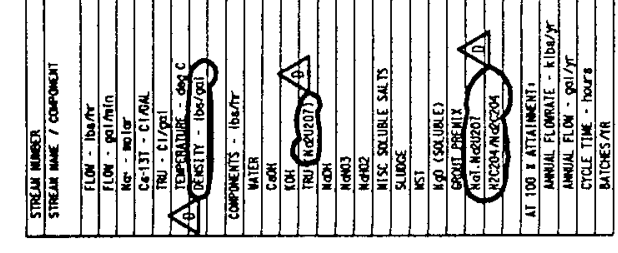
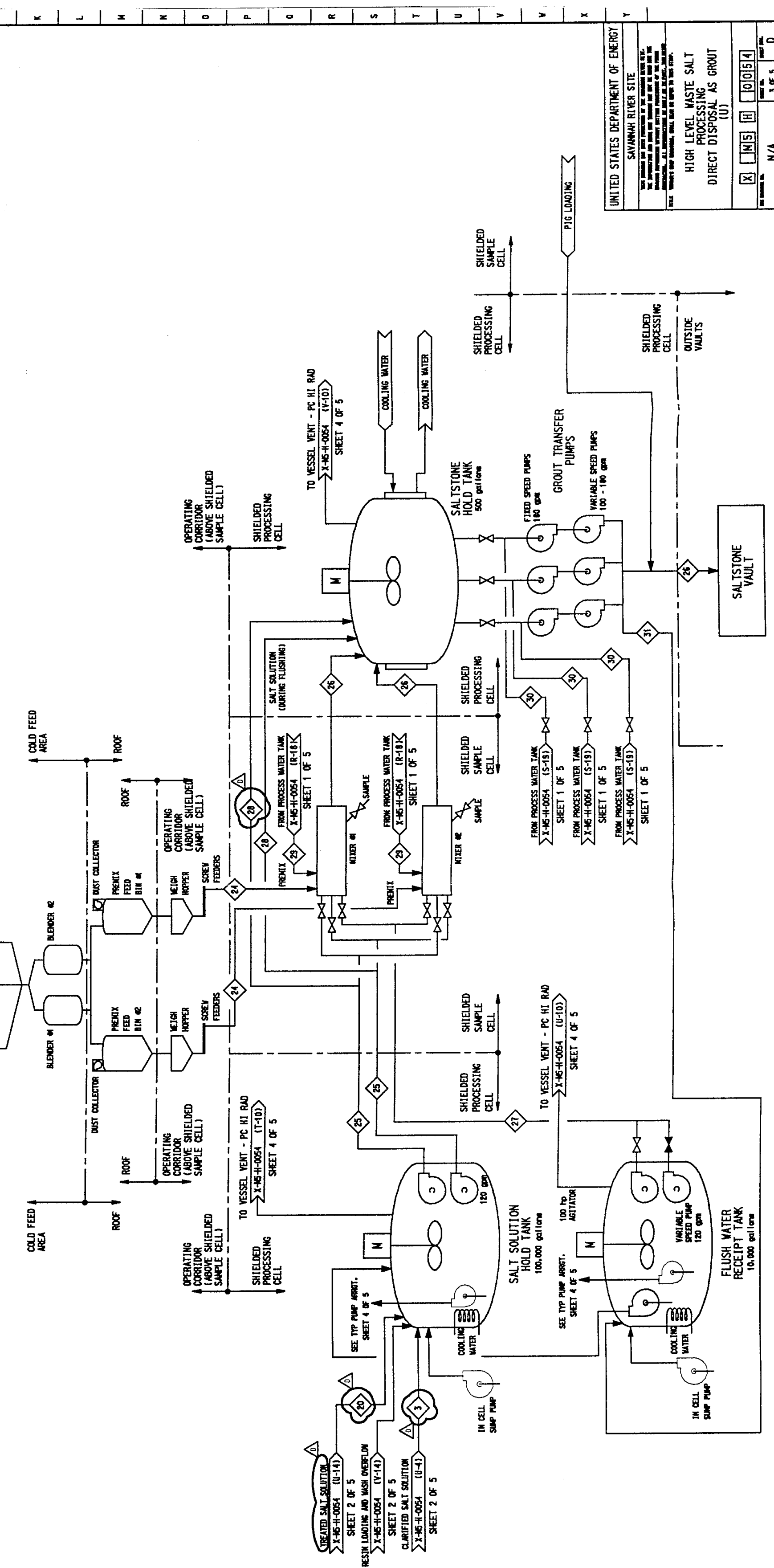


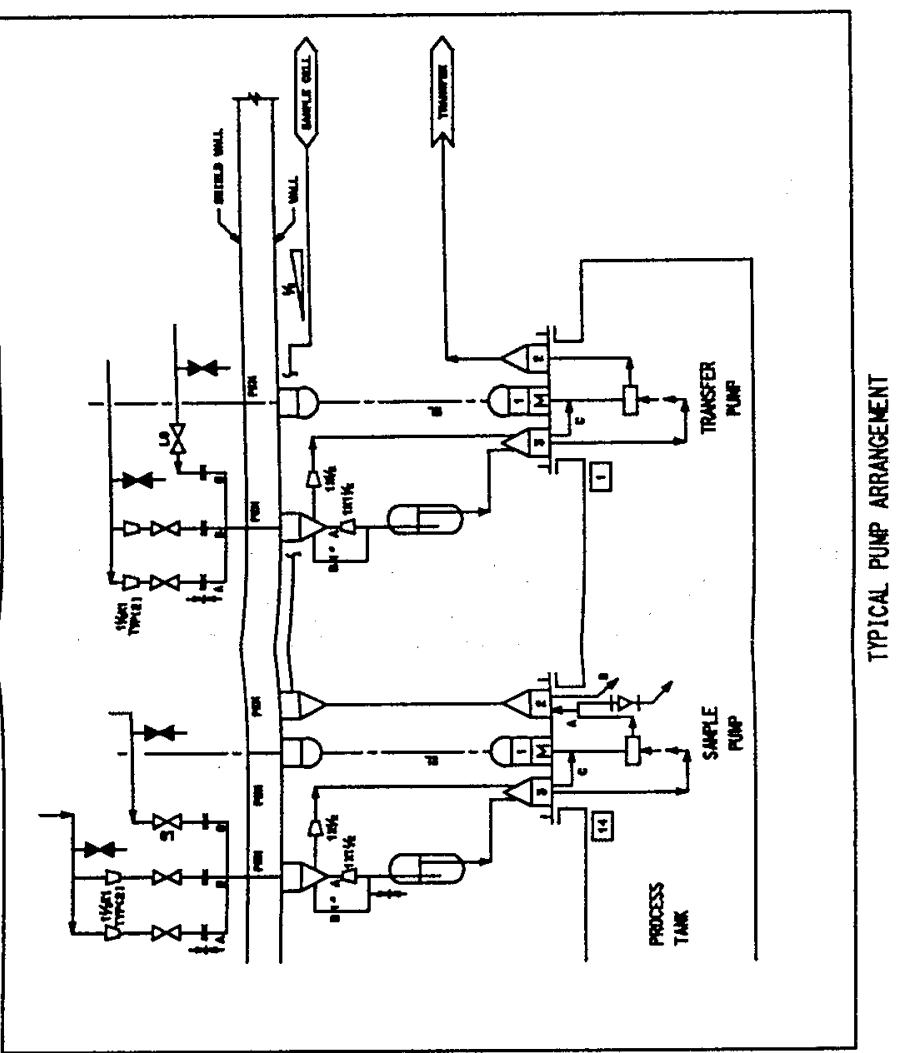

Hid

牙
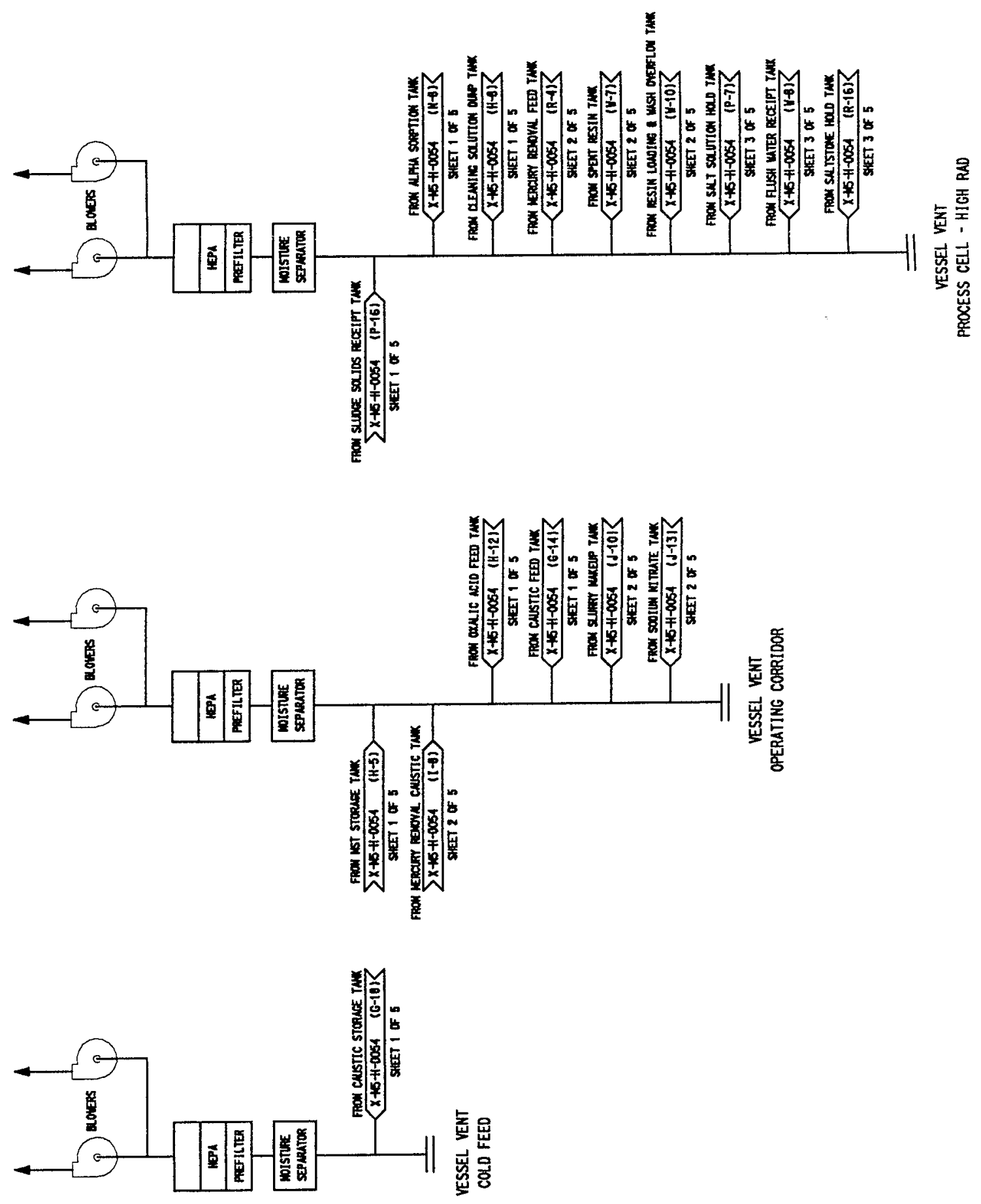
$\frac{m}{1}$
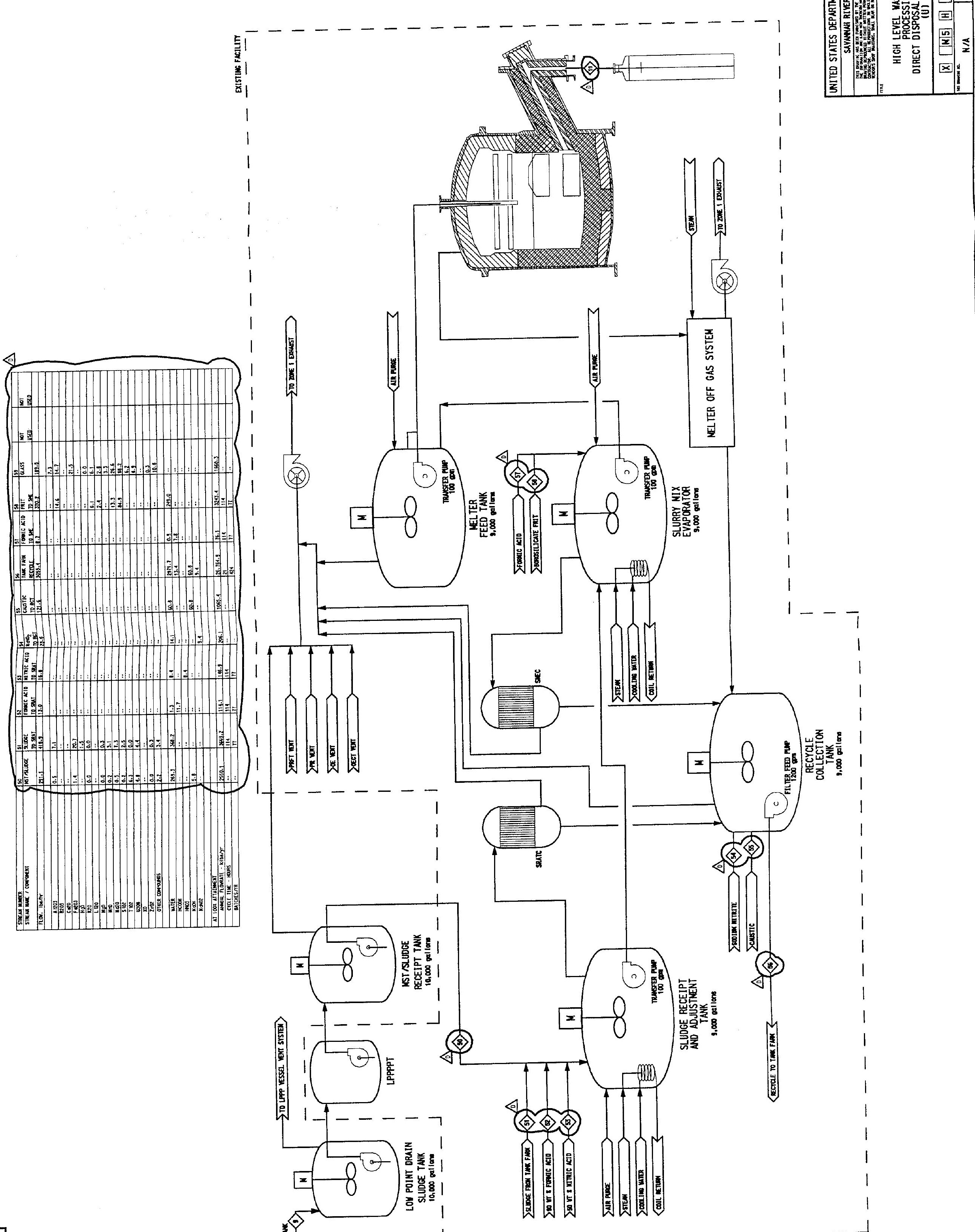

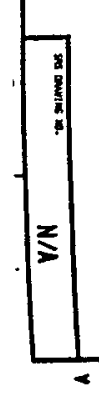

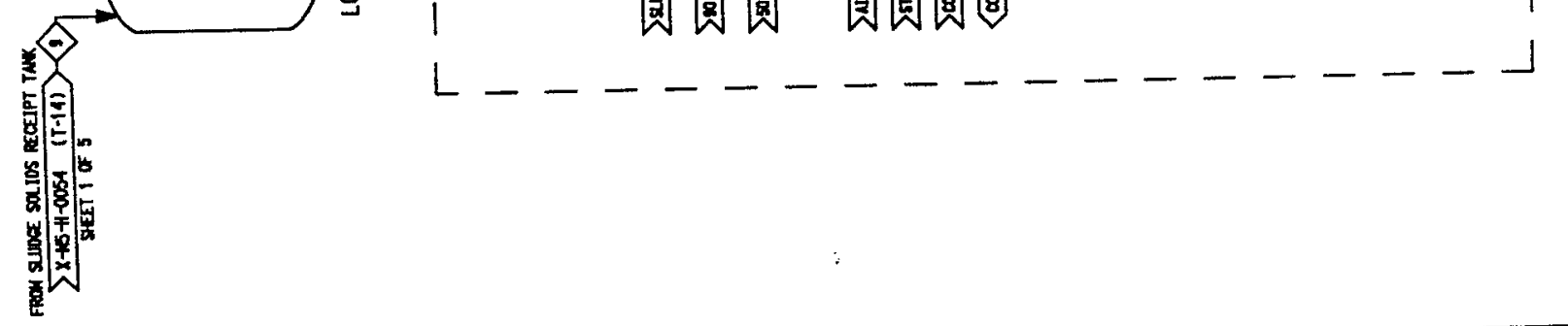




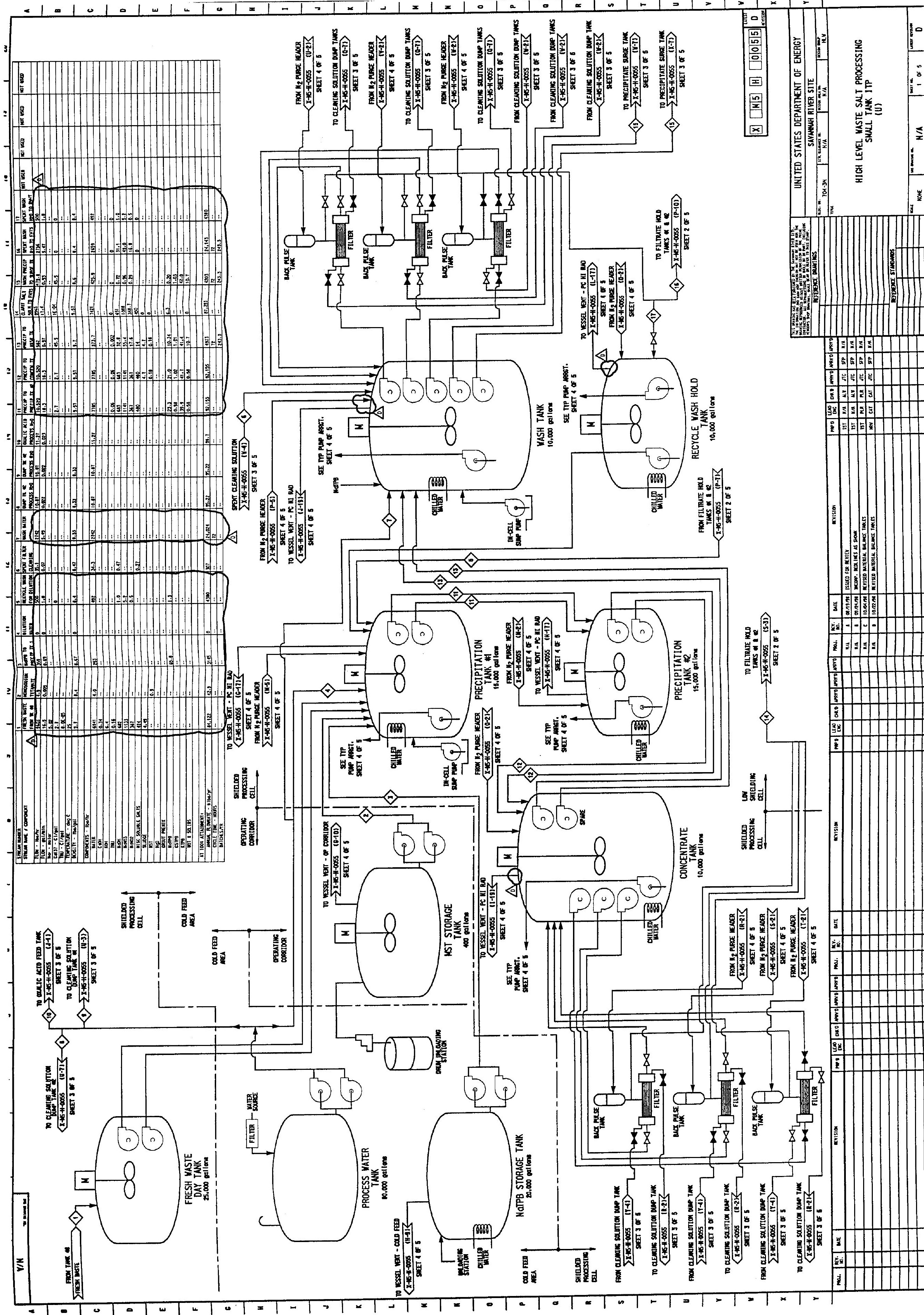




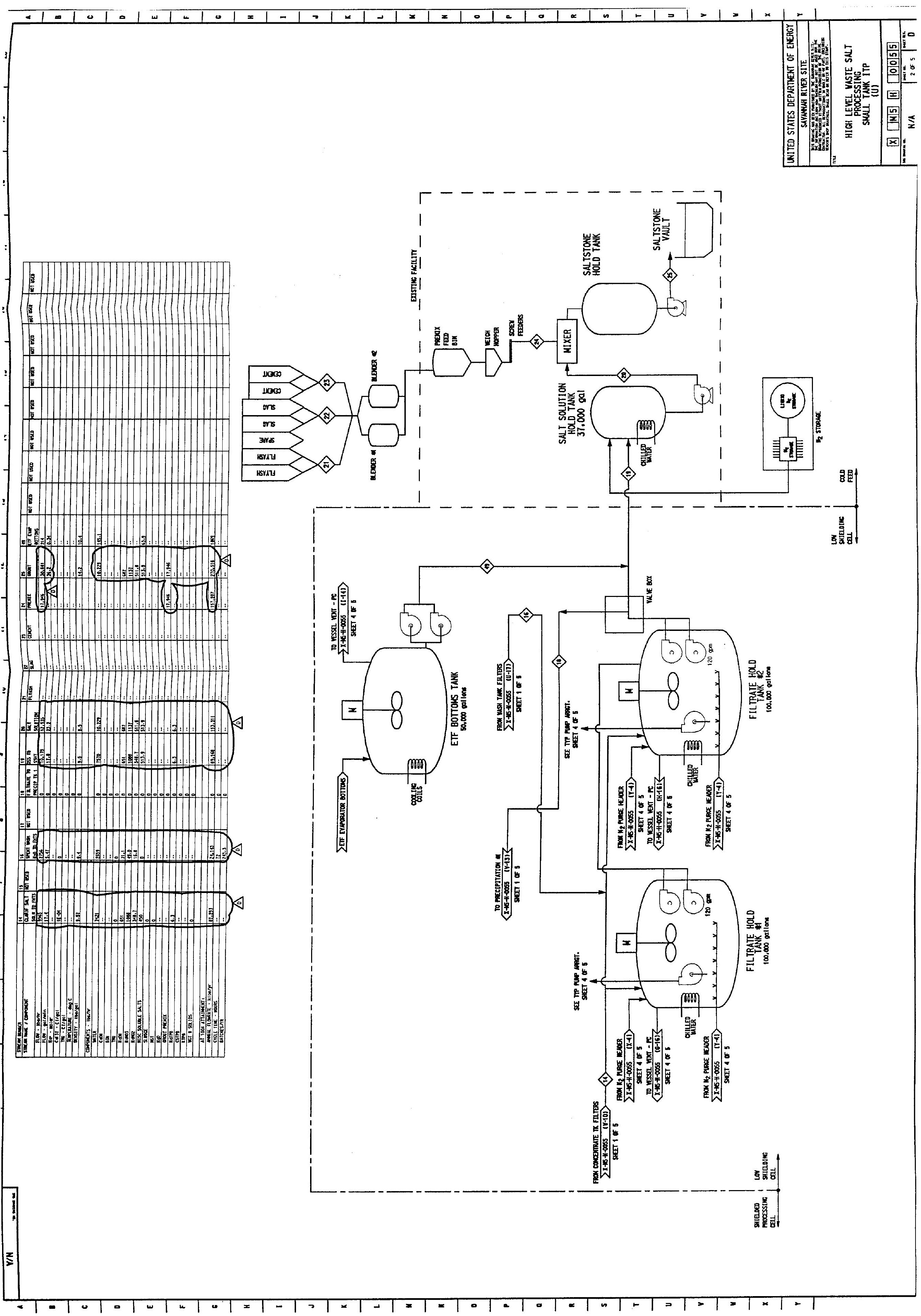



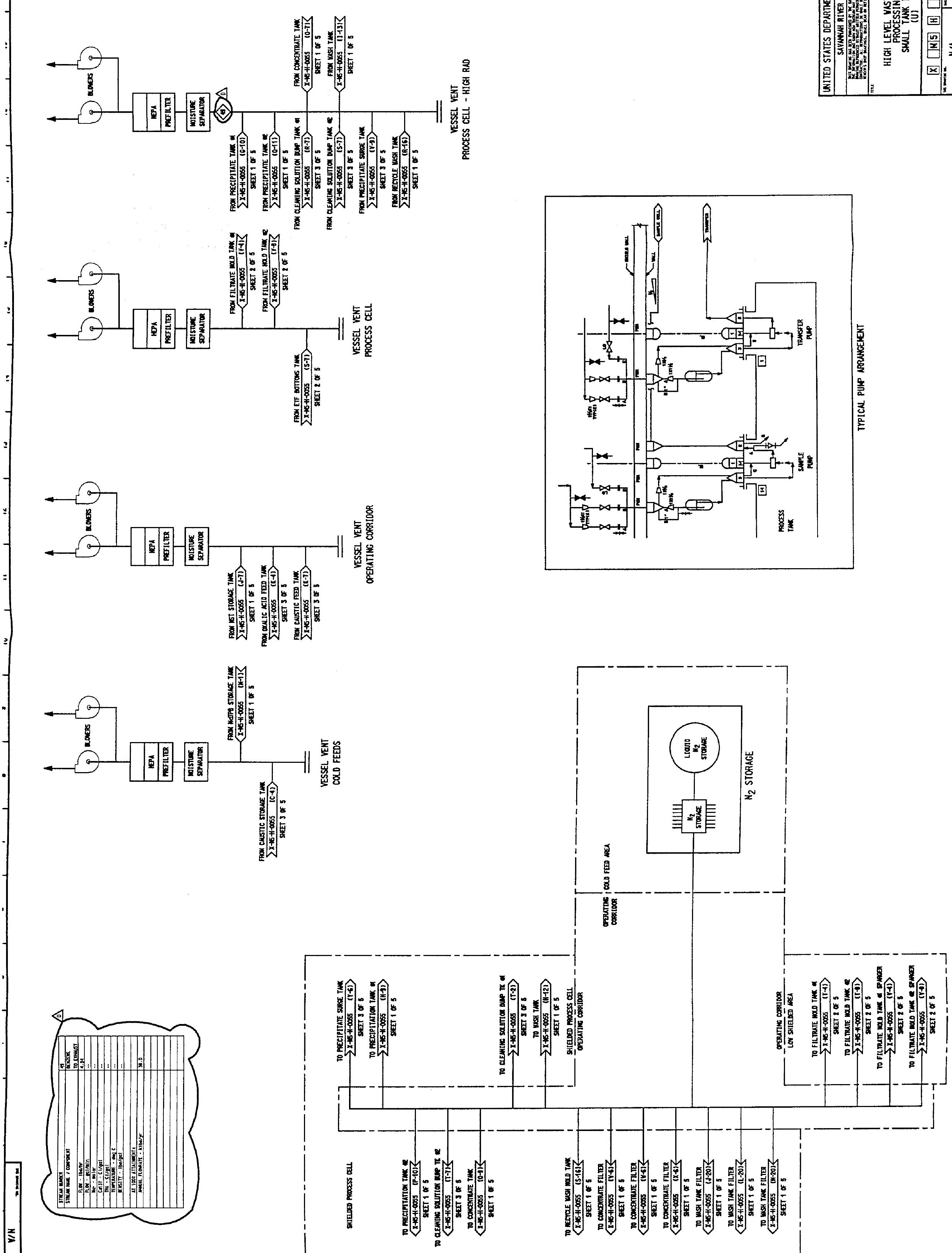

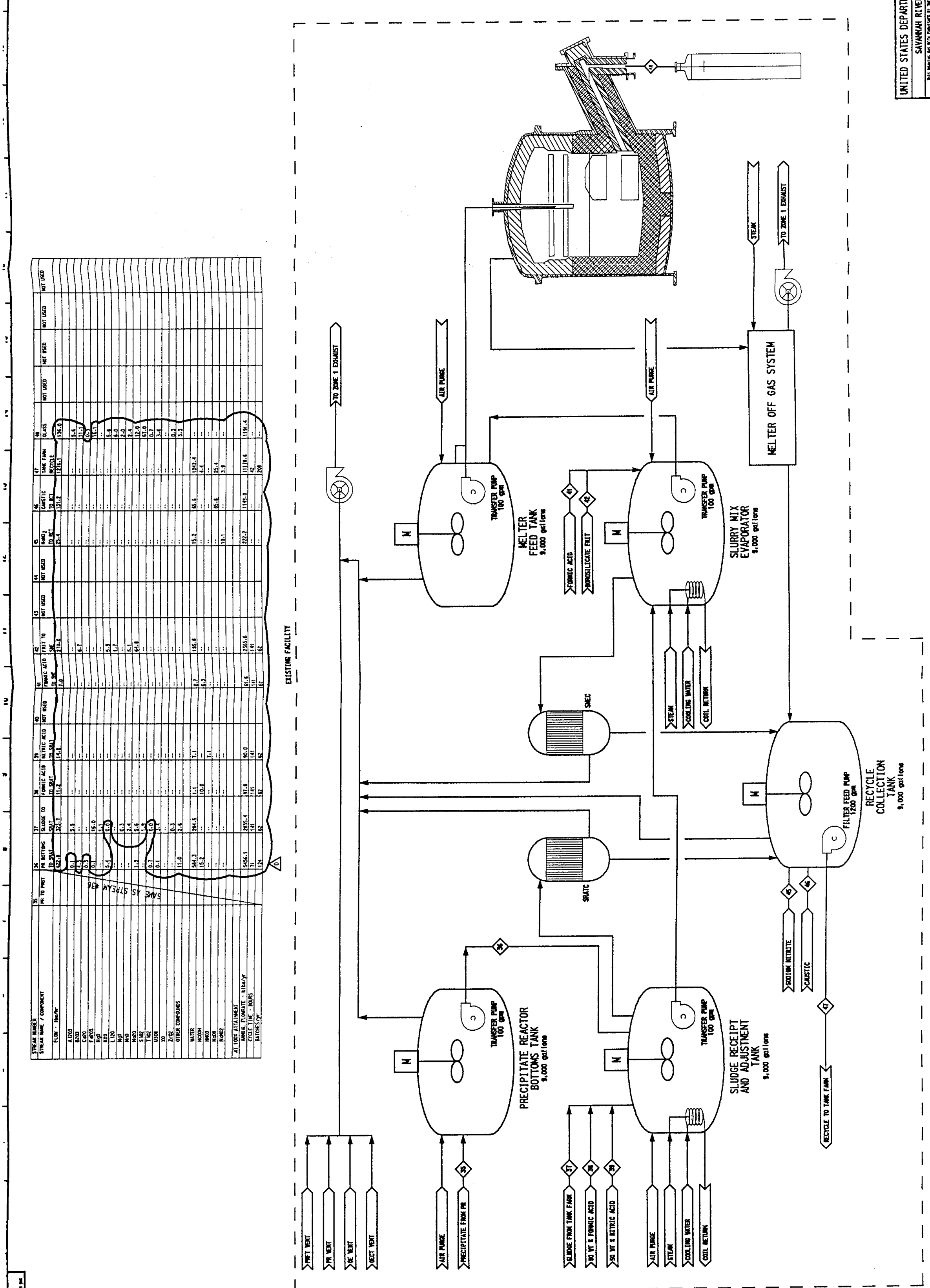


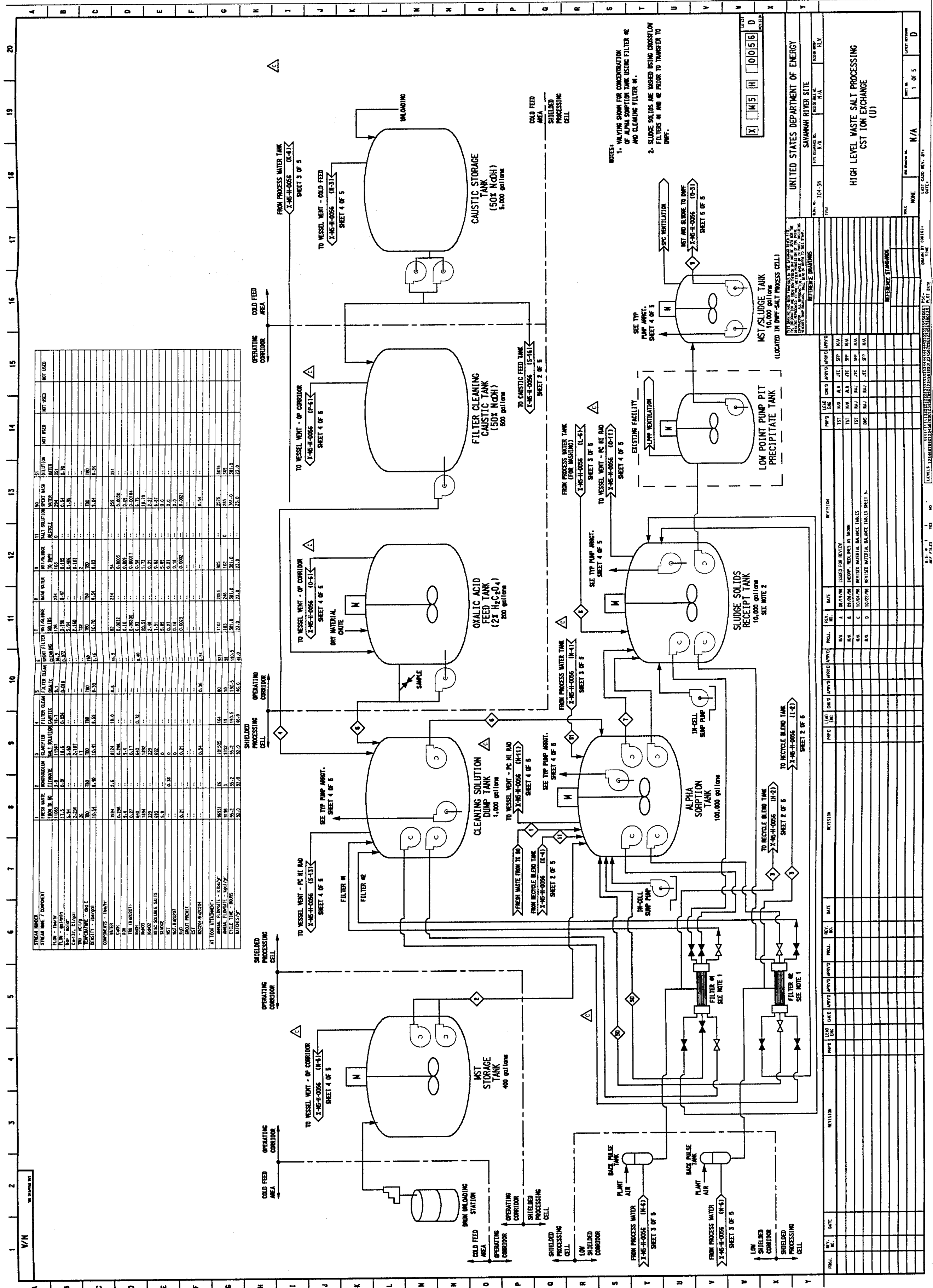




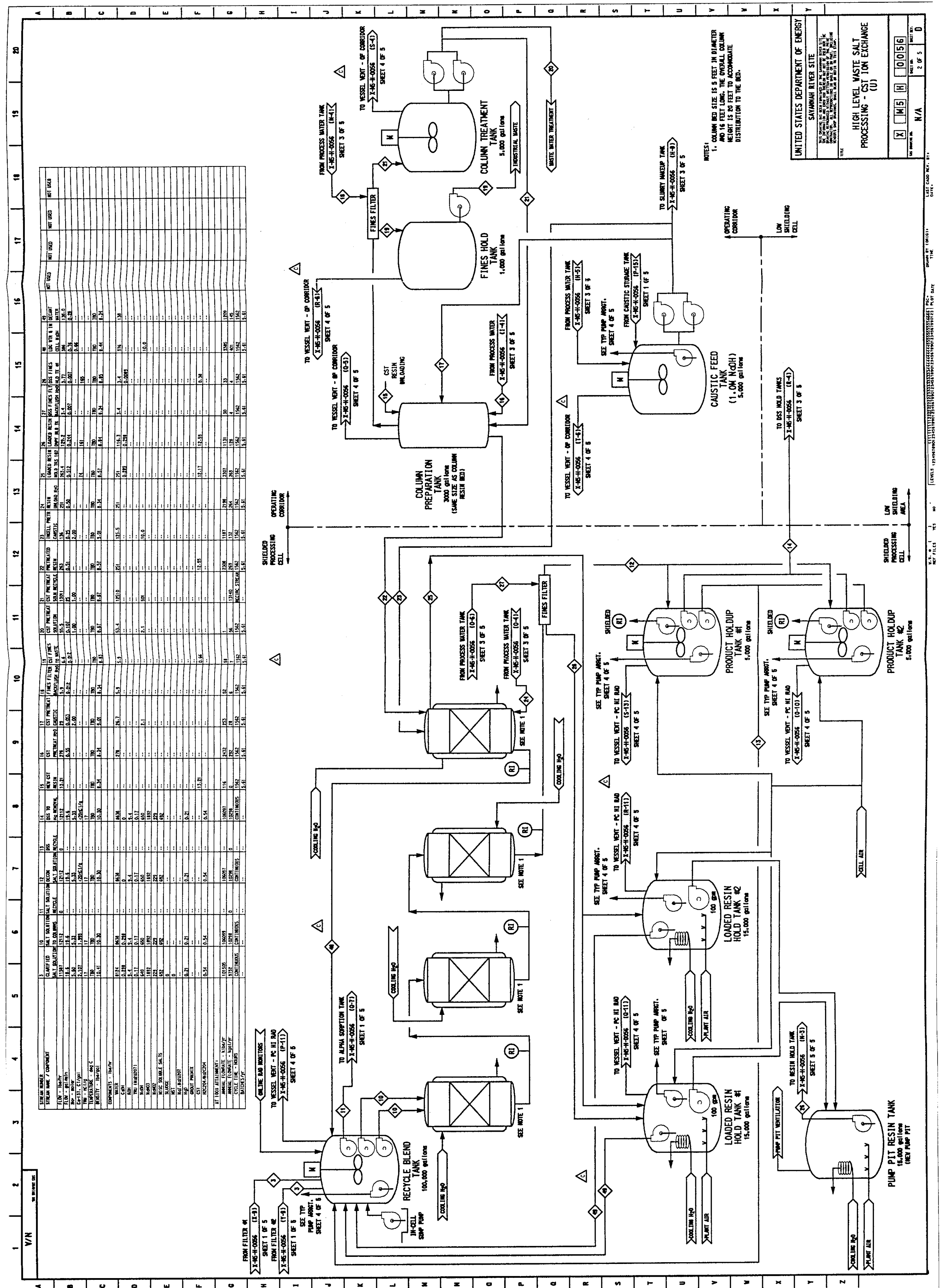




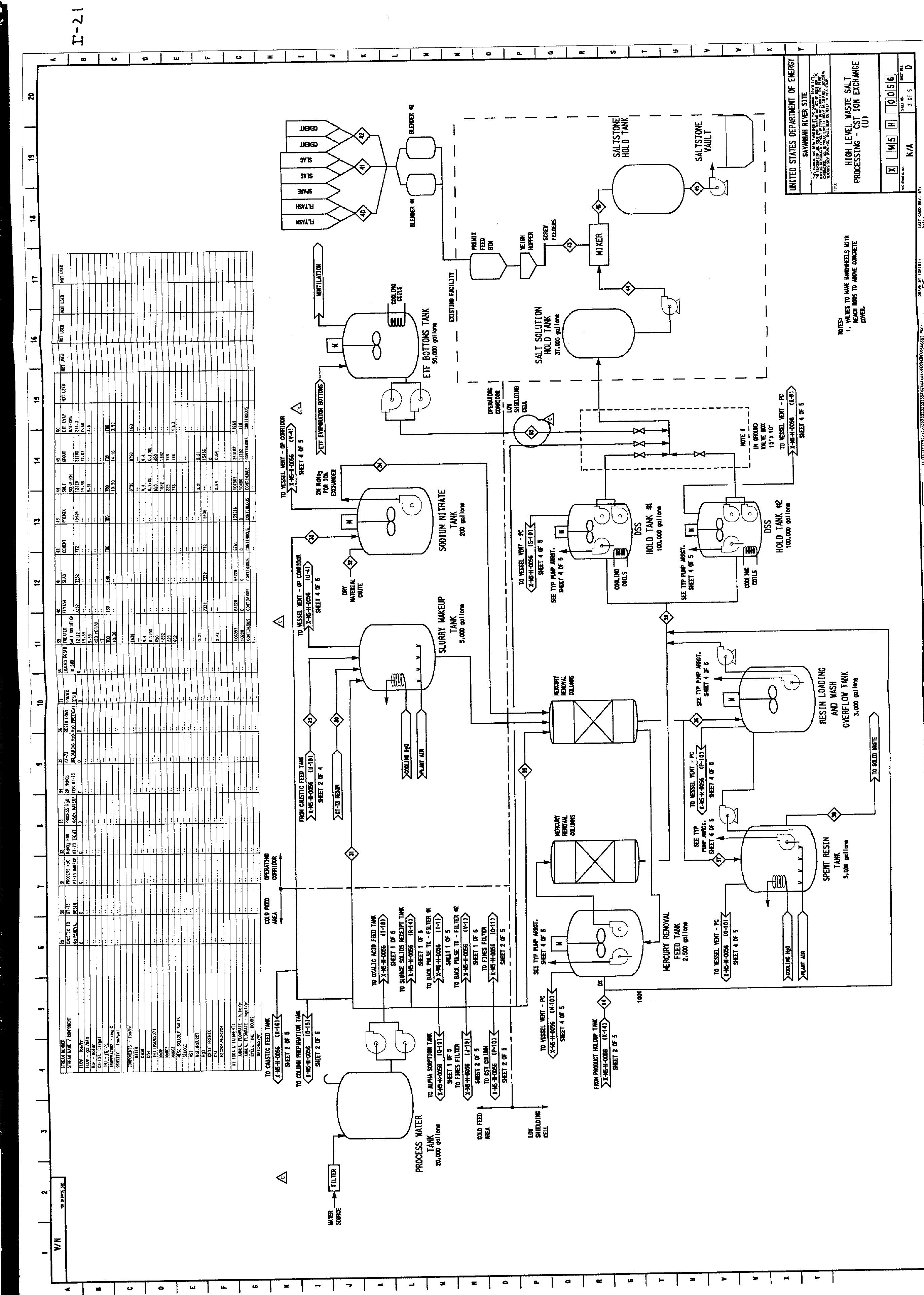




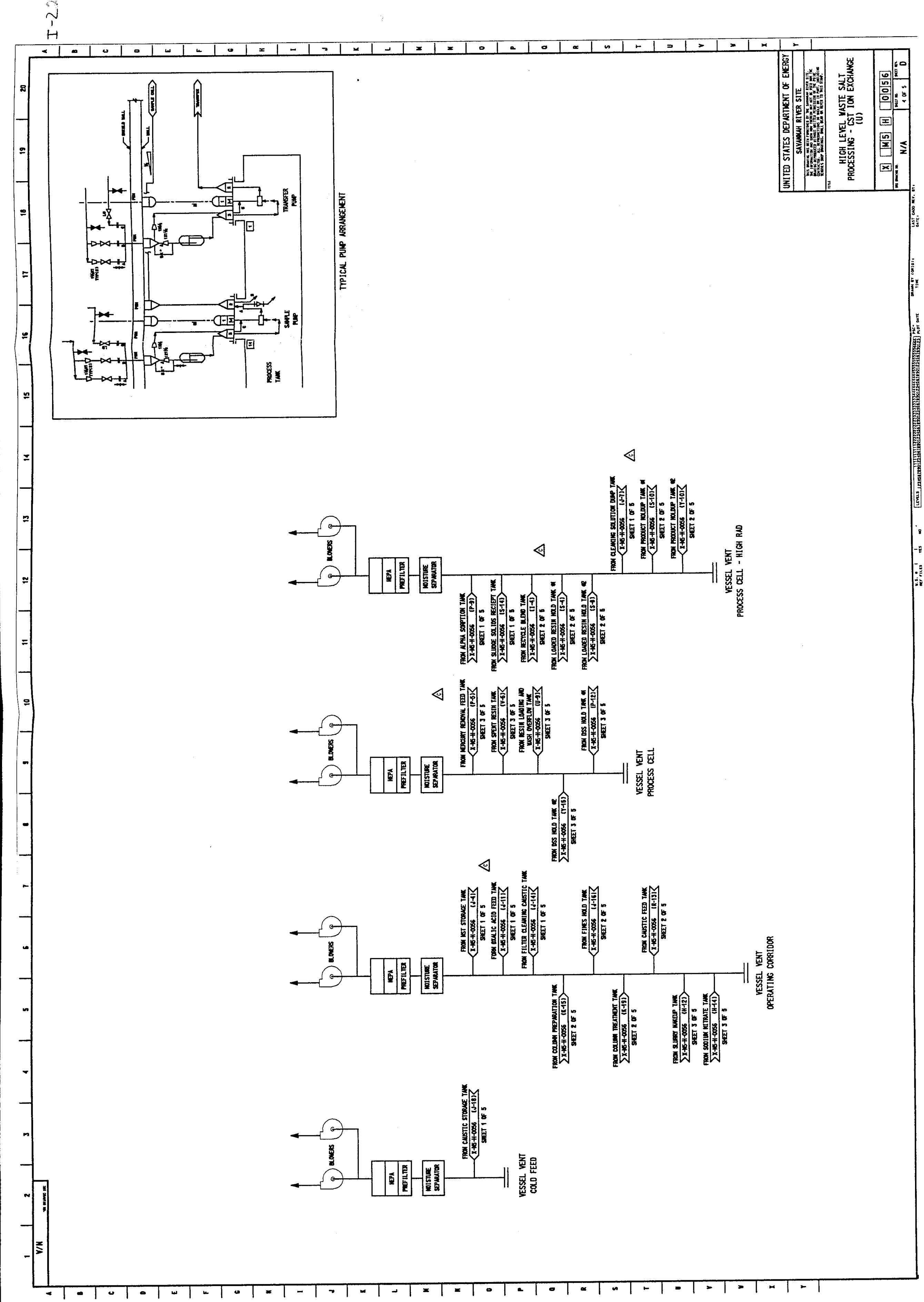


APPENDIX $\mathbf{J}$

EQUIPMENT LAYOUT AND SITE DRAWINGS 


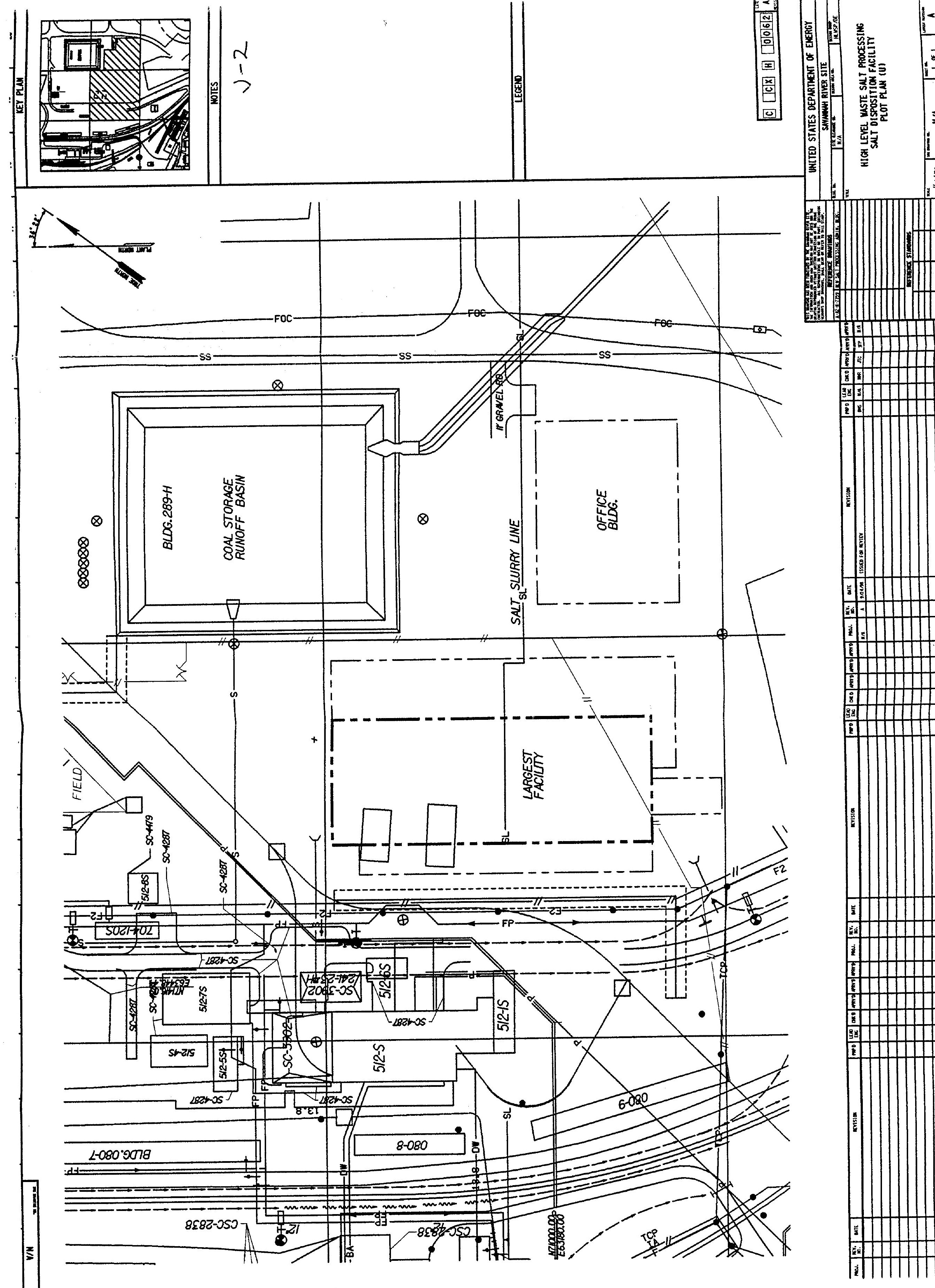




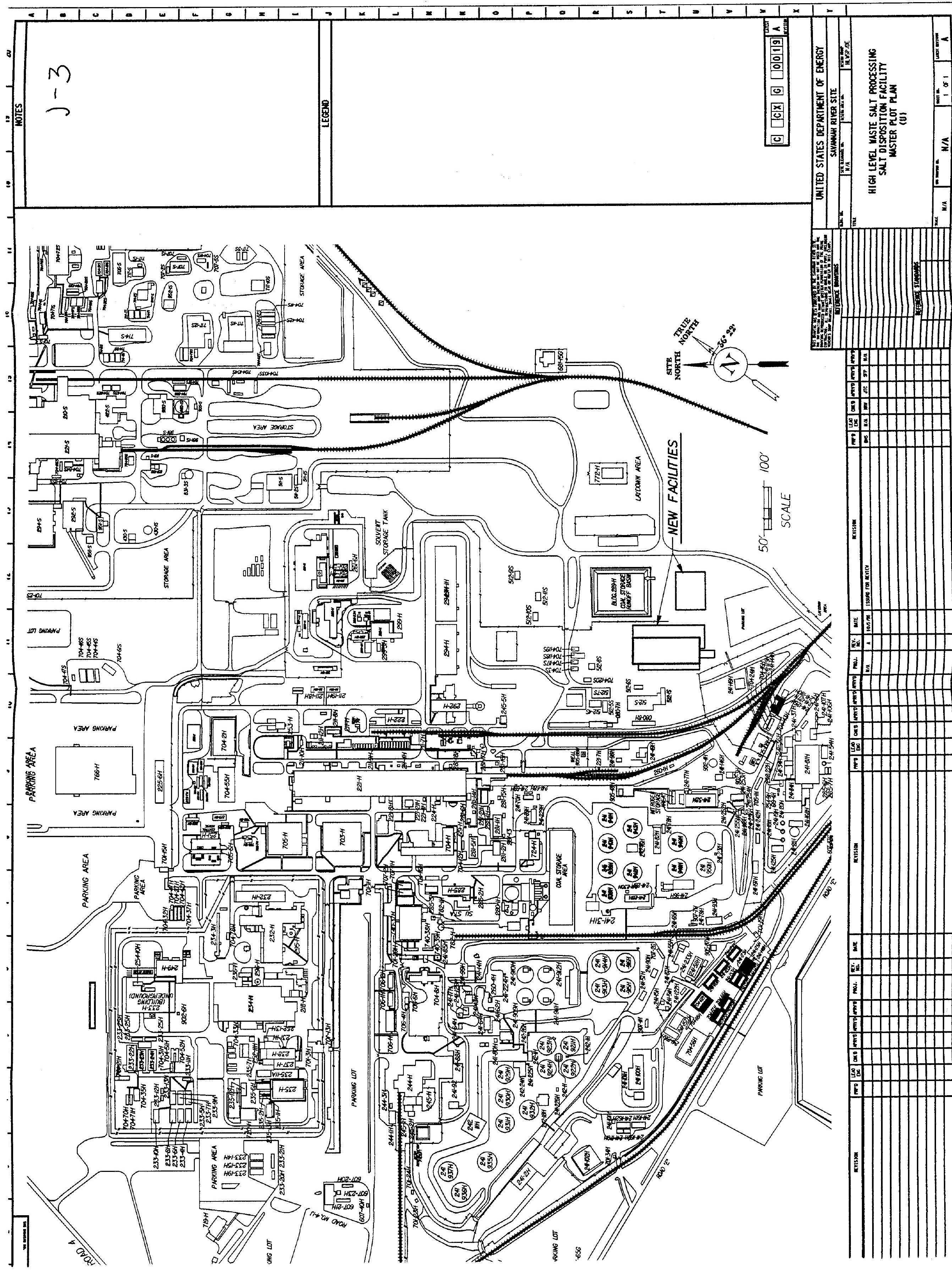




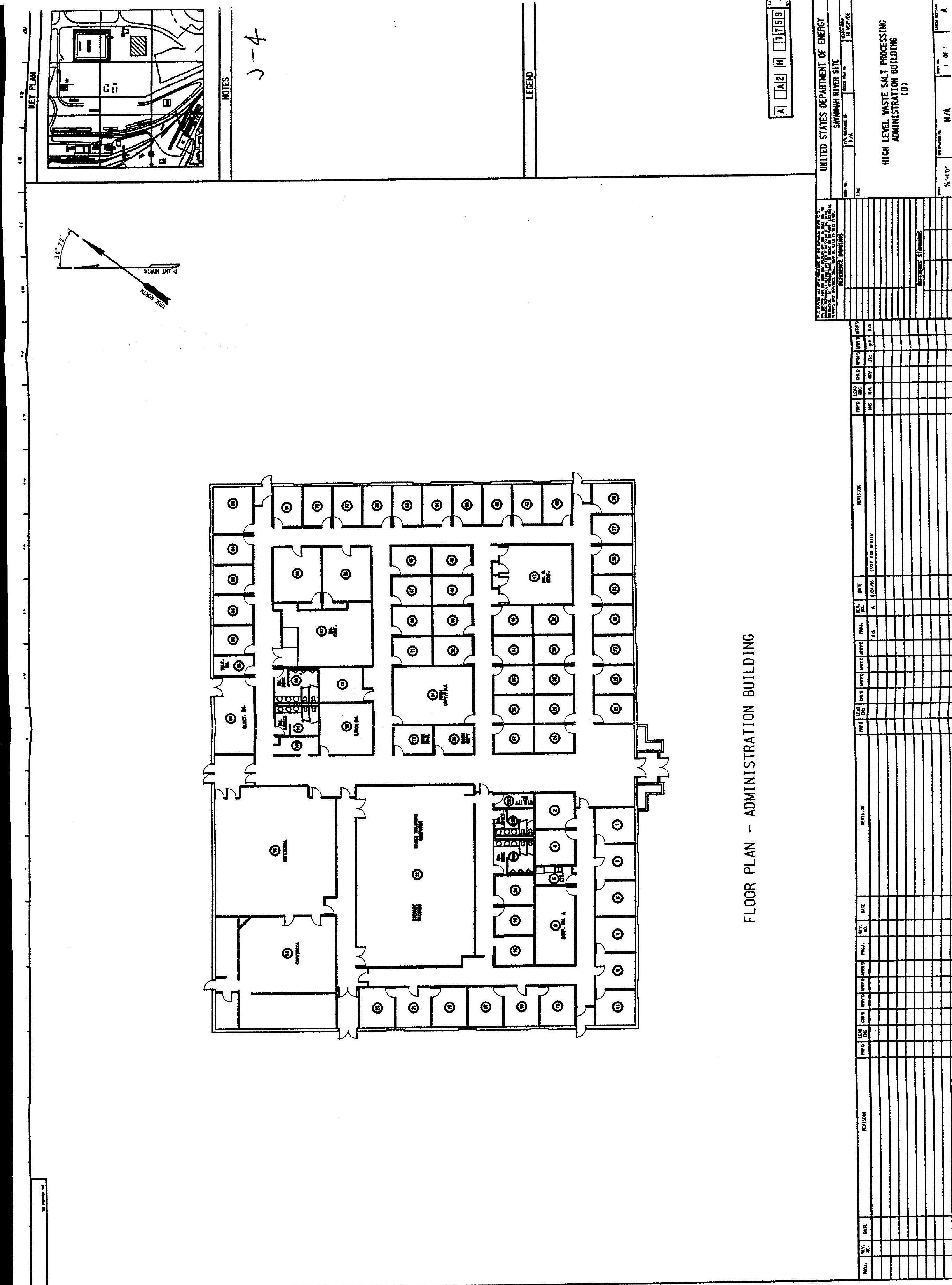


I

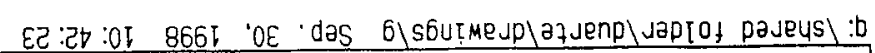

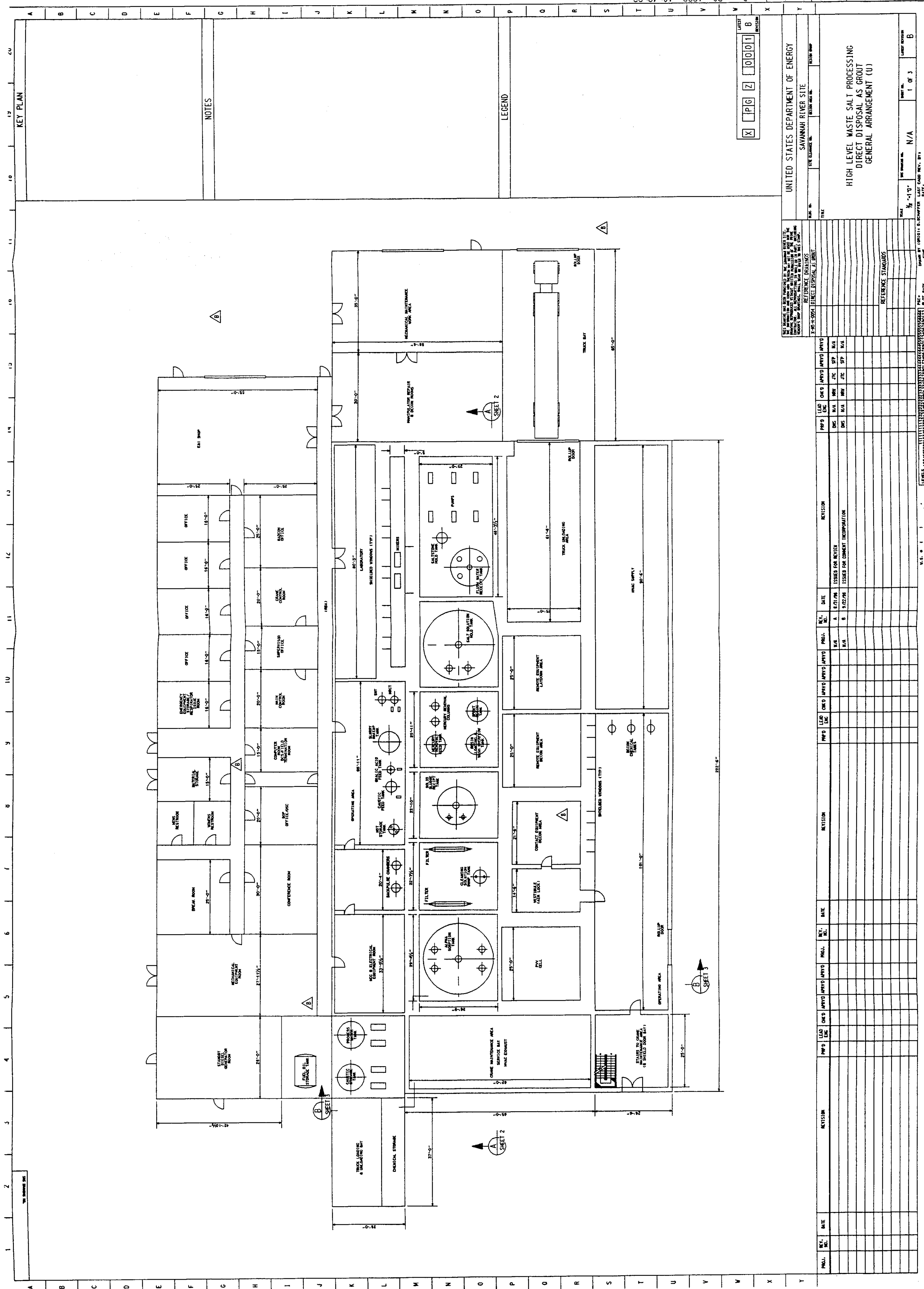


$\hat{1}$

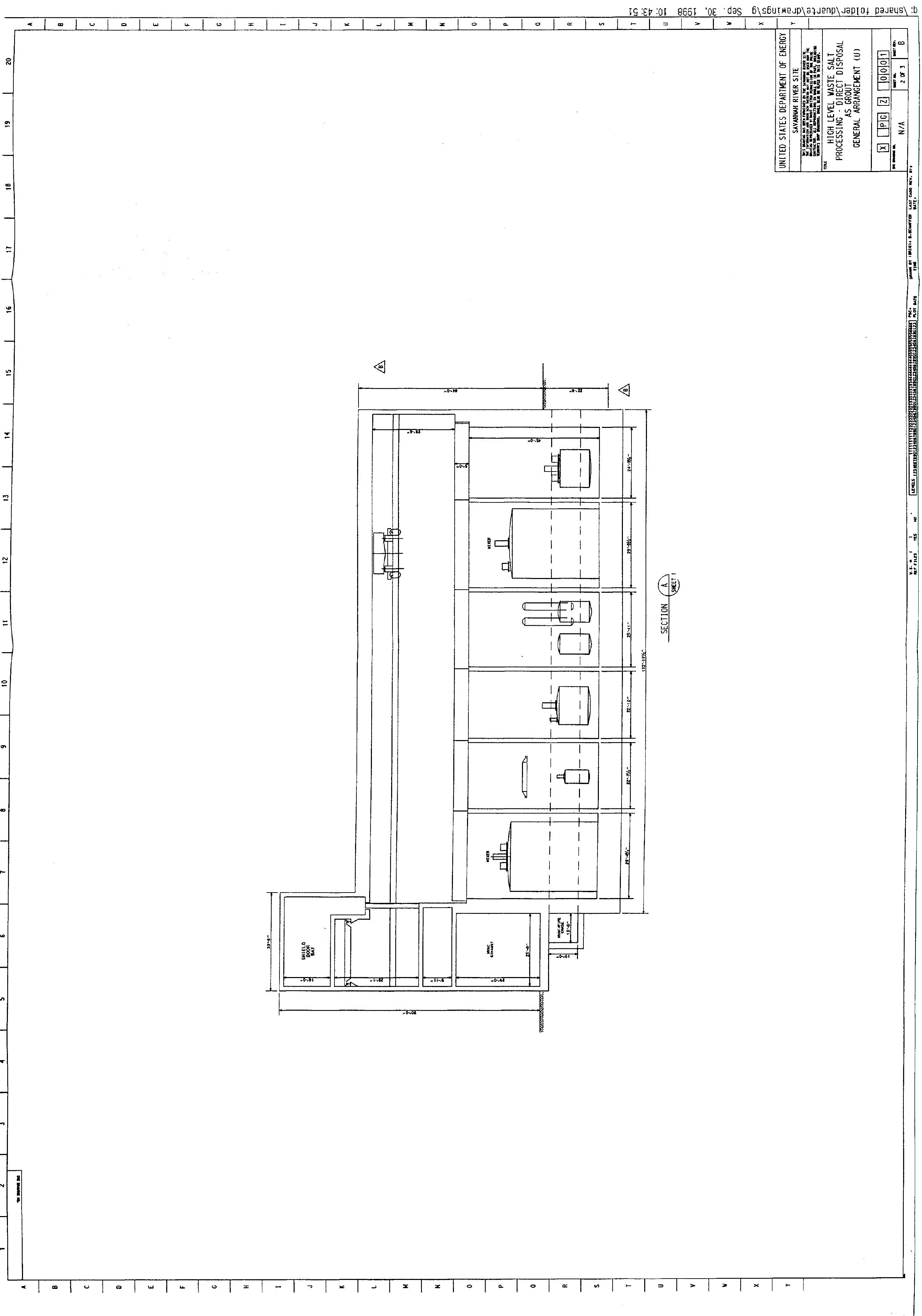




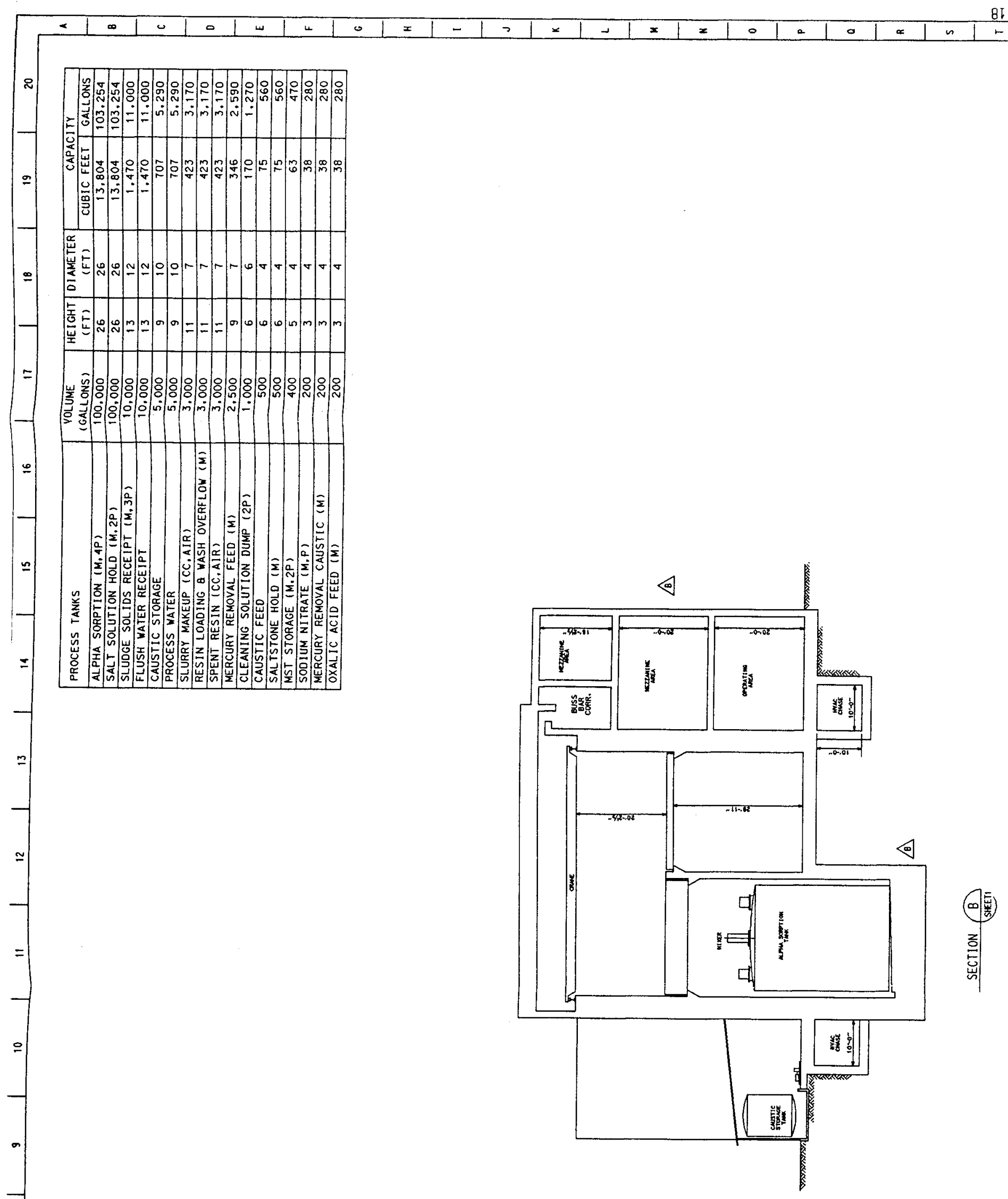

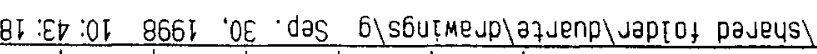

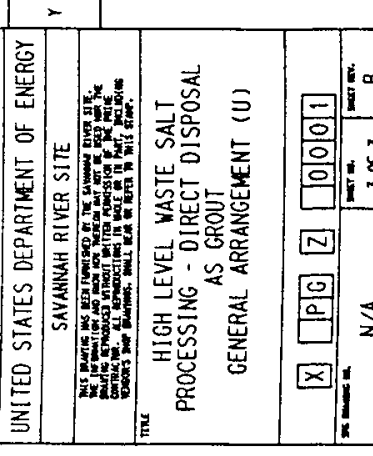




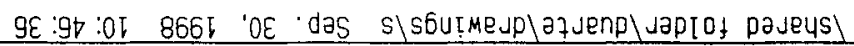

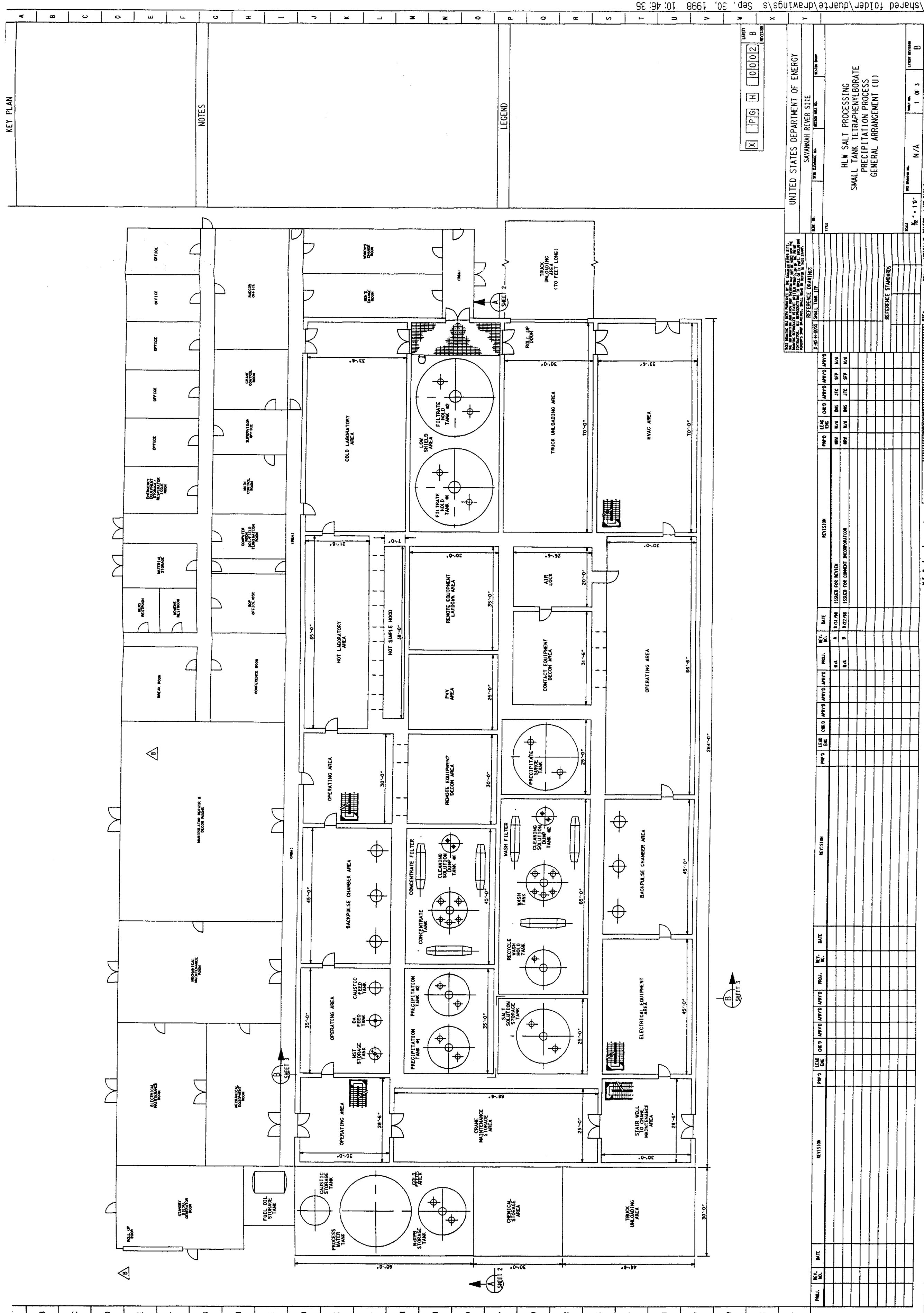


$\frac{0}{1}$

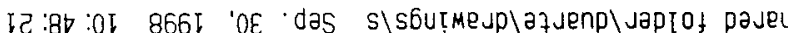
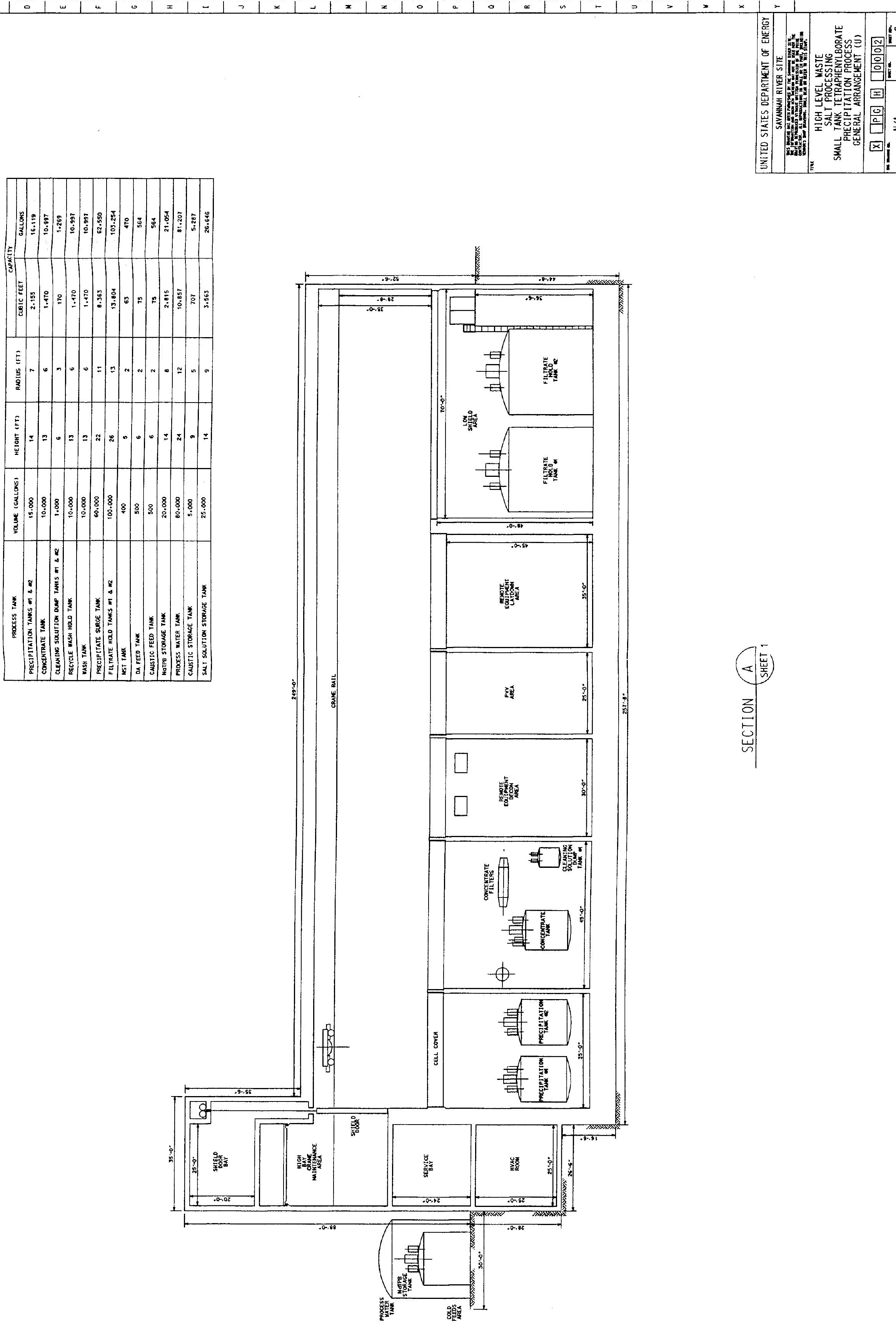

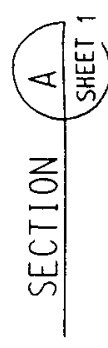




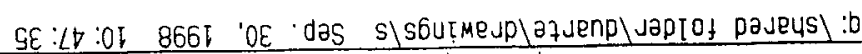
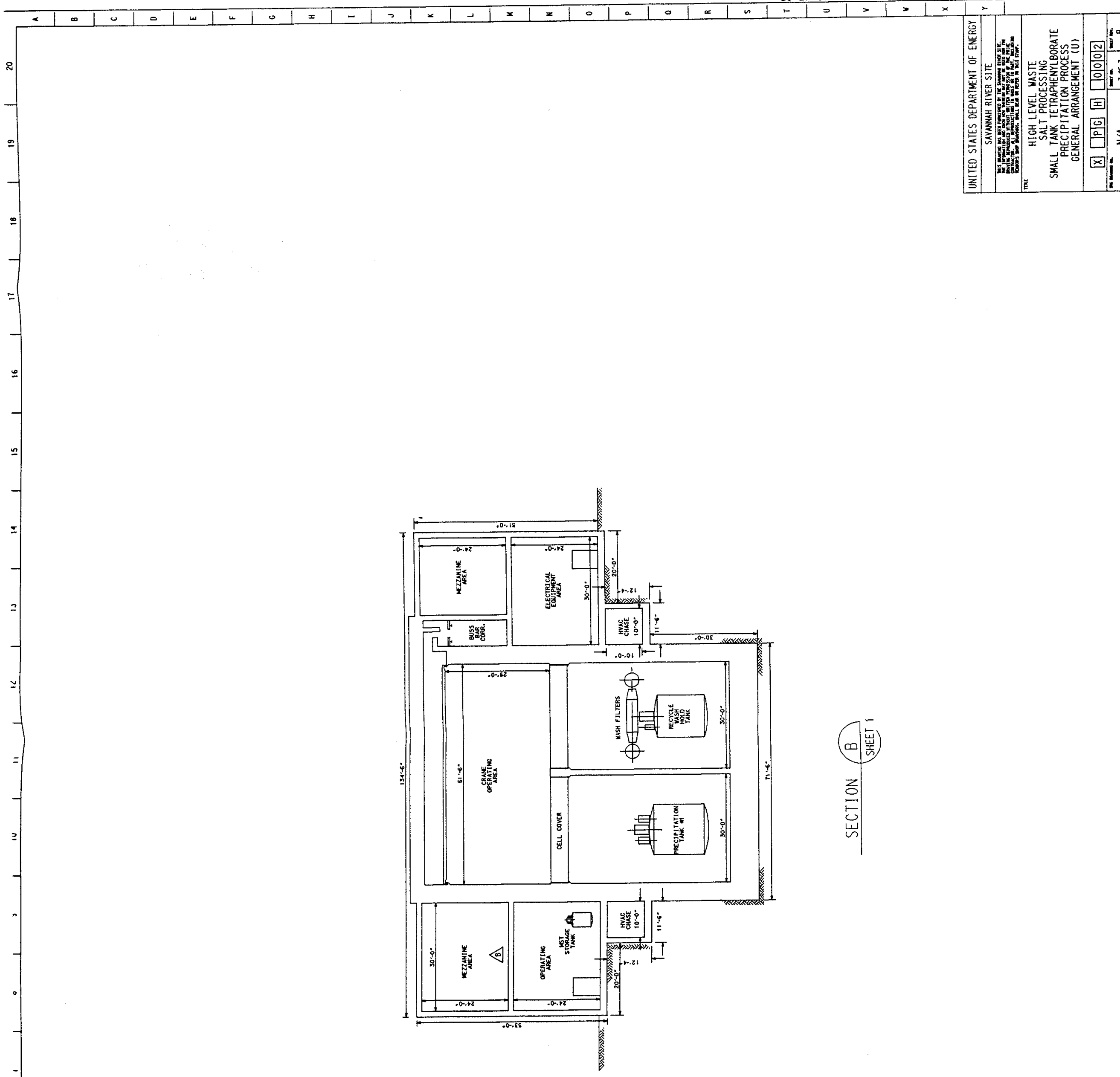
$\frac{\alpha}{1}$
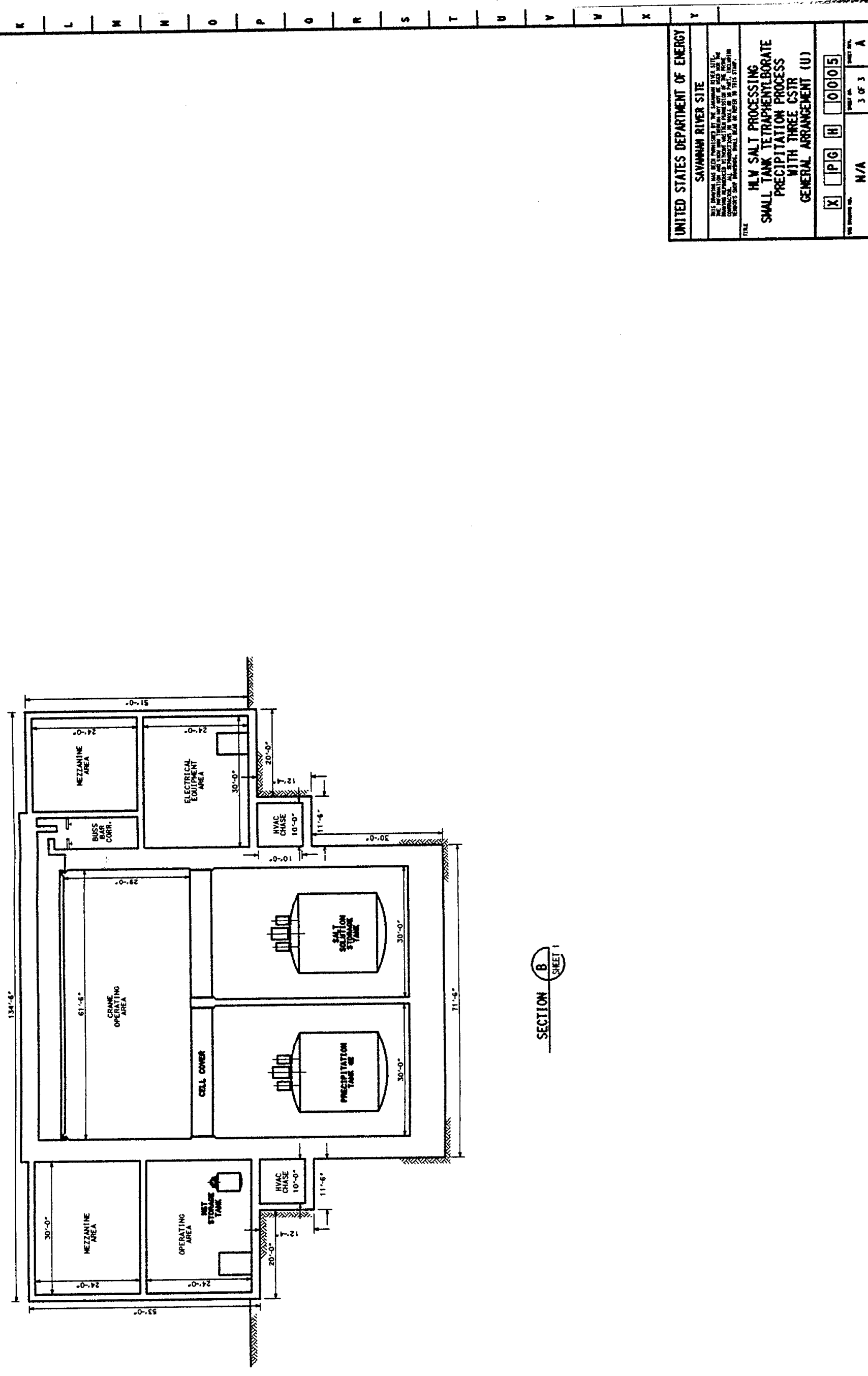

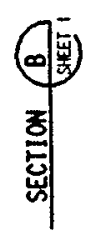


$\frac{n}{i}$

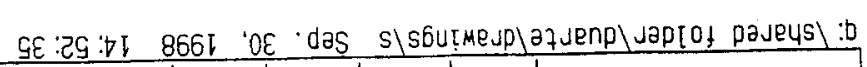

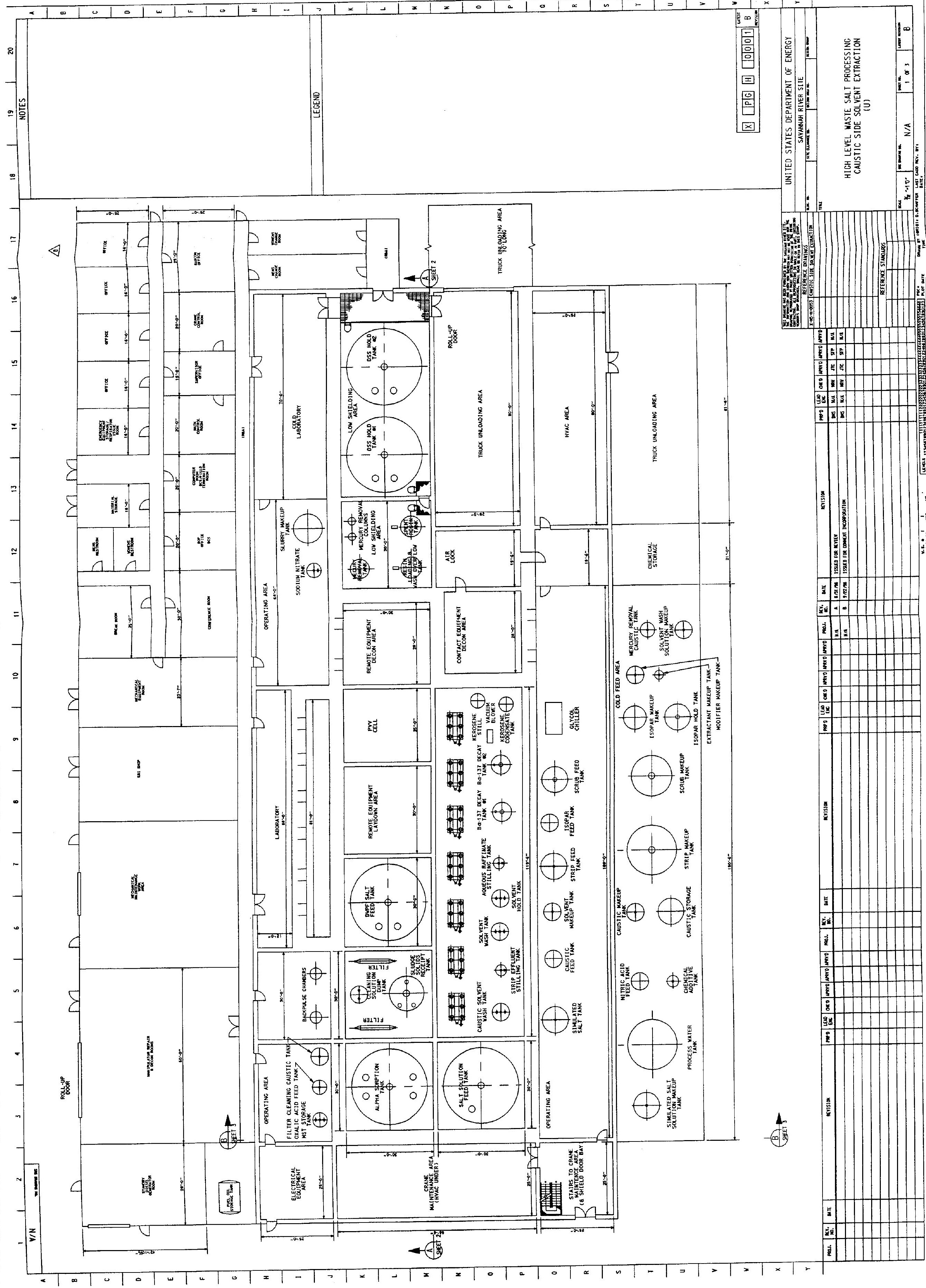


$\stackrel{?}{\stackrel{1}{7}}$

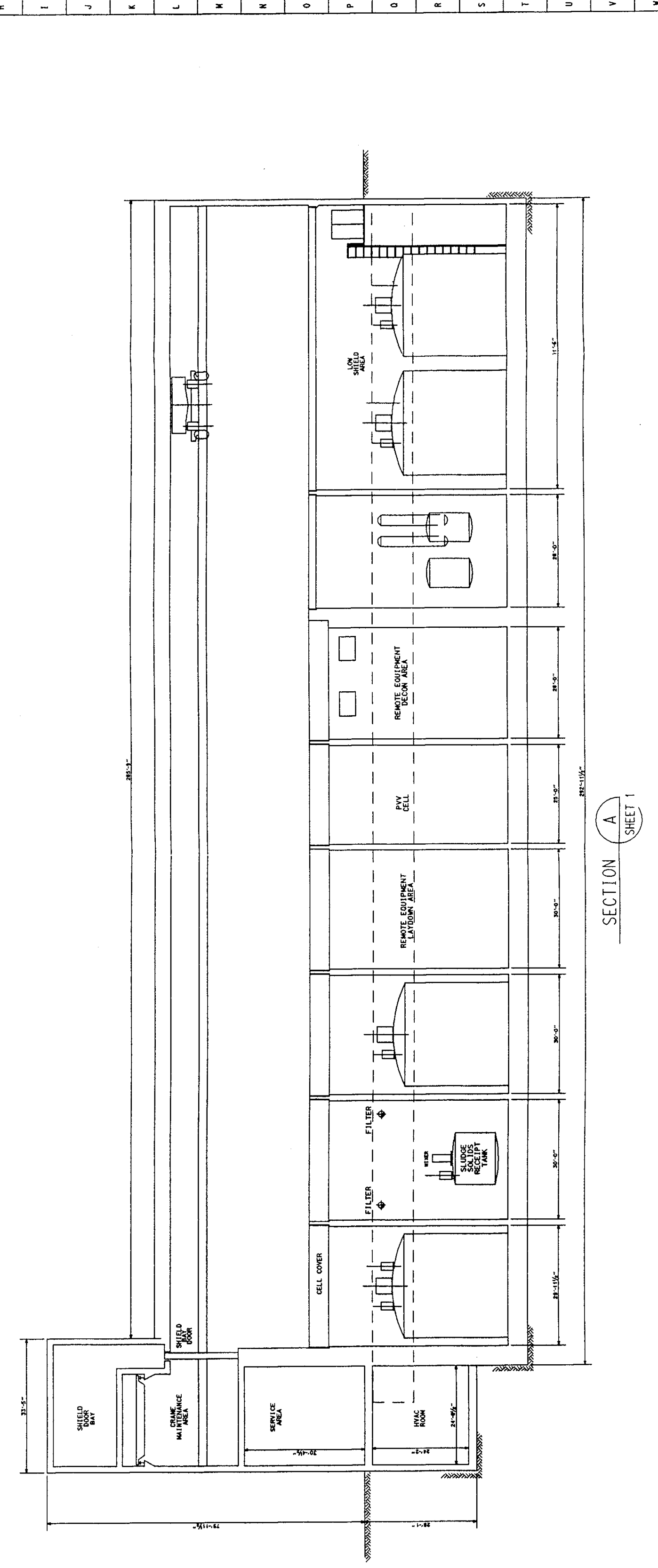

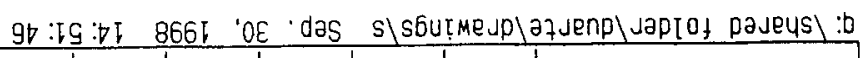

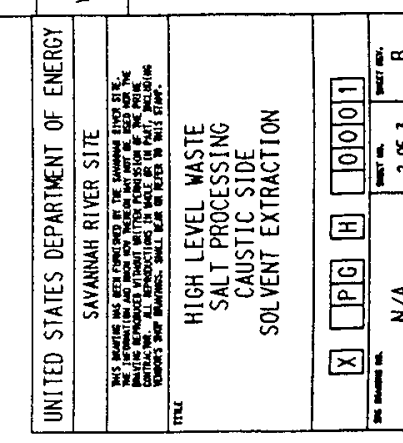

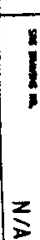



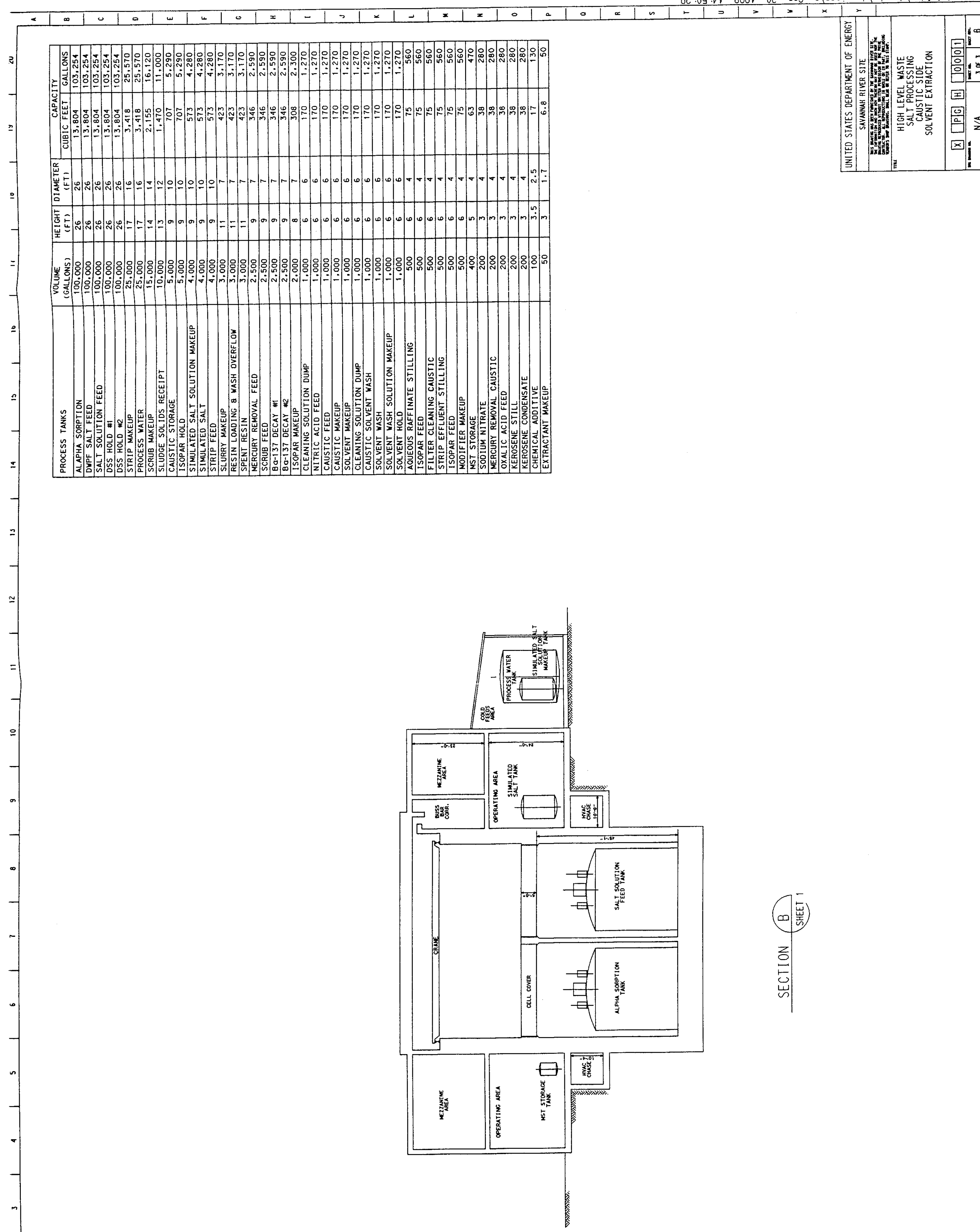

(ه)

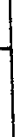

$\underbrace{z}_{2}$ 


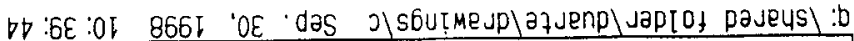

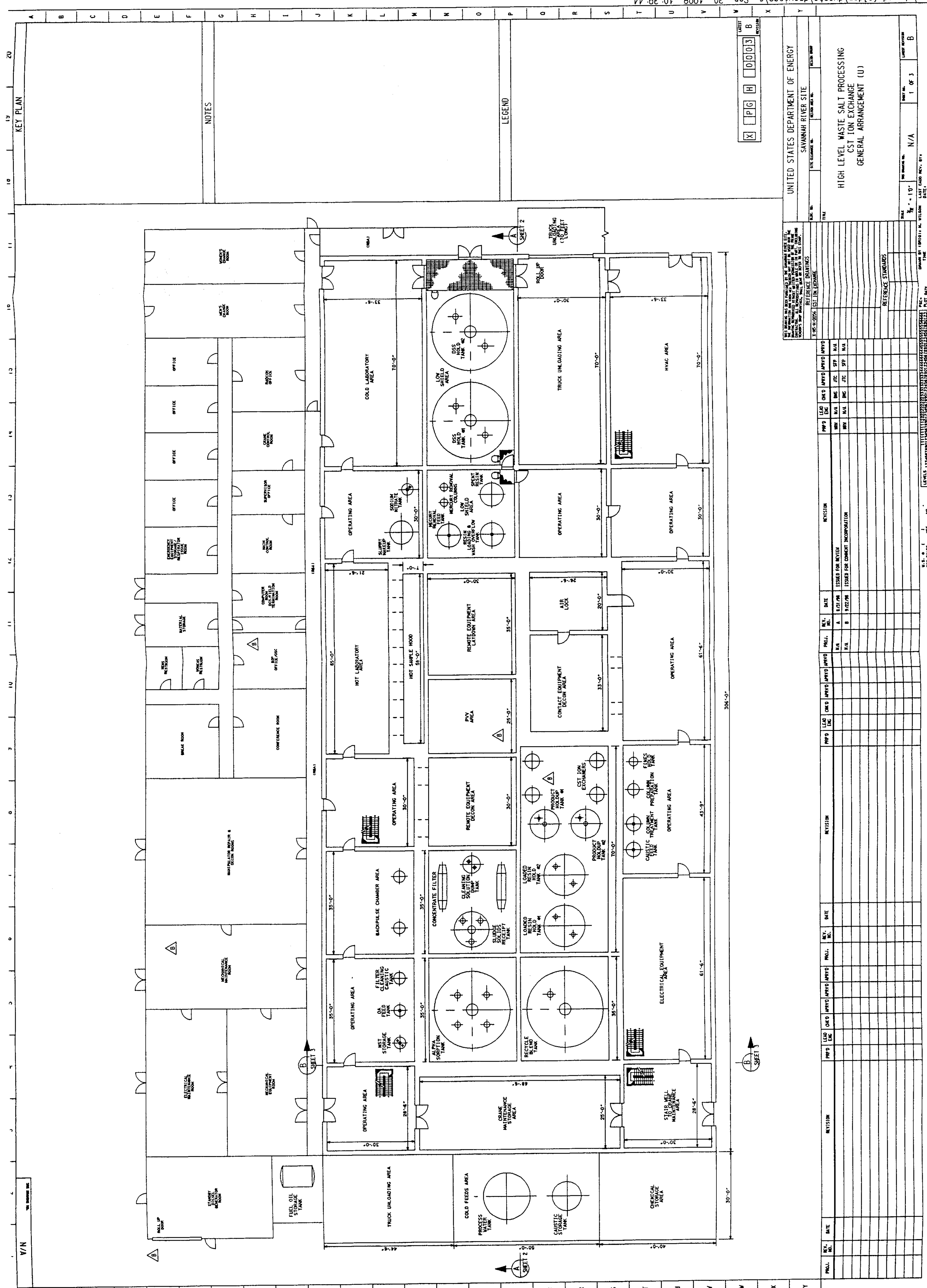




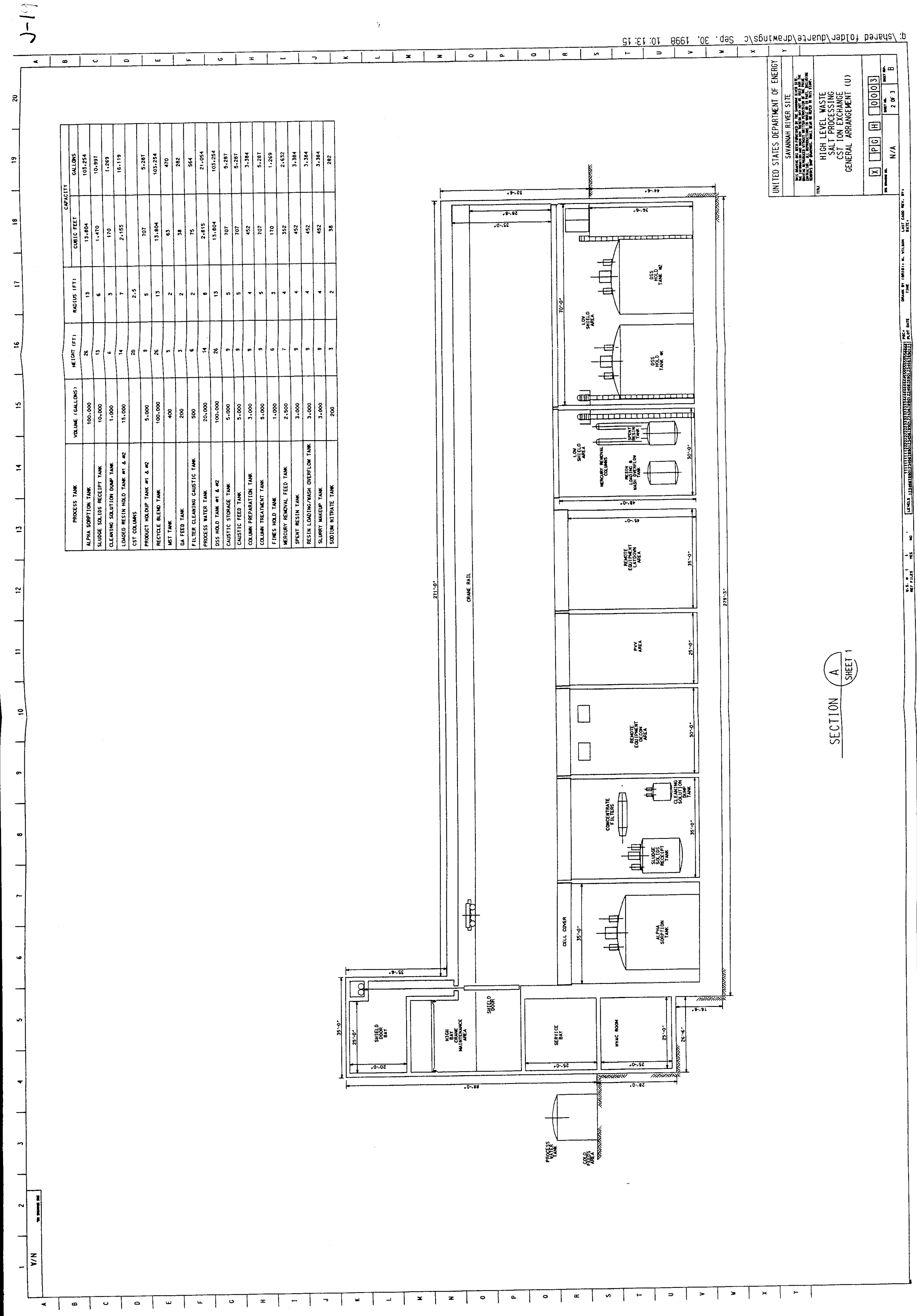



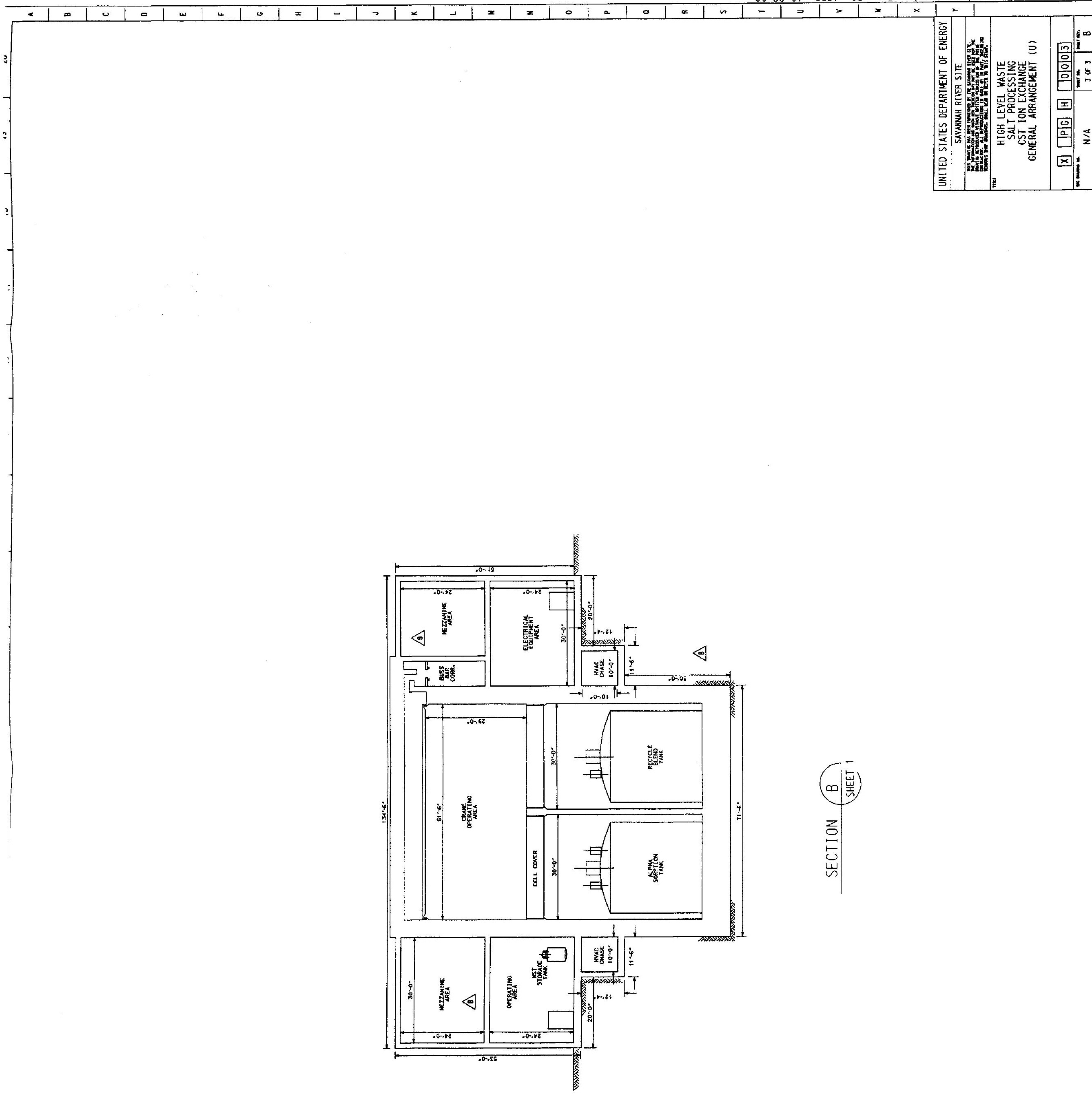

(م)

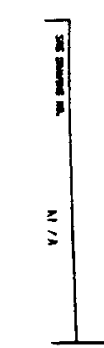


APPENDIX K

VARIATIONS 

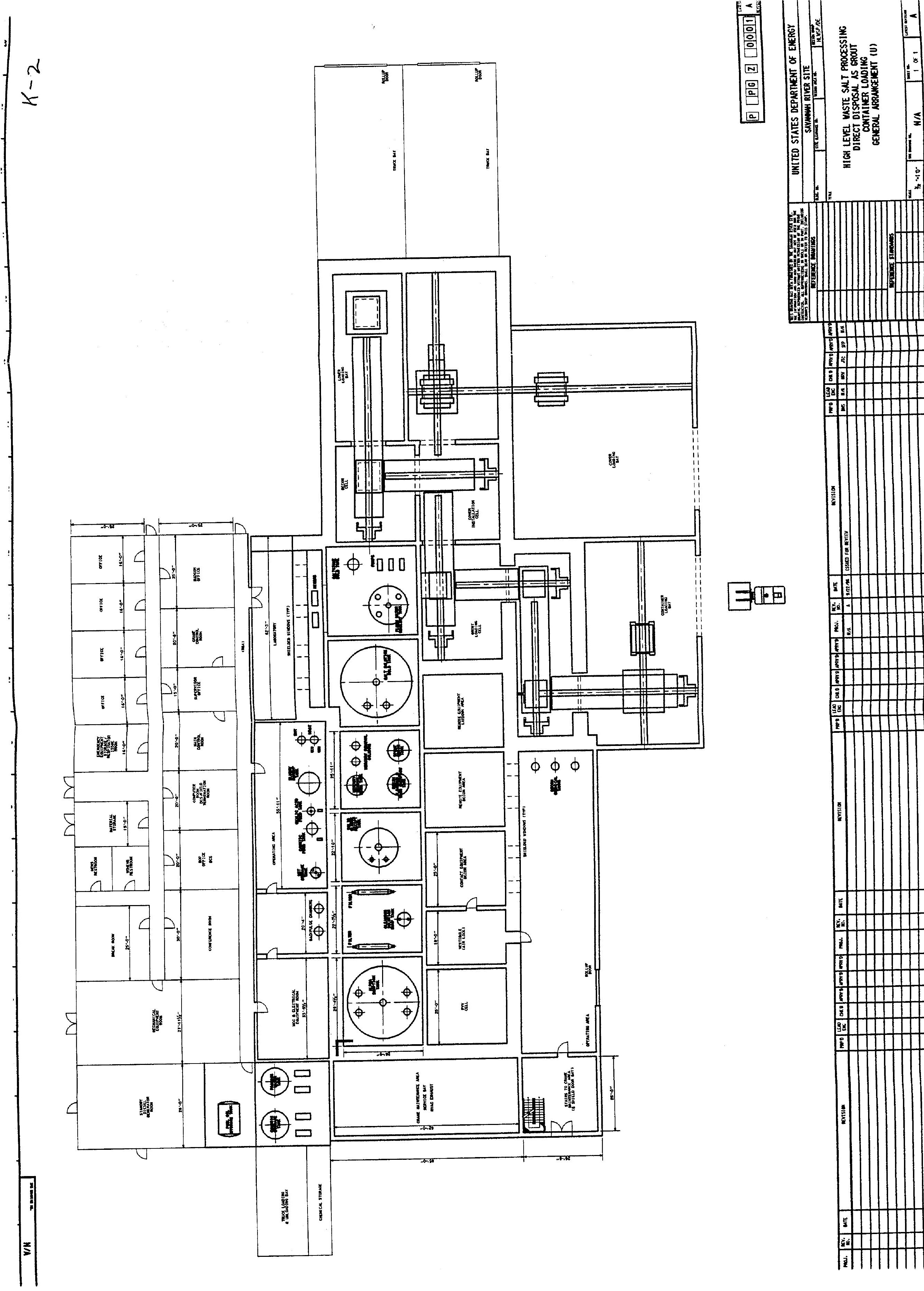


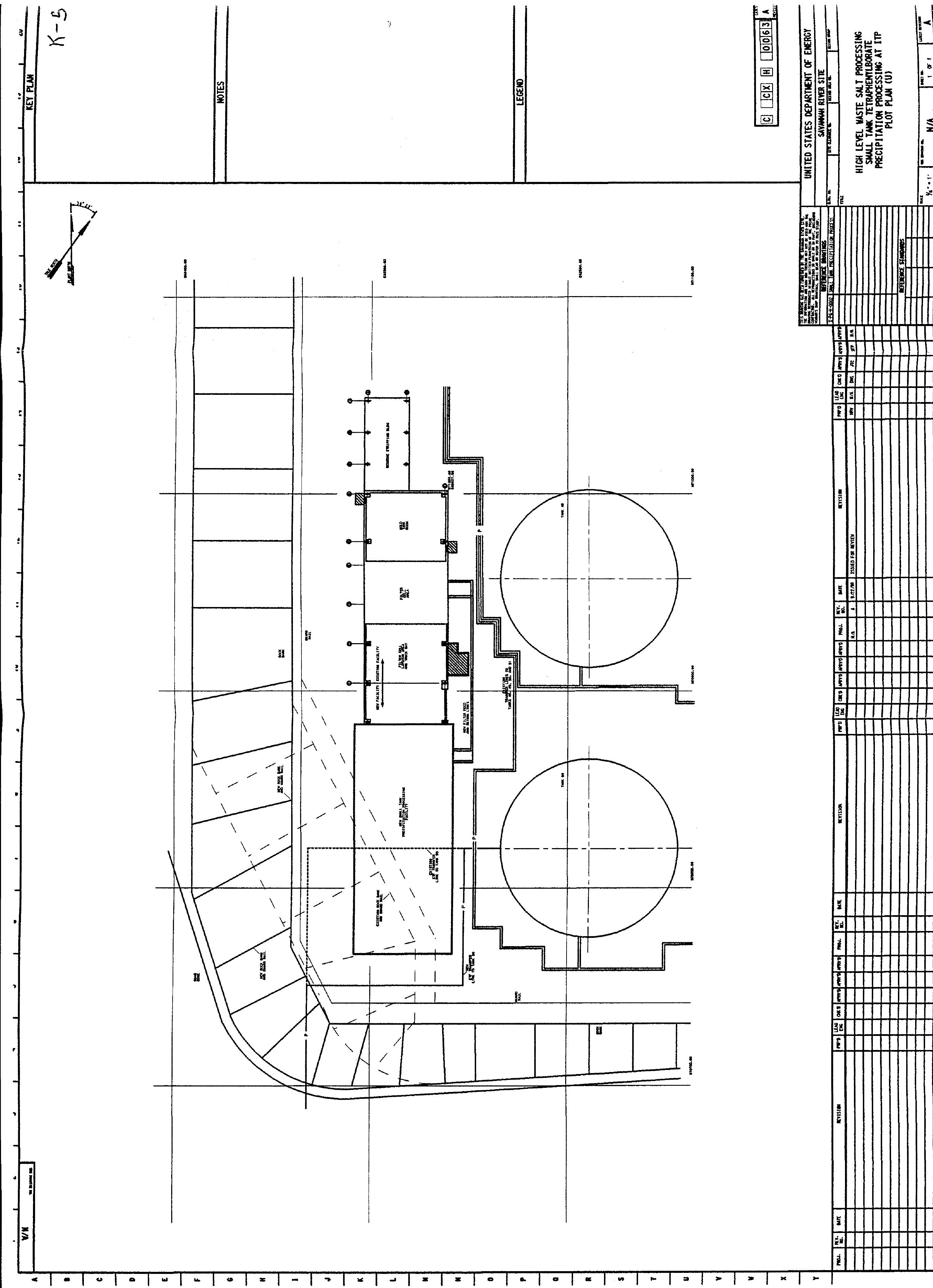




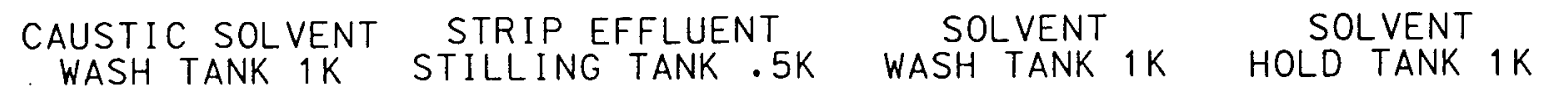

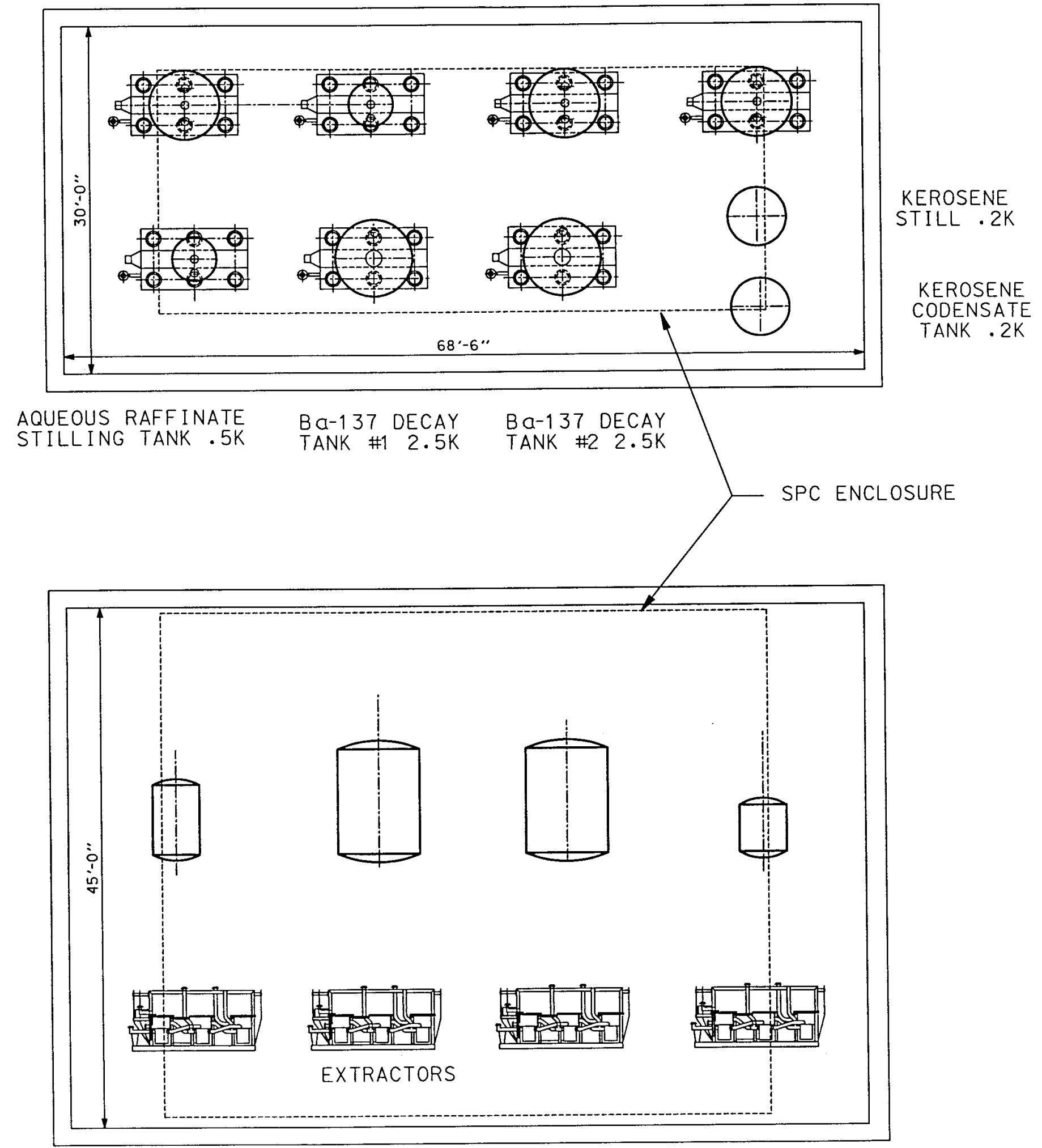

ATTACHMENT 3 - SOLVENT EXTRACTION 

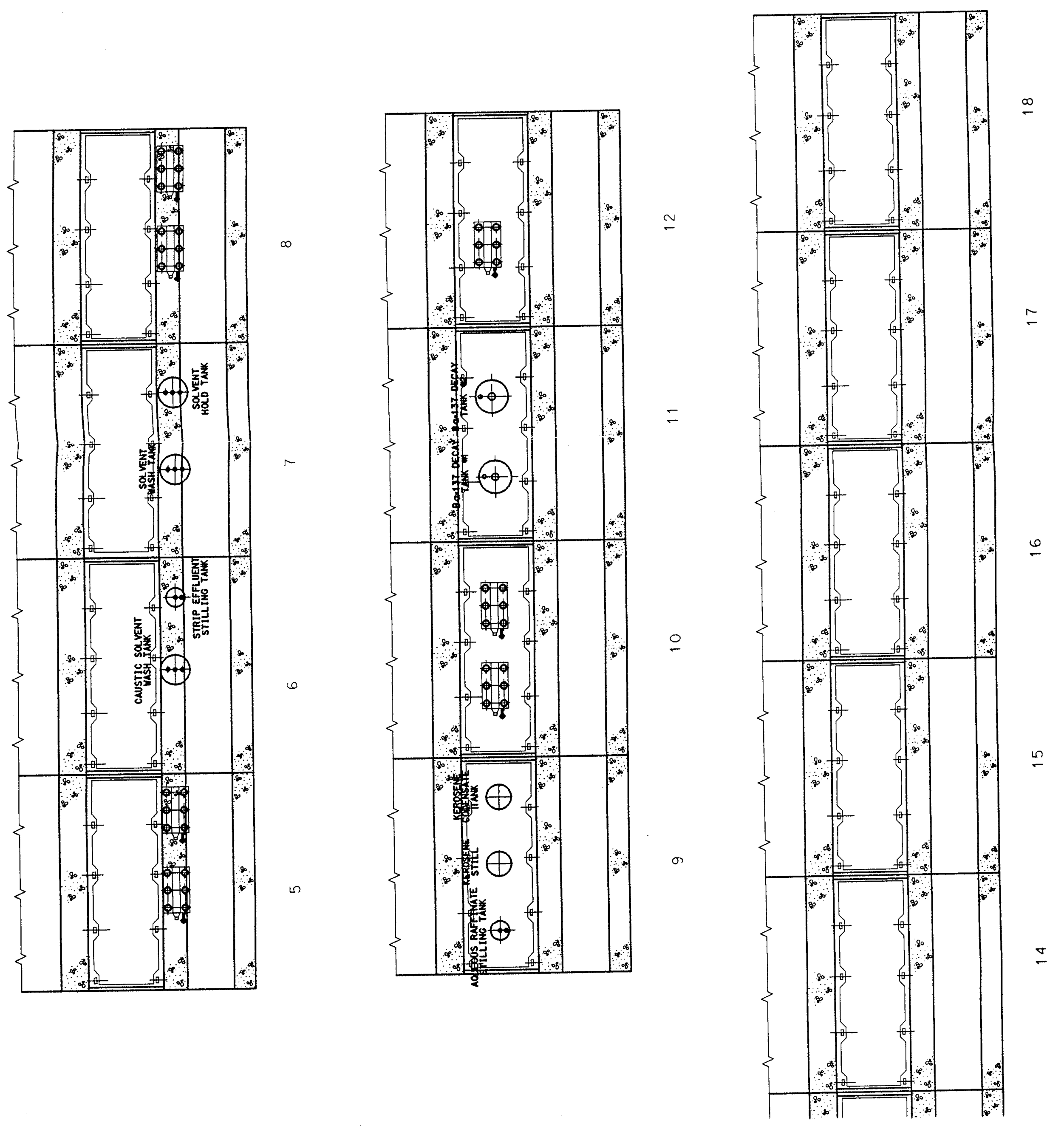

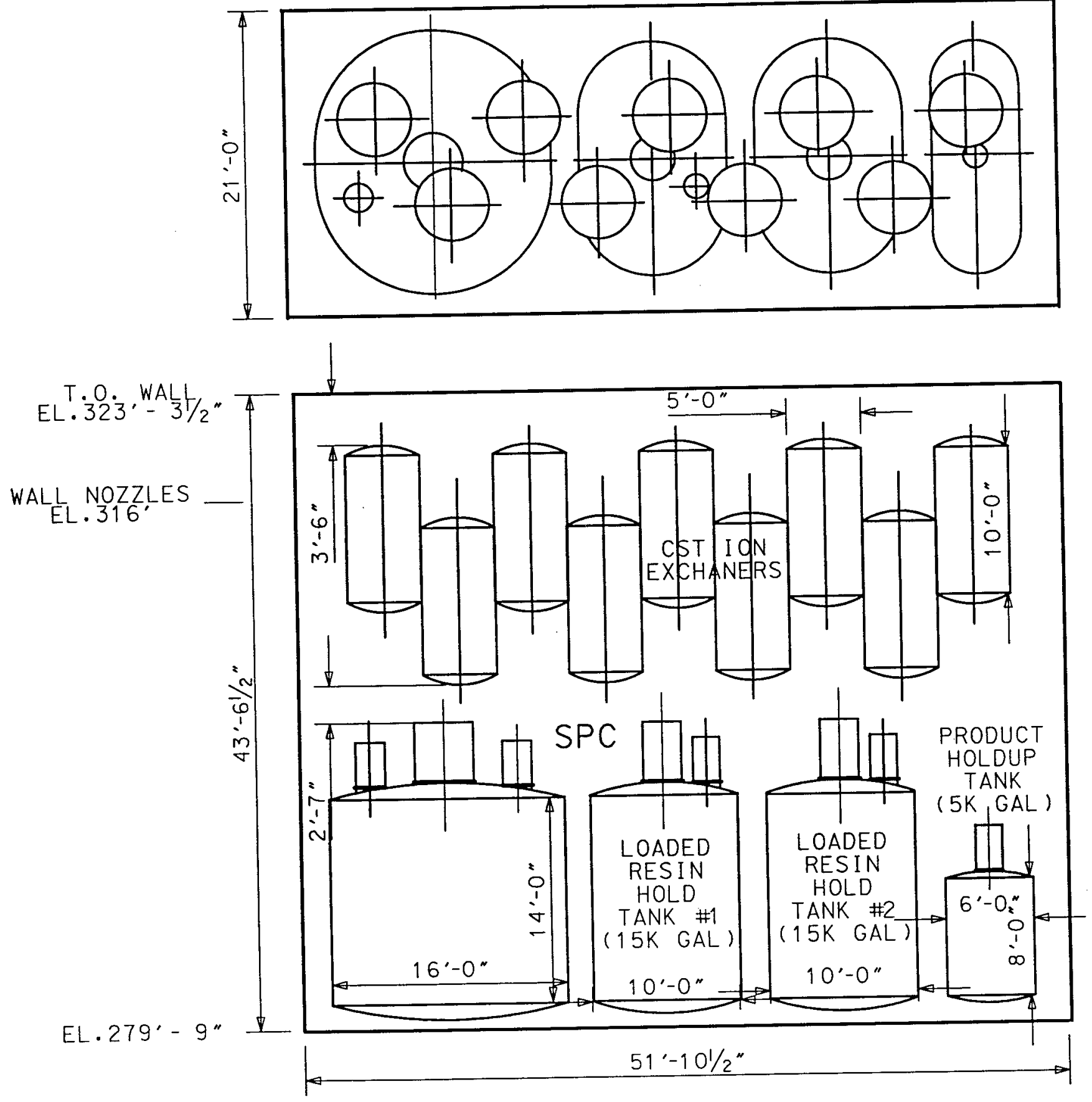

ATTACHMENT 5- CST FACILITIES

IN THE DWPF SPC 


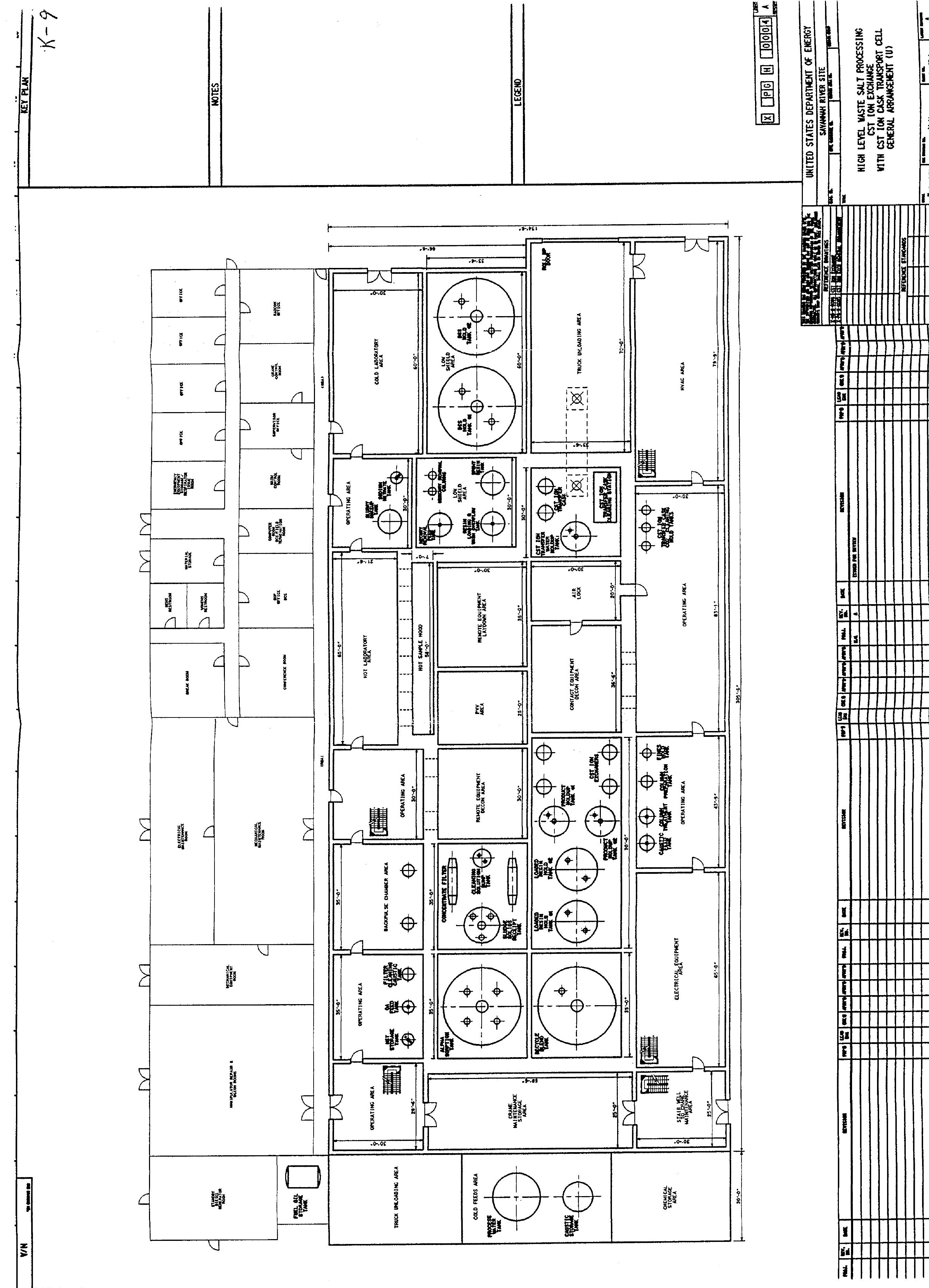

